\title{
IUCN
}

State of protected and conserved areas in Eastern and Southern Africa

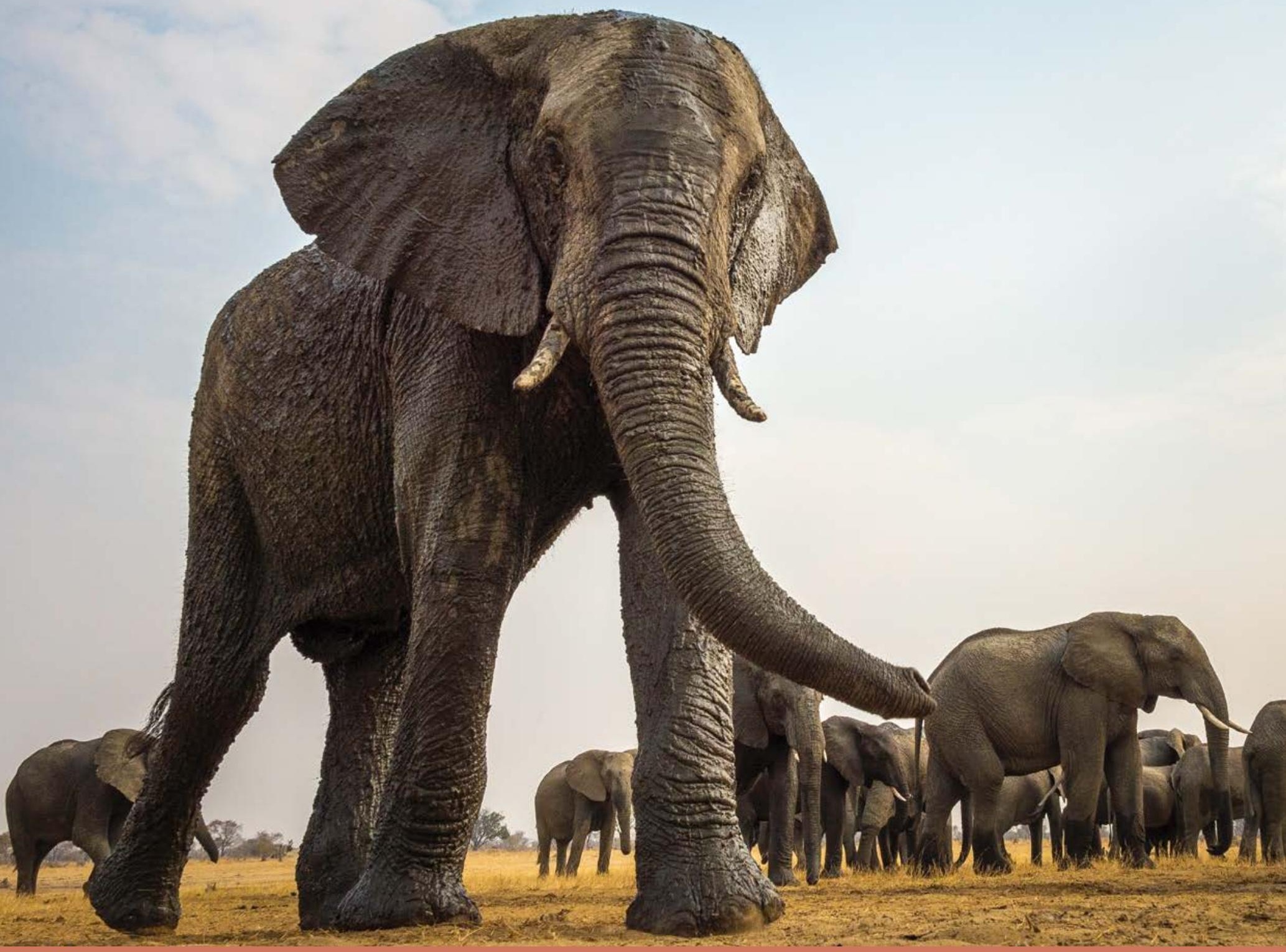

STATE OF PROTECTED AND CONSERVED AREAS REPORT SERIES NO.1

BIOPAMA 



\section{State of protected and conserved areas in Eastern and Southern Africa}


The designation of geographical entities in this book, and the presentation of the material, do not imply the expression of any opinion whatsoever on the part of IUCN or other participating organisations concerning the legal status of any country, territory or area, or of its authorities, or concerning the delimitation of its frontiers or boundaries.

The views expressed in these guidelines do not necessarily reflect those of IUCN or other participating organisations.

IUCN is pleased to acknowledge the support of its Framework Partners who provide core funding: Ministry for Foreign Affairs of Finland; Government of France and the French Development Agency (AFD); the Ministry of Environment, Republic of Korea; the Norwegian Agency for Development Cooperation (Norad); the Swedish International Development Cooperation Agency (Sida); the Swiss Agency for Development and Cooperation (SDC); and the United States Department of State.

The contents of this publication are the sole responsibility of the authors and can in no way be taken to reflect the views of the European Union nor of the ACP Group of States.

This publication has been produced with support of the $11^{\text {th }}$ European Development Fund.

Published by: $\quad$ IUCN, Regional Office for Eastern and Southern Africa, through the BIOPAMA Programme

Copyright: $\quad$ C 2020 IUCN, International Union for Conservation of Nature and Natural Resources

Reproduction of this publication for educational or other non-commercial purposes is authorised without prior written permission from the copyright holder provided the source is fully acknowledged. Reproduction of this publication for resale or other commercial purposes is prohibited without prior written permission of the copyright holder.

Citation: $\quad$ IUCN ESARO (2020). The state of protected and conserved areas in Eastern and Southern Africa. State of Protected and Conserved Areas Report Series No. 1. Nairobi, Kenya: IUCN ESARO.

ISBN: $\quad$ 978-2-8317-2080-7 (PDF)

978-2-8317-2081-4 (print)

DOI:

https://doi.org/10.2305/IUCN.CH.2020.15.en

Cover photo: $\quad$ Elephants, Hwange National Park, Zimbabwe. ( ) Wilderness Safaris

Back cover photo: lle aux Aigrettes Nature Reserve, Mauritius. @ Gina Bonne IOC

Layout by: $\quad$ Mary-Anne van der Byl

Printed by: $\quad$ Minuteman Press

Available from: $\quad$ IUCN South Africa

333 Grosvenor Street

Hatfield Gardens, Block A

Pretoria, South Africa

$+27(0) 123428304 / 6$

info.esaro@iucn.org

https://www.biopama.org/

www.iucn.org/resources/publications

The text of this book is printed on paper made from wood fibre from well-managed forests certified in accordance with the rules of the Forest Stewardship Council (FSC). 


\section{International Union for Conservation of Nature (IUCN)}

IUCN is a membership Union composed of both government and civil society organisations. It harnesses the experience, resources and reach of its [more than] 1,400 Member organisations and the input of more than 15,000 experts. IUCN is the global authority on the status of the natural world and the measures needed to safeguard it.

www.iucn.org

\section{$B I O P \wedge M \wedge$}

\section{Biodiversity and Protected Areas Management}

The Biodiversity and Protected Areas Management (BIOPAMA) programme aims to improve the long-term conservation and sustainable use of natural resources in African, Caribbean and Pacific (ACP) countries, in protected areas and surrounding communities. It is an initiative of the ACP Group of States financed by the European Union's 11th European Development Fund (EDF), jointly implemented by the International Union for Conservation of Nature (IUCN) and the Joint Research Centre of the European Commission (JRC). Building on the first five years of activities financed by the 10th EDF, BIOPAMA's second phase provides tools for data and information management, services for improving the knowledge and capacity for protected area planning and decision making, and funding opportunities for specific site-based actions. www.biopama.org

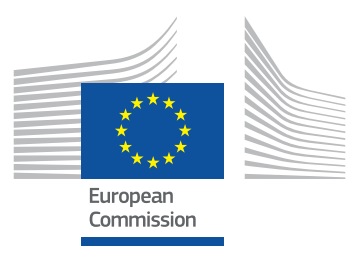

REGIONAL CENTRE FOR MAPPING OF RESOURCES FOR DEVELOPMENT

\section{Joint Research Centre and the European Commission}

The European Commission (EC) is the executive body of the European Union (EU), which is the world's largest donor of official development assistance. As the in-house science service of the EC, the Joint Research Centre (JRC) provides EU policies with independent, evidence-based scientific and technical support, including policies and programmes at global level and specifically those focusing on the African, Caribbean and Pacific Group of States (ACP).

www.ec.europa.eu/jrc/en

\section{Regional Centre for Mapping of Resources for Development}

Regional Centre for Mapping of Resources for Development (RCMRD) is an intergovernmental organization composed today of 20 Member States in Eastern and Southern Africa having been established in 1975 by the African Union (AU) and the United Nations Economic Commission for Africa. RCMRD promotes sustainable development through Generation, Application and Dissemination of Geo-information and Allied Technologies among its Member States and stakeholders. Our mandate is executed through thematic areas such as Natural Resource Management; Environmental Management; Climate Action; Food Security \& Sustainable Agriculture; Knowledge Management \& Capacity Building; Land Management; and Urban Development.

www.rcmrd.org

\section{UN Environment World Conservation Monitoring Centre}

The UN Environment Programme World Conservation Monitoring Centre (UNEP-WCMC) is a global Centre of excellence on biodiversity. The Centre operates as a collaboration between the UN Environment Programme and the UK-registered charity WCMC. Together we are confronting the global crisis facing nature.

www.unep-wcmc.org

\section{Organisation of African, Caribbean and Pacific States}

The Organisation of African, Caribbean and Pacific States (OACPS), formerly known as the ACP Group of States, is an organisation created by the original Georgetown Agreement in 1975, and subsequently revised in 2019. The OACPS' main goals centre around the sustainable development of its Members and their gradual integration into the global economy; coordination of OACPS activities in the framework of the implementation of the existing Partnership Agreement with the European Union; consolidation of unity and solidarity among Members of the OACPS; and the establishment and strengthening of peace, security and stability in free and democratic societies.

www.acp.int 


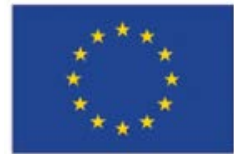

\section{European Union}

The Member States of the European Union have decided to link together their know-how, resources and destinies. Together, they have built a zone of stability, democracy and sustainable development whilst maintaining cultural diversity, tolerance and individual freedoms. The European Union is committed to sharing its achievements and its values with countries and peoples beyond its borders.

www.europa.eu

This publication has been produced with support of the $11^{\text {th }}$ EDF. The contents of this publication are the sole responsibility of the authors and can in no way be taken to reflect the views of the European Union nor of the ACP Group of States.

\section{The Eastern and Southern Africa Regional Economic Communities (RECs)}
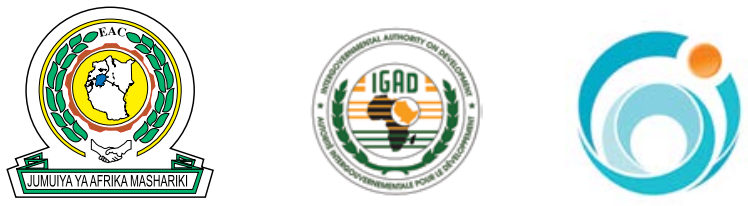

INDIAN OCEAN

C O M MISSION

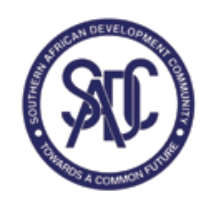

\section{Countries represented in this report}

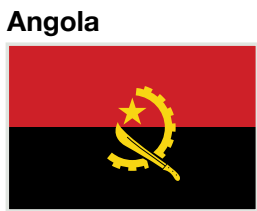

Ethiopia

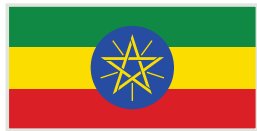

Botswana

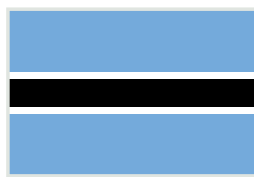

Kenya

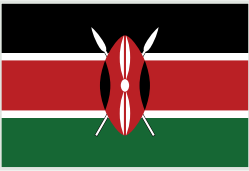

Mozambique

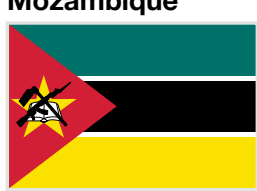

South Sudan
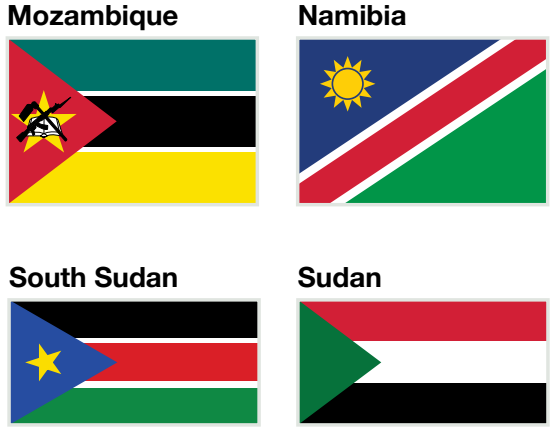

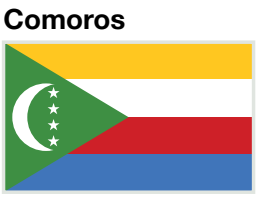

Lesotho
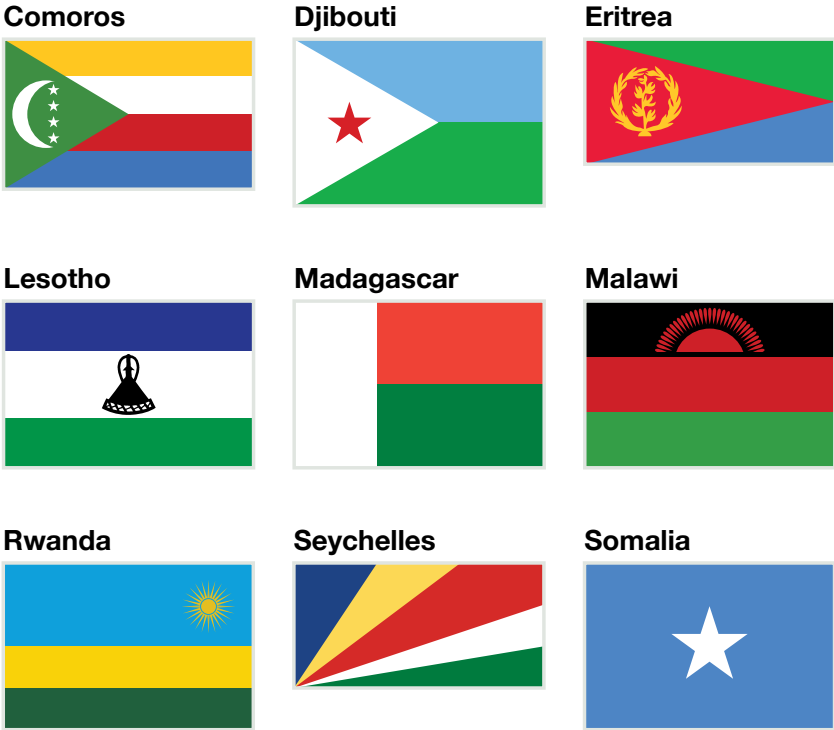

Eswatini

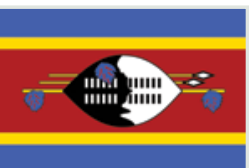

Madagascar
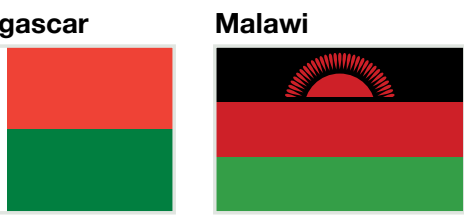

Mauritius

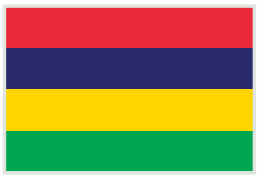

Somalia

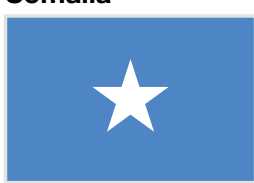

South Africa

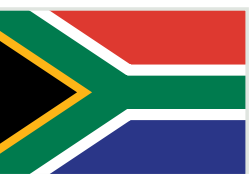

Uganda

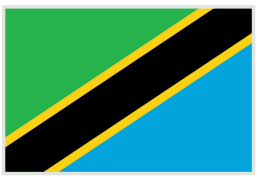

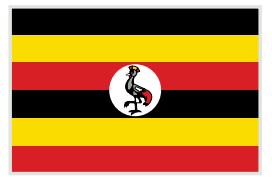

Zambia

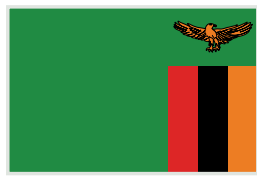

Zimbabwe

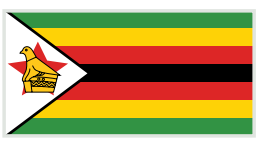




\section{Table of contents}

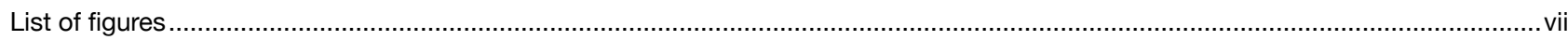

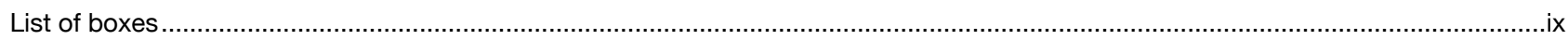

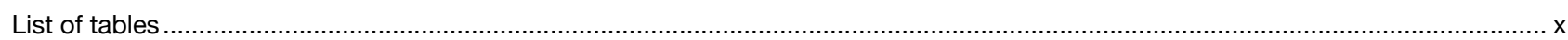

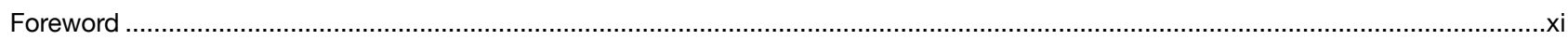

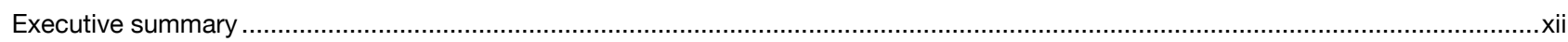

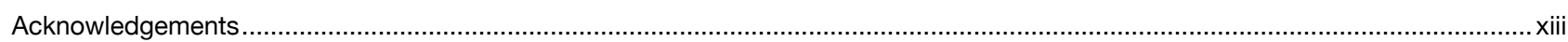

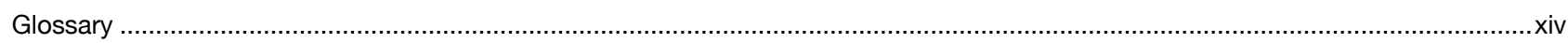

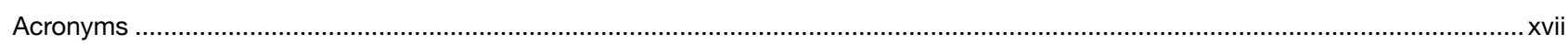

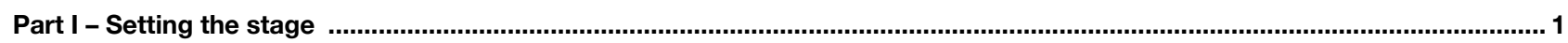

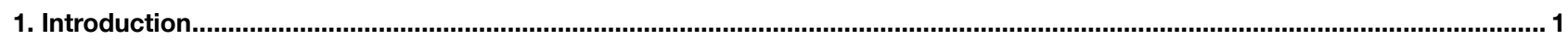

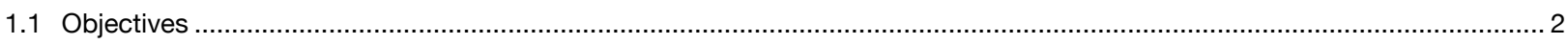

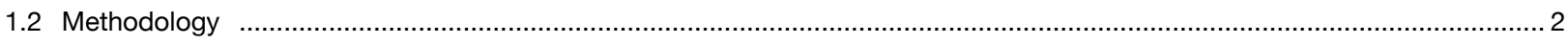

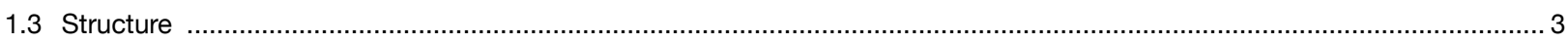

2. Conceptual and international framework ...........................................................................................................................

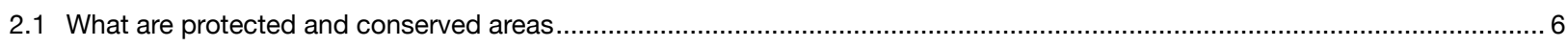

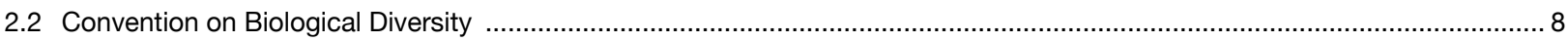

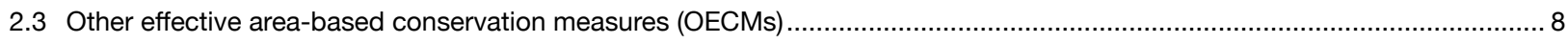

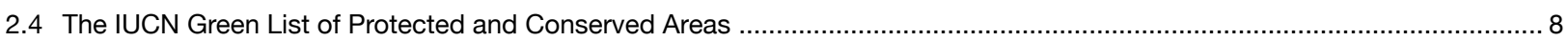

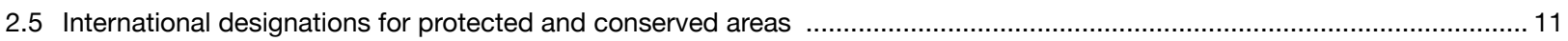

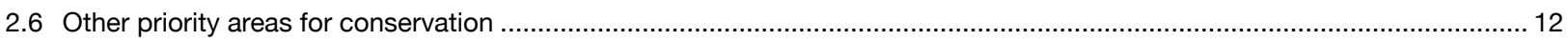

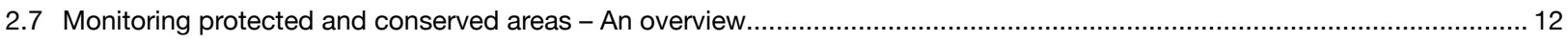

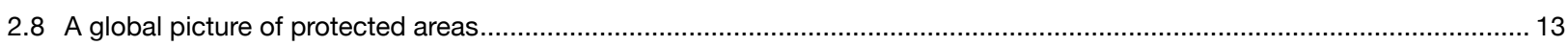

Part II - Regional context, data and country profiles ............................................................................................................ 17

3. Overview of the region ..................................................................................................................................................................... 17

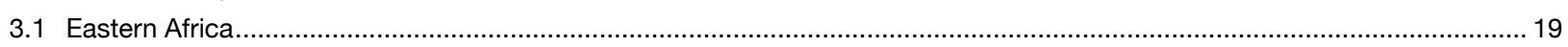

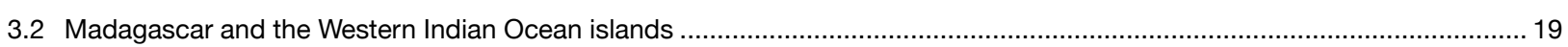

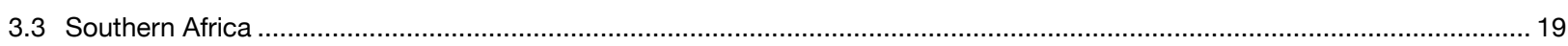

4. Protected and conserved areas in Eastern and Southern Africa ............................................................................................ 21

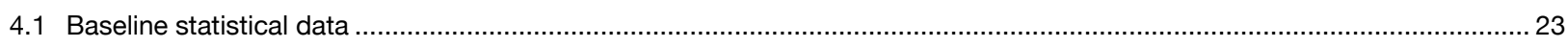

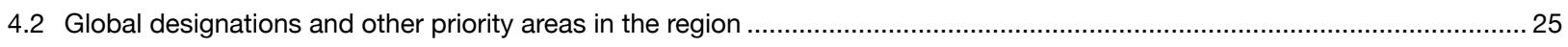

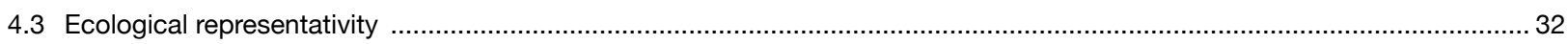

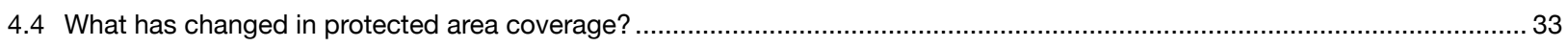

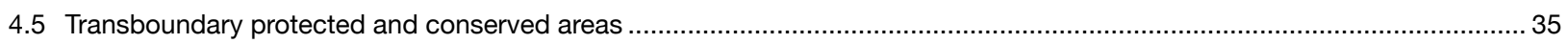

5. Ecosystem services of protected areas in Eastern and Southern Africa ................................................................................43

6. Regional policies and relevant frameworks relating to biodiversity conservation and protected area management ............... 47

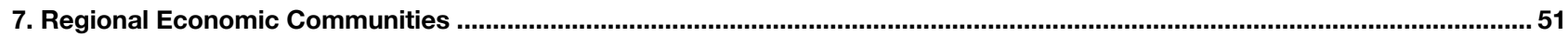

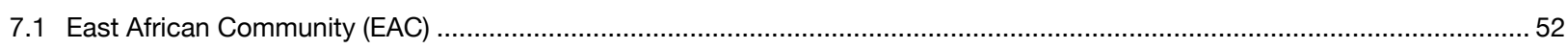

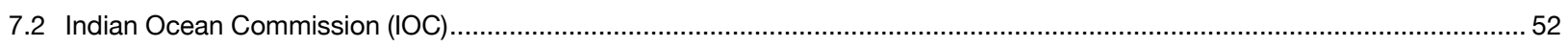

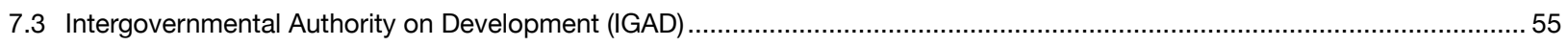

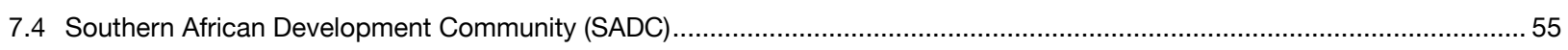

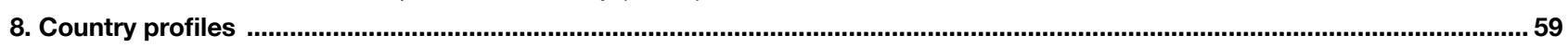

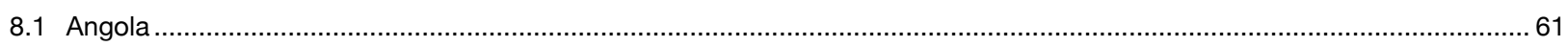

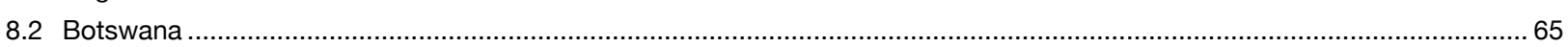

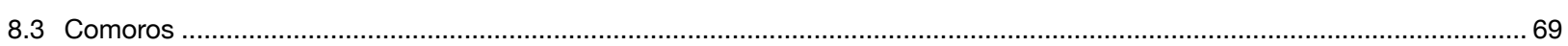

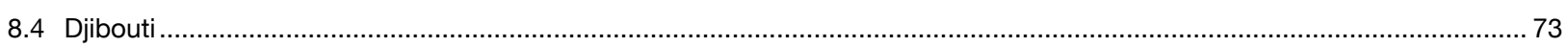

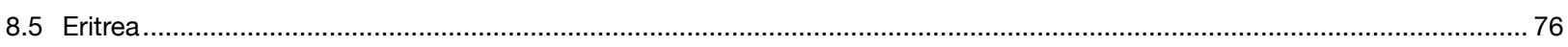

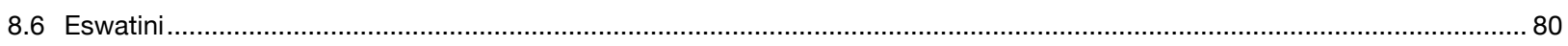

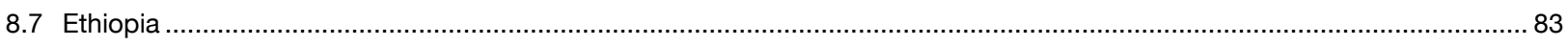

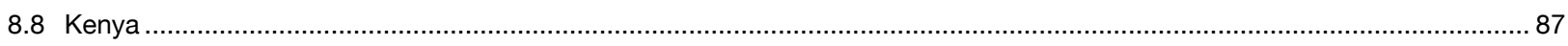

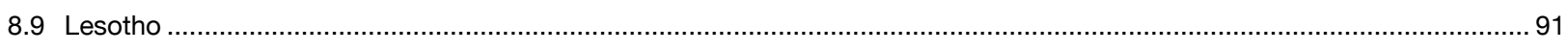

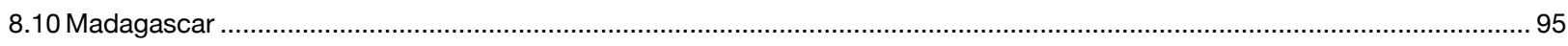




\section{Table of contents (continued)}

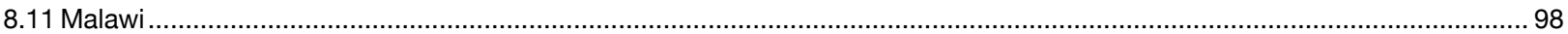

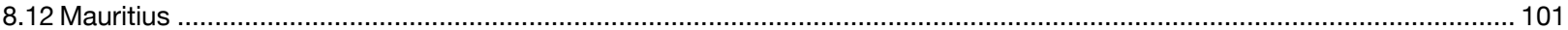

8.13 Mozambique

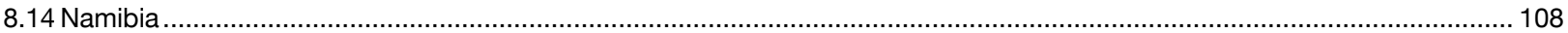

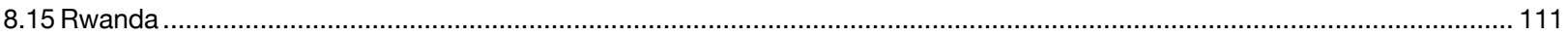

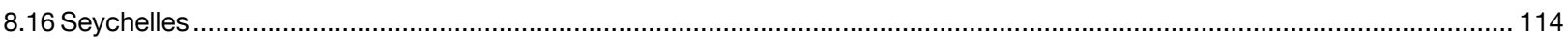

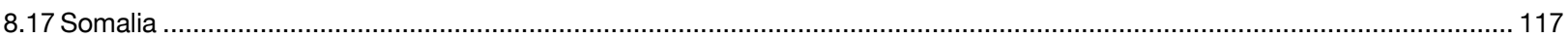

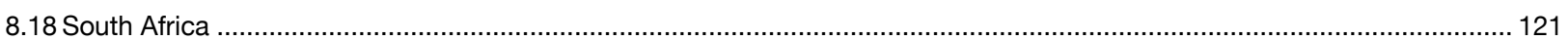

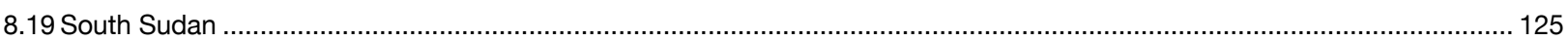

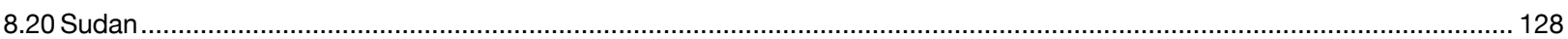

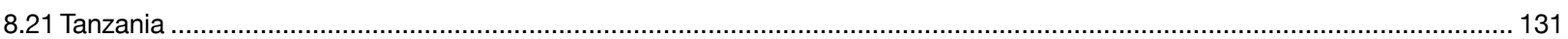

8.22 Uganda

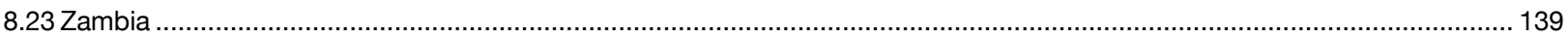

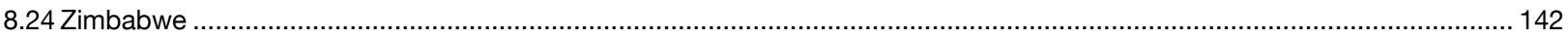

Part III - Governance and management effectiveness ...................................................................................................... 147

9. Protected area governance and equity

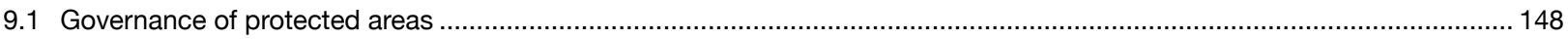

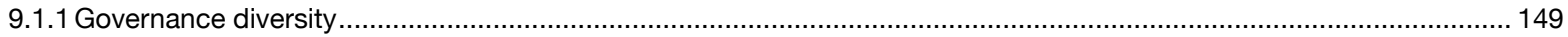

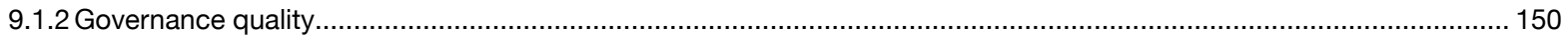

9.2 Good governance and the IUCN Green List of Protected and Conserved Areas...................................................... 150

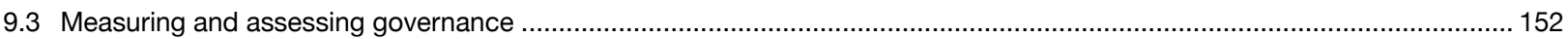

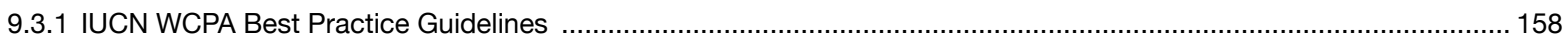

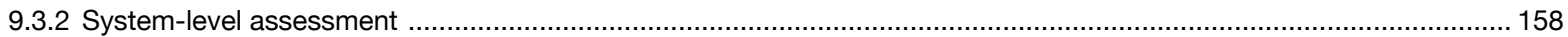

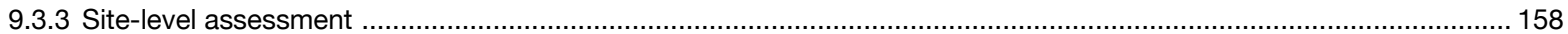

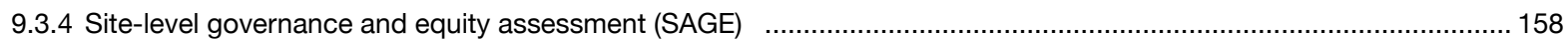

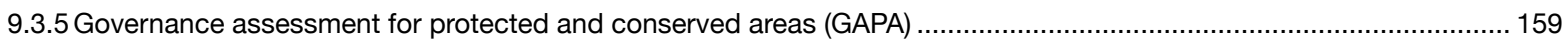

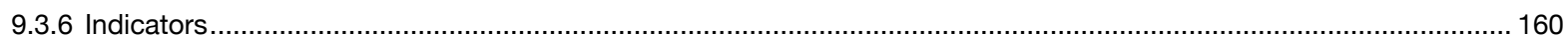

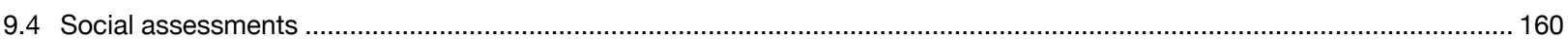

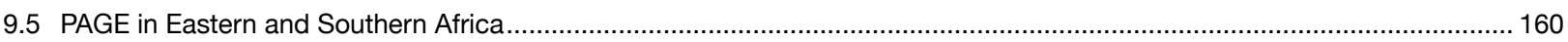

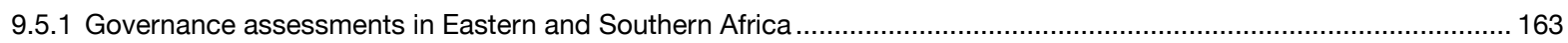

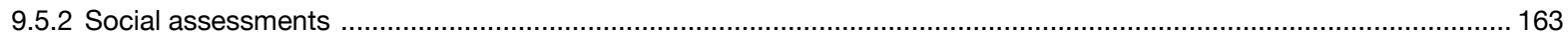

9.6 Results of social and governance assessments in Eastern and Southern Africa .......................................................... 163

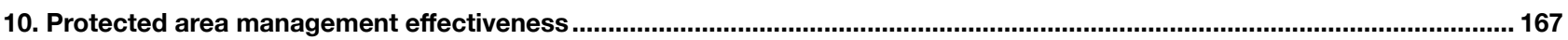

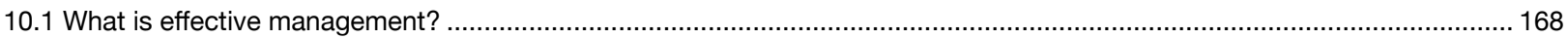

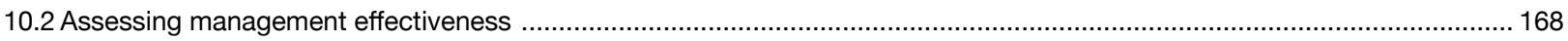

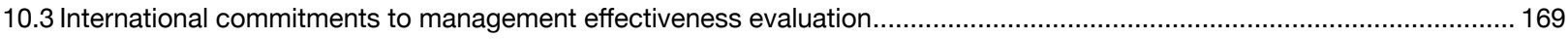

10.4 Global Database on Protected Area Management Effectiveness (GD-PAME) ............................................................ 169

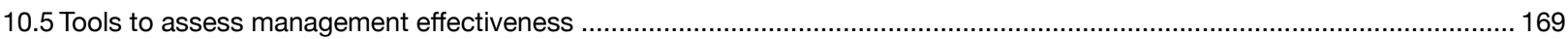

10.6 Principles for PAME assessments

10.7 Integrating management effectiveness with governance and social assessments ........................................................... 170

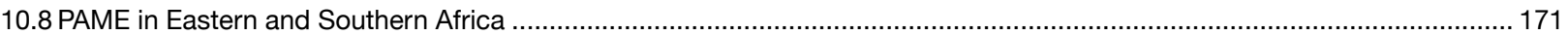

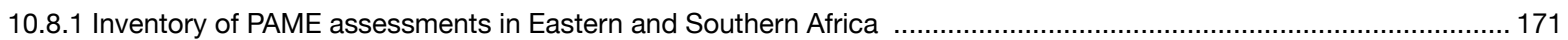

10.8.2 Inventory of combined assessments in Eastern and Southern Africa ............................................................. 174

10.9 Results of PAME assessments in Eastern and Southern Africa

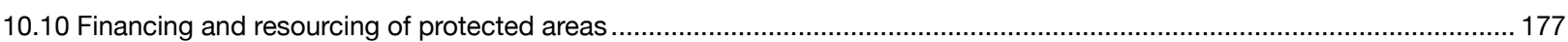

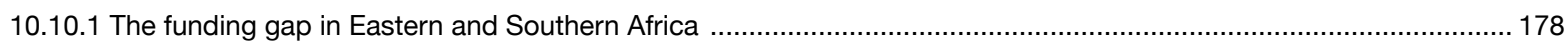

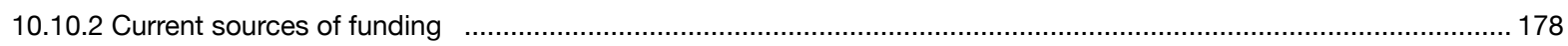

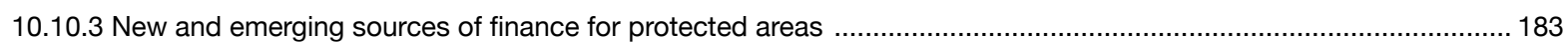

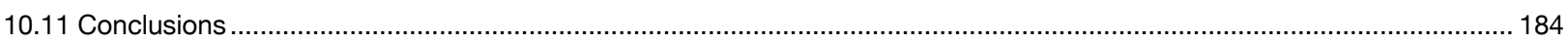

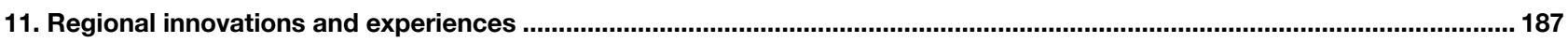




\section{Table of contents (continued)}

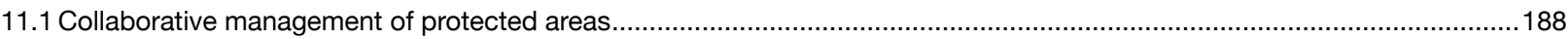

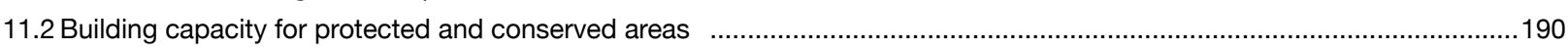

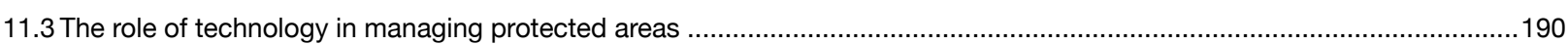

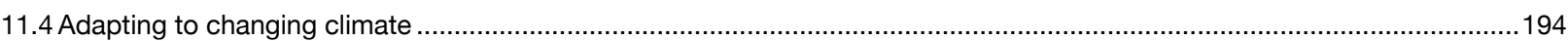

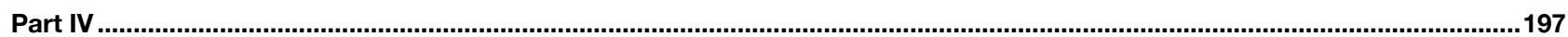

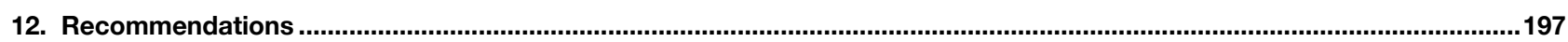

12.1 Increase sustainable financing and political support for protected and conserved areas .................................................198

12.2 Enhance capacities for protected and conserved area management ...............................................................................198

12.3 Diversify governance of protected areas and recognise effective local, community and co-management

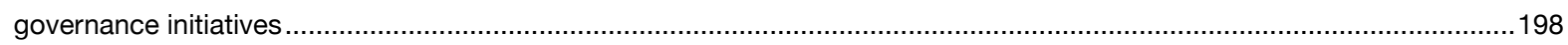

12.4 Address gaps in the coverage of marine and terrestrial ecosystems in protected and conserved area estates ...................198

12.5 Enhance collaboration across borders and sectors to respond to existing and emerging threats .......................................199

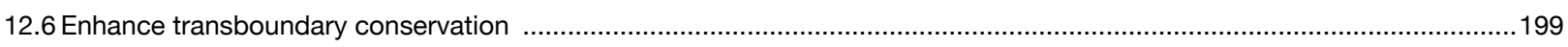

12.7 Improve coverage of assessments of management effectiveness, governance and equity ............................................199

12.8 Enhance frequency and comprehensiveness of reporting to the World Database of Protected Areas .................................199

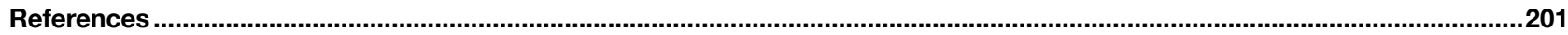

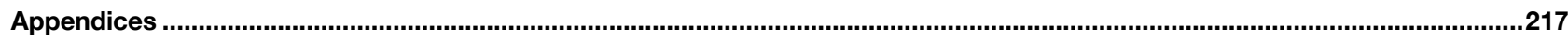

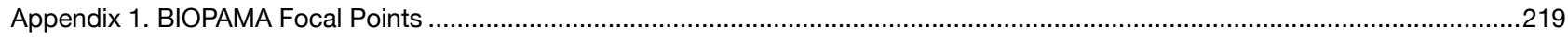

Appendix 2. Regional statistics on protected and conserved areas in Eastern and Southern Africa ...............................................220

A2-Table 1. Terrestrial protected and conserved areas in Eastern and Southern Africa.........................................................220

A2-Table 2. Coastal and marine protected and conserved areas in Eastern and Southern Africa...............................................221

A2-Table 3. IUCN management categories of protected and conserved areas in Eastern and Southern Africa ............................221

A2-Table 4. IUCN governance types of protected and conserved areas in Eastern and Southern Africa...................................222

Appendix 3. Global sites of importance in Eastern and Southern Africa .................................................................................222

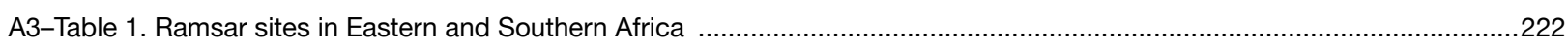

A3-Table 2. Man and Biosphere Reserves in Eastern and Southern Africa ............................................................................226

Appendix 4. Ecological representativity in Eastern and Southern Africa ...............................................................................22

A4-Table 1. Ecological representativity in Eastern and Southern African protected areas .........................................................222

Appendix 5. Legal instruments supporting equity and non-State governance of protected areas .................................................228

Appendix 6. Protected and conserved areas in IUCN Management Categories per country ...........................................................230

Appendix 7. Protected and conserved areas in IUCN Governance Types per country ...................................................................236

\section{List of figures}

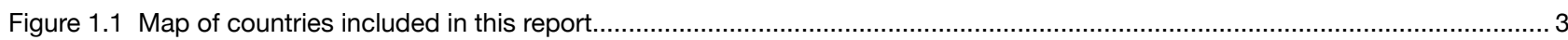

Figure 2.1 Global and regional data management systems for protected areas .......................................................................... 13

Figure 4.1 Protected and conserved areas in Eastern and Southern Africa ................................................................................. 22

Figure 4.2 Terrestrial protected area coverage in Eastern and Southern Africa ......................................................................2 23

Figure 4.3 Coastal and marine protected and conserved areas in Eastern and Southern Africa ....................................................2 24

Figure 4.4 IUCN management categories of protected and conserved areas in Eastern and Southern Africa....................................... 24

Figure 4.5 IUCN governance type categories of protected and conserved areas in Eastern and Southern Africa................................24

Figure 4.6 Protection levels for terrestrial ecoregions represented within the region ................................................................. 33

Figure 4.7 Protection levels for marine ecoregions and pelagic provinces represented within the region ........................................ 33

Figure 4.8 Ecoregion coverage in Eastern and Southern Africa by protection percentage ............................................................ 34

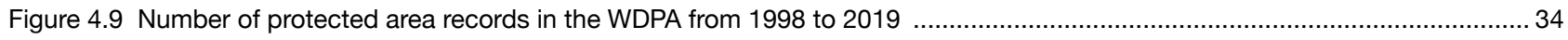

Figure 4.10 Southern African development community trans-frontier conservation areas (sadc tfcas) ............................................... 36

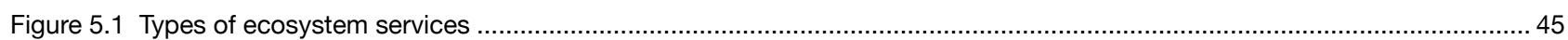

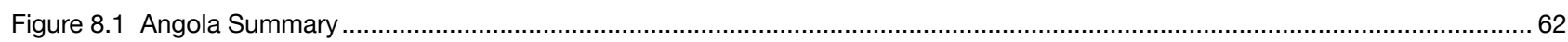

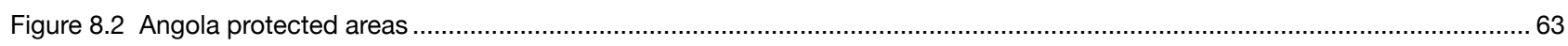

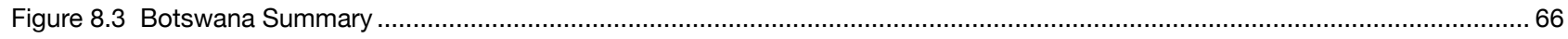




\section{List of figures (continued)}

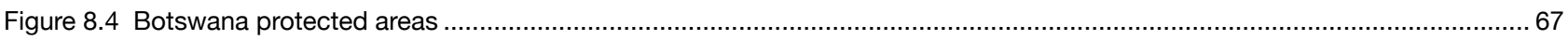

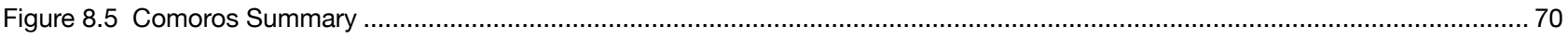

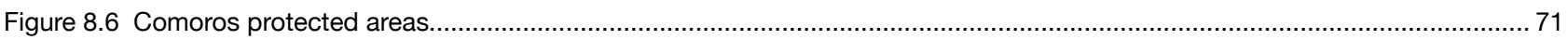

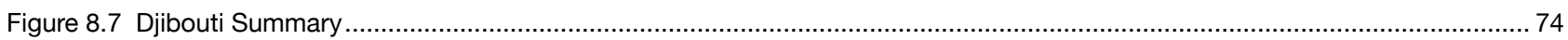

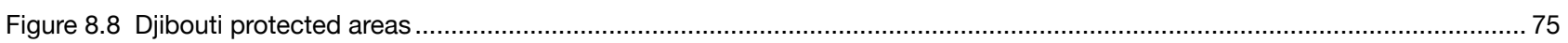

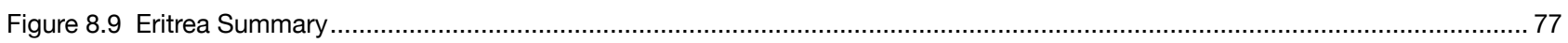

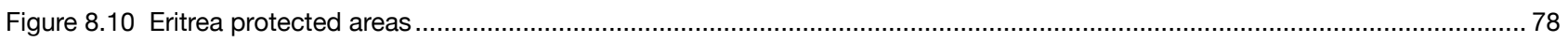

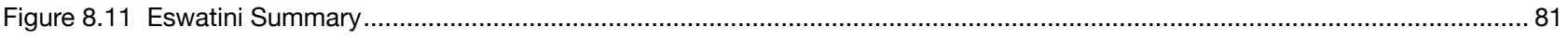

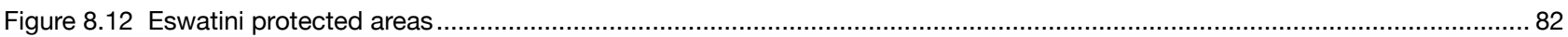

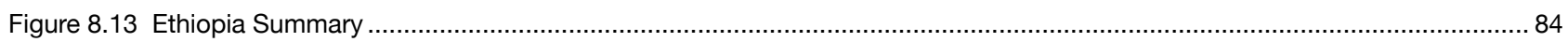

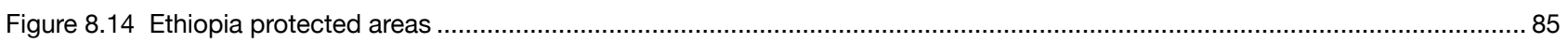

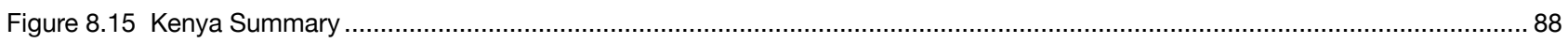

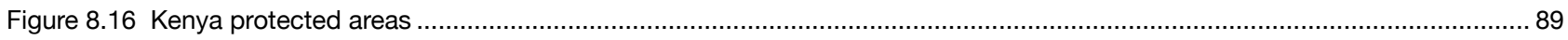

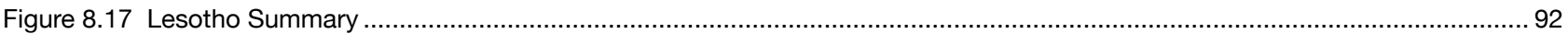

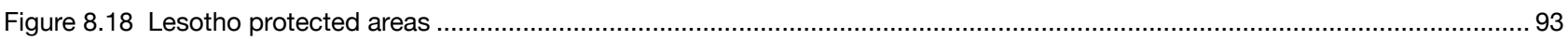

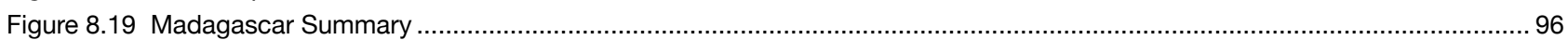

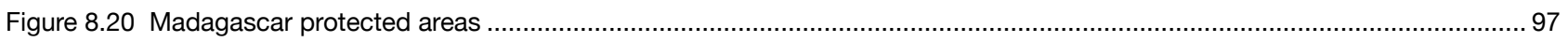

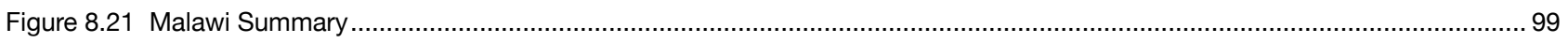

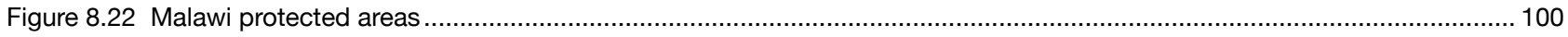

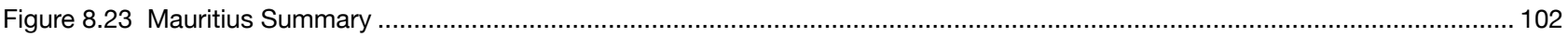

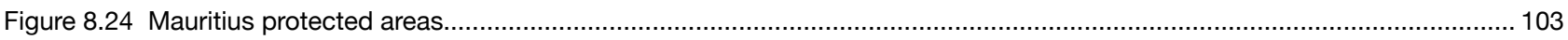

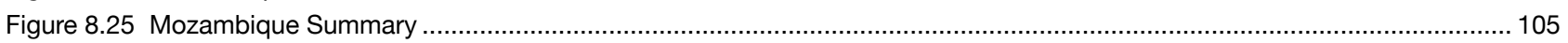

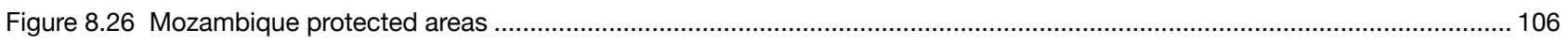

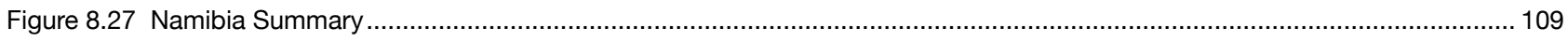

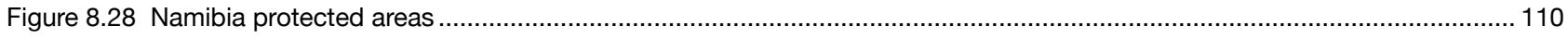

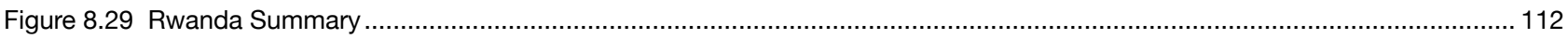

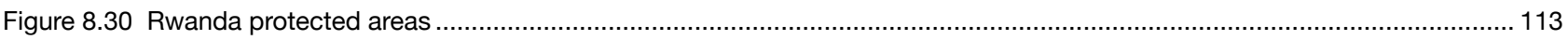

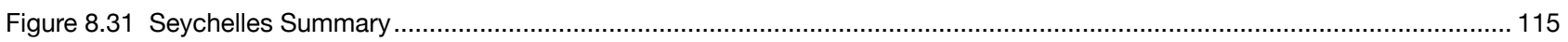

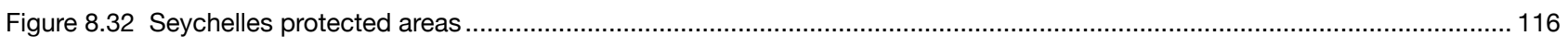

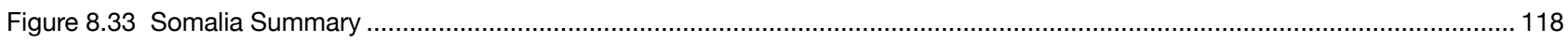

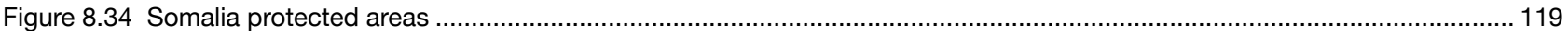

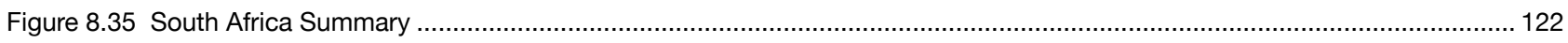

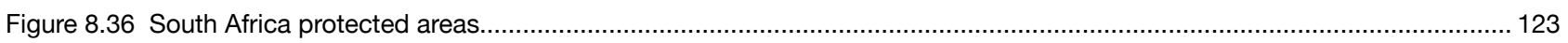

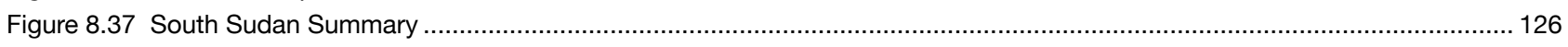

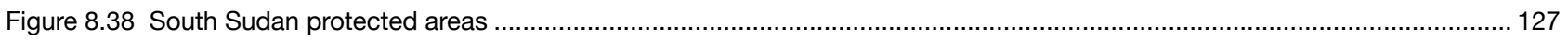

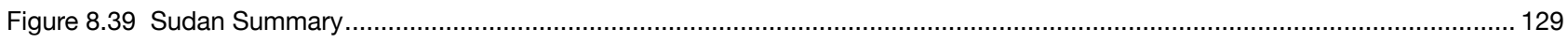

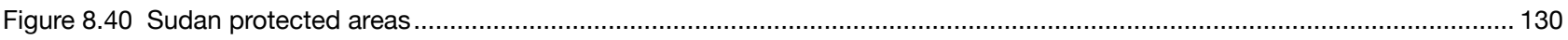

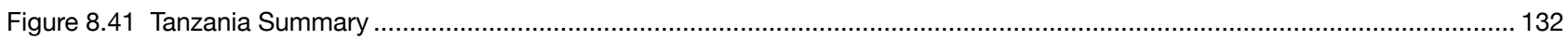

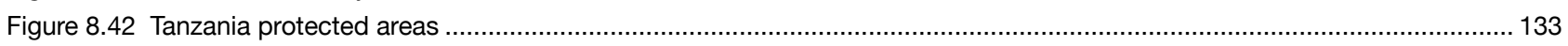

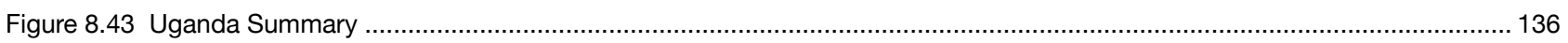

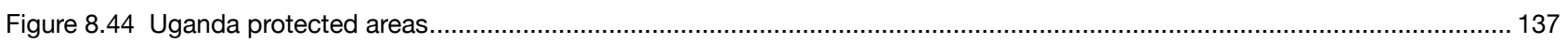

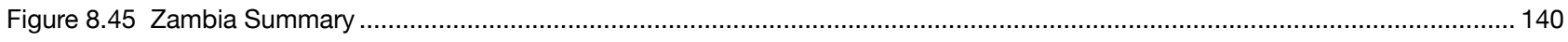

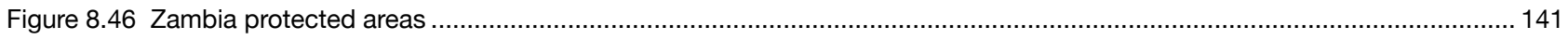

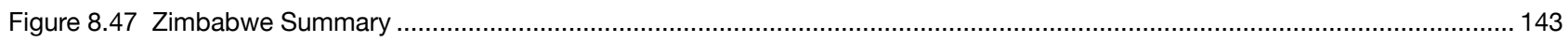

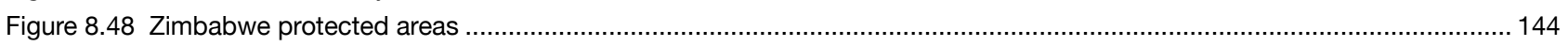

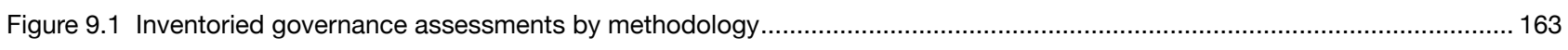

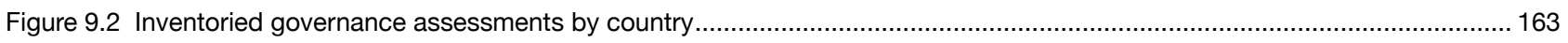

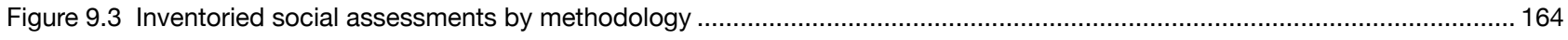

Figure 9.4 Total number of inventoried social assessments by country .............................................................................. 164

Figure 10.1 The management cycle and evaluation of protected area management ........................................................................ 168

Figure 10.2 Percentage coverage of management effectiveness assessments per region ......................................................... 172

Figure 10.3 Number of protected areas with PAME assessments in GD-PAME for Eastern and Southern Africa .............................. 173

Figure 10.4 Percentage of protected area with PAME assessments in the GD-PAME ............................................................. 173

Figure 10.5 Inventoried PAME assessments in Eastern and Southern Africa by methodology/tool............................................... 173 


\section{List of figures (continued)}

Figure 10.6 Distribution of inventoried PAME assessments by country ............................................................................ 173

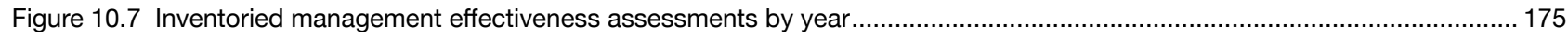

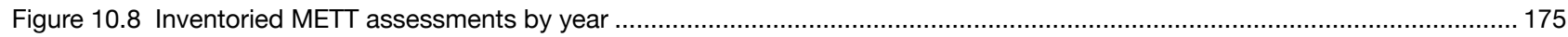

Figure 10.9 Inventoried 'combined' assessments by methodology/tool ............................................................................... 175

Figure 10.10 Management effectiveness results for assessed protected areas in East Africa ........................................................ 175

Figure 10.11 Map showing management effectiveness results for assessed protected areas in East Africa .................................... 176

Figure 10.12 Average scores for headline indicators from the most recent assessments .......................................................... 177

Figure 10.13 Funding gap and available financing resources in 15 countries in Eastern and Southern Africa ................................. 179

Figure 10.14 Breakdown of internally generated revenue in seven countries: Eswatini, Ethiopia, Kenya, Namibia,

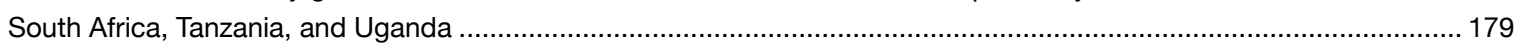

Figure 11.1 The magic quadrant for technology application in protected areas in Africa ........................................................... 191

\section{List of boxes}

Box 2.1 Namibia's communal conservancies

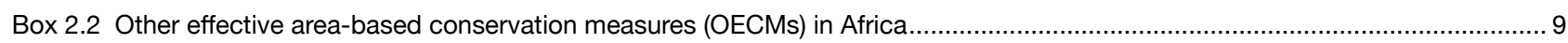

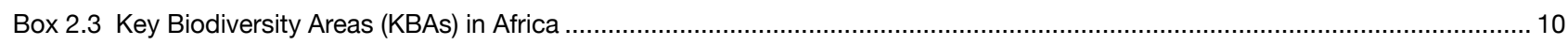

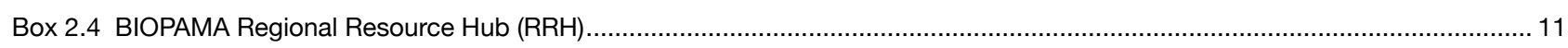

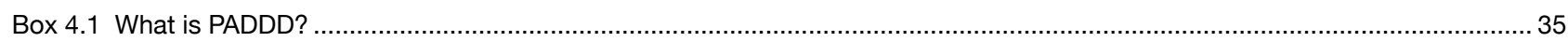

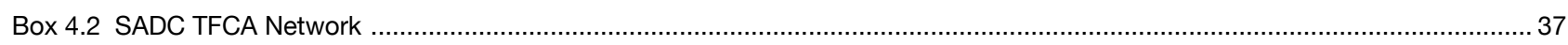

Box 7.3 Marine transboundary conservation between Kenya and Tanzania ......................................................................... 54

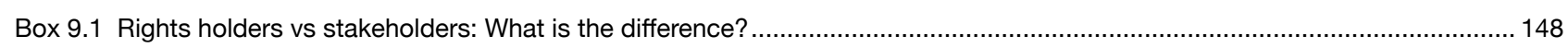

Box 9.2 Kick-starting marine conservation through local fisheries management .................................................................... 151

Box 9.3 Governance diversity in action: initiating locally-managed marine areas to combat fish decline in Kuruwitu,

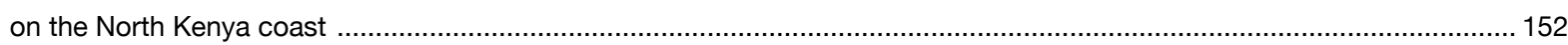

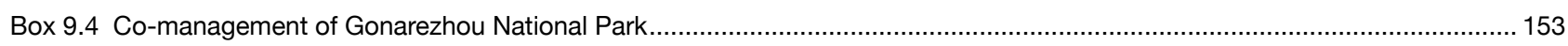

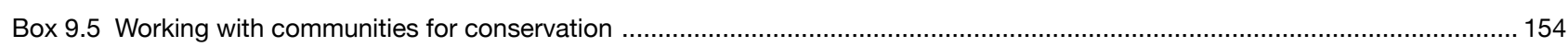

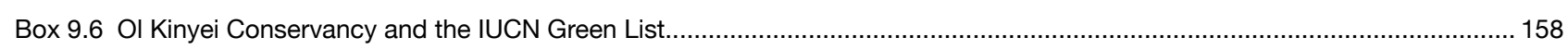

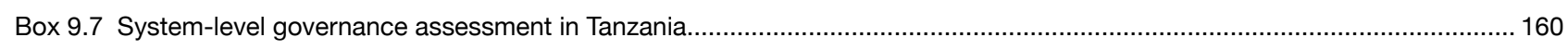

Box 9.8 Site-level governance assessment at Mumbwa GMA in Zambia ............................................................................. 161

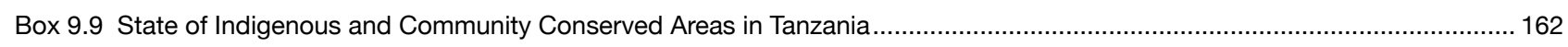

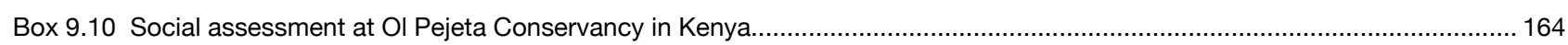

Box 10.1 Why report on protected area management effectiveness? ................................................................................ 169

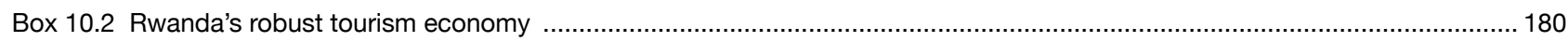

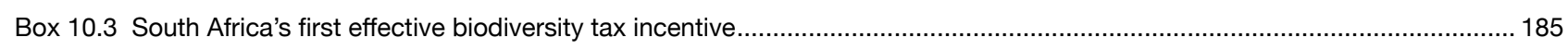

Box 10.4 Impact of COVID-19 pandemic on protected areas in Eastern and Southern Africa ........................................................ 185

Box 11.1 Building capacity to combat poaching: the case of the Southern African Wildlife College ............................................... 190

Box 11.2 EarthRanger: situational awareness to secure protected areas and reduce human-wildlife conflict .................................... 192

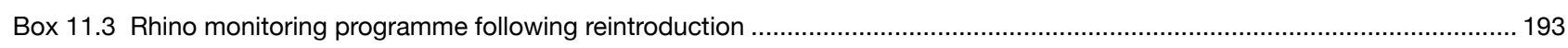

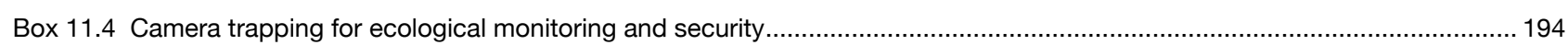

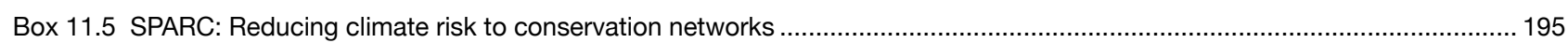




\section{List of tables}

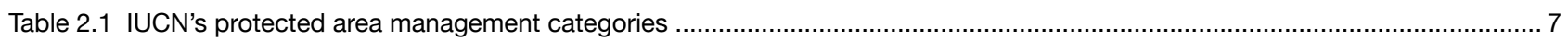

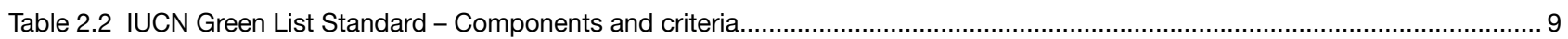

Table 2.3 Three most frequently reported threats in the Afrotropical biome .............................................................................. 14

Table 4.1 Global sites of importance in Eastern and Southern Africa........................................................................................ 25

Table 4.2 Annotated list of Eastern and Southern Africa natural and 'mixed' (natural/cultural) World Heritage Sites (as of 2019), including results of IUCN Conservation Outlook Assessment and dates of World Heritage Centre/IUCN monitoring missions.

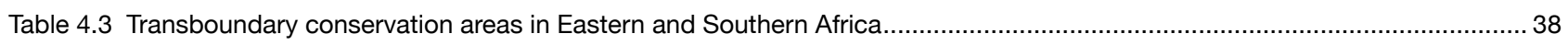

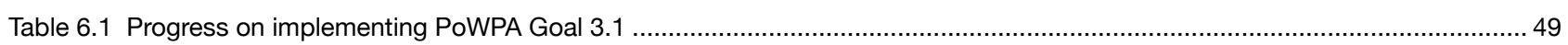

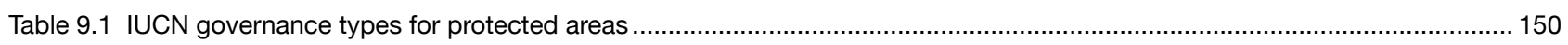

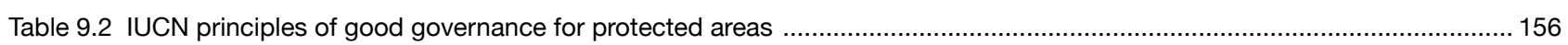

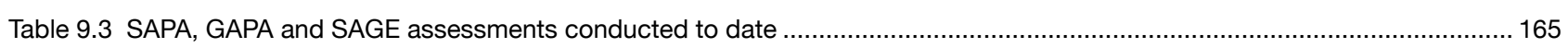

Table 10.1 PAME methodologies used most commonly in Eastern and Southern Africa................................................................ 170

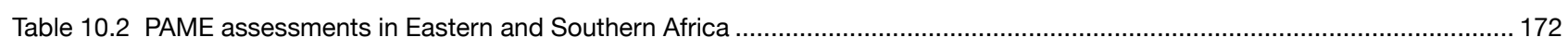

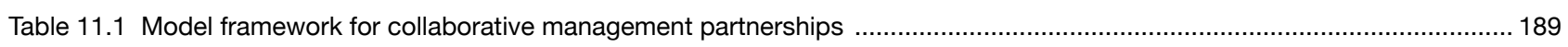

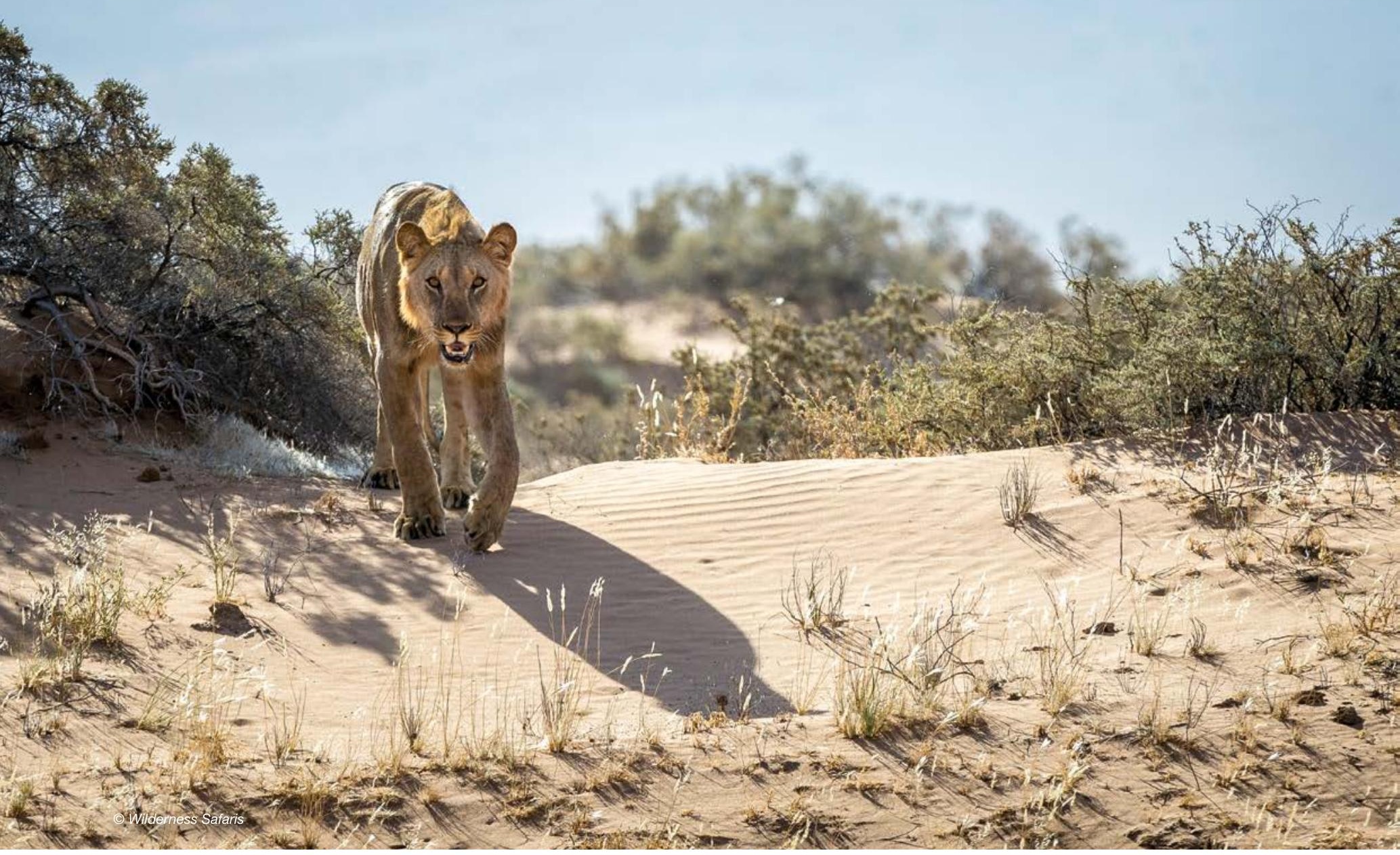




\section{Foreword}

The year 2020 marks a pivotal moment in nature conservation, as the world takes stock of progress on the Strategic Plan for Biodiversity 2011-2020 and negotiates the new post-2020 Global Biodiversity Framework. The publication of this valuable report is an important milestone on a journey that began in the Eastern and Southern Africa region at the Vth IUCN World Parks Congress held in Durban in 2003. At that meeting, the bold Durban Action Plan was crafted forming the basis of the world's first comprehensive multilateral agreement on protected areas. The Programme of Work on Protected Areas was subsequently adopted at the 7th Conference of the Parties to the Convention on Biological Diversity in Kuala Lumpur in 2004. Many of the objectives, principles, methods and actions adopted in that decision are the basis for this report. For example, it was in Durban that the full understanding of governance, equity and rights for protected and conserved areas was documented, and which is highlighted in this publication.

During the course of the Strategic Plan for Biodiversity 2011-2020, national governments and other stakeholders achieved much progress on the many essential elements of Aichi Target 11 on protected areas. A snapshot of these achievements has featured in the biennial Protected Planet Reports, based on the collation of information in the World Database of Protected Areas. This report documents this progress, and illustrates this with numerous case studies from Eastern and Southern Africa. It also demonstrates how systems of protected and conserved areas are an essential conservation strategy for the region, without which the loss of biodiversity would have been much more significant. It also highlights the many gaps in understanding and implementation, and shows us just how challenging it is to achieve effective outcomes for nature conservation.

The report emphasizes the underlying rationale for implementing effective systems of protected and conserved areas. As Nelson Mandela stated at the IUCN World Parks Congress in Durban "We know that the key to a sustainable future for protected areas lies in the development of partnerships. It is only through alliances and partnerships that protected areas can be made relevant to the needs of society". Understanding and documenting the relevance of protected and conserved areas to the needs of society is one of the main contributions of this report. The contemporary crisis of the COVID-19 pandemic throws this into sharp relief. Pandemics that are caused by transfer of pathogens from wildlife to human hosts are often the result of the degradation, fragmentation or disruption of the integrity of natural ecosystems, and increased movement and contact of humans with wildlife. Maintenance of ecosystem integrity, both within and beyond protected areas is therefore key, and efforts to manage ecosystems effectively, or to restore them, will be valuable investments to reduce the risk of zoonoses occurring and to maintain the livelihoods of communities.

Protected and conserved areas are an essential component of most nature conservation programmes, where both governance and management are required to maintain effective programmes that can identify and address threats that lead to ecosystem disruption. With increasing population pressure and consumption of natural resources, there are few places in the world where investment in effective governance and management is not required to address threats and maintain ecosystem integrity. Apart from protecting society against pandemics, natural ecosystems provide a huge range of benefits to society through the provision of clean and safe drinking water, food resources, carbon storage, health and well-being generally, and these all have a human and economic value. Often governments fail to invest in maintaining the essential ecosystems that generate this value. They think only of the relatively minor costs of managing protected areas, but place at risk the enormous contributions that intact ecosystems and protected areas make to the economy, including through dependent livelihoods. Without public funding, not only are the governance and management of these areas weakened, but their essential functions and services to society are compromised.

This State of Protected and Conserved Areas report makes a significant contribution to assessing the current status of the many factors that contribute to successful systems of protected and conserved areas. It examines the progress that has been achieved towards meeting national and global goals, and measures this against credible standards for effectiveness, such as the IUCN Green List of Protected and Conserved Area Standard, that sets the bar for what is meant by effective and equitable systems of protected and conserved areas. It also provides a diagnosis of what is missing, where the gaps are, and how to address these through targeted capacity development.

Taking stock of this situation has been made possible by the BIOPAMA Programme, an investment by the European Union and the Organisation of the African, Caribbean and Pacific States. The report therefore sets a valuable baseline against which further progress can be measured. It contributes to the Regional and Global Reference Information Systems, and the partnerships that will support better informed decision-making at national and global scales. It will help to target where intervention and investment is needed to enhance both governance and management, and to support the effectiveness of these systems as a foundation, not only for life on earth and life under water, but the essential human development goals fundamental to the future of our planet.

\section{Trevor Sandwith}

Director

IUCN Global Protected Areas Programme 


\section{Executive summary}

The Eastern and Southern Africa region covers 24 countries from South Africa in the south to Sudan in the north and four of the six Western Indian Ocean island nations. The region is culturally diverse and extremely rich in biodiversity, with an abundance of spectacular wildlife, and many endemic species of flora and fauna. Considerable efforts are being made to conserve the biodiversity of the region, but growing human populations, land use conflict, overexploitation of resources, unsustainable recreational activities, deforestation and illegal trade are threatening protected areas, species and ecosystems. To add to these challenges, the current COVID-19 pandemic has resulted in the shutdown of the tourism industry and therefore, a significant decrease in conservationrelated funding for the protected areas whose main revenue is tourism-based. The pandemic is exacerbating the gap in funding for protected areas and provides a harsh reminder of the need for revenue diversification.

The State of Protected and Conserved Areas in Eastern and Southern Africa is the first report that brings together information on protected and conserved areas ${ }^{1}$ for the whole Eastern and Southern Africa region. It is a baseline report, which presents currently available data and information. Where possible, novel analyses have been undertaken and case studies and text boxes have been included to add to the baseline information. The report is supplemented by a number of other analyses undertaken through the BIOPAMA programme, which are also available as separate publications. The report consists of twelve chapters, with the overall theme of the report being to focus on protected and conserved area governance, equity and management effectiveness.

The report includes a global overview of conservation and the related policies and programmes, as well as a regional analysis. As a region, Eastern and Southern Africa has $16.54 \%$ of the terrestrial area protected in 4,821 protected areas covering 2,120,112 $\mathrm{km}^{2}$. At least seven countries in the region have exceeded Aichi Target 11 $(17 \%)$ for terrestrial coverage. The region is halfway to meeting the coastal and marine coverage target (10\%) with $5.60 \%$ of the marine and coastal area protected in 411 protected areas covering 473,815 $\mathrm{km}^{2}$. Three countries in the region have exceeded Aichi Target 11 for marine and coastal protected area coverage.

Most protected areas in the region are governed by the relevant national government agency, although many countries in the region are increasingly including areas governed by communities and the private sector, including those managed under private public partnerships. The governance types for many protected areas have not yet been reported to the World Database of Protected Areas. Eastern and Southern Africa is home to 39 Man and Biosphere Reserves, 27 World Heritage Sites, and 109 Ramsar sites (Wetlands of International Importance). The region is also home to 30 transboundary conservation areas, ranging from conceptual designs to transfrontier conservation areas underpinned by full treaties. Southern Africa has a strong Transfrontier Conservation Area programme, where the first Transfrontier Conservation Area was declared in 1990 and from which lessons could be drawn for other parts of Africa.

The purpose of the Regional Economic Communities in the region is to facilitate regional economic integration between member states of the individual regions and through the wider African Economic Community. They also play an important role in terms of promoting transfrontier conservation in the region.

A summary of available data for each of the 24 countries covered in the report brings together information from the World Database on Protected Areas as well as country reports to the Convention on Biological Diversity. This information serves as a baseline of available information. It is intended in future reports to provide greater detail and analysis at the country level as this becomes available.

The report includes an introduction to the governance of protected areas, reviewing the work by IUCN and others to provide tools to assist countries in meeting the Aichi Target 11 requirements that protected areas be equitably governed. The available tools to assess governance diversity and quality at the system-level and at the site level are described and case studies from the region are presented. These tools include the IUCN Green List of Protected and Conserved Areas, which focuses on four components: good governance, sound design and planning; effective management and successful conservation outcomes. A report prepared through the BIOPAMA programme examined 380 governance assessments and 50 social assessments undertaken in Eastern and Southern Africa. It was found that although there is an increase in governance and social assessments, this is still limited across the region and very few repeat assessments are being conducted.

Assessment of protected area management effectiveness (PAME) also supports reporting on progress towards Aichi Target 11, reflecting the requirement for effective management. Approximately $13 \%$ of protected areas in the region have at least one reported PAME assessment. The analysis inventoried 2,686 management effectiveness assessments, most of which were Management Effectiveness Tracking Tool (METT) assessments. The new UNEPWCMC Global Database on Protected Area Management Effectiveness (GD-PAME) was used in the assessment, but there are still large gaps in the data, which need to be filled to allow for a true reflection of the number, location and timing of PAME assessments. Many countries, such as Madagascar and South Africa, have been conducting management effectiveness assessments for a number of years, including repeat assessments in many protected areas. The results from these assessments are being used to improve management at these sites.

There are many challenges in the region, and threats to conservation are growing, but country commitments to international agreements, targets and commitments to ensuring equitable governance and

1 "Conserved areas" currently has no widely accepted definition. It is used in this report following the fifth option outlined by Jonas and Sandwith (2019) as "areas sustaining ecological integrity and/or effective in situ conservation of biodiversity" 
effective management of protected and conserved areas can promote and ensure the conservation of species and ecosystems in the region. These commitments need to be backed up with the necessary political will and resource allocations to ensure full implementation for the benefit of protected and conserved areas. Accurate, current and comparable data to measure progress against targets and commitments is essential to support planning and resource allocation. This report hopes to provide the baseline for these data and to encourage improvements in data collection and reporting to ensure equitable and effective conservation in Eastern and Southern Africa.

\section{Acknowledgements}

Sincere thanks are due to the European Union and the Organisation of African, Caribbean and Pacific States for their financial support to the publication. The IUCN Editorial Board and Publications Committee is thanked for their support and guidance in preparing the document.

All BIOPAMA and State of Protected and Conserved Areas in Eastern and Southern Africa (SoPACA) focal points from the 24 countries featured in this report have provided invaluable input, as have the focal points from the Regional Economic Communities.

The core team involved in putting together this report included: Sue Snyman, Beryl Nyamgeroh, Christine Mentzel and Leo Niskanen (IUCN ESARO); Jessica Stewart (UNEP-WCMC); Bastian Bertzky and Lucy Bastin (JRC), Patrick Kabatha and Ngugi Kimani (RCMRD); and Diane Skinner and Eleanor Shadwell.

Important inputs for specific chapters were very welcome from: Jennifer Kelleher IUCN Global Protected Areas Programme; Phil Franks (International Institute of Environment and Development); Daniel Marnewick (BirdLife South Africa); Rachel Golden Kroner (Conservation International); Lily Arison Réné De Roland (The Peregrine Fund); Ashwell Glasson (Southern African Wildlife College); Drew Bantlin (African Parks); Candice Stevens (Wilderness
Foundation South Africa); Claudia Capitani; Jan Philipp Schägner and Andrew Cottam (JRC); Francois Barnard and Kathleen Fitzgerald (Conservation Capital); Caitlin Kelly (Spatial Planning for Area-Based Conservation in Response to Climate Change project); Ted Schmitt (Vulcan); Lisa Blanken (Deutsche Gesellschaft für Internationale Zusammenarbeit); Elsabé van der Westhuizen (Frankfurt Zoological Society); Stephen Nindi (Tanzania National Land Use Planning Commission); Arthur Tuda (Kenya Wildlife Service); Jessica Campese, Emmanuel Sulle and Yemeserach Tessema; Beatrice Chataigner (IUCN); Des Bowden (Kuruwitu Conservation and Welfare Association); and Rupert Quinan (Blue ventures).

IUCN, RCMRD, UNEP-WCMC, JRC, Peace Parks Foundation and Birdlife International are thanked for providing data underpinning the report.

Three peer reviewers - Peter Lindsey, Evans Mwangi and Andrew Parker - spent significant time and effort on reviewing the report, which has made the report much stronger. Finally, substantive editors Marc Hockings and Fiona Leverington, copy-editor Diwata Hunziker, and designer Mary-Anne van der Byl are thanked for their comprehensive and detailed work to ensure that the report is both accurate and visually appealing.

We also thank all the individuals and organizations who kindly provided photos for the report. 


\section{Glossary}

\begin{tabular}{|c|c|}
\hline Term & Meaning \\
\hline Adaptive management & $\begin{array}{l}\text { The cyclical process of systematically testing assumptions, generating learning by evaluating the } \\
\text { results of such testing, and further revising and improving management practices. The goal of } \\
\text { adaptive management in a protected area context is improved effectiveness and increased progress } \\
\text { towards the achievement of goals and objectives. }\end{array}$ \\
\hline Assessment & The measurement or estimation of an aspect of management. \\
\hline Baseline & $\begin{array}{l}\text { Information collected about a specific target (e.g. condition of a resource, knowledge, population of } \\
\text { a particular species, etc.) at the initial stages of a project, thereby providing a basis for measuring } \\
\text { progress or change over time. }\end{array}$ \\
\hline Biodiversity & $\begin{array}{l}\text { The variability among living organisms from all sources including, inter alia, terrestrial, marine and } \\
\text { other aquatic ecosystems and the ecological complexes of which they are part; this includes diversity } \\
\text { within species, between species and of ecosystems }\end{array}$ \\
\hline Biome & $\begin{array}{l}\text { A major portion of the living environment of a particular region characterised by its distinctive } \\
\text { vegetation and maintained largely by local climatic conditions. }\end{array}$ \\
\hline Biosphere reserve & $\begin{array}{l}\text { Area forming an international network of ecosystems recognised by UNESCO, and which promote } \\
\text { biodiversity, conservation and sustainable use, along with interdisciplinary approaches to } \\
\text { understanding and managing changes and interactions between social and ecological systems. }\end{array}$ \\
\hline Community & $\begin{array}{l}\text { A social group of any size whose members reside in a specific locality, share government and may } \\
\text { have a common cultural and historic heritage/s. It can also refer to a group of individuals who interact } \\
\text { within their immediate surroundings, exhibits cohesion and continuity through time, and displays } \\
\text { characteristics such as social interaction, intimacy, moral commitments, multi-faceted relations, and } \\
\text { reciprocity. }\end{array}$ \\
\hline Community Conserved Area & $\begin{array}{l}\text { Natural and modified ecosystems, including significant biodiversity, ecological services and cultural } \\
\text { values voluntarily conserved by Indigenous peoples and local and mobile communities through } \\
\text { customary laws or other effective means. }\end{array}$ \\
\hline Connectivity (biological) & $\begin{array}{l}\text { The degree to which local production results in recruitment to other populations. For any local } \\
\text { population, connectivity could be characterised by: (1) the proportion of recruitment into the local } \\
\text { population that is self-sustaining; (2) the proportional contributions of other populations to } \\
\text { recruitment into the local population, in a spatially explicit manner; and (3) the spatial distribution and } \\
\text { proportional representation of the contributions of local production to externally-based recruitment } \\
\text { of other populations. }\end{array}$ \\
\hline Conservation & $\begin{array}{l}\text { The maintenance or sustainable use of the Earth's resources in order to maintain ecosystem, species } \\
\text { and genetic diversity and the evolutionary and other processes which shape them. }\end{array}$ \\
\hline Conserved areas & $\begin{array}{l}\text { Conserved areas are defined as areas sustaining ecological integrity and/or effective in situ } \\
\text { conservation of biodiversity. }\end{array}$ \\
\hline Corridor & $\begin{array}{l}\text { Way to maintain vital ecological or environmental connectivity by maintaining physical linkages } \\
\text { between core areas. }\end{array}$ \\
\hline Data management & $\begin{array}{l}\text { The act, process, or means by which data is managed. This may include the compilation, storage, } \\
\text { safeguarding, listing, organisation, extraction, retrieval, manipulation and dissemination of data. }\end{array}$ \\
\hline Ecosystem & $\begin{array}{l}\text { A dynamic complex of plant, animal and micro-organism communities and their non-living } \\
\text { environment interacting as a functional unit. }\end{array}$ \\
\hline Ecosystem services & $\begin{array}{l}\text { The benefits people obtain from ecosystems. These include provisioning services such as food and } \\
\text { water; regulating services such as regulation of floods, drought, land degradation, and disease; } \\
\text { supporting services such as soil formation and nutrient cycling; and cultural services such as } \\
\text { recreational, spiritual, religious and other non-material benefits. }\end{array}$ \\
\hline
\end{tabular}




\begin{tabular}{|c|c|}
\hline Term & Meaning \\
\hline Ecotourism & $\begin{array}{l}\text { Responsible travel to natural areas that conserves the environment, sustains the well-being of the } \\
\text { local people and involves interpretation and education. }\end{array}$ \\
\hline Equity & $\begin{array}{l}\text { It seeks people's access to equal opportunities and the development of basic capacities; this means } \\
\text { that the barriers hindering economic and political opportunities, as well as access to education and } \\
\text { basic services, should be eliminated, so that the people (women and men of all ages, conditions and } \\
\text { positions) may be able to enjoy such opportunities and benefit from them. It means justice; that is, } \\
\text { giving each person or group what is rightfully theirs, recognising the specific conditions or } \\
\text { characteristics of each person or human group (sex, gender, class, religion, age). It is the recognition } \\
\text { of diversity, without giving reason for discrimination. }\end{array}$ \\
\hline Evaluation & $\begin{array}{l}\text { The judgement of the status/condition or performance of some aspect of management against } \\
\text { predetermined criteria (usually a set of standards or objectives); in this case including the objectives } \\
\text { for which the protected areas were established. }\end{array}$ \\
\hline Governance & $\begin{array}{l}\text { In the context of protected areas, governance has been defined as the interactions among structures, } \\
\text { processes and traditions that determine how power is exercised, how decisions are taken on issues } \\
\text { of public concern, and how citizens or other stakeholders have their say. Governance arrangements } \\
\text { are expressed through legal and policy frameworks, strategies, and management plans; they include } \\
\text { the organizational arrangements for following up on policies and plans and monitoring performance. } \\
\text { Governance covers the rules of decision making, including who gets access to information and } \\
\text { participates in the decision-making process, as well as the decisions themselves. }\end{array}$ \\
\hline Governance authority & $\begin{array}{l}\text { The institution, individual, Indigenous peoples or communal group or other body acknowledged as } \\
\text { having authority and responsibility for decision making and management of an area. }\end{array}$ \\
\hline Governance quality & $\begin{array}{l}\text { How well a protected area is being governed - the extent to which it is responding to the principles } \\
\text { and criteria of "good governance" identified and chosen by the relevant peoples, communities and } \\
\text { governments (part of their sense of morality, cultural identity and pride) and generally linked to the } \\
\text { principles espoused by international agencies and conventions. }\end{array}$ \\
\hline Governance types & $\begin{array}{l}\text { The four main governance types for protected areas are (i) government-governed, (ii) shared } \\
\text { governance, (iii) privately governed (including NGO-run), and (iv) areas and territories governed by } \\
\text { Indigenous Peoples and local communities. In each type, it is possible that responsibility for tourism } \\
\text { or some other aspect of management is delegated to another governing authority, or contracted to } \\
\text { private operators. }\end{array}$ \\
\hline Habitat & The place or type of site where an organism or population naturally occurs. (CBD Article 2). \\
\hline $\begin{array}{l}\text { Indigenous peoples and local } \\
\text { communities }\end{array}$ & $\begin{array}{l}\text { This Report follows the Convention on Biological Diversity's uses of the terms "Indigenous peoples" } \\
\text { and "local communities". }\end{array}$ \\
\hline $\begin{array}{l}\text { Indigenous peoples' and } \\
\text { community conserved } \\
\text { territories and areas (ICCAs) }\end{array}$ & $\begin{array}{l}\text { Indigenous peoples' and community conserved territories and areas are natural and/or modified } \\
\text { ecosystems containing significant biodiversity values, ecological services and cultural values, } \\
\text { voluntarily conserved by Indigenous peoples and local communities, both sedentary and mobile, } \\
\text { through customary laws or other effective means. } \\
\text { Areas conserved by Indigenous peoples and local communities could potentially be recognised as } \\
\text { protected or conserved areas, subject to their "prior informed consent" or "free prior informed } \\
\text { consent" or "approval and involvement" or request, according to the national circumstances. }\end{array}$ \\
\hline Invasive species & $\begin{array}{l}\text { An introduced organism (plant, animal, fungus or bacterium) that out-competes native species for } \\
\text { space and resources, causing ecological and/or economic harm. Not all introduced species are } \\
\text { invasive, and when used more broadly the definition can include native species that heavily colonise } \\
\text { and degrade a particular habitat. }\end{array}$ \\
\hline
\end{tabular}

2 https://www.cbd.int/doc/meetings/tk/aheg-lcr-01/official/aheg-lcr-01-02-en.pdf 


\begin{tabular}{|c|c|}
\hline Term & Meaning \\
\hline $\begin{array}{l}\text { Locally Managed Marine } \\
\text { Areas }\end{array}$ & $\begin{array}{l}\text { An area of near-shore waters and its associated coastal and marine resources that is largely or } \\
\text { wholly managed at a local level by the coastal communities, land-owning groups, partner } \\
\text { organisations and/or collaborative government representatives who reside or are based in the } \\
\text { immediate area. }\end{array}$ \\
\hline Management effectiveness & $\begin{array}{l}\text { How well a protected area is being managed - primarily the extent to which it is protecting values } \\
\text { and achieving goals and objectives. }\end{array}$ \\
\hline Monitoring & $\begin{array}{l}\text { Collecting information on indicators repeatedly over time to discover trends in the status of the } \\
\text { protected area or its components, community attributes and the activities and processes of } \\
\text { management. }\end{array}$ \\
\hline $\begin{array}{l}\text { National Biodiversity } \\
\text { Strategies and Action Plans }\end{array}$ & $\begin{array}{l}\text { The principal instruments for implementing the CBD at the national level, NBSAPs lay out each } \\
\text { Contracting Party's commitment to the conservation and sustainable use of biological diversity and } \\
\text { to including that commitment across all sectors of the national economy and policy-making } \\
\text { framework. }\end{array}$ \\
\hline Nature conservation & $\begin{array}{l}\text { In this context nature always refers to biodiversity, at genetic, species and ecosystem-level, and } \\
\text { often also refers to geodiversity, landform and broader natural values. In the context of protected } \\
\text { areas, conservation refers to the in situ maintenance of ecosystems and natural and semi-natural } \\
\text { habitats and of viable populations of species in their natural surroundings and, in the case of } \\
\text { domesticated or cultivated species, in the surroundings where they have developed their distinctive } \\
\text { properties. }\end{array}$ \\
\hline Nature-based tourism & $\begin{array}{l}\text { Forms of tourism that use natural resources in a wild or undeveloped form. Nature-based tourism is } \\
\text { travel for the purpose of enjoying undeveloped natural areas or wildlife. }\end{array}$ \\
\hline Protected area & $\begin{array}{l}\text { The CBD defines a protected area as: "A geographically defined area which is designated or } \\
\text { regulated and managed to achieve specific conservation objectives" (CBD Article 2). IUCN has a } \\
\text { more detailed definition: "A clearly defined geographical space, recognised, dedicated and managed, } \\
\text { through legal or other effective means, to achieve the long-term conservation of nature with } \\
\text { associated ecosystem services and cultural values" (Dudley, 2008). The CBD and IUCN recognise } \\
\text { the two as being equivalent in practice as in both cases these areas are intended to achieve in situ } \\
\text { conservation. }\end{array}$ \\
\hline Protected area categories & $\begin{array}{l}\text { A set of six classes, devised by IUCN, into which a protected area can be grouped according to its } \\
\text { primary overall management objectives. Some protected areas, however, are divided into zones, } \\
\text { each of which may have a different management objective that serves the overall primary objective. }\end{array}$ \\
\hline Protected area manager & $\begin{array}{l}\text { A professional or other stakeholder working in protected areas. The term includes administrators, } \\
\text { managers and planners who may work for and with government agencies, non-governmental } \\
\text { organisations, local community groups, private landowners, or other entities. }\end{array}$ \\
\hline Ramsar Sites & $\begin{array}{l}\text { An international system of protected wetlands recognised as globally important under the Ramsar } \\
\text { Convention. (Ramsar is the name of a city in Iran where the convention was adopted.) }\end{array}$ \\
\hline Rights holders & $\begin{array}{l}\text { People who are socially endowed with legal or customary rights with respect to land, water and } \\
\text { natural resources }\end{array}$ \\
\hline Species & $\begin{array}{l}\text { A group of organisms differing from other groups of organisms and that can breed and produce } \\
\text { fertile offspring. }\end{array}$ \\
\hline Species richness & The number of different species that exist within a given area or community. \\
\hline Stakeholders & $\begin{array}{l}\text { Persons or organisations possessing direct or indirect interests and concerns with respect to land, } \\
\text { water, and natural resources, but who do not necessarily enjoy a legally or socially recognised } \\
\text { entitlement to them. }\end{array}$ \\
\hline Sustainability & $\begin{array}{l}\text { For protected areas, the condition of its persisting for a long time with core natural and cultural } \\
\text { values intact, though not necessarily entirely unchanged. }\end{array}$ \\
\hline
\end{tabular}




\begin{tabular}{l|l}
\hline Term & Meaning \\
\hline Sustainable development & $\begin{array}{l}\text { Development that meets the needs of the present without compromising the ability of future } \\
\text { generations to meet their own needs }\end{array}$ \\
\hline Sustainable use & $\begin{array}{l}\text { The use of components of biological diversity in a way and at a rate that does not lead to the long- } \\
\text { term decline of biological diversity, thereby maintaining its potential to meet the needs and aspirations } \\
\text { of present and future generations. }\end{array}$ \\
\hline Tourism & $\begin{array}{l}\text { The activities of persons travelling to and staying in places outside their usual environment for not } \\
\text { more than one consecutive year for leisure, business and other purposes. }\end{array}$ \\
\hline World Heritage Sites & $\begin{array}{l}\text { An international system of protected areas, created under the World Heritage Convention, which is } \\
\text { intended to include the world's most outstanding examples of natural and cultural heritage. }\end{array}$ \\
\hline
\end{tabular}

\section{Acronyms}

\begin{tabular}{|c|c|}
\hline AZE & Alliance for Zero Extinction \\
\hline BIOFIN & UNDP Biodiversity Finance Initiative \\
\hline BIOPAMA & $\begin{array}{l}\text { Biodiversity and Protected Areas Management } \\
\text { Programme }\end{array}$ \\
\hline CBD & Convention on Biological Diversity \\
\hline DOPA & Digital Observatory for Protected Areas \\
\hline EAC & East African Community \\
\hline EC & European Commission \\
\hline ESARO & Eastern and Southern Africa Regional Office \\
\hline GAPA & $\begin{array}{l}\text { Governance Assessment for Protected and } \\
\text { Conserved Areas }\end{array}$ \\
\hline GD-PAME & $\begin{array}{l}\text { Global Database on Protected Area Management } \\
\text { Effectiveness }\end{array}$ \\
\hline GDP & Gross Domestic Product \\
\hline GMA & Game Management Area \\
\hline IBA & Important Bird \& Biodiversity Area \\
\hline ICCA & Indigenous and Community Conserved Areas \\
\hline IGAD & Intergovernmental Authority for Development \\
\hline IIED & $\begin{array}{l}\text { International Institute for Environment and } \\
\text { Development }\end{array}$ \\
\hline IMET & Integrated Management Effectiveness Tool \\
\hline IOC & Indian Ocean Commission \\
\hline IUCN & International Union for Conservation of Nature \\
\hline JRC & $\begin{array}{l}\text { Joint Research Centre of the European } \\
\text { Commission }\end{array}$ \\
\hline KBA & Key Biodiversity Area \\
\hline METT & Management Effectiveness Tracking Tool \\
\hline MPA & Marine Protected Area \\
\hline NBSAP & National Biodiversity Strategy and Action Plan \\
\hline OECD & $\begin{array}{l}\text { Organisation for Economic Cooperation and } \\
\text { Development }\end{array}$ \\
\hline OECM & $\begin{array}{l}\text { Other Effective Area-based Conservation } \\
\text { Measures }\end{array}$ \\
\hline PADDD & $\begin{array}{l}\text { Protected Area Downgrading, Downsizing and } \\
\text { Degazettement }\end{array}$ \\
\hline PAGE & Protected Area Governance and Equity \\
\hline PAME & Protected Area Management Effectiveness \\
\hline PoWPA & Programme of Work on Protected Areas \\
\hline RAPPAM & $\begin{array}{l}\text { Rapid Assessment and Prioritisation of Protected } \\
\text { Area Management }\end{array}$ \\
\hline
\end{tabular}

RCMRD Regional Centre for Mapping of Resources for Development

REC Regional Economic Community

RRH Regional Resource Hub

RRIS Regional Reference Information System

SADC Southern African Development Community

SAGE Site-level assessment of governance and equity

SAPA Social Assessment of Protected and Conserved Areas

SDG Sustainable Development Goals

SMART Spatial Monitoring and Reporting Tool

SoPACA The State of Protected and Conserved Areas in

Eastern and Southern Africa Report

TFCA Transfrontier Conservation Area

TWIX Trade in Wildlife Information Exchange System

UNDP United Nations Development Programme

UNEP-WCMC United Nations Environment Programme World Conservation Monitoring Centre

UNESCO United Nations Educational, Scientific and Cultural Organization

WD-OECM World Database on Other Effective Area-based Conservation Measures

WCMC World Conservation Monitoring Centre

WCPA IUCN World Commission on Protected Areas

WDPA World Database on Protected Areas 


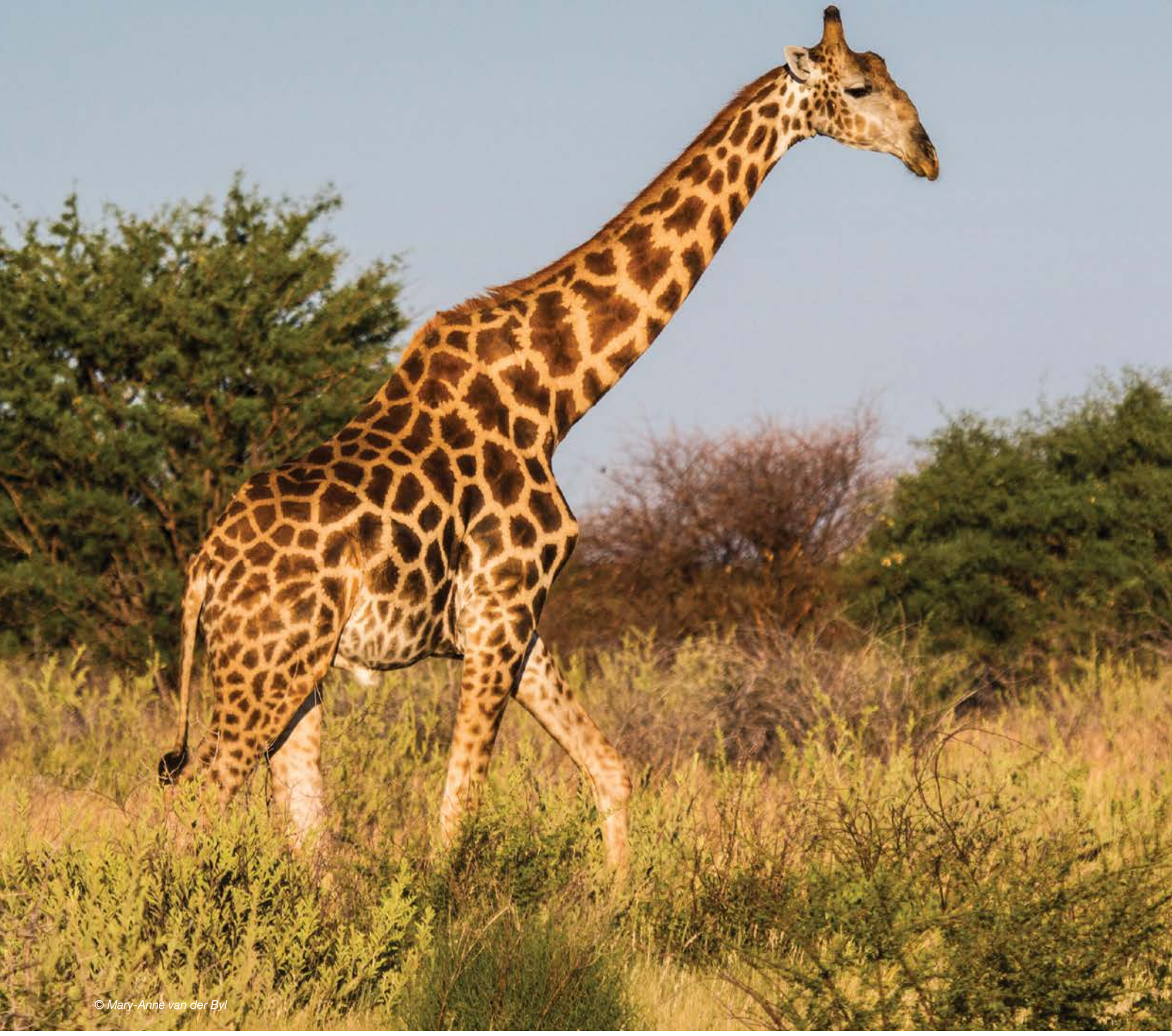


Part I - Setting the stage

\section{Introduction}


The Eastern and Southern African region is one of the world's most biodiversity-rich areas consisting of a number of diverse protected and conserved areas managed by a wide range of stakeholders governments, nongovernmental organisations (NGOs), local communities, the private sector and partnerships among these entities. The region has high levels of poverty and unemployment and, for this reason, governments tend to focus on socio-economic development, increasing employment and reducing poverty. In particular, a focus on the agricultural and mining sector, as well as major infrastructural developments, can result in land use conflicts and low investment in, and financing of, protected and conserved areas.

However, healthy ecosystems can reduce socio-economic vulnerability by supporting well-being, and the environmental knowledge held by Indigenous people can lead to the discovery of new species and populations and can enhance our understanding of status and trends of species and ecosystems, particularly those that contribute to human livelihoods and well-being. Effectiveness of protected areas is poor in many areas in the region due to a combination of factors, such as climate change, overexploitation (bushmeat poaching, logging, livestock herding), civil conflicts, and encroachment from local populations to sustain their livelihoods, and inadequate park design, financing and administration (EC, 2015).

Freshwater biodiversity in Africa is under severe pressure with the majority of threatened species found in areas with high levels of development and demand on water resources, such as southern and eastern South Africa and in the great lakes in eastern Africa. Much of Africa's marine and coastal biodiversity is also threatened. The wide continental shelf along the northwest coast of Africa, mangrove forests of West and Eastern Africa and adjacent islands, provide diverse habitats that support high levels of biodiversity of fish and invertebrate species. Terrestrial biodiversity is also threatened by, amongst other things, mining, poaching, illegal wildlife trade, loss of habitat, alien vegetation and increasing human populations and the resultant land-use conflicts (EC, 2015). From this perspective, an understanding of the state of protected and conserved areas in the region is important to provide a baseline against which the progress of conservation targets to which governments have committed can be measured.

The report covers the following countries in Eastern and Southern Africa: Angola, Botswana, Comoros, Djibouti, Eritrea, Eswatini, Ethiopia, Kenya, Lesotho, Madagascar, Malawi, Mauritius, Mozambique, Namibia, Rwanda, Seychelles, Somalia, South Africa, South Sudan, Sudan, Tanzania, Uganda, Zambia, and Zimbabwe (see Figure 1.1).

\subsection{Objectives}

As the first comprehensive regional assessment of protected and conserved areas for Eastern and Southern Africa, the State of Protected and Conserved Areas in Eastern and Southern Africa (SoPACA) report aims to:

- Provide an overview of the status of protected and conserved areas in the Eastern and Southern Africa region, with special reference to Protected Area Governance and Equity (PAGE) and Protected Area Management Effectiveness (PAME), and the related assessment tools;

- Use available data to provide an overview of the region's progress towards Aichi Biodiversity Target 11 of the Convention on Biological Diversity (CBD), as well as other relevant global and regional targets;

- Analyse and highlight protected and conserved area issues of particular relevance to the region, through the use of case studies;

- Articulate and deepen understanding of successes and key challenges for protected and conserved areas that the region is facing;

- Provide facts and figures required by governments to make informed decisions, track progress and provide guidance for implementation of Aichi Target 11 and other global and regional targets;

- Raise the profile of the value of regional data management systems, including the BIOPAMA-supported Regional Resource Hub;

- Promote the learning of lessons between the countries and regions of Eastern and Southern Africa;

- Explore issues related to the financing of protected and conserved areas and how this affects PAGE and PAME; and

- Provide key recommendations for policy and practice.

Many institutions and individuals could make use of the report. These include governments throughout Eastern and Southern Africa, as well as partner and donor governments, communitybased organisations and associations, Regional Economic Communities, private sector companies, support organisations, and academic institutions and researchers.

The report has a number of potential uses:

- To provide a baseline against which progress can be tracked for national, regional and international targets;

- To provide data for better informed decisions;

- To highlight innovations and potential pathways towards sustainable management of protected areas in the region;

- To demonstrate gaps in knowledge and information, as well as potential research needs and opportunities;

- To identify priorities for further and future action;

- To influence policy through a knowledge-based approach; and

- To provide detailed information for better donor decisions through providing a summary of key regional priorities.

\subsection{Methodology}

The report was developed in partnership with the country governments through their appointed BIOPAMA focal points (see Appendix 1). Planning workshops for the report were held with BIOPAMA country focal points and other relevant organisations in Nairobi (13-14 February 2019) and Johannesburg (26-27 February 2019).

Throughout the development of the report, the team made every effort to consider existing national and regional reports, including National Biodiversity Strategies and Action Plans (NBSAP) and 
Figure 1.1 Map of countries included in this report

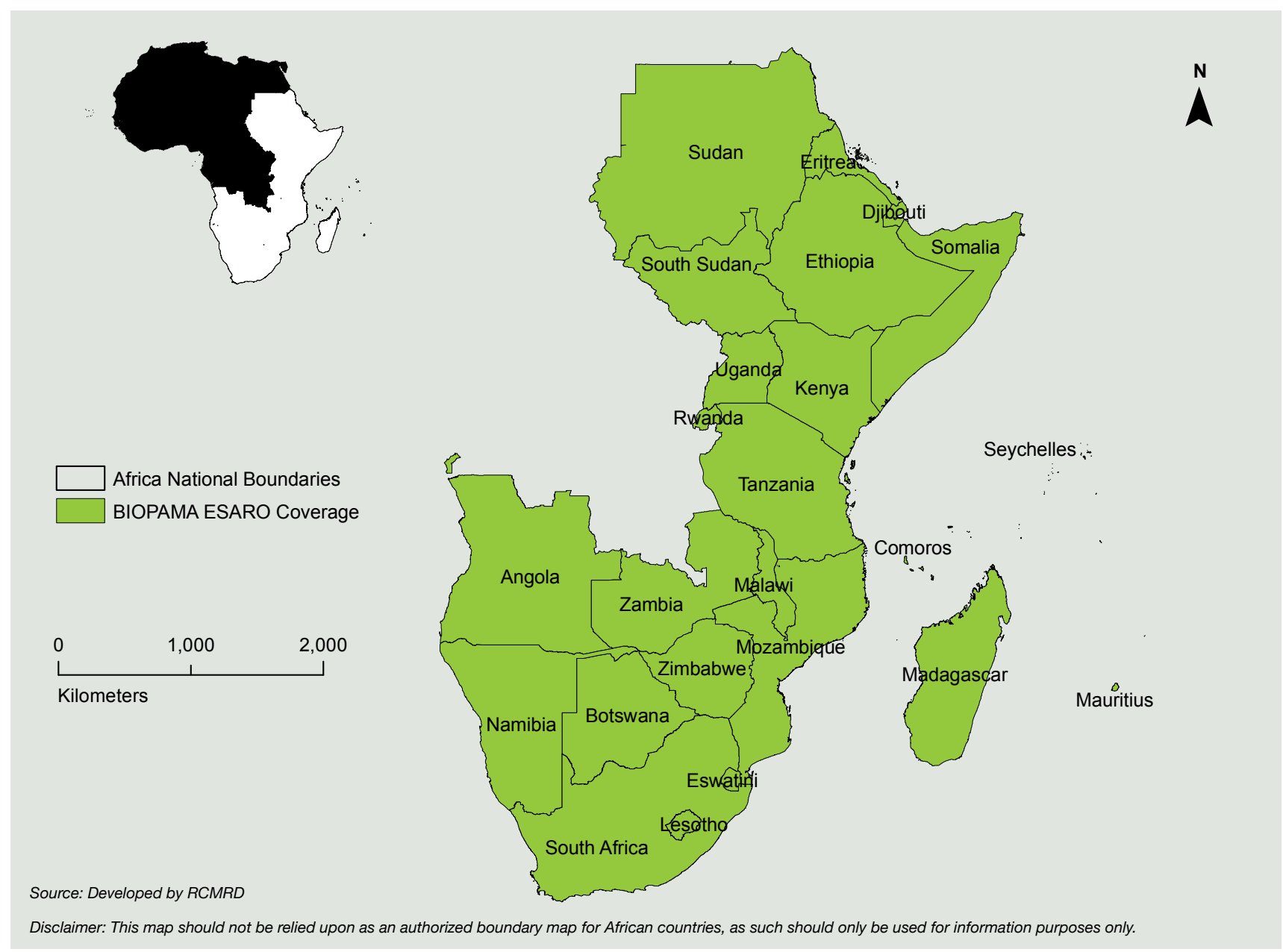

National Reports to the CBD. BIOPAMA national focal points and other relevant national, regional and global experts were contacted throughout the development process to review data, information and narratives to ensure that the latest and most accurate information was included in the report.

\subsection{Structure}

The report and case studies will focus on major themes that affect management and governance of protected and conserved areas in the Eastern and Southern Africa region.

Part I sets the scene and outlines the conceptual and international framework.

Part II provides the regional context, data and country profiles with Chapter 3 providing a regional context, detailing regional policies and statistics, while Chapter 4 focuses on a regional overview of the protected area estate and Chapter 5 on ecosystem services. Chapter 6 (regional policies) and Chapter 7 (regional economic communities) provide a regional context for the national statistics and information for all 24 countries covered in this report that is outlined in Chapter 8.
Part III reviews governance, management effectiveness and innovation. Chapter 9 looks specifically at governance and equity, and includes information on both system- and site-level governance, stakeholder engagement and related assessment tools, while Chapter 10 focuses on management effectiveness and the related assessment tools, and Chapter 11 provides insights into regional innovations and experiences, protected area financing, using technology in conservation management and transboundary conservation.

Part IV includes recommendations for policy and practice based on the findings in the report. 


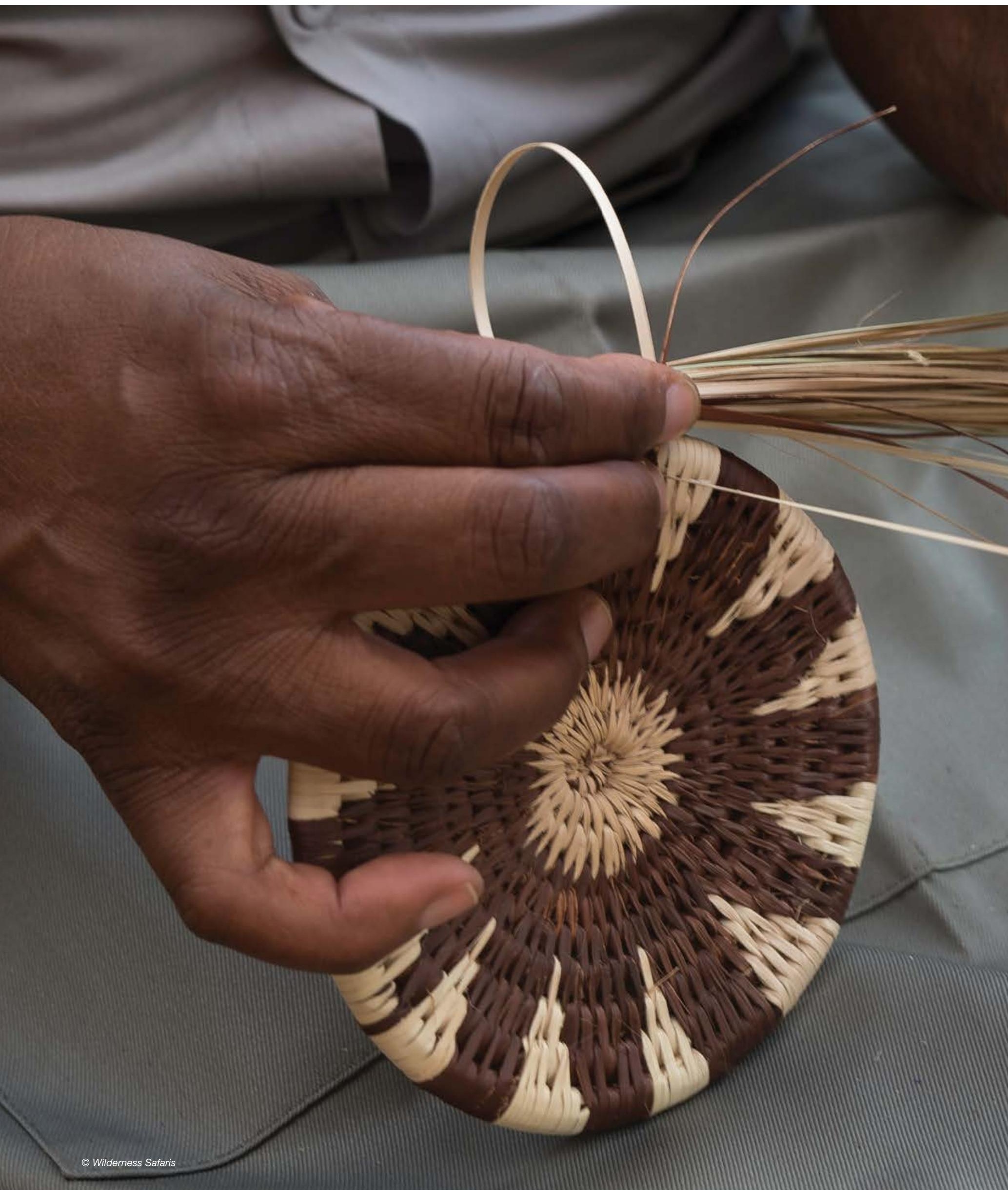




\section{Conceptual and international framework}




\subsection{What are protected and conserved areas}

Protected areas are essential for biodiversity conservation, underpinning most national and regional conservation strategies. Next to their role in maintaining natural ecosystems and conserve species, many contain major features of the Earth's history and processes, while others conserve the interplay between human activity and nature in sustainable use landscapes. Larger and more natural protected areas also provide space for evolution and future ecological adaptation and restoration: both increasingly important under conditions of rapid climate change (UNEP-WCMC et al., 2018).

Protected areas are vital to the cultures and livelihoods of Indigenous peoples and local communities, conserving places of cultural and sacred value. They provide recreation and renewal, deliver clean air and water, and bring benefits to millions of people through tourism (UNEP-WCMC \& IUCN, 2016).

The commonly accepted definition of a protected area, which will be used in this report, is "a clearly defined geographical space, recognised, dedicated and managed, through legal or other effective means, to achieve the long-term conservation of nature with associated ecosystem services and cultural values" (Dudley, 2008, p. 8)

IUCN has developed a set of generalised protected area management categories to assist in the development and understanding of protected area systems across different national contexts and legal systems (Dudley, 2008). Each country in the region has its own suite of protected area types defined in legislation and policy, such as national parks, national reserves and forest reserves. These definitions usually vary from country to country. They can, however, usually be matched to the IUCN categories, although there is not always an 'exact' match and often not all categories are represented in a particular country or region. The full range of categories I - VI (see Table 2.1) allows for protected area systems to include those where human activities are strictly limited, as well as those where sustainable activities are allowed.

The different IUCN protected area management categories and examples in the region are described in Table 2.1. In Eastern and Southern Africa, there has been a change over time from a focus on Category II (national parks) to the use of a broader range of categories, although there are still limited numbers of Categories la and $\mathrm{lb}$ protected areas. It is therefore important to note that two or more categories may overlap.

The protected area management categories are frequently used for purposes well beyond their original intentions, such as the planning of protected areas and protected area systems, improving information management about protected areas, regulating activities in protected areas, providing the basis for legislation and as a tool for advocacy. The main uses have developed in such a way that IUCN supports and encourages some, while opposing others (Dudley, 2008, pp. 5-6).

Any protected area category can be governed and managed by communities, governments, provide bodies or partnerships of these actors. Traditionally, protected areas in the region were set up by governments, but over the last $40-50$ years many protected and conserved areas have been established by local communities, Indigenous peoples, environmental charities, private individuals, companies and others. Community-based conservation has become more prevalent and in some countries such as Namibia and Kenya, legislation grants communities the right to manage and benefit directly from these conservancies (see Box 2.1). Endowed with numerous iconic national parks and reserves (such as Masa

\section{Box 2.1 Namibia's communal conservancies}

In Namibia, community-based natural resource management (CBNRM) allows communities to integrate new land-use options with existing livelihood strategies (e.g. livestock farming) in order to help conserve wildlife and improve the welfare of rural households (Long, 2002). There are currently 86 communal conservancies, covering a total area of 166,045 $\mathrm{km}^{2}$ (approximately $20.2 \%$ of the country) incorporating around 227,941 people (NACSO, n.d.). The relative success of CBNRM in Namibia has largely been due to an enabling policy and legislative environment, which devolves authority directly to the community level. This contrasts with Zimbabwe's Communal Areas Management Programme for Indigenous Resources (CAMPFIRE), which devolves authority to already established district councils and not directly to the community level. This approach was successful in the 1990s in Zimbabwe mainly due to substantial donor support, but has subsequently disappeared owing to the political and economic situation in the country (Snyman, 2012).

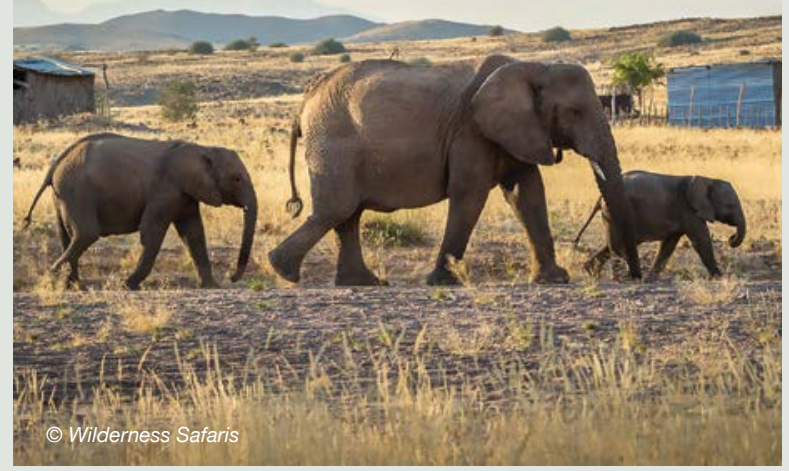


Table 2.1 IUCN's protected area management categories

\begin{tabular}{|c|c|c|}
\hline Category & Description & Examples \\
\hline $\begin{array}{l}\text { la - Strict Nature } \\
\text { Reserve }\end{array}$ & $\begin{array}{l}\text { Strictly protected areas which are set aside to protect } \\
\text { biodiversity and also possibly geological/geomorphical } \\
\text { features, where human visitation, use and impacts are } \\
\text { strictly controlled and limited to ensure protection of the } \\
\text { conservation values. There are few examples of this } \\
\text { category in the region, though some national parks will } \\
\text { have restricted areas within them, rather than being fully } \\
\text { categorised as Category la. }\end{array}$ & $\begin{array}{l}\text { Tsingy de Bermaraha, Tsaratanana and Betampona } \\
\text { (Madagascar) } \\
\text { Aldabra Atoll, Cousin, La Digue and Aride } \\
\text { (Seychelles) }\end{array}$ \\
\hline $\begin{array}{l}\text { lb - Wilderness } \\
\text { Area }\end{array}$ & $\begin{array}{l}\text { Protected areas which are usually large unmodified or } \\
\text { slightly modified areas, retaining their natural character and } \\
\text { influence without permanent or significant human } \\
\text { habitation, which are protected and managed to preserve } \\
\text { their natural condition. }\end{array}$ & $\begin{array}{l}\text { Moremi, Khutse and Central Kalahari Game } \\
\text { Reserves (Botswana) } \\
\text { Koko Hill, Mamboya and lkwamba Forest Reserves } \\
\text { (Tanzania) }\end{array}$ \\
\hline II - National Park & $\begin{array}{l}\text { Large natural or near natural areas set aside to protect } \\
\text { large-scale ecological processes, along with the } \\
\text { complement of species and ecosystems characteristic of } \\
\text { thearea, which also providea foundation for environmentally } \\
\text { and culturally compatible, spiritual, scientific, educational, } \\
\text { recreational, and visitor opportunities. This is the most } \\
\text { common management category in the region. }\end{array}$ & $\begin{array}{l}\text { Parc Marin de Mohéli (Comoros) } \\
\text { Amboseli and Masai Mara (National Reserve) } \\
\text { (Kenya) } \\
\text { Niassa (National Reserve) (Mozambique) } \\
\text { Volcans (Rwanda) } \\
\text { Kruger (South Africa) } \\
\text { Serengeti (Tanzania) } \\
\text { Bwindi Impenetrable (Uganda) } \\
\text { Kafue (Zambia) }\end{array}$ \\
\hline $\begin{array}{l}\text { III - Natural } \\
\text { Monument or } \\
\text { Feature }\end{array}$ & $\begin{array}{l}\text { Protected areas set aside to protect a specific natural } \\
\text { monument, which can be a landform, sea mount, submarine } \\
\text { cavern, or a geological feature such as a cave or even a } \\
\text { living feature such as an ancient grove. }\end{array}$ & $\begin{array}{l}\text { Victoria Falls National Park (Zimbabwe) } \\
\text { Popa Game Park and Gross Barmen Hot Springs } \\
\text { (Namibia) } \\
\text { Toro-Semliki, Karuma, Bugungu and a number of } \\
\text { other wildlife reserves (Uganda) }\end{array}$ \\
\hline $\begin{array}{l}\text { IV - Habitat/ } \\
\text { Species } \\
\text { Management Area }\end{array}$ & $\begin{array}{l}\text { The aim is to protect particular species or habitats and } \\
\text { management reflects this priority. }\end{array}$ & $\begin{array}{l}\text { Partial Reserve Namibe (Angola) } \\
\text { Maun Game Sanctuary (Botswana) } \\
\text { Gash-Setit Wildlife Reserve (Eritrea) } \\
\text { Alledeghi and Bale Wildlife Reserves (Ethiopia) } \\
\text { Sehlabathebe National Park (Lesotho) } \\
\text { Majete and Nkhotakota Wildlife Reserves (Malawi) } \\
\text { Poudre d'Or and Trou d'Eau Douce Fishing } \\
\text { Reserves (Mauritius) } \\
\text { Sabaloka Game Reserve (Sudan) }\end{array}$ \\
\hline $\begin{array}{l}\text { V - Protected } \\
\text { Landscape/ } \\
\text { Seascape }\end{array}$ & $\begin{array}{l}\text { Protected areas where the interaction of people and nature } \\
\text { over time has produced an area of distinct character with } \\
\text { significant, ecological, biological, cultural and scenic value, } \\
\text { and where safeguarding the integrity of this interaction is } \\
\text { vital to protecting and sustaining the area and its associated } \\
\text { nature conservation and other values. }\end{array}$ & $\begin{array}{l}\text { Iles Musha and Maskhali (Djibouti) } \\
\text { Libhetse Nature Reserve (Eswatini) } \\
\text { numerous areas in Madagascar } \\
\text { Imatong Forest Reserve (South Sudan) }\end{array}$ \\
\hline $\begin{array}{l}\mathrm{VI} \text { - Protected } \\
\text { area with } \\
\text { sustainable use of } \\
\text { natural resources }\end{array}$ & $\begin{array}{l}\text { These are protected areas which conserve ecosystems } \\
\text { and habitats together with associated cultural values and } \\
\text { traditional natural resource management systems. They } \\
\text { are generally large, with most of the area in a natural } \\
\text { condition, where a proportion is under sustainable natural } \\
\text { resource management and where low-level non-industrial } \\
\text { use of natural resources compatible with nature } \\
\text { conservation is seen as one of the main aims of the area. }\end{array}$ & $\begin{array}{l}\text { Dabus Valley, Jikao, Tedo, Omo West and } \\
\text { numerous other Controlled Hunting Areas } \\
\text { (Ethiopia) } \\
\text { Beacon, Booby Island, Etoile and Mamelles } \\
\text { Nature Reserves (Seychelles) } \\
\text { Matetsi, Sapi and Hurungwe Safari Areas } \\
\text { (Zimbabwe) }\end{array}$ \\
\hline
\end{tabular}


Mara, Serengeti, Kruger and Volcanoes), the region has major drawcards for wildlife tourism, earning large revenues for national and sub-national governments. While in South Africa and Namibia, private conservation areas comprise a significant proportion of the protected area network, in other countries in the region, private conservation land ownership is not legislated, and all wildlife belongs to the state. Some issues, such as the financing of protected area management activities, have led to some innovative approaches with governments devolving management to NGOs. Public-private partnerships, particularly in the area of wildlife tourism, have become more prevalent in many countries.

\subsection{Convention on Biological Diversity}

The Strategic Plan for Biodiversity 2011-2020 was adopted by the Conference of the Parties of the CBD at its 10th meeting in Nagoya, Japan (CBD, 2010a). The plan outlines an overall strategic approach to implementing the $\mathrm{CBD}$, and includes a vision and mission, as well as strategic goals and targets, known as the Aichi Biodiversity Targets. The five strategic goals ( $A$ to $E$ ) are underpinned by 20 targets. All countries in the region are signatories to the CBD and, therefore, required to report to the $\mathrm{CBD}$ on the progress of the targets.

BIOPAMA is focused on Aichi Target 11, under Strategic Goal C, which calls on Parties to achieve:

- By 2020, at least 17 percent of terrestrial and inland water areas and 10 percent of coastal and marine areas, especially areas of particular importance for biodiversity and ecosystem services, are conserved through effectively and equitably managed, ecologically representative and well-connected systems of protected areas and other effective area-based conservation measures, and integrated into the wider landscape and seascapes (CBD, 2010a, p. 9).

\subsection{Other effective area-based conservation measures (OECMs)}

While OECMs have been part of Aichi Target 11 since 2011, the term was properly clarified in 2018 when the CBD defined OECMs as:

[...] a geographically defined area other than a Protected Area, which is governed and managed in ways that achieve positive and sustained long-term outcomes for the in situ conservation of biodiversity ${ }^{3}$, with associated ecosystem functions and services and where applicable, cultural, spiritual, socioeconomic and other locally relevant values (CBD, 2018, p. 1).

To be considered OECM, an area must have positive biodiversity outcomes, regardless of its primary management objectives, and must demonstrate management actions linked to ensuring biodiversity conservation (IUCN-WCPA Task Force on OECMs,
2019). This contrasts with a protected area, where the primary objective must be conservation. Under the Protected Planet Initiative, UNEP-WCMC now maintains the World Database on Other effective area-based conservation measures (WD-OECM) (UNEP-WCMC, 2019a). The WD-OECM can be combined with the World Database on Protected Areas (WDPA) to provide a more comprehensive picture of the world's conservation network.

It is likely that OECMs may significantly bolster the recognised conservation estate of many countries (Donald et al., 2019), including in Africa, where there are a number of conservation areas that do not fall under the traditional category definitions, such as military bases or community-conserved areas used primarily for livestock farming. Very few countries have begun the process of assessing potential OECMs. In response, the IUCN-World Commission on Protected Areas (WCPA) Task Force on OECMs has drafted a Technical Report for Recognising and Reporting OECMs (IUCN-WCPA Task Force on OECMs, 2019). The framework for an assessment of OECMs in Africa, for example, has been conducted by Candice Stevens and Daniel Marnewick in South Africa (see Box 2.2).

\subsection{The IUCN Green List of Protected and Conserved Areas}

The IUCN Green List of Protected and Conserved Areas Standard (IUCN Green List Standard) is a new international sustainability standard to benchmark protected and conserved areas that are both effective and equitable. Formally approved by the IUCN Council in late 2017, it has been mandated for further implementation by IUCN Members worldwide (Hockings et al., 2019; IUCN \& WCPA, 2017).

The IUCN Green List Standard describes a globally applicable set of seventeen criteria categorised under four components, accompanied by 50 indicators, for successful conservation at the site level, in protected and conserved areas. Sites voluntarily join the IUCN Green List by committing to achieving this standard, and are certified once compliance with the standard is demonstrated. The IUCN Green List Standard addresses four components: good governance, sound design and planning, effective management, and successful conservation outcomes (see Table 2.2) (IUCN \& WCPA, 2017).

The IUCN Green List Standard is designed to be both globally consistent and locally relevant, requirements which collectively describe the efforts needed to fully achieve the Standard. A 'Green List' site is one that is currently evaluated as achieving all criteria, across all four components. The Standard is tailored to each country or region where it is adopted. For each criterion in the Standard, a set of Generic Indicators and associated Means of Verification are maintained by IUCN. These generic indicators may be adapted to the context of each participating jurisdiction to reflect regional and local characteristics and circumstances in which protected and conserved areas operate.

"As defined by Article 2 of the Convention on Biological Diversity and in line with the provisions of the Convention" (CBD, 2018, p. 1). 


\section{Box 2.2 Other effective area-based conservation measures (OECMs) in Africa}

Although the identification of OECMs only began to gain momentum towards the end of the CBD 2011-2020 strategy, it has been suggested that OECMs will contribute significantly to the current Target 11, its inheritor and to SDG 15, and that they will be an important framework for conserving areas outside of formal protected areas. This will support African countries to safeguard and benefit from the biodiversity of these areas.

OECMs will provide a focus for the engagement and strengthening of a broad range of area-based conservation stakeholders, including agricultural sectors, corporations and local communities and Indigenous peoples, who are contributing to area-based conservation outside of the formal protected area estate. This is especially true for Africa, where most natural areas are owned by communal landowners or rights holders. Additionally, OECMs provide an ideal platform to include and develop more diverse economic activities and biodiversity financing, particularly around the wildlife economy.

The IUCN-World Commission on Protected Areas (WCPA) Task Force on OECMs has published a Technical Report for Recognising and Reporting OECMs (IUCN-WCPA Task Force on OECMs, 2019). A draft OECM Assessment Tool, and a draft methodology for identifying and assessing OECMs nationally, are being developed in conjunction with the Technical Report to assist with the identification of OECMs.
In partnership with the IUCN OECM Task Force, and various government and NGO stakeholders, Daniel Marnewick and Candice Stevens have developed and tested the South African national assessment methodology. The results from the OECM Case Study Area in the Kruger to Canyons Biosphere Region in South Africa indicate a number of opportunities to merge OECMs with the existing biodiversity stewardship framework, to identify opportunities to strengthen other national frameworks, and to create synergies with the wildlife economy to strengthen the associated management and governance frameworks, and the biodiversity conservation outcomes (Jonas \& Sandwith, 2019). Using the South Africa OECM assessment methodology, Daniel and Candice have supported the IUCN OECM Task Force to develop a draft global OECM assessment methodology.

OECMs will provide the framework to further develop and support legitimate, diverse and sustainable economic opportunities and biodiversity financing that merge with rural economies, while producing in situ biodiversity conservation outcomes, particularly around the wildlife economy.

Contributed by Daniel Marnewick, KBA Community Chair and the Africa representative of the KBA Community, and the KBA Africa Regional Focal Point.

\section{Table 2.2 IUCN Green List Standard - Components and criteria}

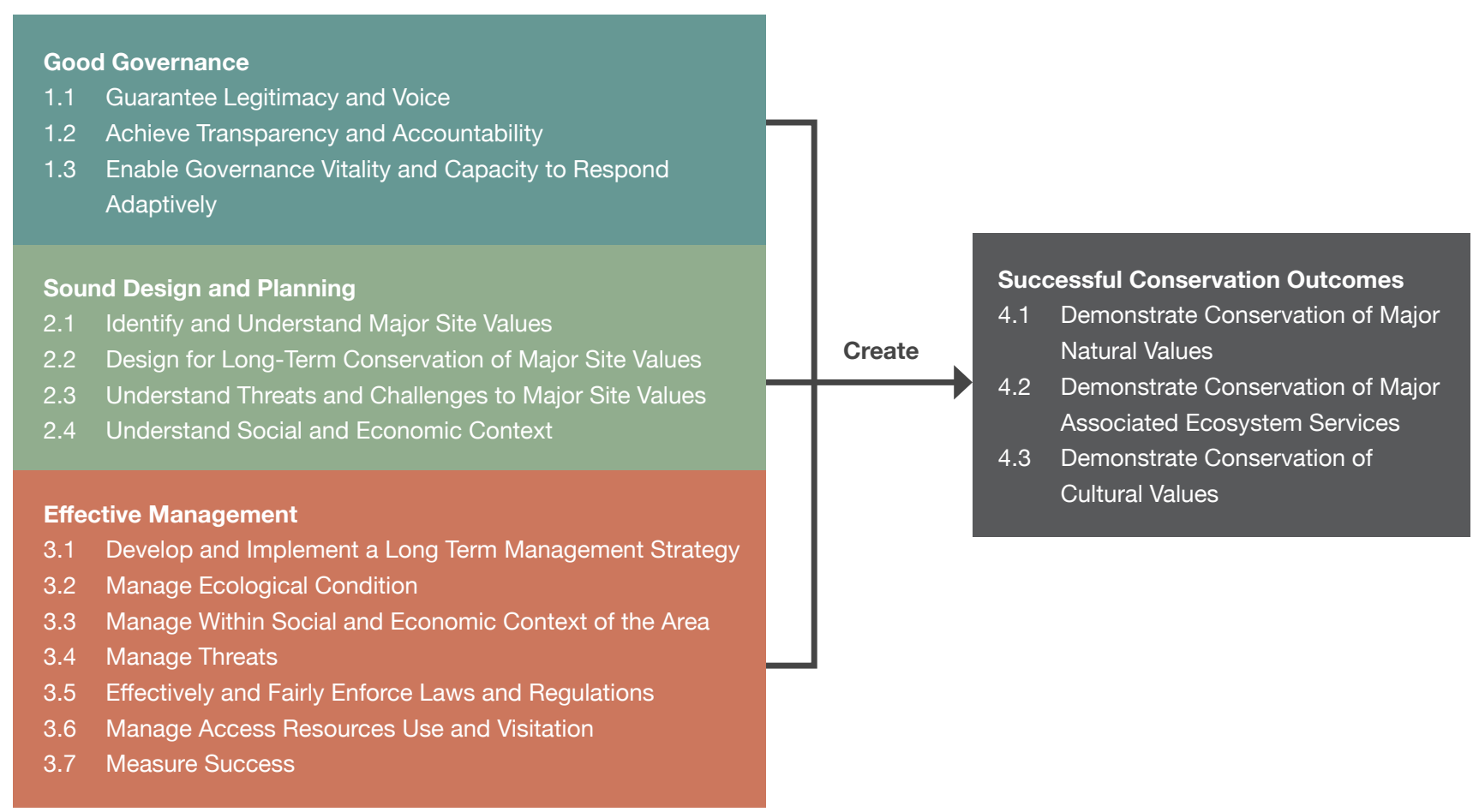




\section{Box 2.3 Key Biodiversity Areas (KBAs) in Africa}

To date, six countries in Africa have established KBA National Coordination Groups, five of whom have completed or are in the process of identifying KBAs. An additional 11 countries are interested in initiating the process. In many African countries, KBAs will be the only spatial mapping to inform biodiversity prioritisation, so it is imperative to continue identifying KBAs in Africa.

The identification of KBAs and their recognition in nationa policy is important to national conservation and development planning. Firstly, countries can better target their conservation investments such as in protected and conserved area expansion. Secondly, development planning can prevent negative impacts on the region's globally important sites. And thirdly, such a map would assist companies in avoiding the high cost of planning developments in biologically-sensitive areas and the subsequent conflict with conservation interests that ensues.

Extensive global guidance is provided for countries to identify KBAs. These include the Global Standard for the Identification of Key Biodiversity Areas (IUCN, 2016a), the Guidelines for using A Global Standard for the Identification of Key Biodiversity Areas (KBA Standards and Appeals Committee, 2019) and the Key Biodiversity Areas Proposal Process: Guidance on Proposing, Reviewing, Nominating and Confirming sites (KBA Secretariat, 2019).

Contributed by Daniel Marnewick (KBA Community Chair and the Africa representative of the KBA Community, and the KBA Africa Regional Focal Point).

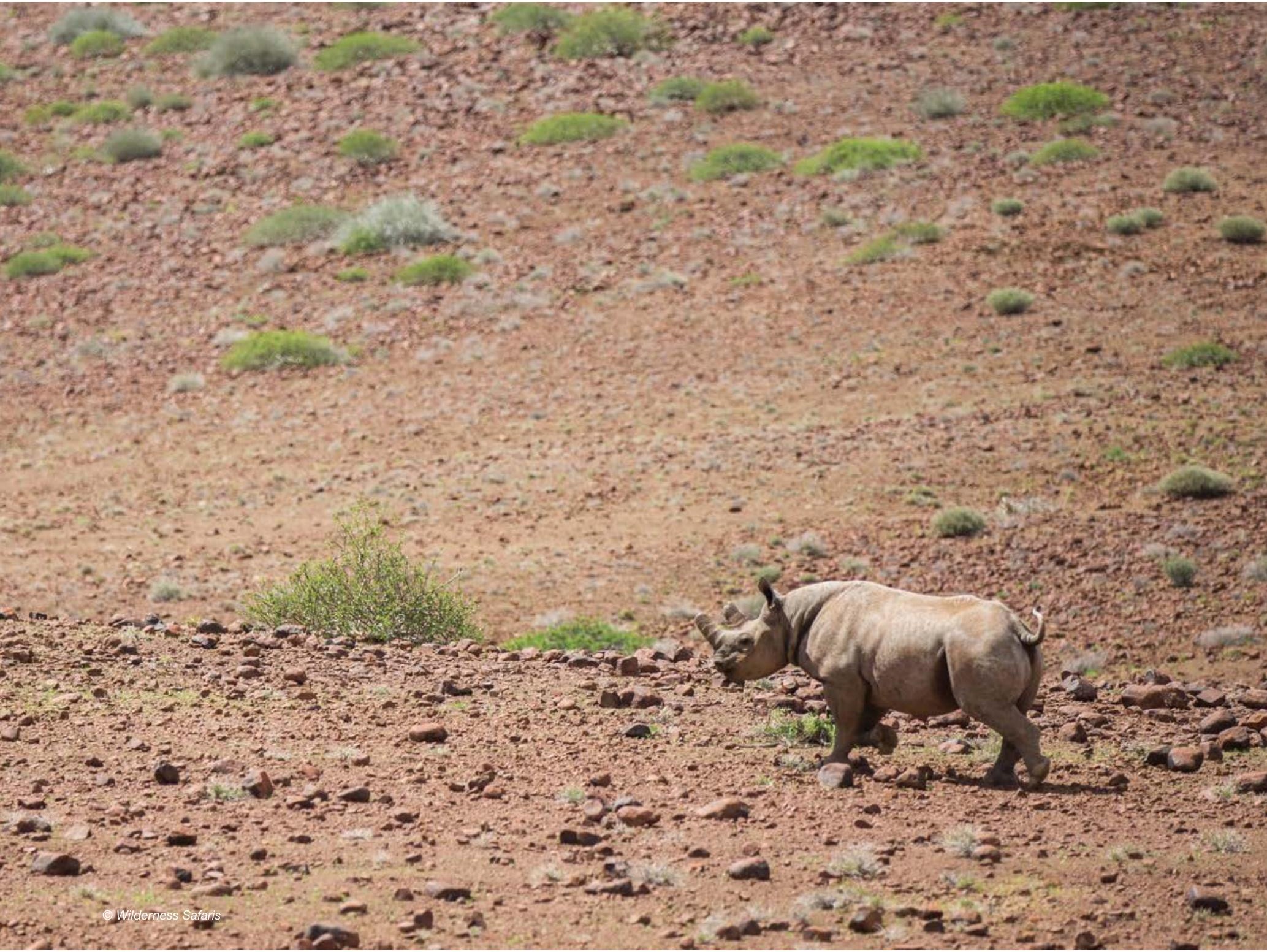




\subsection{International designations for protected and conserved areas}

National and regional policies and international conventions have been implemented to promote the expansion of the world's protected area network, leading to a diversification of protected area strategies, types and designations. As a result, many areas are protected by more than one convention, legal instrument, or other effective means. This overlap may be beneficial if the legal structure means that additional protection is conferred through each designation, but it can result in a lack of clarity around the governance and management regimes of particular locations (Deguignet et al., 2017). Global designations not only confirm the global significance of these areas - they also support the protection, management, promotion and sustainable use of these sites, for example by attracting additional tourism, financial and technical resources, and political and public support. Some of these globally designated areas are also transboundary sites, shared by two or more countries (see section 4.5). The three global designations for such sites are UNESCO Man and Biosphere Reserves, UNESCO World Heritage Sites and Ramsar sites (Wetlands of International Importance) (UNESCO, 1971; 1972; 2019a; 2019b). Each has clear criteria for the listing of sites.

\section{Box 2.4 BIOPAMA Regional Resource Hub (RRH)}

The $\mathrm{RRH}$ is the Eastern and Southern African regional observatory in the BIOPAMA programme. It is a unique platform to facilitate exchange of data/information among decision makers and managers of protected and conserved areas in the region.

The vision of $\mathrm{RRH}$ is to be a leading resource centre that supports (local, national and regional) effective decision making and governance on protected areas and biodiversity and their link to sustainable development objectives.

$\mathrm{RRH}$ is central to BIOPAMA's work and will support data collection, analysis, monitoring and reporting, developing the capacities of staff and organisations to manage the data and provide policy guidance for better decision making on biodiversity conservation. Some of the products that will be prepared through $\mathrm{RRH}$ include story maps, infographics, country and regional profiles, reports, guidelines, tools, news and events, success stories and summarised data from global datasets.

An important component of the Regional Resource Hub is the Regional Reference Information System (RRIS), ${ }^{*}$ which brings together science and knowledge making it easily accessible at regional, country and site levels. RRIS supports policy-making on the inter-linked themes of biodiversity, conservation and development through the following tools:

1. Tracking tool - tracks indicators for policies and conservation targets;

2. Analytical tools - includes a MARXAN ${ }^{4}$ web tool and Earth Observation data;

3. Protected Area Governance and Equity module - links to various governance, social and equity assessment tools;
4. Protected Area Management Effectiveness module includes the tools and types of assessments and links to the Integrated Management Effectiveness Tool, GD-PAME; and

5. Protected Area dashboard - covers basic protected area and biodiversity information.

The aim of RRIS is to create a user community-based content management system that is relevant to policy and supports decision-making. Focused on protected and conserved areas, RRIS will integrate information from data providers while providing linkages with not only global datasets (such as WDPA, DOPA and GD-PAME) but also regional and national datasets. Figure 2.1 shows the flow of data through these various channels. The RRIS and Regional Resource Hub will allow stakeholders in the region to access relevant conservation data at a national and regional level.

In summary, $\mathrm{RRH}$ :

- Works as a platform to facilitate exchange of data/ information among decision makers and managers of protected areas and supports regional priorities for decision support products;

- Is a repository/hub for data and analyses to support reporting, monitoring and decision-making, customised to the region;

- Provides analytical tools, products and other services to the region;

- Promotes networking of experts, links to key partners working on relevant issues; and

- Provides information on training and funding opportunities and identifies priorities for action for funding.

${ }^{*}$ For further information, please see: http://biopama-rris.rcmrd.org/ https://esahub.rcmrd.org/

4 Marxan is an open access conservation planning software. It provides decision support to a range of conservation planning problems, including the design of new reserve systems, reporting on the performance of existing reserve systems, and developing multiple-use zoning plans for natural resource management. 


\subsection{Other priority areas for conservation}

In addition to the globally-designated areas, a number of other classifications of priority areas for conservation have been identified under the umbrella of Key Biodiversity Areas (KBAs) (see also Box 2.3). These are sites contributing significantly to the global persistence of biodiversity and are identified using a standard set of criteria applicable to plants, animals and ecosystems in terrestrial, inland water and marine environments (IUCN, 2016a). The classifications below are all sub-sets of KBAs (Stattersfield et al., 1998).

- Alliance for Zero Extinction (AZE) sites: a programme which was launched globally in 2005, the AZE was established to identify, effectively conserve and safeguard the most important sites for preventing global species extinctions (AZE Secretariat, 2019).

- Endemic Bird Areas (EBA): areas that encompass the overlapping breeding ranges of restricted-range species, such that the complete ranges of two or more restricted-range species are entirely included within the boundary of the EBA (BirdLife International, 2019a).

- Important Bird and Biodiversity Areas (IBAs): KBAs identified for birds using internationally agreed criteria applied locally by BirdLife Partners and experts (IUCN, 2016a).

\subsection{Monitoring protected and conserved areas - An overview}

The World Database on Protected Areas (WDPA) is a joint product of UN Environment Programme and IUCN, and is managed by UNEP-WCMC under the Protected Planet Initiative. The data within this initiative are compiled and managed in collaboration with governments, non-governmental organisations, community and private actors, academia and other industry stakeholders. The WDPA and WD-OECM are updated monthly and made available online through the Protected Planet website, where the data are both viewable and downloadable. A bi-annual Protected Planet report is also published, which is now in the form of a live digital Protected Planet report. ${ }^{5}$

Data in the Protected Planet Initiative are used to report to the CBD on progress towards Aichi Biodiversity Targets (particularly Target 11) and to the United Nations (UN) to track progress towards the 2030 Sustainable Development Goals, some indicators of the Intergovernmental Science-Policy Platform on Biodiversity and Ecosystem Services (IPBES), and other international assessments and reports.

The Protected Planet Initiative relies on regular updates of information from data providers. Sites nominated as protected areas should comply with the IUCN definition (see section 2.1). Each protected area should be reported to the database in GIS format, e.g. shapefile (point or polygon). It must include a series of associated descriptive attributes, such as designation, IUCN management category and IUCN governance type. The Protected Planet data standards are explained in detail in section 3 of the user manual (UNEP-WCMC \& IUCN, 2019a).

The WD-OECM ${ }^{6}$ has a similar structure to the WDPA and the databases are fully inter-operable. For further guidance on how to submit data to the WD-OECM, see section 2 of the user manual (UNEP-WCMC \& IUCN, 2019a).

The Global Database on Protected Area Management Effectiveness (GD-PAME) also falls under the Protected Planet Initiative. It is the most comprehensive global database of management effectiveness assessments for protected areas and is linked to the WDPA. The GD-PAME is a searchable database that includes data on PAME assessments submitted by a wide range of governmental and nongovernmental organizations to UNEP-WCMC and is updated on a monthly basis. By 2019, over 28,000 assessments from 169 countries using 69 different methodologies were recorded in the database. There are, however, very few links to actual assessments or the related reports. Some of the benefits for countries in submitting their PAME assessment information to the database include:

1. Bringing national data into one place;

2. Informing adaptive management practices;

3. Prioritising resource allocation; and

4. Reporting against conservation targets.

The Digital Observatory for Protected Areas (DOPA) is maintained by the Joint Research Centre of the European Commission (JRC). It is a set of web services and applications that can be used primarily to assess, monitor, report and possibly to forecast the state of, and the pressures on, protected areas at multiple scales. The data, indicators, maps and tools provided by DOPA are relevant to end-users, including policy makers, funding agencies, protected area agencies and managers, researchers and the CBD. The information can be used, for example, to support spatial planning, resource allocation, protected area development and management, and national and international reporting. Using global reference datasets, DOPA supports global assessments and provides a broad range of consistent and comparable indicators at country, ecoregion and protected area level (Bastin et al., 2017; Dubois et al., 2016; EC JRC/DOPA, 2019a).

The Regional Observatories for Protected Areas and Biodiversity have been established under the BIOPAMA programme. They support data collection, analysis, monitoring and reporting, as well as develop the capacities of staff and organizations to manage the data, and provide policy guidance for better decision-making on biodiversity conservation. One of the key systems provided under the regional observatory system is the Regional Reference Information System (RRIS) or Regional Resource Hub (RRH), which for Eastern and Southern Africa is hosted by the Regional Centre for Mapping of Resources for Development (RCMRD) in Kenya (see Box 2.4 and Figure 2.1). 


\section{Figure 2.1 Global and regional data management systems for protected areas}

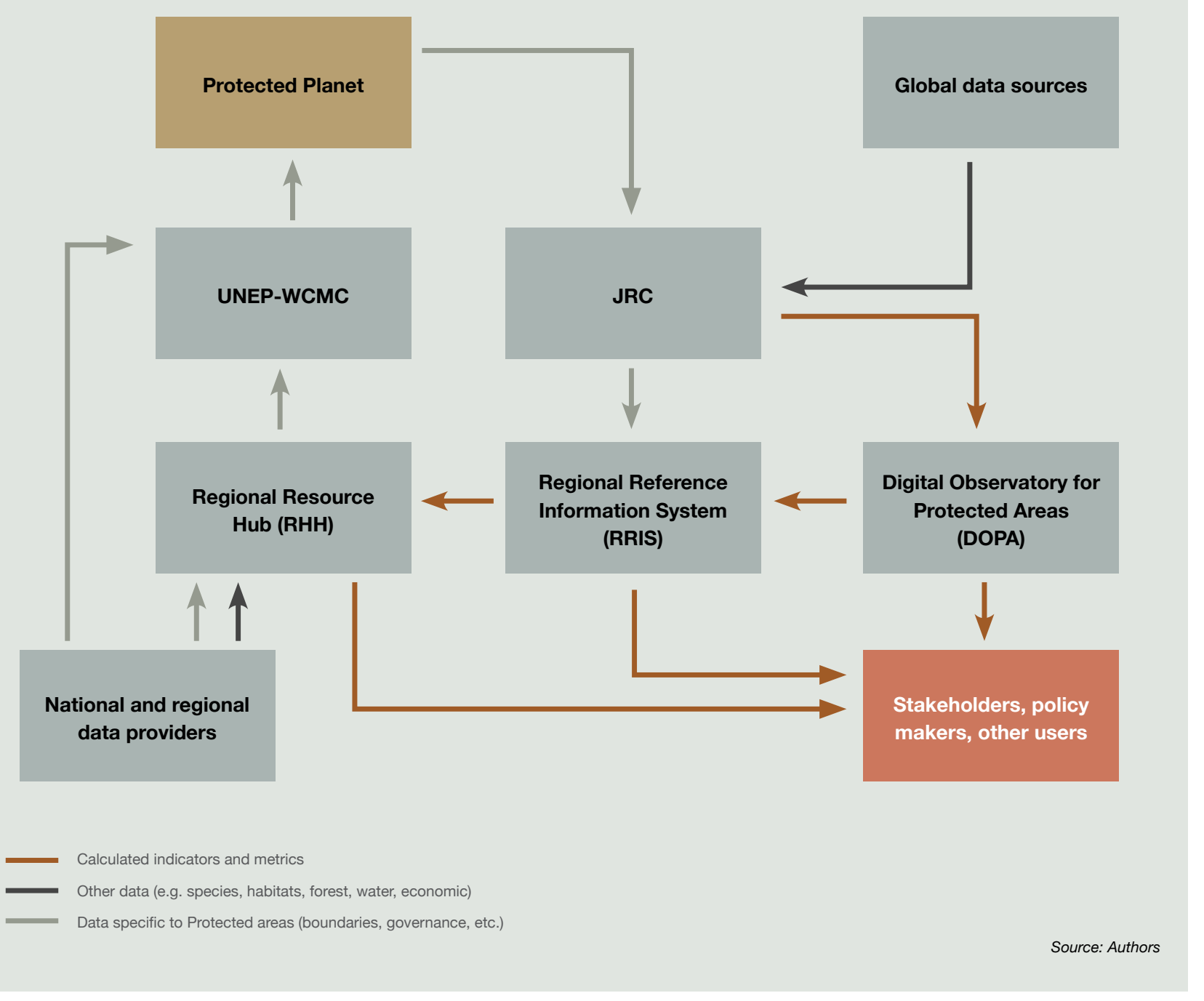

\subsection{A global picture of protected areas}

There is indication from around the world of increasing stress on the environment with the main causes including increased population and industrialisation, both of which are contributing to climate change. A principal objective of protected areas is to conserve nature by eliminating, minimising, or reducing human pressures and threats operating within their boundaries.

A number of initiatives or mechanisms measure and assess pressures and threats at the global and regional level. Remote sensing can be used for measuring some threats, while others require in situ studies in order to obtain a comprehensive understanding of what is affecting protected and conserved areas. IUCN and the Conservation Measures Partnership (CMP) have produced a set of standard classifications of direct threats that conservationists encounter worldwide and of the conservation actions that they can take to counter these threats (TNC, n.d.). The
IUCN Red List of Threatened Species ${ }^{\mathrm{TM}}$ uses this classification scheme to ensure comparability across species and habitats. The IUCN Red List provides information about range, population size, habitat and ecology, use and/or trade, threats, and conservation actions that will help inform necessary conservation decisions.

In addition, many PAME assessments (see Chapter 5) also include a systematic and comparable evaluation of threats to protected area values and/or key taxa, in many cases using the standard classification scheme. This provides a basis for more coordinated efforts and targeted investment to reduce threats and enhance conservation outcomes in protected areas. The Integrated Management Effectiveness Tool (IMET) developed through BIOPAMA also looks at the context of the protected and conserved area in order to ascertain potential future threats (BIOPAMA \& IUCN, 2016).

A study to have a global overview of threats facing terrestrial protected areas globally and per biome analysed data collected as part of PAME evaluations in 1,961 protected areas from 149 
countries, using three different methodologies: the Management Effectiveness Tracking Tool (METT); the World Heritage Outlook assessment; and BirdLife International's IBA monitoring protocol (Schulze et al., 2018). The study found that unsustainable hunting was the most commonly reported threat and occurred in $61 \%$ of all protected areas, followed by disturbance from recreational activities occurring in 55\%, and natural system modifications from fire or its suppression in $49 \%$. The number of reported threats was lower in protected areas with greater remoteness, higher control of corruption and lower human development scores (Schulze et al., 2018). In developing countries, the main reported threats were linked to overexploitation from resource extraction, while negative impacts from unsustainable recreational activities dominated in developed countries (Schulze et al., 2018). The results showed that many of the most serious threats to protected areas are difficult to monitor with remote sensing, and highlight the importance of in situ data on threats to inform the implementation of more effective biodiversity conservation in the global protected area estate (Schulze et al., 2018). It should be noted that this analysis included data up to 2014, after which large-scale poaching for the global illegal wildlife trade has emerged as a major threat to biodiversity across Africa. Table 2.3 summarises findings for the Afrotropical biome which comprises most of sub-Saharan Africa.
In another study, an analysis of the performance of African protected areas, with a focus on lions and their prey, showed that bushmeat poaching was the most serious threat to lions and wildlife in general (Lindsey et al., 2017).

In addition to bushmeat poaching, it is also considered that the main direct threats to conservation in Africa were: habitat loss and fragmentation; overfishing; illegal wildlife trafficking; and alien invasive species. An analysis by the European Commission (EC, 2015) found that the main drivers of these threats in the region were:

- population growth and poverty;

- poor governance;

- inadequate land tenure and local resource rights;

- national and regional conflicts;

- political indifference and lack of awareness;

- climate change;

- endemic and emerging diseases; and

- human-wildlife conflict.

\section{Table 2.3 Three most frequently reported threats in the Afrotropical biome}

\begin{tabular}{l|l|r|l|l|l}
\hline Realm & Biome group & Sites (N) & $\begin{array}{l}\text { Most frequently } \\
\text { documented } \\
\text { threat }\end{array}$ & $\begin{array}{l}\text { Second most } \\
\text { frequently } \\
\text { documented threat }\end{array}$ & $\begin{array}{l}\text { Third most frequently } \\
\text { documented threat }\end{array}$ \\
\hline Afrotropical & Tropical forests & 150 & $\begin{array}{l}\text { Hunting \& collecting } \\
\text { terrestrial animals }\end{array}$ & $\begin{array}{l}\text { Gathering terrestrial } \\
\text { plants }\end{array}$ & $\begin{array}{l}\text { Logging \& wood } \\
\text { harvesting }\end{array}$ \\
\hline Afrotropical & $\begin{array}{l}\text { Savannahs, shrub- and } \\
\text { grasslands }\end{array}$ & 22 & $\begin{array}{l}\text { Invasive non-native/ } \\
\text { alien species/diseases }\end{array}$ & $\begin{array}{l}\text { Fire \& fire } \\
\text { suppression }\end{array}$ & Recreational activities \\
\hline Afrotropical & Mangroves & 7 & Fishing \& harvesting & Hunting \& collecting & Gathering terrestrial plants \\
\hline
\end{tabular}

Source: (Schulze et al., 2018, Table 1, p. 7/10). 


$$
\text { मींखि }
$$




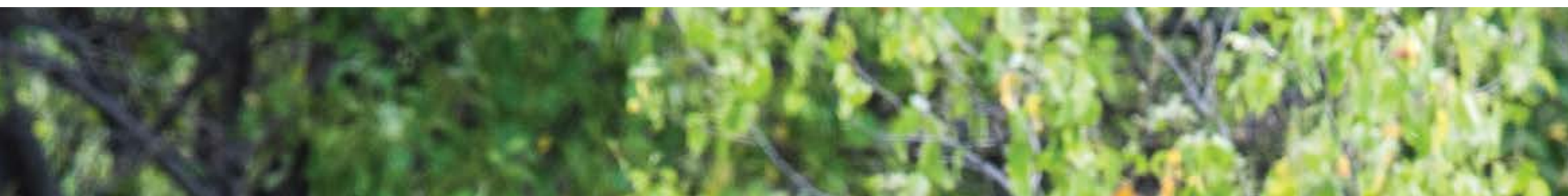
Asta

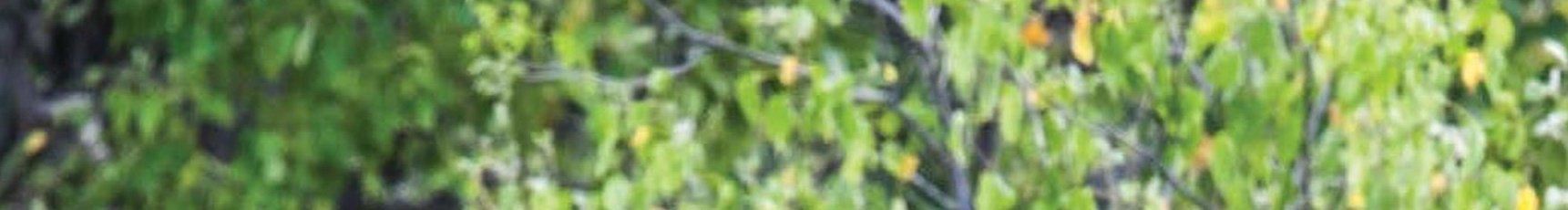
(3)

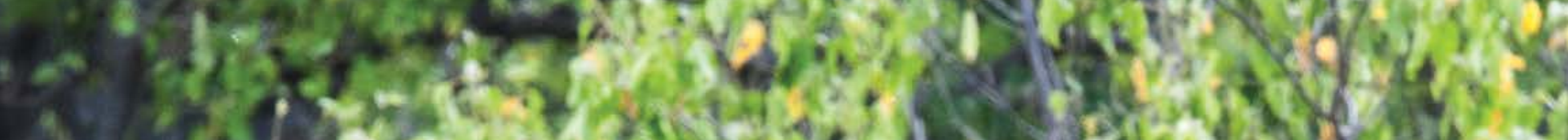
ara

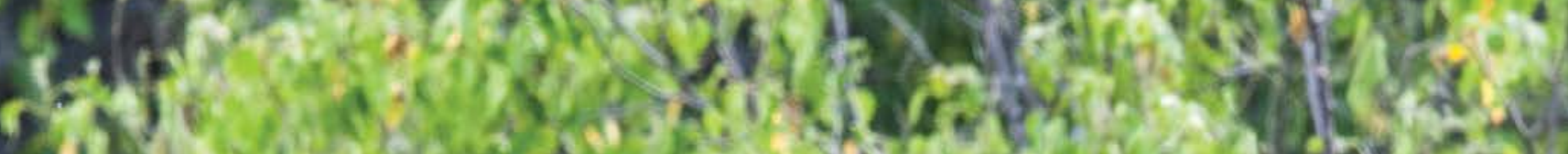
T2.

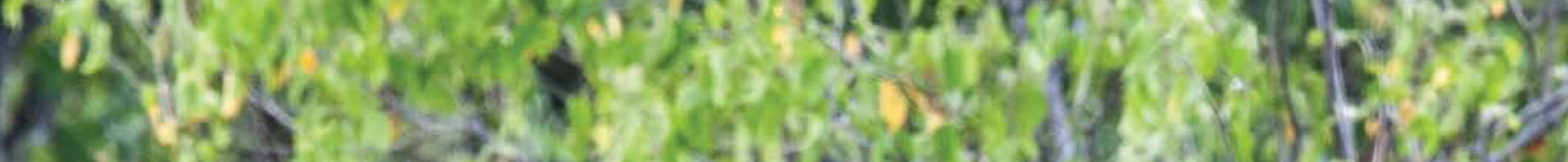

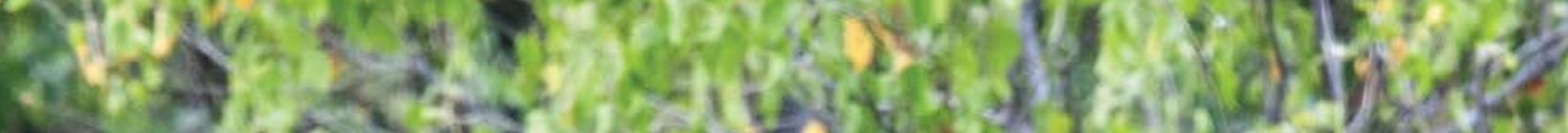

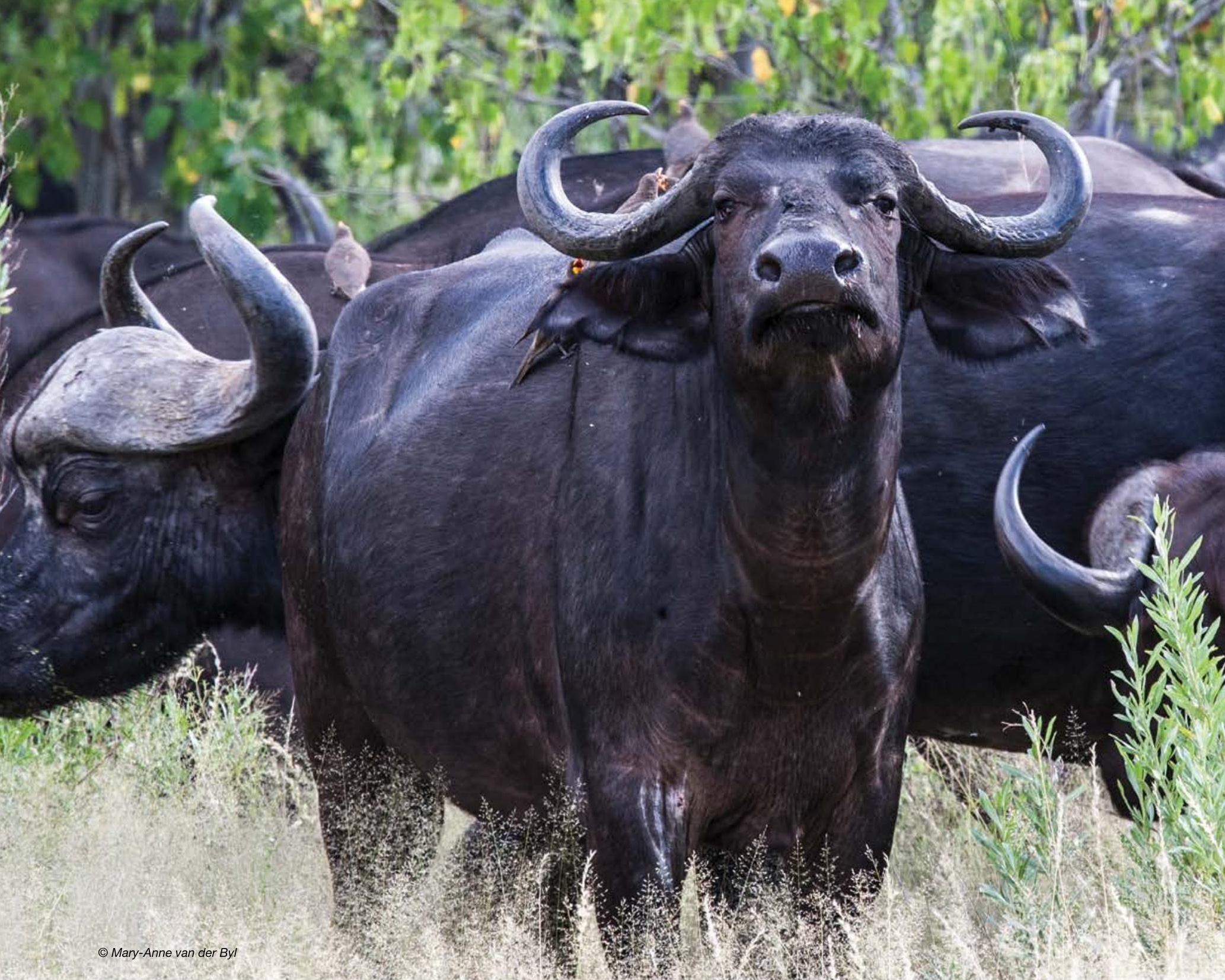


Part II - Regional context, data and country profiles

\section{Overview of the region ${ }^{7}$}




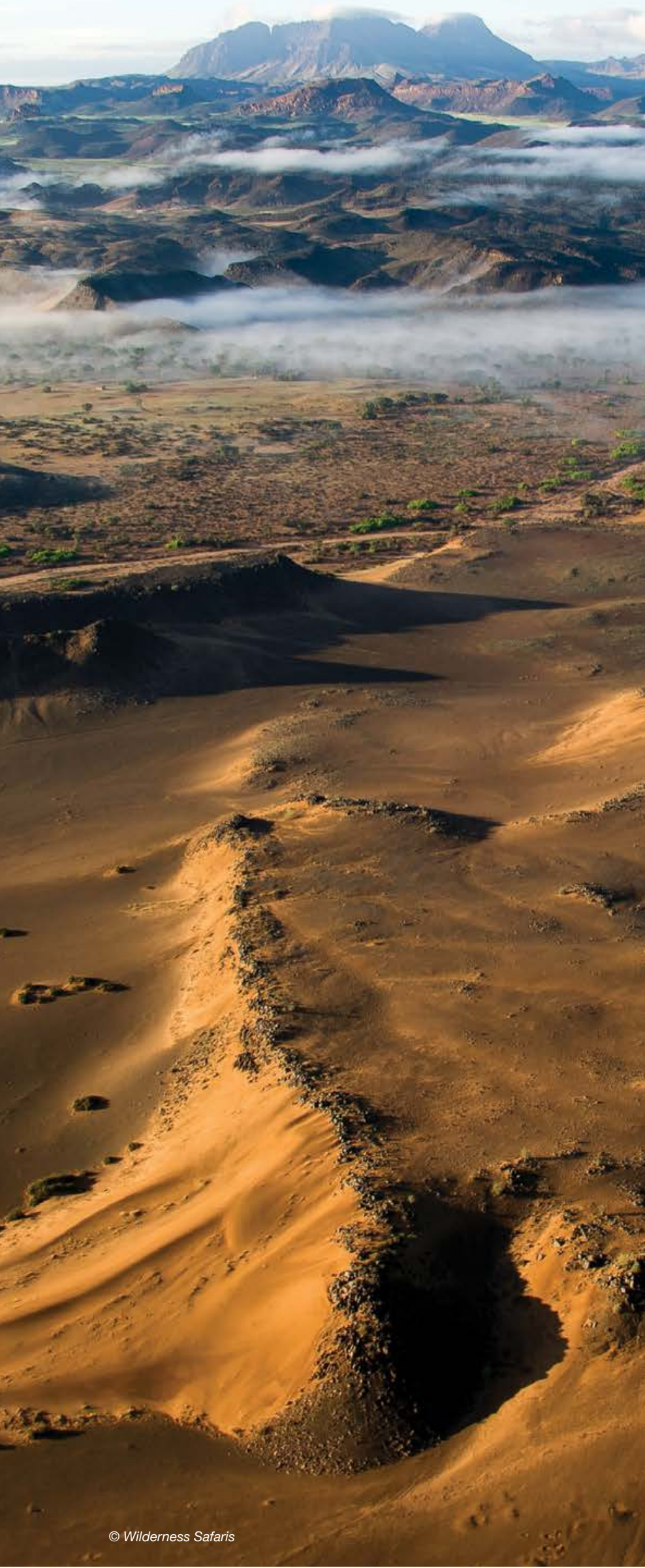

This section provides the context of this report and an overview of the state of protected and conserved areas in the Eastern and Southern Africa region as a whole. Where data are available, full analyses have been undertaken. It presents information on the institutions formed to meet to the specific needs and priorities of the sub-regions, including regional policies and legal instruments. Innovative approaches that inform and demonstrate success are highlighted and recommended.

The Eastern and Southern Africa region covers 24 countries including the Western Indian Ocean islands. It is home to four Regional Economic Communities: the East African Community (EAC); the Indian Ocean Commission (IOC), the Intergovernmental Authority on Development (IGAD) and the Southern African Development Community (SADC). The Eastern and Southern Africa region is vast, covering approximately 16 million $\mathrm{km}^{2}$, an area equivalent to approximately half the African land mass. It is a geographically diverse region that stretches from the Red Sea in the north to the Cape of Good Hope in the south, as well as the Western Indian Ocean islands. The region includes numerous different biomes, including savannah, grassland, dryland and desert, tropical and subtropical dry and humid forest, wetland, and the unique fynbos biome of South Africa.

Sub-regional differences have implications on the management and governance of protected and conserved areas. Among the countries, there is a diversity of needs and priorities for development, including sustainable conservation, such as revising legislation and policies to allow for more inclusive conservation. Areas still undergoing conflict, as the case in South Sudan and Somalia, may require a greater focus on law enforcement, which will impact on management priorities and budgets. Countries are also at vastly different stages of sustainable conservation, with Botswana, Kenya, Namibia, Rwanda, South Africa, Tanzania and Uganda having more advanced policies and processes related to management and governance, while Eritrea, Somalia, South Sudan and Sudan are still in the early stages of policy development, establishment of conservation areas and governance policies. The Western Indian Ocean islands have unique opportunities and challenges.

In 2019, Africa's population reached 1.32 billion (Worldometer, n.d.), representing $16.7 \%$ of the total world population, with a population density for the continent of 44 people per $\mathrm{km}^{2}$. In the same year, Eastern and Southern Africa's population was 512 million, representing $6.6 \%$ of the world population, with a population density of 32 people per $\mathrm{km}^{2}$. This figure varies greatly across the region, with Namibia having one of the lowest population densities (three people per $\mathrm{km}^{2}$ ) and Rwanda having one of the highest (512 people per $\left.\mathrm{km}^{2}\right)$. Population estimates suggest that growth will remain strong in the coming decades such that by 2050, one in four people in the world will be African. A strong population growth presents challenges which need to be effectively managed (IPBES, 2018), along with high levels of poverty and unemployment. A number of the regional threats to conservation are directly related to population growth and competition for land (EC, 2015; IPBES, 2018). 


\subsection{Eastern Africa}

The Eastern African region marks the highest and lowest points on the continent and includes a range of habitats from rainforests and coastal reefs to deserts. Some of the unique features are the montane fauna and flora of the Ethiopian Highlands, including the endemic and endangered Ethiopian Wolf (Canis simensis), the tropical glaciated mountains of the Ruwenzori and Kilimanjaro, the forested escarpments of the Albertine Rift Valley, the great lakes of Africa, the unique Horn of Africa, the largest migrations of savannah wildlife and important relic forests of the Eastern African coasts. The region also includes some of the most famous protected areas of the continent, including the Masai Mara National Reserve and Serengeti National Park. It is home to chimpanzees (Pan troglodytes) and the world's largest population of lion (Panthera leo) (Tanzania).

Lake Tanganyika is the longest freshwater lake in the world and hosts 250 different species of cichlid fish, of which $98 \%$ are endemic. Lake Victoria shows less endemism but is an important fishery for local populations in three countries. ${ }^{8}$

Similar to other tropical regions, the extent of the lowland and mountain rainforests and dry forests in Eastern Africa has been decreasing. In the eastern African coastal forests, loss is primarily through conversion to farmland, mainly through shifting cultivation. In Tanzania, for example, coastal forest cover declined by over a third from 420,765 hectares in 1990 to 358,333 hectares in 2000 , and to 273,709 hectares in 2007. However, the rate of deforestation has been lower within Tanzanian reserves: $0.2 \%$ and $0.4 \%$ per year during 1990-2000 and 2000-2007, respectively, compared to $1.3 \%$ and $0.6 \%$ per year outside the reserves during the same periods (Burgess et al., 2017; Godoy et al., 2012).

\subsection{Madagascar and the Western Indian Ocean islands}

The island of Madagascar has high species richness and extraordinary levels of endemism particularly seen in lemurs, tenrecs and chameleons. There are more plant species in Madagascar than in the entire Congo Basin. The forests in the north and east are humid, with those in the west and south been increasingly arid. The island constitutes a region of disproportionate conservation importance with high levels of endemism and a high proportion of endangered species. The smaller islands of Comoros, Mauritius and Seychelles are also of exceptional conservation importance as part of the Madagascar and Indian Ocean Islands biodiversity hotspot, with many endemic and threatened species and ecosystems, such as the Seychelles white-eye (Zosterops modestus).

The Malagasy eastern rainforests decreased by $1.69 \%$ annually from 1990-2000 and 1.08\% from 2000-2010 (Mayaux et al., 2013), and an estimated $97 \%$ of Malagasy dry western forests have been destroyed since human settlement (WWF, 2017), with an annual deforestation rate of $0.75 \%$ from 1990-2000 (Gorenflo et al., 2011).

\subsection{Southern Africa}

The 10 countries of Southern Africa comprise the wealthiest and most developed sub-region of sub-Saharan Africa, albeit uneven. They also exhibit a high diversity of species and habitats.

Natural wonders in southern Africa include the great Etosha saltpans, the Victoria Falls and Zambezi River, and the unique inland Okavango Delta. The Kalahari and Namib Deserts are both large deserts, with the Namib considered to be the oldest desert in the world. The Karoo Desert in South Africa has the world's richest flora of succulent plants and Fynbos shrubland forms a major element of the Cape Floristic Region in South Africa, which is one of the six recognised floral kingdoms of the world, with more than 9,000 vascular plant species of which $69 \%$ are endemic. The eastern coast of Southern Africa below the Great Escarpment is another important centre of plant endemism.

Lake Malawi/Niassa/Nyasa is $570-\mathrm{km}$ long and is the most southerly lake of the Rift Valley, containing more species of fish than any other lake on earth, including more than 1,000 endemic species of cichlid fish and many endemic molluscs.

Southern Africa contains more elephant and rhinoceros than the rest of the continent, as well as some of the oldest and largest reserves and parks in Africa. Southern African countries have a long history of wildlife conservation and game management and have been pioneers of community-based natural resource use, transfrontier conservation and other innovative conservation approaches. The first Peace Park emerged in Southern Africa in 1990 and the Lubombo Transfrontier Conservation Area established in 2000 was the first marine TFCA in Africa (see section 4.5 for more information on TFCAs).

8 For more information on this important area, please see: https://www.iucn.org/sites/dev/files/content/documents/2018/policy_brief_english_final.pdf. 


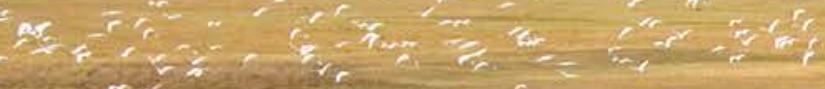

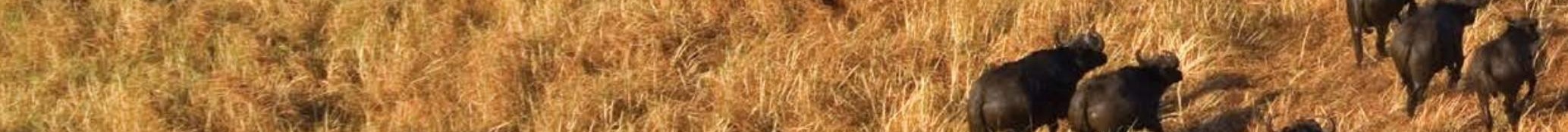
Q

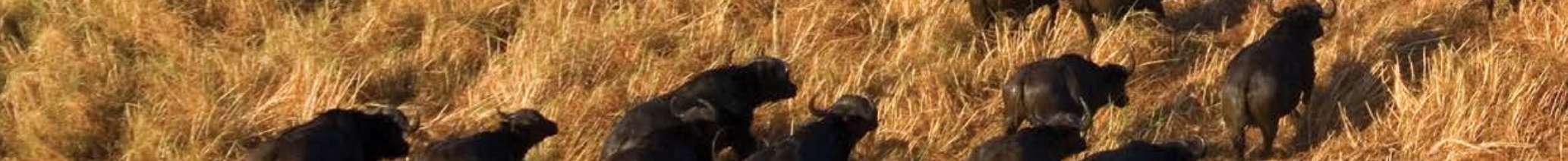

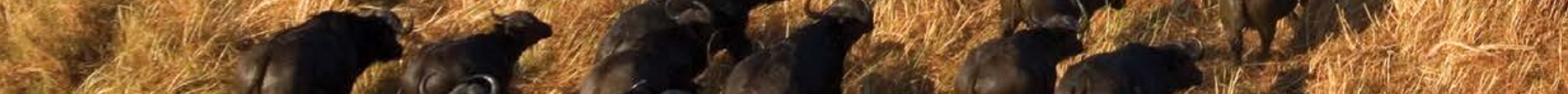

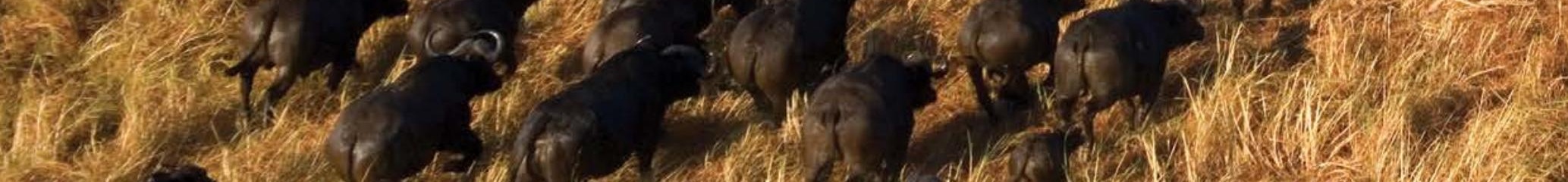

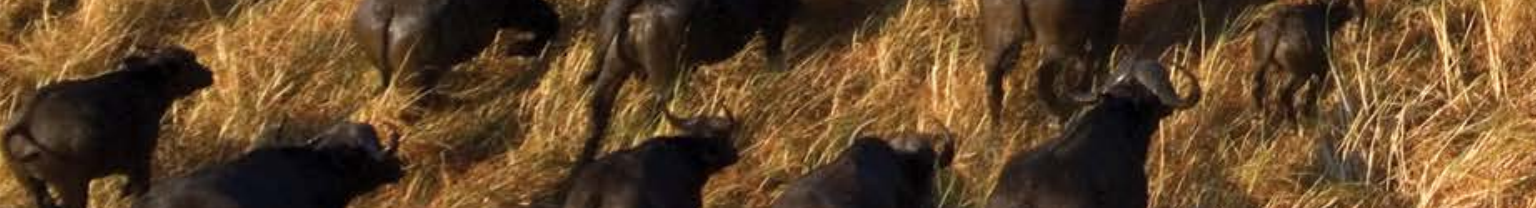
Q 


\section{Protected and conserved areas in Eastern and Southern Africa}


Figure 4.1 Protected and conserved areas in Eastern and Southern Africa

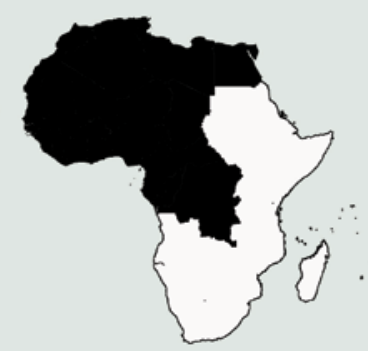

BIOPAMA EASTERN \& SOUTHERN AFRICA PROTECTED AREAS

Protected Areas

Africa National Boundaries

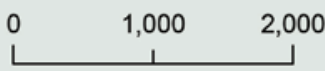

Kilometers

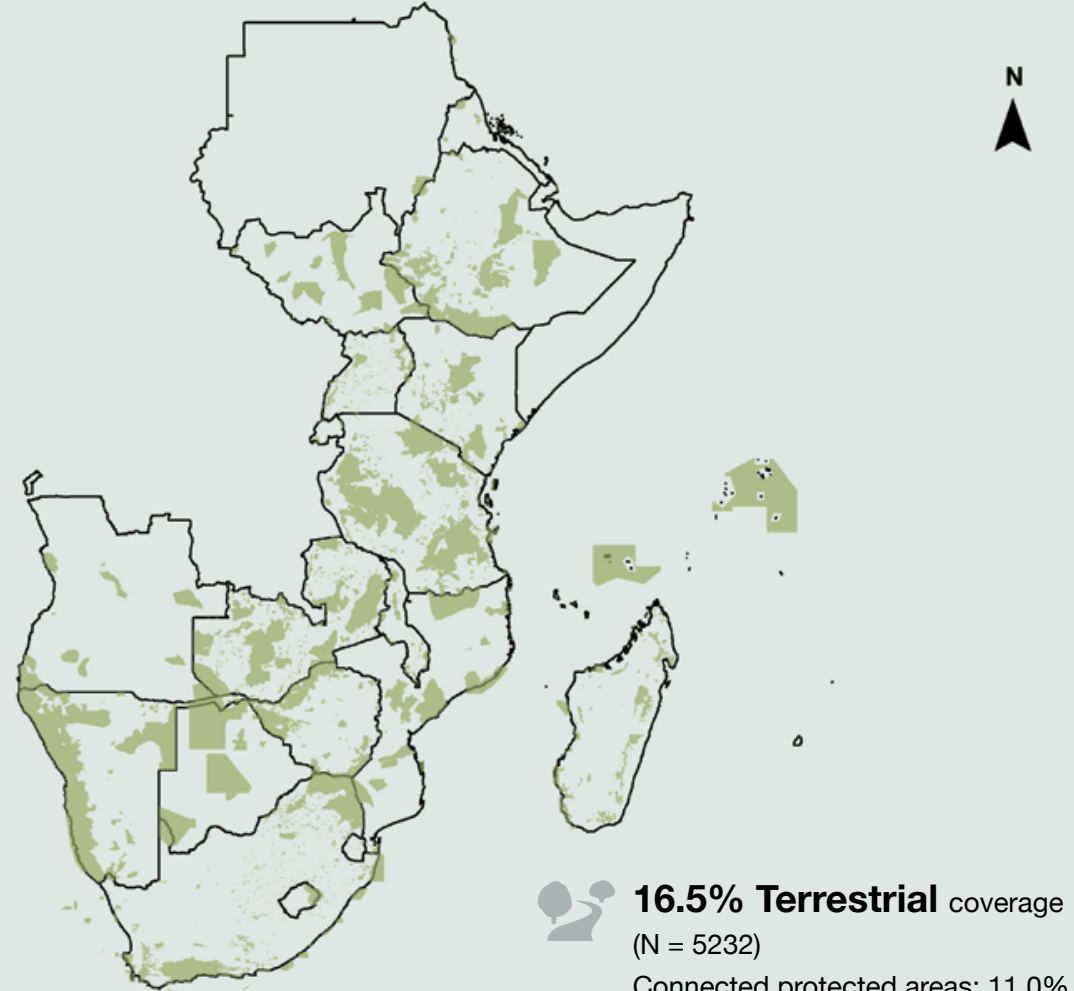

Connected protected areas: $11.0 \%$

\section{6\% Marine}

coverage $(\mathrm{N}=411)$

\section{Country endemic species}

522 Amphibians of which

247 are threatened (47.3\%)

365 Mammals of which

178 are threatened $(48.8 \%)$

306 Birds of which

104 are threatened (34.0\%)

\section{Sharks and rays of which}

6 are threatened $(25 \%)$

\section{Regional land cover statistics}

$88.1 \%$ Natural land* ${ }^{*}$ which

$22.1 \%$ is protected

$32.0 \%$ Forest cover of which

$27.6 \%$ is protected

$1.8 \%$ Inland water of which

$11.3 \%$ is protected

53.1 Pg Total carbon stock of which $21.9 \%$ is protected

\section{$5.3 \%$ Urban and cropland coverage of protected area total surface}

Input data:

- Global Administrative Unit Layers (GAUL). Revision 2015. Available at: $h$ ttp://www.fao.org/geonetwork/srv/en/metadata.show?id=12691

- Exclusive Economic Zones (EEZ) v9 (2016-10-21). Available at: http://www.marineregions.org/downloads.php

- UNEP-WCMC \& IUCN (2019). Protected Planet: The World Database on Protected Areas (WDPA). [On-line]. Data for May 2019 used for PA connectivity and regional land cover

statistics; and data for September 2019 used for PA coverage and the map. Cambridge, UK: UNEP-WCMC and IUCN. Available at: www.protectedplanet.net

- JRC-VITO-IIASA (2019). Copernicus Global 100m Land Cover map for the year 2015. Available at: https://land.copernicus.eu/global/products/lc

- IUCN (2019). IUCN Red List of Threatened Species. Derived from Table 8a. Version 2019.1. Available at: https://www.iucnredlist.org/resources/summary-statistics Avitabile, V., Garcia Bendito, E., Delli, G., Mandrici, A., Battistella, L., Dubois, G. (2019). Global map of total carbon stock. [On-line]. Available at: https://dopa.jrc.ec.europa.eu/sites/ default/files/dopa_explorer_4-total_carbon.zip [10/2019]. Ispra, Italy.

* Natural land category includes all classes except cropland (class 40) and urban (class 50)

Source: EC JRC/DOPA, 2019a. 


\subsection{Baseline statistical data}

For this report, data was taken from WDPA as well as information that is available in each country's reports to the CBD with a focus on the Fifth and Sixth National Reports drafted between 2014 and 2019. Some country reports include information on conserved as well as protected areas.

Eastern and Southern Africa has 5,232 protected areas covering $2,120,112 \mathrm{~km}^{2}$ of the land and $473,815 \mathrm{~km}^{2}$ of the ocean (UNEPWCMC \& IUCN, 2019b). Figure 4.1 presents the map of these areas as well as an overview of threatened species and land cover representation in those protected areas. The data were computed using the spatial information available in the WDPA, in combination with a range of other authoritative datasets. However, in some cases, the protected area boundaries in the WDPA are not up to date or complete, which may affect the accuracy of statistics at country level. For example, in the case of Somalia, 21 protected areas were reported to WDPA, but none have defined polygon boundaries, preventing the generation of a map or applying spatial analysis techniques.

As a region, Eastern and Southern Africa is close to meeting the coverage goal of Aichi Target 11 with $16.54 \%$ of the terrestrial area protected in 5,232 protected areas covering more than 2.1 million $\mathrm{km}^{2}$ (UNEP-WCMC \& IUCN, 2019b). As can be seen in Figure 4.2, at least nine countries in the region have exceeded the Aichi coverage targets for terrestrial protection, according to their national reports. Nonetheless, there is a high variability in the region with $42 \%$ of countries remaining below $10 \%$ on terrestrial coverage based on the WDPA, while this figure can go as high as $33 \%$ based on national statistics.
The connectivity value presented in Figure 4.2 (blue bars) considers the spatial arrangement, size and coverage of protected areas and accounts for the land area that can be reached within the protected area network by organisms with a median dispersal distance of $10 \mathrm{~km}$ (representative of many terrestrial vertebrates). ${ }^{9}$ Similarly, the connectivity varies greatly across the region with less than $1 \%$ in Lesotho and over $36 \%$ in Seychelles.

Eastern and Southern Africa is half-way to meeting the marine protected area coverage element of Aichi Target 11, with $5.60 \%$ of the marine area protected in 411 coastal and marine protected areas covering $473,815 \mathrm{~km}^{2}$ (UNEP-WCMC \& IUCN, 2019b). As Figure 4.2 shows, Seychelles, South Africa and Sudan have exceeded Aichi Targets coverage for marine and coastal protection, according to the WDPA.

IUCN's management categories for most protected areas in Eastern and Southern Africa have not been reported to the WDPA (Figure 4.4), although based on available data, Categories II, IV and $\mathrm{VI}$ are most commonly used. The discrepancy is partly due to a lack of reporting, as well as how the other categories are understood in Africa where the historical concept of 'fortress conservation' focused on formal protection of natural resources through the formation of national parks has been a dominant paradigm. It is likely that there will be an increase in the other categories as policy and legislation to manage these approaches to conservation are developed and implemented across the region. Some countries, such as South Africa, with over 1,500 protected areas, have not specifically classified these according to IUCN management categories.

While the governance type of many protected areas in the region has not been reported in the WDPA, most are governed by the

\section{Figure 4.2 Terrestrial protected area coverage in Eastern and Southern Africa}

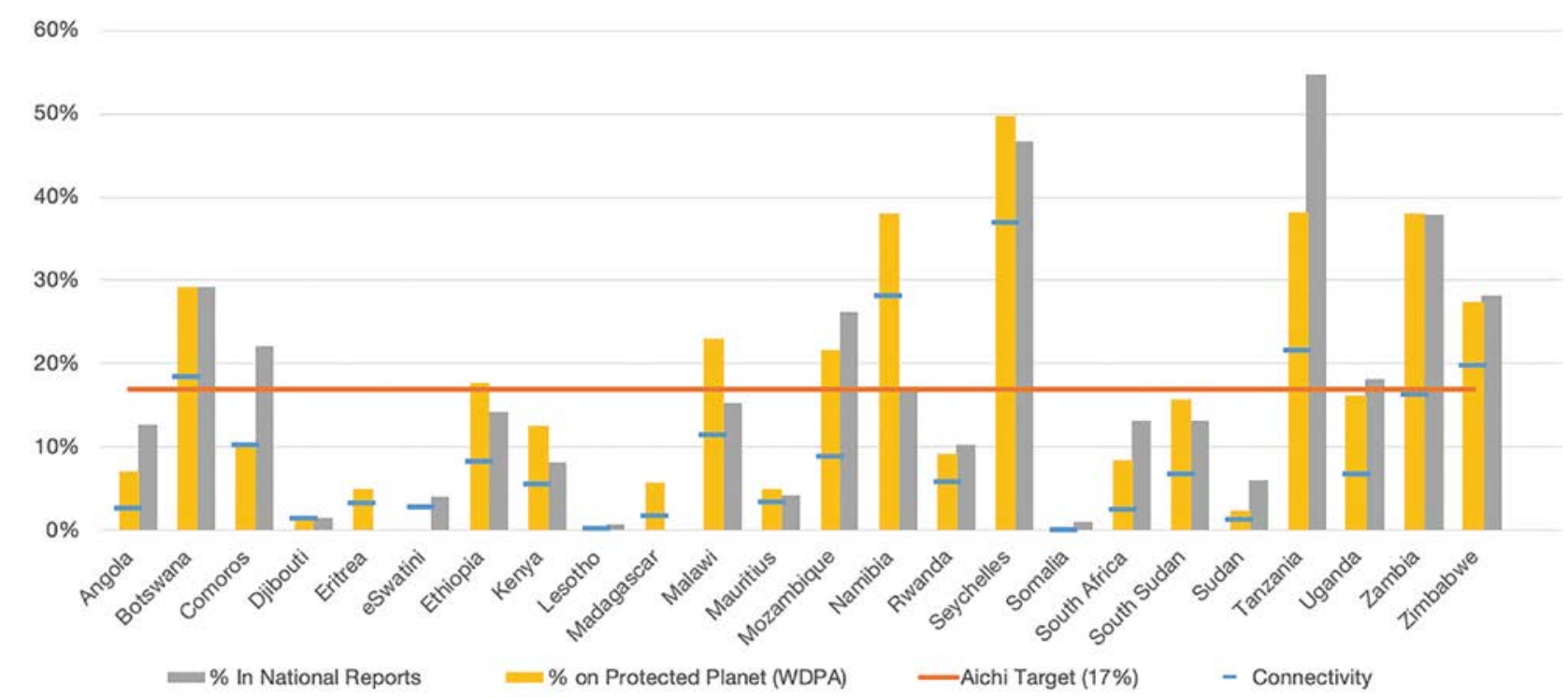

Note: See Appendix 2 for the data source of this figure, and Chapter 8 for detailed information on the country reports.

Sources: World Database on Protected Areas (UNEP-WCMC \& IUCN, 2019b), EC JRC/DOPA (2019a) and National Reports to the Convention on Biological Diversity.

9 The indicator is calculated through network analysis (EC JRC/DOPA, 2019b; Saura et al., 2017, 2018 \& 2019). 
Figure 4.3 Coastal and marine protected and conserved areas in Eastern and Southern Africa

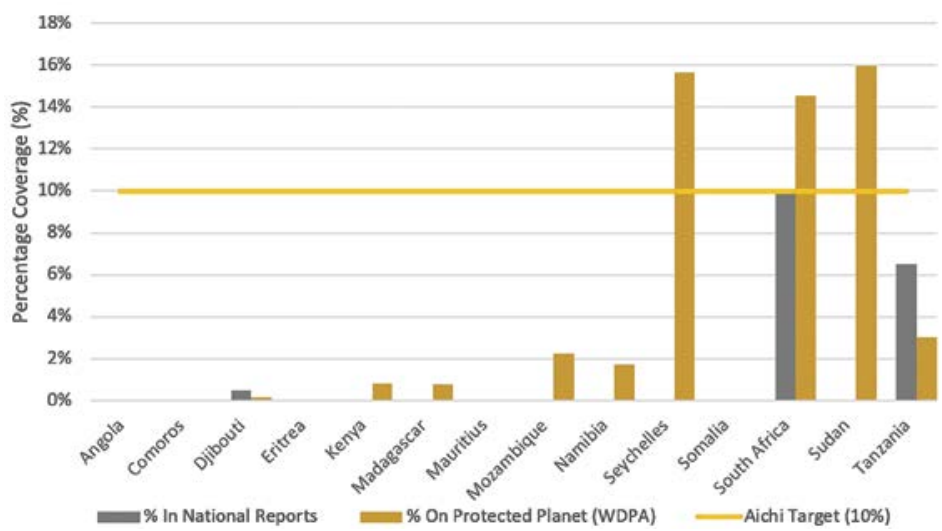

Note: See Appendix 2 for the data underlying this figure, and Chapter 3 for detailed information on the country reports.

Sources: World Database on Protected Areas (UNEP-WCMC \& IUCN, 2019b) and National Reports to the Convention on Biological Diversity.

Figure 4.4 IUCN management categories of protected and conserved areas in Eastern and Southern Africa

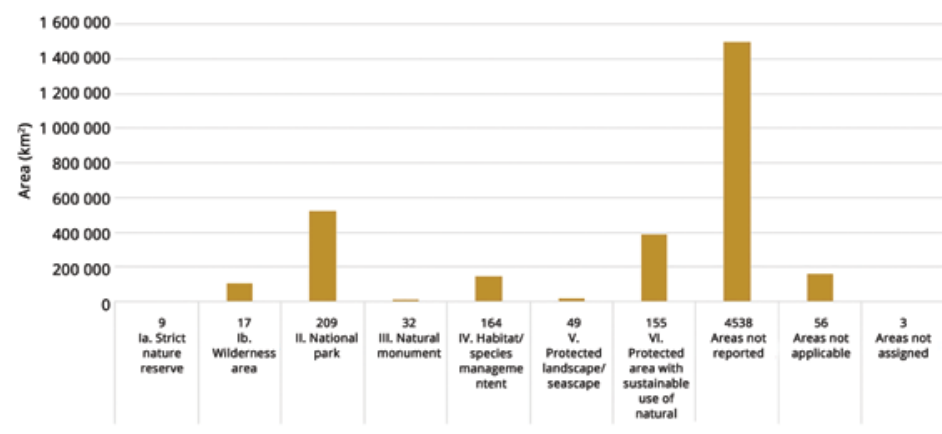

Note: See Appendix 2 for the data on this figure.

Source: World Database on Protected Areas (UNEP-WCMC \& IUCN, 2019a).

Figure 4.5 IUCN governance types of protected and conserved areas in Eastern and Southern Africa

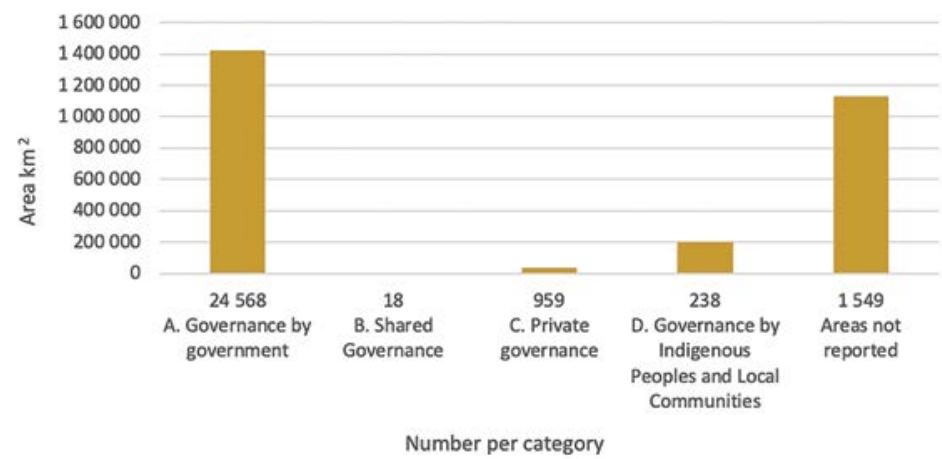

Note: See Appendix 2 for the data underlying this figure.

Source: World Database on Protected Areas (UNEP-WCMC \& IUCN, 2019a). 
State or government agencies (Governance Type A; see Figure 4.5). The dominance of State governance is largely as a result of historical processes related to the establishment of protected areas in line with the concept of 'fortress conservation'. This has been changing over time, with greater inclusion of communities in the governance of conservation and protected areas. For instance, of the 238 protected areas under governance by Indigenous peoples and local communities, $47 \%$ are found in Namibia under governance by local communities and the rest are found in Kenya, Madagascar and Tanzania, with one site in Botswana. In terms of private governance, it is still largely restricted to southern Africa, in countries such as Namibia and South Africa (98\% of the 959 privately governed sites are found in South Africa), and is largely related to wildlife tourism, game breeding and trophy hunting industries.

\subsection{Global designations and other priority areas in the region}

In Eastern and Southern Africa, 175 sites have been designated as of international importance (Table 4.1). Leading the list are Ramsar sites which highlight the importance of wetland conservation in the region.

Table 4.2 provides an annotated list of African natural and 'mixed' (natural/cultural) World Heritage Sites (as of 2019), which includes results of IUCN Conservation Outlook Assessments ${ }^{10}$ and dates of World Heritage Centre/IUCN monitoring missions undertaken (Howard \& Bertzky, 2019).
Many 'areas of particular importance to biodiversity' (as noted in Aichi Target 11) have been recognised as KBAs. Specific subsets of KBAs include the Alliance for Zero Extinction sites (AZEs), which are the last remaining refuges of one or more Endangered or Critically Endangered species, and IBAs which are important for the conservation of the world's birds (see section 2.6). At present, $735 \mathrm{KBAs}$ have been identified in the region of which 107 are AZEs and 692 IBAs (AZE Secretariat, 2019; BirdLife International, 2019b \& 2019c). Since AZEs, IBAs and KBAs are recognised priority sites for biodiversity conservation, many are already covered by protected and conserved areas, including the different global designations just mentioned. Unprotected AZEs, IBAs and KBAs should be considered as priorities for protected area expansion.

\section{Table 4.1 Global sites of importance in Eastern and Southern Africa}

\begin{tabular}{l|r}
\hline Global designation & Number of sites \\
\hline $\begin{array}{l}\text { Ramsar sites (Wetlands of International } \\
\text { Importance) }\end{array}$ & 109 \\
\hline UNESCO Man and Biosphere Reserves & 39 \\
\hline $\begin{array}{l}\text { UNESCO World Heritage Sites (Natural or } \\
\text { Mixed) }\end{array}$ & 27 \\
\hline
\end{tabular}

Source: Ramsar Convention on Wetlands (2019); UNESCO (2019a; 2019b). Detailed information on Ramsar sites and Biosphere Reserves is available in Appendix 3.

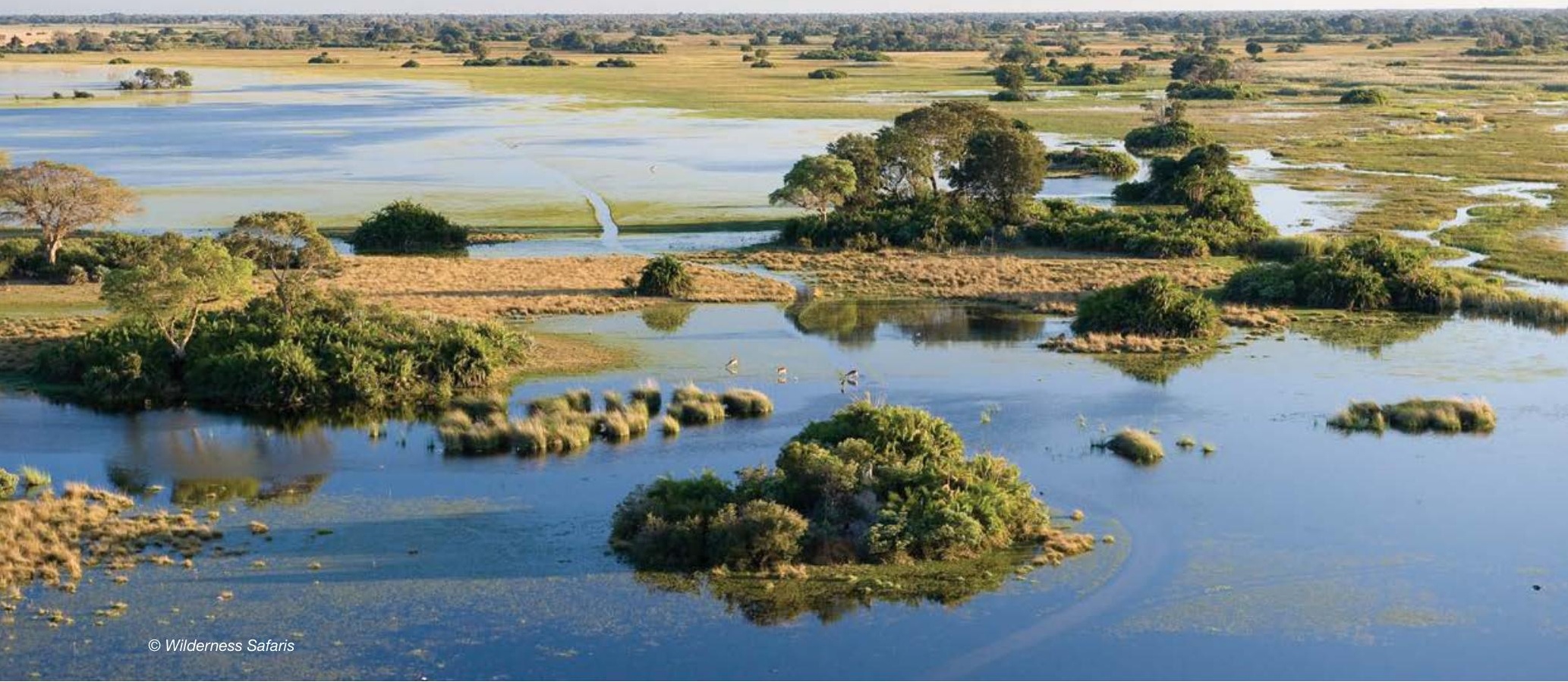

10 For more information, please see: https://www.iucn.org/resources/conservation-tools/iucn-world-heritage-outlook 
Table 4.2 Annotated list of Eastern and Southern African natural and 'mixed' (natural/cultural) World Heritage Sites (as of 2019), including results of IUCN Conservation Outlook Assessment and dates of World Heritage Centre/IUCN monitoring missions

\begin{tabular}{|c|c|c|c|c|c|c|c|c|c|c|c|c|}
\hline$\frac{\stackrel{\Phi}{E}}{\underset{\tilde{E}}{\tilde{L}}}$ & $\begin{array}{l}\frac{2}{1} \\
\frac{1}{2} \\
0 \\
0\end{array}$ & 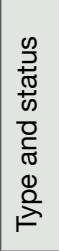 & 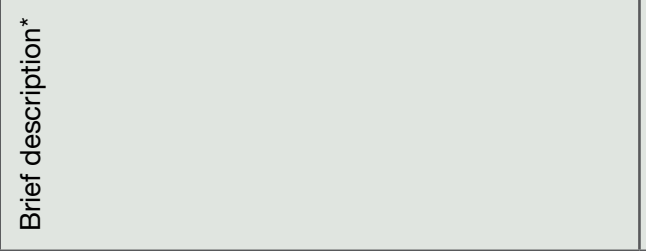 & 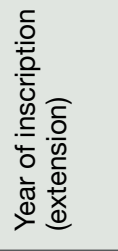 & 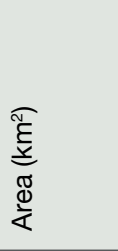 & 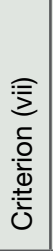 & 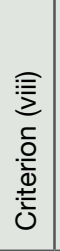 & 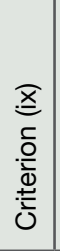 & 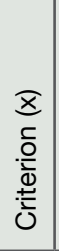 & 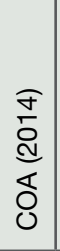 & $\begin{array}{l}\text { E } \\
\bar{D} \\
\text { d } \\
\delta \\
0\end{array}$ & 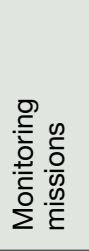 \\
\hline 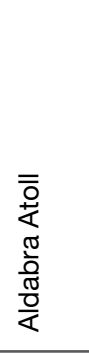 & 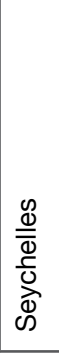 & 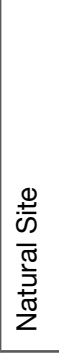 & $\begin{array}{l}\text { The atoll is comprised of four large coral islands } \\
\text { which enclose a shallow lagoon; the group of } \\
\text { islands is itself surrounded by a coral reef. Due to } \\
\text { difficulties of access and the atoll's isolation, } \\
\text { Aldabra has been protected from human influence } \\
\text { and thus retains some } 152,000 \text { giant tortoises, the } \\
\text { world's largest population of this reptile. For } \\
\text { details see: http://whc.unesco.org/en/list/185 }\end{array}$ & 1982 & 350 & & & & & & & - \\
\hline 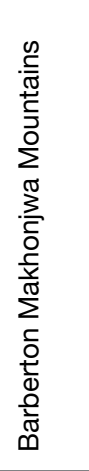 & 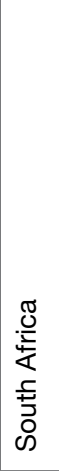 & 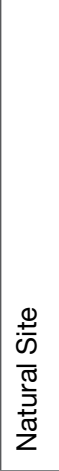 & $\begin{array}{l}\text { Situated in north-eastern South Africa, the } \\
\text { Barberton Makhonjwa Mountains comprise } 40 \% \\
\text { of the Barberton Greenstone Belt, one of the } \\
\text { world's oldest geological structures. The property } \\
\text { represents the best-preserved succession of } \\
\text { volcanic and sedimentary rock dating back } 3.6 \text { to } \\
3.25 \text { billion years and forms a diverse repository } \\
\text { of information on surface conditions, meteorite } \\
\text { impacts, volcanism, continent-building processes } \\
\text { and the environment of early life. For details see: } \\
\text { http://whc.unesco.org/en/list/1575 }\end{array}$ & 2018 & 1131 & & & & & & & - \\
\hline 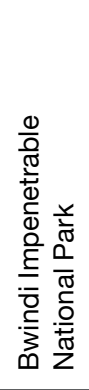 & $\begin{array}{l}\frac{\pi}{0} \\
\text { 胥 } \\
\text { ర్ }\end{array}$ & 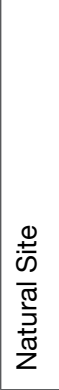 & $\begin{array}{l}\text { Located in south-western Uganda, Bwindi covers } \\
32,000 \text { ha of montane forest and is known for its } \\
\text { exceptional biodiversity, with more than } 160 \\
\text { species of trees and over } 100 \text { species of ferns. } \\
\text { Many types of birds and butterflies can also be } \\
\text { found there, as well as numerous globally } \\
\text { threatened species, including the endangered } \\
\text { mountain gorilla. For details see: } \\
\text { http://whc.unesco.org/en/list/682 }\end{array}$ & 1994 & 321 & & & & & & & - \\
\hline 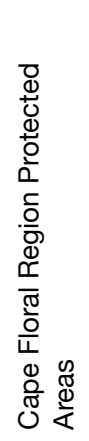 & 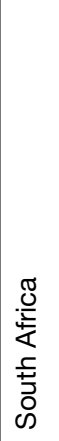 & 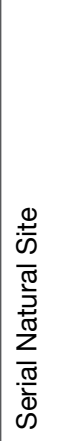 & $\begin{array}{l}\text { The area is one of the world's great centres of } \\
\text { terrestrial biodiversity. The extended area includes } \\
\text { national parks, nature reserves, wilderness areas, } \\
\text { State forests and mountain catchment areas. It } \\
\text { supports a significant number of endemic species } \\
\text { associated with the Fynbos vegetation, a fine- } \\
\text { leaved sclerophyllic shrubland adapted to both a } \\
\text { Mediterranean climate and periodic fires, which is } \\
\text { unique to the Cape Floral Region. For details see: } \\
\text { http://whc.unesco.org/en/list/1007 }\end{array}$ & $\begin{array}{r}2004 \\
(2015)\end{array}$ & 10947 & & & & & & & - \\
\hline
\end{tabular}




\begin{tabular}{|c|c|c|c|c|c|c|c|c|c|c|c|c|}
\hline $\begin{array}{l}\frac{1}{\mathbb{N}} \\
\text { Z }\end{array}$ & 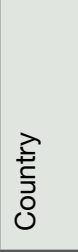 & 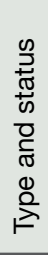 & 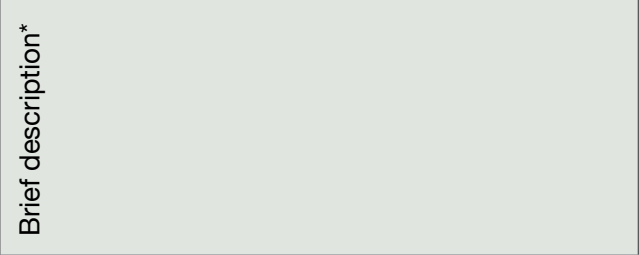 & 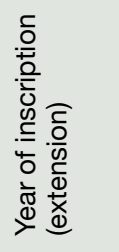 & 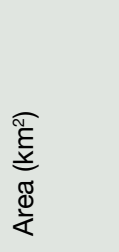 & 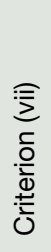 & 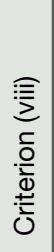 & 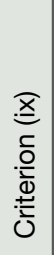 & 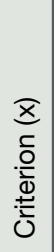 & 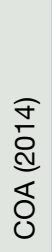 & 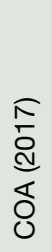 & 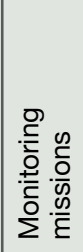 \\
\hline 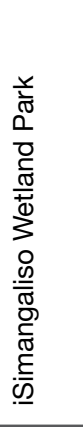 & 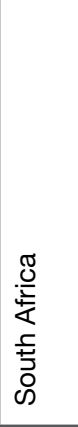 & 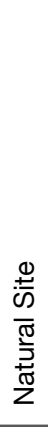 & $\begin{array}{l}\text { The ongoing fluvial, marine and aeolian processes } \\
\text { in the site have produced a variety of landforms, } \\
\text { including coral reefs, long sandy beaches, coastal } \\
\text { dunes, lake systems, swamps, and extensive } \\
\text { reed and papyrus wetlands. The mosaic of } \\
\text { landforms and habitat types creates breathtaking } \\
\text { scenic vistas. The site contains critical habitats } \\
\text { for a range of species from Africa's marine, } \\
\text { wetland and savanna environments. For details } \\
\text { see: http://whc.unesco.org/en/list/914 }\end{array}$ & 1999 & 2396 & & & & & & & - \\
\hline 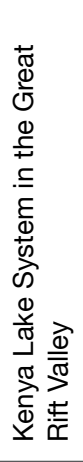 & 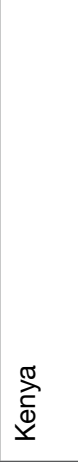 & 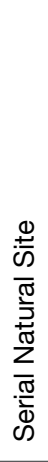 & $\begin{array}{l}\text { The site comprises three inter-linked shallow } \\
\text { lakes: Lake Bogoria, Lake Nakuru and Lake } \\
\text { Elementaita in the Rift Valley. The property is } \\
\text { home to } 13 \text { globally threatened bird species and } \\
\text { some of the highest bird diversities in the world. It } \\
\text { is the single most important foraging site for the } \\
\text { Lesser Flamingo. The area features sizeable } \\
\text { mammal populations, including Black Rhino, } \\
\text { Rothschild's Giraffe, Greater Kudu, lion, cheetah } \\
\text { and wild dogs. For details see: } \\
\text { http://whc.unesco.org/en/list/1060 }\end{array}$ & 2011 & 320 & & & & & & & - \\
\hline 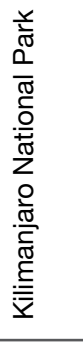 & 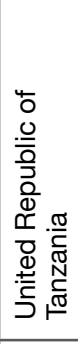 & 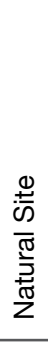 & $\begin{array}{l}\text { At } 5,895 \mathrm{~m} \text {, Kilimanjaro is the highest point in } \\
\text { Africa. This volcanic massif stands in splendid } \\
\text { isolation above the surrounding plains, with its } \\
\text { snowy peak looming over the savanna. The } \\
\text { mountain is encircled by mountain forest. } \\
\text { Numerous mammals, many of them endangered } \\
\text { species, live in the park. For details see: } \\
\text { http://whc.unesco.org/en/list/403 }\end{array}$ & 1987 & 756 & & & & & & & - \\
\hline 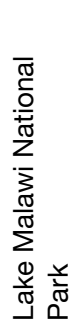 & $\frac{\sum_{\frac{\pi}{\pi}}^{\bar{\pi}}}{\frac{\pi}{\sum}}$ & 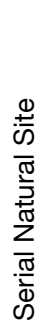 & $\begin{array}{l}\text { Located at the southern end of the great expanse } \\
\text { of Lake Malawi/Nyasa/Niassa, with its deep, clear } \\
\text { waters and mountain backdrop, the national park } \\
\text { is home to many hundreds of fish species, nearly } \\
\text { all endemic. Its importance for the study of } \\
\text { evolution is comparable to that of the Galápagos } \\
\text { Islands. For details see: } \\
\text { http://whc.unesco.org/en/list/289 }\end{array}$ & 1984 & 94 & & & & & & & $\begin{array}{l}1995 \\
2014\end{array}$ \\
\hline
\end{tabular}




\begin{tabular}{|c|c|c|c|c|c|c|c|c|c|c|c|c|}
\hline$\frac{\stackrel{0}{E}}{\underset{\pi}{\tilde{\pi}}}$ & 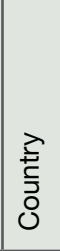 & 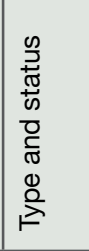 & 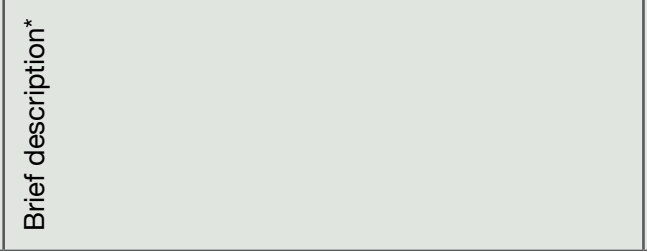 & 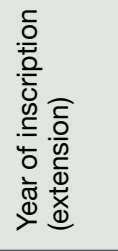 & 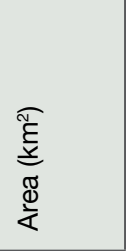 & 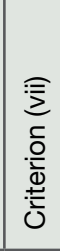 & 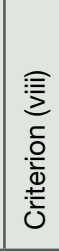 & 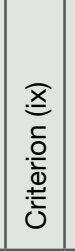 & 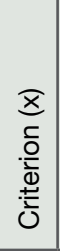 & \begin{tabular}{l}
\multirow{\sigma}{\sigma}{} \\
$\stackrel{d}{d}$ \\
$\delta$ \\
$\delta$ \\
0
\end{tabular} & $\begin{array}{l}\text { E } \\
\bar{d} \\
\text { d } \\
\delta \\
0\end{array}$ & 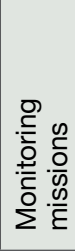 \\
\hline 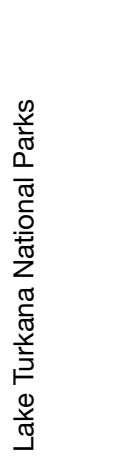 & 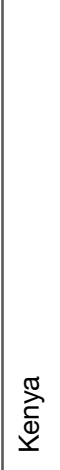 & 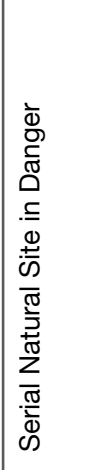 & $\begin{array}{l}\text { The most saline of Africa's large lakes, Turkana is } \\
\text { an outstanding laboratory for the study of plant } \\
\text { and animal communities. The three national parks } \\
\text { serve as a stopover for migrant waterfowl and are } \\
\text { major breeding grounds for the Nile Crocodile, } \\
\text { and other species. The Koobi Fora deposits, rich } \\
\text { in mammalian, molluscan and other fossil remains, } \\
\text { have contributed more to the understanding of } \\
\text { paleo-environments than any other site on the } \\
\text { continent. For details see: } \\
\text { http://whc.unesco.org/en/list/801 }\end{array}$ & 2001 & 1615 & & & & & & & $\begin{array}{l}2012 \\
2015\end{array}$ \\
\hline 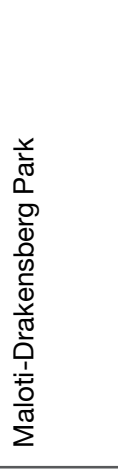 & 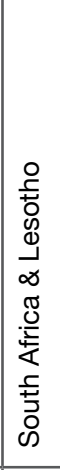 & 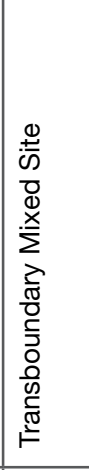 & $\begin{array}{l}\text { The site has exceptional natural beauty in its } \\
\text { soaring basaltic buttresses, incisive dramatic } \\
\text { cutbacks, and golden sandstone ramparts, while } \\
\text { the diversity of habitats protects a high level of } \\
\text { endemic and globally important plants, and } \\
\text { several endangered animal species. This } \\
\text { spectacular natural site contains many caves and } \\
\text { rock-shelters with the largest and most } \\
\text { concentrated group of paintings in Africa south of } \\
\text { the Sahara. For details see: } \\
\text { http://whc.unesco.org/en/list/985 }\end{array}$ & $\begin{array}{r}2000 \\
(2013)\end{array}$ & 2493 & & & & & & & - \\
\hline 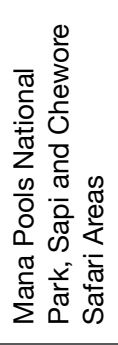 & 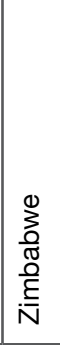 & 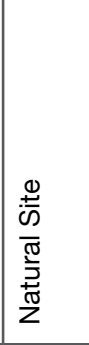 & $\begin{array}{l}\text { On the banks of the Zambezi River, great cliffs } \\
\text { overhang the river and the floodplains. The area is } \\
\text { home to a remarkable concentration of wild } \\
\text { animals, including elephant, buffalo, leopard and } \\
\text { cheetah. An important concentration of Nile } \\
\text { Crocodiles is also found in the area. For details } \\
\text { see: } \\
\text { http://whc.unesco.org/en/list/302 }\end{array}$ & 1984 & 6766 & & & & & & & 2011 \\
\hline 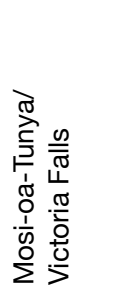 & 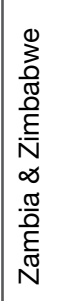 & 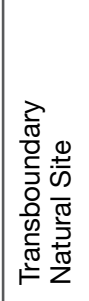 & $\begin{array}{l}\text { These are among the most spectacular waterfalls } \\
\text { in the world. The Zambezi River, which is more } \\
\text { than } 2-\mathrm{km} \text { wide at this point, plunges noisily down } \\
\text { a series of basalt gorges and raises an iridescent } \\
\text { mist that can be seen more than } 20 \mathrm{~km} \text { away. For } \\
\text { details see: } \\
\text { http://whc.unesco.org/en/list/509 }\end{array}$ & 1989 & 69 & & & & & & & $\begin{array}{l}2000 \\
2006\end{array}$ \\
\hline
\end{tabular}




\begin{tabular}{|c|c|c|c|c|c|c|c|c|c|c|c|c|}
\hline$\frac{\mathscr{Q}}{\frac{1}{\pi}}$ & $\begin{array}{l}\text { D } \\
\text { ड̃ } \\
0 \\
0\end{array}$ & 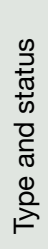 & 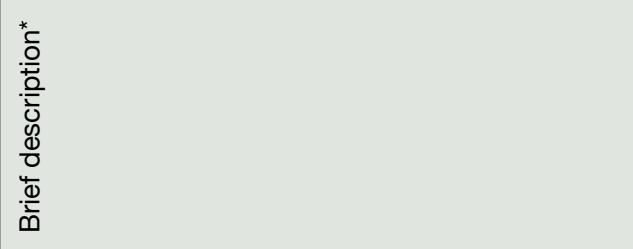 & 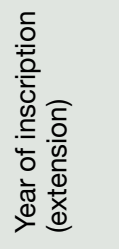 & 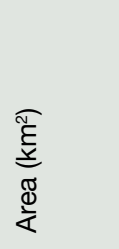 & 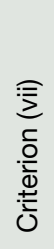 & 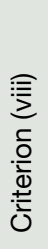 & 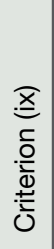 & 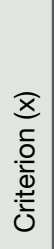 & 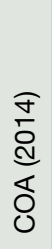 & 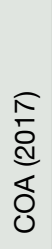 & 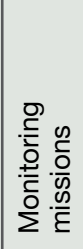 \\
\hline 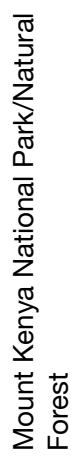 & 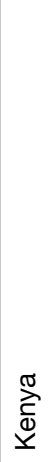 & 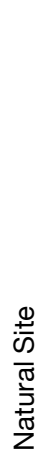 & $\begin{array}{l}\text { Mount Kenya is the second highest peak in Africa, } \\
\text { an ancient extinct volcano. There are } 12 \text { remnant } \\
\text { glaciers on the mountain, all receding rapidly, and } \\
\text { four secondary peaks that sit at the head of } \\
\text { U-shaped glacial valleys. With its rugged glacier- } \\
\text { clad summits and forested middle slopes, Mount } \\
\text { Kenya is one of the most impressive landscapes } \\
\text { in Eastern Africa. The evolution and ecology of its } \\
\text { afro-alpine flora provide an outstanding example } \\
\text { of ecological and biological processes. For details } \\
\text { see: http://whc.unesco.org/en/list/800 }\end{array}$ & $\begin{array}{r}1997 \\
(2013)\end{array}$ & 2023 & & & & & & & 2008 \\
\hline 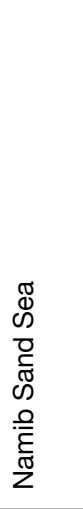 & $\begin{array}{l}\frac{\pi}{0} \\
\frac{\overline{0}}{\bar{\pi}} \\
\frac{\pi}{Z}\end{array}$ & 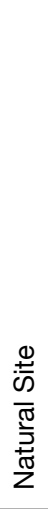 & $\begin{array}{l}\text { Namib Sand Sea is the only coastal desert in the } \\
\text { world that includes extensive dune fields } \\
\text { influenced by fog. The site features gravel plains, } \\
\text { coastal flats, rocky hills, inselbergs within the } \\
\text { sand sea, a coastal lagoon and ephemeral rivers, } \\
\text { resulting in a landscape of exceptional beauty. } \\
\text { Fog is the primary source of water in the site, } \\
\text { accounting for a unique environment in } \\
\text { which endemic invertebrates, reptiles and } \\
\text { mammals adapt to an ever-changing variety of } \\
\text { microhabitats and ecological niches. For details } \\
\text { see: http://whc.unesco.org/en/list/1430 }\end{array}$ & 2013 & 30777 & & & & & & & - \\
\hline 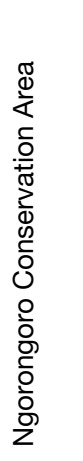 & 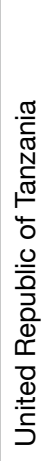 & $\begin{array}{l}\stackrel{0}{ \pm} \\
\dot{0} \\
0 \\
\stackrel{x}{0} \\
\stackrel{x}{\Sigma}\end{array}$ & $\begin{array}{l}\text { This multiple land use area, with wildlife coexisting } \\
\text { with semi-nomadic Maasai pastoralists practicing } \\
\text { traditional livestock grazing, includes the } \\
\text { spectacular Ngorongoro Crater, the world's } \\
\text { largest caldera. The property adjoins Serengeti } \\
\text { National Park and hosts the annual migration of } \\
\text { wildebeest, zebra and gazelle on its northern } \\
\text { plains for part of the year. The site provides } \\
\text { evidence of human evolution, including early } \\
\text { hominid footprints dating back } 3.6 \text { million years. } \\
\text { For details see: http://whc.unesco.org/en/list/39 }\end{array}$ & $\begin{array}{r}1979 \\
(2010)\end{array}$ & 8094 & & & & & & & $\begin{array}{l}1986 \\
2007 \\
2012 \\
2017 \\
2019\end{array}$ \\
\hline 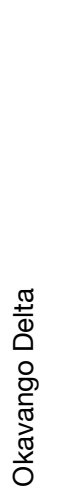 & $\begin{array}{l}\stackrel{\pi}{c} \\
\sum_{00}^{0} \\
\stackrel{0}{0} \\
\oplus\end{array}$ & 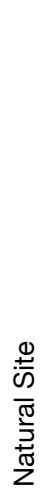 & $\begin{array}{l}\text { This delta comprises permanent marshlands and } \\
\text { seasonally flooded plains. It is one of the very few } \\
\text { major interior delta systems that do not flow into a } \\
\text { sea or ocean with a wetland system that is almost } \\
\text { intact. It is an exceptional example of the } \\
\text { interaction between climatic, hydrological and } \\
\text { biological processes. The Okavango Delta is } \\
\text { home to some of the world's most threatened } \\
\text { species of large mammals, such as the cheetah, } \\
\text { White Rhino, Black Rhino, African wild dog and } \\
\text { lion. For details see: } \\
\text { http://whc.unesco.org/en/list/1432 }\end{array}$ & 2014 & 20236 & & & & & & & - \\
\hline
\end{tabular}




\begin{tabular}{|c|c|c|c|c|c|c|c|c|c|c|c|c|}
\hline 离 & $\begin{array}{l}\text { Dे } \\
\text { 禀 } \\
\text { O }\end{array}$ & 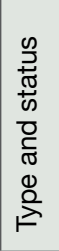 & 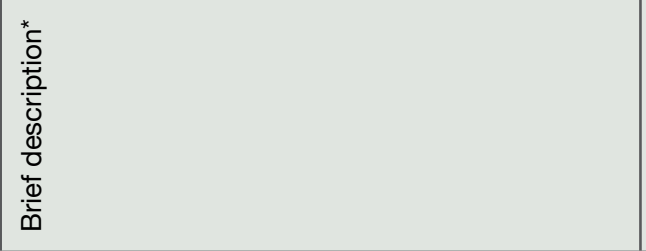 & 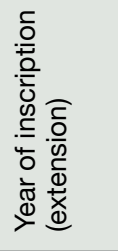 & 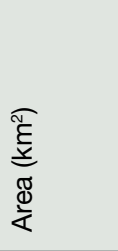 & 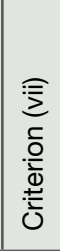 & 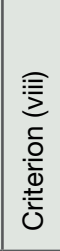 & 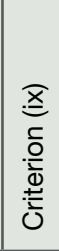 & 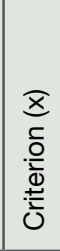 & $\left|\begin{array}{l}\sigma \\
\bar{\sigma} \\
d \\
\mathbb{d} \\
\delta \\
0\end{array}\right|$ & $\begin{array}{l}\text { E } \\
\bar{D} \\
\text { d } \\
\delta \\
0 \\
0\end{array}$ & 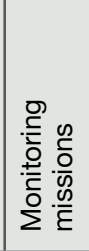 \\
\hline 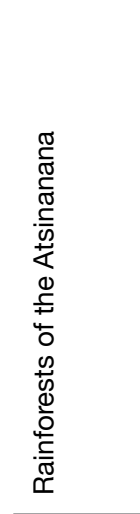 & 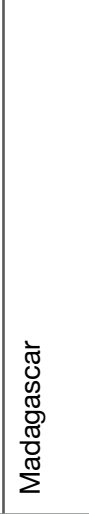 & 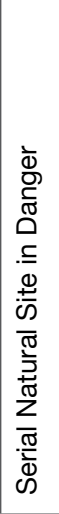 & $\begin{array}{l}\text { The site comprises six national parks that protect } \\
\text { relict forests that are critically important for } \\
\text { maintaining ongoing ecological processes } \\
\text { necessary for the survival of Madagascar's unique } \\
\text { biodiversity. Madagascar's plant and animal life } \\
\text { evolved in isolation and many species are rare } \\
\text { and globally threatened, especially the iconic } \\
\text { lemurs. The rainforests are important to both } \\
\text { ecological and biological processes as well as } \\
\text { their biodiversity and the threatened species they } \\
\text { support. For details see: } \\
\text { http://whc.unesco.org/en/list/1257 }\end{array}$ & 2007 & 4797 & & & & & & & $\begin{array}{l}2011 \\
2015\end{array}$ \\
\hline 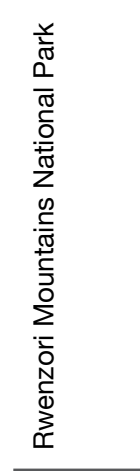 & $\begin{array}{l}\frac{\pi}{0} \\
\stackrel{0}{\widetilde{\pi}} \\
\stackrel{0}{J}\end{array}$ & 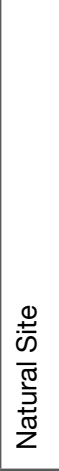 & $\begin{array}{l}\text { The Rwenzori Mountains National Park covers } \\
\text { nearly } 100,000 \text { ha in western Uganda and } \\
\text { comprises the main part of the Rwenzori mountain } \\
\text { chain, which includes Africa's third highest peak } \\
\text { (Mount Margherita: } 5,109 \mathrm{~m} \text { ). The region's } \\
\text { glaciers, waterfalls and lakes make it one of } \\
\text { Africa's most beautiful alpine areas. The park has } \\
\text { many natural habitats of endangered species and } \\
\text { a rich and unusual flora comprising, among other } \\
\text { species, the Giant Heather. For details see: } \\
\text { http://whc.unesco.org/en/list/684 }\end{array}$ & 1994 & 996 & & & & & & & - \\
\hline 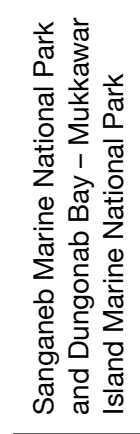 & 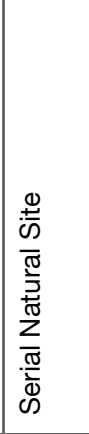 & $\begin{array}{l}\frac{5}{5} \\
0 \\
0 \\
0\end{array}$ & $\begin{array}{l}\text { The site consists of two separate areas: Sanganeb } \\
\text { is an isolated coral atoll in the central Red Sea, } \\
\text { and the Dungonab Bay and Mukkawar Island } \\
\text { component includes a diverse system of coral } \\
\text { reefs, mangroves, seagrass beds, beaches and } \\
\text { islets. The site provides a habitat for an important } \\
\text { population of dugongs, as well as seabirds, } \\
\text { marine mammals, fish, sharks, turtles and manta } \\
\text { rays. For details see: } \\
\text { http://whc.unesco.org/en/list/262 }\end{array}$ & 2016 & 2607 & & & & & & & - \\
\hline 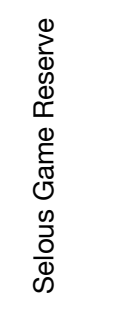 & 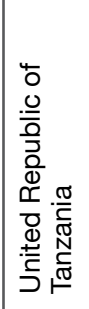 & 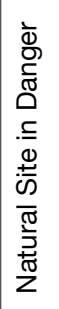 & $\begin{array}{l}\text { Large numbers of elephant, Black Rhino, cheetah, } \\
\text { giraffe, hippo and crocodile live in this immense } \\
\text { sanctuary, which measures } 50,000 \mathrm{~km}^{2} \text { and is } \\
\text { relatively undisturbed by human impact. The park } \\
\text { has a variety of vegetation zones, ranging from } \\
\text { dense thickets to open wooded grasslands. For } \\
\text { details see: http://whc.unesco.org/en/list/199 }\end{array}$ & 1982 & 51200 & & & & & & & $\begin{array}{l}2007 \\
2008 \\
2013 \\
2017\end{array}$ \\
\hline
\end{tabular}




\begin{tabular}{|c|c|c|c|c|c|c|c|c|c|c|c|c|}
\hline$\frac{\mathbb{E}}{\stackrel{\mathbb{\pi}}{Z}}$ & $\begin{array}{l}\text { Dे } \\
\text { 竞 } \\
\text { O }\end{array}$ & 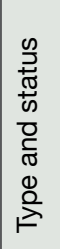 & 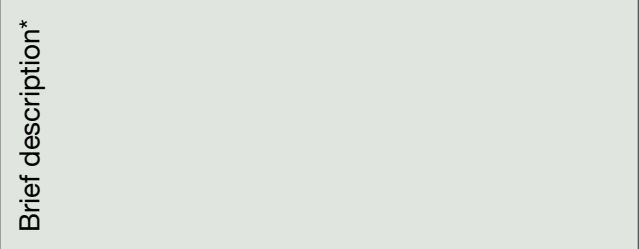 & 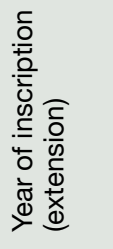 & 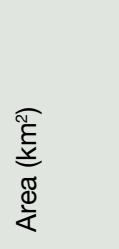 & 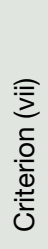 & 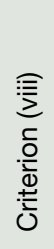 & 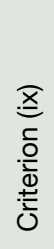 & 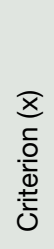 & 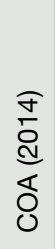 & 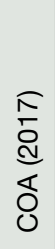 & 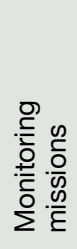 \\
\hline 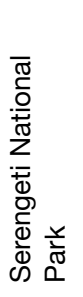 & 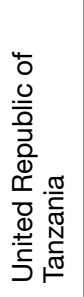 & 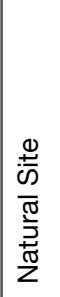 & $\begin{array}{l}\text { The vast plains of the Serengeti comprise } 1.5 \\
\text { million ha of savanna. The annual migration to } \\
\text { permanent water holes of vast herds of herbivores } \\
\text { (wildebeest, gazelle and zebra), followed by their } \\
\text { predators, is one of the most impressive natural } \\
\text { events in the world. For details see: } \\
\text { http://whc.unesco.org/en/list/156 }\end{array}$ & 1981 & 14763 & & & & & & & - \\
\hline 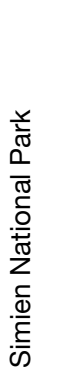 & $\begin{array}{l}\frac{\pi}{0} \\
\frac{0}{\frac{0}{I}} \\
\frac{\tilde{w}}{4}\end{array}$ & & $\begin{array}{l}\text { Massive erosion over millions of years on the } \\
\text { Ethiopian plateau has created one of the most } \\
\text { spectacular landscapes in the world, with jagged } \\
\text { mountain peaks, deep valleys and sharp } \\
\text { precipices dropping some } 1,500 \mathrm{~m} \text {. The park is } \\
\text { home to some extremely rare animals such as the } \\
\text { Gelada Baboon, the Ethiopian Wolf and the Walia } \\
\text { lbex, a goat found nowhere else in the world. For } \\
\text { details see: http://whc.unesco.org/en/list/9 }\end{array}$ & 1978 & 136 & & & & & & & $\begin{array}{l}1981 \\
1996 \\
1997 \\
2017\end{array}$ \\
\hline 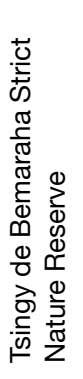 & 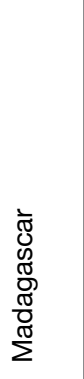 & 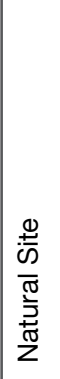 & $\begin{array}{l}\text { This site comprises karstic landscapes and } \\
\text { limestone uplands cut into impressive 'tsingy' } \\
\text { peaks and a 'forest' of limestone needles, the } \\
\text { spectacular canyon of the Manambolo River, } \\
\text { rolling hills and high peaks. The undisturbed } \\
\text { forests, lakes and mangrove swamps are the } \\
\text { habitat for rare and endangered lemurs and birds. } \\
\text { For details see: } \\
\text { http://whc.unesco.org/en/list/494 }\end{array}$ & 1990 & 1520 & & & & & & & - \\
\hline 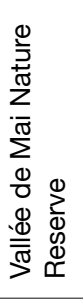 & 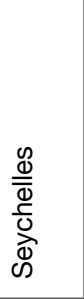 & 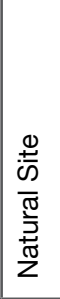 & $\begin{array}{l}\text { In the heart of the small island of Praslin, the } \\
\text { reserve has the vestiges of a unique natural palm } \\
\text { forest preserved in almost its original state. The } \\
\text { famous coco de mer, from a palm-tree once } \\
\text { believed to grow in the depths of the sea, is the } \\
\text { largest seed in the plant kingdom. For details see: } \\
\text { http://whc.unesco.org/en/list/261 }\end{array}$ & 1982 & 0.2 & & & & & & & - \\
\hline 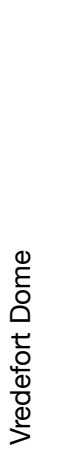 & 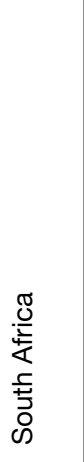 & 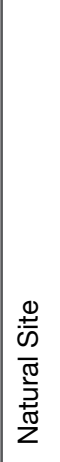 & $\begin{array}{l}\text { Vredefort Dome is a representative part of a } \\
\text { meteorite impact structure, or astrobleme. } \\
\text { It provides evidence of the world's greatest } \\
\text { known single energy release event, which had } \\
\text { devastating global effects including, according to } \\
\text { some scientists, major evolutionary changes on } \\
\text { Earth. Dating back } 2,023 \text { million years, it is the } \\
\text { oldest astrobleme yet found and, with a radius of } \\
190 \mathrm{~km} \text {, it is also the largest and the most deeply } \\
\text { eroded. For details see: } \\
\text { http://whc.unesco.org/en/list/1162 }\end{array}$ & 2005 & 300 & & & & & & & - \\
\hline
\end{tabular}

Source: Howard \& Bertzky (2019). 


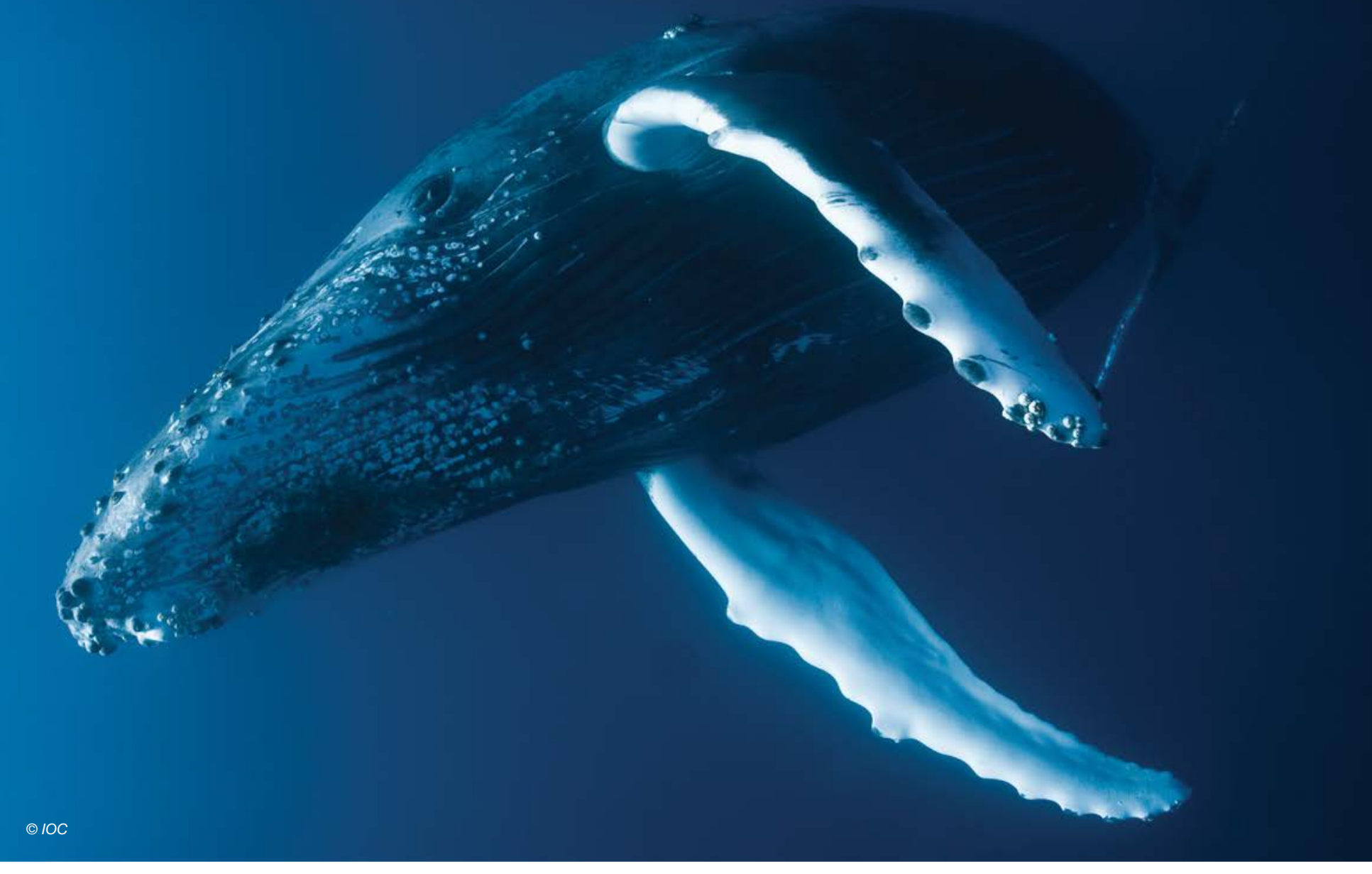

\subsection{Ecological representativity}

One of the core commitments in the CBD is the principle of representative samples of all species and ecosystems being conserved within the protected area network at a sufficient scale to ensure their long-term persistence. Representation gaps refer to species, ecosystems and ecological processes that are not included, or not sufficiently included, within the protected area system. This section provides an initial ecological gap analysis by assessing the extent to which ecoregions are represented in protected areas in the Eastern and Southern Africa region.

It is equally important to ensure that protected areas are equitably and effectively managed (see Chapter 9 and Chapter 10). Only if protected areas are well managed will the species and ecosystems in the protected area network be conserved.

The full regional summary of representativity for marine and terrestrial ecoregions and pelagic provinces is available in Appendix 4. These statistics were compiled by overlaying the protected area network on a combined layer representing the marine and terrestrial ecoregions and pelagic provinces of the world, which was prepared by EC JRC/DOPA based on data defined by Olson et al. (2001) and Spalding et al. (2007 and 2012). The marine ecoregions were clipped to the coastline of the terrestrial ecoregions and an outer boundary corresponding to the 200-meter isobath (Spalding et al., 2007) as described on the DOPA website. ${ }^{11}$

Eighty-six of the world's terrestrial ecoregions fall within the Eastern and Southern African region defined for this report. Sixty-three of these terrestrial ecoregions have more than $97 \%$ of their area in the region, and of those, 32 (around 50\%) achieve protection areas exceeding 17\% (Spalding et al., 2007; 2012).

Some endemic ecoregions, such as the Angolan montane forestgrassland mosaic, Eritrean coastal desert, Hobyo grasslands and shrublands and Somali montane xeric woodlands, have less than $1 \%$ of protected and conserved areas formally delineated in the WDPA. 
Figure 4.6 Protection levels for terrestrial ecoregions represented within the region
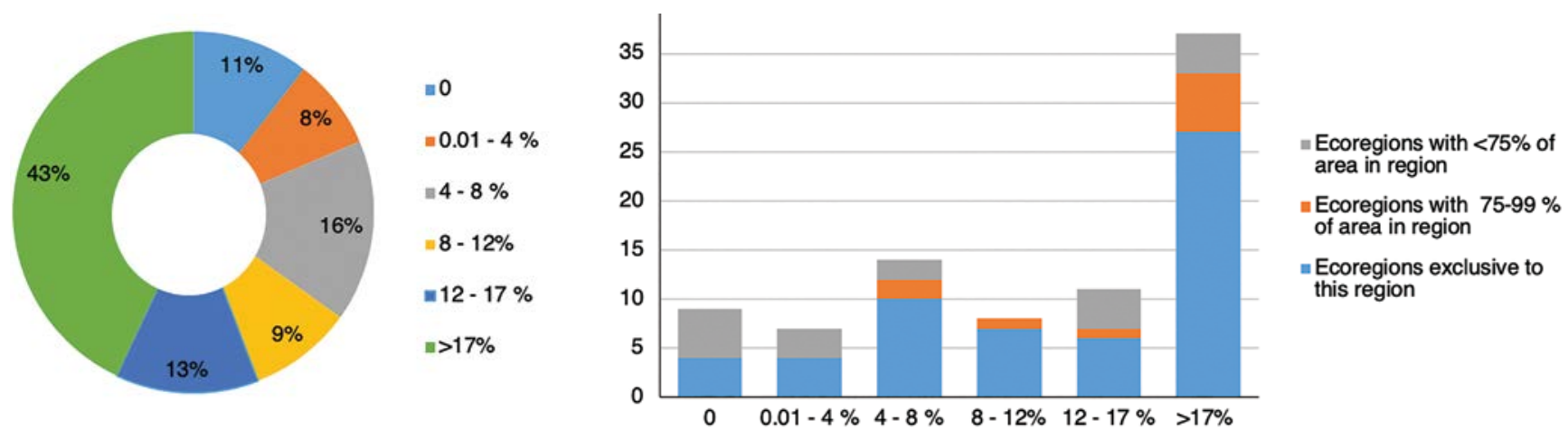

Source: EC JRC/DOPA (2019a).

Figure 4.7 Protection levels for marine ecoregions and pelagic provinces represented within the region
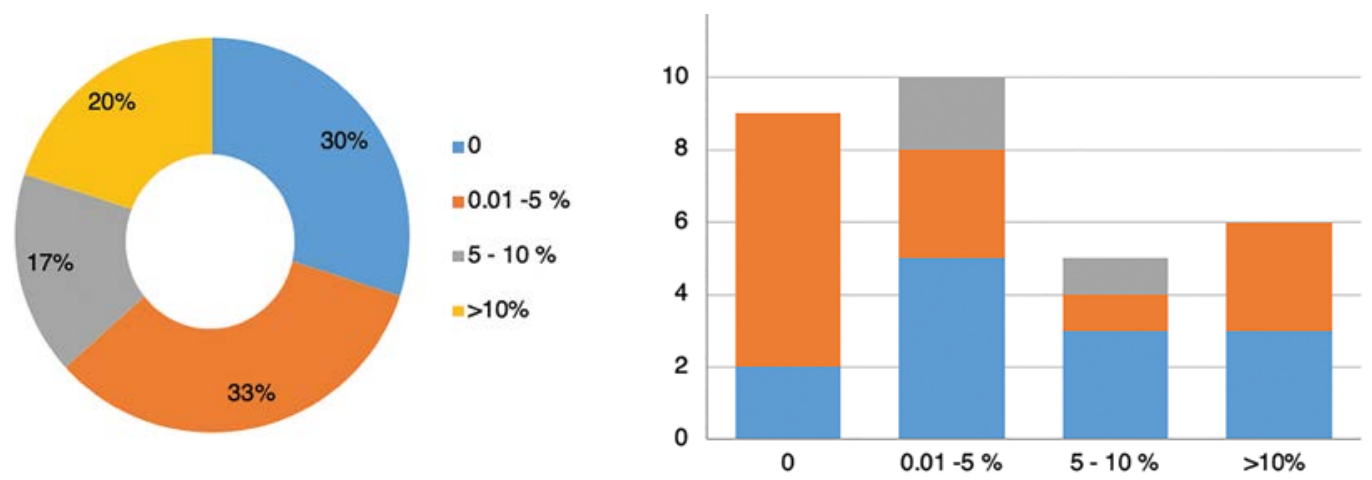

$=$ Ecoregions with $<75 \%$ of area in region

Ecoregions with $75-99 \%$ of area in region

Ecoregions exclusive to this region

Source: EC JRC/DOPA (2019a).

Of the world's marine ecoregions or pelagic provinces, 30 are found in the region (Figure 4.7), 13 lie in the region amounting to more than $95 \%$ of that area. Three have protection areas exceeding $10 \%$ of the regional share: the Bight of Sofala in Mozambique, the East African Coral Coast and Prince Edward Islands. The Prince Edward Islands ecoregion (belonging to South Africa) is $100 \%$ endemic and $100 \%$ protected, but only part of its area is no-take (the highest level of protection, which prohibits removal of any fish or other organisms) as for many other marine protected areas. The full regional summary of representativeness for terrestrial ecoregions as defined by WWF is available in Appendix 4.

Biogeographic classification systems can help planners to include the full range of ecosystems in global and regional conservation and development strategies. The best available mapping for ecological representativeness is the 'terrestrial ecoregion' mapping (see the results in Figure 4.8). However, following current practice, the UNESCO Man and Biosphere Reserves are not included in the calculations, as many of their buffer areas do not meet IUCN's definition of protected areas (UNEP-WCMC \& IUCN, 2016).

Ecoregions are a broad surrogate for ecological representativeness, and selected because the data is consistent for large-scale analyses. At a finer level, countries undertake much more detailed analyses to ensure protection of ecosystems, landscapes and plant and animal species.

\subsection{What has changed in protected area coverage?}

Aichi Target 11 has encouraged countries to protect $10 \%$ of their marine area and $17 \%$ of their land area, and progress is being made in achieving this target. It is sometimes difficult, however, to understand the dynamic nature of the protected area estate. There are many changes, including the creation of new sites through gazettal, the removal of sites by degazettement and the expansion or reduction of existing sites (Golden Kroner et al., 2019; Lewis et al., 2017). Protected area restrictions and regulations can also change, through upgrading or downgrading of protections (Golden Kroner et al., 2019). Sometimes a change in designation or name of a site, or the combination of two protected areas to form a larger one, could appear as a degazettement and at the same time as a new gazettal, perhaps under a different name, making actual changes in extent and protection of sites difficult to interpret. A case in point is Tanzania's Julius Nyerere National Park, which was 
Figure 4.8 Ecoregion coverage in Eastern and Southern Africa by protection percentage

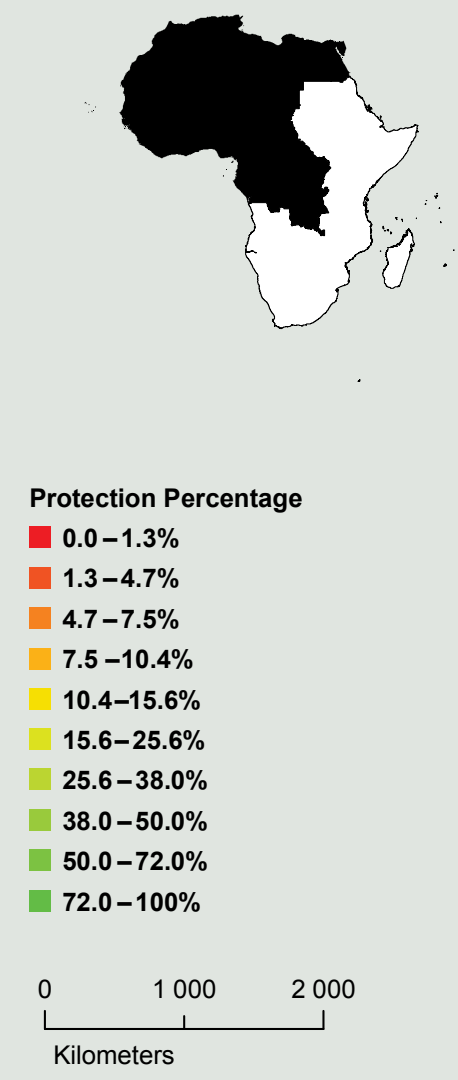

Protection Percentage
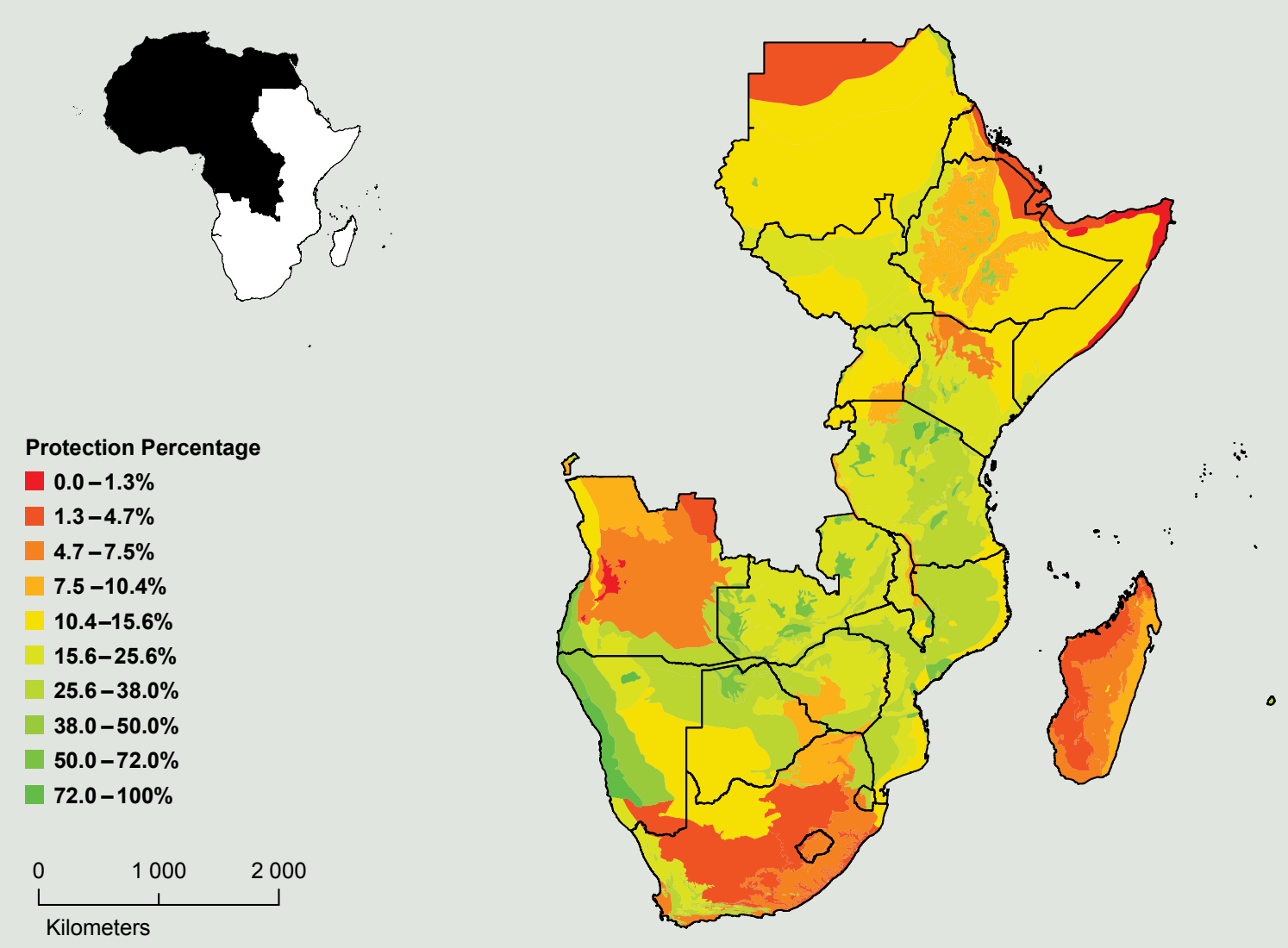

Source: Developed by EC JRC and RCMRD based on data from DOPA2 ${ }^{12}$

12 The terrestrial ecoregion boundaries are provided by WWF The Nature Conservancy and partners (Olson et al., 2001). For coastal and continental shelf waters, the 232 boundaries provided by the Marine Ecoregions of the World (MEoW) dataset (Spalding et al., 2007) were used. These ecoregions extend from the coast (intertidal zone) to the $200 \mathrm{~m}$ depth contour (extended beyond the waters out by a $5 \mathrm{~km}$ buffer). The 37 pelagic provinces of the world (PPOW) which go beyond the $200 \mathrm{~m}$ depth (Spalding et al., 2012) were also used. Protected areas that are proposed (but not yet fully designated or established) and protected areas recorded as points without a reported area are excluded from analyses. In addition, all overlaps between different records are removed from the calculations to avoid double counting. A GIS analysis is used to calculate protection. For this, a global protected area layer is created by buffering the points recorded in the WDPA based on their reported areas and combining them with the polygons recorded in the WDPA. This layer is overlaid with country boundaries and ecoregions to obtain the absolute and relative coverage of protected areas.

\section{Figure 4.9 Number of protected area records in the WDPA from 1998 to 2019}

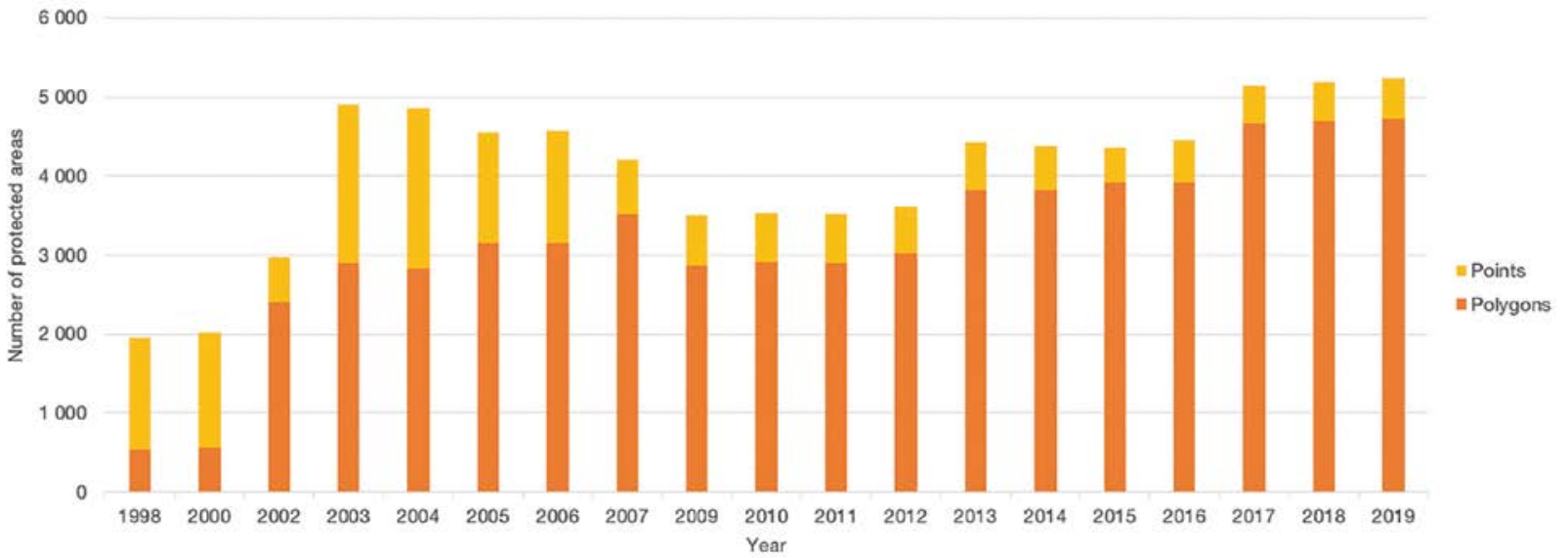

Source: UNEP-WCMC \& IUCN (2019a). 
previously incorporated in the Selous Game Reserve and is now the largest national park in Africa.

The accurate tracking of protected area coverage over time is challenging, as there are limitations to any approach (Lewis et al., 2017). It is particularly difficult in Eastern and Southern Africa due to the variable quality of data in previous releases of the WDPA, most notably the large number of point data. When only point data is available, it is necessary to rely on the reported size of protected areas, which can often be missing or inaccurate, as opposed to the actual areas of polygons. This results in inaccuracies in protected area metrics (Visconti et al., 2013), and yet to omit points entirely would dramatically under-report on protected area coverage. For this reason, instead of the area, the change in the number of protected areas in the region was used in spite of its limitations. In this context and region, it was considered the most accurate approach and resulted in the data presented in Figure 4.9.

Conservation policy and practice generally assume that protected areas are permanent fixtures on the landscape and this is the intention according to the definition, but evidence points to widespread - yet largely overlooked - protected area downgrading, downsizing and degazettement (PADDD) (Mascia \& Pailler, 2011), see Box 4.1. According to the most recent global analysis, at least 3,700 PADDD events have been enacted in 73 countries between 1892 to 2018, affecting an area of about 2 million $\mathrm{km}^{2}$ (Golden Kroner et al., 2019), and more than 800 proposed events have been recorded in the 24 countries of Eastern and Southern Africa over the same period.

Globally, although there are no existing requirements to track or report PADDD (Qin et al., 2019), analyses have shown that PADDD is a patchy, episodic phenomenon largely associated with the following activities: industrial-scale natural resource extraction and development (62\%); local land pressures and land claims (28\%); and conservation planning (1.7\%) (Mascia et al., 2014). Larger protected areas that are closer to population centres are more likely to be downsized or degazetted (Symes et al., 2016).

\section{Box 4.1 What is PADDD?}

PADDD stands for protected area downgrading, downsizing and degazettement

- Downgrading is the legal authorisation of an increase in the number, magnitude, or extent of human activities within a protected area.

- Downsizing is the decrease in size of a protected area as a result of excision of land or sea area through a legal boundary change.

- Degazettement is the loss of legal protection for an entire protected area

PADDD events are compiled by Conservation International and World Wildlife Fund. Data are available on: https://www.padddtracker.org/.

Source: $\mathrm{Cl} \& W W F($ n.d.)
At the regional level in Africa, tracking PADDD events has been conducted on an ad hoc basis, and none of the countries in Eastern and Southern Africa have yet been the subject of a detailed analysis. Up to 2019, the available events in the PADDD database show 296 enacted events and eight proposed events in Eastern and Southern Africa across 13 countries ( $\mathrm{Cl} \&$ WWF, n.d.). The database includes the proximate causes of downgrading, downsizing and degazettement events, which in the region's context include: conservation planning $(21)^{13}$; fishing (1); forestry (9); industrial agriculture (16); industrialisation (5); infrastructure (5); land claims (20); mining (24); oil and gas (3); refugee accommodation (2); rural settlements (18); and subsistence (4).

\subsection{Transboundary protected and conserved areas}

There is increasing recognition of the importance of transboundary cooperation in conservation throughout Eastern and Southern Africa, where ecosystems and wildlife populations do not recognise national boundaries. Transfrontier conservation areas vary from transboundary parks, which include two or more adjacent protected areas, to conservation areas that include a complexity of land uses, such as community land, private land and formally protected areas. These transboundary conservation areas play a critical role in safeguarding regionally important resources that span boundaries, such as forests and other key ecosystems, water catchments, continuous wildlife habitats and refuges, and connectivity corridors for wildlife movement. Transboundary conservation areas are important to national and regional development, providing a focus for the development of nature-based tourism. Transboundary approaches are likely to play an even more important role in climate change adaptation, as they will allow for shifts in habitat as well as movement of species due to their vast size and the landscape approach to land use management. In terms of funding, it tends to be higher in protected areas that are part of transboundary conservation areas (Lindsey et al., 2018).

In Southern Africa, SADC has adopted a programme on Transfrontier Conservation Areas (TFCAs), the mission of which is: To develop SADC into a functional and integrated network of Transfrontier Conservation Areas where shared natural resources are sustainably co-managed and conserved to foster socioeconomic development, and regional integration for the benefit of people living within and around transfrontier conservation areas, the SADC region, and the world (SADC Secretariat, 2013, p. 4).

In support of the programme's implementation, a SADC TFCA Network is in place to bring together practitioners from across the region (see Box 4.2). 

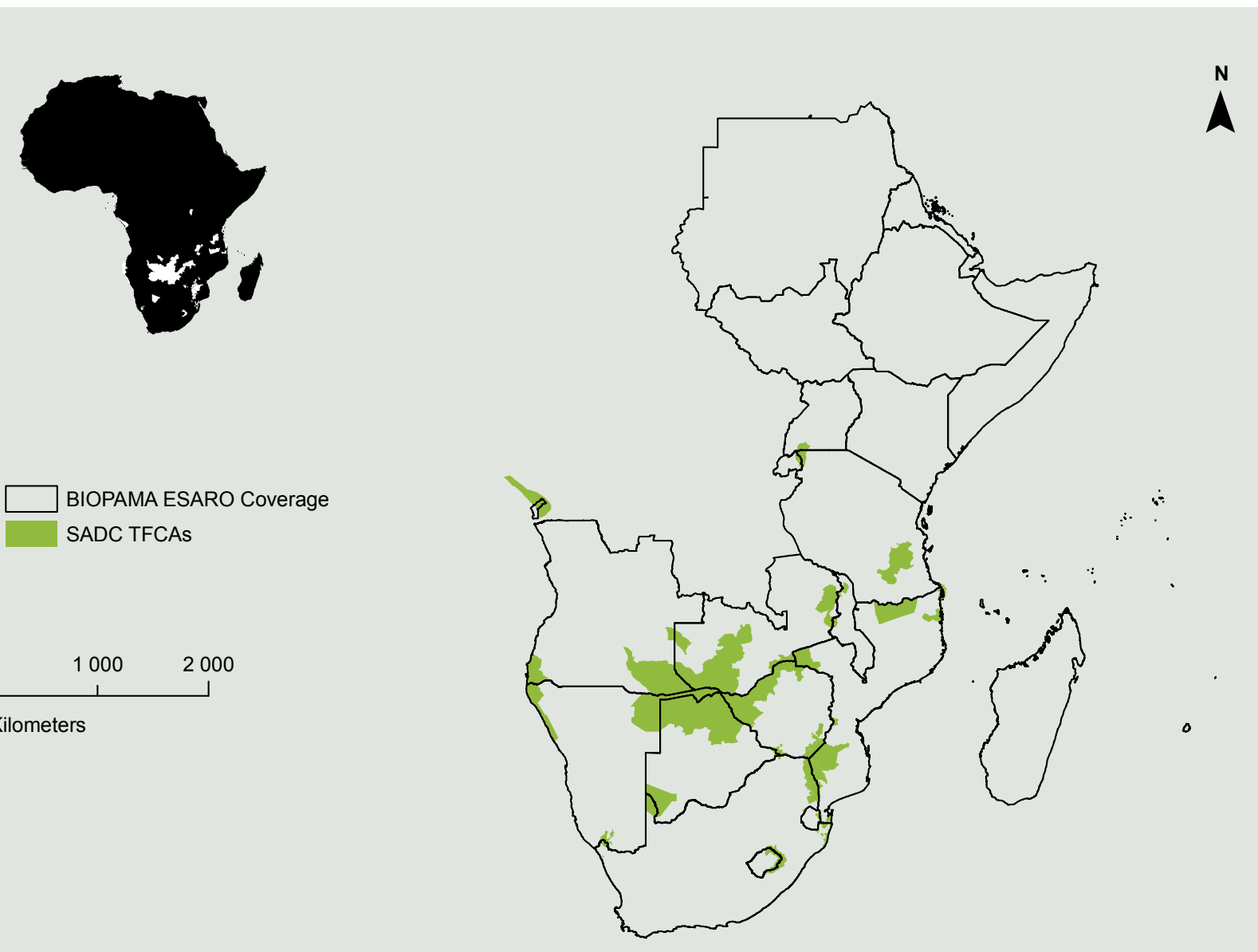

Source: Developed by RCMRD based on data from Peace parks and SADC

The network has developed a number of useful documents to support transboundary conservation. These include:

- Guidelines for community engagement in SADC TFCAs (SADC Secretariat, 2018);

- SADC guidelines for cross-border tourism products (Spenceley, 2018); and

- Guidelines on the establishment and development of TFCA initiatives between SADC member states (Zunckel, 2014).

The first two guidelines are awaiting Ministerial approval, while the guidelines on establishment have already been approved.

In Eastern Africa, there are various initiatives to improve transboundary management of key ecosystems, but these seem to be more driven by individual sites and organisations, rather than by a cohesive approach supported by the national agencies (BIOPAMA, unpublished). In 2010, The EAC tabled a bill for transboundary ecosystem management that provides a potential framework and tool to help facilitate a more coordinated approach to transboundary conservation in the region (EAC, 2010). To date, however, the bill is yet to be ratified by EAC Partner States.
While many of the transboundary conservation areas in the region have been formally adopted by participating governments through a treaty signed by Heads of State, others are managed under a Memorandum of Agreement (MOU) between various government departments or agencies, or remain conceptual (see Table 4.3). Figure 4.10 shows the established TFCAs in the region. 


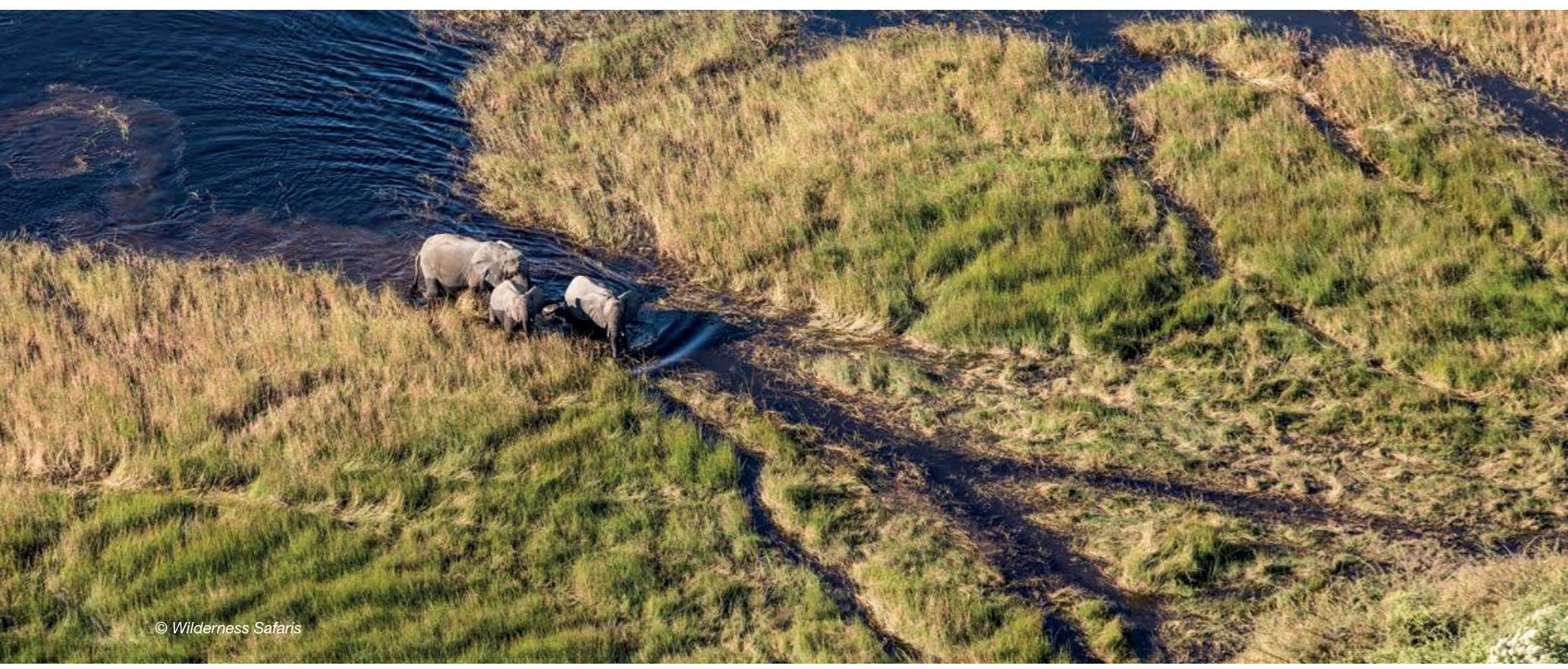

\section{Box 4.2 SADC TFCA Network}

Since the establishment in 1990 of Kgalagadi Transfrontier Park, the first Transfrontier Park in southern Africa between Botswana and South Africa, SADC has been at the forefront of transfrontier conservation. In order promote the establishment and development of TFCAs as a conservation and development model across the region, a SADC TFCA Programme was approved in October 2013. Currently, there are 18 existing and potential terrestrial and marine TFCAs across the SADC region covering more than one million square kilometres, which is more than half of the protected area estate in southern Africa.

The SADC TFCA Network was established in the same year as the TFCA Programme to accelerate implementation of the programme and enhance regional learning and cooperation between governments, implementers, the international donor community, community representatives, private sector and specialists in transfrontier conservation. Specifically, they agreed to: share information among practitioners and the public alike; learn from each other and create and expand knowledge on TFCAs; foster innovation on the ground as well as on policy level; mobilise resources; and contribute to the empowerment of the ultimate stewards of the natural resources, the communities.

To date, the network comprises of more than 350 members of all relevant stakeholder groups that communicate and share information through an anchor SADC TFCA Web-Portal www.tfcaportal.org. It network is embedded in the SADC Governance structures and guided by a Steering Committee comprising of the Secretariat and the Member States' TFCA focal points. In this manner, the SADC TFCA Network Steering
Committee and Network have facilitated and accelerated SADC decision-making processes in, for example, the development and promotion of cross-border tourism products and the guidelines listed above, as well the adoption in 2019 of the SADC TFCA Tourism Programme, both of which were driven by the network.

Some of its achievements include:

1. Membership of more than 350 active adherents, regionally and globally, demonstrating the success of SADC TFCAs;

2. Convening of annual SADC TFCA network meetings and participation at global events, such as the 2014 IUCN World Parks Congress, the 2016 CITES COP 17 and the 2018 CBD COP14

3. Enabled cross-border community meetings, such as the Transboundary Intercommunity Exchange Forum;

4. Supported the establishment of a regional SADC TFCA Financing Facility;

5. Documentation of lessons learned by supporting the development of regional SADC TFCA Guidelines on TFCA Development, Tourism Concessions, Cross-border Tourism Productions and Community Engagement; and

6. Establishment of five Communities of Practice to help inform SADC statutory structures with experts in the fields of:

- Data management and monitoring and evaluation;

- Capacity building and training;

- Tourism;

- Community engagement; and

- Law enforcement and anti-poaching.

Contributed by Lisa Blanken, Deutsche Gesellschaft für Internationale Zusammenarbeit. 
Table 4.3 Transboundary conservation areas in Eastern and Southern Africa

\begin{tabular}{|c|c|c|c|c|c|c|}
\hline Name & $\begin{array}{l}\text { Countries } \\
\text { included }\end{array}$ & $\begin{array}{l}\text { Area } \\
\left(\mathbf{k m}^{2}\right)\end{array}$ & Status & $\begin{array}{l}\text { Ecotype/ } \\
\text { biome }\end{array}$ & Protected Areas & $\begin{array}{l}\text { Special features/ } \\
\text { significance }\end{array}$ \\
\hline $\begin{array}{l}\text { /Ai-/Ais- } \\
\text { Richtersveld } \\
\text { TFCA }\end{array}$ & $\begin{array}{l}\text { Namibia, } \\
\text { South Africa }\end{array}$ & 5920 & $\begin{array}{l}\text { Treaty } \\
\text { signed }\end{array}$ & $\begin{array}{l}\text { Desert; } \\
\text { Riverine }\end{array}$ & $\begin{array}{l}\text { Namibia: } \\
\text { Ais-Ais Hot Spring Game Park } \\
\text { South Africa: } \\
\text { Richtersveld National Park }\end{array}$ & Fish River Canyon \\
\hline $\begin{array}{l}\text { Amboseli } \\
\text { - Kilimanjaro- } \\
\text { Longido }\end{array}$ & $\begin{array}{l}\text { Kenya, } \\
\text { Tanzania }\end{array}$ & N/A & Conceptual & $\begin{array}{l}\text { Montane; } \\
\text { Forest; } \\
\text { Savannah }\end{array}$ & $\mathrm{N} / \mathrm{A}$ & $\begin{array}{l}\text { Montane endemics; } \\
\text { carnivores; Very } \\
\text { important elephant area }\end{array}$ \\
\hline $\begin{array}{l}\text { Boma- } \\
\text { Gambella } \\
\text { Landscape }\end{array}$ & $\begin{array}{l}\text { South Sudan, } \\
\text { Ethiopia }\end{array}$ & N/A & Conceptual & $\begin{array}{l}\text { Savannah; } \\
\text { Wetland }\end{array}$ & $\mathrm{N} / \mathrm{A}$ & $\begin{array}{l}\text { Major plains game } \\
\text { migration }\end{array}$ \\
\hline $\begin{array}{l}\text { Chimanimani } \\
\text { TFCA }\end{array}$ & $\begin{array}{l}\text { Mozambique, } \\
\text { Zimbabwe }\end{array}$ & 4091 & $\begin{array}{l}\text { Treaty } \\
\text { signed }\end{array}$ & $\begin{array}{l}\text { Mountains } \\
\text { and miombo } \\
\text { woodland }\end{array}$ & $\begin{array}{l}\text { Zimbabwe: } \\
\text { Chimanimani National Park } \\
\text { Mozambique: } \\
\text { Chimanimani Nature Reserve }\end{array}$ & $\begin{array}{l}\text { Forest, scenery, wildlife } \\
\text { and culture }\end{array}$ \\
\hline $\begin{array}{l}\text { Great Limpopo } \\
\text { Transfrontier } \\
\text { Park \& } \\
\text { Conservation } \\
\text { Area }\end{array}$ & $\begin{array}{l}\text { Mozambique, } \\
\text { South Africa, } \\
\text { Zimbabwe }\end{array}$ & 37572 & $\begin{array}{l}\text { Treaty } \\
\text { signed }\end{array}$ & $\begin{array}{l}\text { Miombo } \\
\text { woodlands }\end{array}$ & $\begin{array}{l}\text { Mozambique: } \\
\text { Limpopo National Park 0 } \\
\text { South Africa: } \\
\text { Kruger National Park 0 } \\
\text { Zimbabwe: } \\
\text { Gonarezhou National Park0 }\end{array}$ & $\begin{array}{l}\text { Riverine woodlands; } \\
\text { regional endemism; } \\
\text { important elephant } \\
\text { dispersal areas }\end{array}$ \\
\hline $\begin{array}{l}\text { Greater } \\
\text { Mapungubwe } \\
\text { TFCA }\end{array}$ & $\begin{array}{l}\text { Botswana, } \\
\text { South Africa, } \\
\text { Zimbabwe }\end{array}$ & 5909 & $\begin{array}{l}\text { MOU } \\
\text { signed }\end{array}$ & Savannah & $\begin{array}{l}\text { Botswana: } \\
\text { Northern Tuli GR } 0 \\
\text { Zimbabwe: } \\
\text { Tuli Circle Safari Area 0 } \\
\text { South Africa: } \\
\text { Mapungubwe National Park and } \\
\text { the Mapungubwe Cultural } \\
\text { Landscape, WHS 0 }\end{array}$ & $\begin{array}{l}\text { Cultural artefacts; } \\
\text { unique geology; } \\
\text { distinctive fauna and } \\
\text { flora }\end{array}$ \\
\hline $\begin{array}{l}\text { Greater } \\
\text { Virunga } \\
\text { Landscape }\end{array}$ & $\begin{array}{l}\text { Rwanda, } \\
\text { Uganda, DRC }\end{array}$ & 15000 & $\begin{array}{l}\text { Treaty } \\
\text { signed } \\
\text { (ratification } \\
\text { pending) }\end{array}$ & $\begin{array}{l}\text { Albertine Rift } \\
\text { mid-altitude } \\
\text { and montane } \\
\text { forest; East } \\
\text { Sudanese } \\
\text { savannah; } \\
\text { Wetlands }\end{array}$ & $\begin{array}{l}\text { DRC: } \\
\text { Virunga World Heritage Site / } \\
\text { National Park } \\
\text { Rwanda: } \\
\text { Volcans National Park } \\
\text { Uganda: } \\
\text { Mgahinga National Park } \\
\text { Queen Elizabeth National Park } \\
\text { Bwindi World Heritage Site / } \\
\text { National Park } \\
\text { Semuliki National Park } \\
\text { Ruwenzori World Heritage Site / } \\
\text { National Park } \\
\text { Kibale National Park } \\
\text { Kasyoha-Kitomi Forest Reserve } \\
\text { Kalinzu-Maramgambo Forest } \\
\text { Reserve } \\
\text { Kayumbura Wetland Reserve }\end{array}$ & $\begin{array}{l}\text { Albertine Rift Ecoregion; } \\
3 \text { World Heritage Sites; } \\
\text { entire Mountain Gorilla } \\
\text { population and } \\
\text { important chimpanzee } \\
\text { populations; majority of } \\
\text { Albertine endemics; } \\
\text { exceptional tourism } \\
\text { potential; protection of } \\
\text { vital freshwater fish } \\
\text { stocks; watershed } \\
\text { protection }\end{array}$ \\
\hline $\begin{array}{l}\text { lona Skeleton } \\
\text { Coast TFCA }\end{array}$ & $\begin{array}{l}\text { Angola, } \\
\text { Namibia }\end{array}$ & 47698 & $\begin{array}{l}\text { MOU } \\
\text { signed }\end{array}$ & Desert & $\begin{array}{l}\text { Angola: } \\
\text { lona National Park } \\
\text { Namibia: } \\
\text { Skeleton Coast National Park }\end{array}$ & $\begin{array}{l}\text { Kunene River and } \\
\text { ecosystem } \\
\text { Natural springs } \\
\text { Endemic plant species }\end{array}$ \\
\hline
\end{tabular}




\begin{tabular}{|c|c|c|c|c|c|c|}
\hline Name & $\begin{array}{l}\text { Countries } \\
\text { included }\end{array}$ & $\begin{array}{l}\text { Area } \\
\left(\mathbf{k m}^{2}\right)\end{array}$ & Status & $\begin{array}{l}\text { Ecotype/ } \\
\text { biome }\end{array}$ & Protected Areas & $\begin{array}{l}\text { Special features/ } \\
\text { significance }\end{array}$ \\
\hline Kagera TFCA & $\begin{array}{l}\text { Still to be } \\
\text { finalized, but } \\
\text { includes } \\
\text { Rwanda, } \\
\text { Tanzania, } \\
\text { Uganda }\end{array}$ & 2500 & $\begin{array}{l}\text { MOU } \\
\text { signed }\end{array}$ & $\begin{array}{l}\text { Savanna; } \\
\text { Grasslands; } \\
\text { Moist } \\
\text { woodland; } \\
\text { Wetlands; } \\
\text { Afro-montane } \\
\text { forest; } \\
\text { Tropical } \\
\text { rainforest }\end{array}$ & $\begin{array}{l}\text { Rwanda: } \\
\text { Akagera National Park } \\
\text { Tanzania: } \\
\text { lbanda and Rumanyika National } \\
\text { Parks }\end{array}$ & $\begin{array}{l}\text { Kagera River; largest } \\
\text { protected wetland in } \\
\text { eastern Africa; sacred } \\
\text { forest waterfalls, cave } \\
\text { systems and ancient } \\
\text { rock paintings; } \\
\text { exceptional biodiversity }\end{array}$ \\
\hline $\begin{array}{l}\text { Kavango- } \\
\text { Zambezi TFCA }\end{array}$ & $\begin{array}{l}\text { Angola, } \\
\text { Botswana, } \\
\text { Namibia, } \\
\text { Zambia, } \\
\text { Zimbabwe }\end{array}$ & 520000 & $\begin{array}{l}\text { Treaty } \\
\text { signed }\end{array}$ & $\begin{array}{l}\text { Miombo } \\
\text { woodland; } \\
\text { Zambezian } \\
\text { flooded } \\
\text { grassland; } \\
\text { Savannah }\end{array}$ & $\begin{array}{l}\text { Angola: } \\
\text { Luengue-Luiana National Park } \\
\text { Mavinga National Park } \\
\text { Botswana: } \\
\text { Chobe National Park } \\
\text { Makgadikgadi National Park } \\
\text { Nxai Pan National Park } \\
\text { Moremi Game Reserve } \\
\text { Namibia: } \\
\text { Mamili National Park } \\
\text { Mudumu National Park } \\
\text { Bwabwata National Park } \\
\text { Zambia: } \\
\text { Kafue National Park } \\
\text { Mosi-oa-Tunya National Park } \\
\text { Sioma Ngwezi National Park } \\
\text { Zimbabwe: } \\
\text { Hwange National Park } \\
\text { Kazuma Pan National Park } \\
\text { Matusadona National Park } \\
\text { Zambezi National Park } \\
\text { Victoria Falls National Park }\end{array}$ & $\begin{array}{l}\text { Unique Okavango Delta } \\
\text { Wetlands; wildlife } \\
\text { migrations; } \\
\text { large elephant } \\
\text { population; } \\
\text { other large mammals; } \\
\text { Peace Park; exceptional } \\
\text { tourism potential }\end{array}$ \\
\hline $\begin{array}{l}\text { Kidepo } \\
\text { Landscape }\end{array}$ & $\begin{array}{l}\text { Uganda, } \\
\text { South Sudan }\end{array}$ & $\mathrm{N} / \mathrm{A}$ & $\begin{array}{l}\text { Partial } \\
\text { MOU (for } \\
\text { some } \\
\text { forest } \\
\text { reserves) }\end{array}$ & Savannah & N/A & $\begin{array}{l}\text { Cheetah, African Wild } \\
\text { Dog, Lesser Kudu, } \\
\text { Karamoja Apalis }\end{array}$ \\
\hline $\begin{array}{l}\text { Kgalagadi } \\
\text { Transfrontier } \\
\text { Park }\end{array}$ & $\begin{array}{l}\text { Botswana, } \\
\text { South Africa }\end{array}$ & 35551 & $\begin{array}{l}\text { Treaty } \\
\text { signed }\end{array}$ & Desert & $\begin{array}{l}\text { Botswana: } \\
\text { Gemsbok National Park } \\
\text { South Africa: } \\
\text { Kalahari Gemsbok National } \\
\text { Park }\end{array}$ & $\begin{array}{l}\text { Unique Kalahari } \\
\text { ecosystem; Black- } \\
\text { maned lions; Gemsbok, } \\
\text { etc. }\end{array}$ \\
\hline $\begin{array}{l}\text { Liuwa } \\
\text { Plains- } \\
\text { Mussuma } \\
\text { TFCA }\end{array}$ & $\begin{array}{l}\text { Angola, } \\
\text { Zambia }\end{array}$ & 14464 & $\begin{array}{l}\text { Conceptual } \\
\text { TFCA }\end{array}$ & $\begin{array}{l}\text { Zambezian } \\
\text { flooded } \\
\text { grassland } \\
\text { eco-region, the } \\
\text { miombo } \\
\text { woodland } \\
\text { eco-region and } \\
\text { the Zambezian } \\
\text { cryptosepalum } \\
\text { dry forest } \\
\text { eco-region }\end{array}$ & $\begin{array}{l}\text { Zambia: } \\
\text { Liuwa Plains National Park } \\
\text { Angola: } \\
\text { Massuma National Park }\end{array}$ & $\begin{array}{l}\text { Second largest } \\
\text { wildebeest migration in } \\
\text { Africa, significant } \\
\text { portion of the } \\
\text { catchment area of the } \\
\text { Zambezi River, Africa's } \\
\text { fourth largest river } \\
\text { system }\end{array}$ \\
\hline $\begin{array}{l}\text { Lower } \\
\text { Awash-Lake } \\
\text { Abbé } \\
\text { Landscape }\end{array}$ & $\begin{array}{l}\text { Djibouti, } \\
\text { Ethiopia }\end{array}$ & $\mathrm{N} / \mathrm{A}$ & Conceptual & Dryland & N/A & N/A \\
\hline
\end{tabular}




\begin{tabular}{|c|c|c|c|c|c|c|}
\hline Name & $\begin{array}{l}\text { Countries } \\
\text { included }\end{array}$ & $\begin{array}{l}\text { Area } \\
\left(\mathbf{k m}^{2}\right)\end{array}$ & Status & $\begin{array}{l}\text { Ecotype/ } \\
\text { biome }\end{array}$ & Protected Areas & $\begin{array}{l}\text { Special features/ } \\
\text { significance }\end{array}$ \\
\hline $\begin{array}{l}\text { Lower } \\
\text { Zambezi } \\
\text { - Mana Pools } \\
\text { TFCA }\end{array}$ & $\begin{array}{l}\text { Zambia, } \\
\text { Zimbabwe }\end{array}$ & 17745 & $\begin{array}{l}\text { Conceptual } \\
\text { TFCA }\end{array}$ & $\begin{array}{l}\text { Miombo } \\
\text { woodlands }\end{array}$ & $\begin{array}{l}\text { Zimbabwe: } \\
\text { Mana Pools National Park/WHS } \\
\text { Sapi and Chewore Safari Areas } \\
\text { Lower Zambezi National Park } \\
+6 \text { additional reserves }\end{array}$ & $\begin{array}{l}\text { Zambezi River; } \\
\text { floodplain; escarpment; } \\
\text { large mammal } \\
\text { populations }\end{array}$ \\
\hline $\begin{array}{l}\text { Lubombo } \\
\text { TFCA }\end{array}$ & $\begin{array}{l}\text { Eswatini, } \\
\text { Mozambique, } \\
\text { South Africa, }\end{array}$ & 10029 & $\begin{array}{l}\text { Treaty } \\
\text { signed }\end{array}$ & Coastal plain & $\begin{array}{l}\text { Links } 5 \text { TFCA projects } \\
\text { Eswatini: } \\
\text { Hlana Royal National Park } \\
\text { South Africa: } \\
\text { Tembe Elephant Park } \\
\text { Mozambique: } \\
\text { Maputo Special Reserve } \\
+12 \text { state protected areas and } \\
\text { other reserves, as well as } \\
\text { private land }\end{array}$ & $\begin{array}{l}\text { High biodiversity; } 5 \\
\text { Ramsar sites; wetlands; } \\
\text { woodlands }\end{array}$ \\
\hline $\begin{array}{l}\text { Malawi- } \\
\text { Zambia TFCA }\end{array}$ & $\begin{array}{l}\text { Malawi, } \\
\text { Zambia }\end{array}$ & 32278 & $\begin{array}{l}\text { Treaty } \\
\text { signed }\end{array}$ & $\begin{array}{l}\text { Montane; } \\
\text { Grassland; } \\
\text { Wetland; }\end{array}$ & $\begin{array}{l}3 \text { protected areass including } \\
\text { Nyika National Park, Vwaza } \\
\text { Marsh Wildlife Reserve }\end{array}$ & $\begin{array}{l}\text { Montane grassland and } \\
\text { flora; Wetlands; } \\
\text { Restocking programme }\end{array}$ \\
\hline $\begin{array}{l}\text { Maloti } \\
\text { Drakensberg } \\
\text { TFCA (also a } \\
\text { transboundary } \\
\text { World Heritage } \\
\text { site) }\end{array}$ & $\begin{array}{l}\text { Lesotho, } \\
\text { South Africa }\end{array}$ & 14740 & $\begin{array}{l}\text { MOU } \\
\text { signed }\end{array}$ & Montane & $\begin{array}{l}\text { Lesotho: } \\
\text { Maloti Drakensberg } \\
\text { Transboundary World Heritage } \\
\text { Site, comprises Sehlabathebe } \\
\text { National Park and } \\
\text { South Africa: } \\
\text { uKhahlamba Drakensberg Park }\end{array}$ & $\begin{array}{l}\text { Southern mountains; } \\
\text { Escarpments; Rich } \\
\text { endemic flora; } \\
\text { Wetlands; San culture }\end{array}$ \\
\hline $\begin{array}{l}\text { Mayombe } \\
\text { Forest } \\
\text { Transfrontier } \\
\text { Protected Area }\end{array}$ & $\begin{array}{l}\text { Angola, } \\
\text { Democratic } \\
\text { Republic of } \\
\text { Congo, } \\
\text { Gabon, } \\
\text { Republic of } \\
\text { Congo }\end{array}$ & 36000 & $\begin{array}{l}\text { MOU } \\
\text { signed }\end{array}$ & $\begin{array}{l}\text { Tropical } \\
\text { rainforest }\end{array}$ & $\begin{array}{l}\text { Angola: } \\
\text { Mayombe National Park } \\
\text { DRC: } \\
\text { Luki National Park } \\
\text { Republic of Congo: } \\
\text { Dimonika Biosphere Reserve, } \\
\text { Conkouati-Douli National Park } \\
\text { and Tchimpounga National } \\
\text { Reserve }\end{array}$ & $\begin{array}{l}\text { Basin rainforest; } \\
\text { Chimpanzees and } \\
\text { lowland gorilla }\end{array}$ \\
\hline $\begin{array}{l}\text { Mnazi Bay } \\
\text { - Quirimbas } \\
\text { TFCA }\end{array}$ & $\begin{array}{l}\text { Mozambique, } \\
\text { Tanzania }\end{array}$ & 8150 & $\begin{array}{l}\text { Conceptual } \\
\text { TFCA }\end{array}$ & $\begin{array}{l}\text { East African } \\
\text { coastal forest } \\
\text { and scrub } \\
\text { biome }\end{array}$ & $\begin{array}{l}\text { Mozambique: } \\
\text { Quirimbas National Park } \\
\text { Tanzania: } \\
\text { Mnazi Bay-Ruvuma Estuary } \\
\text { Marine Park }\end{array}$ & $\begin{array}{l}\text { An important refuge for } \\
\text { reef diversity to } \\
\text { downstream areas in } \\
\text { the north and south on } \\
\text { mainland coastal areas }\end{array}$ \\
\hline $\begin{array}{l}\text { Mosi-oa-Tunya } \\
\text { / Victoria Falls } \\
\text { Transboundary } \\
\text { World Heritage } \\
\text { Site }\end{array}$ & $\begin{array}{l}\text { Zambia, } \\
\text { Zimbabwe }\end{array}$ & 69 & $\begin{array}{l}\text { Treaty } \\
\text { signed }\end{array}$ & Riverine & $\begin{array}{l}\text { Zambia: } \\
\text { Mosi-oa-Tunya National Park } \\
\text { Zimbabwe: } \\
\text { Victoria Falls National Park }\end{array}$ & $\begin{array}{l}\text { Victoria Falls; } \\
\text { World Heritage site; } \\
\text { exceptional geological } \\
\text { and geomorphological } \\
\text { features }\end{array}$ \\
\hline Mt Elgon & $\begin{array}{l}\text { Uganda, } \\
\text { Kenya }\end{array}$ & $\mathrm{N} / \mathrm{A}$ & $\begin{array}{l}\text { MOU } \\
\text { drafted }\end{array}$ & Montane & $\begin{array}{l}\text { Uganda: } \\
\text { Mount Elgon National Park } \\
\text { Kenya: } \\
\text { Mt Elgon National Park } \\
\text { Mount Elgon and Trans-Nzoia } \\
\text { Forest Reserves } \\
\text { Chepkitale National Reserve }\end{array}$ & Extinct shield volcano \\
\hline
\end{tabular}




\begin{tabular}{|c|c|c|c|c|c|c|}
\hline Name & $\begin{array}{l}\text { Countries } \\
\text { included }\end{array}$ & $\begin{array}{l}\text { Area } \\
\left(\mathbf{k m}^{2}\right)\end{array}$ & Status & $\begin{array}{l}\text { Ecotype/ } \\
\text { biome }\end{array}$ & Protected Areas & $\begin{array}{l}\text { Special features/ } \\
\text { significance }\end{array}$ \\
\hline $\begin{array}{l}\text { Niassa-Selous } \\
\text { TFCA }\end{array}$ & $\begin{array}{l}\text { Mozambique, } \\
\text { Tanzania }\end{array}$ & 154000 & $\begin{array}{l}\text { MOU } \\
\text { signed }\end{array}$ & $\begin{array}{l}\text { Miombo } \\
\text { woodland; } \\
\text { Wetlands; } \\
\text { Savannah }\end{array}$ & $\begin{array}{l}\text { Mozambique: Niassa NR } \\
\text { Tanzania: } \\
\text { Selous World Heritage Site/GR } \\
\text { Mikumi National Park } \\
\text { Udzungwa National Park } \\
\text { Kilombero GCA } \\
+ \text { WMAs, conservancies, and } \\
\text { hunting blocks }\end{array}$ & $\begin{array}{l}\text { Migration corridor; very } \\
\text { important elephant area; } \\
\text { buffalo, hippo }\end{array}$ \\
\hline $\begin{array}{l}\text { Nyungwe- } \\
\text { Kibira }\end{array}$ & $\begin{array}{l}\text { Burundi, } \\
\text { Rwanda }\end{array}$ & 1171 & $\begin{array}{l}\text { MOU } \\
\text { signed }\end{array}$ & $\begin{array}{l}\text { Mid-altitude } \\
\text { montane } \\
\text { forest }\end{array}$ & $\begin{array}{l}\text { Rwanda: } \\
\text { Nyungwe NP } \\
\text { Burundi: } \\
\text { Kibira }\end{array}$ & Forest and endemics \\
\hline $\begin{array}{l}\text { Sango Bay } \\
\text { - Minziro }\end{array}$ & $\begin{array}{l}\text { Tanzania, } \\
\text { Uganda }\end{array}$ & 861 & Conceptual & $\begin{array}{l}\text { Wetlands and } \\
\text { swamp } \\
\text { forests }\end{array}$ & $\begin{array}{l}\text { Tanzania: } \\
\text { Minziro Forest Nature Reserve } \\
\text { Uganda: } \\
\text { Sango Bay-Musambwa } \\
\text { Island-Kagera Wetland System }\end{array}$ & $\begin{array}{l}\text { Baikiaea-Podocarpus } \\
\text { forests, papyrus } \\
\text { endemics }\end{array}$ \\
\hline $\begin{array}{l}\text { Serengeti- } \\
\text { Mara }\end{array}$ & $\begin{array}{l}\text { Tanzania, } \\
\text { Kenya }\end{array}$ & 25000 & Conceptual & Savanna & $\begin{array}{l}\text { Serengeti National Park } \\
\text { Masai Mara National Reserve }\end{array}$ & $\begin{array}{l}\text { Annual migration of } \\
\text { close to } 2 \text { million } \\
\text { herbivores }\end{array}$ \\
\hline $\begin{array}{l}\text { Tana-Kipini- } \\
\text { Laga Badana } \\
\text { Bushbush } \\
\text { Land and } \\
\text { Seascape }\end{array}$ & $\begin{array}{l}\text { Kenya, } \\
\text { Somalia }\end{array}$ & N/A & Conceptual & $\mathrm{n} / \mathrm{a}$ & N/A & $\mathrm{N} / \mathrm{A}$ \\
\hline $\begin{array}{l}\text { Tanga Marine } \\
\text { Reserves } \\
\text { System and } \\
\text { Tanga } \\
\text { Coelacanth } \\
\text { Marine Park } \\
\text { (TZ) and (KE) } \\
\text { Diani Chale } \\
\text { MPA and } \\
\text { Kisite- } \\
\text { Mpunguti MPA }\end{array}$ & $\begin{array}{l}\text { Tanzania, } \\
\text { Kenya }\end{array}$ & N/A & Conceptual & & $\mathrm{N} / \mathrm{A}$ & N/A \\
\hline $\begin{array}{l}\text { Western Indian } \\
\text { Ocean } \\
\text { Transfrontier } \\
\text { Marine Park }\end{array}$ & $\begin{array}{l}\text { Still to be } \\
\text { finalized, but } \\
\text { includes } \\
\text { Madagascar, } \\
\text { Mauritius, } \\
\text { Mozambique, } \\
\text { Seychelles, } \\
\text { Tanzania }\end{array}$ & N/A & Conceptual & Marine & N/A & $\begin{array}{l}\text { Third largest coral reef } \\
\text { on the planet; home to } \\
\text { five of the seven marine } \\
\text { turtle species; dugong }\end{array}$ \\
\hline ZIMOZA TFCA & $\begin{array}{l}\text { Mozambique, } \\
\text { Zambia, } \\
\text { Zimbabwe }\end{array}$ & 29859 & Conceptual & $\begin{array}{l}\text { Grasslands, } \\
\text { riverine } \\
\text { woodlands } \\
\text { and dry } \\
\text { forests }\end{array}$ & $\begin{array}{l}\text { No formally protected area in } \\
\text { Mozambique } \\
\text { Zambia: } \\
\text { Lower Zambezi National Park } \\
\text { and the entire Rufunsa Game } \\
\text { Management Area } \\
\text { Zimbabwe: } \\
\text { Chewore and the Dande Safari } \\
\text { Area }\end{array}$ & $\begin{array}{l}\text { Many wildlife corridors; } \\
\text { variety of species } \\
\text { including elephant, } \\
\text { hippopotamus, buffalo, } \\
\text { lion, leopard, sable and } \\
\text { roan }\end{array}$ \\
\hline
\end{tabular}

Note: There are some TFCAs whose area size cannot be determined to be $100 \%$ accurate as they are mostly conceptual, such as Kagera, Liuwa Plains, Lower Zambezi-Mana Pools, Mnazi Bay-Quirimbas and ZIMOZA. Hence the borders are not defined in any official document. In the case of Western Indian Ocean Transfrontier Marine Park, it is completely impossible to determine before any agreement has taken place, hence stated as N/A.

Sources: BIOPAMA (2017); EC (2015); SADC TFCA Portal (n.d.). 

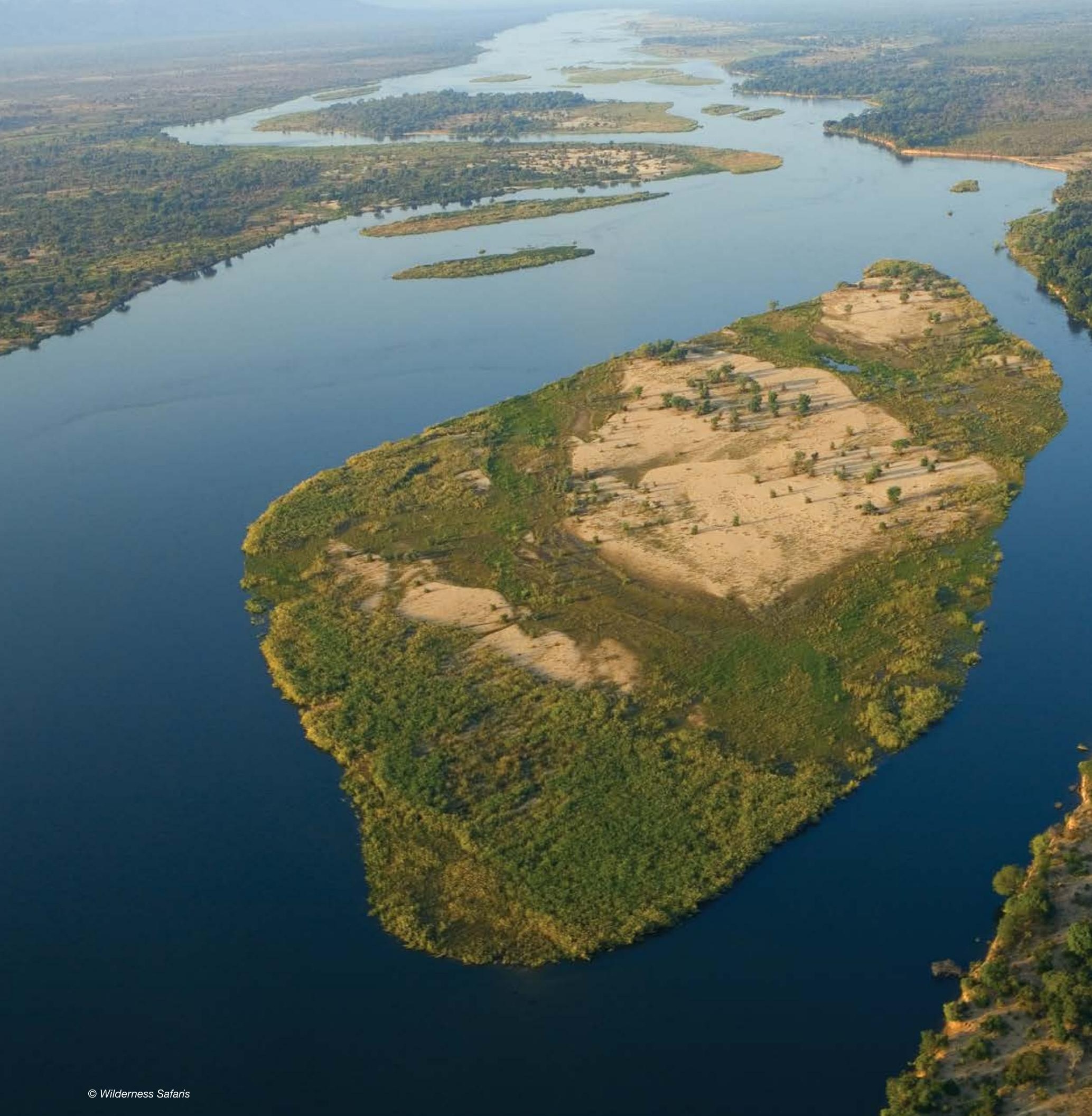


\section{Ecosystem services of protected areas in Eastern and Southern Africa}




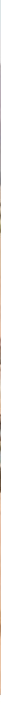

Ecosystem services (ES) describe the benefits or contributions of nature to people. Nature provides humans not just with oxygen, water, food and raw materials to meet basic needs, but also with countless other services that contribute to human well-being, such as recreational opportunities, climate regulation, flood regulation and spiritual values (see Figure 5.1)

ES first emerged in the 1980s to assess and communicate the benefits and contributions of nature to people within a comprehensive and consistent framework. Its aim is to recognise the multiple services supplied by nature in order to improve the management of ecosystems and natural resources within various policy fields, such as land-use policies, agricultural practice, nature conservation or protected area management. The Millennium Ecosystem Assessment (MEA) is widely known for examining the links between ecosystems and human well-being (MEA, 2005).

The concept has become increasingly applied in developing nature conservation policies in a broad range of activities. For example, in the field of nature conservation advocacy, the concept facilitates communicating the benefits of protected areas observable and understandable enough to enhance political and financial commitments. Highlighting the benefits and values of protected areas can increase acceptance of nature conservation policies among politicians and the general public, and stimulate funding.

In the field of protected areas, the concept of ecosystem services was introduced in management strategies and spatial conservation planning (Hummel et al., 2019). It is also widely adhered to in other sectors, such as protected area tourism, sustainable agriculture and hydropower production. Although its application increases the complexity and information required, the concept offers great opportunities for improved protected area zoning, planning and management, while improving knowledge to address the interests and needs of different stakeholder groups within and around protected areas. The concept may help facilitate protected arearelated negotiations and decision processes.
Depending on the protected area category, this shift is also reflected in recent policy goals in protected area management strategies, for example in Kruger National Park in South Africa where local community members are allowed to collect mopane worms on an annual basis to earn income and as a food source.

In Eastern and Southern Africa, an important ecosystem service is recreation in the form of wildlife tourism, which brings in a large amount of revenue for many countries in the region. Food provisioning services and traditional medicines are also key and the dependence of many communities on natural resources for survival is high. In a research undertaken in an area adjacent to Mosi-oa-Tunya National Park in Zambia in 2017, it was found that $79 \%$ of the 136 community households interviewed collect the natural resources from around the village, with 5\% saying that they collect from inside the forest reserve and $2 \%$ collect inside the National Park (Snyman, 2012); it is illegal to collect in either of these places. In order to ascertain the approximate value of natural resources to rural households, respondents were asked to give an approximate value to the resources collected, i.e. if they had to buy the resources what would the approximate value be? The results reveal that the mean value was approximately US\$ 340 per household per month. In relation to the average total household incomes, this is a substantial contribution to overall household welfare, providing almost an additional $30 \%$ to monthly household incomes and highlighting community dependence on natural resources for overall household welfare and food provisioning services.

Critical ecosystems services provided by protected and conserved areas in the region include carbon sequestration and water provision. Supporting services (habitat, primary production, biomass, pollination, soil formation, waste treatment, nutrient cycling and erosion control) are also all of importance in the region. 


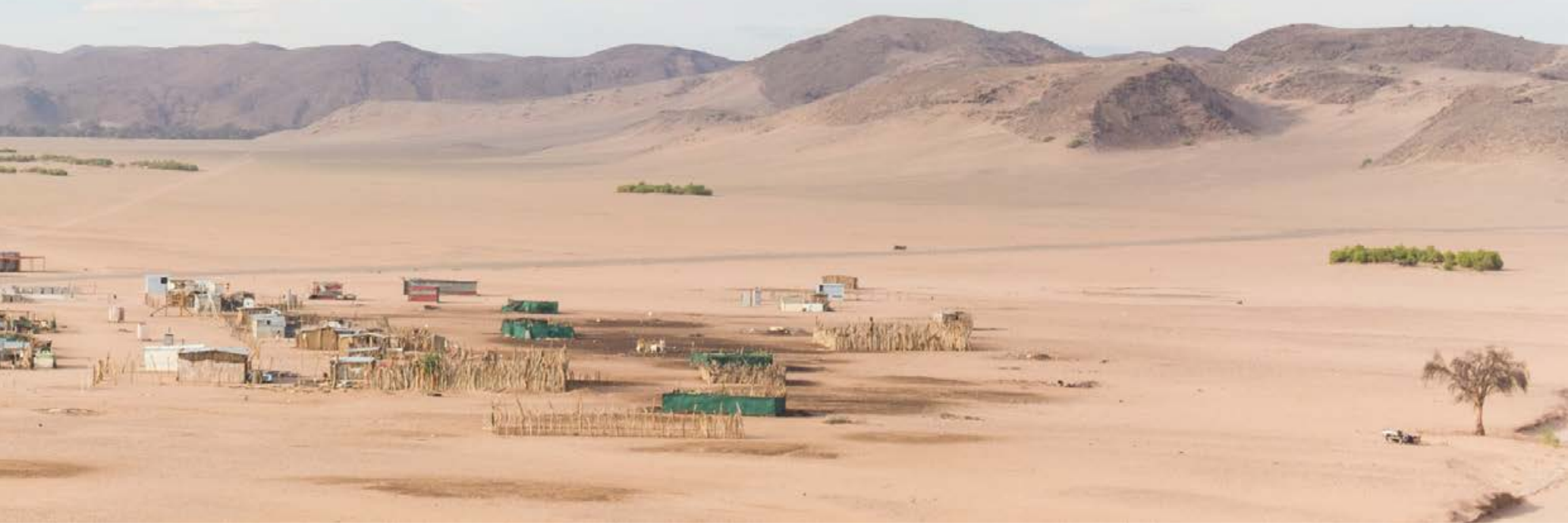

\section{Figure 5.1 Types of ecosystem services}
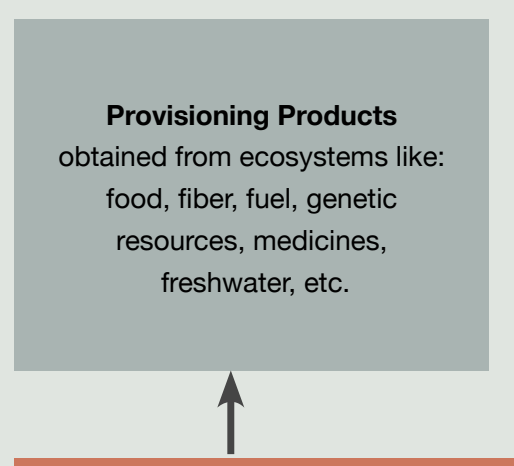
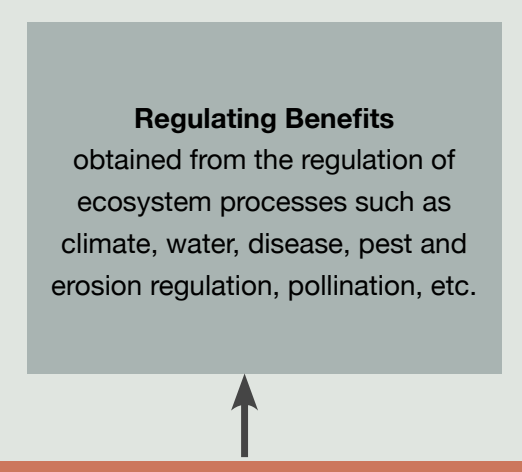

Supporting ecosystem services

Necessary for the production of all other services. Supporting services include: Soil formation, photosynthesis, nutrient and water cycling, etc.

\section{Cultural Services}

Non-material benefits from ecosystems such as: cultural diversity, spiritual and religious values, knowledge systems, cultural heritage, recreation and tourism, etc. 


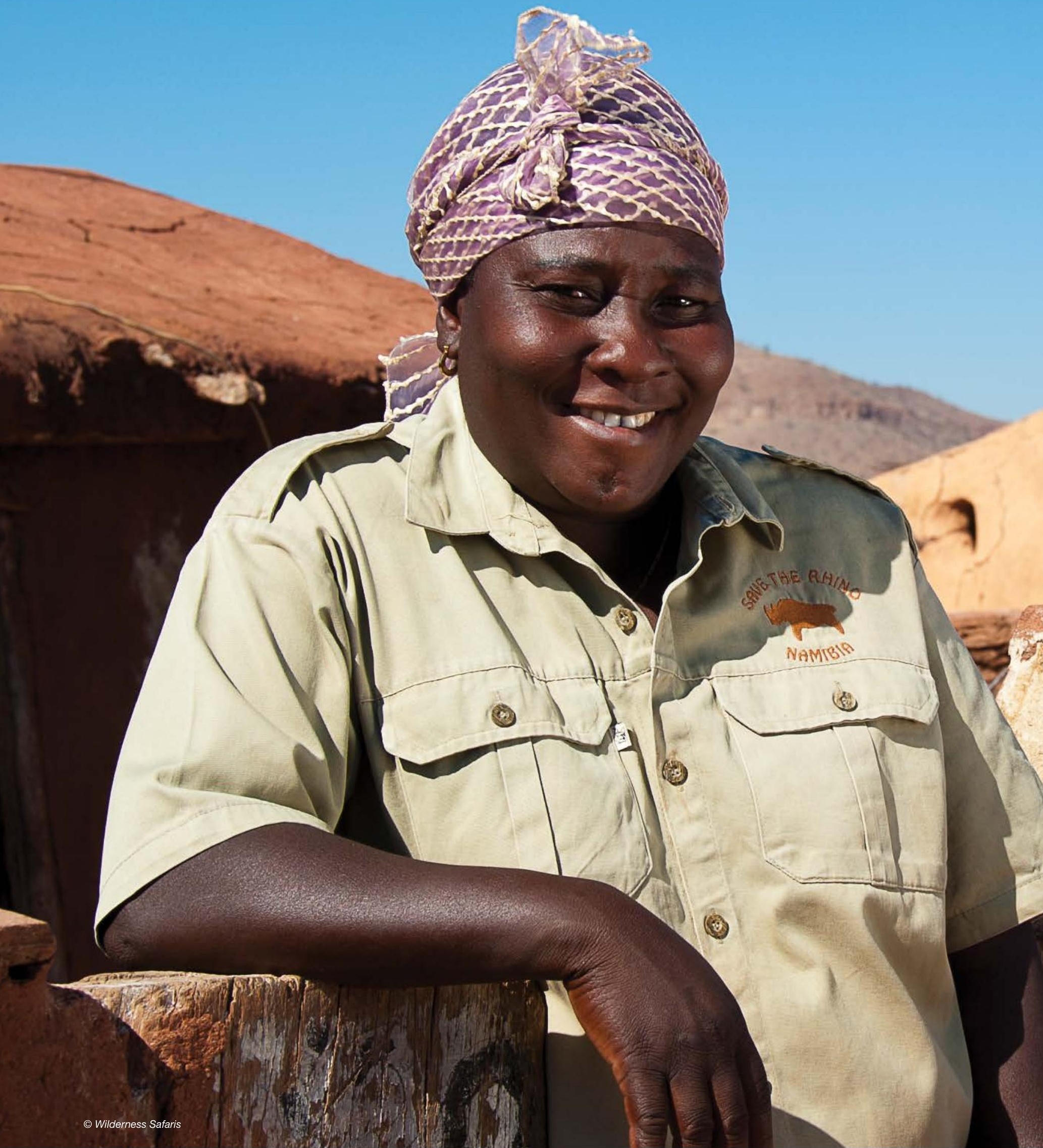




\section{Regional policies and relevant frameworks relating to biodiversity conservation and protected area management}


Agenda $2063^{14}$ is the Africa's strategic blueprint that aims to deliver on its goal to promote inclusive and sustainable development, complemented by NBSAPs as national instruments to incorporate biodiversity strategy into development planning. Some countries, such as Botswana and Tanzania, have gone further by including biodiversity and ecosystem services into their Poverty Reduction Strategies, while countries like Malawi and Seychelles have incorporated biodiversity conservation into development plans concerning agriculture and forestry (IPBES, 2018). A number of countries, including Ethiopia, Kenya and Mauritius, have also incorporated Strategic Environmental Assessments in their legal frameworks (UNEP-WCMC \& IUCN, 2016), although in several others it is less explicit (IPBES, 2018). Ideally, conservation and protected areas should be mainstreamed into national and regional policies to ensure their inclusion in decision-making, especially in relation to land use planning.

A review of policy and legislation related to protected area management, governance and equity in the Eastern and Southern Africa region was carried out under the BIOPAMA Programme (Tessema, 2019). The review finds that although several countries have made great strides in developing robust legal frameworks that are geared towards strengthening the management, governance and equity of protected and conserved areas, substantial differences in legislation portfolios remain between countries, and between the countries of EAC, IGAD and SADC. However, the review finds that even as State governance remains the dominant model, there is an encouraging trend of policies and legislation that advances a variety of non-State governance types involving communities, private individuals and collaborative arrangements.

These changes also support the expansion of protected areas and conserved areas, and seek greater equity in protected area management and benefit sharing. Another important finding refers to the joint management of transfrontier conservation areas, and how policies and legislation are largely lacking in all but the SADC region (Tessema, 2019) (see section 4.5).

The key findings of the BIOPAMA review of Eastern and Southern Africa's policy and legislation include:

Relatively new countries, such as South Sudan and Sudan, need support in developing their legal framework for protected and conserved areas;

- Some of the laws governing protected areas in Botswana, Eswatini, Djibouti, Eritrea, Comoros, Lesotho, Seychelles, Somalia, Sudan and Zimbabwe were developed since a while, and could be revised to incorporate current thinking and practice in protected area management;

- Several countries, such as Namibia, South Africa and Rwanda, have robust legal frameworks for protected area management, so cross-country exchange of experience and expertise should be encouraged;

- There are similarities between countries of the regional organisations of EAC, IGAD and SADC, which can be explored as platforms for targeted regional capacity building;
- Legal frameworks that recognise and support the growing trend of diversified and collaborative governance types need to be strengthened;

- Lack of synergy and conflicting laws are reported in many EAC countries, particularly between laws that govern natural resources and those of the extractive industry; and

- The principles of transboundary cooperation are well advanced in SADC and can inform those in EAC and IGAD.

Overall, countries in the Eastern and Southern Africa region have made progress in the development of protected and conserved area-related policies and legislation over the past decade. Tessema (2019) found that 14 out of the 24 Eastern and Southern Africa countries submitted Action Plans to CBD's Programme of Work on Protected Areas (PoWPA) (CBD, 2004) during the 2010-2014 period. Under Programme Element 3 (Enabling Activities) and Goal 3.1 "To provide an enabling policy, institutional and socio-economic environment for protected areas” of PoWPA (CBD, 2004, p. 15), countries self-assessed their implementation progress from 1 to 4 , with 1 for just started, limited progress to 4 for activity completed. The overall rank for implementation progress in the region is 2 (activity fully underway), and 11 out of the 14 countries have reported to be at or above the overall range of implementation progress to achieve Goal 3.1 (see Table 4.4).

It must be noted that a number of countries have developed legal instruments specifically to support equity and non-State governance types, namely Kenya, Mozambique, Namibia, South Africa, Uganda and Zimbabwe. However, the number of legal frameworks may not necessarily suggest a progress in implementation. Similarly, the number of laws per country as shown in Table 4.4 is not an indicator of the effectiveness of the legislation, since as one single well-implemented law may be more effective than 20 sub-standard or fragmented laws. In this connection, further research into the implementation of legislation and its effectiveness would be useful in providing a more detailed analysis of policy and legislation in the region. 
Table 6.1 Progress on implementing PoWPA Goal 3.1

\begin{tabular}{|c|c|c|}
\hline Country & $\begin{array}{r}\text { Goal } 3.1 \\
\text { Implementation } \\
\text { Progress }{ }^{15} \\
\text { (scale } 1 \text { to } 4)\end{array}$ & $\begin{array}{r}\text { No. of legal } \\
\text { instruments } \\
\text { developed since } \\
2010^{16}\end{array}$ \\
\hline Angola & 3 & 28 \\
\hline Botswana & - & 8 \\
\hline Comoros & - & 5 \\
\hline Djibouti & - & 2 \\
\hline Eritrea & - & 3 \\
\hline Eswatini & 1 & 1 \\
\hline Ethiopia & 3 & 10 \\
\hline Kenya & 3 & 24 \\
\hline Lesotho & - & 3 \\
\hline Madagascar & 1 & 23 \\
\hline Malawi & - & 6 \\
\hline Mauritius & - & 10 \\
\hline Mozambique & 4 & 30 \\
\hline Namibia & - & 11 \\
\hline Rwanda & 2 & 36 \\
\hline Seychelles & - & 4 \\
\hline Somalia & - & 4 \\
\hline South Africa & 4 & 58 \\
\hline South Sudan & - & 2 \\
\hline Sudan & 2 & 3 \\
\hline Tanzania & - & 11 \\
\hline Uganda & 4 & 16 \\
\hline Zambia & 2 & 16 \\
\hline Zimbabwe & - & 8 \\
\hline
\end{tabular}

Source: Tessema (2019). 


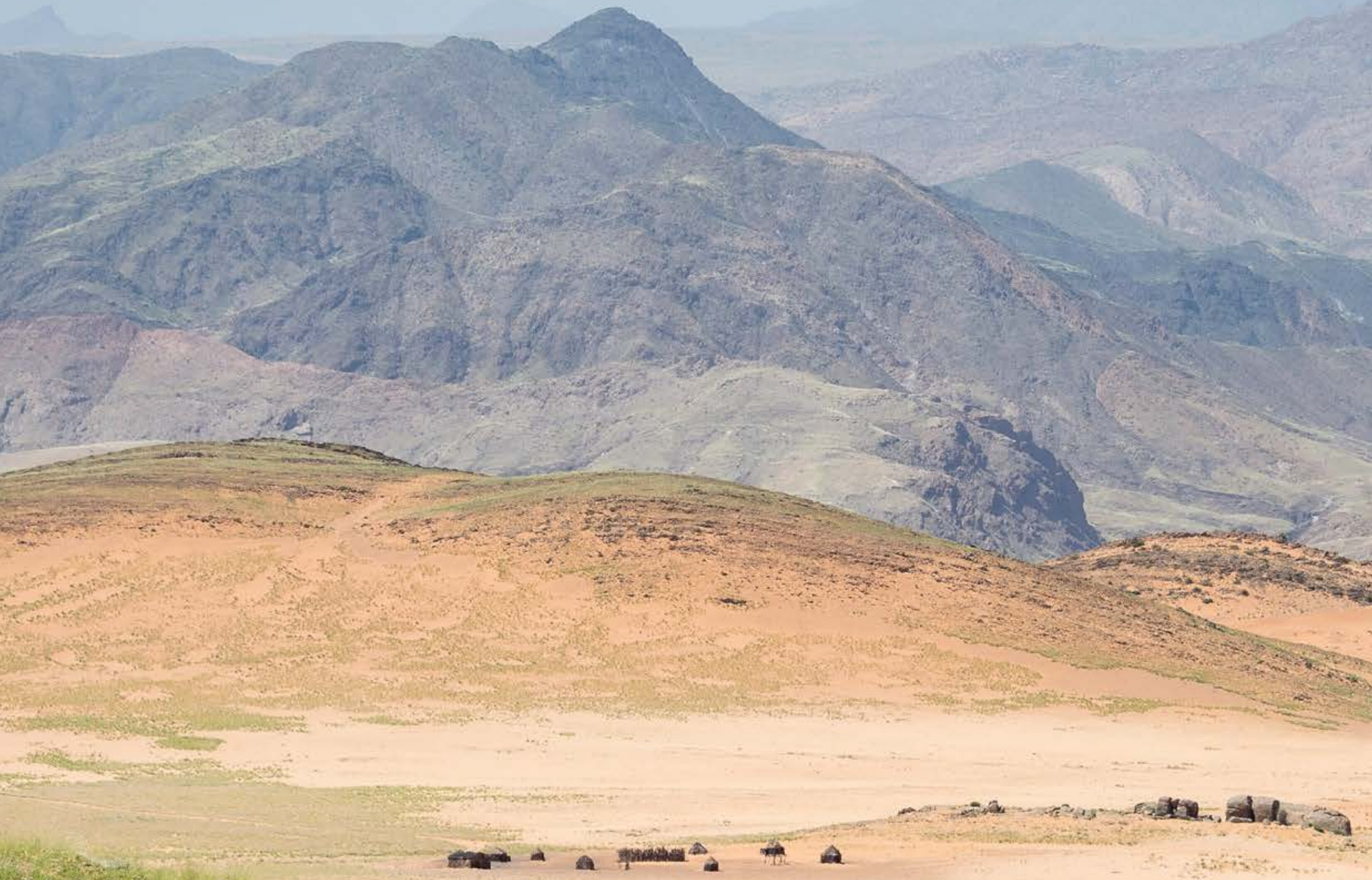

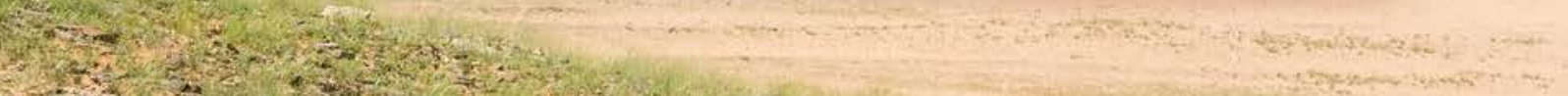

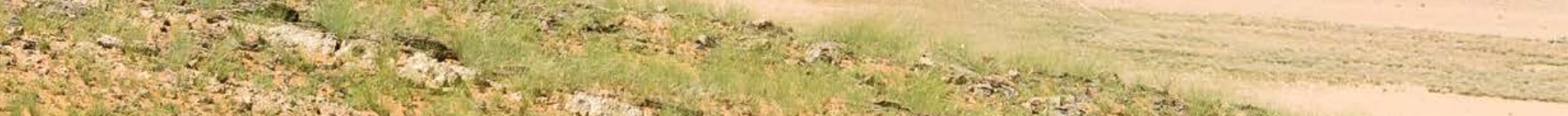

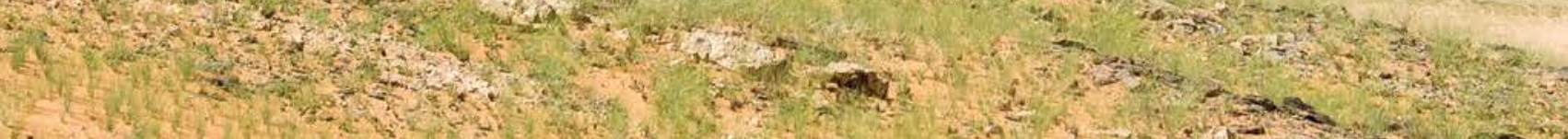

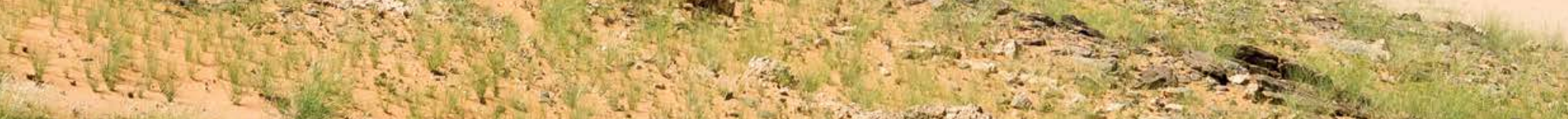

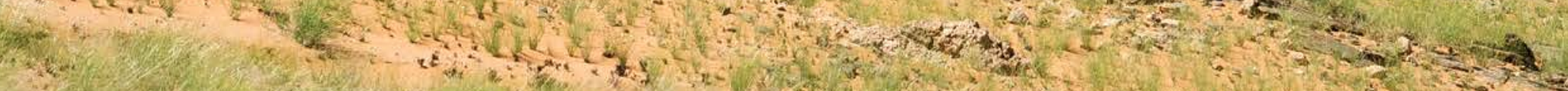

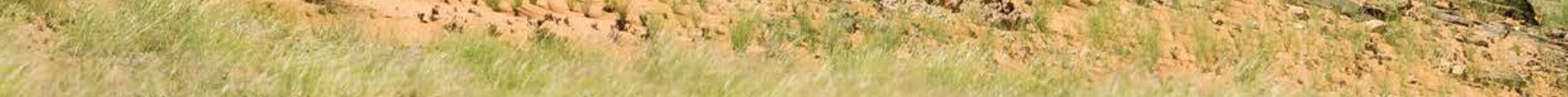

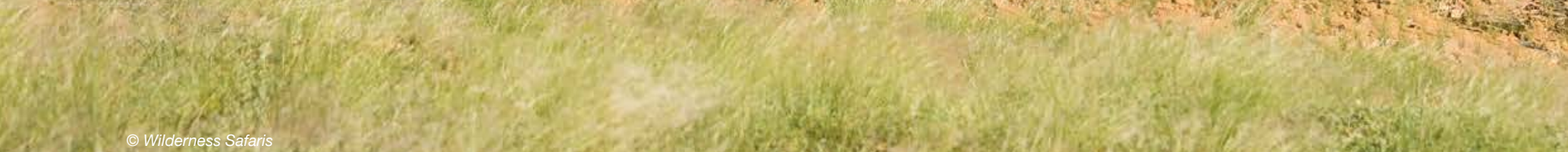
the 


\section{Regional Economic Communities}


Regional Economic Communities (RECs) are regional groupings of African States whose purpose is to facilitate regional economic integration between members of the individual regions and through the wider African Economic Community. They also play an important role in terms of promoting transfrontier conservation in the region. In Eastern and Southern Africa, BIOPAMA programme collaborates with the EAC, IGAD, SADC and IOC. They are important partners in the BIOPAMA programme and in the region as a whole, as they coordinate regional activities with the member states, including addressing the specific regional priorities and needs.

RECs assist with the development of priorities for specific regional needs. In addition, they collaborate to determine useful analytical and decision-making tools and products for their region together with the preparing of policy briefs and other documents. RECs also assist with communication of protected areas issues to higher-level decision-makers, thus ensuring that the research and information produced by the programme from the programme play an important role in policy-making.

Countries under the regional organisations ${ }^{17}$ of EAC, IGAD and SADC provide ready groupings for current and future comparisons of protected area-related legal frameworks that can potentially provide and promote a platform for knowledge exchange between the regions.

\subsection{East African Community (EAC)}

The EAC is a regional intergovernmental organisation of six Partner States, comprising Burundi, Kenya, Rwanda, South Sudan, Tanzania $^{18}$ and Uganda, with its headquarters in Arusha, Tanzania. Considering that natural resources are the drivers of national and regional economic development, the objective of the Environment and Natural Resources Management sector within the EAC is to promote sustainable use and management of natural resources and promote adaptation to climate change.

The EAC Treaty established in July 2000 provides for co-operation in environment and natural resources, and EAC Partner States have agreed to make a joint effort to co-operate in the efficient management of these resources. EAC is focused on strengthening the resilience and sustainable management of biologically significant transboundary freshwater ecosystems (EAC, 2010) and supporting adaptive capacities, and resilience to the negative impacts of climate change.

The East African Legislative Assembly (EALA), which is a branch of the EAC, passed the East Africa Transboundary Ecosystem Bill on January 2012. The Bill has yet to be ratified by EAC Partner States and consequently, the related Commission has not been established and EIAs are being undertaken by virtue of EAC Partner States laws. For that matter, the Lake Victoria Basin Commission and the Nile Basin Initiative have provided a collaborative platform for the management of shared water and land resources for a number of years. However, an EAC wide plan to harmonise policies and laws to better manage transboundary natural resources is still in development (Tessema, 2019).

Further instruments developed by EAC to improve conservation in the region include a 2017-2022 strategy to combat poaching, illegal trade and trafficking of wildlife and wildlife products (EAC, 2018). This is a significant transboundary cooperation related to conservation of shared resources. It will support implementation of activities, including the development of a regional wildlife conservation policy, economic and non-economic valuation of wildlife, strengthening community participation in the management of transboundary wildlife resources and establishment of Trade in Wildlife Information Exchange System (TWIX).

EAC's Protocol on the Environment and Natural Resources Management 2006 (yet to be ratified by Tanzania) governs the Partner States in their cooperation in the management of environment and natural resources over areas within their jurisdiction including transboundary environment and natural resources.

\subsection{Indian Ocean Commission (IOC)}

The IOC is an intergovernmental organisation established in 1984 through a general cooperation agreement known as the Victoria Agreement. ${ }^{19}$ The members of IOC are the Comoros, Madagascar, Mauritius, Seychelles and the island of La Réunion (an overseas department of France).

The islands share commonalities in terms of natural resources rich in biodiversity, as well as environmental features which have significant influence on their national development. Economy is highly dependent on their natural coastal and marine resources, and tourism based on natural resources' endowment. Good environmental quality is essential for the high value-added ecotourism pursued by the countries. The environment and management of natural resources has been one of the main areas of cooperation amongst the member States with over EUR 205 million invested in the sector, representing almost 20 projects implemented by the IOC since 1999.

With the development of the tuna industrial fishing activities in the Indian Ocean, IOC implemented its first regional tuna fisheries project where emphasis was laid on the management of tuna stock and assisting countries to develop its capacity for fisheries management. In early 2000, IOC in collaboration with Indian Ocean Tuna Commission implemented the first regional tuna tagging project and supported the national fisheries authorities to build capacity for monitoring, control and surveillance of fisheries. 
The activities of IOC in the marine and coastal environment continue to increase, with a focus on the management of the marine protected areas, monitoring and surveillance of the coral reef and associated ecosystems, marine pollution resulting from oil spills, integrated coastal zone management and marine invasive species. Capacity has been built at the institutional and at the community levels and tools have been developed to support the management of the coastal habitats and the conservation of marine and coastal resources, including:

\section{- Participation in regional marine environment tools}

The Indian Ocean Commission has directly and indirectly contributed to the establishment of regional instruments and the development of tools in marine environment. Major regional strategic action frameworks, platforms and networks have been set up and supported, such as the Coral Reef Network and Marine Protected Area Network to mention a few. Given the importance of the coastal and marine environment to the member states of the IOC, a Blue Economy Strategy is being developed and was adopted by the Council of Ministers meeting of the IOC in March 2020.

- Development of a Regional Strategy and Action Plan for Conserving Marine Ecosystems \& Fisheries for the Western Indian Ocean Island Marine Ecoregion

The IOC strategic framework comprises the following areas of intervention:

1. Organise data acquisition on marine ecosystems, marine resources and their uses, sharing and valuing them sustainably through a regional observatory;

2. Share knowledge with all stakeholder communities, provide and promote decision making support tools;

3. Train all stakeholders, capitalise and exchange good practices on marine sustainable development;

4. Support to the implementation of the strategy on fisheries management to promote coordinated, responsible and sustainable fisheries and aquaculture;

5. Strengthen the sustainable management of marine protected areas and their networking;

6. Implement actions to conserve migratory species and / or with broad scope in accordance with their relevant conventions;

7. Support the implementation of the Regional Strategy for adaptation to climate change to contribute to a better resilience and reduced vulnerability of marine ecosystems; and

8. Develop a responsible and concerted approach to the exploitation of non-renewable resources (gas, oil, renewable energy, minerals, biomolecules, etc.).

- Establishment of an Integrated Coastal Zone Management (ICZM) Protocol

The approach to integrated coastal zone management within the IOC member states was developed through its regional environmental programme implemented in the late 1990s. The main course of action was to raise awareness towards an integrated and concerted approach for the management of the coast. Building on the outcome of the regional environmental programme 'PRE-COI', from 1996 to 2011, IOC implemented the Regional Sustainable Coastal Zone Management Programme. This allowed the countries to set up and/or strengthen their national Integrated Coastal Zone Management Committee. IOC, in collaboration with its regional partners, supported development of the ICZM Protocol to be established under the Nairobi Convention (see next section). The draft protocol has now been agreed upon and is expected to be submitted for endorsement at the next Nairobi Convention COP.

- Adoption of Nairobi Convention for the Protection, Management and Development of Coastal and Marine Environment of the Western Indian Ocean (1985) ${ }^{20}$

The member States of the IOC are all Parties to the Nairobi Convention and the environmental programmes of the IOC consider the provisions of the Convention. IOC and the Nairobi Convention Secretariat collaborate on the various regional programmes. In 2012, UNEP on behalf of the Nairobi Convention Secretariat and IOC formalised its collaboration and signed a Memorandum of Understanding to strengthen collaboration on areas of common interest to include marine protected areas. IOC has an observer status in the COP of Nairobi Convention and participates in various working groups and programmes of the Convention. To this effect, IOC has aligned all its programmes and activities with respect to coastal and marine ecosystems to the provisions of the Convention and its relevant protocols. Much has been achieved through this collaboration, particular: the development of the ICZM Protocol; strengthening of the Science to Policy Forum; establishment of the Transboundary Conservation Area between Kenya and Tanzania (Box 7.3); strengthening the monitoring of the coral reefs; capacity building for the management of the Marine Protected Areas; capacity building for the prevention and management of marine pollution derived from oil spills, amongst others.

\section{- Creation of Indian Ocean Cetacean Consortium}

The actions of IOC in relation to the conservation of migratory species and large mammals began in 2005. The IOC was tasked by its member states to raise awareness on the need for the protection of the marine migratory species. In 2008, IOC embarked on a regional initiative for the conservation of cetaceans and dugong species. The objective was to improve the scientific knowledge regarding cetaceans, study the movement of the population, create a network of stakeholders involved in the protection of cetaceans and reduce the impact of human activities on the cetaceans, such as fishing, whale watching and sound/acoustics. IOC collaborated with the French Agency for Marine Protected Areas in conducting the Indian Ocean Campaign to study the migration of Cetaceans. It has also supported the establishment of the Indian Ocean Network for Cetacean Research and Conservation (IndoCet) of NGOs in the Western Indian Ocean region working towards the protection of Cetaceans, mainly whales and dolphins. The network has created a website and developed a tool to assist in the identification of Cetaceans. ${ }^{21}$ 


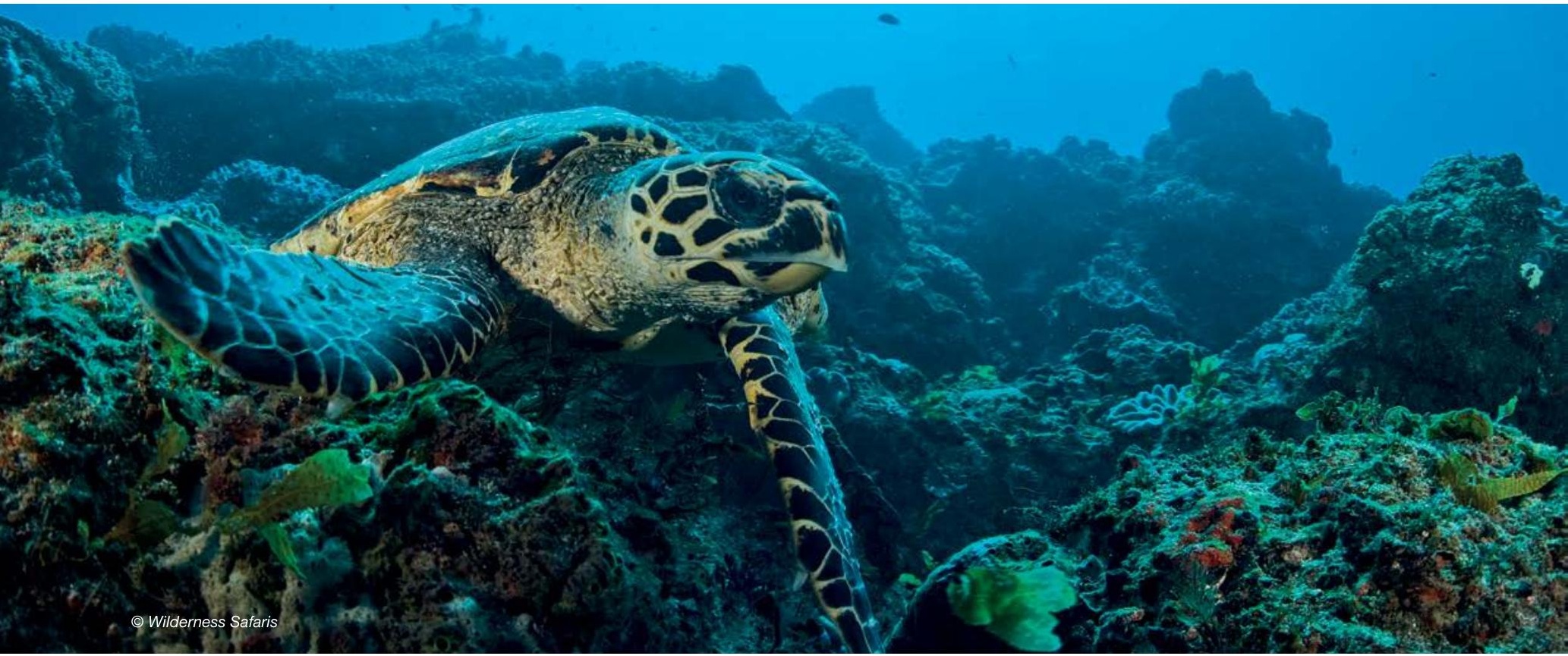

\section{Box 7.3 Marine transboundary conservation between Kenya and Tanzania}

The coastline of Eastern Africa, which Kenya and Tanzania, is rich in natural marine resources, with pristine beaches of coral, estuaries, mangroves, lagoons and several beautiful islands rich in biodiversity. These environments sustain a diverse marine life and are critical for the subsistence of the coastal communities. However, the coastal environment is threatened by climate change, pollution, habitat destruction and the pressure from growing coastal populations, tourism and urbanisation. Coral reefs of Kenya and Tanzania were extensively bleached during the 1997-1998 El Niño with coral cover reducing by more than $80 \%$ in most areas. Recovery from bleaching has been very slow in many coral reef systems due to increasing pressures of human-related activities. The increasing coastal population in both Kenya and Tanzania is also exerting pressure on the marine and coastal resource with increasing demand for food and materials. Because of the two countries' contiguous coast lines, there is a potential for the loss and degradation of coastal habitats in one to have impacts on the other as a result of disturbance and fragmentation.

To reverse loss of marine biodiversity, both Kenya and Tanzania have made efforts to improve marine resources management through policy and legal frameworks. A number of marine protected areas (MPAs) have been established in both countries to protect critical habitats and species. Recently, Kenya and Tanzania have begun to explore the possibility of cross border cooperation in marine conservation, by establishing a marine transboundary conservation area (TBCA). UNEP, through the Nairobi Convention Secretariat, has initiated a series of discussions between the protected area management agencies of the two countries to take this process forward.
The aim of the marine TBCA in Kenya and Tanzania is to mainstream ecosystem management objectives and priorities into productive sector practices and policies. The concept seeks to strengthen capacity for restoring ecosystem health and conserving biodiversity at the local, national and transboundary levels in the two countries. The initiative seeks to pilot ecosystem-oriented approaches to spatial planning, water management, agriculture, forest, fisheries and protected area management. The proposed site extends from the northern boundary of the Diani-Chale Marine National Reserve in Kenya to the southern boundary of Mkinga District in Tanzania, north of the Tanga Coelacanth Marine Park. The area of interest harbours highly significant marine and coastal biodiversity. Due to its rich biodiversity and contribution to the socio-economic life of coastal communities, the area has been recognized by several international agencies as an area of significance deserving special conservation attention.

The proposed TBCA is complementary to the two countries' efforts to sustainably manage and conserve coastal and marine resources, contribute to poverty alleviation of coastal communities, and to promote the implementation of key regional and international instruments for the conservation of marine and coastal resources and biodiversity. Further, the protection of TBCA complements the Tanzanian efforts to protect all small islands marine reserves south of its border, namely Ulenge, Kwale, Kirui and Mwewe Marine Reserves. It will also increase the area that Kenya and Tanzania have set aside for marine conservation which goes in the direction of meeting the CBD Aichi Target 11 and SDG 14.

Contributed by Arthur Tuda (Kenya Wildlife Service). 
- International collaboration under the Cotonou Agreement (2000)

In accordance with the Cotonou Agreement, ${ }^{22}$ IOC has benefitted from several regional development programmes in agriculture, fisheries, environment and maritime security amounting to over $€ 156$ million. The programmes have contributed to strengthening collaboration and cooperation among the countries of Eastern, Southern and Indian Ocean region towards sustainable fishing, management of natural resources, protection, integrated coastal zone management, environmental education, conservation and utilisation of biodiversity, climate change and to improving maritime security in the region. In particular, it also opened opportunities for interregional cooperation between IOC, the Caribbean and Pacific on matters affecting Small Island States, such as climate change and natural disasters and the ocean. Through the agreement's comprehensive European development aid to the Africa, Caribbean and Pacific regions, IOC along with the African Union and other African regional communities was able to improve access to European Space Agency's Earth Observation data for natural resources management and coastal degradation monitoring.

Under the Cotonou Agreement, IOC is collaborating with the ACP secretariat on programmes to raise awareness on Small Island States of Africa with regards to climate change and coastal and marine biodiversity.

\subsection{Intergovernmental Authority on Development (IGAD)}

Composed of eight countries in Eastern and Southern Africa Djibouti, Eritrea, Ethiopia, Kenya, Somalia, South Sudan, Sudan and Uganda - IGAD's main purpose is to achieve peace and sustainable development in the region. Rich in biodiversity, IGAD members' major factors for growth are its natural resources, more specifically fresh water and marine and coastal water ecosystems, forests and wildlife, wetlands, rangelands, arable land and mountains, and minerals and energy resources.

Two of IGAD's priorities for coastal and marine environments include the support and implementation of the Abidjan and Nairobi Conventions and the African Process for the management of Africa's coastal and marine resources. In concrete terms, these involve: pollution control and coastal erosion; and promotion of sustainable use of living resources, sustainable management of key habitats and ecosystems and sustainable economic development.

Instruments developed by IGAD for environmental conservation include:

- 2007 IGAD Natural Resource and Environment Strategy: aims to support the harmonisation of natural resource and environmental policies, as well as promote transboundary resource management.
- IGAD Natural Resources and Environment Protection Strategy 2016-2020 a part of IGAD's five-year regional strategy: developed by conducting extensive baseline studies to identify key issues and challenges in each country, including land, wetland and forest degradation, climate change, population growth, resource governance, lack of investments in development markets and value change, and the ongoing issue of the marginalisation of arid and semi-arid ecosystems.

- Regional Biodiversity Policy: aims to help conserve and sustainably manage biodiversity resources, and foster socioeconomic development for sustainable livelihoods, environmental sustenance, peaceful and secure coexistence, and regional integration through sustainable management of biodiversity resources in the region.

- Regional Biodiversity Protocol: developed and approved at the Ministerial level in July 2017 to implement the Regional Biodiversity Policy. It provides a guide on how to foster cooperation in the implementation of the regional policy and the issue of sustainable ecosystem development in the region.

- Strategy on Biodiversity Benefit Sharing: developed and approved at the Ministerial level; promotes sharing biodiversity benefits equitably among the IGAD State members, while respecting the situation of less-endowed countries so as to help develop unity and peace in the region.

- Strategy on Invasive Species Control and Management: developed and approved at the Ministerial level; addresses the introduction of alien invasive species through controlled expansion, management, use or, where possible, eradication, in particular in agriculture and forestry sectors in the region.

- IGAD Wildlife Management Strategy: developed and approved at the Ministerial level; provides a joint strategy on how to manage wildlife resources in the region.

- IGAD Specialized Network: established as part of the IGAD structure to follow up and coordinate wildlife law enforcement activities in the region.

- Djibouti Seascape Management Plan: developed under the Biodiversity Management Programme, where local communitybased marine conservation areas were identified and established. ${ }^{23}$

- IGAD Regional Strategy Implementation Plan (2016-2020): seeks to actively promote economic cooperation and integration in the IGAD region through enhanced regional capacity, including but not limited to natural resources management and environmental protection, by promoting sustainable management of environment and natural resources.

\subsection{Southern African Development Community (SADC)}

SADC is a regional intergovernmental organisation with its headquarters in Gaborone, Botswana and comprising 16 Partner States - Angola, Botswana, Comoros, Democratic Republic of Congo, Eswatini, Lesotho, Madagascar, Malawi, Mauritius, Mozambique, Namibia, Seychelles, South Africa, United Republic of Tanzania, Zambia, and Zimbabwe. ${ }^{24}$ 
Natural resources are vitally important to the economy of the region and to its growth. SADC and its Member States recognise the importance of improved use and stewardship of natural resources to ensure sustainable development and growth into the future. Important natural resources include forests, water, wildlife (aquatic, terrestrial and marine species) and minerals. To help protect these resources and foster regional cooperation, protocols and initiatives, such as the development of TFCAs, have been spearheaded by SADC.

Under the Protocol of Wildlife Conservation and Law Enforcement, the 2013 SADC Programme for Transfrontier Conservation Areas defines its mission to be the development of SADC into a functional and integrated network of transfrontier conservation areas, where shared natural resources are sustainably co-managed and conserved to foster socio-economic development and regional integration for the benefit of those living within and around TFCAs.

The harmonisation of policies and legislation for the effective management of these transfrontier conservation areas is a recognized part of SADC TFCA Programme. Some of SADC's regional policies and legal instruments include:

\section{- Protocol on the Development of Tourism (1998). ${ }^{25}$}

The protocol sets out SADC's objective to build upon the region's potential as a tourist destination. SADC intends to ensure even distribution of tourism development throughout the region and to create a favourable environment for tourism, thereby using tourism as a vehicle for socio-economic development.

- Protocol on Wildlife Conservation and Law Enforcement (1999). ${ }^{26}$

Entered into force in 2003 and is legally binding for countries that have signed and ratified it. The Protocol's objectives include the harmonisation of wildlife legal instruments, exchange of information relevant for wildlife conservation, national and regional capacity building for conservation, the establishment of transfrontier conservation areas and the promotion of community-based resource management. It provides the mechanisms for the conservation and management of shared resources, while recognising the rights of individual States to manage their respective wildlife resources.

- Revised Protocol on Shared Watercourses (2000). ${ }^{27}$

Many watercourses in the region are shared among several Member States, a situation that demands their development in an environmentally-sound manner. The Protocol aims to foster closer cooperation among Member States for protection, management and use of shared watercourses in the region.
Member States agree to cooperate on projects and exchange information on shared watercourses, consulting with each other and collaborating on initiatives that balance development of watercourses with conservation of the environment.

\section{- Protocol on Forestry (2002). ${ }^{2}$}

The Protocol aims to promote the development, conservation, sustainable management and use of all types of forest and trees, trade in forest products and to achieve effective protection of the environment. Provides guidance on the undertaking of national forest assessments and national forest policies, programmes and laws. Policies and mechanisms adopted in Member States should enable local people and women to effectively participate in forest management activities as well as respect the traditional knowledge related to forests.

- Regional Water Policy (2005). . $^{29}$

The SADC region has 15 major transboundary river basins which are. The policy provides the context and intent for water resources management at the SADC regional level, representing the aspirations and interests of Member States. The Protocol on Shared Watercourses is the legal instrument for the implementation of this policy, under which bilateral and multilateral agreements between Watercourse States may be developed.

\section{- SADC Regional Water Strategy (2006). . $^{30}$}

The strategy is aimed at providing a strategic framework for sustainable, integrated and coordinated development, use, protection and control of national and transboundary water resources. It outlines the plans for implementing the strategy, including the associated targets in the Regional Indicative Strategic Action Plan and the Strategic Implementation Programme driven by the Regional Strategic Action Plans for the SADC Water Sector (RSAP). The document concludes with a discussion of the monitoring and evaluation indicators that will be used to provide oversight on the implementation framework.

\section{- SADC Protocol on Fisheries (2006). ${ }^{31}$}

The Protocol aims to advance responsible and sustainable use of the living aquatic resources and aquatic ecosystems of interest to the State Parties, in order to: (i) promote and enhance food security and human health, (ii) safeguard the livelihood of fishing communities, (iii) generate economic opportunities from nationals in the region, (iv) ensure that future generations benefit from these renewable resources; and (v) alleviate poverty with the ultimate objective of its eradication.

- Tourism Concession Guidelines for TFCAs in SADC (2015). ${ }^{32}$ The aim of the guidelines is to provide direction for the management of tourism concessions in TFCAs within SADC, while ensuring that both the conservation and development

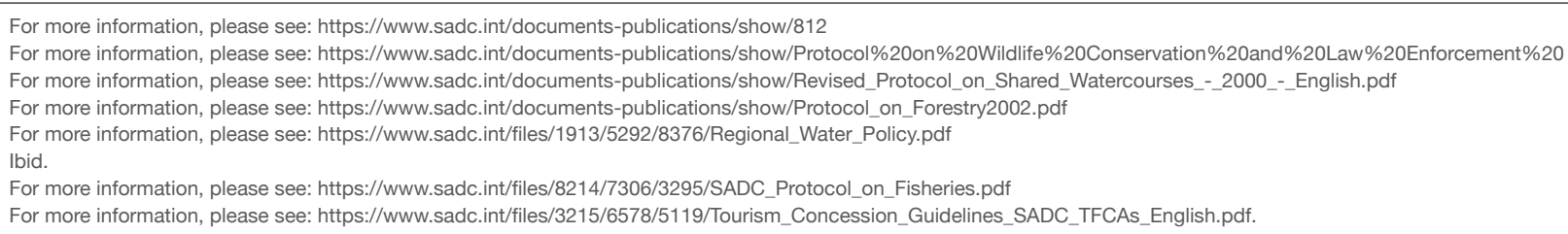


objectives of regional TFCAs are met, including rural development and community participation. The main benefit of the guideline is the acquirement of basic information on how to encourage, develop and operate tourism concessions in TFCAs within SADC.
There is scope for regional knowledge sharing, especially in terms of transfrontier conservation and SADC's 20-year experience in this field. Anti-poaching and law enforcement efforts would also benefit from regional cross-sharing of information related to policies, legislation and the sharing of information through the TWIX networks.

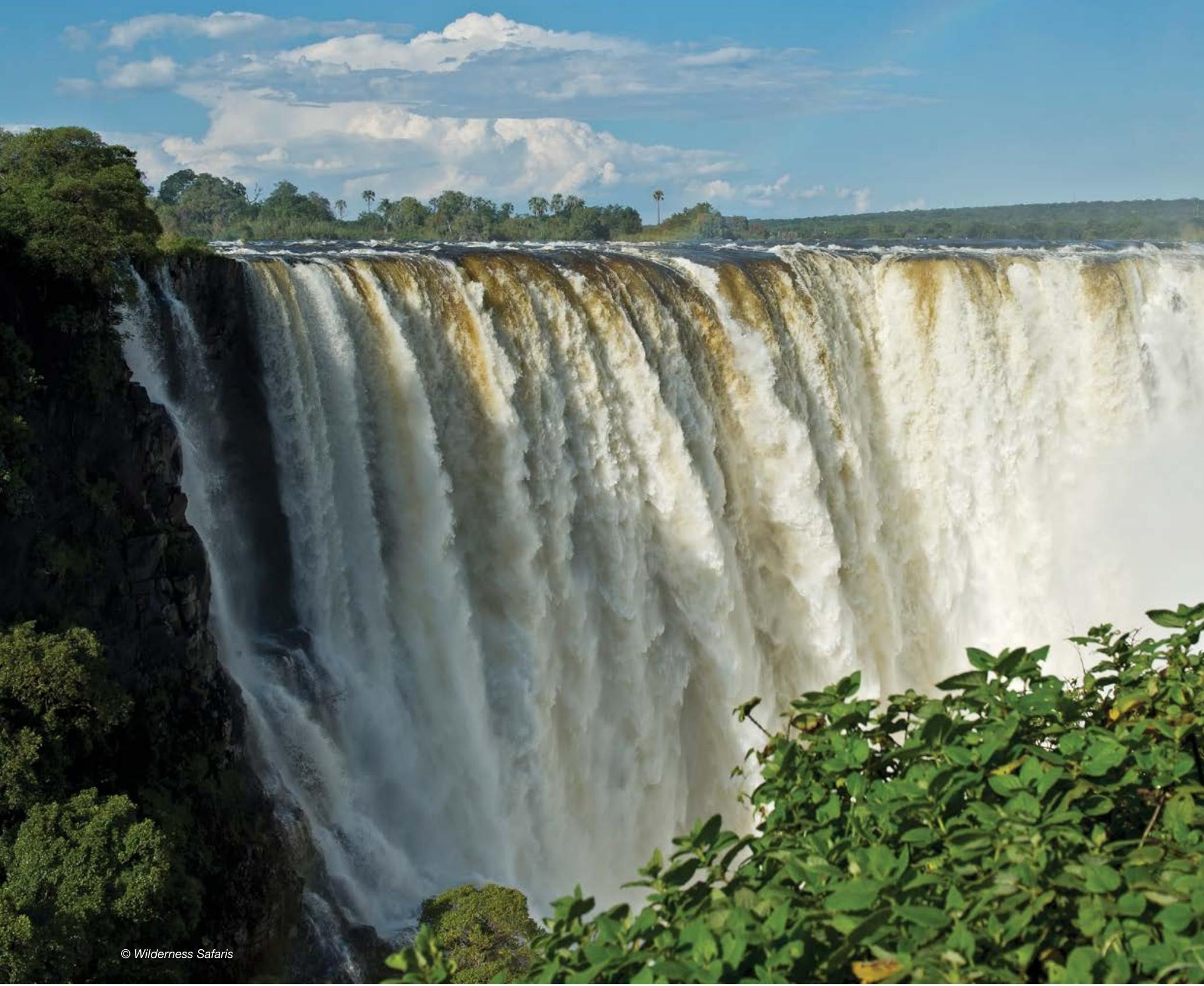



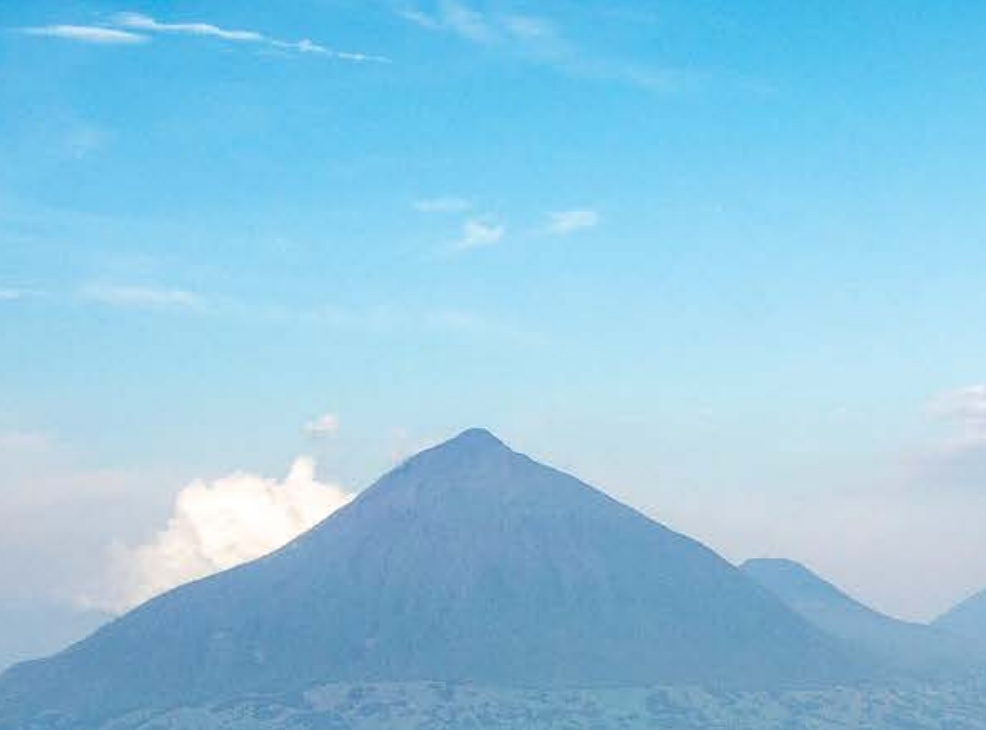

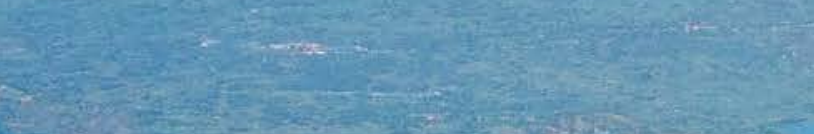

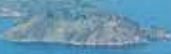

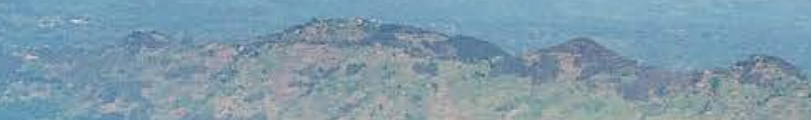

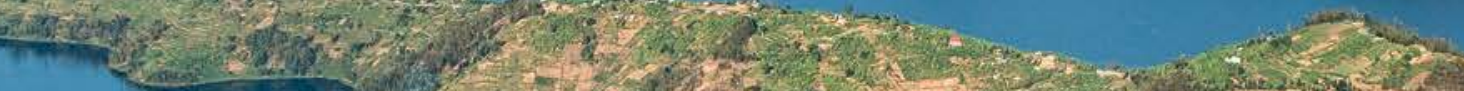

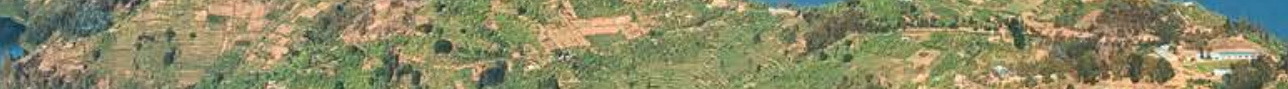

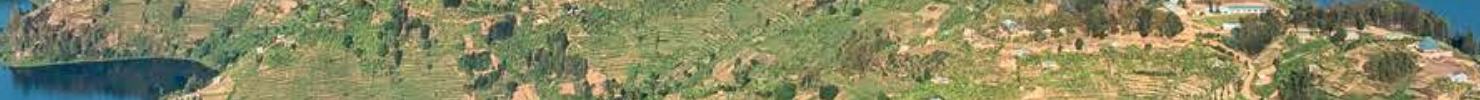

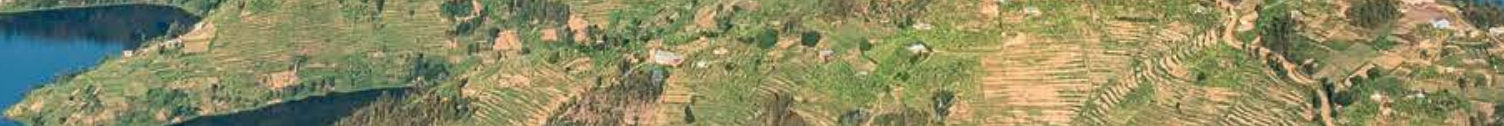

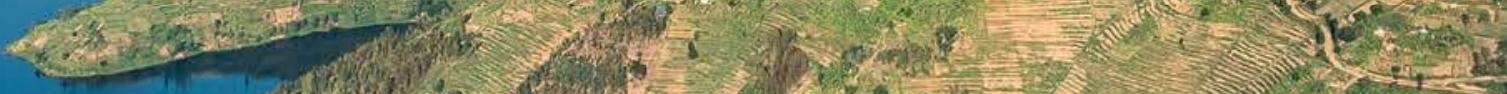

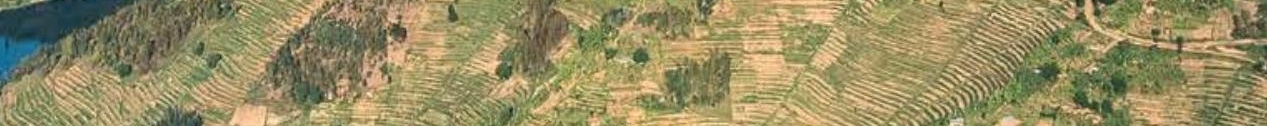
3.

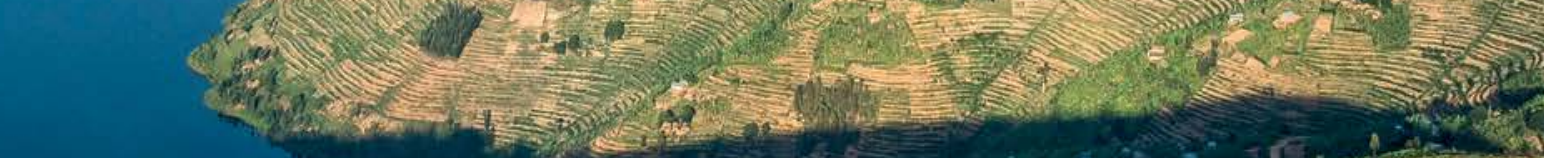
W.

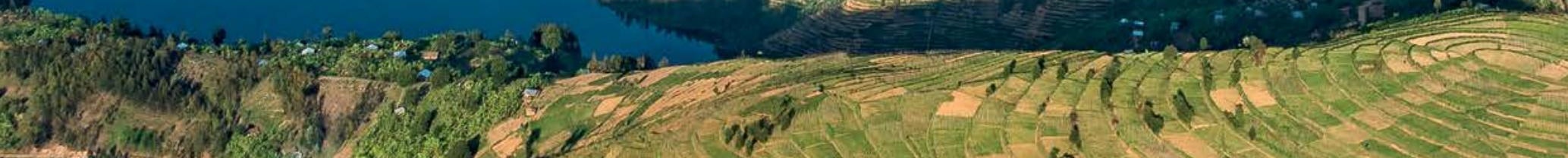

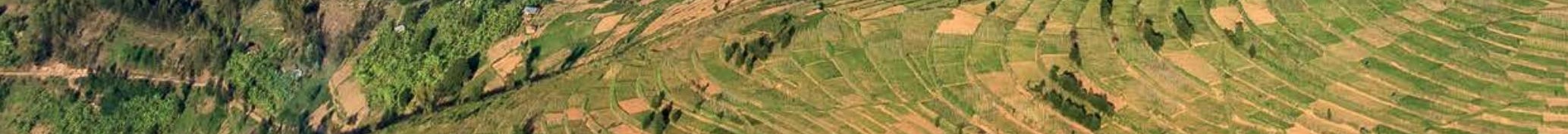

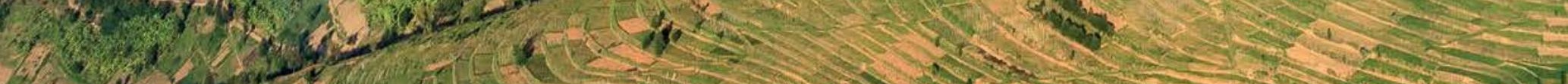
4.

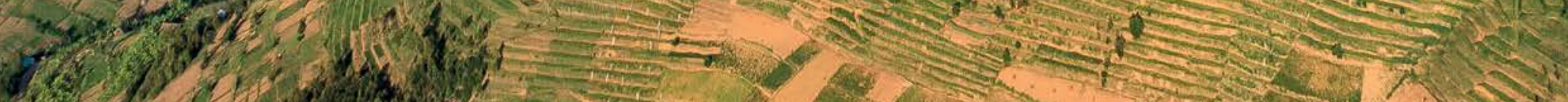




\section{Country profiles}




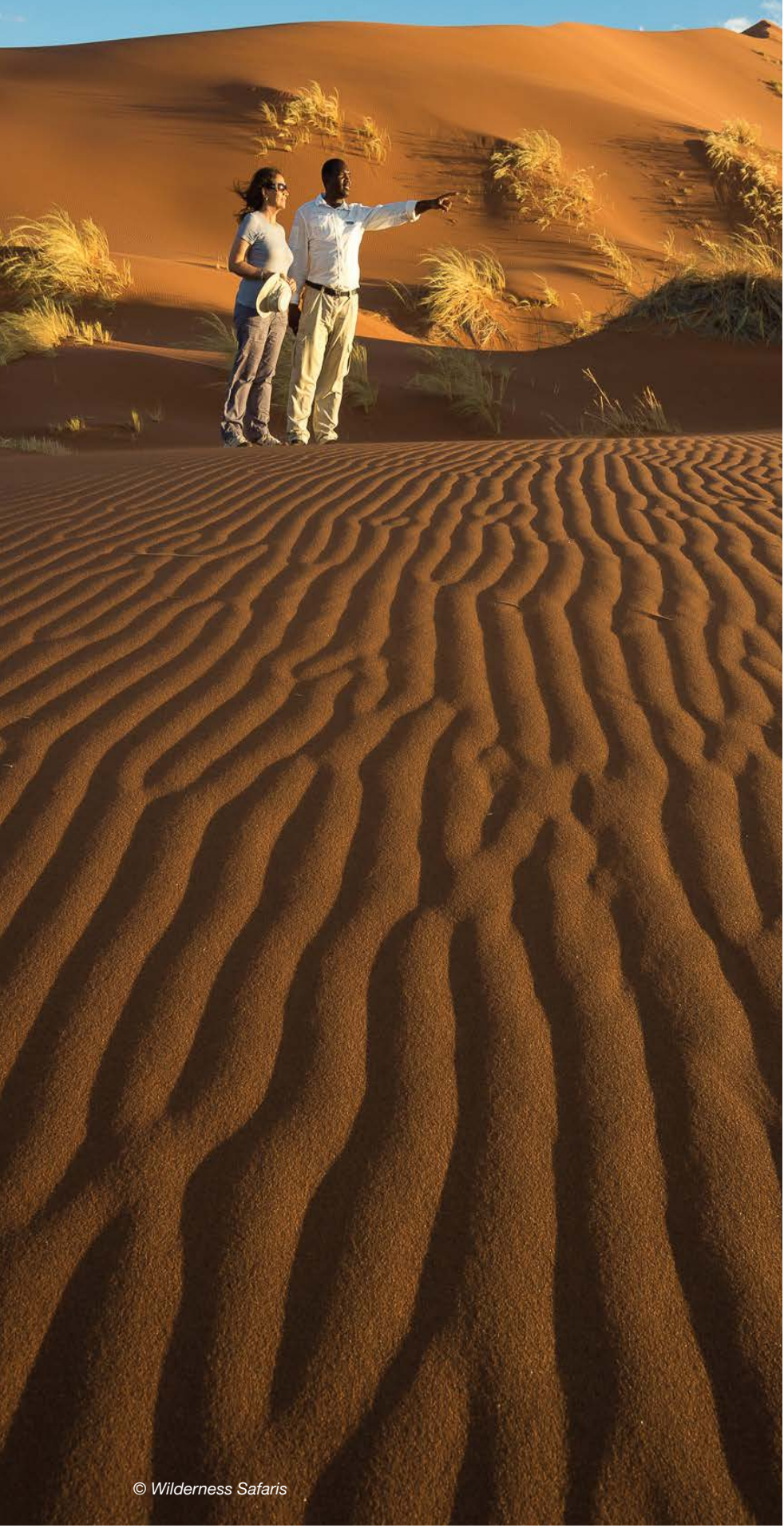

This section presents a profile of the protected and conserved areas of each of the 24 countries in the Eastern and Southern Africa region. Each profile includes the following data:

- A brief description of the protected and conserved areas, and their coverage;

- Data on the number of protected and conserved areas under the IUCN Governance types and Management categories;

- Date on the number and area of national designations of protected and conserved areas;

- Priority areas according to three designations: Alliance for Zero Extinction, BirdLife International's Important Bird \& Biodiversity Areas (IBAs) and IUCN's Key Biodiversity Areas (KBAs); and

- Other data: transboundary conservation areas, policy context, key species, and pressures and threats

Appendix 6 and 7 provides detailed information (statistics) according to IUCN Management Categories and Governance Types respectively per country. Each country profile in this section has a hyperlink to the relevant page in the Appendix to facilitate the reader.

To allow for comparability across the region, the same analyses and datasets have been used for all 24 countries. For statistics on protected areas, WDPA, the authoritative global source of protected areas data was used, specifically the September 2019 update. Some countries, however, are not yet up to date in the WDPA. Country statistics different from the WDPA are indicated accordingly.

Country statistics were extracted from national reports to the CBD and National Biodiversity Strategies and Action Plans (NBSAPs). In most cases, the date was taken from the country's fifth national report and in some cases from the sixth national report when it was available at the time of writing (September 2019).

\section{Methodology used to create the WDPA statistics}

All count statistics, such as the number of protected areas in a country, or the number of protected areas under a given IUCN Management Category, are derived from the unmodified September 2019 version of the WDPA for the 24 countries. Coverage statistics, such as the area covered in protected areas for a country, or the area covered by a given IUCN Management Category, are also derived from a subset of the September 2019 version of the WDPA. In this subset, certain sites have been removed in line with the standard method for calculating coverage using the WDPA. ${ }^{33}$ Sites with the following characteristics were removed from the WDPA subset:

- Those with the status of 'Proposed' or 'Not Reported'

- Points that do not have a reported area

- UNESCO Man and Biosphere Reserves. These sites are excluded on the basis that they have been reported having an area that includes the buffer and transition zones, even though these zones do not often meet the definition of a protected area

\section{Disclaimer}

The coverage $\left(\mathrm{km}^{2}\right)$ may overlap between, but not within, the categories. This is negligible. However, where overlapping occurs, the combined totals will add up to over $100 \%$ of the protected area of the country. The WDPA is an aggregation of national data, and therefore the quality of the boundaries depends on the quality of the data in the country. UNEP-WCMC do not alter boundaries or locations of sites, but we work with data providers to try and ensure accuracy.

33 For more information, please see: https://www.protectedplanet.net/c/calculating protected-area-coverage 
Figure 8.1 Angola Summary

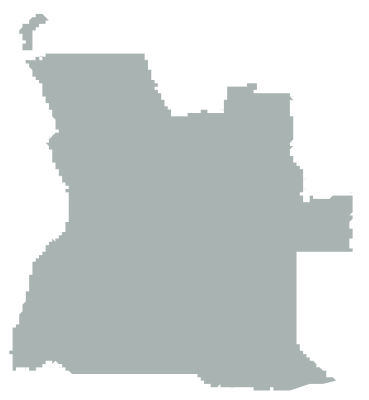

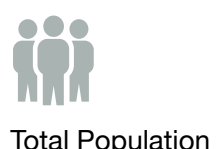

(millions)

30.81

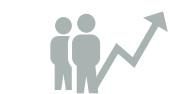

Population growth (annual \%)

3.30

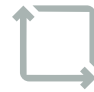

Surface area $\left(\mathrm{km}^{2}\right)$ (thousands)

1246.70

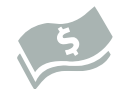

GDP (current US\$) (billions) 105.75

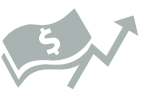

GDP growth (annual \%) $-2.10$

Source: The World Bank Group, 2018.

Area Protected:
14 protected areas

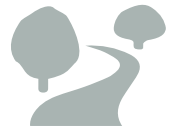

covering 87531 km $^{2}$ of land

Source: UNEP-WCMC \& IUCN, 2019c.
Protected and conserved areas in Angola in IUCN Management Categories

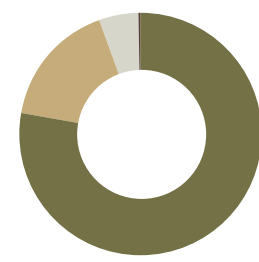

II. National ParkNational Park (No. 8)

IV. Habitat / Species Management (No. 4)

V. Protected Landscape / Seascape (No. 1)

Not Reported (No. 1)

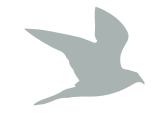

25 endemic bird species

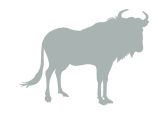

291 native animal species high marine and freshwater biodiversity
Coverage of protected areas in Angola

\begin{tabular}{l|r|r}
\hline Type of protected area & $\begin{array}{r}\text { Area protected } \\
\text { or conserved }\end{array}$ & $\begin{array}{r}\text { Area protected } \\
\text { or conserved }\end{array}$ \\
\hline Terrestrial and inland water & $6.97 \%$ & $12.50 \%$ \\
\hline Coastal and marine & $0.00 \%$ & Not found \\
\hline
\end{tabular}

* WDPA dataset

Source: Republic of Angola From National Report on Biodiversity

Protected and conserved areas in Angola in IUCN Governance Types

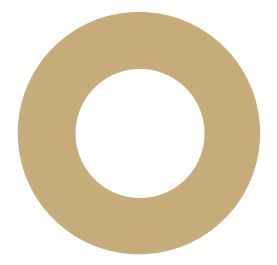

Not Reported (No. 14)
Priority areas for conservation

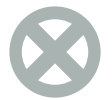

\section{1 sites}

Alliance for Zero

Extinction sites

\section{3 sites}

Important Bird \&

Biodiversity Areas

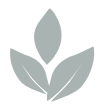

2 sites

Key Biodiversity

Areas 
Figure 8.2 Angola protected areas

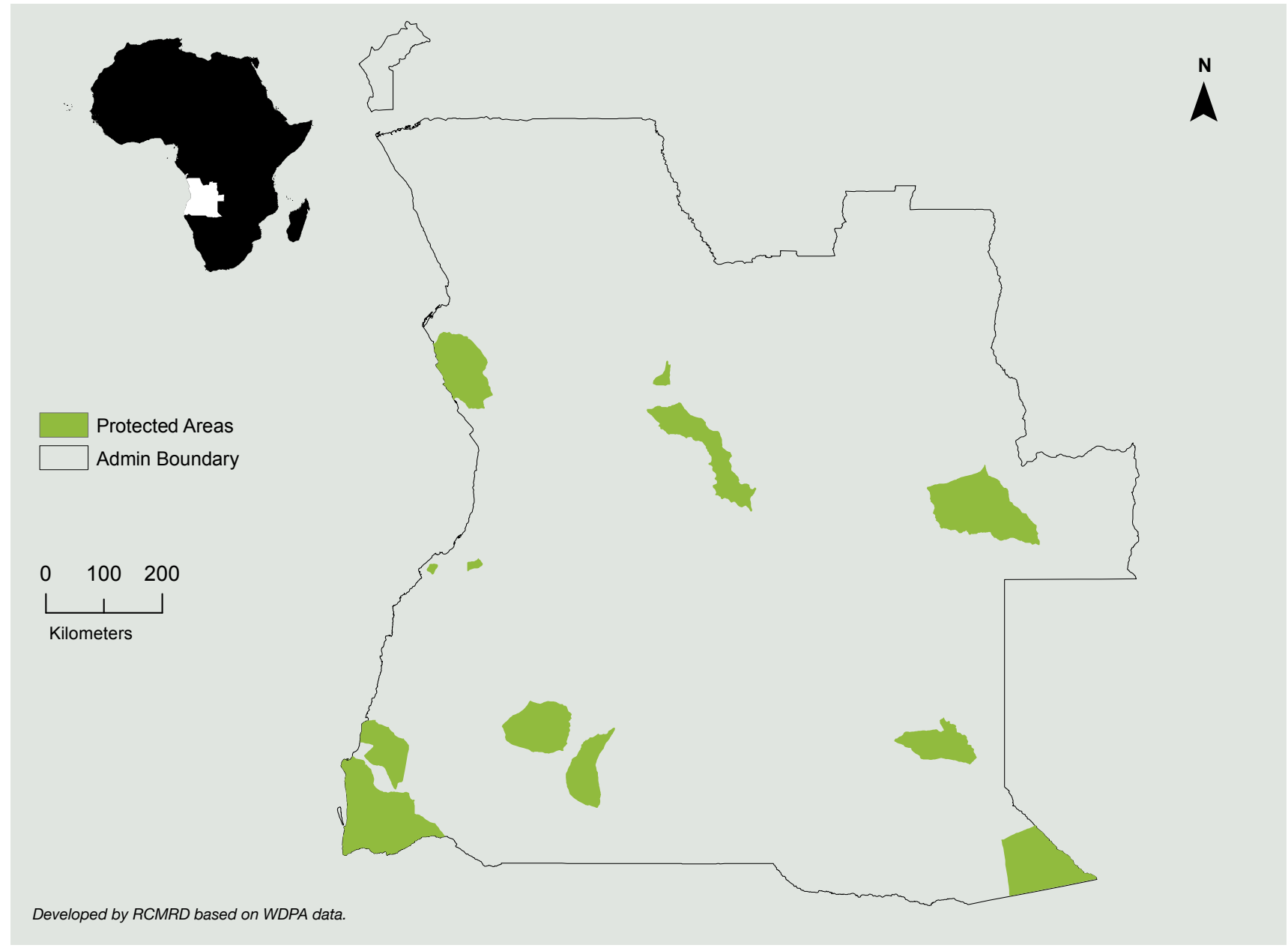

\section{Key species ${ }^{35}$}

Angola is home to an incredible diversity of habitats, and therefore also to a huge variety of species, with up to 291 native species, most of which are from the Rodentia (85), Chiroptera (73), Carnivora (39) and Cetartiodactyla (33) orders. There is a large number of endemic and near endemic species, most of which are rodents or bats.

According to Angola's Fifth National Report to the CBD (2014), mammals of particular interest include the endemic giant sable (Hippotragus niger variani), the Western lowland gorilla (Gorilla gorilla ssp. gorilla), the African manatee (Trichechus senegalensis), and the mountain zebra (Equus zebra). The conservation status of many of these species is poorly understood. Populations of African elephant (Loxodonta africana), hippopotamus (Hippopotamus amphibius) and brown fur seal (Arctocephalus pusillus) are considered stable.

Angola is home to 25 endemic bird species. Little is known about Angola's diversity of microfauna and flora, but it is known that many species suffer from high harvesting levels for timber, charcoal, food, as well as local and international live trade.

The country also has high marine and freshwater biodiversity, including five species of sea turtles, and many species of cetaceans. Small-scale fishing of fish and crustaceans is a critical part of the subsistence of rural coastal communities. Mackerel has been critically overharvested, resulting in the imposition of an annual four-month ban. The introduction of alien species of Tilapia is likely due to the prevalence of fish farming projects.

\section{Pressures and threats $^{36}$}

Angola's biodiversity is subject to many threats and pressures. The main pressures are from habitat due to subsistence agriculture, mining, infrastructure, deforestation for charcoal and timber, and a very high incidence of fires. Poaching, including for the bushmeat trade, is also a major threat. Overfishing, particularly of mackerel, has resulted in an annual four-month ban. Angola is in the process of updating its legislation, but implementation and enforcement are required.

This section draws on information contained in Angola's Fifth National Report to the CBD (Republic of Angola, 2014).

36 Data on information contained in Angola's Fifth National Report to the CBD (Republic of Angola, 2014). 


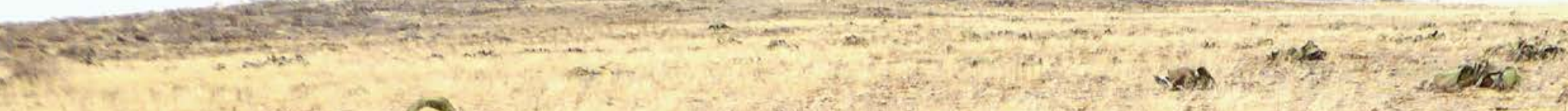

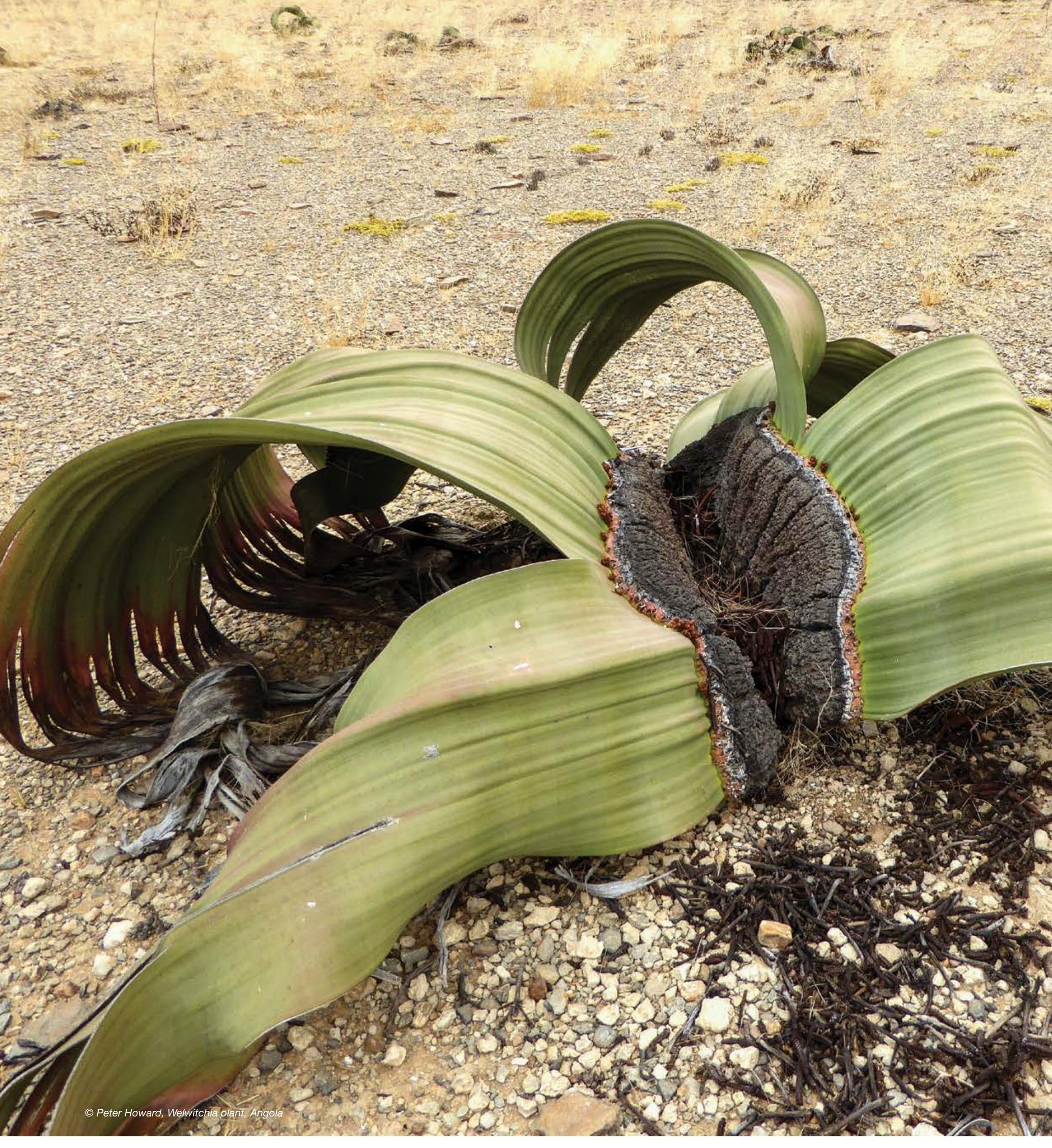




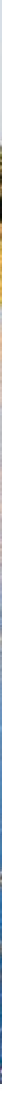

\subsection{Botswana}

\section{Protected and conserved areas in Botswana ${ }^{37}$}

Botswana has 22 protected areas covering $169,370 \mathrm{~km}^{2}$ of land (UNEP-WCMC \& IUCN, 2019d).

Within Botswana, land use is divided into protected areas, wildlife management areas (WMAs), pastoral residential areas, farms and mining concessions areas. As Botswana is a large country with a low population, it has been possible to establish expansive protected areas with over $45 \%$ of the country under some form of environmental management. The majority of the country's ecosystems are either moderately or well represented which means they are either within $50 \%$ or more than $100 \%$ of the $17 \%$ of the Aichi Target. A high proportion of the ecosystems falls completely within protected areas.

Since 2009 there has been some change in the cover of formal protected areas. Although there has been an increase in protected areas, there are areas where the likelihood of protected status is being diminished. These include several areas that have been listed as proposed wildlife management areas (WMAs) for more than 15 years. These have never been officially gazetted. Botswana is a part of large transfrontier conservation areas (TFCA) and this promotes the linkages and conservation goals of the country and region.

\section{Transboundary protected and conserved areas}

Botswana includes part of three transboundary conservation areas, namely Greater Mapungubwe TFCA, Kavango-Zambezi TFCA and Kgalagadi TFCA.

\section{Policy context}

A comprehensive report on legislation and policy related to protected area management, governance and equity was undertaken by the BIOPAMA programme. It identified 49 relevant laws and policies in Botswana (Tessema, 2019).

\section{Key species ${ }^{38}$}

Botswana has a high biodiversity, especially in and around the Okavango Delta, with a species richness index between 9.3 and 15. Plant species are estimated at between 2,150 and 3,000, of which 15 are endemic and 43 are on the IUCN Red List.

There is a rich and diverse number of fauna with 157 identified species of mammals, of which three are endemic and 112 are red-listed. Botswana is home to one of the largest remaining populations of the African wild dog (Lycaon pictus) and the largest remaining population of African elephant (Loxodonta africana). The seasonal flood plains around the Okavango and Zambezi and extensive wilderness areas support some of the major wildlife

7 The section draws on information contained in Botswana's Sixth National Report to the CBD and Third NBSAP (Republic of Botswana, 2016 and 2019 ).

38 The section draws on information contained in Botswana's Fifth and Sixth National Reports to the CBD and Third NBSAP (Republic of Botswana, 2015; 2016; 2019). 
Figure 8.3 Botswana Summary
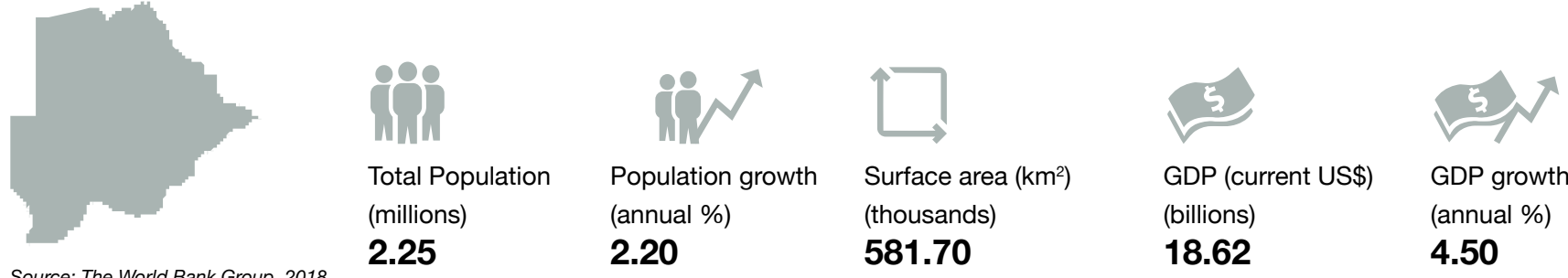

GDP growth (annual \%)

Source: The World Bank Group, 2018

covering 169370 km $^{2}$ of land

Source: UNEP-WCMC \& IUCN, 2019d

\section{Priority areas for conservation}

\section{2 sites}

Source: AZE Secretariat (2019; BirdLife Internationa,( 2019b, 2019c).
Protected and conserved areas in Botswana in IUCN Management Categories

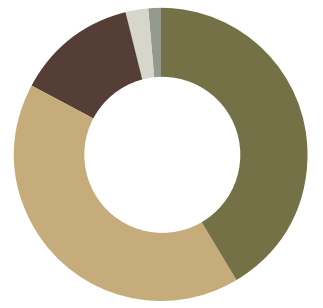

Ib. Wilderness Area (No. 7)

Not Reported (No. 1)

Not Applicable (No. 1)

II. National Park (No. 6)

IV. Habitat/Species Management (No. 7)

Source: UNEP-WCMC \& IUCN (2019C).

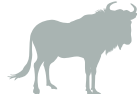

157 mammal species

112 red-listed

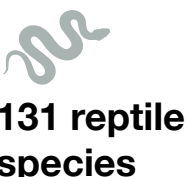

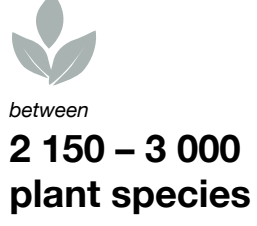

15 endemic

43 are red-listed

\section{Coverage of protected areas in Botswana}

\begin{tabular}{l|r|r}
\hline Type of protected area & $\begin{array}{r}\text { Area protected } \\
\text { or conserved }\end{array}$ & $\begin{array}{l}\text { Area protected } \\
\text { or conserved }\end{array}$ \\
\hline Terrestrial and inland water & $29.14 \%$ & $29.10 \%$ \\
\hline
\end{tabular}

\section{* WDPA dataset $\quad$ ** From National Report on Biodiversity}

Source: Republic of Botswana (2019; UNEP-WCMC \& IUCN (2019d).

\section{Protected and conserved areas in Botswana in} IUCN Governance Types

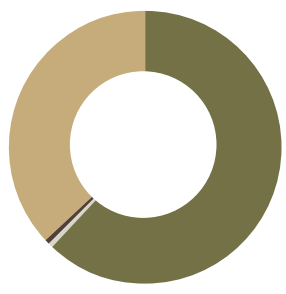

Not Reported (No. 2)

D. Governance by Indigenous peoples and Local Communities (No. 1)

C. Private Governance (No. 1)

A. Governance by Government (No. 18)
National designations of protected and conserved areas in Botswana

\begin{tabular}{l|r|r}
\hline National designation & No. & Area $\left.\mathbf{( k m}^{\mathbf{2}}\right)$ \\
\hline National Park & 4 & 43926 \\
\hline Game Reserve & 6 & 60352 \\
\hline Game Sanctuary & 1 & 89 \\
\hline Forest Reserve & 6 & 4057 \\
\hline Bird Sanctuary & 3 & 974 \\
\hline
\end{tabular}

Source: UNEP-WCMC \& IUCN (2019C).

Protected and conserved areas designated as global sites of importance in Botswana

\begin{tabular}{l|r}
\hline Global designation & No. of sites \\
\hline UNESCO World Heritage Sites (Natural or Mixed) & 1 \\
\hline Wetlands of International Importance (Ramsar & 1 \\
sites) & \\
\hline
\end{tabular}

Source: Ramsar (2019); UNESCO (2019a, 2019b). 
migration routes in Southern Africa, making Botswana one of the last refuges for species requiring open range.

Botswana is home to 587 species of birds. There are 25 globally threatened bird species in Botswana and a further eight regarded as national threatened and two near-endemic species.

Of the 99 species of freshwater fish recorded in Botswana, two are globally threatened. In addition, 131 species of reptiles and 44 species of amphibians recorded. There is little information available on invertebrates, although butterflies and dragonflies have been inventoried more closely than others.

Botswana is home to 13 endemic species of plants, with another 10 potentially endemic and seven near-endemic.

\section{Pressures and threats ${ }^{39}$}

The primary threat to biodiversity in Botswana is habitat loss and degradation. The indirect causes of these threats include: overgrazing through unregulated cattle grazing; range degradation; fires; mining; wind erosion; increased water extraction for irrigation resulting in increased salinity; lack of protection for avian breeding sites; uncontrolled tourism; and disruption of migration routes through fencing. Poaching for wildlife products and bushmeat is another serious threat to the biodiversity of the country. Human-wildlife conflict is a critical and ongoing issue in the country.

Botswana's Fifth National Report to the CBD presented the major threats to Botswana's biodiversity, linking direct threats to underlying causes, main impacts and key implications (Republic of Botswana, 2015). The report lists the primary internal threats as habitat destruction, barriers to wildlife movement, poaching, disturbed fire regimes and overharvesting, while key external threat are climate change and changes to hydrology.

Secondary threats include invasive species in both terrestrial and freshwater ecosystems. Climate change is emerging as a major threat to the Okavango Delta ecosystem and the Kalahari Basin.

\section{Figure 8.4 Botswana protected areas}

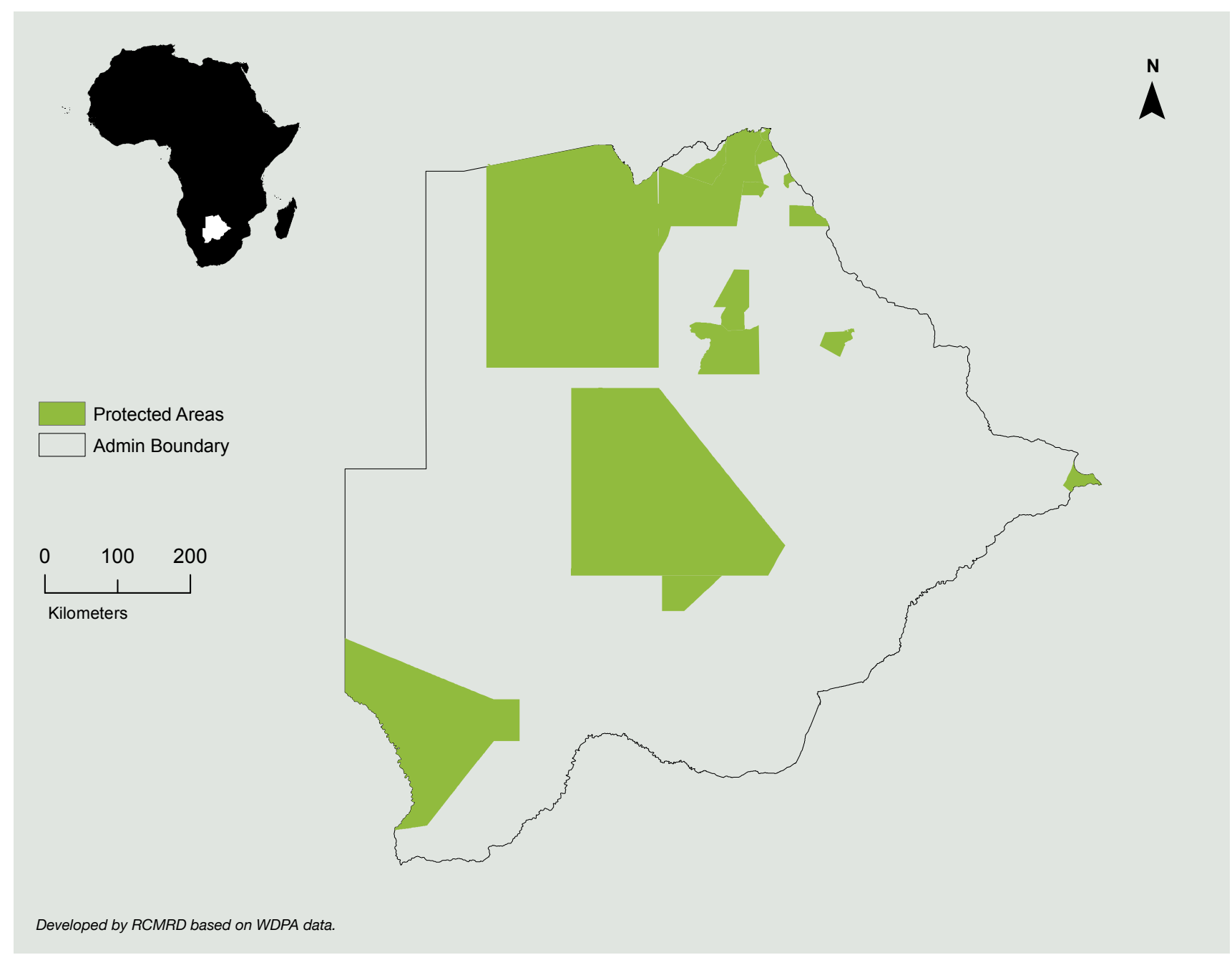

39 The section draws on information contained in Botswana's Sixth National Report to the CBD and Third NBSAP (Republic of Botswana, 2016, 2019). 


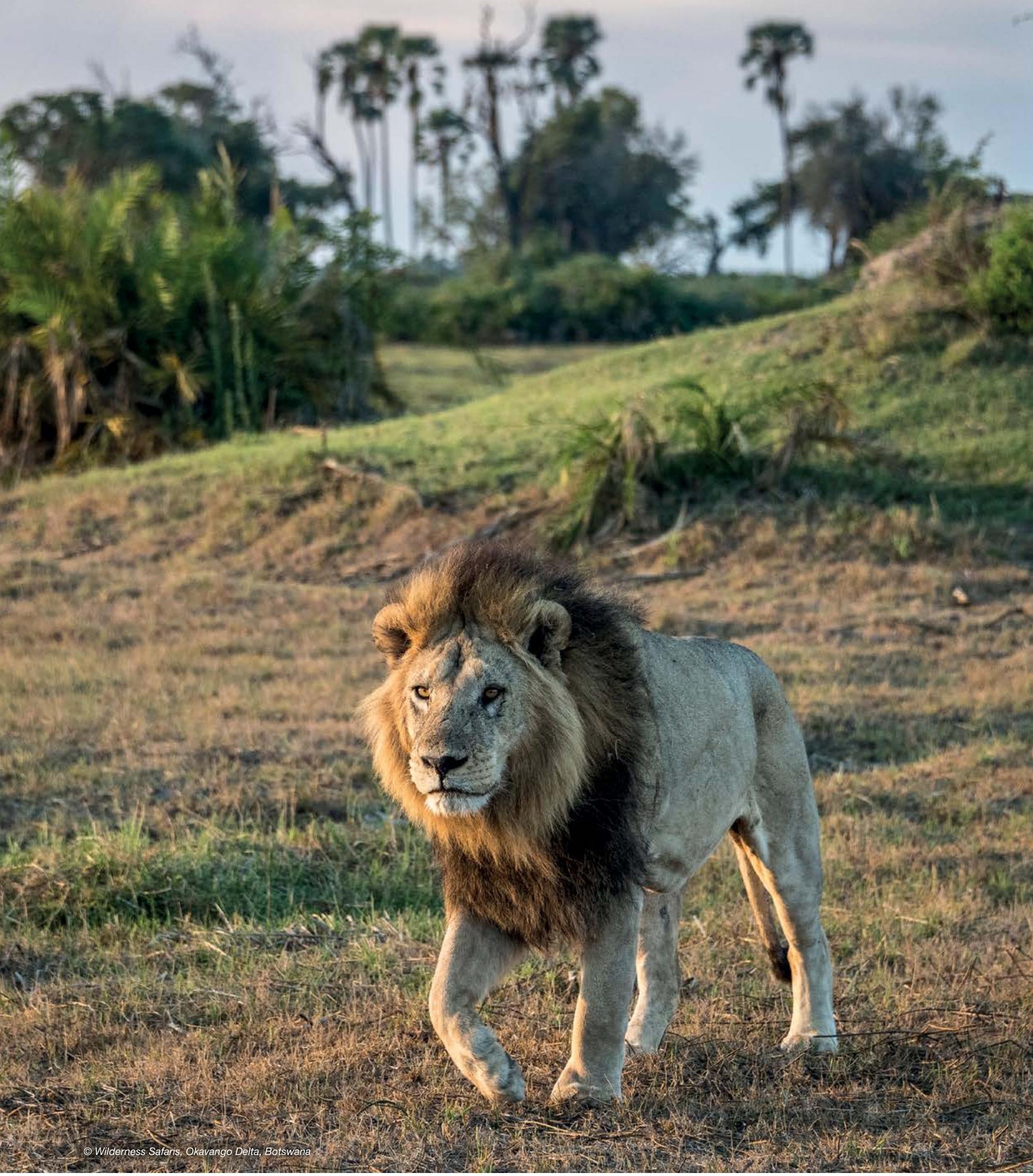




\subsection{Comoros}

\section{Protected and conserved areas in Comoros ${ }^{40}$}

Comoros has eight protected areas covering $173 \mathrm{~km}^{2}$ of land and $37 \mathrm{~km}^{2}$ of the ocean (UNEP-WCMC \& IUCN, 2019d).

Terrestrial and inland areas in protected areas remain small and are not connected in ecologically representative protected areas networks. There is a need to increase the coverage to meet Aichi Target 11, which will involve creating new protected areas in fragile ecosystems with high and sensitive biodiversity and increasing conservation and biodiversity management actions of NGOs and private individuals. However, it is important to note that since 2014, the Union of the Comoros has increased its protected area estate from one to five protected areas. This increase in protected area coverage involves local communities in the development process and management of the protected areas. The creation of new protected areas in addition to the existing Mohéli National Park is part of the commitment of the Government to reach Aichi Target 11.

\section{Transboundary protected and conserved areas}

Comoros is not a part of any transboundary conservation areas.

\section{Policy context}

A comprehensive report on legislation and policy related to protected area management, governance, and equity was undertaken by the BIOPAMA programme. It identified 15 relevant laws and policies in Comoros (Tessema, 2019).

\section{Key species ${ }^{41}$}

Ninety-six bird species have been recorded in Comoros, of which 33 are threatened. The Union of the Comoros is home to a number of threatened mammals, including the endemic Comoros rousette (Rousettus obliviosus), the mongoose lemur (Eulemur mongoz), the endemic Livingstone's flying fox (Pteropus livingstonii), the dugong (Dugong dugon), the humpback whale (Megaptera novaeangliae) and the tailess tenrec (Tenrec ecaudatus).

More than 1,200 insect species have been recorded in the Comoros and at least 16 plants species are threatened with extinction.

Two species of amphibian and 29 reptiles have also been recorded. The two amphibian species and 14 of the 29 terrestrial reptiles are endemic. A number of the reptiles are threatened with extinction. A number of species of marine turtles also nest in the Comoros, and their conservation status is improving.

40 The section draws on information contained in the Sixth National Report to the CBD (Union des Comores, 2019).

41 The section draws on information contained in Comoros' Fifth National Report to the CBD and its Second National Biodiversity Strategy and Action Plan (NBSAP) (Union des Comores, 2014; 2016) and its 2017-2021 Strategy to expand the national system of protected areas (Union des Comores, 2017). 
Figure 8.5 Comoros Summary

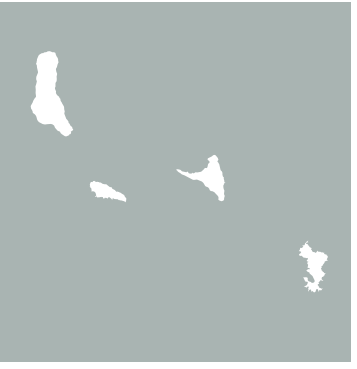

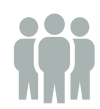

Total Population (millions) 0.83

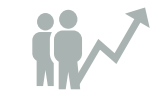

Population growth (annual \%)

2.20

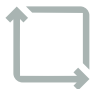

Surface area $\left(\mathrm{km}^{2}\right)$ (thousands)

1.90

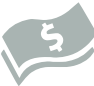

GDP (current US\$) (billions)

1.20
GDP growth (annual \%) 2.80

\section{Area Protected:}

\section{8 protected} areas

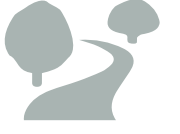

covering $173 \mathrm{~km}^{2}$ of land

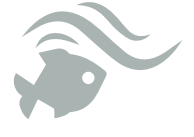

covering

$37 \mathrm{~km}^{2}$ of ocean
Protected and conserved areas in Comoros in IUCN Management Categories

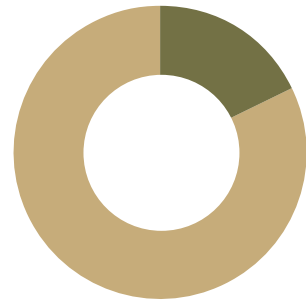

Source: UNEP-WCMC \& IUCN (2019d).
Not Reported (No. 7)

II. National Park (No. 1)

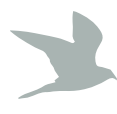

96 bird species

33 are threatened
16 plants species threatened
2 endemic amphibian species
14 endemic reptiles

\section{Coverage of protected areas in Comoros}

\begin{tabular}{l|r|r}
\hline Type of protected area & $\begin{array}{r}\text { Area protected } \\
\text { or conserved }\end{array}$ & $\begin{array}{r}\text { Area protected } \\
\text { or conserved }^{\star *}\end{array}$ \\
\hline Terrestrial and inland water & $10.15 \%$ & $22.00 \%$ \\
\hline Coastal and marine & $0.02 \%$ & Not found \\
\hline
\end{tabular}

*WDPA dataset $\quad$ ** From National Report on Biodiversity

Source: UNEP-WCMC \& IUCN (2019d); Union des Comores (2014).

\section{Protected and conserved areas in Comoros in} IUCN Governance Types

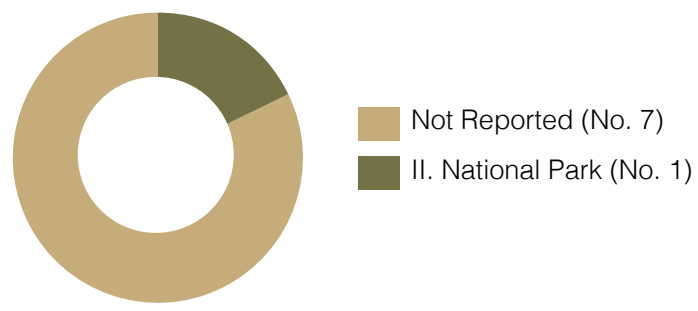

Source: UNEP-WCMC \& IUCN (2019d).
National designations of protected and conserved areas in Comoros

\begin{tabular}{l|r|r}
\hline National designation & No. & Area $\left.\mathbf{( k m}^{2}\right)$ \\
\hline National Park & 1 & 37 \\
\hline Aire Protégée Nationale & 4 & 573 \\
\hline Source
\end{tabular}

Protected and conserved areas designated as global sites of importance in Comoros

\begin{tabular}{l|r}
\hline Global designation & No. of sites \\
\hline Wetlands of International Importance & 3 \\
(Ramsar sites) & \\
\hline
\end{tabular}

Source: Ramsar (2019; UNESCO (2019a, 2019b).

\section{Priority areas for conservation}

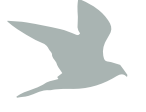

\section{3 sites}

Alliance for Zero

Extinction sites

\section{4 sites}

Important Bird \&

Biodiversity Areas
20 sites

Key Biodiversity

Areas 


\section{Figure 8.6 Comoros protected areas}

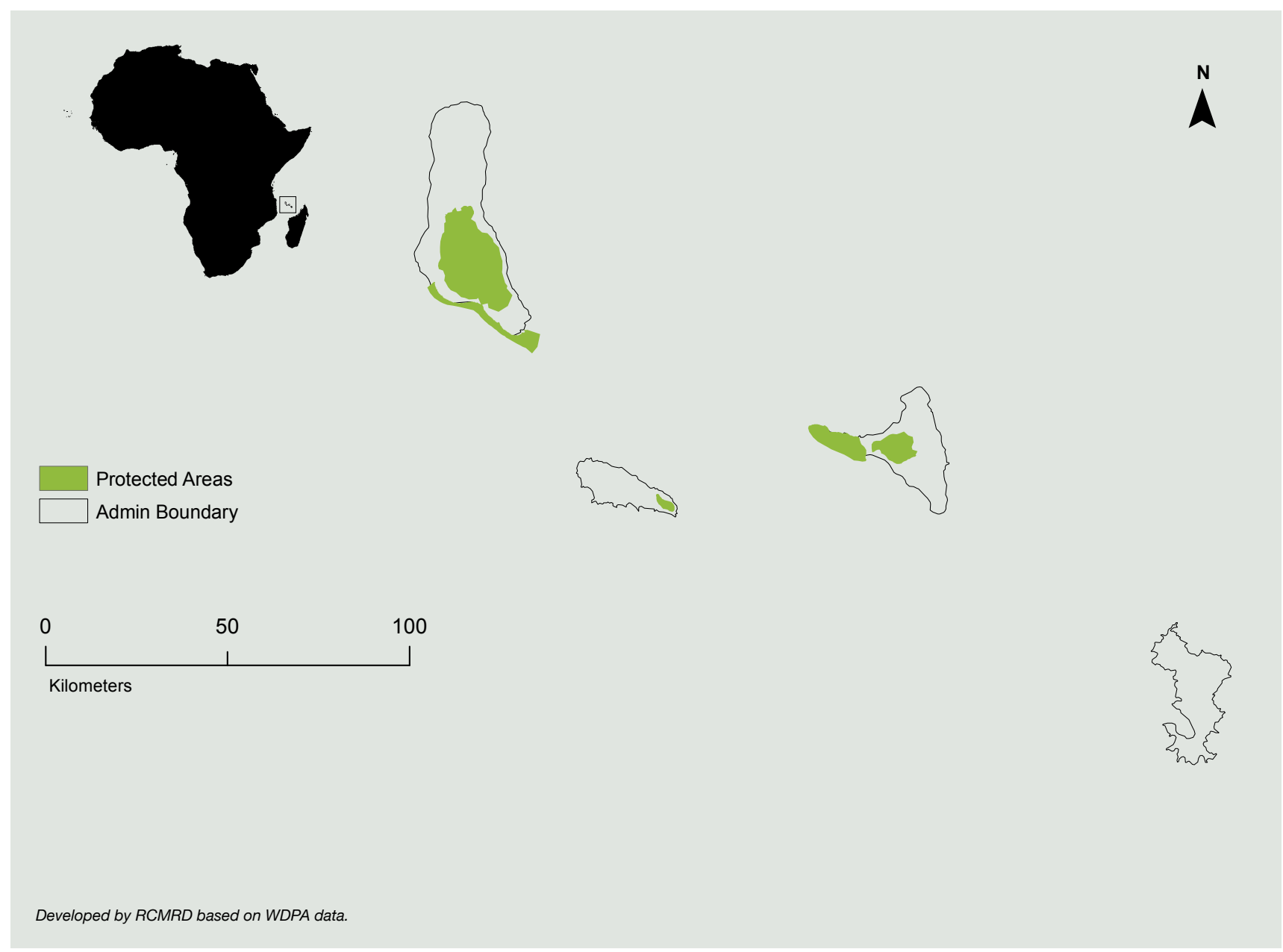

The country is also home to the coelacanth (Latimeria chalumnae) which is classified as critically endangered. There are a number of cetacean species protected by the CITES, such us the humpback whale (Megaptera novaeangliae), Southern right whale (Eubalaena australis), Bryde's whale (Balaenoptera edeni) and the sperm whale (Physeter macrocephaleus), which frequent the Comorian marine waters.

Certain coral species, such as the black coral (Antipathes dichotoma), are listed on the CITES appendices due to high demand for jewellery. At least 16 plant species are threatened with extinction.

\section{Pressures and threats ${ }^{42}$}

The main direct pressures on biodiversity in the Comoros is habitat loss and degradation due to slash-and-burn agriculture, invasive alien species, the growing need for firewood for ylang-ylang distillation, over extraction of coral and sand for construction, and pollution. Overharvesting of certain species, including reptiles and a number of different marine species, is a major threat. A number of mollusc species have disappeared due to overharvesting.
The key indirect causes of these threats include the natural fragility of the ecosystem, with a growing human population that has a very high level of poverty. There are weaknesses in the institutional framework, including low human capacities, insecure tenure, inadequate and unenforced regulatory framework and inefficient public policies.

Climate change represents a major short- and long-term threat to the biodiversity of the Comoros. In some places, reefs have suffered more than $60 \%$ bleaching due to rising sea temperatures, while 30-40 meters of coastal grasslands have disappeared due to rising sea levels.

42 The section draws on information contained in Comoros' Fifth National Report to the CBD and its Second NBSAP (Union des Comores, 2014, 2016) and its 2017-2021 National system of explanation of protected area strategy (DGEF, 2017). 


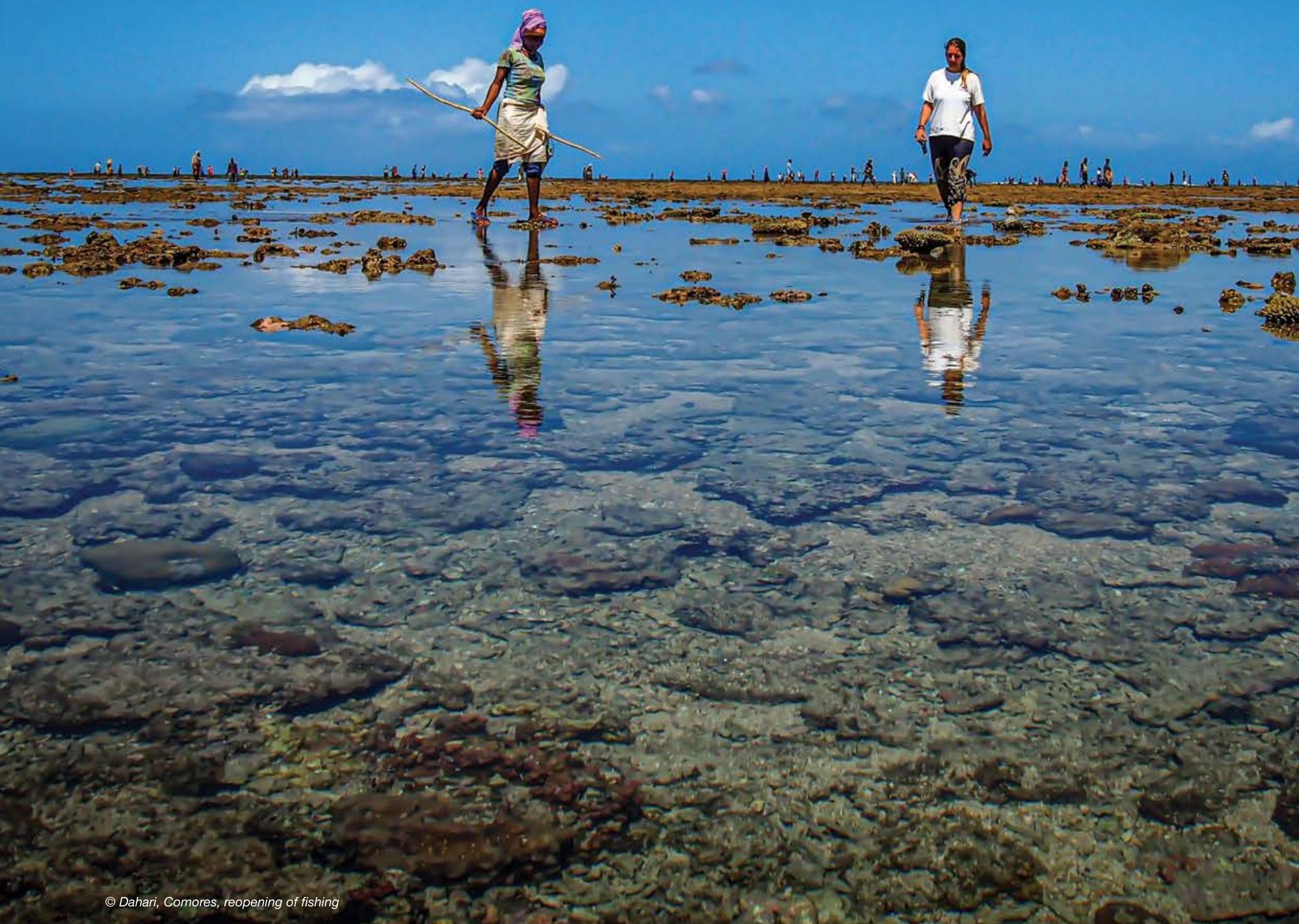




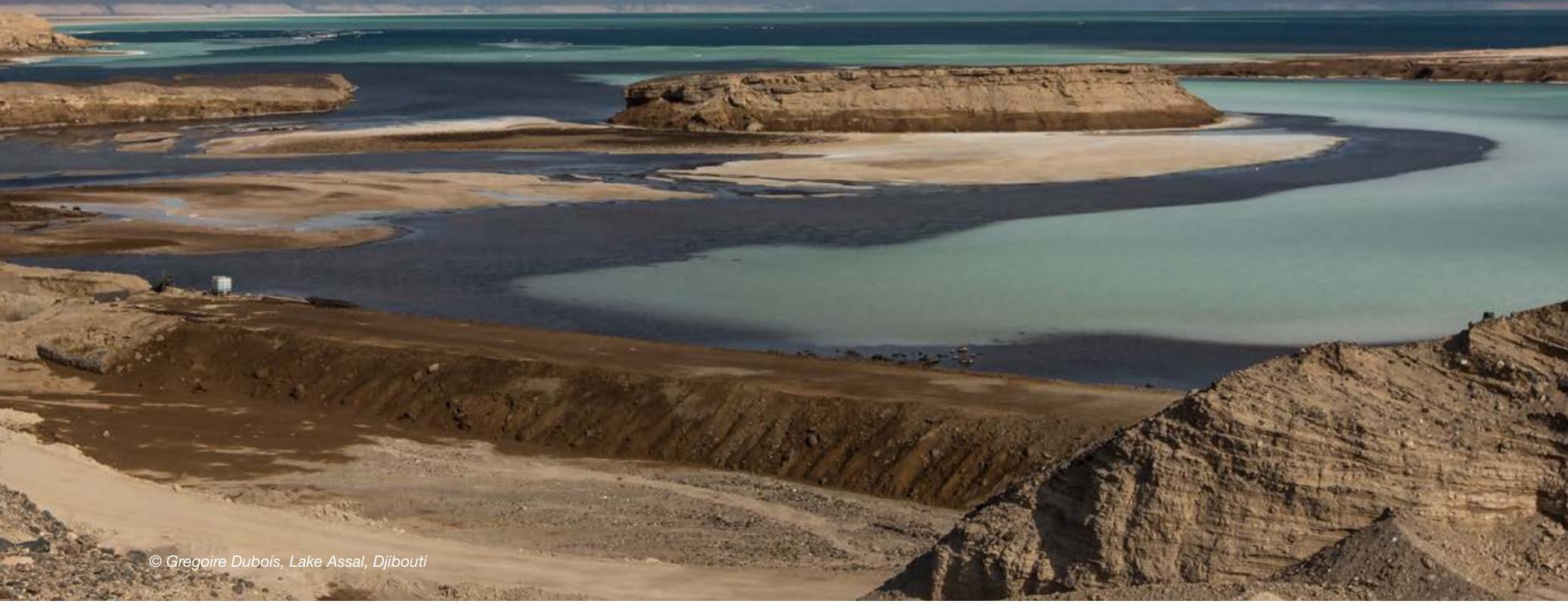

\subsection{Djibouti}

\section{Protected and conserved areas in Djibouti ${ }^{43}$}

Djibouti has seven protected areas covering $344 \mathrm{~km}^{2}$ of land and $12 \mathrm{~km}^{2}$ of the ocean (UNEP-WCMC \& IUCN (2019e).

In 2015, it was proposed to extend the network of MPAs to the maritime and coastal sector. The objective is to form a large management unit extending the MPA area to a total cover of 56,500 ha of seascape. In addition, in 2019, several terrestrial sites were identified as candidates for protection.

In Djibouti, terrestrial and marine protected areas are not closed areas. Traditional farming and fishing activities, as well as ecotourism, are authorized but regulated and controlled with a view to preserving biodiversity. However, restrictions like the felling or pruning of trees, the picking or uprooting of plants is regulated and controlled in terrestrial protected areas.

\section{Transboundary protected and conserved areas}

Djibouti includes part of the Lower Awash-Lake Abbé Landscape transboundary conservation area.

\section{Policy context}

A comprehensive report on legislation and policy related to protected area management, governance, and equity was undertaken by the BIOPAMA programme. It identified 21 relevant laws and policies in Djibouti (Tessema, 2019).

\section{Key species ${ }^{44}$}

These reports do not provide an overall summary of species in the country, but take note of key ecosystems, including forests and mangroves. Attention is paid in particular to the Day Forest and the Goda Massif, home to a variety of plants, animals and birds, including the endemic critically endangered Djibouti francolin (Francolinus ochropectus).

\section{Pressures and threats ${ }^{45}$}

Djibouti's biodiversity faces major threats. The country's scarce freshwater resources are threatened by salinisation, infrastructure deterioration, pollution and degradation of key watersheds, through deforestation for firewood and charcoal. Djibouti is also suffering from a severe invasion of the Prosopis, or mesquite, which degrades rangelands. Marine environments are also impacted by pollution, including from the storage of petroleum products. Illegal and unregulated fishing results in overharvesting of certain species. Indirect pressures include drought, urban growth, population increase, pressure from refugee populations in neighbouring countries, and persistent rural poverty and food insecurity.

43 The section draws on information contained in Djibouti's Sixth National Report to the CBD (République de Djibouti, 2019) and Second NBSAP (République de Djibouti, 2017).

44 The section draws on information contained in Djibouti's Fifth National Report to the CBD and Second NBSAP (République de Dijibouti, 2014; 2017).

45 Ibid. 
Figure 8.7 Djibouti Summary

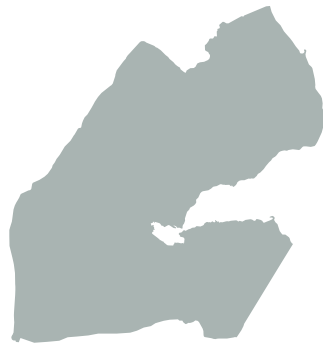

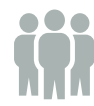

Total Population (millions) 0.96

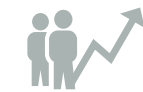

Population growth (annual \%)

1.60

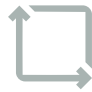

Surface area $\left(\mathrm{km}^{2}\right)$ (thousands)

23.2

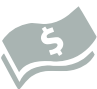

GDP (current US\$) (billions)

1.97
GDP growth (annual \%) 6.00
Area Protected:

\section{7 protected} areas

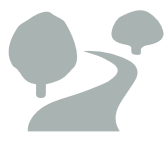

covering $344 \mathrm{~km}^{2}$ of land

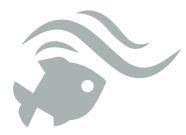

covering

$12 \mathrm{~km}^{2}$ of ocean
Source: UNEP-WCMC \& IUCN, $2019 e$

\section{key ecosystems include:} forests and mangroves
Protected and conserved areas in Djibouti in IUCN Management Categories

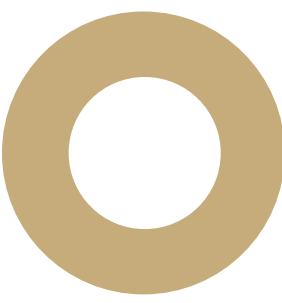

Not Reported (No. 3)

VI. Protected Area with Sustainable Use of Natural Resources (No.1)

IV. Habitat/Species Management (No. 1)

V. Protected Landscape/Seascape (No. 2)

\section{Coverage of protected areas in Djibouti}

\begin{tabular}{l|r|r}
\hline Type of protected area & $\begin{array}{r}\text { Area protected } \\
\text { or conserved }\end{array}$ & $\begin{array}{r}\text { Area protected } \\
\text { or conserved }^{* *}\end{array}$ \\
\hline Terrestrial and inland water & $1.57 \%$ & $1.34 \%$ \\
\hline Coastal and marine & $0.17 \%$ & $0.46 \%$ \\
\hline "WDPA dataset ${ }^{* *}$ From National Report on Biodiversity \\
Source: République de Djibouti (2014; UNEP-WCMC \& IUCN (2019e).
\end{tabular}

\section{Protected and conserved areas in Djibouti in} IUCN Governance Types

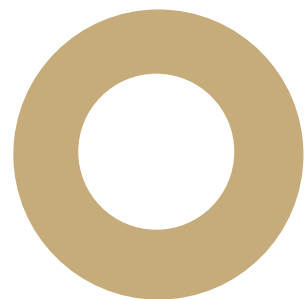

Not Reported (No. 4)

Source: UNEP-WCMC \& IUCN (2019e).

National designations of protected and conserved areas in Djibouti

\begin{tabular}{l|r|r}
\hline National designation & Number & Area $\left.\mathbf{( k m}^{2}\right)$ \\
\hline Terrestrial protected area & 2 & 323 \\
\hline Marine protected landscape & 3 & 514 \\
\hline $\begin{array}{l}\text { Area protected for habitat } \\
\text { and species }\end{array}$ & 1 & 26 \\
\hline
\end{tabular}

Source: UNEP-WCMC \& IUCN (2019e).

Protected and conserved areas designated as global sites of importance in Djibouti

\begin{tabular}{l|r}
\hline Global designation & No. of sites \\
\hline $\begin{array}{l}\text { Wetlands of International Importance (Ramsar } \\
\text { sites) }\end{array}$ & 1 \\
\hline Source: Ramsar (2019); UNESCO (2019a, 2019b). &
\end{tabular}

Priority areas for conservation

7 sites

Important Bird \& Biodiversity Areas

Source: BirdLife International (2019c). 


\section{Figure 8.8 Djibouti protected areas}
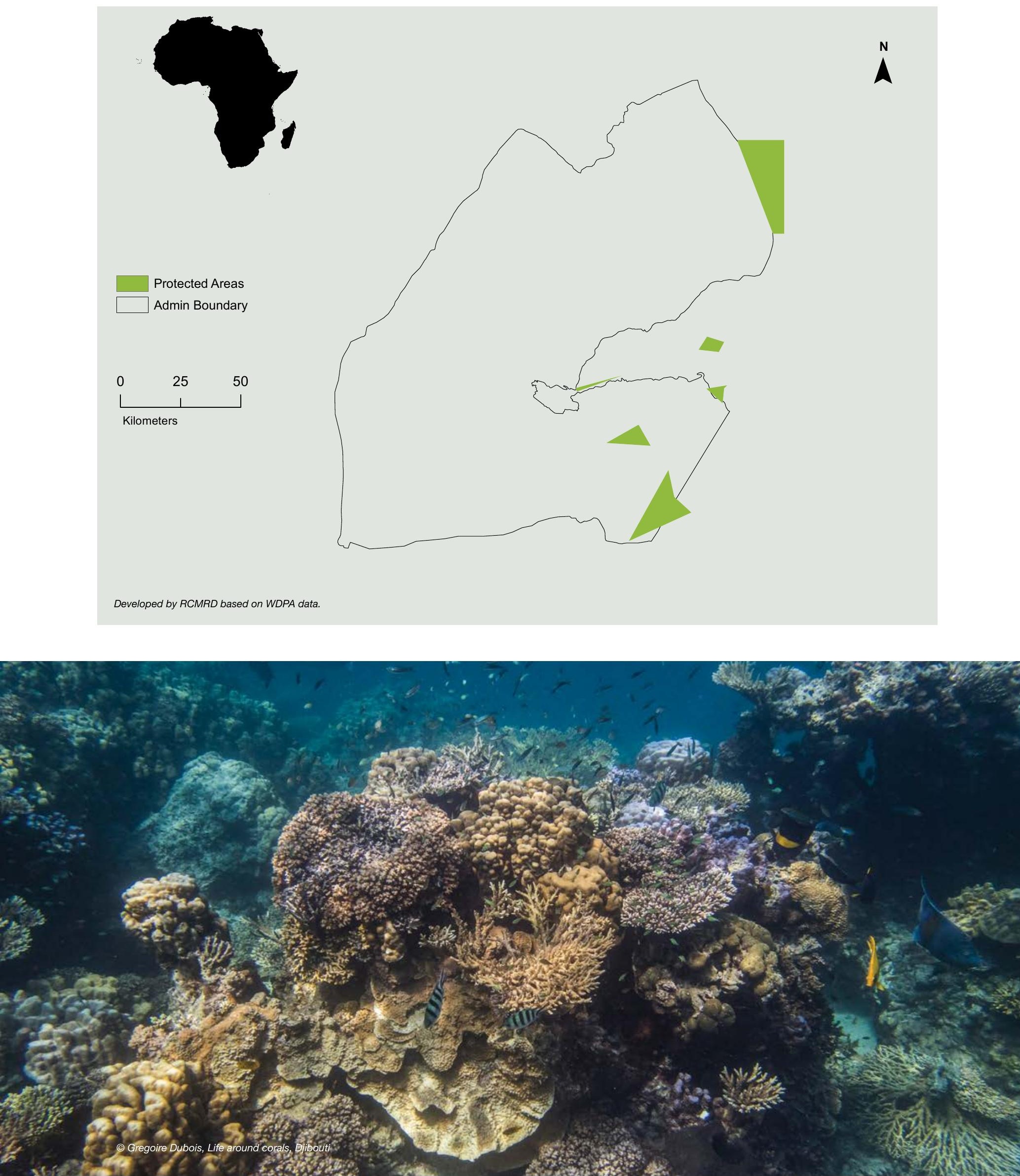


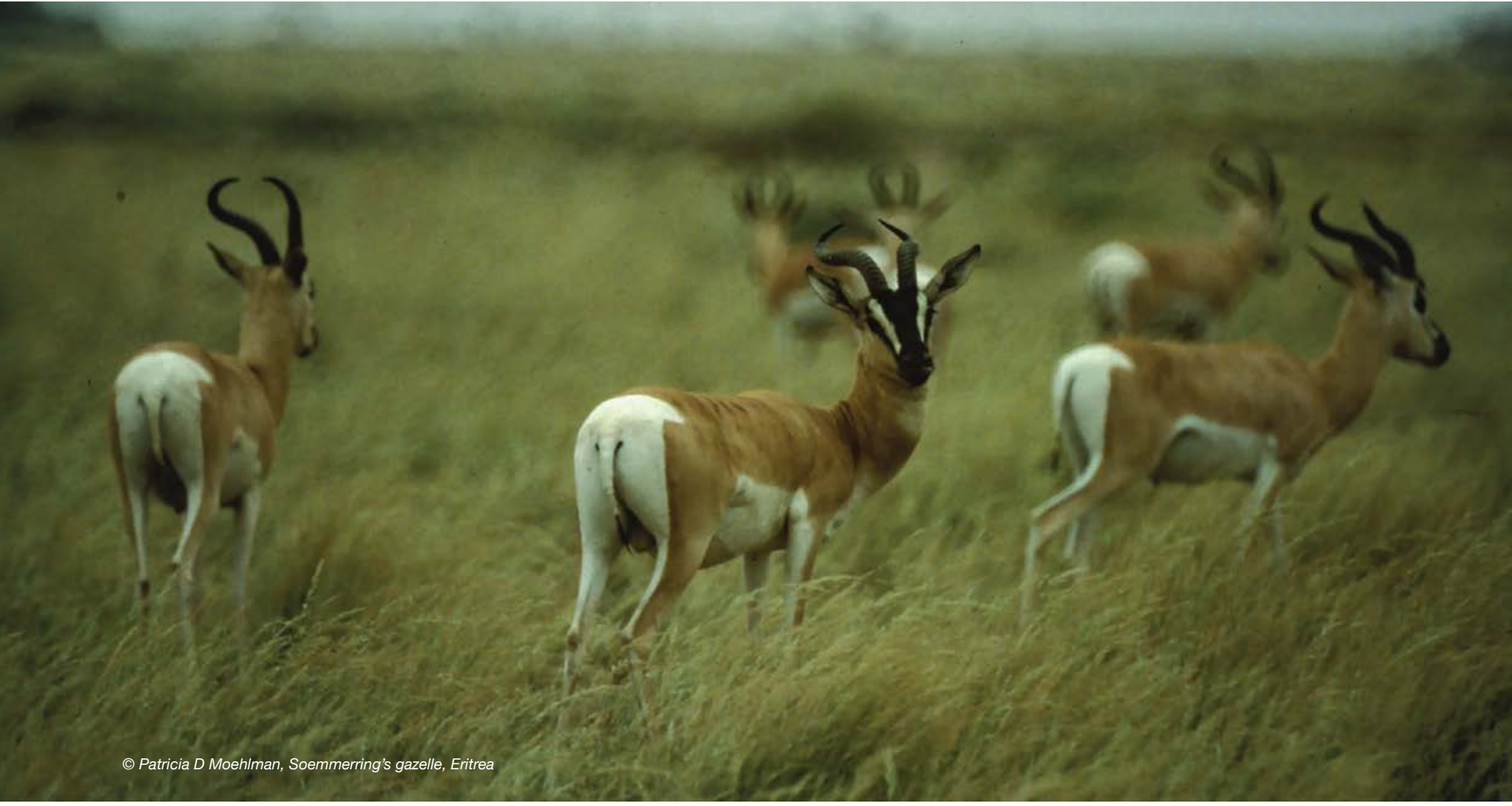

\subsection{Eritrea}

\section{Protected and conserved areas in Eritrea ${ }^{46}$}

Eritrea has four protected areas covering $5,936 \mathrm{~km}^{2}$ of land and does not have any marine protected areas (UNEP-WCMC \& IUCN (2019f).

Although there are no officially gazetted protected areas in the country, there are some areas set aside for protection through government directives. The de facto protected areas have no management or business plans. A draft Protected Area Proclamation was prepared and proposed protected areas were identified in 2018. The implementation of the proposed protected area system is hindered due to inadequate human capacity.

\section{Transboundary protected and conserved areas}

Eritrea does not have any transboundary conservation areas.

\section{Policy context}

A comprehensive report on legislation and policy related to protected area management, governance, and equity was undertaken by the BIOPAMA programme. It identified seven relevant laws and policies in Eritrea (Tessema (2019).

\section{Key species ${ }^{47}$}

Eritrea has recorded the presence of approximately 600 bird species and is a very important migration route and stopover location for many species. A total of 90 reptiles and 19 amphibian species have been recorded in Eritrea, including two possibly endemic reptiles and one possibly endemic amphibian. Offshore areas are important for turtle foraging and nesting of sea turtles.

There is no comprehensive plant inventory for the country, but one site has recorded almost 700 species. Eritrea is recognized as a centre of origin and diversity for a number of crop species, and has major areas of mangroves and seagrasses. The country also has a remarkable diversity in seaweeds, halophytes, and plankton.

There is a high diversity of corals and fish, with at least 38 coral genera representing 220 species, some of which are endemic to Eritrea. Eritrea is also home to five of the world's seven marine turtle species and a large number of cetaceans, as well as a wide range of invertebrates.

Finally, Eritrea is home to a number of globally rare mammal species, including the African wild ass (Equus africanus) and the Nubian ibex (Capra nubiana). 
Figure 8.9 Eritrea Summary

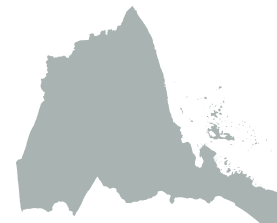

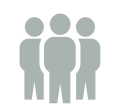

Total Population (millions) 3.17

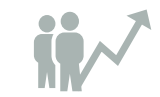

Population growth (annual \%)

1.60

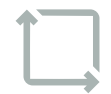

Surface area $\left(\mathrm{km}^{2}\right)$ (thousands) 117.6

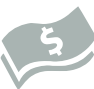

GDP (current US\$) (billions)

2.12

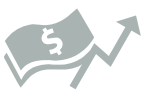

GDP growth (annual \%) 2.20
Area Protected:

4 protected areas

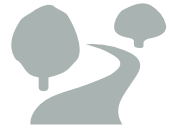

covering

5936 km² $^{2}$

of land
Protected and conserved areas in Eritrea in IUCN Management Categories

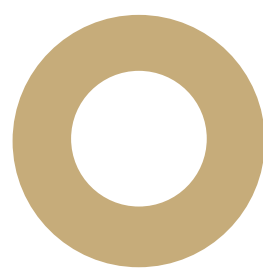

Source: UNEP-WCMC \& IUCN (2019f).
Not Reported (No 1)

IV. Habitat / Species Management (No. 3)

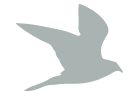

600 bird species
90 reptile species
19 amphibian species

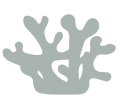

220 coral species

\section{Coverage of protected areas in Eritrea}

\begin{tabular}{l|r|r}
\hline Type of protected area & $\begin{array}{r}\text { Area protected } \\
\text { or conserved* }\end{array}$ & $\begin{array}{r}\text { Area protected } \\
\text { or conserved }\end{array}$ \\
\hline Terrestrial and inland water & $4.87 \%$ & Not found \\
\hline Coastal and marine & $0.00 \%$ & Not found \\
\hline${ }^{*}$ WDPA dataset ${ }^{* *}$ From National Report on Biodiversity
\end{tabular}

Source: UNEP-WCMC \& IUCN (2019f).

Protected and conserved areas in Eritrea in IUCN Governance Types

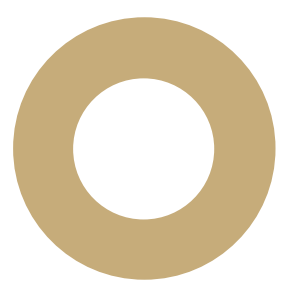

Not Reported (No. 4)
National designations of protected and conserved areas in Eritrea

\begin{tabular}{l|r|r}
\hline National designation & No. & Area $\left.\mathbf{( k m}^{2}\right)$ \\
\hline Wildlife Reserve & 3 & 5903 \\
\hline Marine National Park & 1 & 652 \\
\hline
\end{tabular}

Source: UNEP-WCMC \& IUCN (2019f).

\section{Priority areas for conservation}

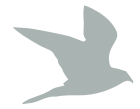

\section{4 sites 9 sites \\ Important Bird \& Key Biodiversity \\ Biodiversity Areas Areas}

Source: BirdLife International (2019b, 2019c). 


\section{Pressures and threats ${ }^{48}$}

One of the largest direct threats to biodiversity in Eritrea is habitat transformation, due to expansion of agriculture and pollution of freshwater and marine ecosystems, as well as transformation for urban and industrial development. Seagrass and seaweeds are impacted by increasing sedimentation. Invasive alien species are major threats. Deforestation and excessive pollarding are impacting forest resources. Illegal hunting of wildlife for the bushmeat trade is an issue, particularly in grassland ecosystems.

Overharvesting of corals, fish and other marine species represent serious pressures on these species. Invasive species are a threat to many species and ecosystems, including predatory mammal species which prey on island breeding birds. Sea turtles are threatened by the disturbance of nesting sites, poaching of eggs and illegal hunting of mature animals, as well as bycatch in trawlers.

\section{Figure 8.10 Eritrea protected areas}

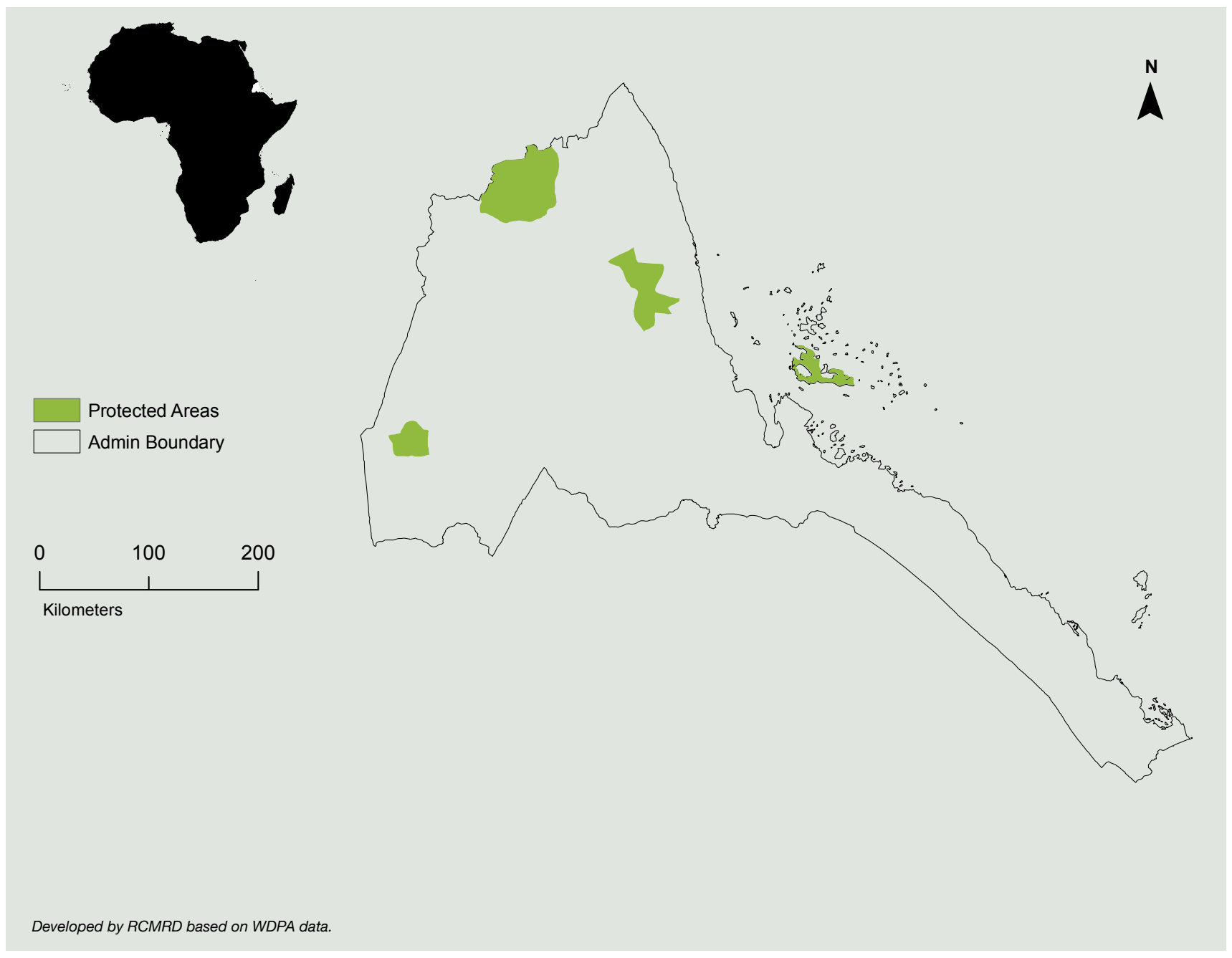




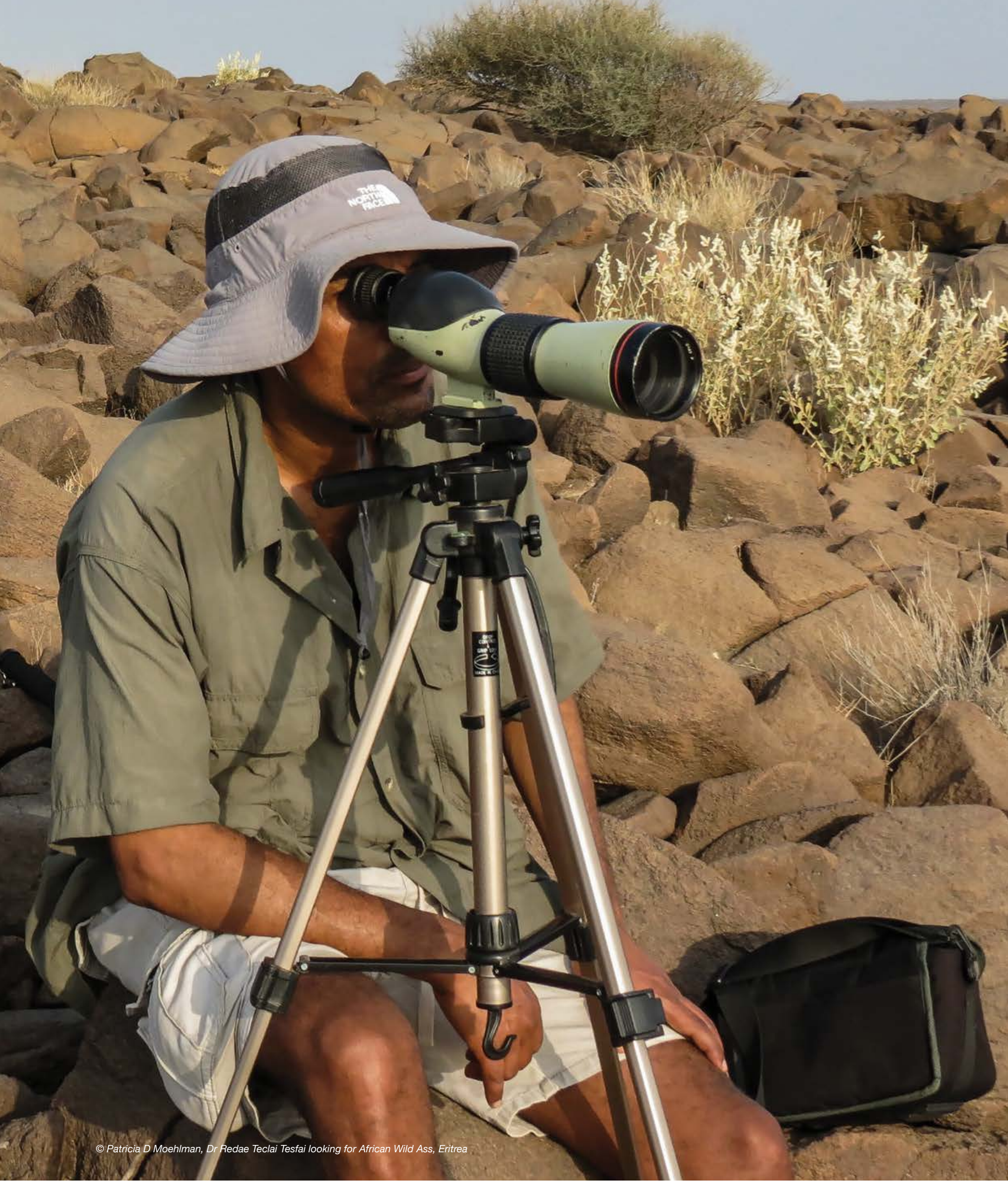




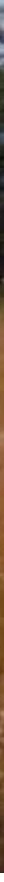

\subsection{Eswatini}

\section{Protected and conserved areas in Eswatini ${ }^{49}$}

Eswatini has 14 protected areas covering $738 \mathrm{~km}^{2}$ of land (UNEPWCMC \& IUCN (2019g).

The country's protected area estate has increased in a span of one year, from $3.9 \%$ in 2017 to $4.26 \%$ in 2018 . Eswatini's protected area estate is comprised of very small and vulnerable protected areas poorly distributed across ecosystems. There is, thus, a need to expand the protected area estate, while strengthening protected area management competencies. This in turn will require the participation of a broad range of stakeholders, including private landholders, local communities and the tourism industry.

\section{Transboundary protected and conserved areas}

Eswatini includes part of the Lubombo transboundary conservation area.

\section{Policy context}

A comprehensive report on legislation and policy related to protected area management, governance, and equity was undertaken by the BIOPAMA programme. It identified 10 relevant laws and policies in Eswatini (Tessema, 2019).

\section{Key species ${ }^{50}$}

For a small country, Eswatini has a rich floral and faunal diversity. Of the over 3,500 plant species that have been recorded, 12 are endemic. 89 species of vertebrates and 305 species of plants are listed in National Red Lists. 813 species of vertebrates have been recorded, with just one endemic, the major rock gecko (Afroedura major).

\section{Pressures and threats ${ }^{51}$}

The main pressures behind the country's changing biodiversity include habitat loss and habitat change for increasing agriculture and for urbanisation and settlements, as well as wildfires, and invasive species. $80 \%$ of Eswatini is infested with at least one invasive plant species. Unsustainable harvesting of plant and animal species for medicinal purposes is a major threat to many species. Likewise, unsustainable harvesting of trees for charcoal production has had a major impact on habitat for many bird and mammal species.

Climate change is an emerging pressure in Eswatini, likely to disrupt natural ecosystems across Eswatini. Indirect threats include economic, demographic, social-political, and cultural pressures. With over $40 \%$ of the population below the age of 25 , it is anticipated that the population will double in the near future. 
Figure 8.11 Eswatini Summary

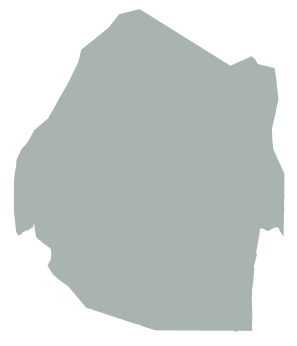

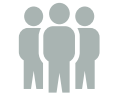

Total Population (millions) 1.14

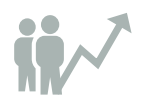

Population growth (annual \%) 1.00

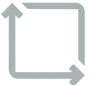

Surface area $\left(\mathrm{km}^{2}\right)$ (thousands) 17.40
Protected and conserved areas in Eswatini in IUCN Management Categories

Area Protected:

14 protected
areas

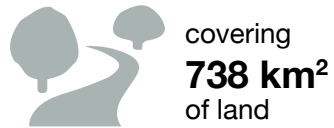

of land

Source: UNEP-WCMC \& IUCN, (2019g)

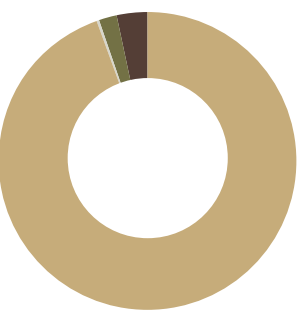

Source: UNEP-WCMC \& IUCN (2019g).
Not Reported

V. Protected Landscape/Seascape (No. 1)

IV. Habitat/Species Management (No. 2)

II. National Park (No. 6)
GDP (current US\$) (billions)

4.70

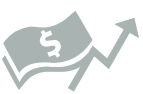

GDP growth (annual \%) 0.60

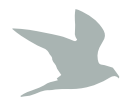

Rich floral and faunal diversity
3500 plant species

12 are endemic

\section{Coverage of protected areas in Eswatini}

\begin{tabular}{l|r|r}
\hline Type of protected area & $\begin{array}{r}\text { Area protected } \\
\text { or conserved }\end{array}$ & $\begin{array}{r}\text { Area protected } \\
\text { or conserved }^{* *}\end{array}$ \\
\hline Terrestrial and inland water & $4.26 \%$ & $3.90 \%$ \\
\hline${ }^{*}$ WDPA dataset & ${ }^{* *}$ From National Report on Biodiversity
\end{tabular}

Source: Eswatini Environment Authority (2014); UNEP-WCMC and IUCN (2019g).

\section{Protected and conserved areas in Eswatini in} IUCN Governance Types

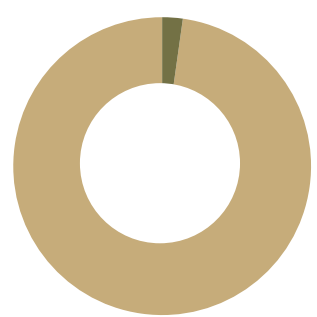

Not Reported (No. 11)

B. Private (No. 3)

National designations of protected and conserved areas in Eswatini

\begin{tabular}{l|r|r}
\hline National designation & No. & Area $\left.\mathbf{( k m}^{\mathbf{2}}\right)$ \\
\hline National Park & 1 & 217 \\
\hline Nature Reserve & 10 & 520 \\
\hline
\end{tabular}

Source: UNEP-WCMC \& IUCN (2019g).

Protected and conserved areas designated as global sites of importance in Eswatini

\begin{tabular}{l|r}
\hline Global designation & No. of sites \\
\hline Wetlands of International Importance & 3 \\
(Ramsar sites) & \\
\hline Source: Ramsar (2019); UNESCO (2019a, 2019b)
\end{tabular}

Priority areas for conservation

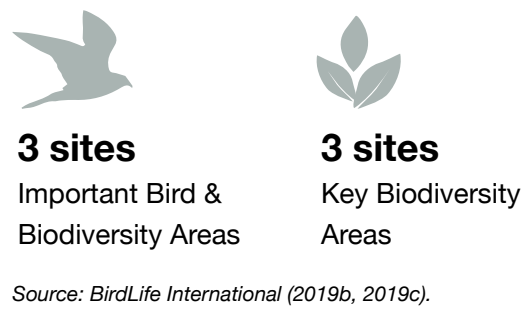




\section{Figure 8.12 Eswatini protected areas}
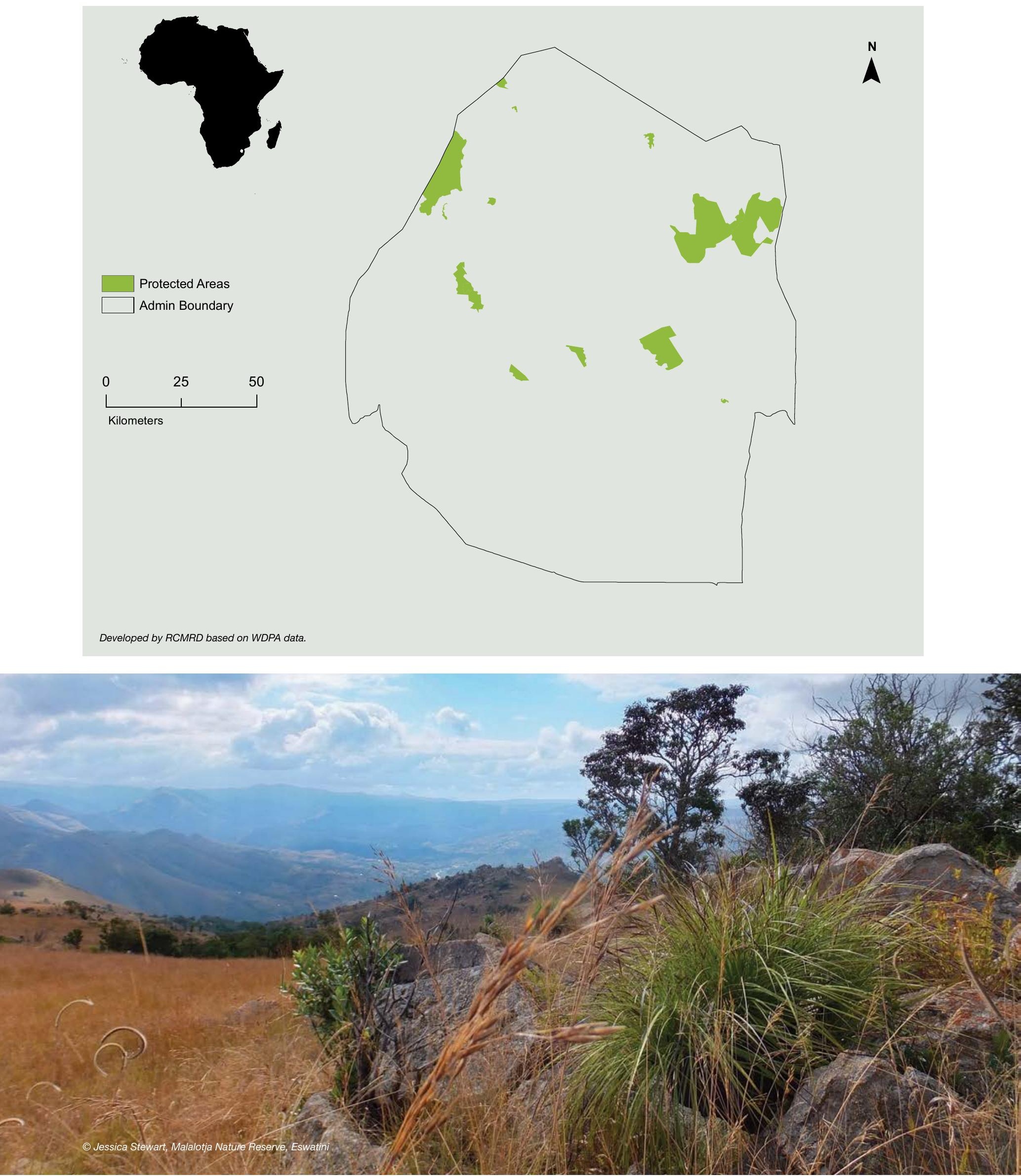


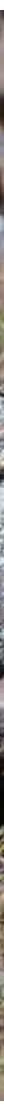

\subsection{Ethiopia}

\section{Protected and conserved areas in Ethiopia ${ }^{52}$}

Ethiopia has 104 protected areas covering $200,074 \mathrm{~km}^{2}$ of land (UNEP-WCMC \& IUCN, 2019h).

Located in the Horn of Africa, Ethiopia is a relatively large landlocked country with a wide diversity of topography, parental bedrocks and climates. This topographic diversity, across a 4,620-meter altitude span, has resulted in wide variations in rainfall, humidity, temperature and soils, which qualifies it to harbour six of the world's major terrestrial biomes (alpine, coniferous forests, deciduous forest, tropical rain forest, savanna and desert) and nine distinct ecosystem types.

International funding under different forms of international trade mechanisms for climate change mitigation, such as the Clean Development Mechanism (CDM) and REDD+, helps to finance the protection of the four Ethiopian national parks, one of the wildlife sanctuaries and three of the community conservation areas.

A major challenge in Ethiopia is the absence of legal status of most protected areas. The Ethiopian Wildlife Conservation Authority created in 2008 manages only 13 National Parks, wildlife reserves and sanctuaries. The rest are managed by regional authorities, rural communities and the private sector, and are inadequately protected, particularly wetland and freshwater ecosystems. There is a need to increase the coverage of formally protected areas, with due attention to their ecosystem representation as well as effectiveness in terms of management.

\section{Transboundary protected and conserved areas}

Ethiopia includes part of the Boma-Gambella Landscape and the Lower Awash-Lake Abbé Landscape transboundary conservation areas.

\section{Policy context}

A comprehensive report on legislation and policy related to protected area management, governance, and equity was undertaken by the BIOPAMA programme. It identified 29 relevant laws and policies in Ethiopia (Tessema, 2019).

\section{Key species ${ }^{53}$}

Ethiopia is home to an estimated 6,000 species of higher plants $10 \%$ of which are endemic. The country has 284 species of wild mammals and 861 species of birds.

52 The section draws on information contained in Ethiopia's Sixth National Report to the CBD (Republic of Ethiopia \& Ethiopian Biodiversity Institute, 2014) and its Second NBSAP (Republic of Ethiopia, 2019).

53 The section draws on information contained in Ethiopia's Fifth and Sixth National Reports to the CBD and its Second NBSAP (Government of the Federal Democratic Republic of Ethiopia \& Ethiopian Biodiversity Institute, 2014; 2015; Republic of Ethiopia, 2019). 
Figure 8.13 Ethiopia Summary

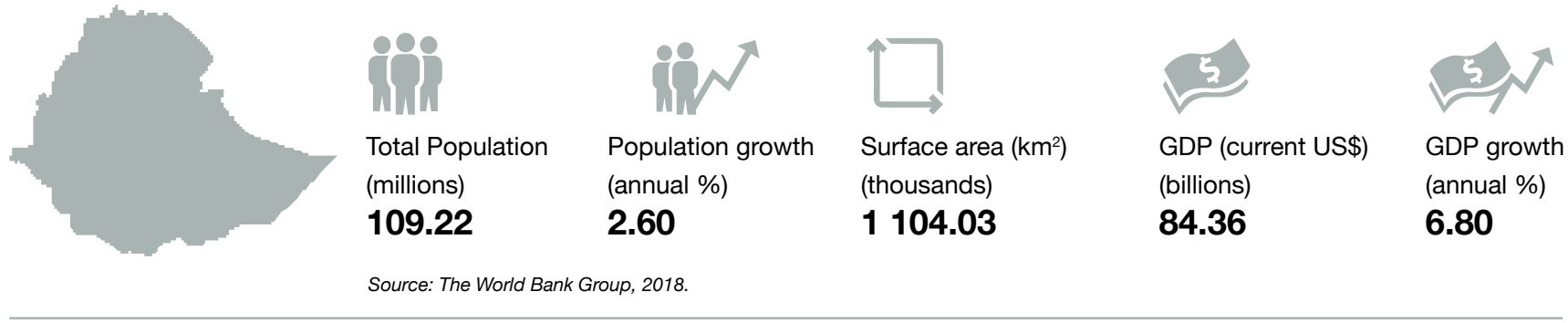

\section{Area Protected:}

104 protected areas

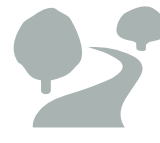

covering 200074 km² of land
Protected and conserved areas in Ethiopia in IUCN Management Categories

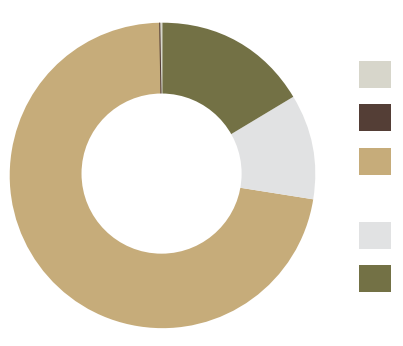

Not Applicable (No. 3)

Not Reported (No. 58)

VI. Protected Area with Sustainable Use of Natural Resources (No. 18)

IV. Habitat/Species Management (No. 8)

II. National Park (No.17)

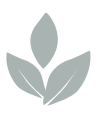

6000 plant species $10 \%$ are endemic

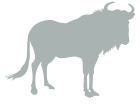

284 mammal species

29 are endemic

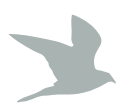

861 bird species

18 are endemic
63 amphibians
200 fish species

\section{Coverage of protected areas in Ethiopia}

\begin{tabular}{l|r|r}
\hline Type of protected area & $\begin{array}{r}\text { Area protected } \\
\text { or conserved }\end{array}$ & $\begin{array}{r}\text { Area protected } \\
\text { or conserved }^{\star *}\end{array}$ \\
\hline Terrestrial and inland water & $17.62 \%$ & $14.00 \%$ \\
\hline
\end{tabular}

"WDPA dataset $\quad$ ** From National Report on Biodiversity

Source: Republic of Ethiopia (2019); UNEP-WCMC \& IUCN (2019h).

Protected and conserved areas designated as global sites of importance in Ethiopia

\begin{tabular}{l|r}
\hline Global designation & No. of sites \\
\hline UNESCO Man and Biosphere Reserves & 5 \\
\hline UNESCO World Heritage Sites (natural or mixed) & 1 \\
\hline
\end{tabular}

Source: Ramsar (2019); UNESCO (2019a, 2019b).

Protected and conserved areas in Ethiopia in IUCN Governance Types

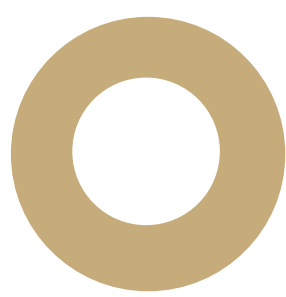

Not Reported (No. 105)
National designations of protected and conserved areas in Ethiopia

\begin{tabular}{l|r|r}
\hline National designation & No. & Area $\left.\mathbf{( k m}^{\mathbf{2}}\right)$ \\
\hline Sanctuary & 4 & 11037 \\
\hline National Park & 13 & 23672 \\
\hline Wildlife Reserve & 8 & 23392 \\
\hline National Forest Priority Area & 58 & 44132 \\
\hline Controlled Hunting Area & 18 & 151577 \\
\hline
\end{tabular}

Source: UNEP-WCMC \& IUCN (2019h).

\section{Priority areas for conservation}
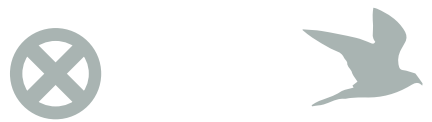

\section{3 sites}

Alliance for Zero

Extinction sites

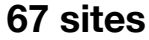

Important Bird \&

Biodiversity Areas

79 sites

Key Biodiversity

Areas 


\section{Figure 8.14 Ethiopia protected areas}

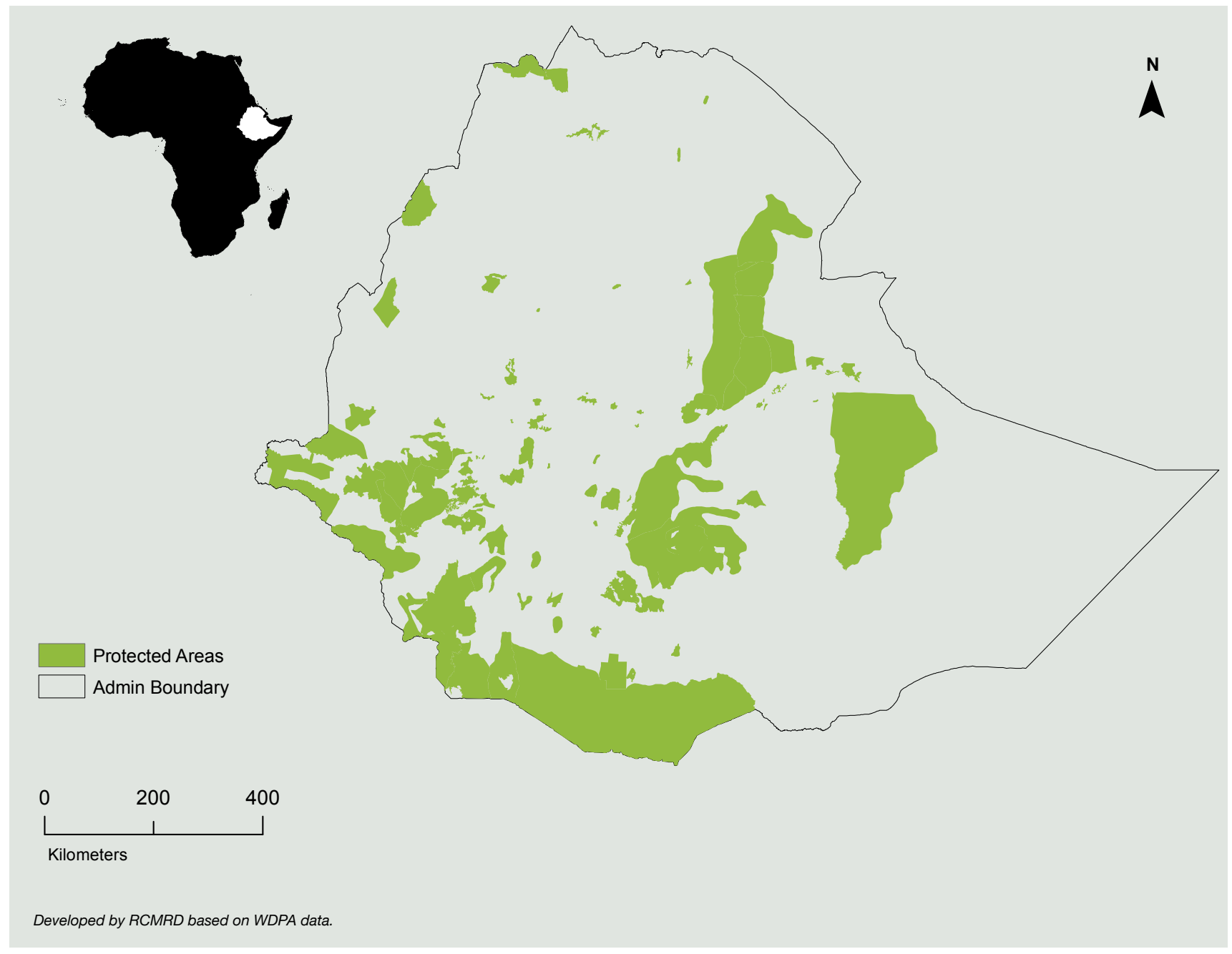

Data on other wild animals are lacking, and so far the number of species identified are: 201 reptiles, 200 fishes, 63 amphibians and 1,225 arthropods. Of these faunal resources, 29 wild mammals, 18 birds, 10 reptiles, 40 fishes, 25 amphibians and seven arthropod species are endemic to Ethiopia, such as the Ethiopian Wolf (Canis simensis). Ethiopia also has a wide diversity of microbial biodiversity, which is hardly explored.

\section{Pressures and threats ${ }^{54}$}

The main direct threats to Ethiopia's biodiversity include: habitat loss and degradation due to expansion of agriculture and settlements and encroachment of invasive species; unsustainable utilisation of biodiversity from overgrazing, overharvesting, and unregulated hunting; proliferation of invasive species; and pollution. Indirect causes of biodiversity loss in the country are demographic change, poverty, and lack of awareness and coordination. Longterm, climate change represents challenges, particularly by shifting growing seasons.

54 The section draws on information contained in Ethiopia's Fifth and Sixth National Reports to the CBD and its Second NBSAP (Government of the Federal Democratic Republic of Ethiopia \& Ethiopian Biodiversity Institute, 2014 \& 2015; Republic of Ethiopia, 2019). 


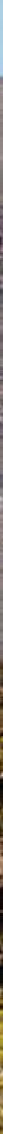
W.

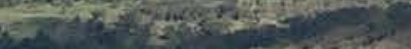
$6+2 x^{3}$

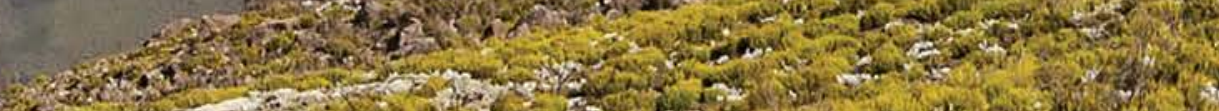

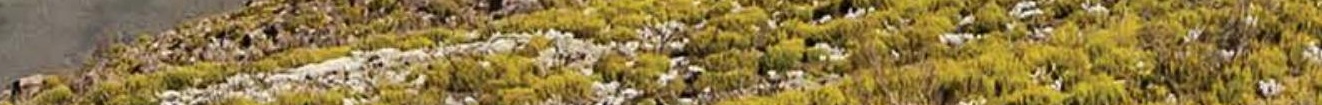

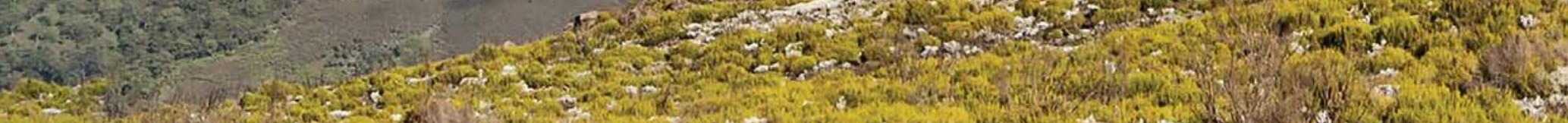

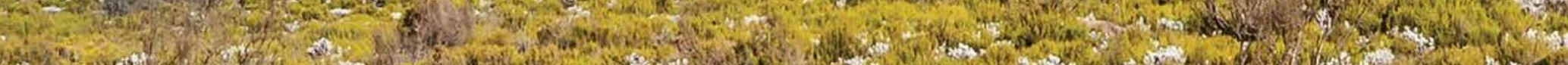

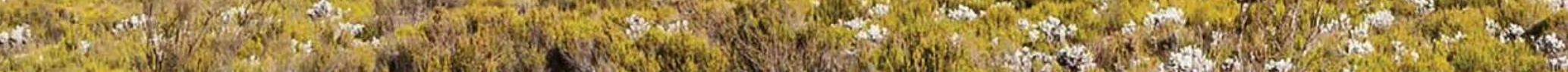

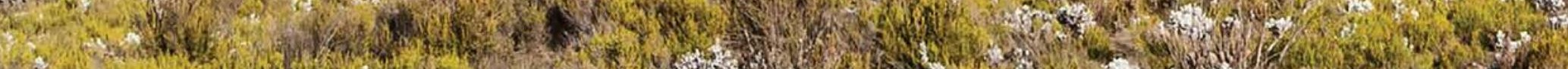

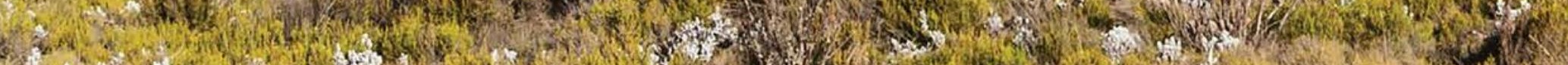
-

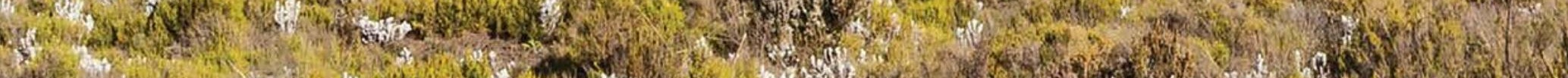

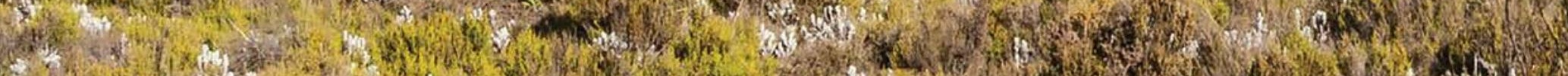

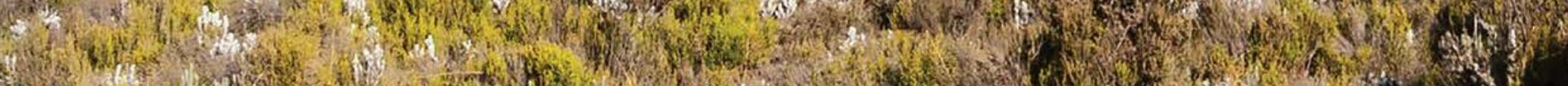

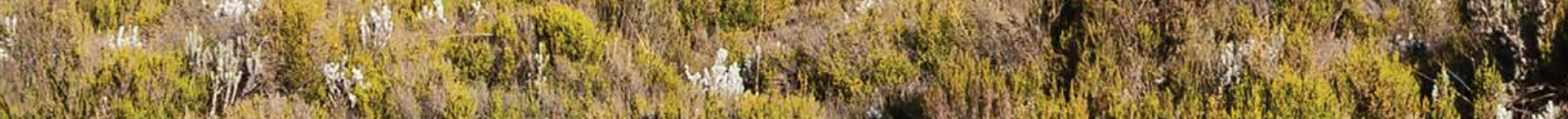

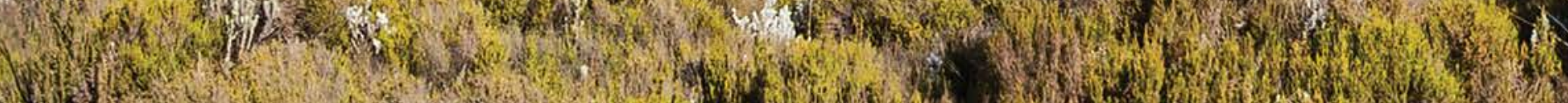
Wy

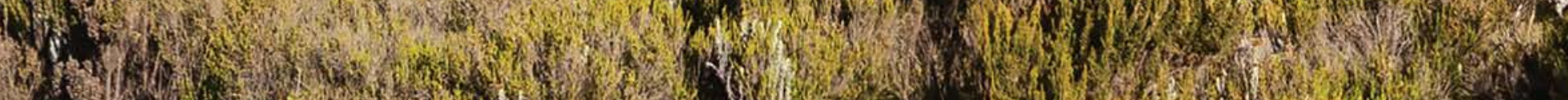

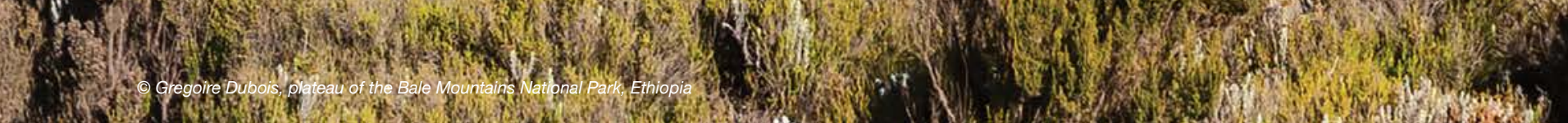




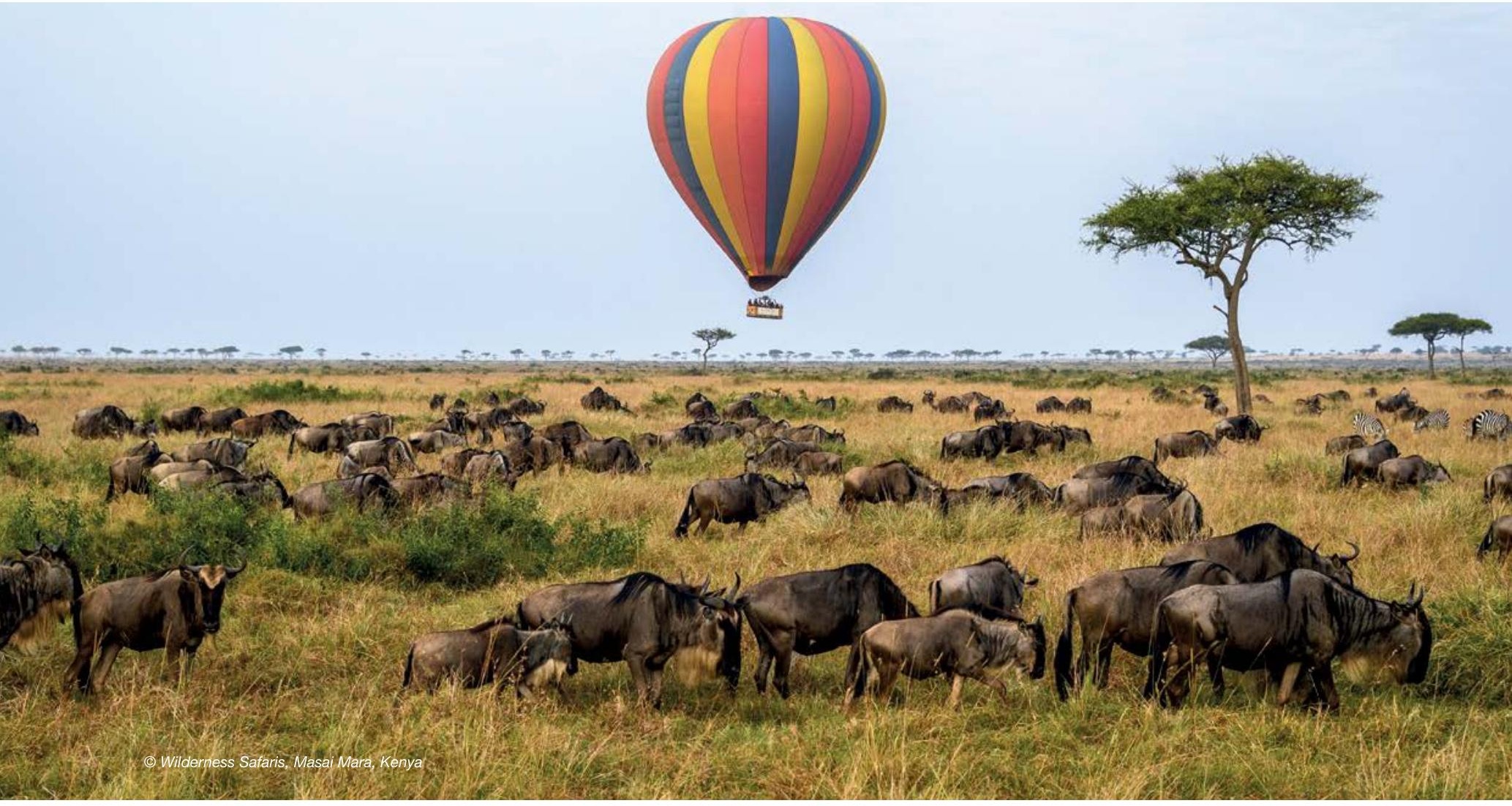

\subsection{Kenya}

\section{Protected and conserved areas in Kenya ${ }^{55}$}

Kenya has 411 protected areas covering $72,545 \mathrm{~km}^{2}$ of land and $904 \mathrm{~km}^{2}$ of the ocean (UNEP-WCMC \& IUCN (2019i).

The post-independence government inherited four national parks and six game reserves, gazetted through a parliamentary process. In addition, there are quite a number of game reserves that are under the management of local authorities. There also a host of privately or/and communally owned wildlife conservancies. Subsequently the numbers of the parks and reserves have greatly increased.

Of the $12 \%$ of land designated as protected areas including forests, $50 \%$ are found in arid and semi-arid lands. The current trend shows a sharp decline in animal species diversity and population abundance in these ecosystems. Realising that these protected areas were incapable of adequately meeting biodiversity conservation goals and providing support to livelihoods, the idea of establishing private sanctuaries and community conservancies has gained momentum over the last few decades in Kenya. These form the lifeblood of the current protected areas system, with more than $70 \%$ of all large wildlife living permanently or seasonally outside of protected areas managed by government agencies.

\section{Transboundary protected and conserved areas}

Kenya includes part of five transboundary conservation areas, namely: i) Amboseli-Kilimanjaro-Longido, ii) Mount Elgon, iii) Serengeti-Mara, iv) Tana-Kipini-Laga Badana Bushbush Land and Seascape, and v) Tanga Marine Reserves System and Tanga Coelacanth Marine Park and Diani Chale and Kisitee-Mpunguti.

\section{Policy context}

A comprehensive report on legislation and policy related to protected area management, governance, and equity was undertaken by the BIOPAMA programme. It identified 41 relevant laws and policies in Kenya (Tessema, 2019).

\section{Key species ${ }^{56}$}

Kenya is endowed with diverse ecosystems and habitats that are home to unique and diverse flora and fauna. Over 7,000 plant species have been recorded in Kenya with over 1,000 of those endemic or near-endemic. Some 356 plant species have been assessed through the IUCN Red List process as threatened, a third of which are endemic to Kenya. It is estimated that over 5,000 species of fungus occur in the country although only 2,000 have been documented.

Kenya's 1,100 bird species include eight endemics.

55 The section draws on information contained in Kenya's Fifth National Report to the CBD (Republic of Kenya, 2015)

56 Ibid. 
Figure 8.15 Kenya Summary

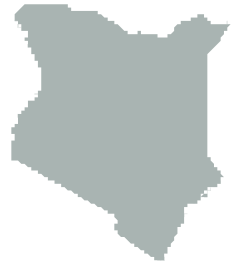

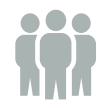

Total Population (millions)

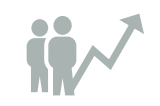

Population growth (annual \%)

2.30

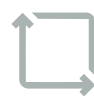

Surface area $\left(\mathrm{km}^{2}\right)$ (thousands)

580.40
GDP (current US\$) (billions)

87.91
GDP growth

(annual \%)
411 protected areas
Source: The World Bank Group, 2018.

\section{Area Protected:}

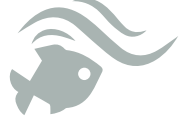

covering

$904 \mathbf{k m}^{2}$

of ocean
Source: UNEP-WCMC \& IUCN, 2019i

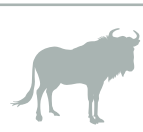

315 mammal
species

1100 bird species

\section{Coverage of protected areas in Kenya}

\begin{tabular}{l|r|r}
\hline Type of protected area & $\begin{array}{r}\text { Area protected } \\
\text { or conserved }^{*}\end{array}$ & $\begin{array}{r}\text { Area protected } \\
\text { or conserved }^{* *}\end{array}$ \\
\hline Terrestrial and inland water & $12.36 \%$ & $8.00 \%$ \\
\hline Coastal and marine & $0.80 \%$ & Not found \\
\hline
\end{tabular}

*WDPA dataset $\quad$ ** From National Report on Biodiversity

Source: Republic of Kenya (2015); UNEP-WCMC \& IUCN (2019i).

Protected and conserved areas in Kenya in IUCN Governance Types

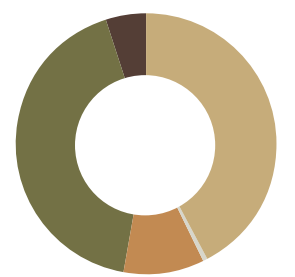

Not Applicable (No. 9)

Not Reported (No. 345)

VI. Protected Area with Sustainable Use of Natural Resources (No. 16)

IV. Habitat / Species Management (No. 5)

II. National Park (No. 36)

Source: UNEP-WCMC \& IUCN (2019i).

\section{Priority areas for conservation}

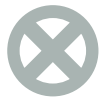

\section{6 sites}

Alliance for Zero

Extinction sites

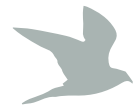

\section{8 sites}

Important Bird \&

Biodiversity Areas
72 sites

Key Biodiversity Areas
Protected and conserved areas designated as global sites of importance in Kenya

\begin{tabular}{l|r}
\hline Global designation & No. of sites \\
\hline UNESCO Man and Biosphere Reserves & 6 \\
\hline UNESCO World Heritage Sites (Natural or Mixed) & 3 \\
\hline Wetlands of International Importance (Ramsar sites) & 6 \\
\hline Source: Ramsar (2019); UNESCO (2019a (2019b).
\end{tabular}

National designations of protected and conserved areas in Kenya

\begin{tabular}{l|r|r}
\hline National designation & No. & Area $\left.\mathbf{( k m}^{2}\right)$ \\
\hline Community Wildlife Sanctuary & 1 & 223 \\
\hline National Park & 23 & 28844 \\
\hline National Reserve & 31 & 17941 \\
\hline Group Ranch & 1 & 66 \\
\hline Private Nature Reserve & 1 & 197 \\
\hline Game Sanctuary & 1 & 0 \\
\hline Private Protected Area & 2 & 522 \\
\hline National Sanctuary & 6 & 36 \\
\hline Private Ranch & 4 & 645 \\
\hline Marine National Reserve & 5 & 510 \\
\hline Marine National Park & 4 & 61 \\
\hline Nature Reserve & 2 & 17941 \\
\hline Not Reported & 5 & 8 \\
\hline Forest Reserve & 234 & 18776 \\
\hline National Park (proposed) & 1 & 145 \\
\hline Community Conservancy & 21 & 2719 \\
\hline Community Nature Reserve & 28 & 30016 \\
\hline Private Reserve & 16 & 8121 \\
\hline Wildlife Sanctuary & 1 & 109 \\
\hline Locally Managed Marine Area & 9 & 37 \\
\hline Source: UNEP-WCMC \& IUCN (2019i). & &
\end{tabular}

Protected and conserved areas in Kenya in IUCN Management Categories

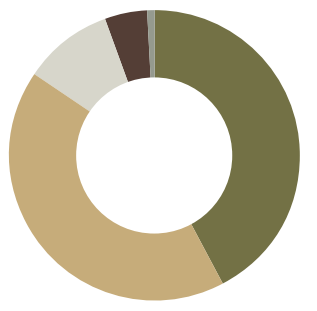

Not Applicable (No. 9)

Not Reported (No. 345)

VI. Protected Area with Sustainable Use of Natural Resources (No. 16)

IV. Habitat/Species Management (No. 5)

II. National Park (No. 36)

Source: UNEP-WCMC \& IUCN (2019i). 
Over 200 reptiles (five marine turtle, five tortoise, 100 snake, 100 lizard, one crocodile and five terrapin species) and 110 amphibian species occur throughout the country except at the top of high mountains such as Mount Kenya. Kenya is also home to 315 mammal species, including a number of endemics and nearendemics, including the Grevy's zebra (Equus grevyi) and the hirola (Beatragus hunteri). Declines in many mammal species, apart from the African elephant (Loxodonta africana), have been attributed to land use change, drought, poaching, disease and competition for resources.

Kenya's freshwater and marine ecosystems contain both biologically diverse and commercially important fish populations. Over 60 of these species are threatened according to the IUCN Red List. Over 35,000 invertebrate taxa have been recorded and described, with many thousands more remaining to be described.

\section{Pressures and threats ${ }^{57}$}

The overriding threat facing biodiversity in Kenya is habitat degradation, fragmentation and loss, such as land use changes, physical modification of rivers or excessive withdrawal from rivers, loss of coral reefs and damage to sea floors due to trawling. The main drivers are: human population growth, exerting pressure on biodiversity habitats and land resources; and poverty leading to unsustainable use of land resources and biodiversity and limited financial resources to support biodiversity conservation.

Other critical threats include climate change, invasive alien species, overexploitation and pollution. Certain taxa, such as amphibians and reptiles, are particularly impacted by overexploitation for local and international trade. The illegal international trade in ivory and rhino horn has also been a threat to populations of elephant and rhino in the country, while the lesser known African sandalwood (Osyris lanceolata) is also seriously threatened by illegal overexploitation. The illegal bushmeat trade has seriously impacted many antelope species.

\section{Figure 8.16 Kenya protected areas}

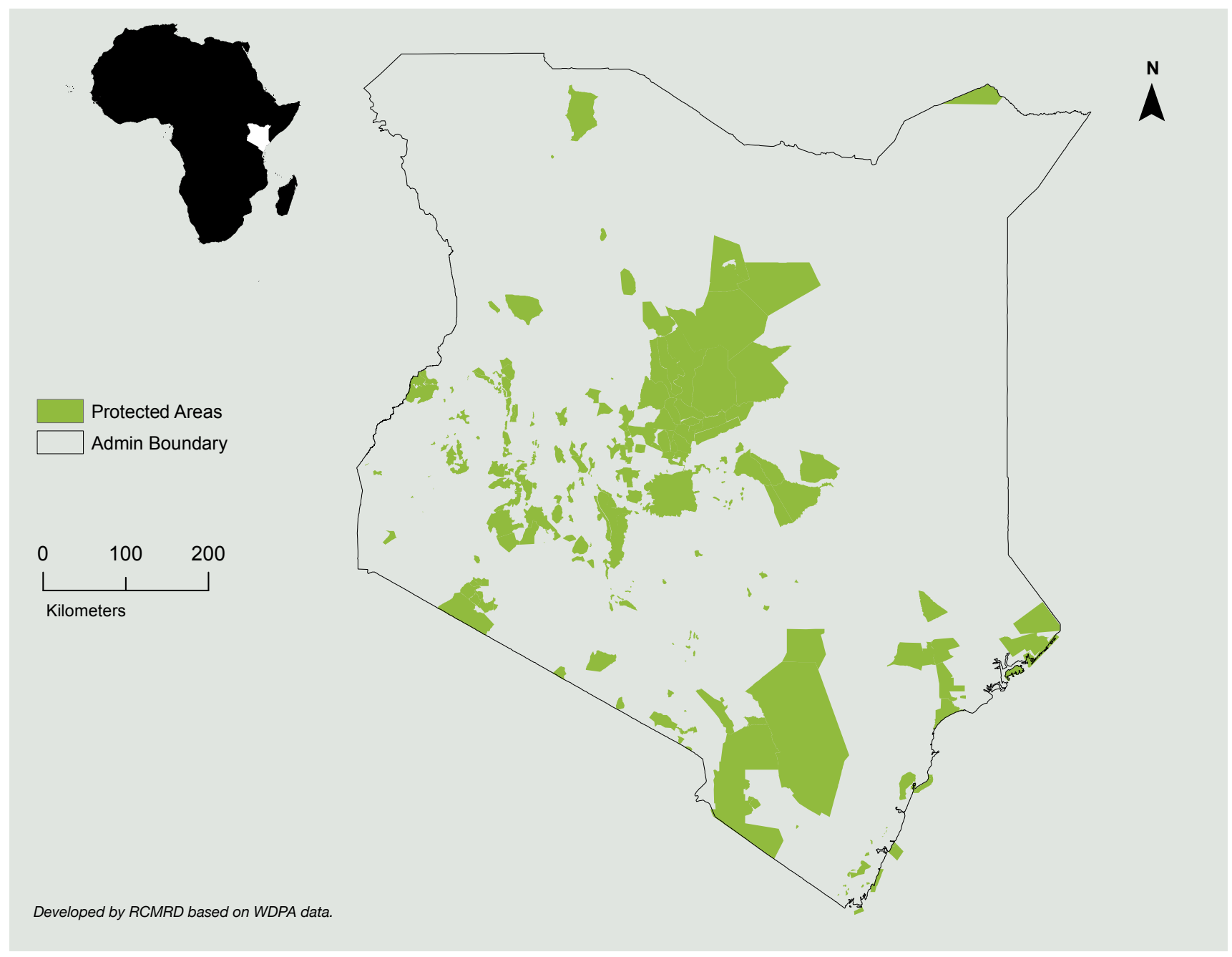



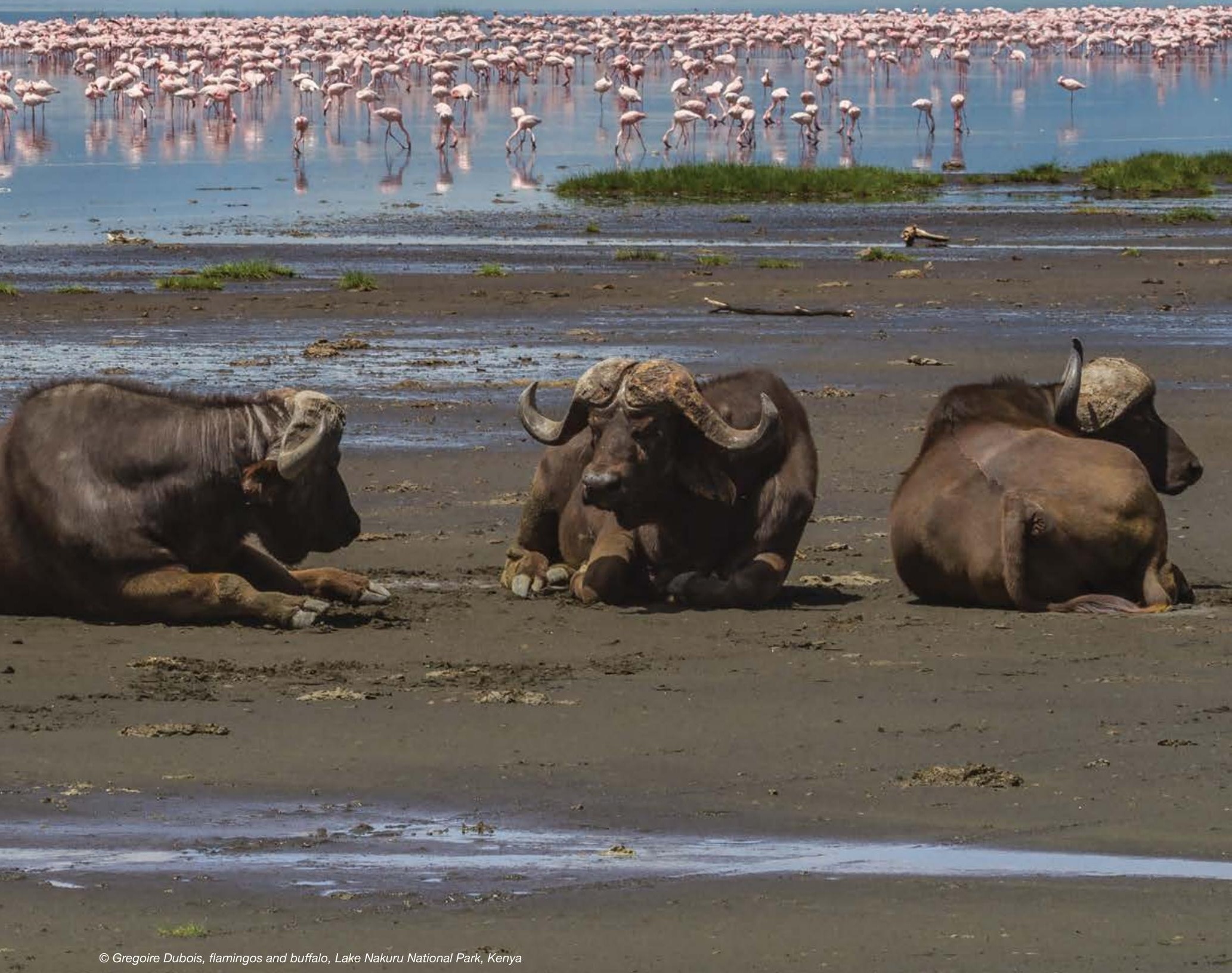

(c) Gregoire Dubois, flamingos and buffalo, Lake Nakuru National Park, Kenya 


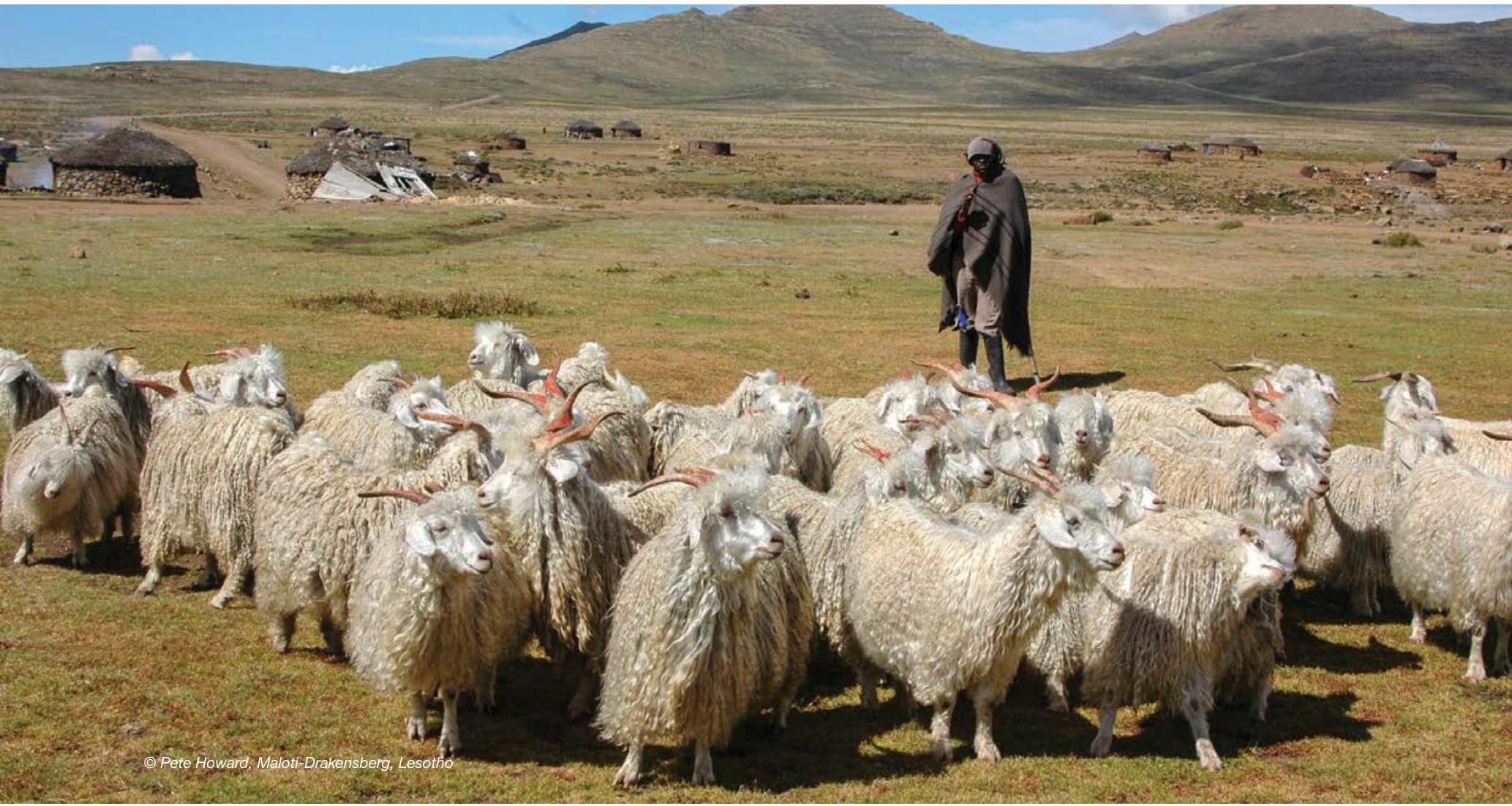

\subsection{Lesotho}

\section{Protected and conserved areas in Lesotho ${ }^{58}$}

Lesotho has four protected areas covering $80 \mathrm{~km}^{2}$ of land (UNEPWCMC \& IUCN, 2019j).

One of Lesotho's parks, the Sehlabathebe National Park is a mixed natural/cultural World Heritage Site and together with the Khahlamba Drakensberg National Park in South Africa forms a transboundary protected area, known as the Maloti Drakensberg Park, a haven for many threatened and endemic species.

In addition to the formally designated protected areas, there are several areas that are either informally designated or proposed for protection in various parts of the country. There are plans to proclaim Letsa-La-Letsie Nature Reserve and Tsatsane as protected areas. In order to meet all the biodiversity targets, $49 \%$ of Lesotho Highlands should be under some form of conservation management - possibly a mix of managed resource areas and smaller protected areas. Eight key areas for priority action have been identified by Maloti-Drakensberg Transfrontier Project.

\section{Transboundary protected and conserved areas}

Lesotho includes part of the Maloti Drakensberg Park World Heritage Site which is inside the Maloti Drakensberg TFCA.

\section{Policy context}

A comprehensive report on legislation and policy related to protected area management, governance, and equity was undertaken by the BIOPAMA programme. It identified 17 relevant laws and policies in Lesotho (Tessema, 2019).

\section{Key species ${ }^{59}$}

Despite its small size, Lesotho has very high levels of plant endemism with at least 54 endemic species. Lesotho is also home to 340 bird species and a number of mammal species, including the endemic ice rat (Otomys sloggetti) and white-tailed mouse (Mystromys albicaudatus). The chacma baboon (Papio ursinus), once abundant, has suffered a precipitous decline.

Lesotho also has high levels of endemism in the reptile and amphibian groups. The 14 recorded fish species include one endemic species.

\section{Pressures and threats ${ }^{60}$}

One of the main threats to biodiversity in Lesotho is habitat loss and degradation, particularly of wetlands and rangelands. Poor range management practices have resulted in the loss of plant cover and topsoil. Uncontrolled fires are also a threat in the

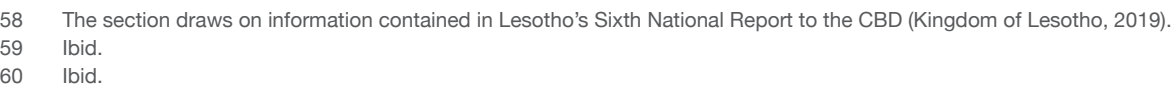


Figure 8.17 Lesotho Summary

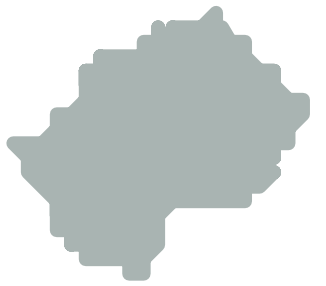

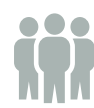

Total Population (millions) 2.11

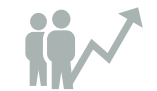

Population growth (annual \%)

0.80

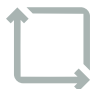

Surface area $\left(\mathrm{km}^{2}\right)$ (thousands) 30.40

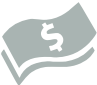

GDP (current US\$) (billions) 2.79
GDP growth (annual \%) 1.50

Source: The World Bank Group, 2018.

Area Protected:

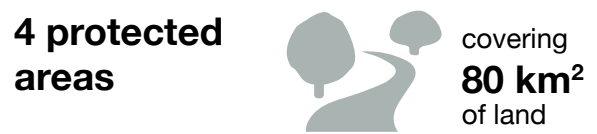

Source: UNEP-WCMC \& IUCN, (2019j)

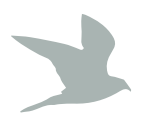

340 bird species
$80 \mathbf{k m}^{2}$ of land

\begin{tabular}{|c|c|c|}
\hline $\begin{array}{l}340 \text { bird } \\
\text { species }\end{array}$ & 14 fish & \\
\hline \multicolumn{3}{|c|}{ Coverage of protected areas in Lesotho } \\
\hline Type of protected area & $\begin{array}{l}\text { Area protected } \\
\text { or conserved* }\end{array}$ & $\begin{array}{l}\text { Area protected } \\
\text { or conserved }^{\star \star}\end{array}$ \\
\hline Terrestrial and inland water & $0.26 \%$ & $0.50 \%$ \\
\hline
\end{tabular}

* WDPA dataset $\quad$ ** From National Report on Biodiversity

Source: Kingdom of Lesotho (2019); UNEP-WCMC \& IUCN (2019j).

National designations of protected and conserved areas in Lesotho

\begin{tabular}{l|r|r}
\hline National designation & No. & Area $\left.\mathbf{( k m}^{2}\right)$ \\
\hline National Park & 2 & 6394 \\
\hline
\end{tabular}

Source: UNEP-WCMC \& IUCN (2019j).

Protected and conserved areas in Lesotho in IUCN Governance Types

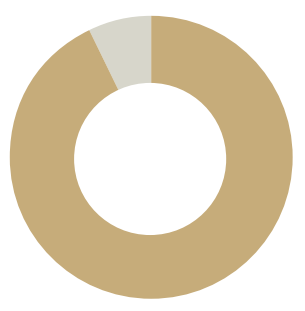

Not Reported (No. 1)

A. Governance by Government (3)
Protected and conserved areas in Lesotho in IUCN Management Categories

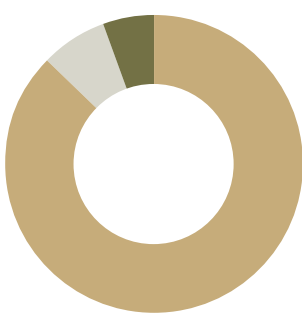

Not Applicable (No. 1)

Not Reported (No. 2)

IV. Habitat/Species Management (No. 1)

ource: UNEP-WCMC \& IUCN (2019j).

Protected and conserved areas designated as global sites of importance in Lesotho

\begin{tabular}{l|r}
\hline Global designation & No. of sites \\
\hline $\begin{array}{l}\text { UNESCO World Heritage Sites } \\
\text { (Natural or Mixed) }\end{array}$ & 1 \\
\hline Wetlands of International Importance & 1 \\
(Ramsar sites) & \\
\hline
\end{tabular}

Source: Ramsar (2019); UNESCO (2019a, 2019b)

\section{Priority areas for conservation}

\section{6 sites}

Important Bird \& Biodiversity Areas

Source: BirdLife International (2019c). 
rangelands. Initiatives for economic development, such as mining, can also represent threats to habitats in Lesotho. With increasing climate uncertainty, subsistence agriculture is increasingly encroaching into remaining habitats.
Invasive species represent a major threat in both terrestrial and aquatic ecosystems. In addition, climate change is increasing climate uncertainty.

\section{Figure 8.18 Lesotho protected areas}

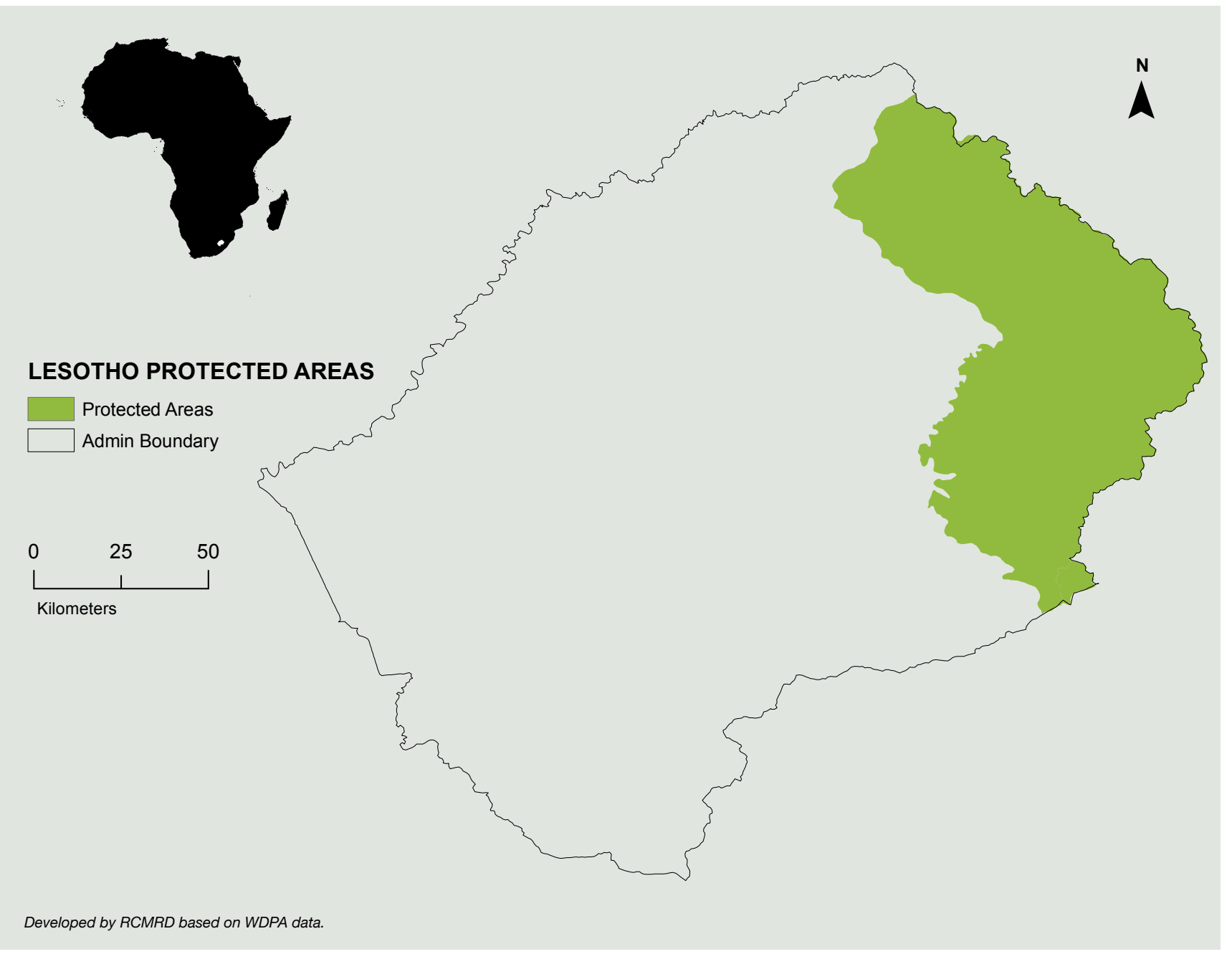



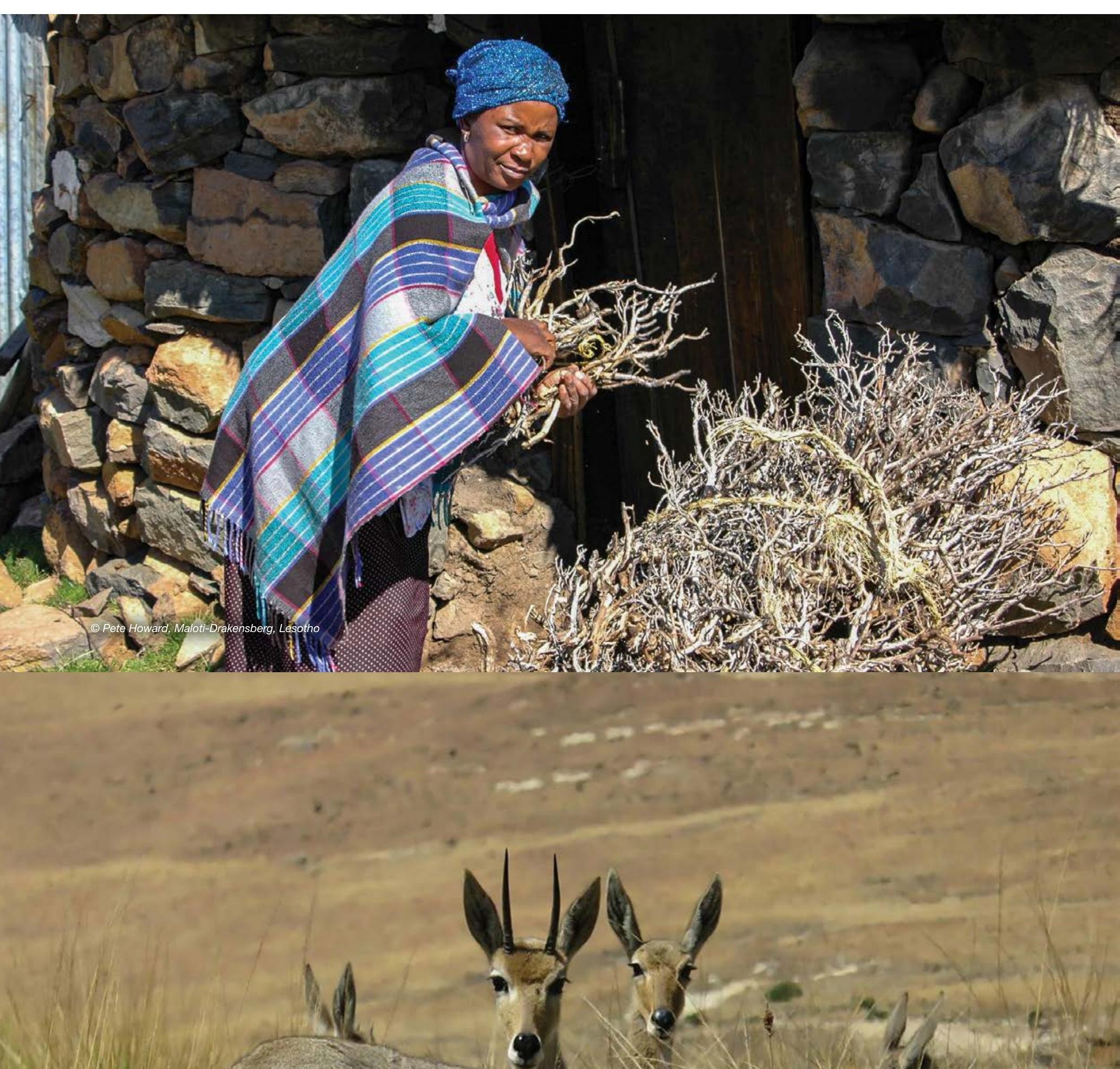
- (x)

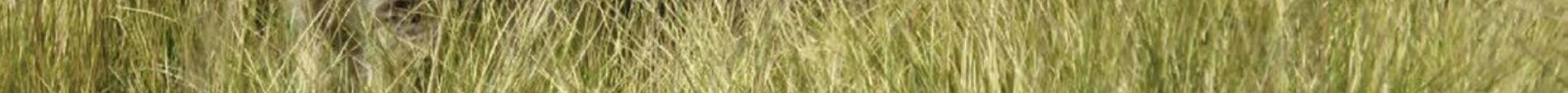

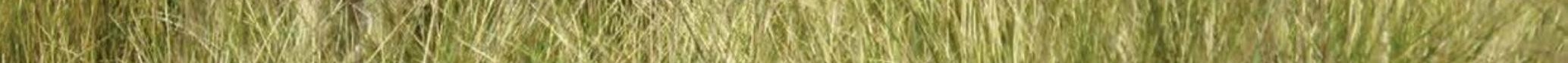
W. 


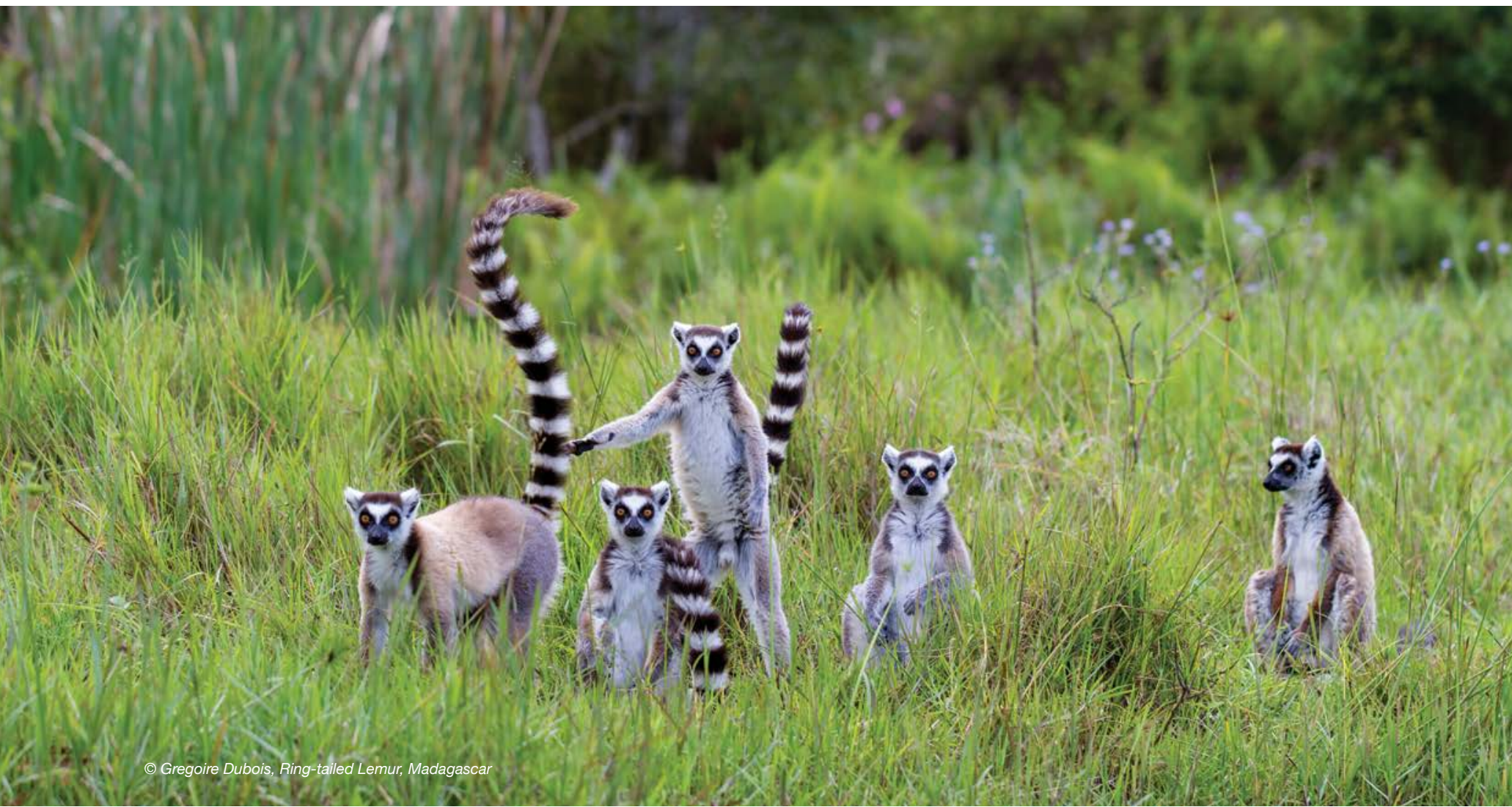

\subsection{Madagascar}

\section{Protected and conserved areas in Madagascar ${ }^{61}$}

Madagascar has 157 protected areas covering $33,242 \mathrm{~km}^{2}$ of the land and $8,998 \mathrm{~km}^{2}$ of the ocean (UNEP-WCMC \& IUCN, 2019k).

Madagascar took the challenge from the Sydney World Parks Congress to triple the surface area of marine protected areas, an objective that has been largely achieved. Some sites are still in the process of being set up and others in the process of extension. A focus of this work is to ensure the participation of local communities. The biggest challenge currently is the effective management and sustainable funding of these protected areas. In addition, corridors of protected areas have been established over a total length of approximately $1,200 \mathrm{~km}$, linking link six protected areas which are part of the World Heritage Sites.

\section{Transboundary protected and conserved areas}

Madagascar includes part of the Western Indian Ocean Transfrontier Marine Park.

\section{Policy context}

A comprehensive report on legislation and policy related to protected area management, governance, and equity was undertaken by the BIOPAMA programme. It identified 75 relevant laws and policies in Madagascar (Tessema, 2019).

\section{Key species ${ }^{62}$}

Madagascar is estimated to have between 13,000 and 14,000 plant species, $80 \%$ of which are endemic. Endemism is particularly high amongst baobabs, palm trees and orchids, including six of the world's eight species of baobab. Likewise, mammals also display a high level of endemism, particularly amongst lemurs and other primates. Madagascar is home to many different species of birds. Knowledge of the invertebrates of Madagascar is incomplete, but there are high levels of endemism amongst ants, freshwater shrimps and crabs, and crayfish. Likewise, freshwater and marine fish, amphibians, reptiles all display high levels of endemism, some close to $100 \%$. 23 out of the 37 sea mammal species of the Western Indian Ocean Region have been observed in Madagascar's coastal zones.

\section{Pressures and threats ${ }^{63}$}

The major threats to Madagascar's biodiversity include: deforestation and forest degradation; illegal exploitation of natura resources, including timber, as well as many terrestrial and marine species; the impact of alien invasive species and disease; and as environmental impacts from extractive industries such as mining. Climate change remains a short and long-term threat to Madagascar's ecosystems, particularly marine ecosystems.

61 The section draws on information contained in Madagascar's Sixth National Report to the CBD (Republic of Madagascar, 2019).

62 The section draws on information contained in Madagascar's Fifth National Report to the CBD (Republic of Madagascar, 2014).

63 The section draws on information contained in Madagascar's Fifth National Report to the CBD and its Second NBSAP (Republic of Madagascar, 2014; 2016). 
Figure 8.19 Madagascar Summary

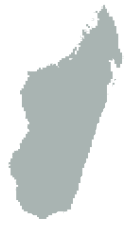

Source: The World Bank Group, 2018.

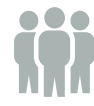

Total Population (millions)

26.26

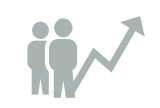

Population growth (annual \%)

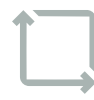

Surface area $\left(\mathrm{km}^{2}\right)$ (thousands)

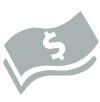

GDP (current US\$) (billions)

12.10
GDP growth

(annual \%)

\section{Area Protected:}

157 protected areas

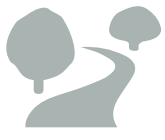

covering 33242 km$^{2}$ of land

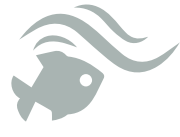

covering 8998 km $^{2}$ of ocean

Source: UNEP-WCMC \& IUCN, (2019k)

Protected and conserved areas in Madagascar in IUCN Management Categories

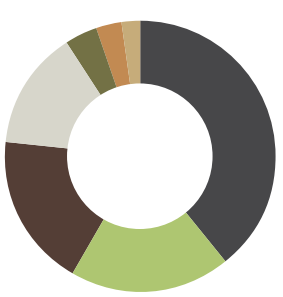

Source: UNEP-WCMC \& IUCN $(2019 k)$

Coverage of protected areas in Madagascar

*WDPA dataset $\quad$ ** From National Report on Biodiversity

Source: UNEP-WCMC \& IUCN (2019k).

Protected and conserved areas designated as global sites of importance in Madagascar

\begin{tabular}{l|r}
\hline Global designation & No. of sites \\
\hline UNESCO Man and Biosphere Reserves & 3 \\
\hline UNESCO World Heritage Sites (Natural or Mixed) & 2 \\
\hline $\begin{array}{l}\text { Wetlands of International Importance } \\
\text { (Ramsar sites) }\end{array}$ & 20 \\
\hline
\end{tabular}

Source: Ramsar (2019); UNESCO (2019a, 2019b).

Protected and conserved areas in Madagascar in IUCN Governance Types

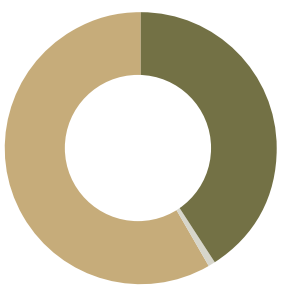

C. Private Governance (No. 2)

B. Shared Governance (No. 2)

A.Governance by Government (No. 8)

\begin{tabular}{l|r|r}
\hline Type of protected area & $\begin{array}{r}\text { Area protected } \\
\text { or conserved* }\end{array}$ & $\begin{array}{r}\text { Area protected } \\
\text { or conserved }\end{array}$ \\
\hline Terrestrial and inland water & $5.59 \%$ & Not found \\
\hline Coastal and marine & $0.75 \%$ & Not found \\
\hline
\end{tabular}

National designations of protected and conserved areas in Madagascar

\begin{tabular}{l|r|r}
\hline National designation & No. & Area $\mathbf{~ ( k m}^{2} \mathbf{)}$ \\
\hline Hunting Reserve & 2 & 150 \\
\hline Protected Harmonious Landscape & 1 & 139 \\
\hline Natural Park & 1 & 3649 \\
\hline Paysage Harmonieux Protégé & 20 & 14015 \\
\hline National Park & 26 & 19136 \\
\hline Réserve de Ressources Naturelles & 1 & 443 \\
\hline Proposed Protected Area & 14 & 5215 \\
\hline Marine Park & 4 & 119 \\
\hline Marine National Park & 1 & $0 *$ \\
\hline Collaborative Fishery Management & 1 & 2865 \\
Area & & \\
\hline Strict Nature Reserve & 3 & 1356 \\
\hline Reserve de ressource naturel & 1 & 443 \\
\hline Proposed Marine Park & 1 & 1564 \\
\hline Not Reported & 1 & 469 \\
\hline Classified Forest & 1 & 400 \\
\hline New Protected Area & 5 & 3701 \\
\hline Special Reserve & 22 & 3550 \\
\hline Locally Managed Marine Area & 26 & 2173 \\
\hline Marine Protected Area & 1 & 451 \\
\hline Sour unFPWMC\&ucN & &
\end{tabular}

Source: UNEP-WCMC \& IUCN (2019k)

* No area reported to the WDPA

\section{Priority areas for conservation}

Source: UNEP-WCMC \& IUCN (2019k)

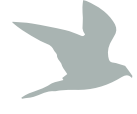

\section{0 sites}

Alliance for Zero

Extinction sites

\section{4 sites}

Important Bird \&

Biodiversity Areas
227 sites

Key Biodiversity

Areas
Source: AZE Secretariat (2019); BirdLife International (2019b, 2019c). 


\section{Figure 8.20 Madagascar protected areas}
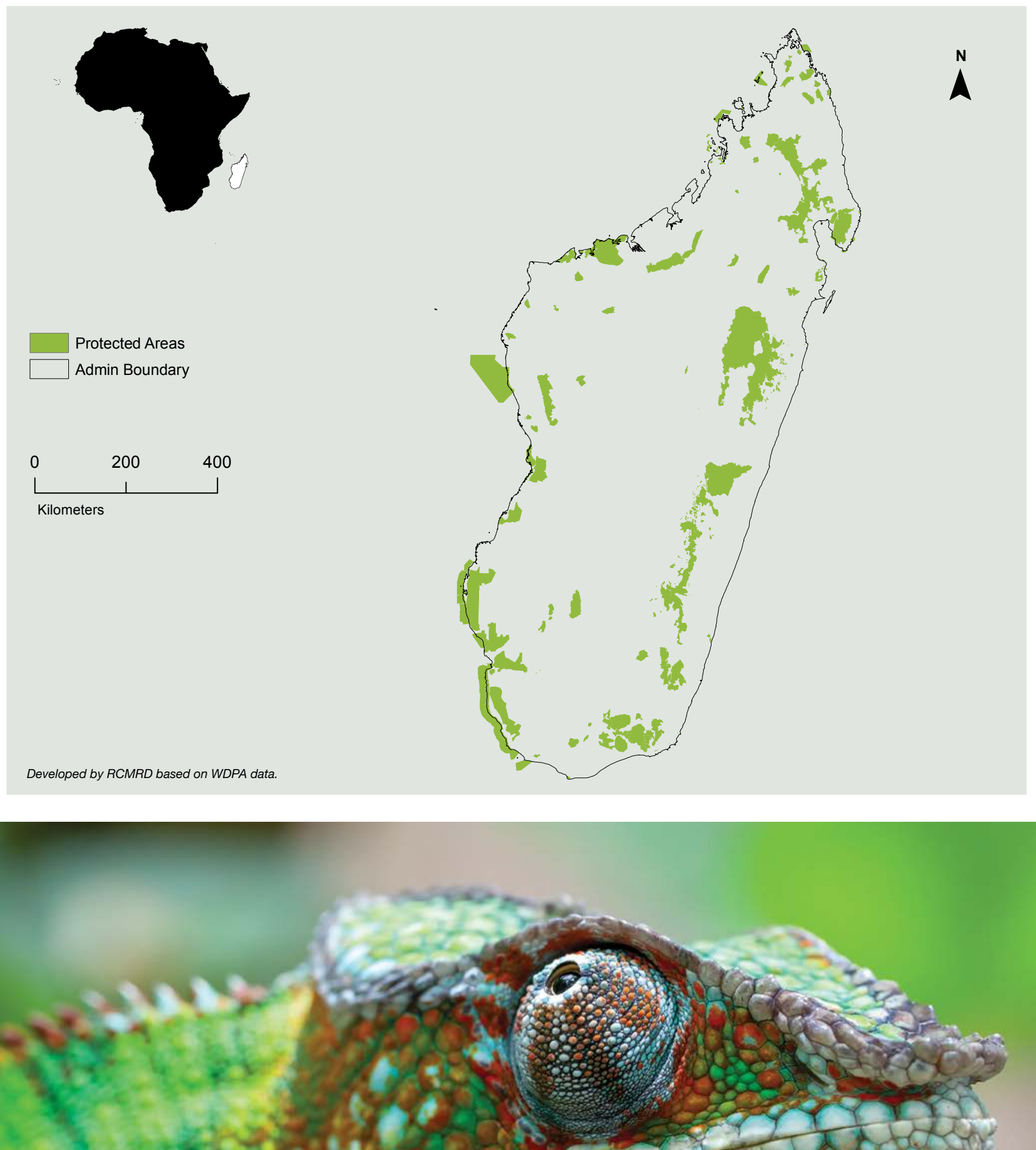


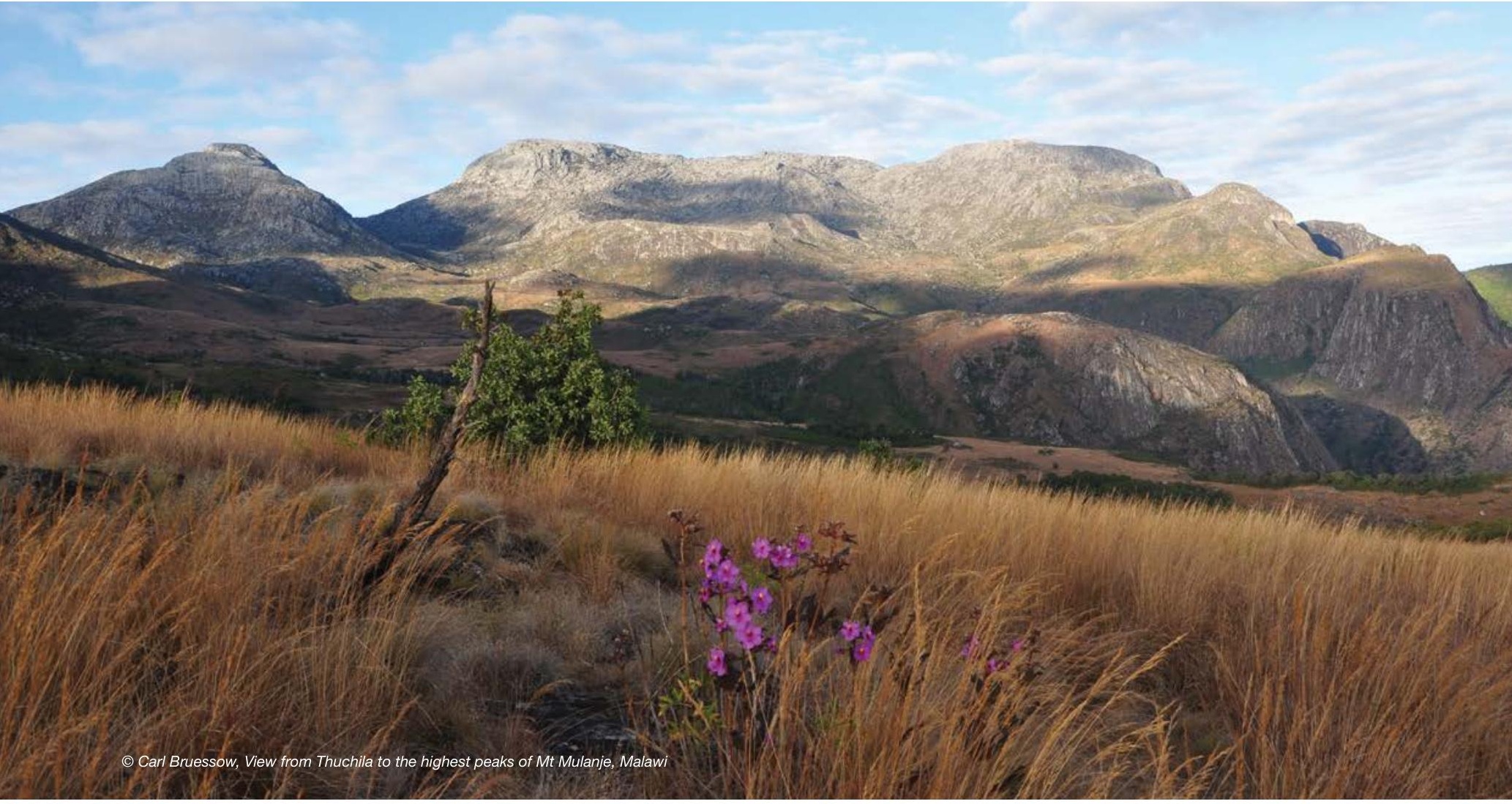

\subsection{Malawi}

\section{Protected and conserved areas in Malawi ${ }^{64}$}

Malawi has 133 protected areas covering $27,190 \mathrm{~km}^{2}$ of the land (UNEP-WCMC \& IUCN, 2019I).

Malawi has a high population density with protected areas having hard boundaries, resulting in most of the ecosystems in protected areas being vulnerable. The Government of Malawi has entered into an agreement with the private sector, with African Parks Network increasing their management of protected areas from two to five, to include Nkhotakota Game Reserve, Liwonde National Park and Mangochi Forest Reserve, in order to restore and protect them for sustainability.

\section{Transboundary protected and conserved areas}

Malawi has one protected area which is part of the Malawi Zambia transboundary conservation area.

\section{Policy context}

A comprehensive report on legislation and policy related to protected area management, governance, and equity was undertaken by the BIOPAMA programme. It identified 25 relevant laws and policies in Malawi (Tessema, 2019).

\section{Key species ${ }^{65}$}

Malawi has rich plant diversity, with over 6,000 flowering plant species of which 122 are endemic. Of Malawi's 192 mammal species, eight are listed as threatened on the IUCN Red List. 83 species of amphibians have been recorded in Malawi, six of which are endemic, while eight of the 145 species of reptiles are endemic. Malawi has over 630 recorded bird species with just one endemic. On the other hand, of the over 850 freshwater fish species, $99 \%$ are endemic to Malawi. Malawi is also home to a wide variety of invertebrates and microorganisms.

\section{Pressures and threats ${ }^{66}$}

Threats to biodiversity in Malawi are mainly human-induced and include habitat loss and fragmentation, over-exploitation of biological resources, introduction of alien species and climate change. Increasing human population and economic development have led to major land use change in Malawi, creating demand for land for agriculture and settlements. High levels of poverty have increased the reliance on natural resources, and particularly forests, which provide fuel for cooking for the vast majority of Malawi's population. 
Figure 8.21 Malawi Summary

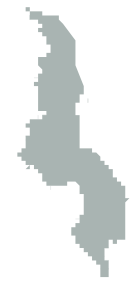

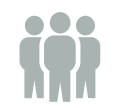

Total Population (millions) 18.14

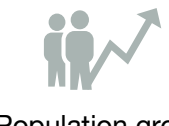

Population growth (annual \%)

2.60

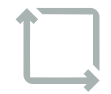

Surface area $\left(\mathrm{km}^{2}\right)$ (thousands) 118.50

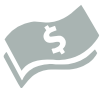

GDP (current US\$) (billions) 7.06

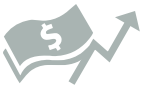

GDP growth (annual \%) 3.50

Source: The World Bank Group, 2018.

Area Protected:

133 protected
areas

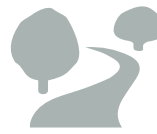

covering

$27190 \mathbf{k m}^{2}$

of land

Source: UNEP-WCMC \& IUCN, 2019/
Protected and conserved areas in Malawi in IUCN Management Categories

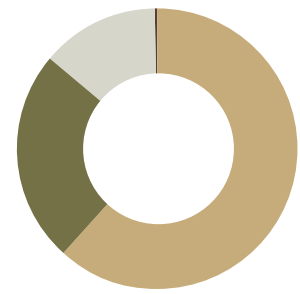

Not Applicable (No. 3)

Not Reported (No. 121)

IV. Habitat/Species Management (No. 4)

II. National Park (No. 5)

Source: UNEP-WCMC \& IUCN (2019l)

\begin{tabular}{llllll}
\hline & 000 flowering & 192 mammal & 83 amphibian & 145 reptile & 630 bird \\
plant species & species & species & species & species & $99 \%$ are endemic
\end{tabular}

122 are endemic

\section{Coverage of protected areas in Malawi}

\begin{tabular}{l|r|r}
\hline Type of protected area & $\begin{array}{r}\text { Area protected } \\
\text { or conserved* }\end{array}$ & $\begin{array}{l}\text { Area protected } \\
\text { or conserved** }\end{array}$ \\
\hline Terrestrial and inland water & $22.88 \%$ & $15.12 \%$ \\
\hline${ }^{*}$ WDPA dataset & ${ }^{* *}$ From National Report on Biodiversity
\end{tabular}

Source: Government of Malawi (2015); UNEP-WCMC \& IUCN (2019l).

National designations of protected and conserved areas in Malawi

\begin{tabular}{l|r|r}
\hline National designation & Number & Area $\left.\mathbf{( k m}^{2}\right)$ \\
\hline Conservation Area & 1 & 6493 \\
\hline National Park & 5 & 6961 \\
\hline Wildlife Reserve & 4 & 3816 \\
\hline Forest Reserve & 118 & 1485 \\
\hline
\end{tabular}

Source: UNEP-WCMC \& IUCN (2019l).

Protected and conserved areas in Malawi in IUCN Governance Types

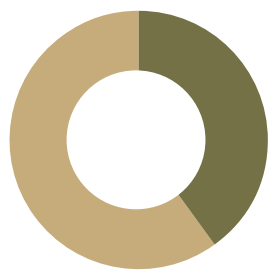

Not Reported (No. 123)

A. Governance by Government (No. 10)
Protected and conserved areas designated as global sites of importance in Malawi

\begin{tabular}{l|r}
\hline Global designation & No. of sites \\
\hline UNESCO Man and Biosphere Reserves & 2 \\
\hline $\begin{array}{l}\text { UNESCO World Heritage Sites } \\
\text { (Natural or Mixed) }\end{array}$ & 1 \\
\hline $\begin{array}{l}\text { Wetlands of International Importance } \\
\text { (Ramsar sites) }\end{array}$ & 2 \\
\hline
\end{tabular}

Source: Ramsar (2019); UNESCO (2019a, 2019b).

\section{Priority areas for conservation}

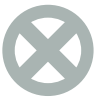

3 sites

Alliance for Zero

Extinction sites

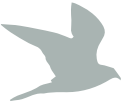

21 sites

Important Bird \&

Biodiversity Areas
11 sites

Key Biodiversity Areas 


\section{Figure 8.22 Malawi protected areas}
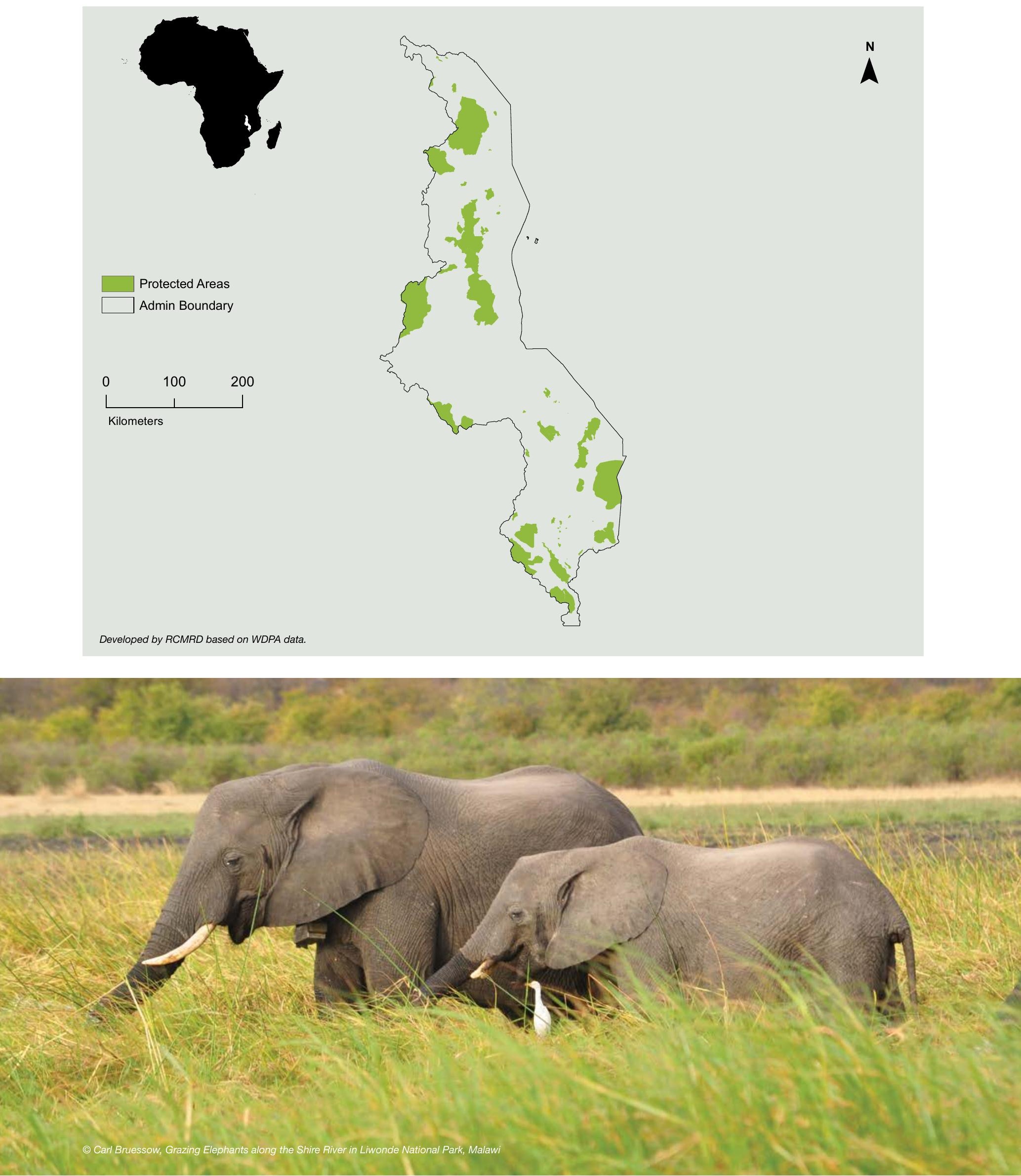


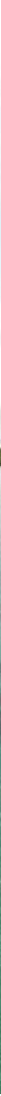

\subsection{Mauritius}

\section{Protected and conserved areas in Mauritius ${ }^{67}$}

Mauritius has 44 protected areas covering $97 \mathrm{~km}^{2}$ of the land and $50 \mathrm{~km}^{2}$ of the ocean (UNEP-WCMC \& IUCN, 2019m).

While the coverage of terrestrial protected areas remains unchanged since 2010, there has been a focus on the restoration of native forests, and a large system of marine protected areas comprising fishing reserves, marine parks and marine reserves has been established in the waters around Mauritius and Rodrigues. Mauritius has also established a new paradigm for protected areas, fostering private sector involvement in ownership and management of protected areas.

\section{Transboundary protected and conserved areas}

Mauritius includes part of the Western Indian Ocean Transfrontier Marine Park.

\section{Policy context}

A comprehensive report on legislation and policy related to protected area management, governance, and equity was undertaken by the BIOPAMA programme. It identified 41 relevant laws and policies in Mauritius (Tessema, 2019).

\section{Key species ${ }^{68}$}

Mauritius and Rodrigues are home to high levels of endemism amongst plants, reptiles, invertebrates and birds, although there have been several extinctions due to invasive species. There are 691 native flowering plants species, of which 273 are endemic (150 endemic to the Mascarene Archipelago) in Mauritius and 150 native flowering plants species, of which 47 are endemic (72 endemic to the Mascarene Archipelago) in Rodrigues. The only native mammals are bats (fruit bats and tomb bats) and to-date nine endemic species of land bird and eleven endemic reptile species exist on the island. Two species of fruit bat currently occur in the Republic of Mauritius: Pteropus niger in Mauritius and Pteropus rodricensis in Rodrigues. Of the 17 reptile species that used to be found in Mauritius, only 12 remain of which 11 endemic species, and 7 of these are restricted to offshore islets where they escaped extinction from rats. Moreover, five of these species are restricted to Round Island.

\section{Pressures and threats ${ }^{69}$}

Habitat clearance and invasive alien species have been the most significant threat to the biodiversity of Mauritius to date. Climate change and pollution have also caused pressure on the island's ecosystems. Indirect drivers of biodiversity loss include demographic change, and socio-political factors, particularly funding and capacity for biodiversity conservation. 
Figure 8.23 Mauritius Summary

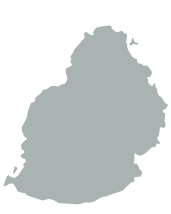

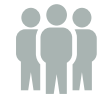

Total Population (millions)

1.27

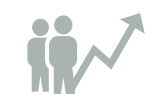

Population growth (annual \%)

0.10

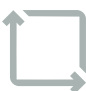

Surface area $\left(\mathrm{km}^{2}\right)$ (thousands) 2.00

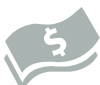

GDP (current US\$) (billions)

14.22

\section{Area Protected:}

44 protected areas

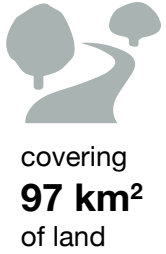

Protected and conserved areas in Mauritius in IUCN Management Categories

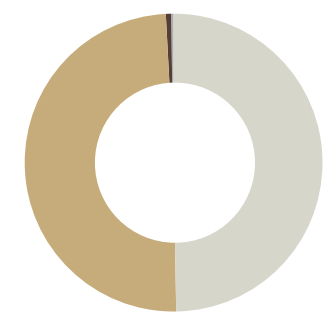

Not Assigned (No. 1)

Not Reported (No. 10)

IV. Habitat / Species Management (No. 21)

II. National Park (No. 10)

la. Strict Nature Reserve (No. 1)

Source: UNEP-WCMC \& IUCN (2019m).

\section{1 native flowering plants species}

only native mammals are bats
12 reptile species

\section{Coverage of protected areas in Mauritius}

\begin{tabular}{l|r|r}
\hline Type of protected area & $\begin{array}{r}\text { Area protected } \\
\text { or conserved* }\end{array}$ & $\begin{array}{r}\text { Area protected } \\
\text { or conserved }\end{array}$ \\
\hline Terrestrial and inland water & $4.73 \%$ & $4.00 \%$ \\
\hline Coastal and marine & $0.00 \%$ & $0.01 \%$ \\
\hline${ }^{*}$ WDPA dataset ${ }^{* *}$ From National Report on Biodiversity
\end{tabular}

Source: Republic of Mauritius (2017); UNEP-WCMC \& IUCN (2019m).

Protected and conserved areas designated as global sites of importance in Mauritius

\begin{tabular}{l|r}
\hline Global designation & No. of sites \\
\hline UNESCO Man and Biosphere Reserves & 1 \\
\hline $\begin{array}{l}\text { Wetlands of International Importance } \\
\text { (Ramsar sites) }\end{array}$ & 3 \\
\hline
\end{tabular}

Source: Ramsar (2019; UNESCO (2019a, 2019b)

\section{Protected and conserved areas in Mauritius in IUCN Governance Types}

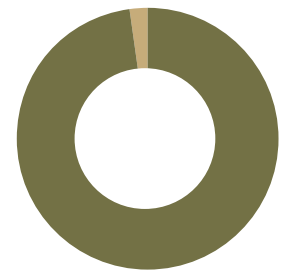

C. Private Governance (No. 2)

A. Governance by Government (No. 42)

National designations of protected and conserved areas in Mauritius

\begin{tabular}{l|r|r}
\hline National designation & No. & Area $\left.\mathbf{( k m}^{2}\right)$ \\
\hline National Park & 2 & 61 \\
\hline Marine Park & 2 & 6 \\
\hline Nature Reserve & 18 & 9 \\
\hline Turtle Reserve & 2 & 0 \\
\hline Fishing Reserve & 6 & 68 \\
\hline Islet National Park & 8 & 2 \\
\hline Endemic Garden & 1 & 3 \\
\hline Ancient Monument & 1 & 0 \\
\hline
\end{tabular}

Source: UNEP-WCMC \& IUCN (2019m)

\section{Priority areas for conservation}

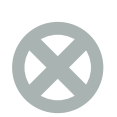

\section{2 sites}

Alliance for Zero

Extinction sites

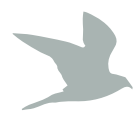

\section{6 sites}

Important Bird \&

Biodiversity Areas
18 sites

Key Biodiversity Areas 
Figure 8.24 Mauritius protected areas
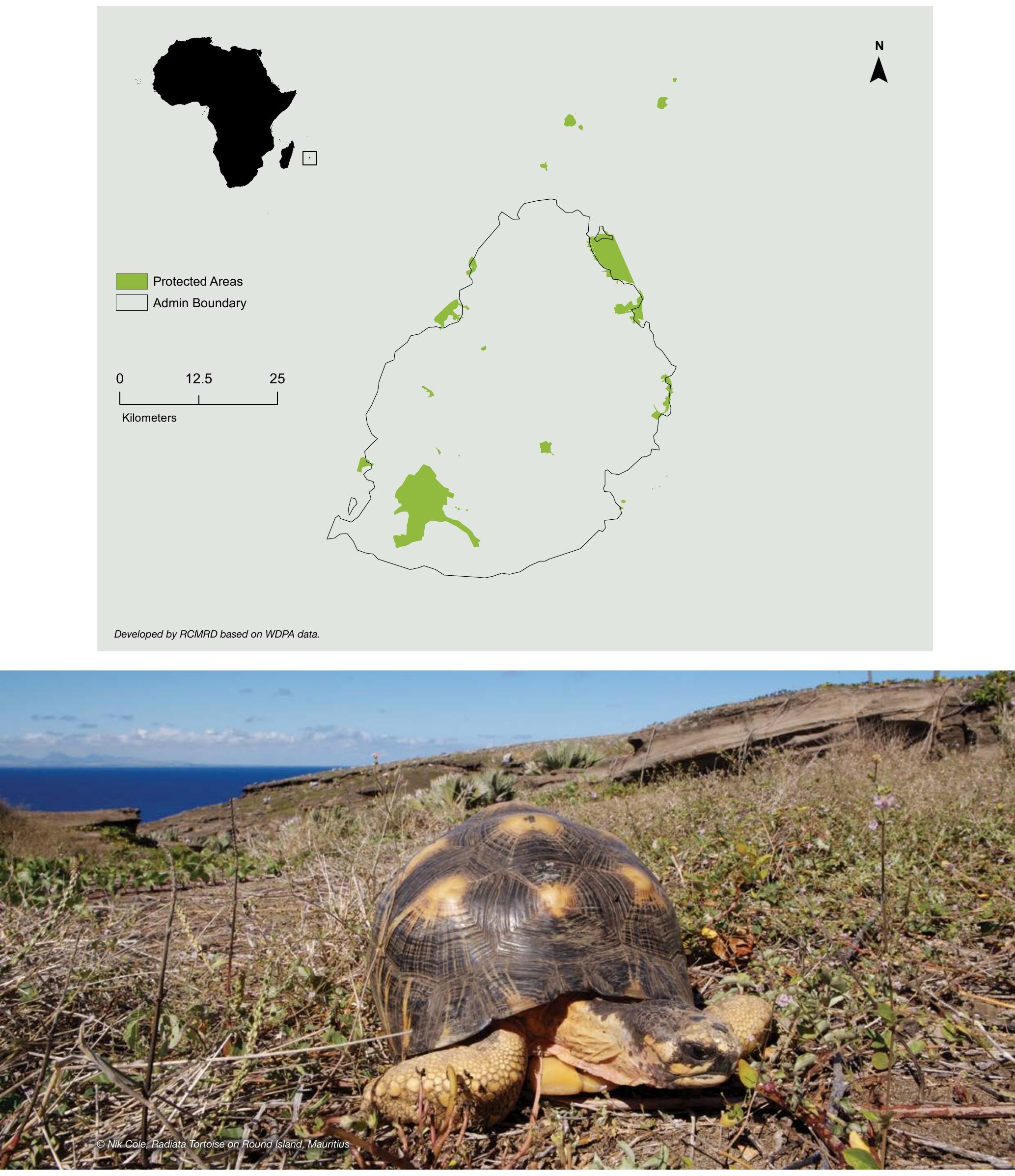


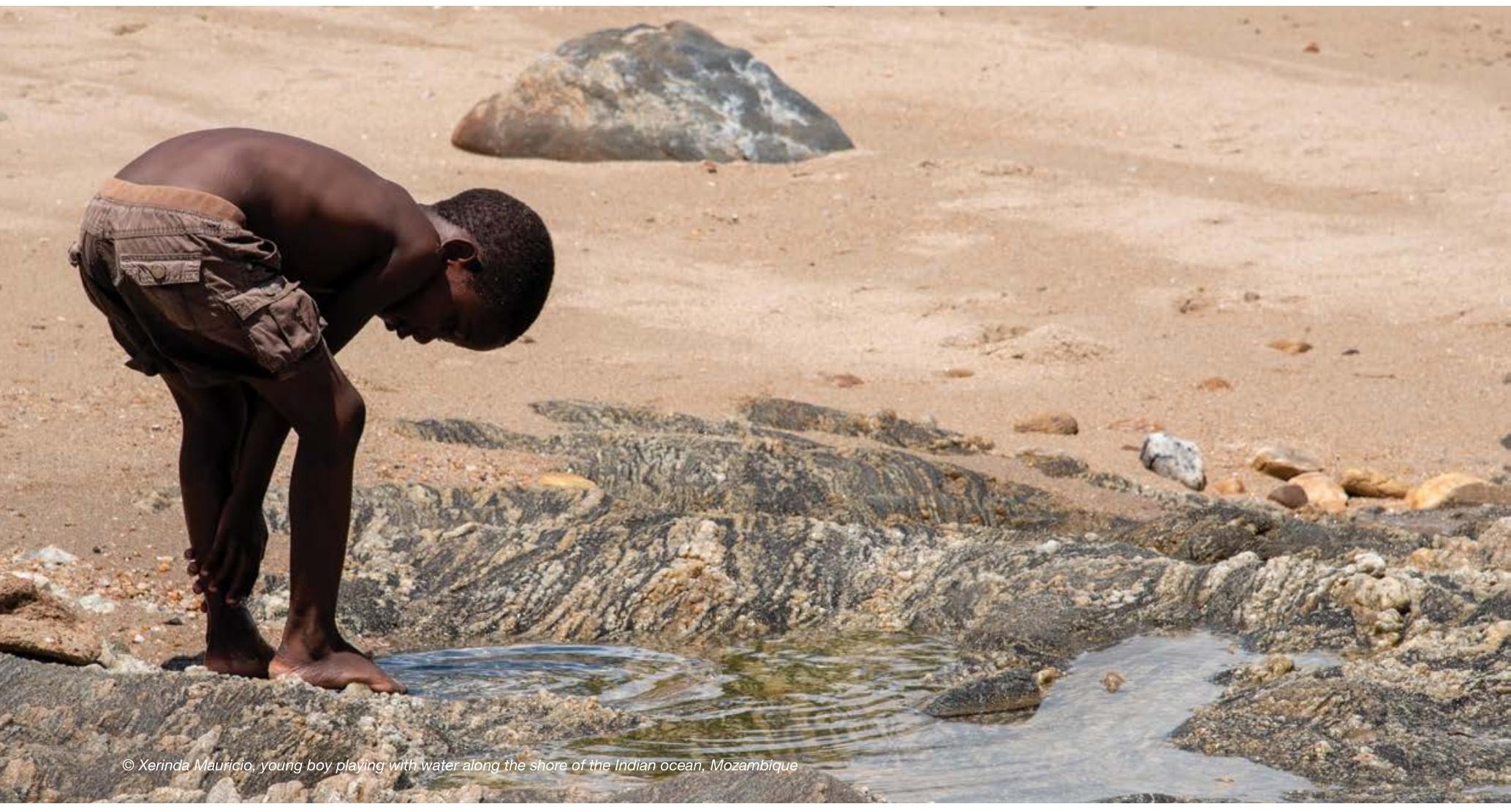

\subsection{Mozambique}

\section{Protected and conserved areas in Mozambique ${ }^{70}$}

Mozambique has 44 protected areas covering $170,662 \mathrm{~km}^{2}$ of the land and 12,821 $\mathrm{km}^{2}$ of the ocean (UNEP-WCMC \& IUCN, 2019n). The terrestrial coverage of protected areas in the country has been increasing over the last 10 years. Recognising the national and global value of biodiversity, the Government of Mozambique has focused on ensuring the inclusion of ecosystems that were not previously represented, such as the country's only protected freshwater ecosystem, the Partial Reserve of Lake Niassa.

Marine protected areas were also expanded with the creation of the Environmental Protection Area of the Primeiras and Segundas Islands and the Partial Marine Reserve Maputo-Ponta do Ouro. Some marine sanctuaries were also declared.

The Government of Mozambique has undertaken a review of the various different co-management models and has embraced public private partnerships to improve the management of its protected area estate. This includes the Carr Foundation for Gorongosa National Park and the African Parks for Bazaruto Archipelago National Parks, among others.

\section{Transboundary protected and conserved areas}

Mozambique is a part of seven transboundary conservation areas, namely Chimanimani TFCA, Great Limpopo Transfrontier Park and
Conservation Area (GLTP) TFCA, Lubombo TFCA, Conservancy Area Mnazi Bay-Quirimbas TFCA, Niassa-Selous TFCA, Ponta de Ouro Marine Reserve-Cosibay TFCA, REM-Tembe_Ndumo TFCA and ZIMOZA TFCA.

\section{Policy context}

A comprehensive report on legislation and policy related to protected area management, governance, and equity was undertaken by the BIOPAMA programme. It identified 80 relevant laws and policies in Mozambique (Tessema, 2019).

\section{Key species ${ }^{71}$}

The knowledge of Mozambique's biodiversity remains low, but is improving. 4,271 terrestrial animal species have been recorded, $72 \%$ of which are represented by insects, birds by $17 \%$, with only $5 \%$ mammals and amphibians remaining $2 \%$. The most recent assessment of plants indicates the occurrence of close to 6,000 species. Studies of endemic species are scarce, although there are two centres of plant endemism - in the Maputaland area and the Chimanimani.

Of the number of plant species recorded in Mozambique, about 800 species are endemic and nearly endemic. The mountainous areas of Mozambique are relatively rich in endemic species with at least 45 species of plants that are only found in Chimanimani.

70 The section draws on information contained in Mozambique's Fifth National Report to the CBD and the National Strategy and Action Plan Of Biological Diversity of Mozambique (2015-2035) (Republic of Mozambique, 2014; 2015).

71 The section draws on information contained in Mozambique's Fifth National Report to the CBD (Republic of Mozambique, 2014). 
Figure 8.25 Mozambique Summary

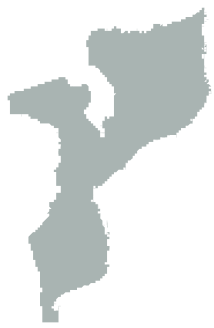

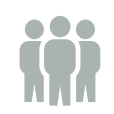

Total Population (millions) 29.50

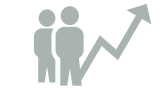

Population growth (annual \%) 2.90

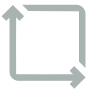

Surface area $\left(\mathrm{km}^{2}\right)$ (thousands) 786.40

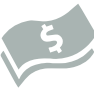

GDP (current US\$) (billions)

14.46
GDP growth (annual \%) 3.30

\section{Area Protected:}

\section{4 protected} areas

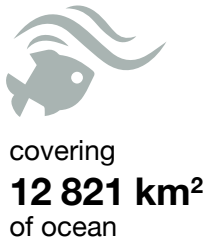

of ocean

Source: UNEP-WCMC \& IUCN, 2019n

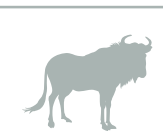

\section{1 terrestrial} animal species

Protected and conserved areas in Mozambique in IUCN Management Categories

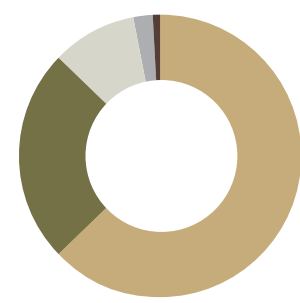

Not Assigned (No. 2)

Not Reported (No. 29)

VI. Protected Area with Sustainable

Use of Natural Resources (No. 3)

IV. Habitat/Species Management (No. 4)

II. National Park (No. 6)

\section{Coverage of protected areas in Mozambique}

\begin{tabular}{l|r|r}
\hline Type of protected area & $\begin{array}{r}\text { Area protected } \\
\text { or conserved* }\end{array}$ & $\begin{array}{r}\text { Area protected } \\
\text { or conserved }\end{array}$ \\
\hline Terrestrial and inland water & $21.57 \%$ & $26.00 \%$ \\
\hline Coastal and marine & $2.23 \%$ & Not found \\
\hline${ }^{*}$ WDPA dataset ${ }^{* *}$ From National Report on Biodiversity
\end{tabular}

Source: Ministry for the Coordination of Environmental Affairs, Republic of Mozambique (2014; UNEP-WCMC \& IUCN (2019n)

Protected and conserved areas designated as global sites of importance in Mozambique

\begin{tabular}{l|r}
\hline Global designation & No. of sites \\
\hline Wetlands of International Importance & 2 \\
(Ramsar sites) & \\
\hline
\end{tabular}

Source: Ramsar (2019); UNESCO (2019a, 2019b)

Protected and conserved areas in Mozambique in IUCN Governance Types

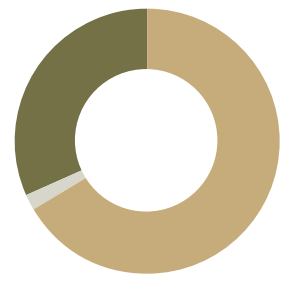

Not Reported (No. 14)

D. Governance by Indigenous peoples and Local Communities (No. 1)

B. Shared Governance (No. 1)

A. Governance by Government (No. 28)

National designations of protected and conserved areas in Mozambique

\begin{tabular}{l|r|r}
\hline National designation & No. & Area $\left.\mathbf{( k m}^{2}\right)$ \\
\hline National Park & 6 & 33569 \\
\hline Game Reserve & 2 & 1683 \\
\hline National Reserve & 2 & 44981 \\
\hline Special Reserve & 1 & 1040 \\
\hline Hunting Reserve & 14 & 38887 \\
\hline Natural Reserve & 1 & 1 \\
\hline Faunal Reserve & 1 & 20 \\
\hline Forest Reserve & 13 & 5286 \\
\hline Environmental Protection Area & 1 & 24589 \\
\hline Not Reported & 1 & 1148 \\
\hline Source: UNEP-WCMC \& IUCN (2019n). & &
\end{tabular}

\section{Priority areas for conservation}

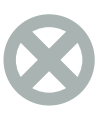

4 sites

Alliance for Zero

Extinction sites

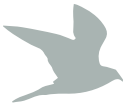

16 sites

Important Bird \&

Biodiversity Areas

\section{1 sites}

Key Biodiversity Areas 
New species were discovered in Mozambique as a result of new scientific studies and expeditions in previously inaccessible locations. Some of the species have been identified e.g. in Monte Inago and these include: pygmy chameleon (Rhampholeon sp.), butterfly (Cymothoe sp.), carrangueijo freshwater (Potamonautes sp.) and possibly a new species (Encephalartos sp.).

The number of threatened species shows a tendency to increase in Mozambique. More than 300 species of plants are on the IUCN Red List, $22 \%$ of which are confirmed as being endemic. Some species of the Encefalartos that deserve attention include the Munch's cycad (Encephalartos munchii) and cycad (E. pterogonus). On the other hand, Jozini cycad ( $E$. senticosus) is critically endangered and Lebombo cycad (E. lebomboensis), Umbeluzi cycad (E. umbeluziensis) and Chimanimani cycad ( $E$. chimanimaniensis) are threatened.

The most endangered mammals in Mozambique include the white rhino (Ceratotherium simum), common tsessebe (Damaliscus lunatus), sitatunga (Tragelaphus spekei), black rhino (Diceros bicornis), the giraffe (Giraffa camelopardalis), reedbuck (Redunca fulvorufula) and the cheetah (Acinomyx jutabus). The white rhino, giraffe and grey-palapala were re-introduced in the Limpopo National Park and giraffes were re-introduced in the National Reserve of Maputo.

Mozambique is also home to many species of endangered birds as well as sea turtles and dugongs. Nature Science magazine is currently conducting research in marine ecosystems in Inhambane, Zambezia and Nampula provinces that will help ANAC to establish a database on marine species occurrence in Mozambique.

\section{Pressures and threats ${ }^{72}$}

The main proximal threats to biodiversity are: land conversion, loss and fragmentation of natural ecosystems, habitats and species by anthropogenic factors; overexploitation of certain species; invasion by non-native species that damage ecosystems and native species; pollution or contamination by chemical products of natural ecosystems habitats or species; uncontrolled forest burnings and climate change that damages natural habitats or species, development and natural disasters.

\section{Figure 8.26 Mozambique protected areas}

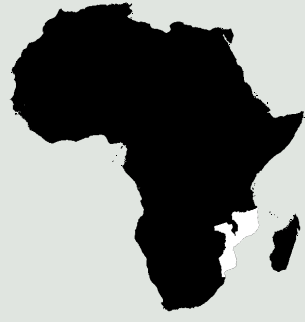

Protected Areas

Admin Boundary

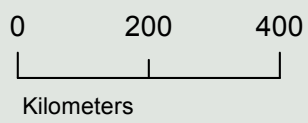

Developed by RCMRD based on WDPA data.

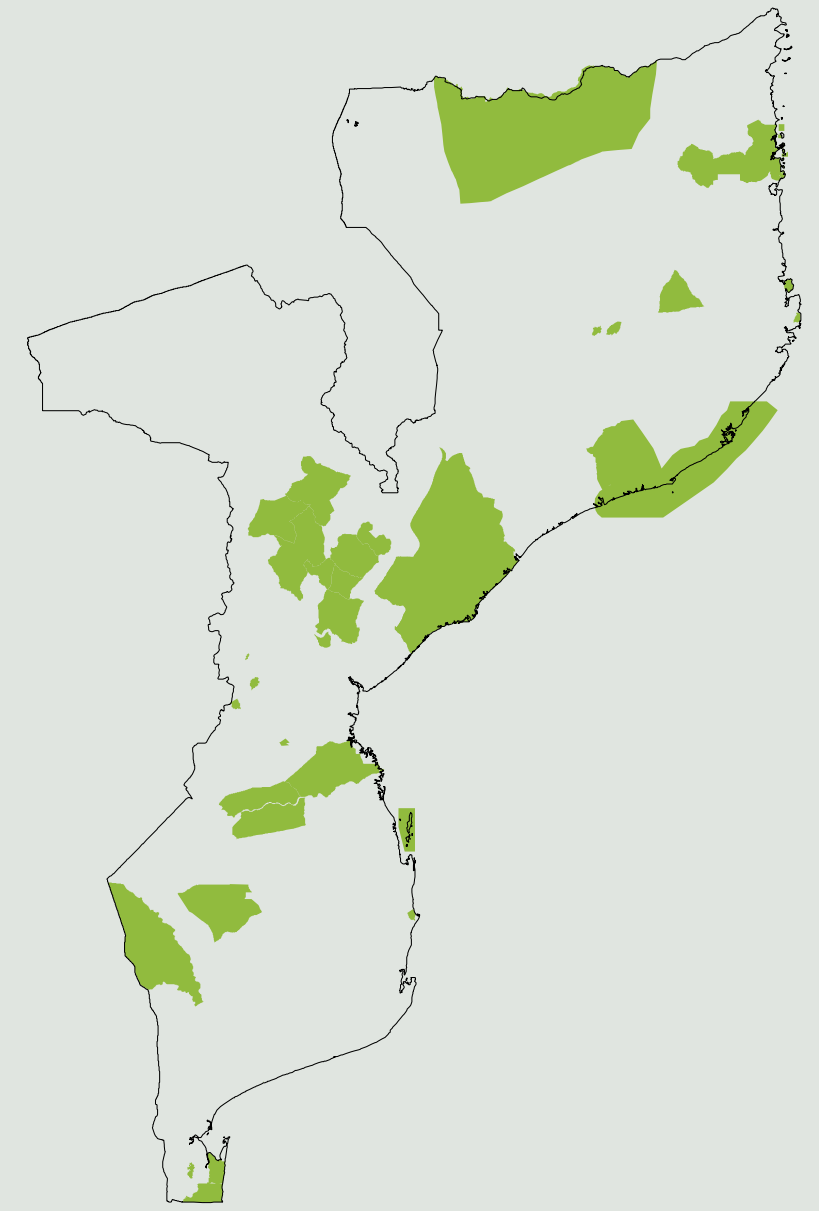

$\mathbf{N}$ 


\section{ckin}

$=$

$=$

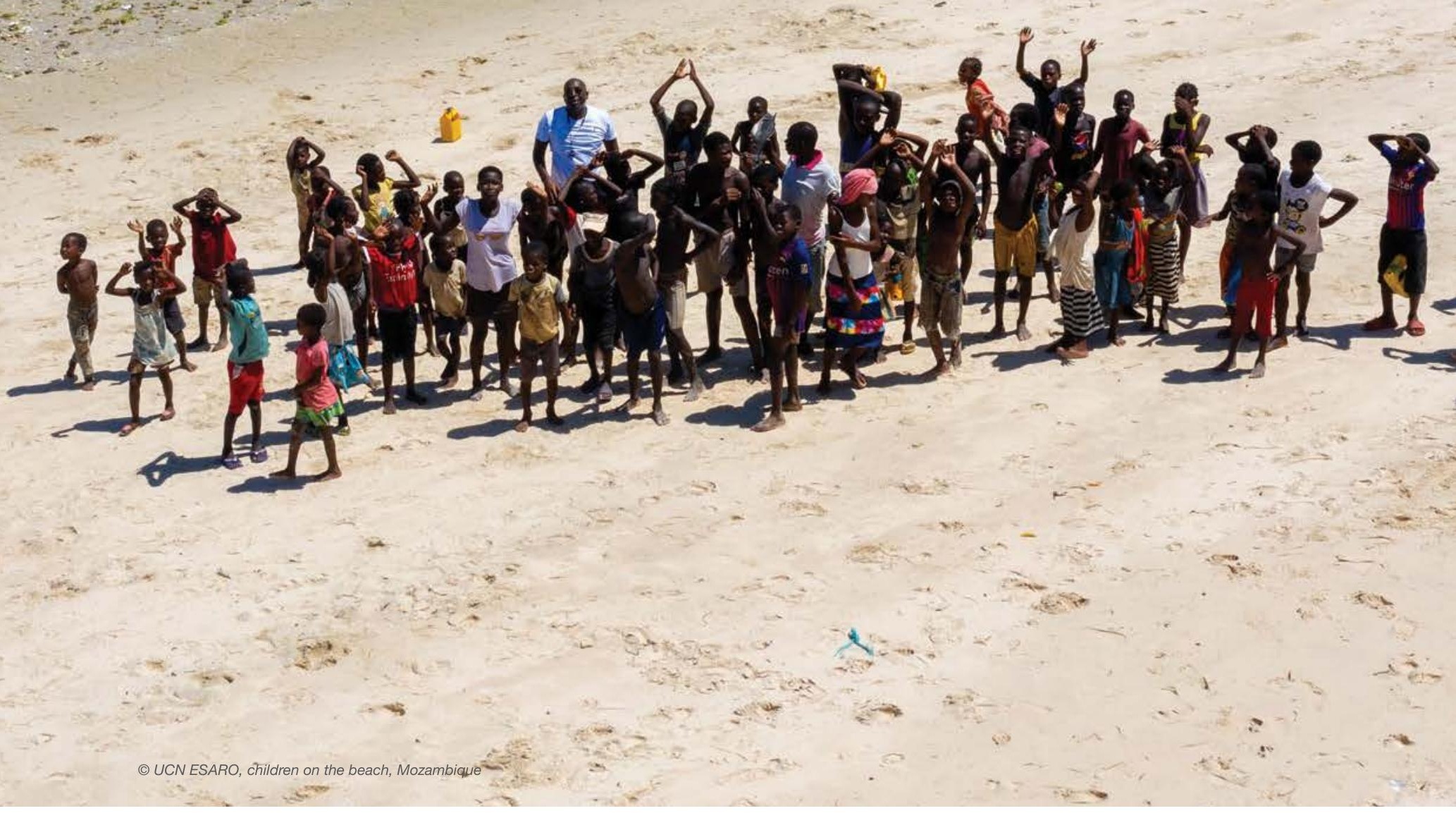




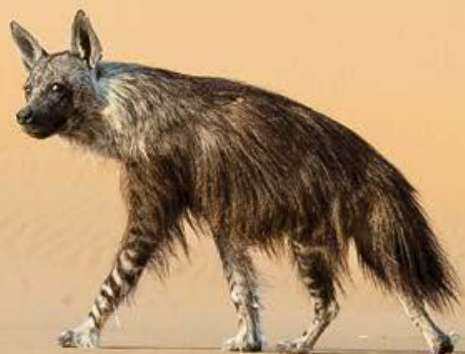

\subsection{Namibia}

\section{Protected and conserved areas in Namibia ${ }^{73}$}

Namibia has 148 protected areas covering $313,534 \mathrm{~km}^{2}$ of the land and $9,646 \mathrm{~km}^{2}$ of the ocean (UNEP-WCMC \& IUCN, 2019o).

To protect its rich biodiversity, Namibia has established a system of 21 state-managed protected areas with the goal of protecting and conserving biological diversity, and also generating much needed revenue through tourism. These protected areas are being complemented by strong community-based natural resource management through communal conservancies. Remarkably, the entire coastline of Namibia is protected. Namibia has a rich marine ecosystem, as a result of the Benguela upwelling system, which brings the nutrient rich waters from around 200-300 m deep and fuels high rates of phytoplankton growth, making it one of the most productive marine ecosystems in the world.

\section{Transboundary protected and conserved areas}

Namibia includes part of three transboundary conservation areas, namely /Ai/Ais-Richtersveld TFCA, lona Skeleton Coast TFCA and the Kavango Zambezi TFCA.

\section{Policy context}

A comprehensive report on legislation and policy related to protected area management, governance, and equity was undertaken by the BIOPAMA programme. It identified 31 relevant laws and policies in Namibia (Tessema, 2019).

\section{Key species ${ }^{74}$}

While Namibia has generally had a relatively lower number of species compared to those countries with wetter climates, it does have a high level of endemism, particularly among plants, invertebrates, reptiles and frogs. Namibia is home to 50 species of amphibians (12 endemic), 618 species of arachnids ( 11 endemic), 592 species of birds (2 endemic), 114 species of fish (8 endemic), over 6,400 species of insects (24 endemic), 229 species of mammals ( 7 endemic), more than 4,000 species of plants (14 endemic), and 254 species of reptiles (28 endemic).

\section{Pressures and threats ${ }^{75}$}

The main threats to biodiversity in Namibia are: unsustainable water use (large-scale irrigation, pollution, damming and overabstraction of groundwater); impacts of climate change (increased drought and flood events, shifts in species distribution, and impacts on vulnerable ecosystems); extractive industries (expansion of mining and prospecting in ecologically sensitive areas); unsustainable land management (soil erosion, land degradation, deforestation and bush encroachment); alien invasive species; illegal harvesting and trade of wildlife and plant resources; humanwildlife conflict; and uncontrolled bush fires.

Many of these threats are driven by the expansion of urban areas and increasing industrialisation, leading to increasing demand for resources and services and increasing the types and volumes of waste and pollution. 
Figure 8.27 Namibia Summary

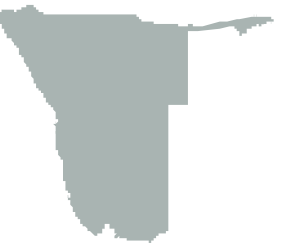

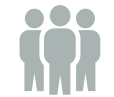

Total Population (millions)

2.45

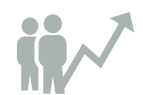

Population growth (annual \%)

1.90

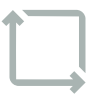

Surface area $\left(\mathrm{km}^{2}\right)$ (thousands)

824.30

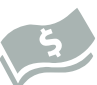

GDP (current US\$) (billions)

14.52

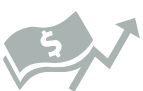

GDP growth (annual \%) $-0.10$

Source: The World Bank Group, 2018.

\section{Area Protected:}

\section{8} protected areas
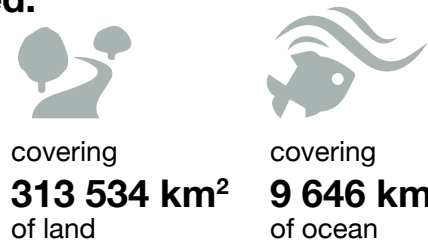

covering (1) $9646 \mathrm{~km}^{2}$ of ocean

Source: UNEP-WCMC \& IUCN, 20190

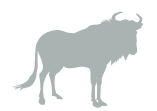

229 mammal species

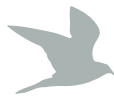

592 bird species

\section{4 reptile species}

Protected and conserved areas in Namibia in IUCN Management Categories

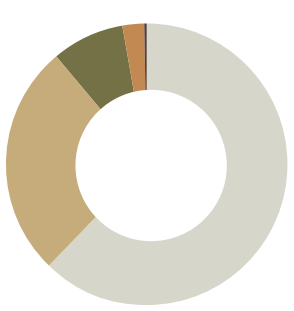

Not Applicable (No. 1)

Not Reported (No. 131)

VI. Protected Area with Sustainable Use of Natural Resources (No. 1)

V. Protected Landscape/Seascape (No. 3)

IV. Habitat / Species Management (No. 1)

III. Natural Monument (No. 2)

II. National Park (No. 9)

Source: UNEP-WCMC \& IUCN (2019o).

\section{Coverage of protected areas in Namibia}

\begin{tabular}{l|r|r}
\hline Type of protected area & $\begin{array}{r}\text { Area protected } \\
\text { or conserved }^{\star}\end{array}$ & $\begin{array}{r}\text { Area protected } \\
\text { or conserved }^{\star *}\end{array}$ \\
\hline Terrestrial and inland water & $37.89 \%$ & $17.00 \%$ \\
\hline Coastal and marine & $1.71 \%$ & - \\
\hline
\end{tabular}

* WDPA dataset $\quad$ ** From 2014 National Report on Biodiversity

Source: Ministry of Environment \& Tourism, Republic of Namibia (2014); UNEP-WCMC \& IUCN (2019o).

Protected and conserved areas designated as global sites of importance in Namibia

\begin{tabular}{l|r}
\hline Global designation & No. of sites \\
\hline $\begin{array}{l}\text { UNESCO World Heritage Sites } \\
\text { (Natural or Mixed) }\end{array}$ & 1 \\
\hline $\begin{array}{l}\text { Wetlands of International Importance } \\
\text { (Ramsar sites) }\end{array}$ & 5 \\
\hline
\end{tabular}

Source: Ramsar (2019); UNESCO (2019a, 2019b).

Protected and conserved areas in Namibia in IUCN Governance Types

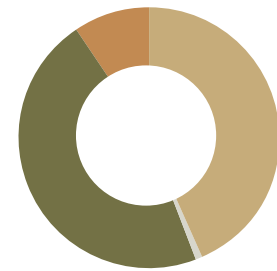

Not Reported (No. 3)

D. Governance by Indigenous Peoples and Local Communities (No. 112)

C. Private Governance (No. 2)

A. Governance by Government (No. 31)
National designations of protected and conserved areas in Namibia

\begin{tabular}{l|r|r}
\hline National designation & No. & Area $\left.\mathbf{( k m}^{2}\right)$ \\
\hline Private Reserve & 2 & 2887 \\
\hline Community Forest & 33 & 31998 \\
\hline National Park & 19 & 137446 \\
\hline Marine Protected Area & 1 & 9492 \\
\hline Communal Conservancy & 79 & 160425 \\
\hline Concession & 7 & 14535 \\
\hline Forest Reserve & 1 & 1485 \\
\hline
\end{tabular}

Source: UNEP-WCMC \& IUCN (2019o).

\section{Priority areas for conservation}

\section{9 sites}

Important Bird \& Biodiversity Areas

Source: BirdLife International (2019c). 


\section{Figure 8.28 Namibia protected areas}
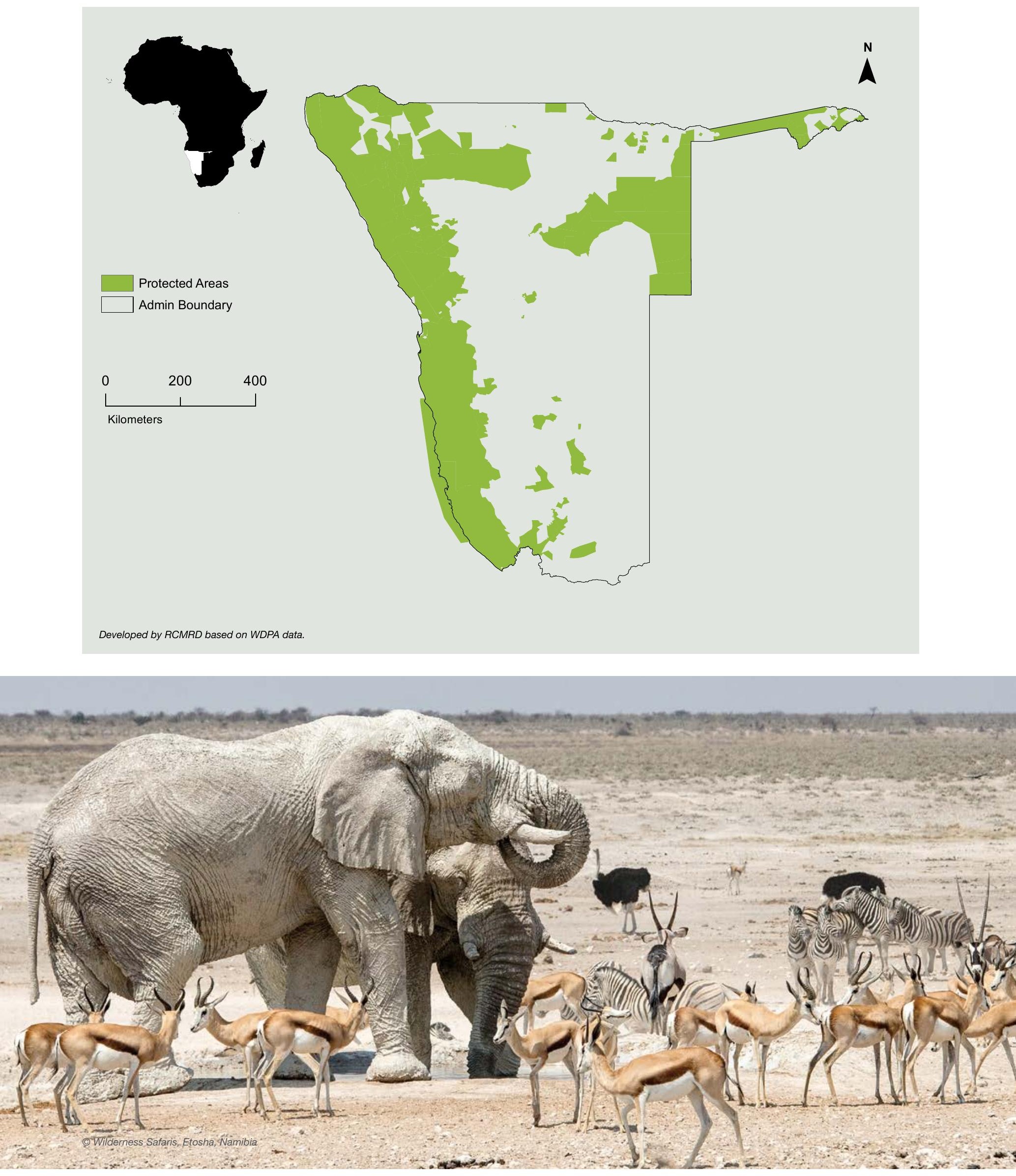


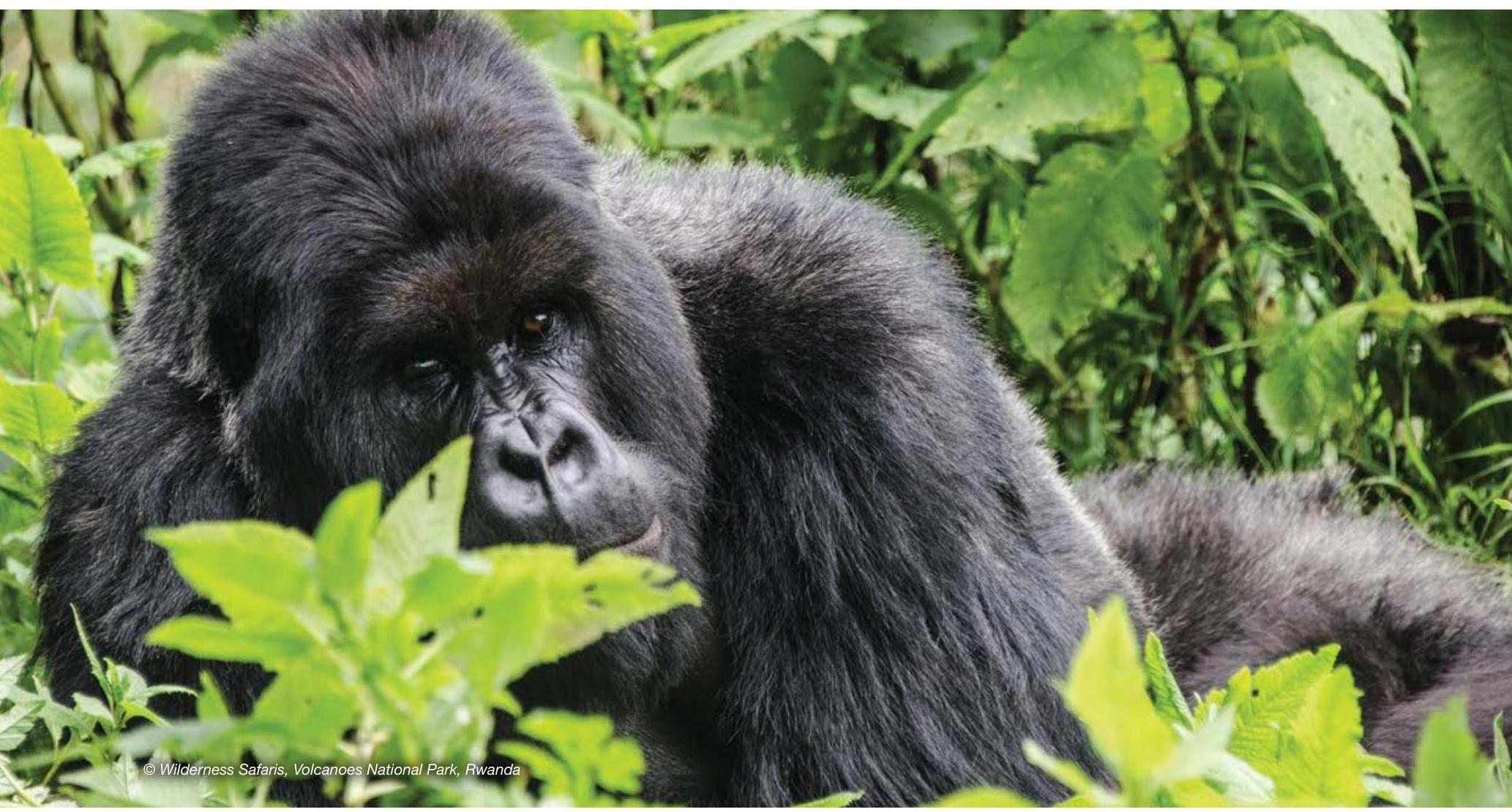

\subsection{Rwanda}

\section{Protected and conserved areas in Rwanda ${ }^{76}$}

Rwanda has 10 protected areas covering $2320 \mathrm{~km}^{2}$ of the land (UNEP-WCMC \& IUCN, 2019p).

The majority of the national ecoregions in the country are under protected, in particular wetlands which are recognized as sanctuaries of rich biological diversity. An ecological gap analysis for Rwanda has been identifying new sites to be designated as protected areas. Akagera National Park is managed through a public-private partnership with African Parks.

\section{Transboundary protected and conserved areas}

Rwanda includes part of three transboundary conservation areas, namely Greater Virunga Landscape, Kagera TFCA, and NyungweKibira.

\section{Policy context}

A comprehensive report on legislation and policy related to protected area management, governance, and equity was undertaken by the BIOPAMA programme. It identified 47 relevant laws and policies in Rwanda (Tessema, 2019).

\section{Key species ${ }^{77}$}

Biodiversity is highly threatened due to high human populations and the associated pressures on natural resources. Within the protected areas, including national parks and forests, biodiversity is well-protected, and represents a diverse set of ecosystems. Rwanda is home to the mountain gorilla (Gorilla beringei beringei), a population shared with the Democratic Republic of the Congo and Uganda that has shown a significant increase in population size. Akagera National Park has undergone an intensive restoration effort. Rwanda's bird diversity is very rich, particularly as there are so many diverse habitats across the country. Freshwater systems are also home to a diversity of fish species, including some endemics.

\section{Pressures and threats ${ }^{78}$}

The threats to biodiversity in Rwanda include: poaching and other illegal activities; fires; alien invasive species; deforestation; mining; illegal grazing; damming; dropping water levels; unsustainable fishing; lack of connectivity; unsustainable tourism use and infrastructure development; wetlands encroachment; and pollution. Rwanda has a very high human population density, which puts increasing pressure on available natural resources.

\footnotetext{
76 The section draws on information contained in Rwanda's Fourth National Report to the CBD (Republic of Rwanda, 2009).

77 The section draws on information contained in Rwanda's Fifth National Report to the CBD (Republic of Rwanda, 2014).

78 Ibid
} 
Figure 8.29 Rwanda Summary
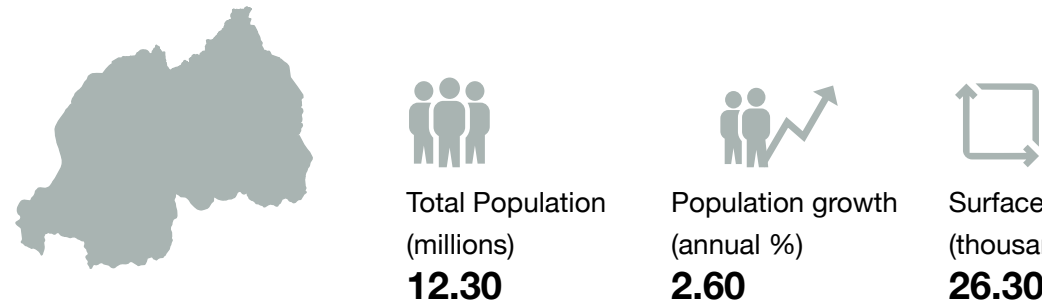

Surface area $\left(\mathrm{km}^{2}\right)$ (thousands)

2.60

26.30
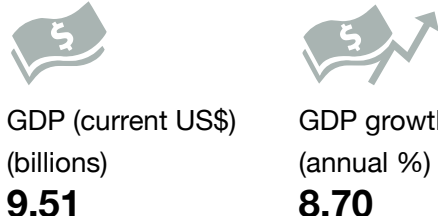

GDP growth (annual \%)

Source: The World Bank Group, 2018.

\section{Protected and conserved areas in Rwanda in IUCN} Management Categories

\section{Area Protected:}

\section{0 protected} areas

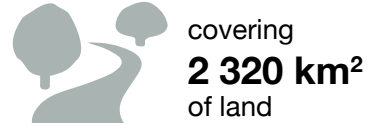

Source: UNEP-WCMC \& IUCN, (2019p)

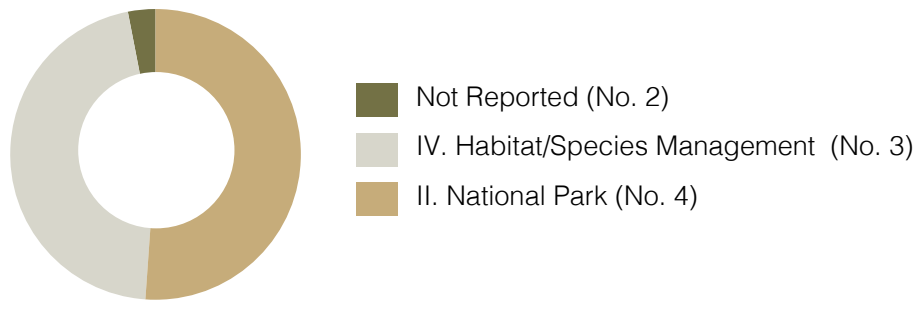

Source: UNEP-WCMC \& IUCN (2019p).

\section{Coverage of protected areas in Rwanda}

\begin{tabular}{l|r|r}
\hline Type of protected area & $\begin{array}{r}\text { Area protected } \\
\text { or conserved* }\end{array}$ & $\begin{array}{r}\text { Area protected } \\
\text { or conserved }\end{array}$ \\
\hline Terrestrial and inland water & $9.11 \%$ & $10.10 \%$ \\
\hline${ }^{*}$ WDPA dataset ${ }^{* *}$ From National Report on Biodiversity
\end{tabular}

Source: Republic of Rwanda (2014); UNEP-WCMC \& IUCN (2019p).

National designations of protected and conserved areas in Rwanda

\begin{tabular}{l|r|r}
\hline National designation & No. & \multicolumn{1}{|l}{ Area $\left.\mathbf{( k m}^{2}\right)$} \\
\hline Other Area & 3 & 308 \\
\hline National Park & 3 & 2201 \\
\hline Forest Reserve & 2 & 34 \\
\hline
\end{tabular}

Source: UNEP-WCMC \& IUCN (2019p).

\section{Protected and conserved areas in Rwanda in} IUCN Governance Types

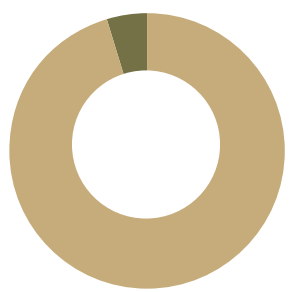

Not Reported (No. 7)

A.Governance by Government (No. 3)
Protected and conserved areas designated as global sites of importance in Rwanda

\begin{tabular}{l|r}
\hline Global designation & No. of sites \\
\hline UNESCO Man and Biosphere Reserves & 1 \\
\hline Wetlands of International Importance & 1 \\
(Ramsar sites) & \\
\hline
\end{tabular}

Source: Ramsar (2019; UNESCO (2019a, 2019b).

\section{Priority areas for conservation}
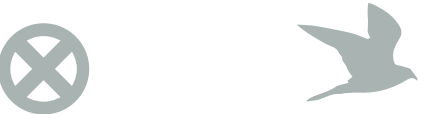

\section{2 sites}

7 sites

Alliance for Zero

Extinction sites

Important Bird \&

Biodiversity Areas

14 sites

Key Biodiversity

Areas 
Figure 8.30 Rwanda protected areas

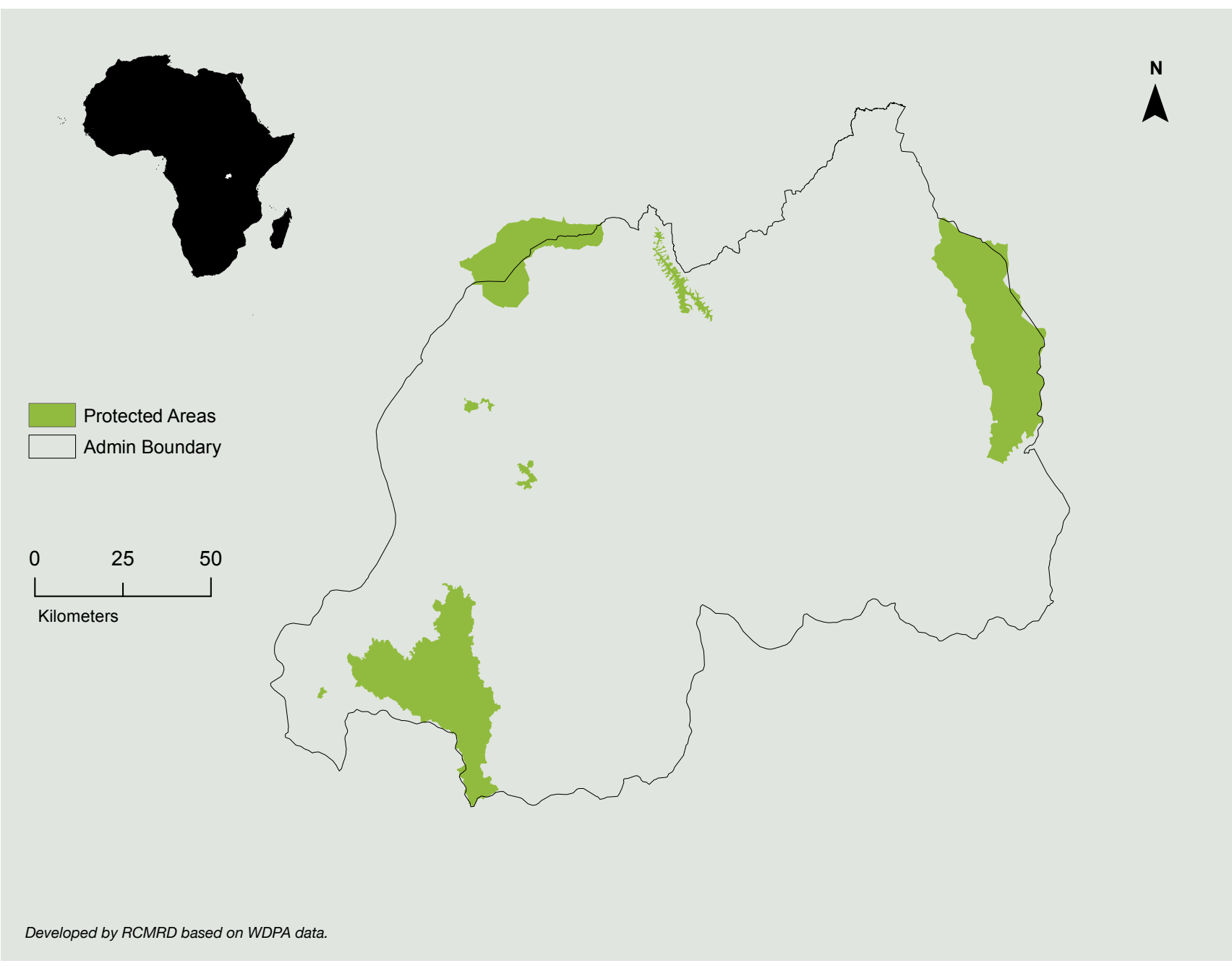




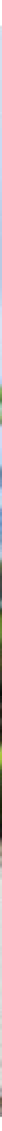

\subsection{Seychelles}

\section{Protected and conserved areas in Seychelles ${ }^{79}$}

Seychelles has 40 protected areas covering $242 \mathrm{~km}^{2}$ of the land and $209,930 \mathrm{~km}^{2}$ of the ocean (UNEP-WCMC \& IUCN, 2019q).

A large proportion of the Seychelles terrestrial area is protected. Seychelles has one of the oldest networks of marine protected areas in Eastern Africa, but until recently, this only covered some $0.03 \%$ of its coastal and marine ecosystems. The shortfall was recognised, and the Government of Seychelles announced its intention to protect $30 \%$ of its waters, half of which (or $15 \%$ ) would be a strict no-take zones. The Seychelles is engaging in a debt swap mechanism to enable this designation.

\section{Transboundary protected and conserved areas}

Seychelles includes part of the Western Indian Ocean Transfrontier Marine Park.

\section{Policy context}

A comprehensive report on legislation and policy related to protected area management, governance, and equity was undertaken by the BIOPAMA programme. It identified 28 relevant laws and policies in Seychelles (Tessema, 2019).

\section{Key species ${ }^{80}$}

Marine and coastal species are economically important to the Seychelles, and the diversity and abundance of species has been influenced by harvesting patterns for the last two centuries. The country's national report provides data in great detail of marine and coastal species, including current trends and conservation efforts. Seychelles is home to a number of different cetaceans, as well as five species of marine turtles.

In terms of terrestrial and inland water biodiversity, fungal diversity is poorly known, but the country has high levels of diversity in invertebrate species, as well as plants. Levels of endemism are high amongst most groups. Of 11 recorded amphibian species and two snakes, all are endemic. The Aldabra giant tortoise (Aldabrachelys gigantea) is endemic to the country. Seychelles is home to at least 65 bird species, of which 13 are endemic. All native mammals in the Seychelles are bats, of which there are six species (four endemic).

\section{Pressures and threats ${ }^{81}$}

The primary threat to terrestrial ecosystems is the continued incursions by alien invasive species. With high levels of endemism, the islands are particularly susceptible to the impacts of invasive species. The secondary threat is land use change and habitat loss, where development pressures are threatening many habitats. The primary threat in marine ecosystems is over-fishing, which has impacts beyond the species targeted. Climate change represents a major threat to both terrestrial and marine ecosystems.

79 The section draws on information contained in Seychelles' Fifth National Report to the CBD and the NBSAP (Government of Seychelles, 2014b; 2014a)

80 The section draws on information contained in Seychelles' Fifth National Report to the CBD (Government of Seychelles, 2014a)

81 The section draws on information contained in Seychelles' Second NBSAP (Government of Seychelles, 2014b). 
Figure 8.31 Seychelles Summary

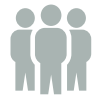

Total Population (millions)

0.10

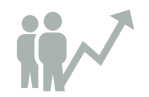

Population growth (annual \%)

1.00

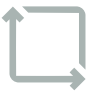

Surface area $\left(\mathrm{km}^{2}\right)$ (thousands)

0.50

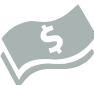

GDP (current US\$) (billions) 1.59

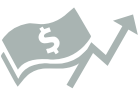

GDP growth (annual \%) 3.60

Source: The World Bank Group, 2018.

\section{Area Protected:}

40

\section{protected} areas

covering $242 \mathrm{~km}^{2}$ of land covering 209930 km $^{2}$ of ocean

Source: UNEP-WCMC \& IUCN, 2019q

11 amphibian
species $\quad \begin{aligned} & 65 \text { bird } \\ & \text { species }\end{aligned} \quad \begin{aligned} & 6 \text { bat } \\ & \text { species }\end{aligned}$

Protected and conserved areas in Seychelles in IUCN Management Categories

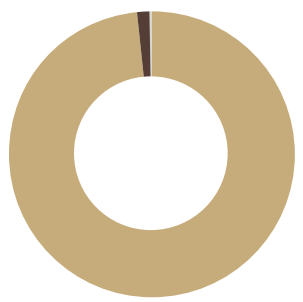

Not Applicable (No. 2)

Not Reported (No. 18)

VI. Protected Area with Sustainable Use of Natural Resources (No. 6)

II. National Park (No. 8)

lb. Wilderness Area (No. 1)

la. Strict Nature Reserve (No. 5)

Source: UNEP-WCMC \& IUCN (2019q)

Coverage of protected areas in Seychelles

\begin{tabular}{l|r|r}
\hline Type of protected area & $\begin{array}{r}\text { Area protected } \\
\text { or conserved* }\end{array}$ & $\begin{array}{r}\text { Area protected } \\
\text { or conserved** }\end{array}$ \\
\hline $\begin{array}{l}\text { Terrestrial and inland } \\
\text { water }\end{array}$ & $49.64 \%$ & $46.60 \%$ \\
\hline Coastal and marine & $15.66 \%$ & $0.03 \%$ \\
\hline${ }^{*}$ WDPA dataset ${ }^{* *}$ From National Report on Biodiversity
\end{tabular}

Source: Government of Seychelles (2014a); UNEP-WCMC \& IUCN (2019q).

Protected and conserved areas designated as global sites of importance in Seychelles

\begin{tabular}{l|r}
\hline Global designation & No. of sites \\
\hline $\begin{array}{l}\text { UNESCO World Heritage Sites (Natural or } \\
\text { Mixed) }\end{array}$ & 2 \\
\hline Wetlands of International Importance & 4 \\
(Ramsar sites)
\end{tabular}

Source: Ramsar (2019); UNESCO (2019a, 2019b).

Protected and conserved areas in Seychelles in IUCN Governance Types

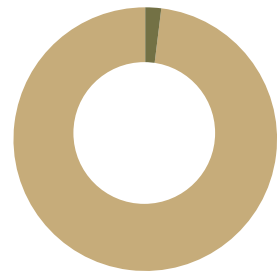

Not Reported (No. 20)

A.Governance by Government (No. 20)
National designations of protected and conserved areas in Seychelles

\begin{tabular}{l|r|r}
\hline National designation & Number & Area (km²) \\
\hline National Park & 4 & 55 \\
\hline Special Reserve & 8 & 2436 \\
\hline Marine National Park & 6 & 48 \\
\hline Nature Reserve & 9 & 0 \\
\hline MSP Zone 2 & 1 & 136717 \\
\hline MSP Zone 1 & 1 & 69524 \\
\hline Shell Reserve & 4 & 8 \\
\hline Protected Area & 1 & 8 \\
\hline Source: UNEP-WCMC \& IUCN (2019q). & &
\end{tabular}

\section{Priority areas for conservation}

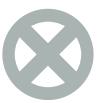

\section{2 sites}

Alliance for Zero

Extinction sites

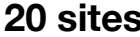

Important Bird \&

Biodiversity Areas

\section{9 sites}

Key Biodiversity Areas 


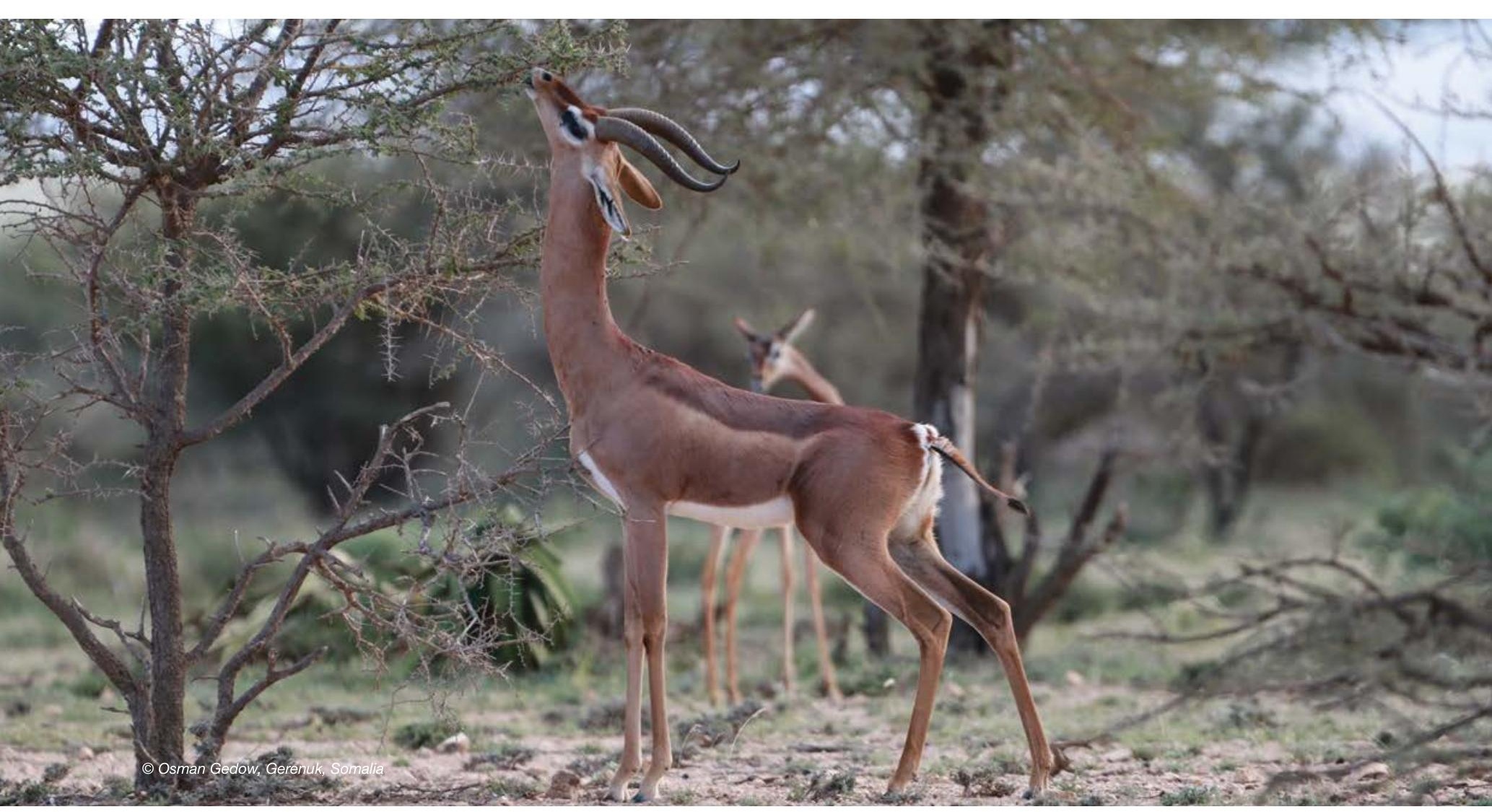

\subsection{Somalia}

\section{Protected and conserved areas in Somalia ${ }^{82}$}

Somalia has 21 protected areas. These are point records, with no reported area, so it is not possible to provide an area for the coverage of these protected areas (UNEP-WCMC \& IUCN, 2019r). There has been no effective biodiversity resource management and formal protection for protected areas since the collapse of the central government in 1991. The most serious concern is the lack of effective legislation concerning the management of the protected areas and the absence of a functioning conservation infrastructure. Eleven wildlife areas have been declared since the 1970s, but only two were thought to be functional. In practice, there has been no formal protection offered to any of these sites since the early 1990s.

In the marine environment, four marine protected areas have been proposed: the Saad ad- Dim Island and Aibat in Western Somaliland close to Zeila, a historic town; Maydh Island in Puntland with the neighbouring Daalo forest on the mainland; and Gara'ad on the Indian Ocean coast of Puntland. The latter was declared as an MPA in 2005 by the local fishers' association GARFISH. Saad-ad-din Island and Maydh Island are important sea bird breeding areas. The coral reefs at Saad ad-Din Island represent the most diverse and well-formed reefs on the Gulf of Aden coast.

\section{Transboundary protected and conserved areas}

Somalia includes part of the Tana-Kipini-Laga Badana Bushbush Land and Seascape transboundary conservation areas.

\section{Policy context}

A comprehensive report on legislation and policy related to protected area management, governance, and equity was undertaken by the BIOPAMA programme. It identified 10 relevant laws and policies in Somalia (Tessema, 2019).

\section{Key species $^{83}$}

Endemism in the Horn of Africa, of which Somalia is part, is high. Studies of species diversity in Somalia have been infrequent, but it is believed to be home to more than 175 mammal species and 671 bird species. Over 3,000 plant species have been recorded, 836 of which are believed to be endemic to the country. Somalia has unique reptiles of 230 species, $80 \%$ of them are endemic to Somalia with 29 species of amphibians. There are additional species from Somaliland that have not been recorded.

Knowledge of marine and coastal species is low, although these underpin many economic activities on the coast.

2 The section draws on information contained in Somalia's Sixth National Report to the CBD (The Somali Republic, 2019).

83 The section draws on information contained in Somalia's Fifth National Report to the CBD (Federal Republic of Somalia, 2014). 
Figure 8.33 Somalia Summary
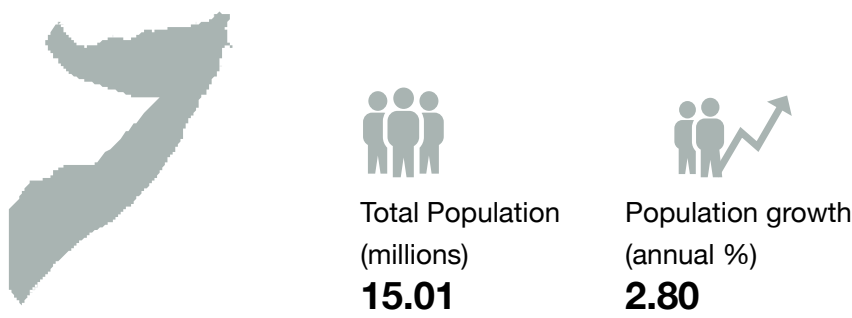

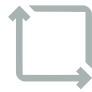

Surface area $\left(\mathrm{km}^{2}\right)$ (thousands) 637.70

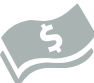

GDP (current US\$) (billions)

4.72

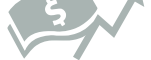

GDP growth (annual \%)

$-1.50$

Source: The World Bank Group, 2018

Area Protected:

Source: UNEP-WCMC \& IUCN, 2019r
21 protected areas
Protected and conserved areas in Somalia in IUCN Management Categories

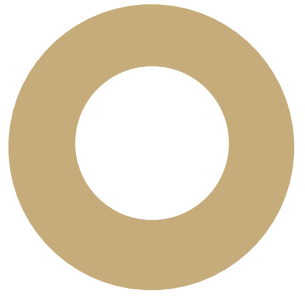

Source: UNEP-WCMC \& IUCN (2019r).
Not Reported (No. 21)

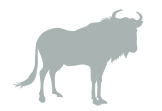

3000 plant species
175 mammal species

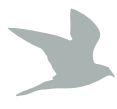

671 bird species
29 amphibian species

\section{Coverage of protected areas in Somalia}

\begin{tabular}{l|r|r}
\hline Type of protected area & $\begin{array}{r}\text { Area protected } \\
\text { or conserved* }\end{array}$ & $\begin{array}{l}\text { Area protected } \\
\text { or conserved** }\end{array}$ \\
\hline Terrestrial and inland water & $0.00 \%$ & $0.80 \%$ \\
\hline Coastal and marine & $0.00 \%$ & Not found \\
\hline${ }^{*}$ WDPA dataset ${ }^{* *}$ From National Report on Biodiversity
\end{tabular}

Source: Federal Republic of Somalia (2014); UNEP-WCMC \& IUCN (2019r).

Protected and conserved areas in Somalia in IUCN Governance Types

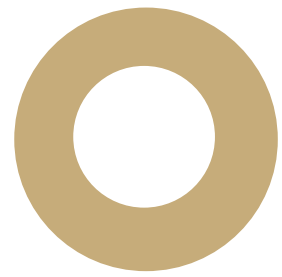

Not Reported

Governance by Government (No. 21)

Source: UNEP-WCMC \& IUCN (2019r)

National designations of protected and conserved areas in Somalia

\begin{tabular}{l|r}
\hline National designation & Number \\
\hline National Park & 12 \\
\hline Wildlife Reserve & 9 \\
\hline
\end{tabular}

Source: UNEP-WCMC \& IUCN (2019r).

Priority areas for conservation

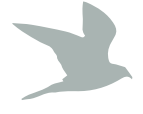

2 sites

Alliance for Zero

Extinction sites

\section{2 sites}

Important Bird \&

Biodiversity Areas
2 sites

Key Biodiversity Areas 


\section{Figure 8.34 Somalia protected areas}
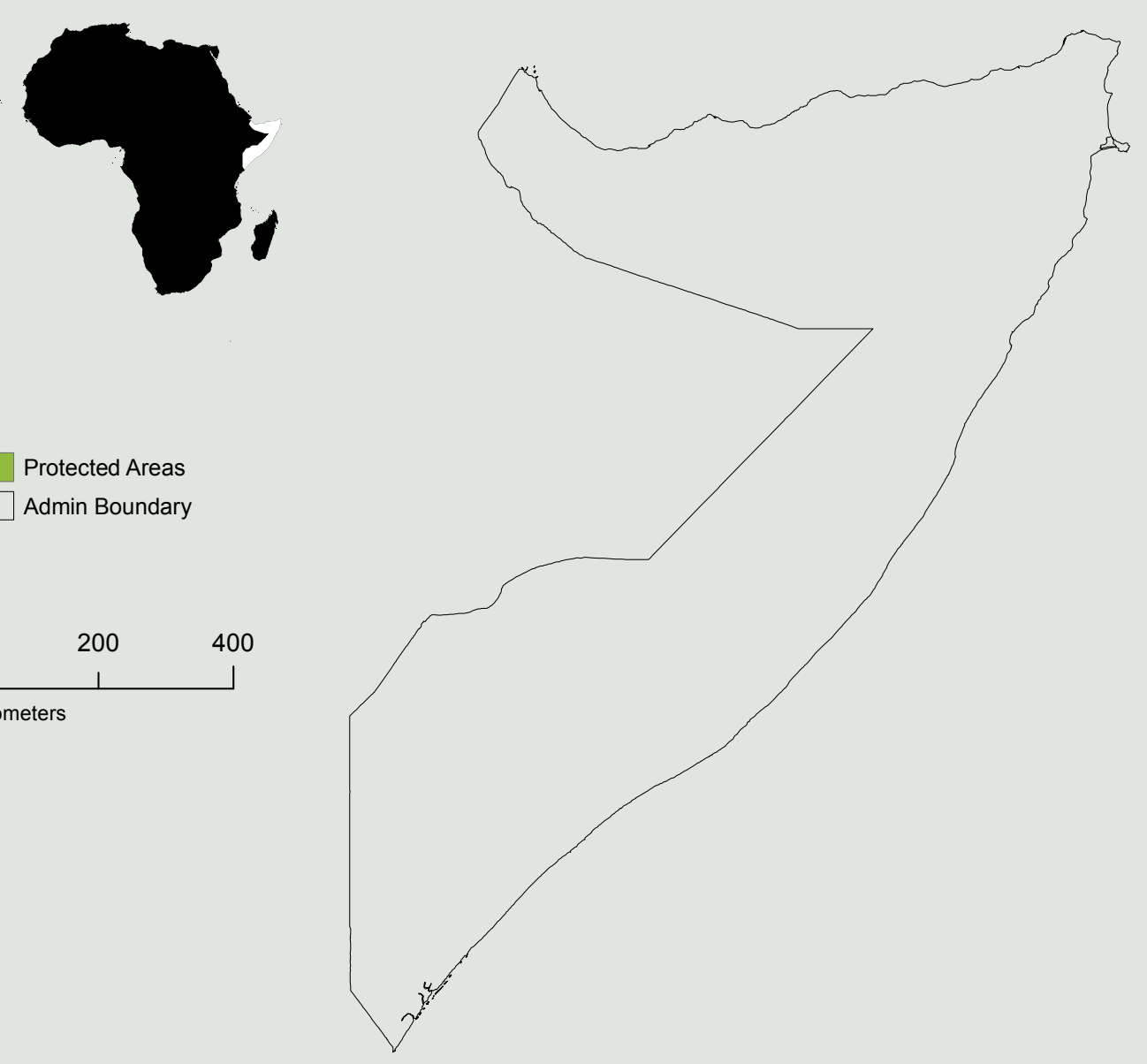

Protected Areas

Admin Boundary

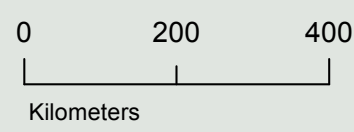

Kilometers

Developed by RCMRD based on WDPA data.

\section{Pressures and threats ${ }^{84}$}

The critical threats to biodiversity in Somalia include: habitat loss and degradation, deforestation, poverty, pollution, political pressure, climate change, woodland conversion to agricultural and urbanisation, unsustainable harvesting and invasive alien species. These are underpinned by indirect drivers, such as poverty, insecurity and civil conflict and lack of institutional capacity for conservation. 


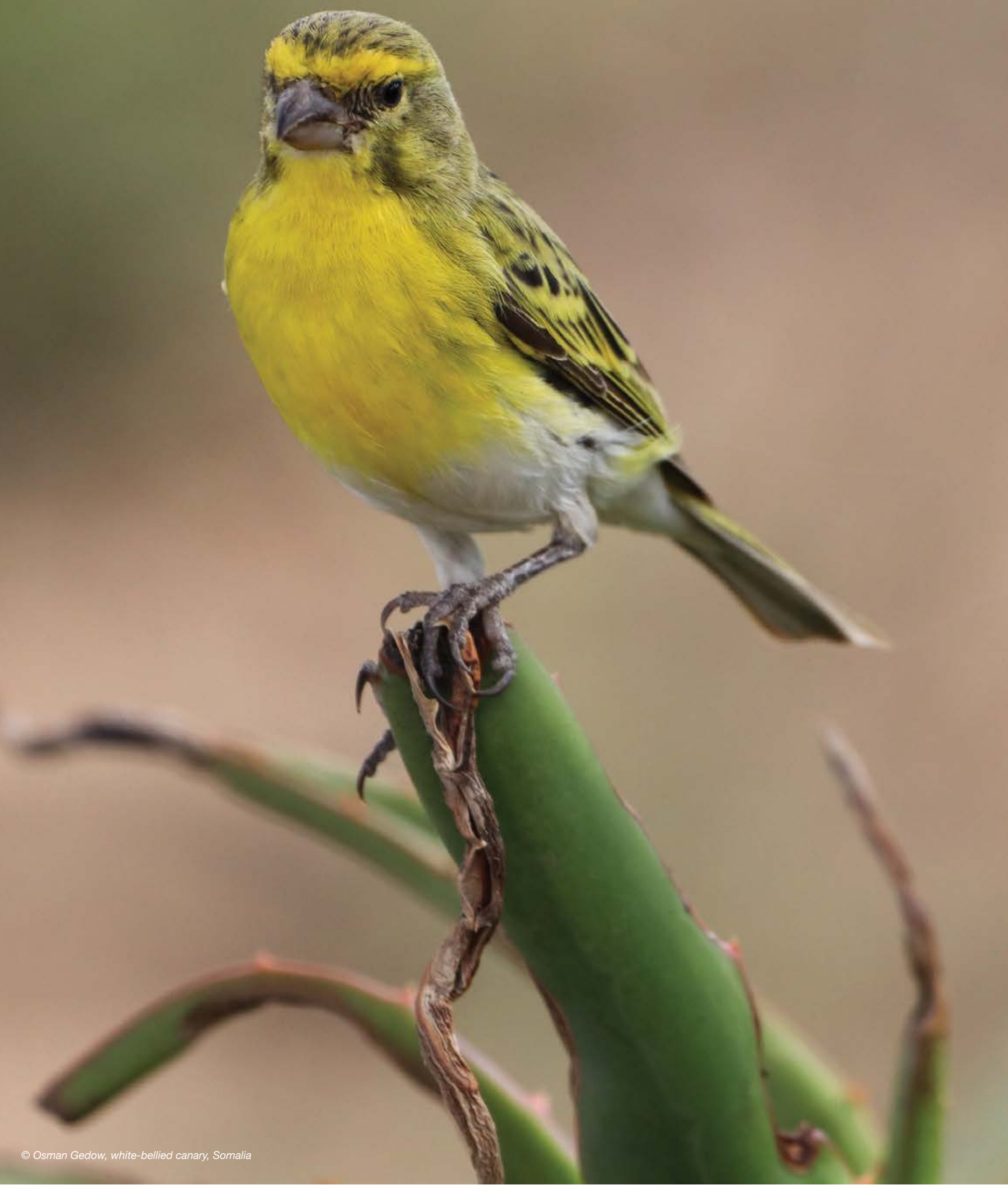




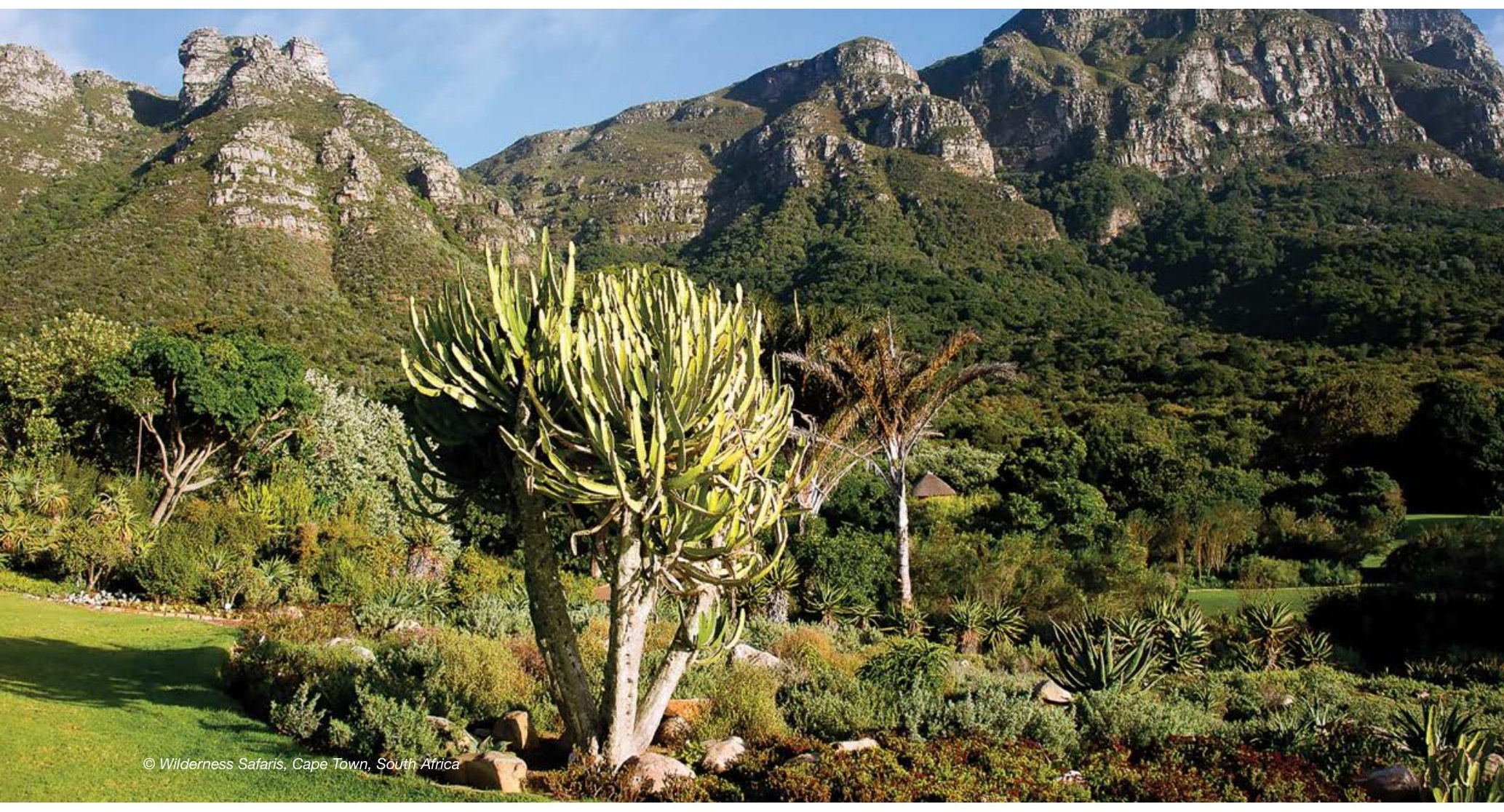

\subsection{South Africa}

\section{Protected and conserved areas in South Africa ${ }^{85}$}

South Africa has 1,580 protected areas covering $102,060 \mathrm{~km}^{2}$ of the land and $224,640 \mathrm{~km}^{2}$ of the ocean (UNEP-WCMC \& IUCN, 2019s).

In October 2018, South Africa's cabinet approved the declaration of 18 new protected areas, thus increasing the network of protected areas. There are nine provincial conservation authorities and the South African National Parks Agency who manage protected areas and implement conservation of plant diversity outside of reserves. Protection level is not evenly spread across South Africa's nine biomes, with a few (desert, forest and fynbos) having more than $17 \%$ of their area protected, while the remaining six all have far less than $17 \%$ of their area protected. Of particular concern are the grassland and Nama-Karoo biomes which have less than $5 \%$ of their areas protected.

With regards to the marine environment, MPAs around mainland South Africa cover approximately $0.4 \%$ of the marine area around South Africa. There is also a large offshore MPA around the Prince Edward Islands Exclusive Economic Zone. Altogether, the total protected coastal and marine area is over $10 \%$.

\section{Transboundary protected and conserved areas}

South Africa includes part of six transboundary conservation areas, namely /Ai/Ais-Richtersveld TFCA, Great Limpopo Transfrontier Park and Conservation Area, Greater Mapungubwe TFCA, Kgalagadi Transfrontier Park, Lubombo TFCA, and Maloti Drakensburg TFCA, which is also a transboundary World Heritage Site.

\section{Policy context}

A comprehensive report on legislation and policy related to protected area management, governance and equity was undertaken by the BIOPAMA programme. It identified 158 relevant laws and policies in South Africa (Tessema, 2019).

\section{Key species ${ }^{86}$}

South Africa is considered one of the most biologically diverse countries in the world. It has a high rate of endemism and diverse ecosystems. While it occupies only $2 \%$ of the world's land surface area, South Africa is home to over 95,000 species, contributing a significant proportion to world plant species $(6 \%)$, reptile species $(5 \%)$, bird species $(8 \%)$ and mammal species $(6 \%)$, with more species regularly discovered and described. Furthermore, it harbours around $15 \%$ of the world's marine species. Endemism rates reach $56 \%$ for amphibians, $65 \%$ for plants, $49 \%$ for freshwater fish, $48 \%$ for reptiles, $36 \%$ for sea breams, and up to $70 \%$ for invertebrates.

85 The section draws on information contained in South Africa's Sixth National Report to the CBD (Republic of South Africa, 2019).

86 The section draws on information contained in South Africa's Fifth and Sixth National Reports to the CBD (Republic of South Africa, 2014; 2019). 
Figure 8.35 South Africa Summary

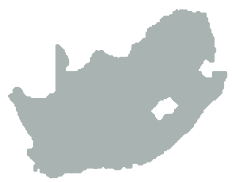

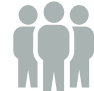

Total Population (millions)

57.78

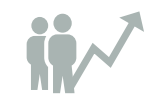

Population growth (annual \%)

1.40

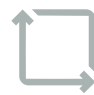

Surface area $\left(\mathrm{km}^{2}\right)$ (thousands) 1219.10

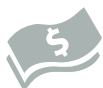

GDP (current US\$) (billions)

368.29
GDP growth (annual \%) 0.80

Source: The World Bank Group, 2018.

\section{Area Protected:}

1580
protected
areas
areas covering 102060 km² of land

Source: UNEP-WCMC \& IUCN, 2019s

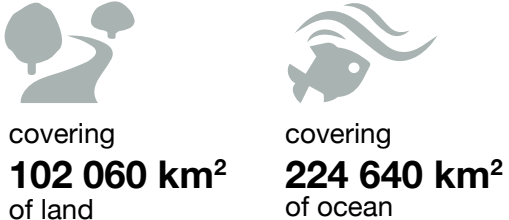

One of the most biologically diverse countries in the world
Protected and conserved areas in South Africa in IUCN Management Categories

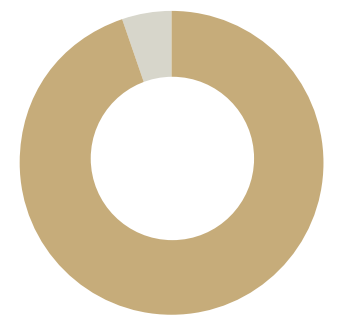

Not Applicable (No. 13)

Not Reported (No. 1567)

Source: UNEP-WCMC \& IUCN (2019s).

Coverage of protected areas in South Africa

\begin{tabular}{l|r|r}
\hline Type of protected area & $\begin{array}{r}\text { Area protected } \\
\text { or conserved }\end{array}$ & $\begin{array}{r}\text { Area protected } \\
\text { or conserved }^{\star *}\end{array}$ \\
\hline Terrestrial and inland water & $8.34 \%$ & $12.96 \%$ \\
\hline Coastal and marine & $14.56 \%$ & $10.00 \%$ \\
\hline
\end{tabular}

*WDPA dataset $\quad$ ** From National Report on Biodiversity

Source: Republic of South Africa (2019); UNEP-WCMC \& IUCN (2019s.)

Protected and conserved areas designated as global sites of importance in South Africa

\begin{tabular}{l|r}
\hline Global designation & No. of sites \\
\hline UNESCO Man and Biosphere Reserves & 10 \\
\hline $\begin{array}{l}\text { UNESCO World Heritage Sites } \\
\text { (Natural or Mixed) }\end{array}$ & 5 \\
\hline $\begin{array}{l}\text { Wetlands of International Importance } \\
\text { (Ramsar sites) }\end{array}$ & 23 \\
\hline
\end{tabular}

Source: Ramsar (2019); UNESCO(2019a (2019b).

Protected and conserved areas in South Africa in IUCN Governance Types

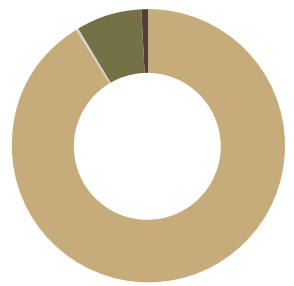

Not Reported (No. 2)

C. Private Governance (No. 932)

B. Shared Governance (No. 1)

A.Governance by Government (No. 645)
National designations of protected and conserved areas in South Africa

\begin{tabular}{l|r|r}
\hline National designation & No. & Area $\left.\mathbf{( k m}^{2}\right)$ \\
\hline National Park & 21 & 39781 \\
\hline Forest Wilderness Area & 12 & 2745 \\
\hline Forest Nature Reserve & 53 & 1732 \\
\hline Special Nature Reserve & 2 & 336 \\
\hline Nature Reserve & 1371 & 38719 \\
\hline Protected Environment & 30 & 7436 \\
\hline Mountain Catchment Area & 16 & 6246 \\
\hline Marine Protected Area & 39 & 224682 \\
\hline
\end{tabular}

Source: UNEP-WCMC \& IUCN (2019s).

Priority areas for conservation

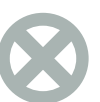

\section{0 sites}

Alliance for Zero

Extinction sites

99 sites

Important Bird \&

Biodiversity Areas
76 sites

Key Biodiversity

Areas 


\section{Figure 8.36 South Africa protected areas}

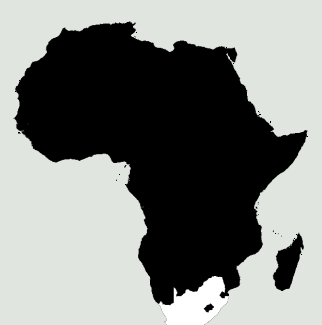

Protected Areas

Admin Boundary

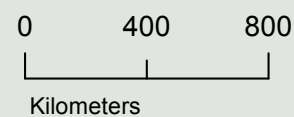

Developed by RCMRD based on WDPA data.

\section{Pressures and threats ${ }^{87}$}

The major pressures on South Africa's biodiversity include: loss and degradation of natural habitat in terrestrial, freshwater, estuarine and marine ecosystems due to unsustainable land-use practices, inappropriate or poorly-located land uses; invasive alien species (both plant and animal); destructive and over-harvesting of species, especially in the marine environment; illegal wildlife trafficking and other illegal resource use; over-abstraction of water and pollution of aquatic ecosystems; disruption of natural drivers of ecosystem functioning (such as fire cycles); and impacts induced by climate change. 


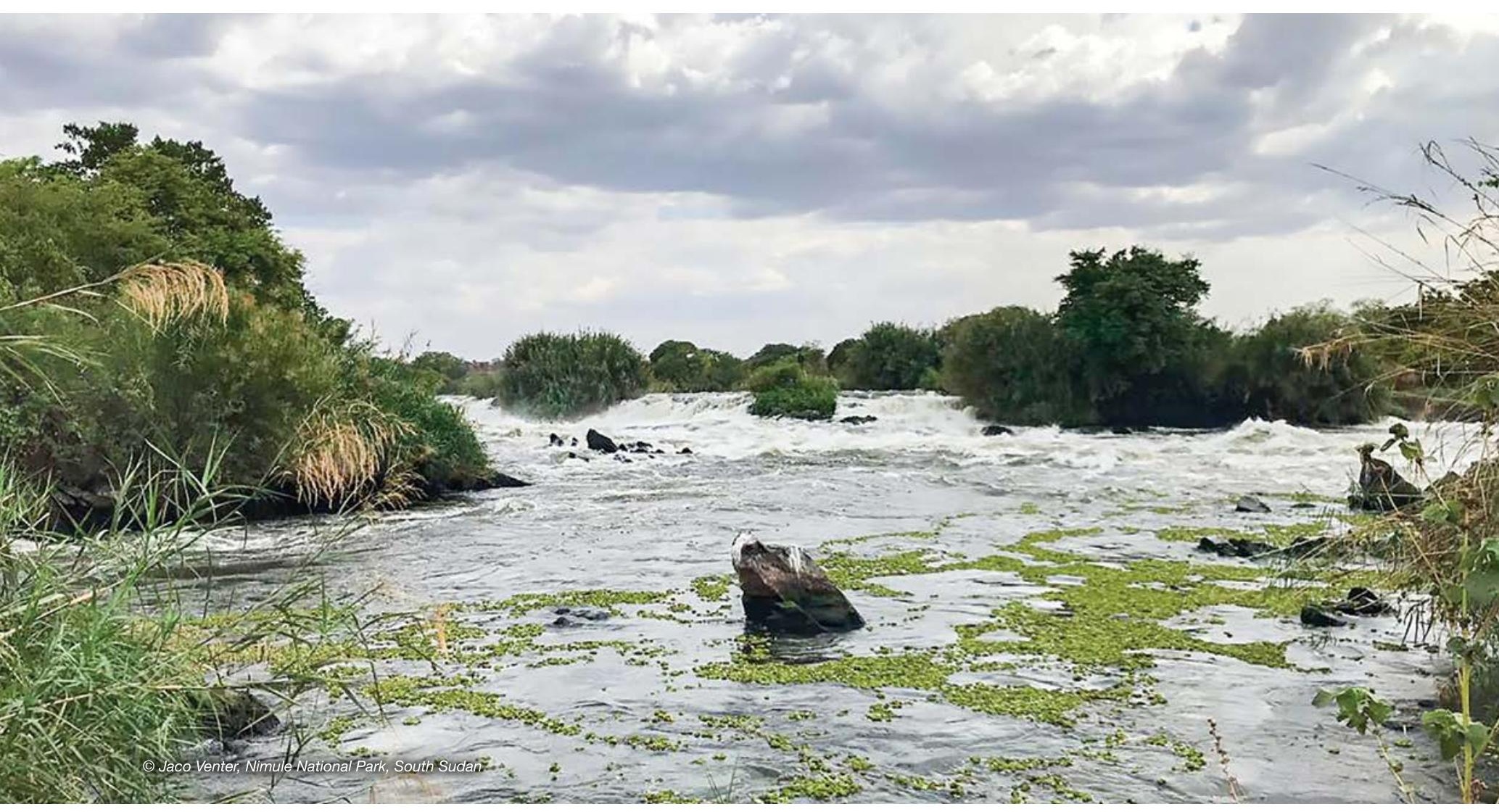

\subsection{South Sudan}

\section{Protected and conserved areas in South Sudan ${ }^{88}$}

South Sudan has 27 protected areas covering $98,214 \mathrm{~km}^{2}$ of the land (UNEP-WCMC \& IUCN, 2019t).

Several areas have been proposed for gazettement as protected areas, which would help exceed the Aichi Target 11. Despite having a large protected area coverage, there is lack of active or adequate management in most of the protected areas. A major challenge relates to the boundaries of several protected areas which are not clear delineated, limiting effective policing. In addition, there seems to be lack of clarity in the forestry sector as to who at the different levels of management owns which forest resource.

Due to many years of conflict, which inhibited actions on the ground, the protected area estate needs to be re-evaluated to ensure that it is still representative and ecologically relevant.

\section{Transboundary protected and conserved areas}

South Sudan includes part of four transboundary conservation areas. Boma-Gambella National Park with Ethiopia, Kidepo Game Reserve-Kidepo Valley with Uganda, Lantoto- Garamba with Congo and Nimule National Park-Otze Wildlife Reserve with Uganda.

\section{Policy context}

A comprehensive report on legislation and policy related to protected area management, governance and equity was undertaken by the BIOPAMA programme. It identified eight relevant laws and policies in South Sudan (Tessema, 2019).

\section{Key species ${ }^{89}$}

South Sudan has a wide range of habitats supporting a rich diversity of animals and plants. It is home to one of the great migrations in the world - the white-eared kob (Kobus kob leucotis), tiang (Damaliscus lunatus tiang), Mongalla gazelle (Eudorcas albonotata), and bohor reedbuck (Redunca redunca). The country is a stronghold for the endangered shoebill (Balaeniceps rex) and the black-crowned crane (Balearica pavonina).

South Sudan also has many species of reptiles, freshwater fish and plants, including many endemic species.

\section{Pressures and threats ${ }^{90}$}

Direct threats to biodiversity in South Sudan include: wildlife poaching and trafficking; deforestation from charcoal production and illegal logging of hardwoods; expansion of livestock and agriculture; habitat fragmentation, including from extractive industries; human-wildlife conflict; and impacts of climate change, including increasing desertification and changing growing seasons.

88 The section draws on information contained in South Sudan's Sixth National Report to the CBD (Republic of South Sudan, 2019).

89 The section draws on information contained in South Sudan's Fifth National Report to the CBD (Republic of South Sudan, 2015).

90 lbid. 
Figure 8.37 South Sudan Summary

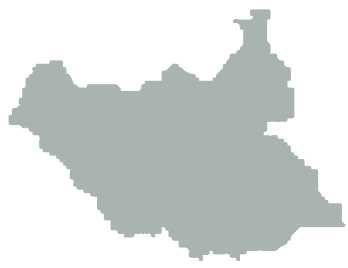

Source: The World Bank Group, 2018.

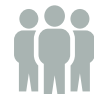

Total Population (millions)

10.98

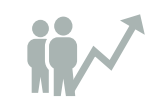

Population growth (annual \%)

0.60

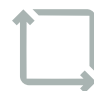

Surface area $\left(\mathrm{km}^{2}\right)$ (thousands) 1882.00

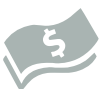

GDP (current US\$) (billions) 3.07
GDP growth (annual \%) $-11.2$

\section{Area Protected:}

27 protected areas

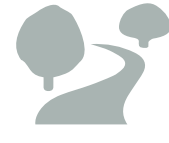

covering 98214 km$^{2}$ of land

\section{Protected and conserved areas in South Sudan in IUCN Management Categories}

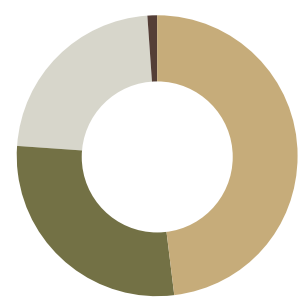

Not Reported (No. 1)

VI. Protected Area with Sustainable Use of Natural Resources (No. 13)

V. Protected Landscape / Seascape (No. 1)

IV. Habitat / Species Management (No. 3)

II. National Park (No. 9)

Source: UNEP-WCMC \& IUCN, (2019t)

\section{Coverage of protected areas in South Sudan}

\begin{tabular}{l|r|r}
\hline Type of protected area & $\begin{array}{r}\text { Area protected } \\
\text { or conserved }^{*}\end{array}$ & $\begin{array}{r}\text { Area protected } \\
\text { or conserved }\end{array}$ \\
\hline Terrestrial and inland water & $15.50 \%$ & $13.00 \%$ \\
\hline
\end{tabular}

*WDPA dataset $\quad$ "** From National Report on Biodiversity

Source: Republic of South Sudan (2015); UNEP-WCMC \& IUCN (2019t).

Protected and conserved areas designated as global sites of importance in South Sudan

\begin{tabular}{l|r}
\hline Global designation & No. of sites \\
\hline Wetlands of International Importance & 1 \\
(Ramsar sites) & \\
\hline
\end{tabular}

Source: Ramsar (2019); UNESCO (2019a, 2019b)

\section{Protected and conserved areas in South Sudan in} IUCN Governance Types

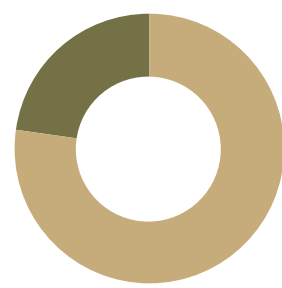

Not Reported (No. 1)

A.Governance by Government (No. 26)
National designations of protected and conserved areas in South Sudan

\begin{tabular}{l|r|r}
\hline National designation & No. & Area $\left.\mathbf{( k m}^{2}\right)$ \\
\hline National Park & 10 & 74991 \\
\hline Game Reserve & 12 & 29792 \\
\hline Nature Conservation Area & 2 & 2499 \\
\hline Forest Reserve & 1 & 1160 \\
\hline Bird Sanctuary & 1 & 4999 \\
\hline
\end{tabular}

Source: UNEP-WCMC \& IUCN (2019t).

\section{Priority areas for conservation}

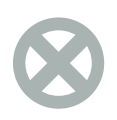

1 sites

Alliance for Zero

Extinction sites

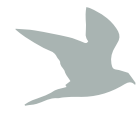

12 sites

Important Bird \&

Biodiversity Areas
Key Biodiversity

Areas

\section{3 sites}

Source: AZE Secretariat (2019); BirdLife International (2019b, 2019c). 
Indirect threats include: past and continuing armed conflicts and the resulting crisis of internally-displaced populations and proliferation of firearms; inadequate and ineffective legal, institutional and administrative capacities; negative impacts of population growth and economic development; lack of land use planning; low public awareness; and emerging oil exploration and production.

\section{Figure 8.38 South Sudan protected areas}
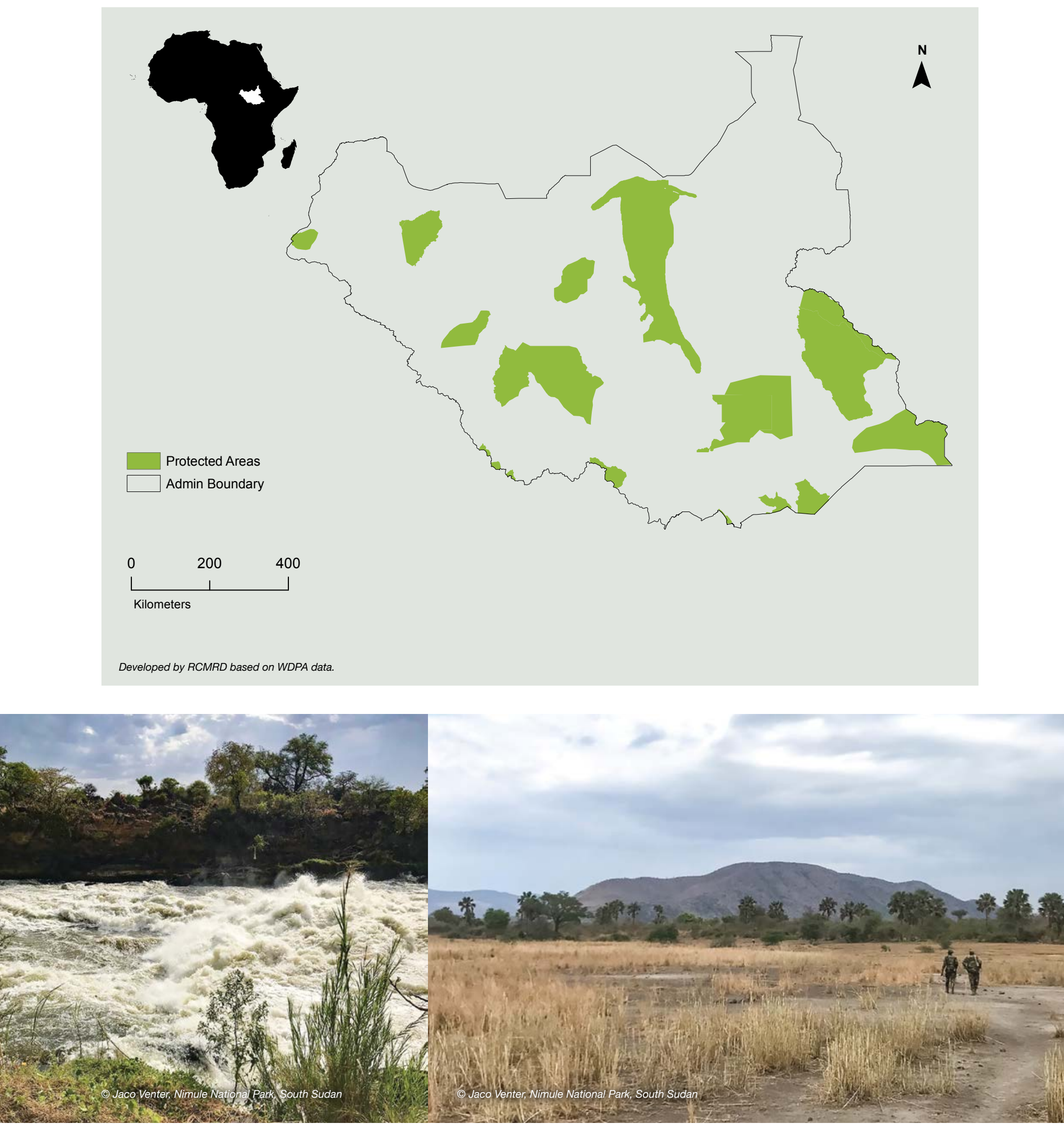


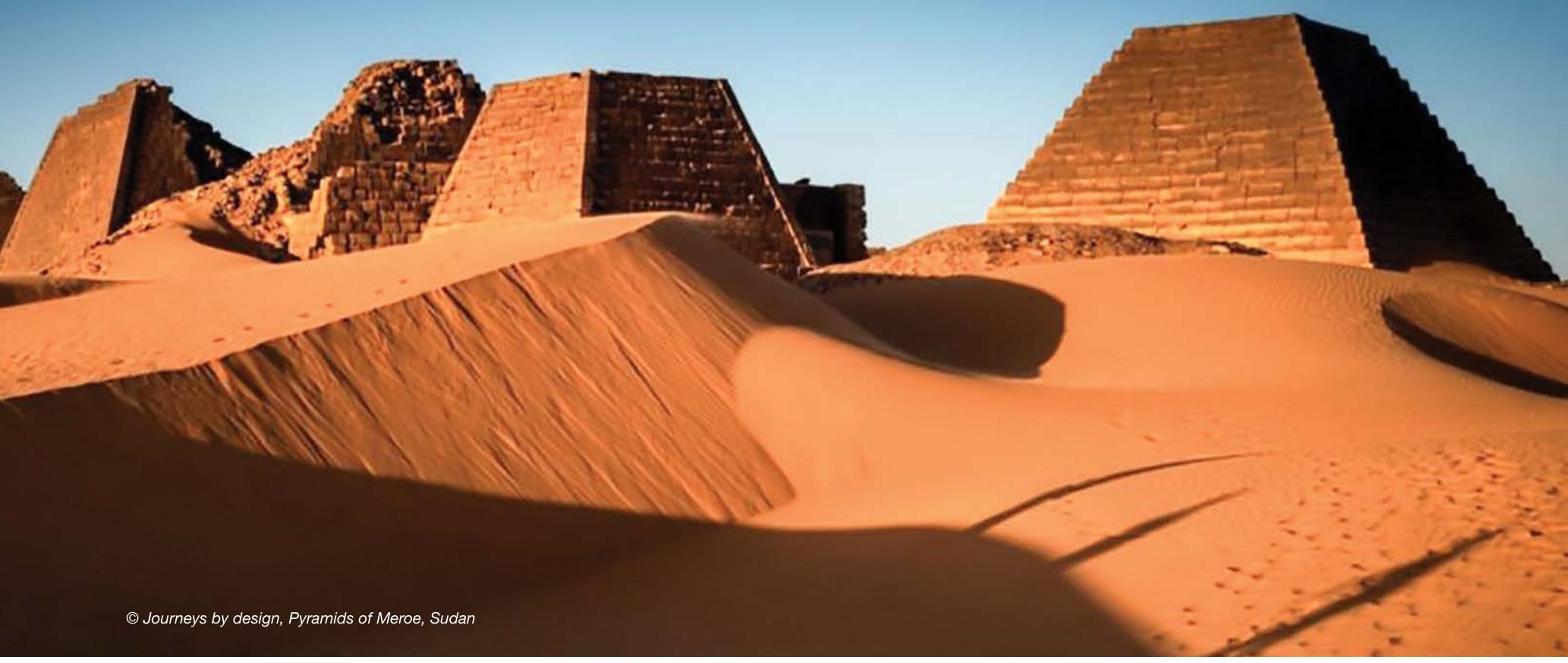

\subsection{Sudan}

\section{Protected and conserved areas in Sudan ${ }^{91}$}

Sudan has 23 protected areas covering $42,698 \mathrm{~km}^{2}$ of the land and $10,662 \mathrm{~km}^{2}$ of the ocean (UNEP-WCMC \& IUCN, 2019u).

Wildlife occurs in protected areas and in fragmented habitats outside protected areas in desert, semi-desert, low rainfall savannah woodland, high rainfall savannah woodland and marine ecosystems. The number of species has either declined or disappeared from many of their former habitats.

There is no designated protected area representing fresh water ecosystems except the proposed Umgur Wetland protected area.

\section{Transboundary protected and conserved areas}

Sudan does not have any transboundary conservation areas.

\section{Policy context}

A comprehensive report on legislation and policy related to protected area management, governance and equity was undertaken by the BIOPAMA programme. It identified 18 relevant laws and policies in Sudan (Tessema, 2019).

\section{Key species ${ }^{92}$}

Sudan's wide range of ecosystems is home to a wide diversity of species. Information on present distribution and abundance of wildlife resources in the Sudan is very limited. Sudan is home to 937 species of birds, including 17 species of global conservation concern. In the coastal habitats, mangroves are an important species, but are very threatened. Sudan has diverse freshwater and marine biodiversity, including coral reefs, seagrass beds, and a wide range of species such as sharks, dugongs, turtles and seabirds. Information on the species composition is not wellknown, particularly since the separation from South Sudan.

\section{Pressures and threats ${ }^{93}$}

Sudan faces a number of threats: environmental degradation; expansion in civil construction and economic activities; climate change and drought; expansion of land cultivation; pollution and alien invasive species. 
Figure 8.39 Sudan Summary

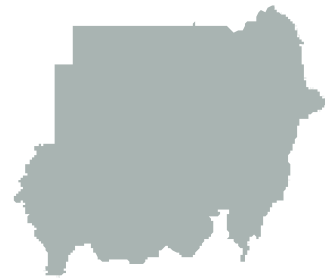

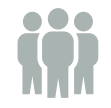

Total Population (millions) 41.80

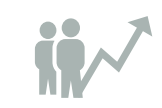

Population growth (annual \%) 2.40

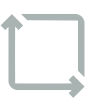

Surface area $\left(\mathrm{km}^{2}\right)$ (thousands) 658.84

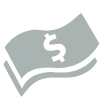

GDP (current US\$) (billions) 40.85

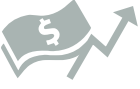

GDP growth (annual \%)

Source: The World Bank Group, 2018.

\section{Area Protected:}

\section{3} protected areas covering 42698 km$^{2}$ of land

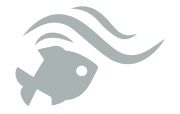

covering 10662 km$^{2}$ of ocean

Source: UNEP-WCMC \& IUCN, (2019u)

Protected and conserved areas in Sudan in IUCN Management Categories

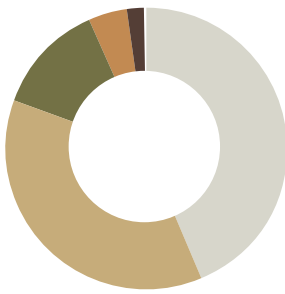

Not Applicable (No. 3)

Not Reported (No. 13)

VI. Protected Area with Sustainable Use of Natural Resources (No. 3 )

IV. Habitat / Species Management (No. 1)

II. National Park (No. 3)

Information on the species composition is not well-known

\section{Coverage of protected areas in Sudan}

\begin{tabular}{l|r|r}
\hline Type of protected area & $\begin{array}{r}\text { Area protected } \\
\text { or conserved }\end{array}$ & $\begin{array}{r}\text { Area protected } \\
\text { or conserved }^{\star *}\end{array}$ \\
\hline Terrestrial and inland water & $2.28 \%$ & $5.80 \%$ \\
\hline Coastal and marine & $15.96 \%$ & $10.00 \%$ \\
\hline "WDPA dataset ${ }^{* *}$ From National Report on Biodiversity \\
Source: Republic of SUdan (2019); UNEP-WCMC \& IUCN (2019u).
\end{tabular}

Protected and conserved areas designated as global sites of importance in Sudan

\begin{tabular}{l|r}
\hline Global designation & No. of sites \\
\hline $\begin{array}{l}\text { UNESCO World Heritage Sites } \\
\text { (Natural or Mixed) }\end{array}$ & 1 \\
\hline Wetlands of International Importance & 3 \\
(Ramsar sites) & \\
\hline
\end{tabular}

Source: Ramsar (2019); UNESCO (2019a, 2019b).

Protected and conserved areas in Sudan in IUCN Governance Types

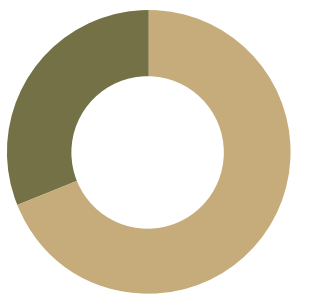

Not Reported (No. 14)

A.Governance by Government (No. 9)

\section{7 bird species}

17 of global conservation concern
National designations of protected and conserved areas in Sudan

\begin{tabular}{l|r|r}
\hline National designation & No. & Area $\left.\mathbf{( k m}^{2}\right)$ \\
\hline Managed Nature Reserve & 1 & 300 \\
\hline National Park & 4 & 22398 \\
\hline Game Reserve & 2 & 7459 \\
\hline Nature Conservation Area & 2 & 6299 \\
\hline Marine National Park & 2 & 1012 \\
\hline Bird Sanctuary & 4 & 1150 \\
\hline Wildlife Sanctuary & 2 & 940 \\
\hline Source: UNEP-WCMC \& IUCN (2019u). & \multicolumn{3}{|c}{} \\
\end{tabular}

\section{Priority areas for conservation}

\section{1 sites}

Important Bird \& Biodiversity Areas

Source: BirdLife International (2019c). 


\section{Figure 8.40 Sudan protected areas}
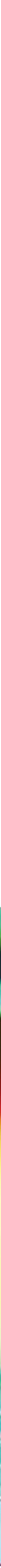


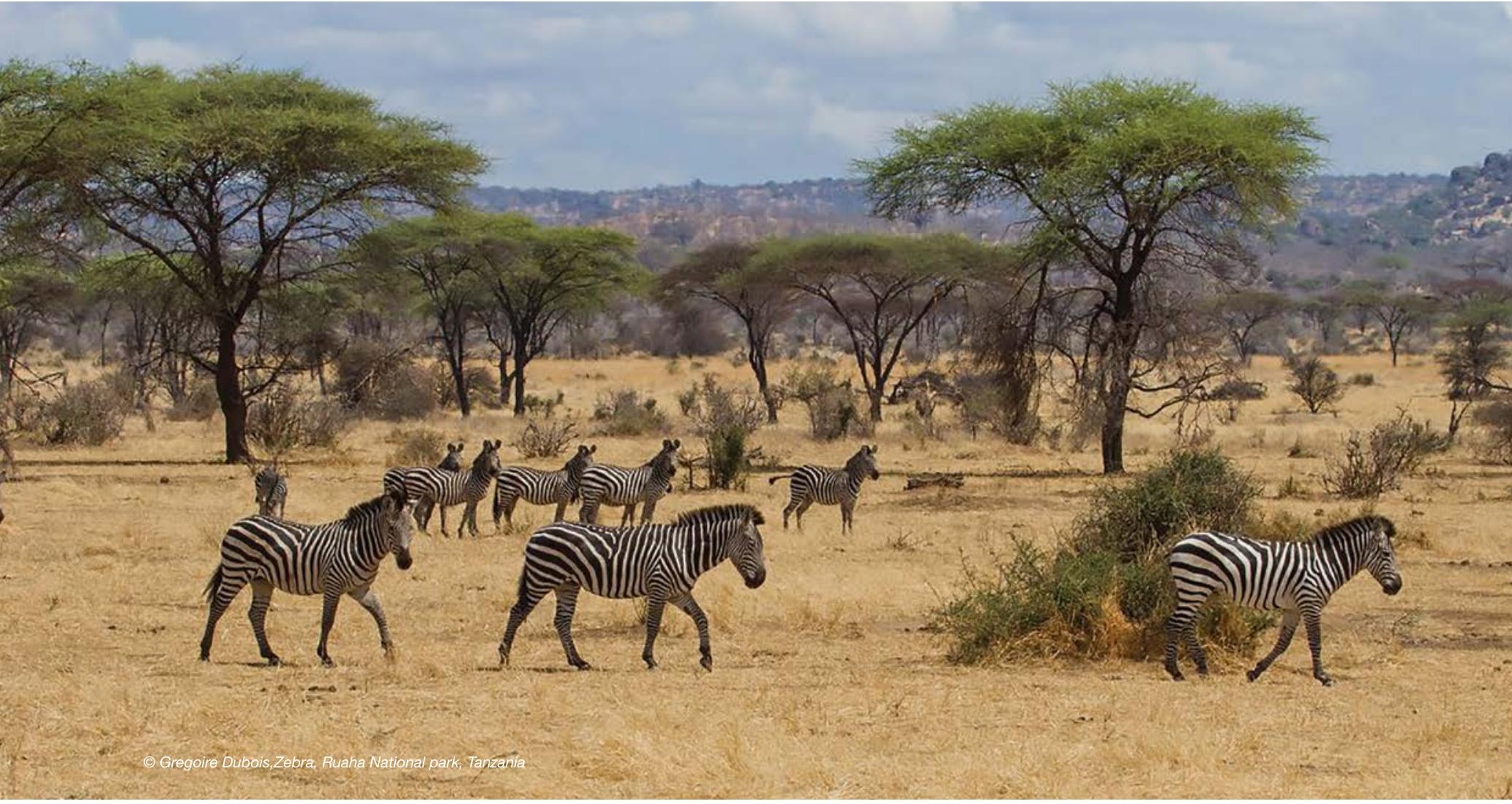

\subsection{Tanzania}

\section{Protected and conserved areas in Tanzania ${ }^{94}$}

Tanzania has 840 protected areas covering $361,594 \mathrm{~km}^{2}$ of the land and $7,330 \mathrm{~km}^{2}$ of the ocean (UNEP-WCMC \& IUCN, 2019v).

Terrestrial ecosystems have the highest protection while the coastal and marine environments have the least protection. The extensive national parks, 'the Eastern Arc' mountains, wetlands, coastal forests, marine and freshwater systems as outstanding reservoirs of plant and animal species make Tanzania one of the world's greatest reservoirs of biodiversity. Tanzania is also home to a variety of endemic species of amphibians, lizards, snakes, birds, wild coffee varieties and the famous African violet flowers.

Ngorongoro Conservation Area and Serengeti National Park are Biosphere Reserves and World Heritage Sites known for the world's most spectacular migration of large mammals each year. In Serengeti National Park, they traverse the wide-sweeping grasslands and associated Acacia-Commiphora woodlands, one of the major forest ecosystems in the country, while in Ngorongoro Conservation Area, they traverse the upper Kitete/Selela corridor along the Great Rift Valley that connects it to Lake Manyara National park utilised by elephants and buffalos. Needless to say, wildlife corridors are under serious threat in Tanzania, facing an intense pressure from land use change. Recently, the President has signed into law the establishment of the Julius Nyerere, Kigosi and River Ugalla National Parks.

\section{Transboundary protected and conserved areas}

Tanzania includes parts of eight transboundary conservation areas, namely Amboseli-Kilimanjaro-Longido, Kagera TFCA, Mnazi BayQuirimbas TFCA, Niassa-Selous TFCA, Sango Bay-Minziro, Serengeti-Mara, Tanga Marine Reserves System and Tanga Coelacanth Marine Park and Diani Chale and Kisitee-Mpunguti and the Western Indian Ocean Transfrontier Marine Park.

\section{Policy context}

A comprehensive report on legislation and policy related to protected area management, governance and equity was undertaken by the BIOPAMA programme. It identified 74 relevant laws and policies in Tanzania (Tessema, 2019).

\section{Key species ${ }^{95}$}

Tanzania has extensive diversity of species with at least 14,500 known and confirmed species, and is among 15 countries globally with the highest number of endemic as well as threatened species. It accounts for more than one third of total plant species in Africa and ranks twelfth globally in terms of bird species. The country is a home to about $20 \%$ of Africa's large mammal population.

Of the total number of species existing in the country, more than half $(54 \%)$ constitute plant species. Notably, over $25 \%$ of all plant species are used as wild-harvested medicinal plants. 
Figure 8.41 Tanzania Summary

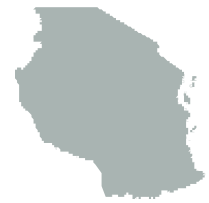

Source: The World Bank Group, 2018.

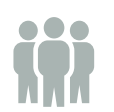

Total Population (millions) 56.32

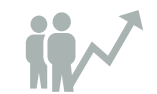

Population growth (annual \%)

3.00

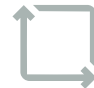

Surface area $\left(\mathrm{km}^{2}\right)$ (thousands) 947.30

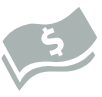

GDP (current US\$) (billions) 57.44
GDP growth (annual \%)

5.20

\section{Area Protected:}

840 protected areas

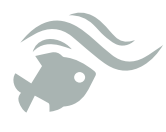

covering $7330 \mathrm{~km}^{2}$ of ocean

Source: UNEP-WCMC \& IUCN (2019v).

Protected and conserved areas in Tanzania in IUCN Management Categories
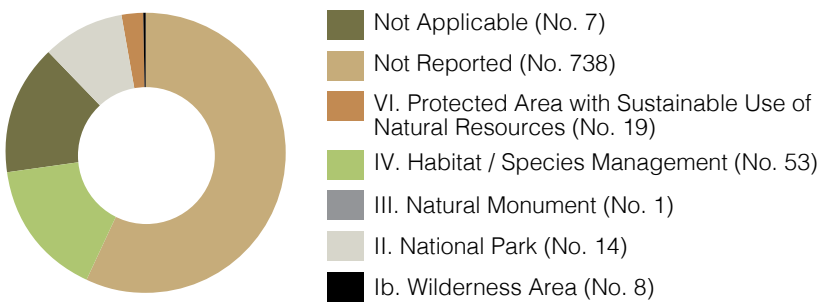

Source: UNEP-WCMC \& IUCN (2019v).

\section{Coverage of protected areas in Tanzania}

\begin{tabular}{l|r|r}
\hline Type of protected area & $\begin{array}{r}\text { Area protected } \\
\text { or conserved }^{\star}\end{array}$ & $\begin{array}{r}\text { Area protected } \\
\text { or conserved }^{\star *}\end{array}$ \\
\hline Terrestrial and inland water & $38.17 \%$ & $54.60 \%$ \\
\hline Coastal and marine & $3.02 \%$ & $6.50 \%$ \\
\hline
\end{tabular}

*WDPA dataset $\quad$ ** From National Report on Biodiversity

Source: UNEP-WCMC \& IUCN (2019v); United Republic of Tanzania (2019).

Protected and conserved areas designated as global sites of importance in Tanzania

\begin{tabular}{l|r}
\hline Global designation & No. of sites \\
\hline UNESCO Man and Biosphere Reserves & 5 \\
\hline $\begin{array}{l}\text { UNESCO World Heritage Sites } \\
\text { (Natural or Mixed) }\end{array}$ & 4 \\
\hline $\begin{array}{l}\text { Wetlands of International Importance } \\
\text { (Ramsar sites) }\end{array}$ & 4 \\
\hline
\end{tabular}

Source: Ramsar (2019); UNESCO (2019a, 2019b).

\section{Protected and conserved areas in Tanzania in IUCN Governance Types}

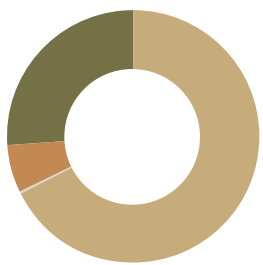

Not Reported (No. 19)

D. Governance by Indigenous peoples and Local Communities (No. 39)

C. Private Governance (No. 1)

B. Shared Governance (No. 4)

A. Governance by Government (No. 777)

Source: UNEP-WCMC \& IUCN (2019v).
National designations of protected and conserved areas in Tanzania

\begin{tabular}{l|r|r}
\hline National designation & No. & Area (km²) \\
\hline Nature Forest Reserve & 1 & 257 \\
\hline Conservation Area & 4 & 9674 \\
\hline Game Reserve & 19 & 94050 \\
\hline National Park & 17 & 48430 \\
\hline Game controlled area & 19 & 70901 \\
\hline Collaborative Fishery & 1 & 1913 \\
Management Area & 2 & 35 \\
\hline Marine Reserve & 14 & 33162 \\
\hline Wildlife Management Area & 23 & 730 \\
\hline Forest Plantation & 1 & 3 \\
\hline Locally Managed Marine Area & 2 & 1445 \\
\hline Marine Park & 6 & 1996 \\
\hline Nature Reserve & 24 & 53235 \\
\hline Open area & 13 & 3999 \\
\hline Wildlife management area & 694 & 92195 \\
\hline Forest Reserve & 1 & 1 \\
\hline Sanctuary and Closed Forest & 1 & 1015 \\
Reserve & & \\
\hline Forest Reserve and Game & & \\
Controlled Area & & \\
\hline
\end{tabular}

Source: UNEP-WCMC \& IUCN (2019v).

Priority areas for conservation

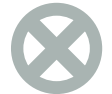

13 sites

Alliance for Zero

Extinction sites

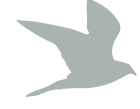

77 sites

Important Bird \&

Biodiversity Areas
84 sites

Key Biodiversity

Areas 
Figure 8.42 Tanzania protected areas

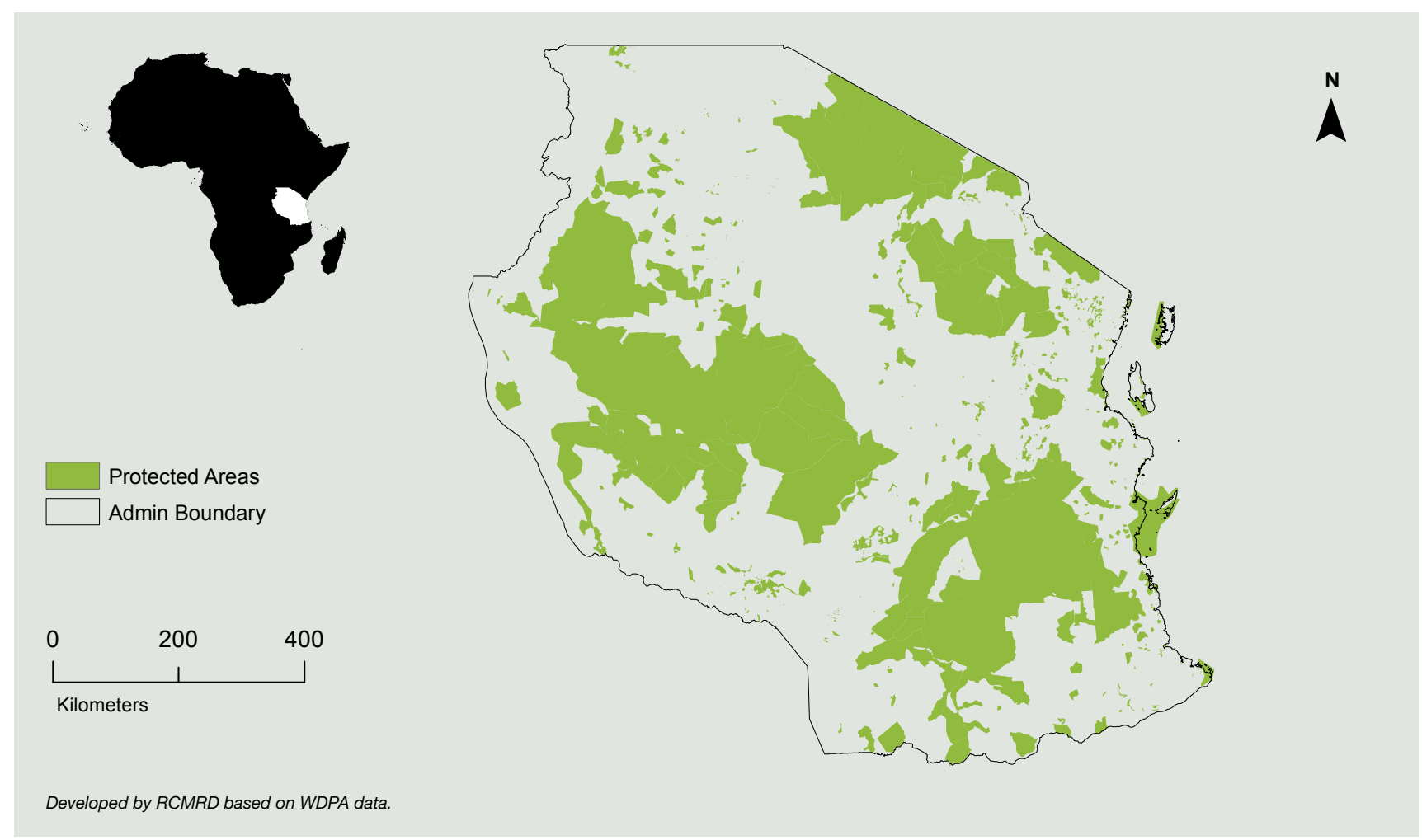

The exact number of endemic species in the country is not known. However, available information indicates endemic species to be ranging between 400 and 3,000 species.

Based on the analysis of threatened species in the country, taking into account ecological, economic and social significance, species of concern include, but are not limited to: Black Rhino (Diceros bicornis) and elephants (Loxodonta africana), which are endangered due to poaching. Other keystone species of critical importance include chimpanzee (Pan troglodytes), colobus monkeys (e.g. Procolobus gordonorum and Procolobus kirkii), mangabey monkeys (e.g. Rungwecebus kipunji, Cercocebus sanjei), leopard (Panthera pardus), cheetah (Acinonyx jubatus) and African wild dog (Lycaon pictus). Tanzania is home to the world's largest population of lions (Panthera leo). There also high-value timber species (e.g. Afzelia spp, Pterocarpus spp., Diospyros mespiliformis). In addition there are important marine species, including prawns (Metapenaeus monocerus, Penaeus indicus, P. monodon), tuna, dugong and marine turtles.

\section{Pressures and threats $^{96}$}

Tanzania's richness in biodiversity experiences increasing threat like in other countries due to a number of natural and human drivers. The main threat to biodiversity in Tanzania is habitat loss and destruction by conversion to other land uses, such as settlements, agriculture and grazing, overexploitation of plant and animal species, the introduction of non-native species, pollution and climate change.

Human activities, such as: poaching; deforestation, bottom trawling in the oceans and unsustainable fishing practices; the damming and dredging of streams, rivers, and lakes; and the draining and degradation of wetlands, estuaries and mangroves are responsible for biodiversity loss in water bodies. These activities are aggregated by economic growth, population growth, poverty, global trade in plant and animal species and climate change.

Other serious threats to habitats include deforestation, coral destruction, habitat degradation due to fires, unplanned land use, unmanaged natural resource extraction, increased bush meat trade and the building of roads and other infrastructures. Wildlife corridors are one such type of habitat facing intense pressure of being converted into other land forms.

Habitats in marine ecosystems face serious threats of mangrove destruction, coral destruction, dynamite fishing and illegal fishnets while Inland water habitats have a major threats related to declining water levels due to reduced rainfall and increased evaporation, decline in fish species diversity due to over-exploitation of the fish stocks, illegal fishing, introduction exotic fish and species especially Nile perch and water hyacinth; pollution and eutrophication due to nutrients enrichment especially phosphorus and nitrogen.

Habitats on terrestrial ecosystems are under tremendous pressure from unsustainable exploitation of the animal species. The key species that are under this pressure include the larger carnivores such as lions, leopards, cheetahs, wild dogs and the herbivores group including population of elephants, giraffe (Giraffa camelopardalis), zebra (Equus burchelli), buffalo (Syncerus caffer), antelopes, wildebeest (Connochaetus taurinus) and black rhino (Diceros bicornis). 

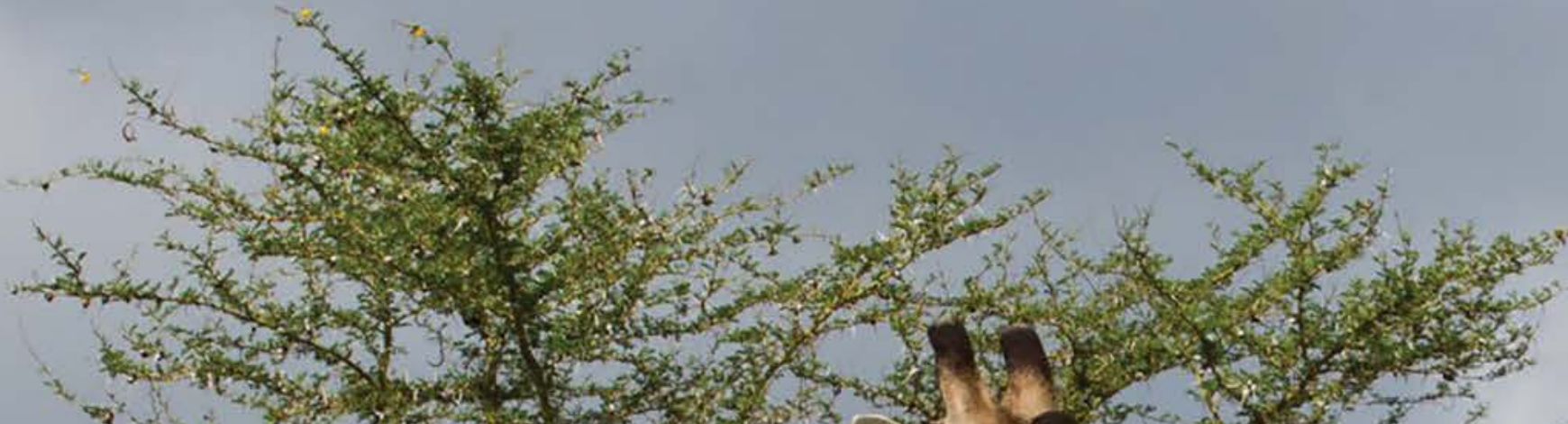

6)

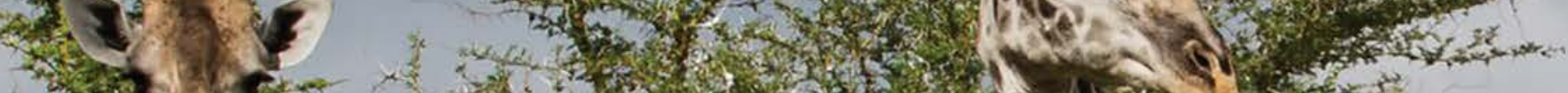

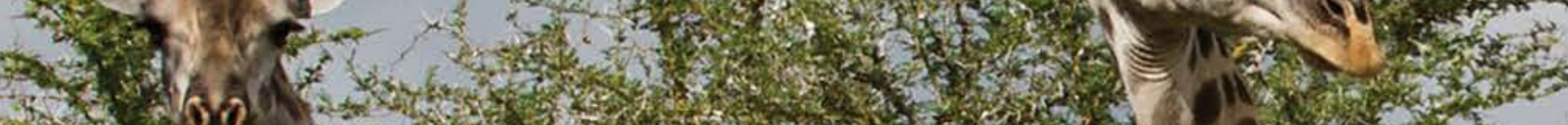

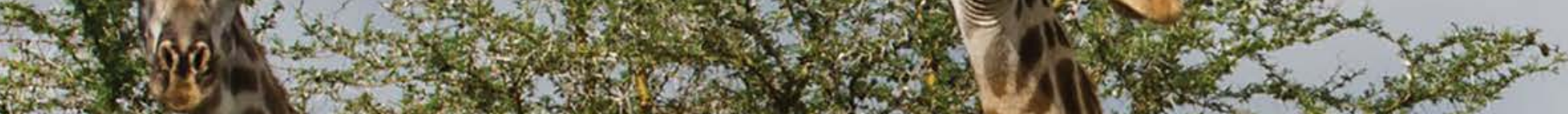

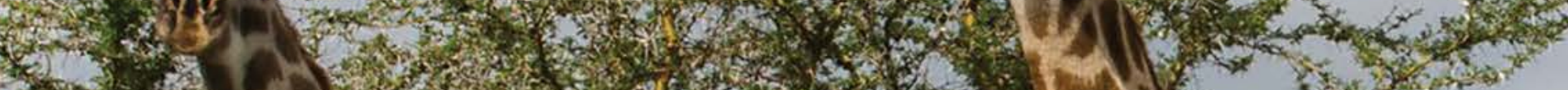

3.5.

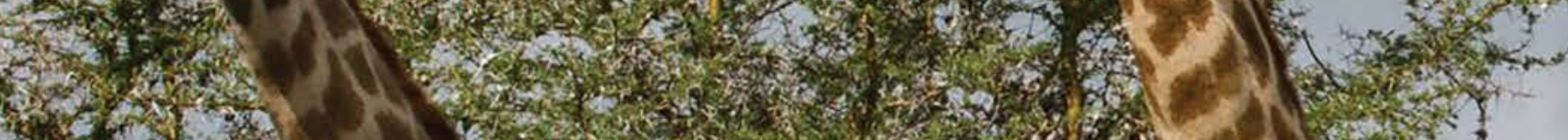

1.5.

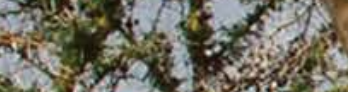

(f)

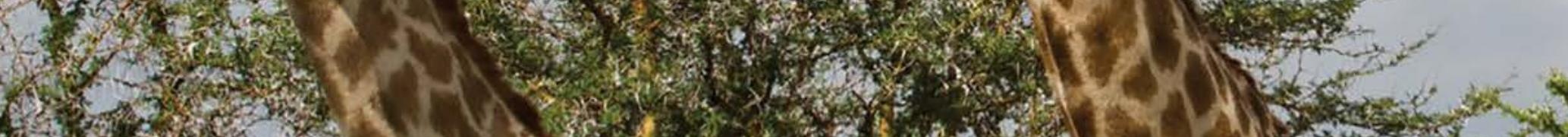

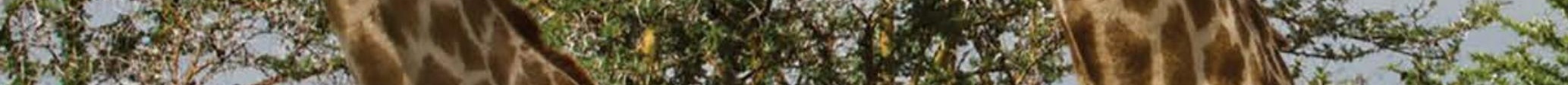

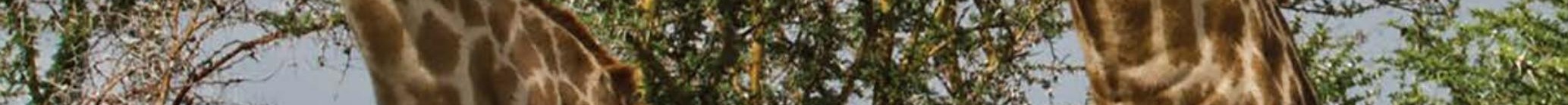

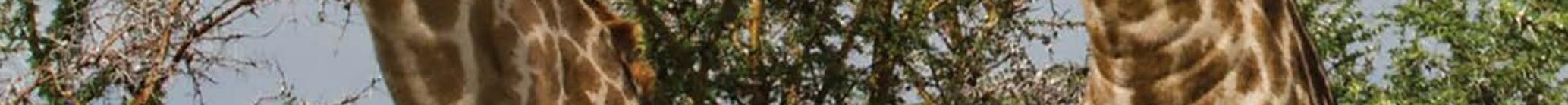

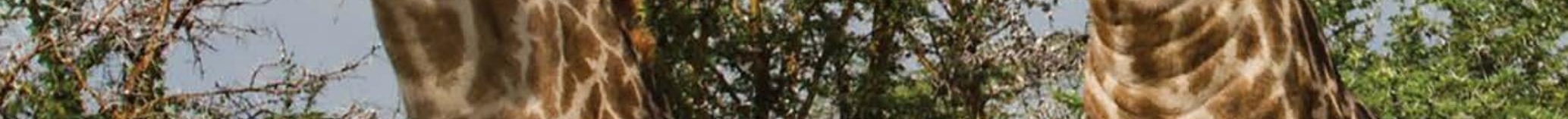

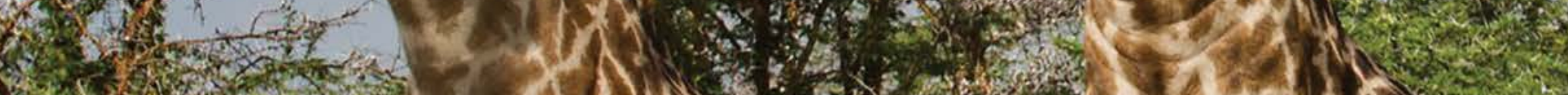

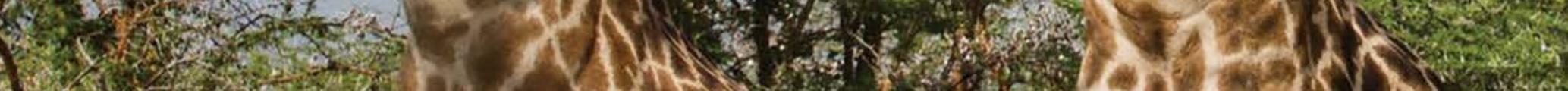

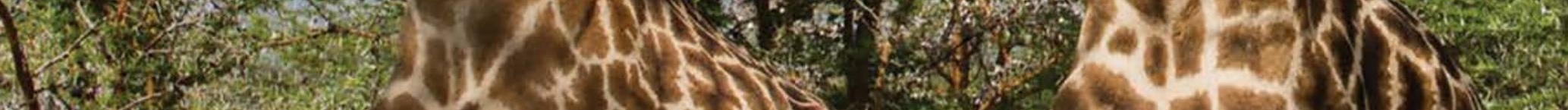

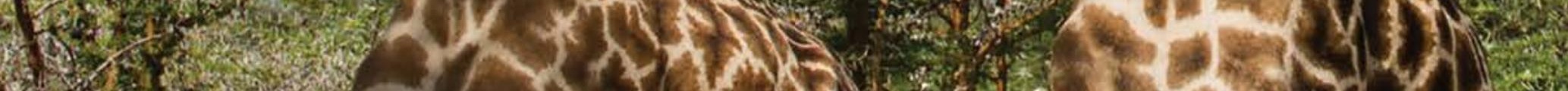

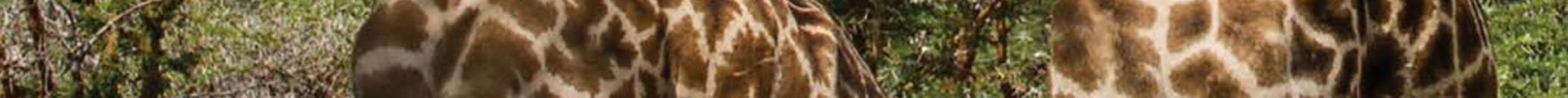

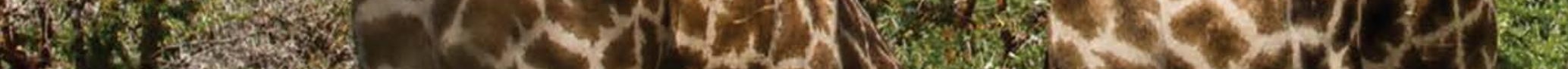
for.

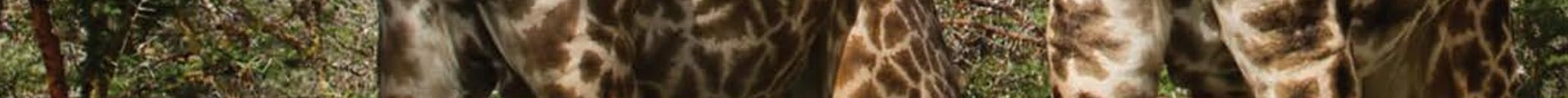

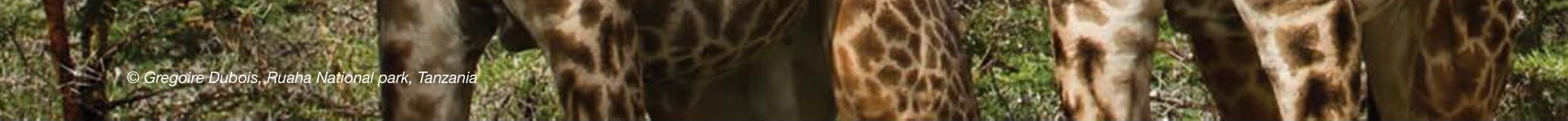




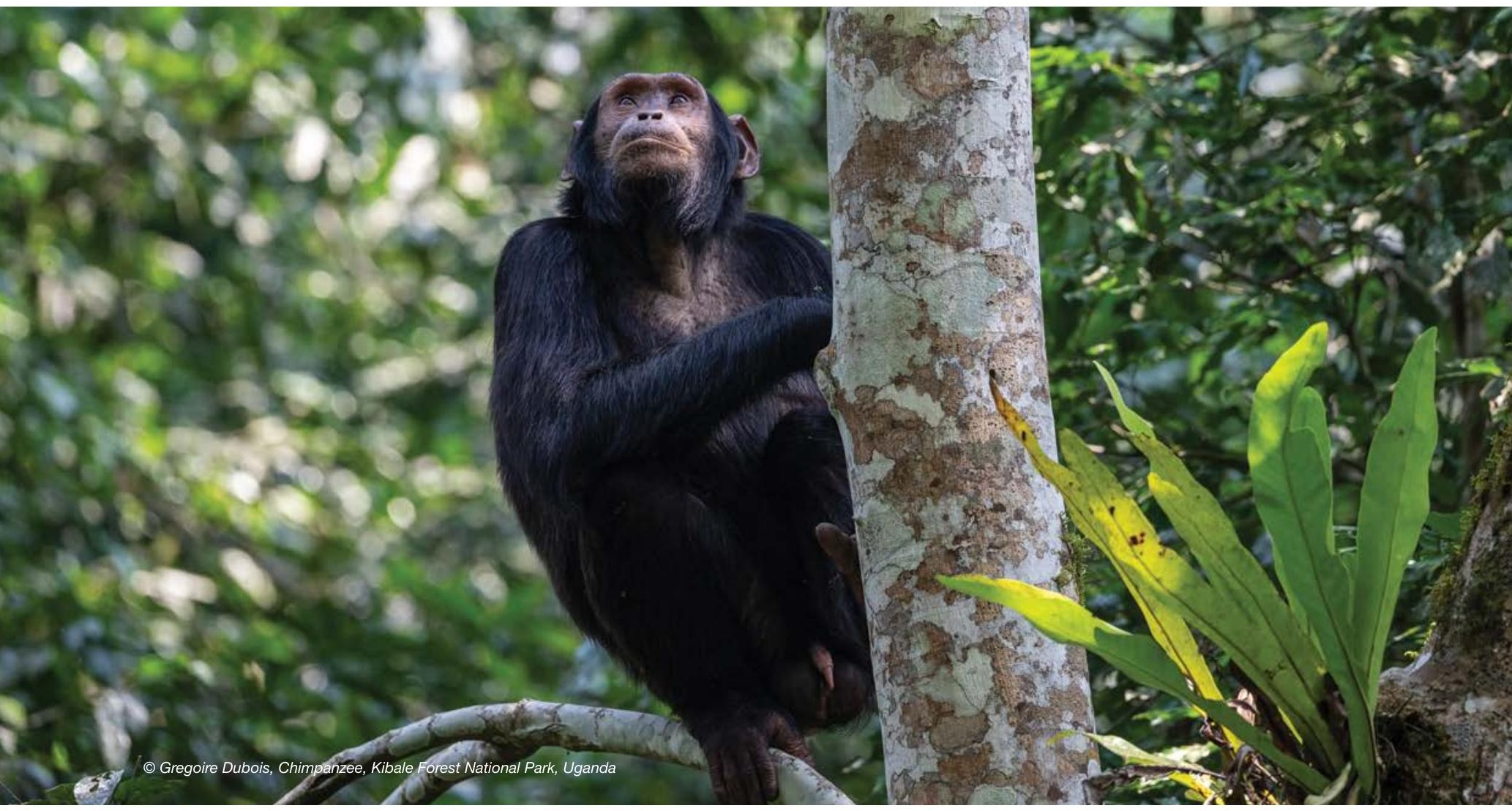

\subsection{Uganda}

\section{Protected and conserved areas in Uganda ${ }^{97}$}

Uganda has 712 protected areas covering $39,059 \mathrm{~km}^{2}$ of the land (UNEP-WCMC \& IUCN, 2019w).

Uganda is a convergence zone for five of Africa's important ecological zones and home to an estimate of half the world's mountain. In recent years Uganda has been seen as a model case study for numerous and varied approaches to address complex and connected conservation and development challenges such as community-based conservation to payments for ecosystem services. An example is the project funded by Global Environment Facility (GEF) providing incentives to individual landowners to conserve and restore forest habitats important for chimpanzees and other flora and fauna. It provided incentives to some 400 farmers (private forest owners) in 68 villages for conserving biodiversity in forests on private and public land not gazetted as forest reserves.

In 2018, the government embarked on a process of gazetting and declaring some of Uganda's wetland cover as a protected area. Uganda's wetlands cover an area of $11 \%$ of the land area. One of the major trends for protected areas in Uganda is the reduction of forested areas in protected areas, in national parks and wildlife reserves and central forest reserves. The forest cover declined from 1.59 million ha in 1990 to 1.13 million ha in 2015.
Transboundary protected and conserved areas

Uganda includes parts of five transboundary conservation areas, namely Greater Virunga Landscape, Kagera TFCA, Kidepo Landscape, Mount Elgon and Sango Bay-Minziro.

\section{Policy context}

A comprehensive report on legislation and policy related to protected area management, governance and equity was undertaken by the BIOPAMA programme. It identified 48 relevant laws and policies in Uganda (Tessema, 2019).

\section{Key species ${ }^{98}$}

Uganda is rich in biodiversity, with close to 19,000 species of flora and fauna. Knowledge about these species is skewed towards mammals, birds, butterflies, some plants, reptiles, amphibians and fish. Uganda is home to about 380 mammal species and over 1,000 bird species, representing almost half of all species recorded in Africa. Fish biodiversity in Uganda is dominated by the Cichlid family, with a high level of endemism. There are 98 species of amphibians and 150 species of reptiles found in Uganda. Of the approximately 5,000 species of higher plants, 70 are endemic. Fungi, lichen and insects are less well documented.

9 The section draws on information contained in Uganda's Fifth National Report to the CBD (Uganda National Environment Management Agency, 2014)

98 The section draws on information contained in Uganda's Fifth National Report to the CBD and its Second NBSAP (Republic of Uganda, 2016; Uganda National Environment Management Agency, 2014) 
Figure 8.43 Uganda Summary

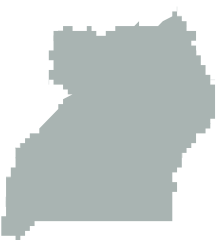

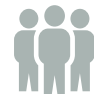

Total Population (millions)

42.72

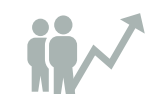

Population growth (annual \%)

3.70

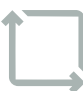

Surface area $\left(\mathrm{km}^{2}\right)$ (thousands) 241.60

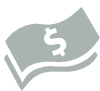

GDP (current US\$) (billions)

27.48
GDP growth (annual \%)

6.10

Source: The World Bank Group, 2018.

\section{Area Protected:}

712 protected areas

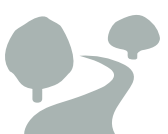

vering 39059 km$^{2}$ of land

\section{0 species of flora and fauna}

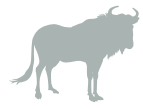

380 mammal
species

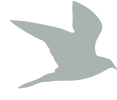

1,000 bird
species

Protected and conserved areas in Uganda in IUCN Management Categories

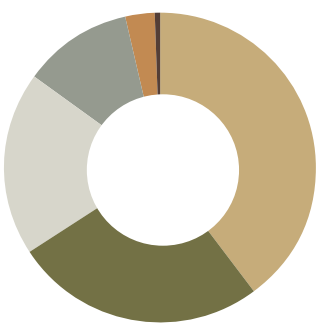

Not Applicable (No. 4)

Not Reported (No. 673)

VI. Protected Area with Sustainable Use of Natural Resources (No. 13)

IV. Habitat/Species Management (No. 1)

III. Natural Monument (No. 11)

II. National Park (No. 10)

Source: UNEP-WCMC \& IUCN (2019w).

\section{Coverage of protected areas in Uganda}

\begin{tabular}{l|r|r}
\hline Type of protected area & $\begin{array}{r}\text { Area protected } \\
\text { or conserved }^{\star}\end{array}$ & $\begin{array}{l}\text { Area protected } \\
\text { or conserved }^{\star *}\end{array}$ \\
\hline Terrestrial and inland water & $16.06 \%$ & $0.80 \%$ \\
\hline
\end{tabular}

*WDPA dataset $\quad$ ** From National Report on Biodiversity

Source: Uganda National Environment Management Agency (2014); UNEP-WCMC \& IUCN (2019w).

Protected and conserved areas designated as global sites of importance in Uganda

\begin{tabular}{l|r}
\hline Global designation & No. of sites \\
\hline UNESCO Man and Biosphere Reserves & 2 \\
\hline $\begin{array}{l}\text { UNESCO World Heritage Sites } \\
\text { (Natural or Mixed) }\end{array}$ & 2 \\
\hline $\begin{array}{l}\text { Wetlands of International Importance } \\
\text { (Ramsar sites) }\end{array}$ & 12 \\
\hline
\end{tabular}

Source: Ramsar (2019); UNESCO (2019a, 2019b).

\section{Protected and conserved areas in Uganda in} IUCN Governance Types

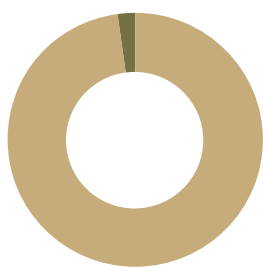

Not Reported (No. 13)

A.Governance by Government (No. 699)

National designations of protected and conserved areas in Uganda

\begin{tabular}{l|r|r}
\hline National designation & No. & Area $\left.\mathbf{( k m}^{2}\right)$ \\
\hline Sanctuary & 1 & 187 \\
\hline National Park & 10 & 11251 \\
\hline Wildlife Reserve & 12 & 8461 \\
\hline $\begin{array}{l}\text { Community Wildlife } \\
\text { Management Area }\end{array}$ & 5 & 4239 \\
\hline Forest Reserve & 661 & 12342 \\
\hline Wildlife Sanctuary & 7 & 554 \\
\hline
\end{tabular}

Source: UNEP-WCMC \& IUCN (2019w).

Priority areas for conservation

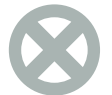

\section{4 sites}

Alliance for Zero

Extinction sites

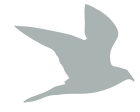

\section{4 sites}

Important Bird \&

Biodiversity Areas
5000 plant species
33 sites

Key Biodiversity

Areas 
Figure 8.44 Uganda protected areas

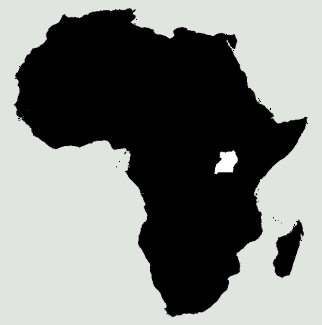

Protected Areas

Admin Boundary
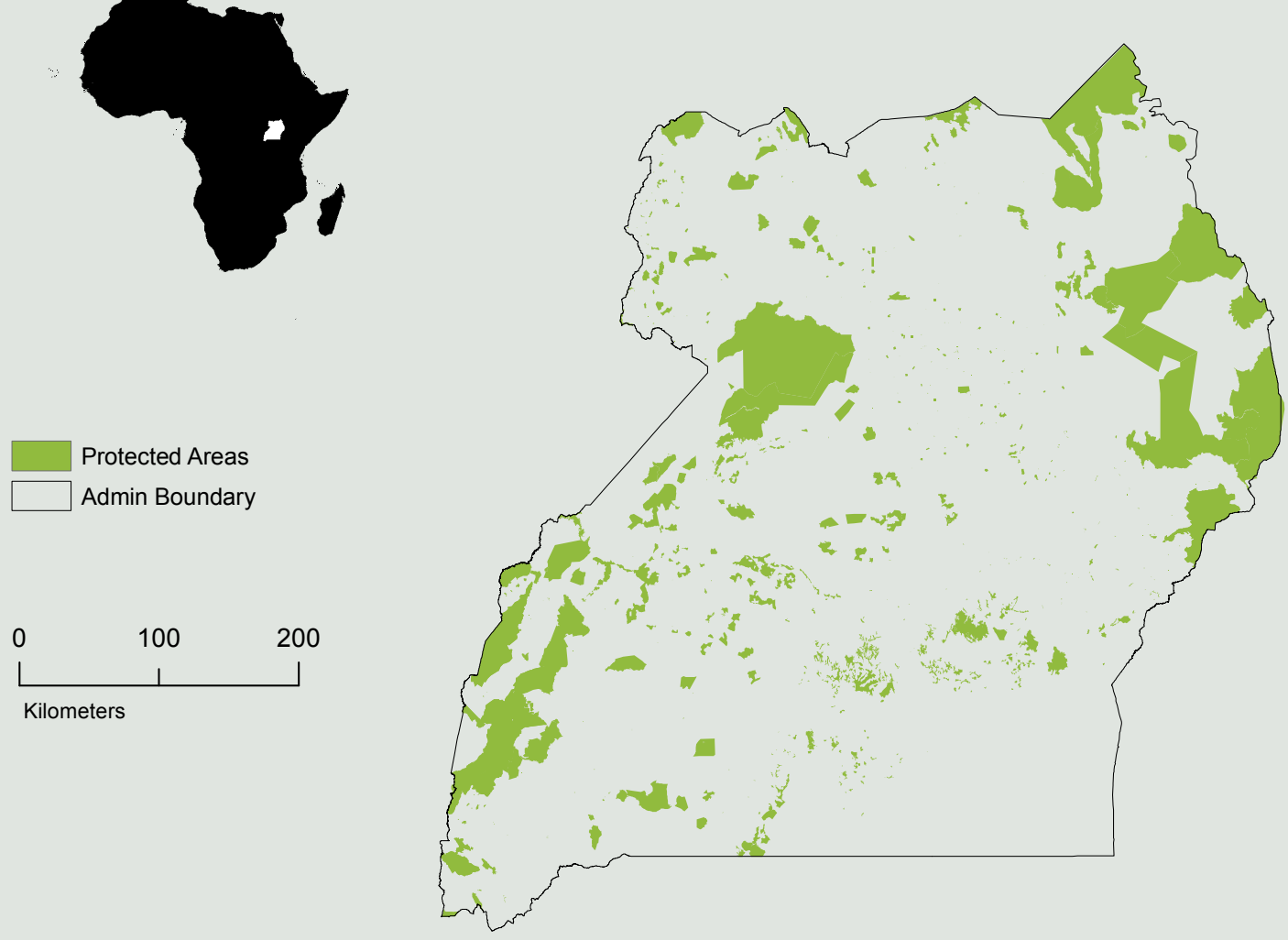

\section{Pressures and threats ${ }^{99}$}

Uganda has many threats to its biodiversity, the most serious of which is the loss and degradation of habitat. Encroachment is prevalent and human-wildlife conflict is a perennial and growing problem. Poaching and the illicit trade in wildlife is also a serious problem, as is destructive fishing practices. Alien invasive species pose particular threats to certain ecosystems.

The high rate of human population growth and the rapid development in Uganda are taking a toll on the remaining natural habitats in the country. High levels of poverty mean that people are still reliant on natural resources for survival.

99 The section draws on information contained in Uganda's Fifth National Report to the CBD and its Second NBSAP (Republic of Uganda, 2016; Uganda National Environment Management Agency, 2014). 


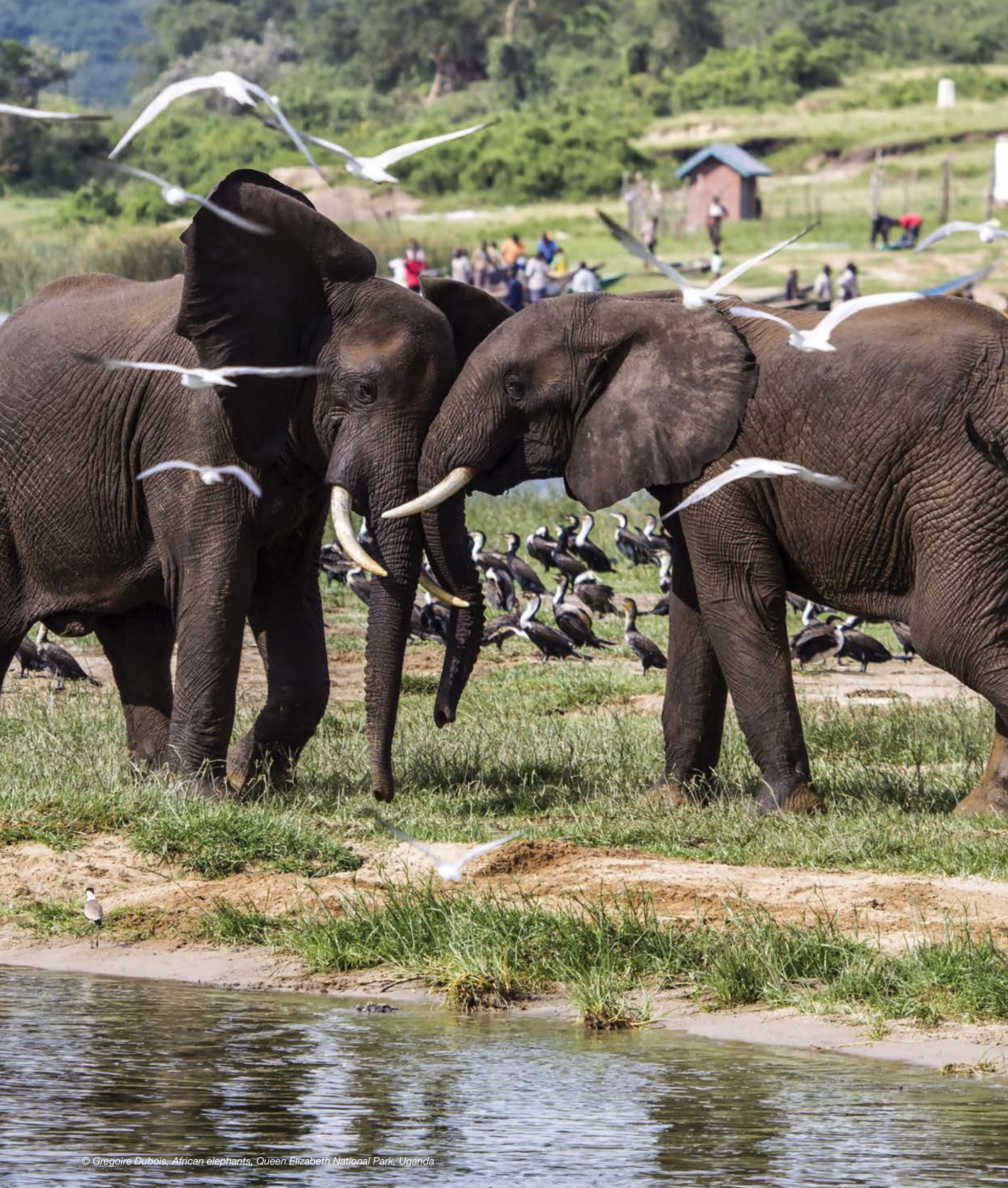




\subsection{Zambia}

\section{Protected and conserved areas in Zambia ${ }^{100}$}

Zambia has 635 protected areas covering $286,161 \mathrm{~km}^{2}$ of the land (UNEP-WCMC \& IUCN, 2019x).

A land-locked country in southern Africa comprising forests, Zambia's agro-ecosystems and wetlands are the most important ecosystems to the national economy and rural livelihoods. Biodiversity conservation to date has been undertaken through the management of the existing protected areas system, and promotion of sustainable utilisation of natural resources in open areas.

The key changes in the status of national parks, forest reserves and game management protected area system since 2009 have been the creation of a new Lusaka National Park, degazetting of some forest reserves and the identification of gaps of representation of plant and animal species within the existing national parks and game management areas as far as possible by the reclassification conservation plan to guide conservation action.

\section{Transboundary protected and conserved areas}

Zambia includes parts of six transboundary conservation areas, namely Kavango-Zambezi TFCA, Liuwa Plain-Mussuma TFCA, Lower Zambezi-Mana Pools TFCA, Malawi-Zambia TFCA, Mosioa-Tunya Nictoria Falls Transboundary World Heritage Site, and ZIMOZA TFCA.

\section{Policy context}

A comprehensive report on legislation and policy related to protected area management, governance and equity was undertaken by the BIOPAMA programme. It identified 79 relevant laws and policies in Zambia (Tessema, 2019).

\section{Key species ${ }^{101}$}

Zambia is home to over 12,500 species, of which almost 200 have been assessed as threatened according to the IUCN Red List. Almost 4,000 plant species and 563 micro-organisms have been recorded. There are 224 mammal species recorded, many of which are economically important through hunting and tourism, and 490 species of fish species. Zambia is also home to over 750 bird species, comparatively high for a landlocked country dominated by a single biome.

\section{Pressures and threats ${ }^{102}$}

Zambia's ecosystems face major threats: degazettement of forest reserves, mostly for purposes of mining; deforestation and habitat degradation; human encroachment into protected areas; uncontrolled late bush fires; overexploitation of certain tree species, as well as mammals for the bushmeat and illegal wildlife trade ,and overfishing of freshwater ecosystems; pollution from agriculture, mining and other industrial activities; and alien invasive species.

100 The section draws on information contained in Zambia's Fifth and Sixth National Reports to the CBD (Republic of Zambia, 2015; 2019).

01 The section draws on information contained in Zambia's Fifth National Report to the CBD (Republic of Zambia, 2015).

102 lbid. 
Figure 8.45 Zambia Summary

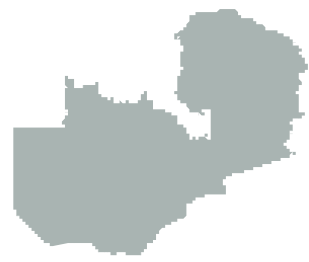

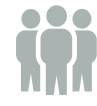

Total Population (millions)

17.35

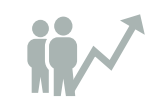

Population growth (annual \%)

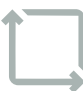

Surface area $\left(\mathrm{km}^{2}\right)$ (thousands) 752.60

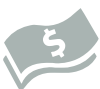

GDP (current US\$) (billions)

26.72
Protected and conserved areas in Zambia in IUCN Management Categories

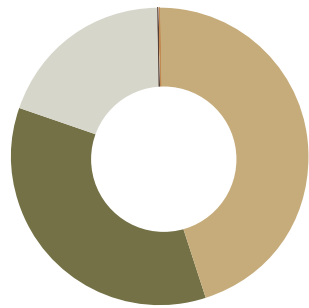

Not Applicable (No. 1)

Not Reported (No.562)

VI. Protected Area with Sustainable Use of Natural Resources (No. 36)

IV. Habitat/Species Management (No. 1)

III. Natural Monument (No. 16)

II. National Park (No. 19)

\section{Over 12500 species}

\section{of land}

Source: UNEP-WCMC \& IUCN, (2019x)

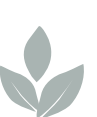

4000 plant species

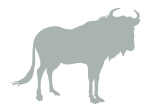

224 mammal species
490 fish species

\section{Coverage of protected areas in Zambia}

\begin{tabular}{l|r|r|}
\hline Type of protected area & $\begin{array}{r}\text { Area protected } \\
\text { or conserved }\end{array}$ & $\begin{array}{l}\text { Area protected } \\
\text { or conserved }^{\star *}\end{array}$ \\
\hline Terrestrial and inland water & $37.87 \%$ & $37.80 \%$ \\
\hline
\end{tabular}

*WDPA dataset $\quad$ ** From National Report on Biodiversity

Source: Republic of Zambia (2019); UNEP-WCMC \& IUCN (2019x).

Protected and conserved areas designated as global sites of importance in Zambia

\begin{tabular}{l|r}
\hline Global designation & No. of sites \\
\hline $\begin{array}{l}\text { UNESCO World Heritage Sites } \\
\text { (Natural or Mixed) }\end{array}$ & 1 \\
\hline $\begin{array}{l}\text { Wetlands of International Importance } \\
\text { (Ramsar sites) }\end{array}$ & 8 \\
\hline
\end{tabular}

Source: Ramsar (2019); UNESCO (2019a, 2019b).

Protected and conserved areas in Zambia in IUCN Governance Types

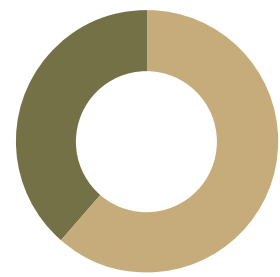

Not Reported (No. 586)

A.Governance by Government (No. 49)
National designations of protected and conserved areas in Zambia

\begin{tabular}{l|r|r}
\hline National designation & No. & Area $\left.\mathbf{( k m}^{2}\right)$ \\
\hline Conservation Area* & 1 & Unknown \\
\hline National Park & 19 & 60457 \\
\hline Natural Monument & 16 & 74 \\
\hline Game Management Area & 34 & 140447 \\
\hline Forest Reserve & 555 & 79893 \\
\hline Bird Sanctuary & 1 & 127 \\
\hline Source: UNEP-WCMC \& IUCN (2019x). & & \\
${ }^{*}$ This site had no reported area in the WDPA & & \\
& & \\
\hline
\end{tabular}

Priority areas for conservation

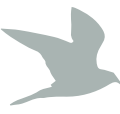

42 sites

Important Bird \& 6 sites

Biodiversity Areas Key Biodiversity Areas 


\section{Figure 8.46 Zambia protected areas}

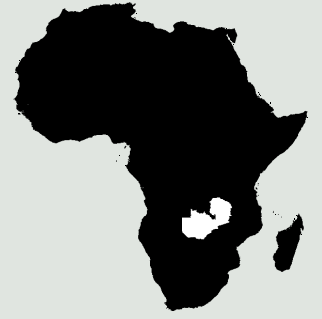

Admin Boundary
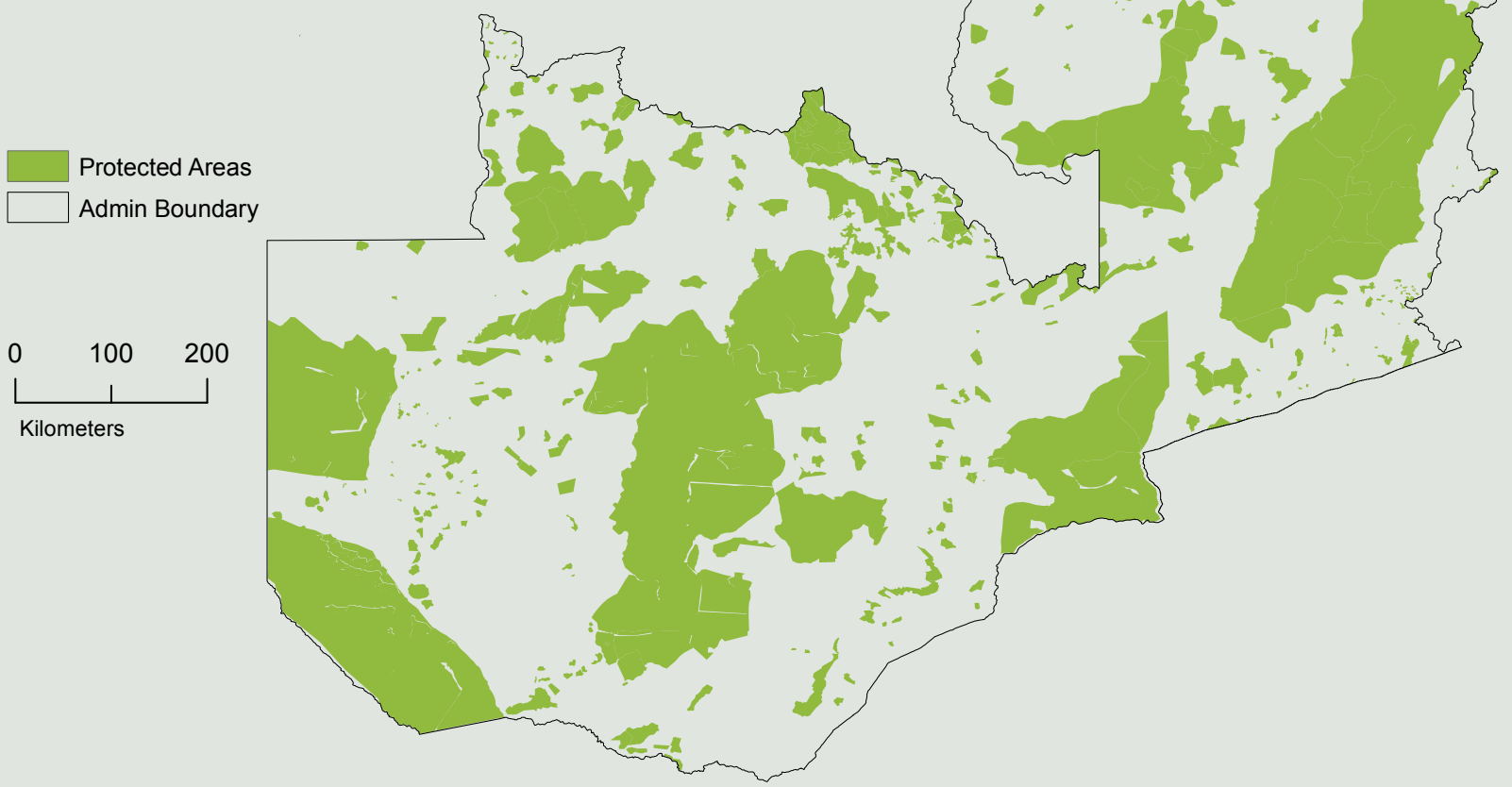

Developed by RCMRD based on WDPA data.

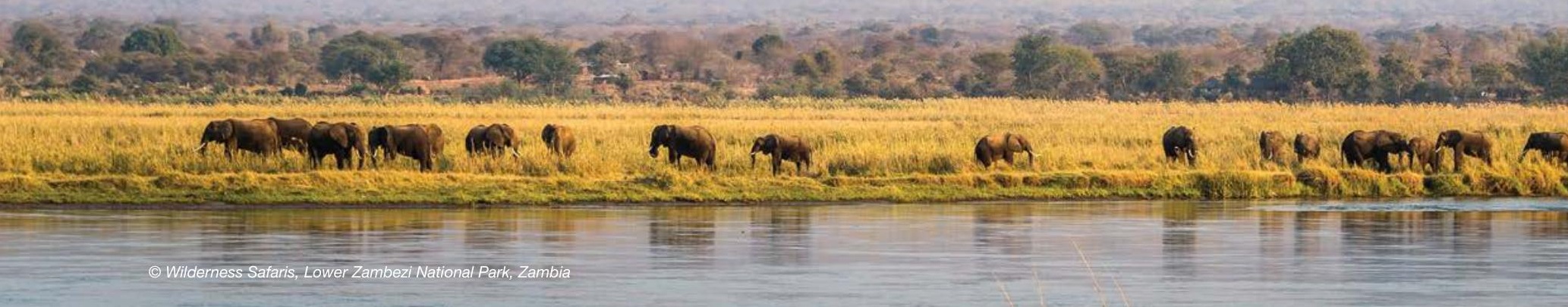




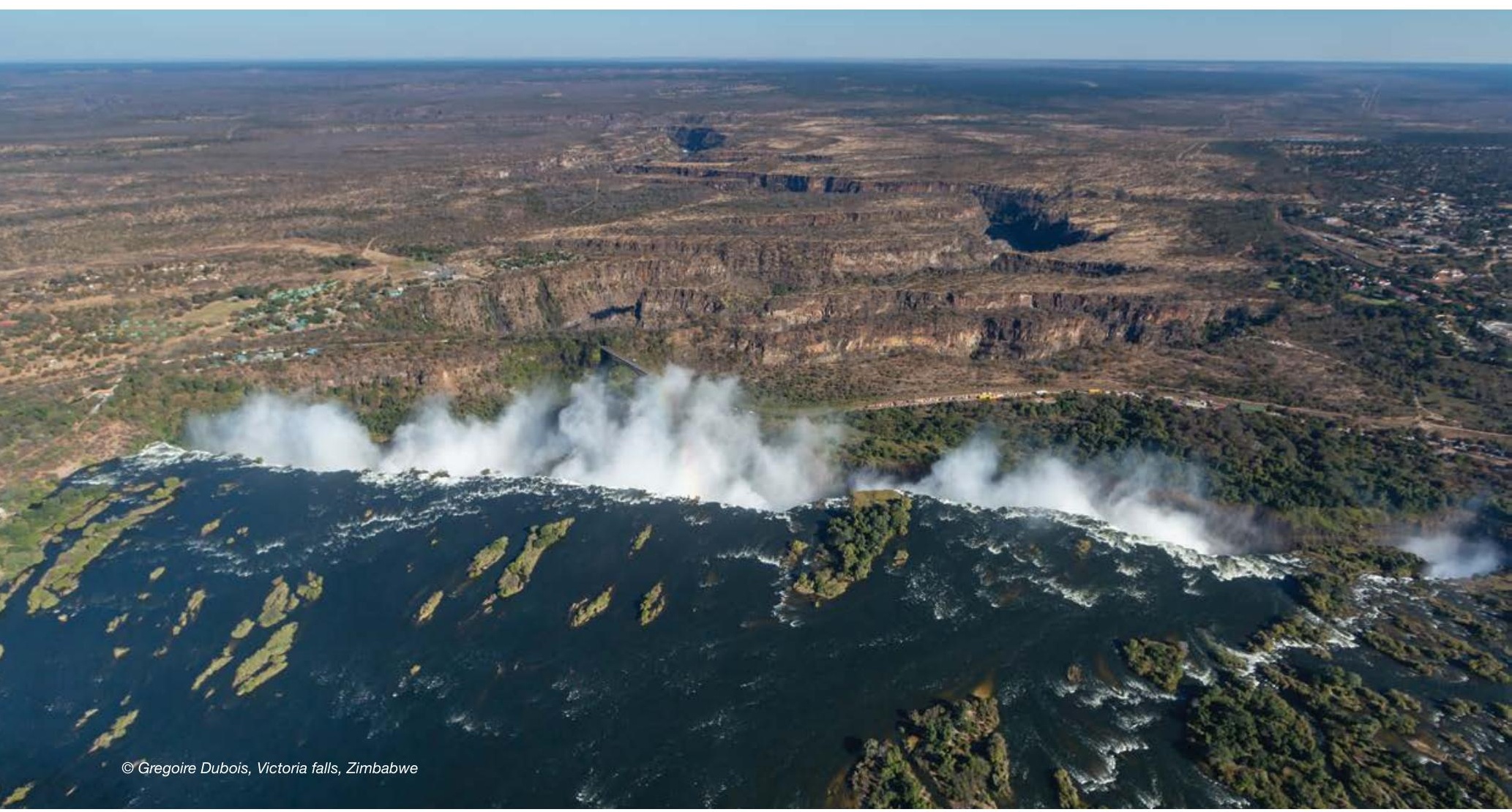

\subsection{Zimbabwe}

\section{Protected and conserved areas in Zimbabwe ${ }^{103}$}

Zimbabwe has 232 protected areas covering 106,838 $\mathrm{km}^{2}$ (UNEPWCMC \& IUCN, 2019y)

Zimbabwe has a rich history of biodiversity conservation. It has established an extensive protected areas network and enacted legislation for strict conservation and preservation in some areas and sustainable utilisation in others. Its protected areas network puts Zimbabwe among the top 50 countries globally with respect to protected area coverage. Biodiversity is an important base for Zimbabwe's economy and supports the livelihoods of the majority of its population. The policy framework and strategies that have been developed over the last decade acknowledge the importance of biodiversity conservation for sustainable development and biodiversity has been streamlined in all sectors.

The government introduced the CAMPFIRE programme to maximise the livelihood options for resettled farmers, particularly those living in areas where crop production has limited potential, by ensuring profitable, equitable and sustainable use of wildlife and other resources. CAMPFIRE projects involve communities in the co-management of wildlife in communal areas.

\section{Transboundary protected and conserved areas}

Zimbabwe includes parts of seven transboundary conservation areas, namely Chimanimani TFCA, Great Limpopo Transfrontier Park and Conservation Area, Greater Mapungubwe TFCA, Kavango-Zambezi TFCA, Lower Zambezi-Mana Pools TFCA, Mosi-oa-Tunya Victoria Falls Transboundary World Heritage Site and ZIMOZA TFCA.

\section{Policy context}

A comprehensive report on legislation and policy related to protected area management, governance and equity was undertaken by the BIOPAMA programme. It identified 25 relevant laws and policies in Zimbabwe (Tessema, 2019).

\section{Key species ${ }^{104}$}

Zimbabwe is home to almost 6,000 vascular plant species, of which 214 are endemic. There are 211 species considered threatened, but this is not a full count as only $10 \%$ have been assessed for threat status. Zimbabwe is also home to 670 bird species, 270 mammals, 156 reptile species, 120 amphibians and 151 fish species. There is limited knowledge of micro-organisms.

103 The section draws on information contained in Zimbabwe's Sixth National Report to the CBD (Republic of Zimbabwe, 2019).

104 The section draws on information contained in Zimbabwe's Fifth National Report to the CBD and its Second NBSAP (Republic of Zimbabwe, 2014, 2015). 
Figure 8.47 Zimbabwe Summary

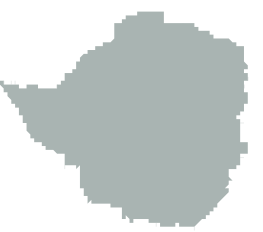

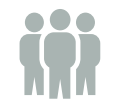

Total Population (millions) 14.44

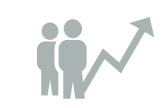

Population growth (annual \%)

1.40

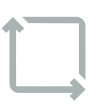

Surface area $\left(\mathrm{km}^{2}\right)$ (thousands) 390.80

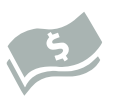

GDP (current US\$) (billions)

31.00

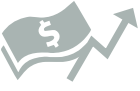

GDP growth (annual \%)

6.20
Area Protected:

232
protected
areas

Source: UNEP-WCMC \& IUCN, (2019y)

\section{Protected and conserved areas in Zimbabwe in IUCN} Management Categories

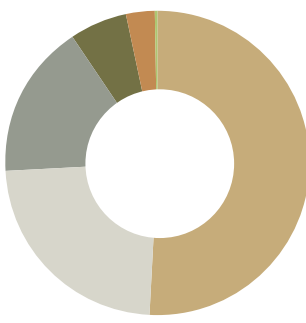

Not Applicable (No. 3)

Not Reported (No. 166)

VI. Protected Area with Sustainable

Use of Natural Resources (No. 19)

V. Protected Landscape / Seascape (No. 12)

IV. Habitat/Species Management (No. 19)

III. Natural Monument (No. 2)

II. National Park (No. 10)

Source: UNEP-WCMC \& IUCN (2019y).

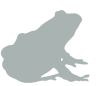

120 amphibians

151 fish species

156 reptile species

270 mammals

670 bird species

\section{Coverage of protected areas in Zimbabwe}

\begin{tabular}{l|r|r}
\hline Type of protected area & $\begin{array}{r}\text { Area protected } \\
\text { or conserved }\end{array}$ & $\begin{array}{r}\text { Area protected } \\
\text { or conserved }^{\star *}\end{array}$ \\
\hline Terrestrial and inland water & $27.21 \%$ & $28.00 \%$ \\
\hline
\end{tabular}

*WDPA dataset $\quad$ ** From National Report on Biodiversity

Source: Republic of Zimbabwe (2015); UNEP-WCMC \& IUCN (2019y).

Protected and conserved areas designated as global sites of importance in Zimbabwe

\begin{tabular}{l|r}
\hline Global designation & No. of sites \\
\hline UNESCO Man and Biosphere Reserves & 1 \\
\hline $\begin{array}{l}\text { UNESCO World Heritage Sites } \\
\text { (Natural or Mixed) }\end{array}$ & 2 \\
\hline $\begin{array}{l}\text { Wetlands of International Importance } \\
\text { (Ramsar sites) }\end{array}$ & 7 \\
\hline
\end{tabular}

Source: Ramsar (2019); UNESCO (2019a, 2019b).

Protected and conserved areas in Zimbabwe in IUCN Governance Types

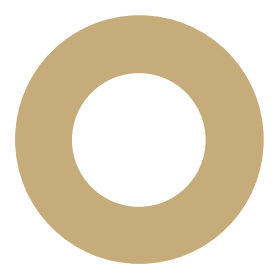

Not Reported (No. 232)

Source: UNEP-WCMC \& IUCN (2019y).
National designations of protected and conserved areas in Zimbabwe

\begin{tabular}{l|r|r}
\hline National designation & No. & Area $\left.\mathbf{( k m}^{2}\right)$ \\
\hline Sanctuary & 11 & 6660 \\
\hline National Park & 11 & 26896 \\
\hline Recreation Park & 9 & 3642 \\
\hline National Monument & 1 & 7 \\
\hline Wildlife Management Area & 104 & 39376 \\
\hline Botanical Reserve & 14 & 16 \\
\hline Nature Reserve & 1 & 17 \\
\hline Recreational Park & 3 & 129 \\
\hline Botanical Garden & 3 & 6 \\
\hline Safari Area & 16 & 18988 \\
\hline State Forest & 43 & 9341 \\
\hline Protected Forest & 6 & 608 \\
\hline
\end{tabular}

Source: UNEP-WCMC \& IUCN (2019y).

\section{Priority areas for conservation}

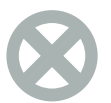

1 sites

Alliance for Zero

Extinction sites

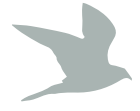

18 sites

Important Bird \&

Biodiversity Areas
6 sites

Key Biodiversity

Areas 
Figure 8.48 Zimbabwe protected areas

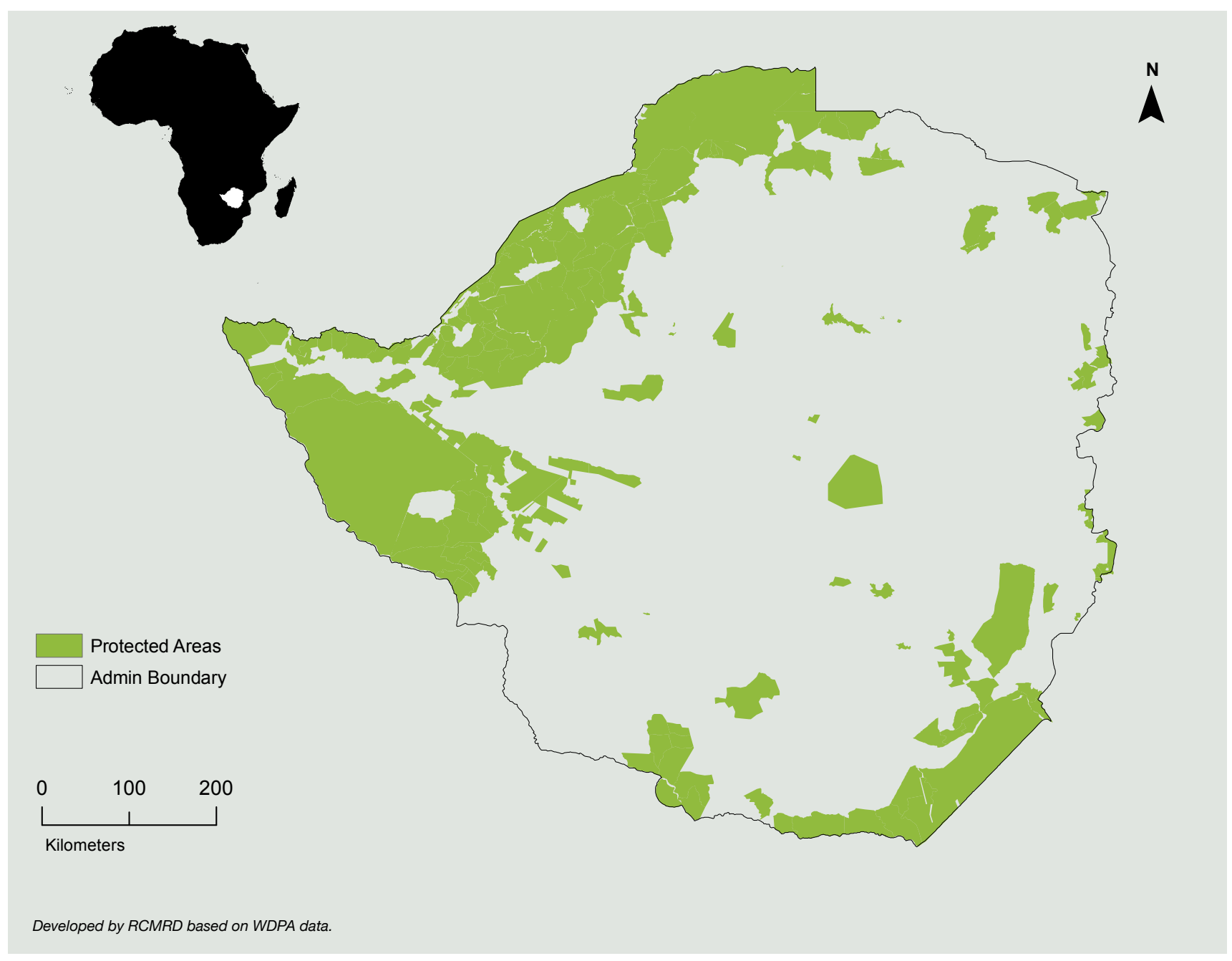

\section{Pressures and threats ${ }^{105}$}

The major causes of biodiversity loss in Zimbabwe are: habitat loss and degradation due to unsustainable agricultural expansion, overgrazing, use of trees as an energy source, fire damage, mining, and infrastructural development; invasive alien species; and climate change. Many birds, reptiles, amphibians and mammals are also directly threatened by illegal or unsustainable harvesting, for the illegal bushmeat wildlife trade. High levels of pollution in Zimbabwe's aquatic systems have also had a large impact on biodiversity in the country.

Underpinning these direct threats are the longer-term challenges of poverty, uncontrolled economic development and a lack of institutional capacity to sustainably manage natural resources. 

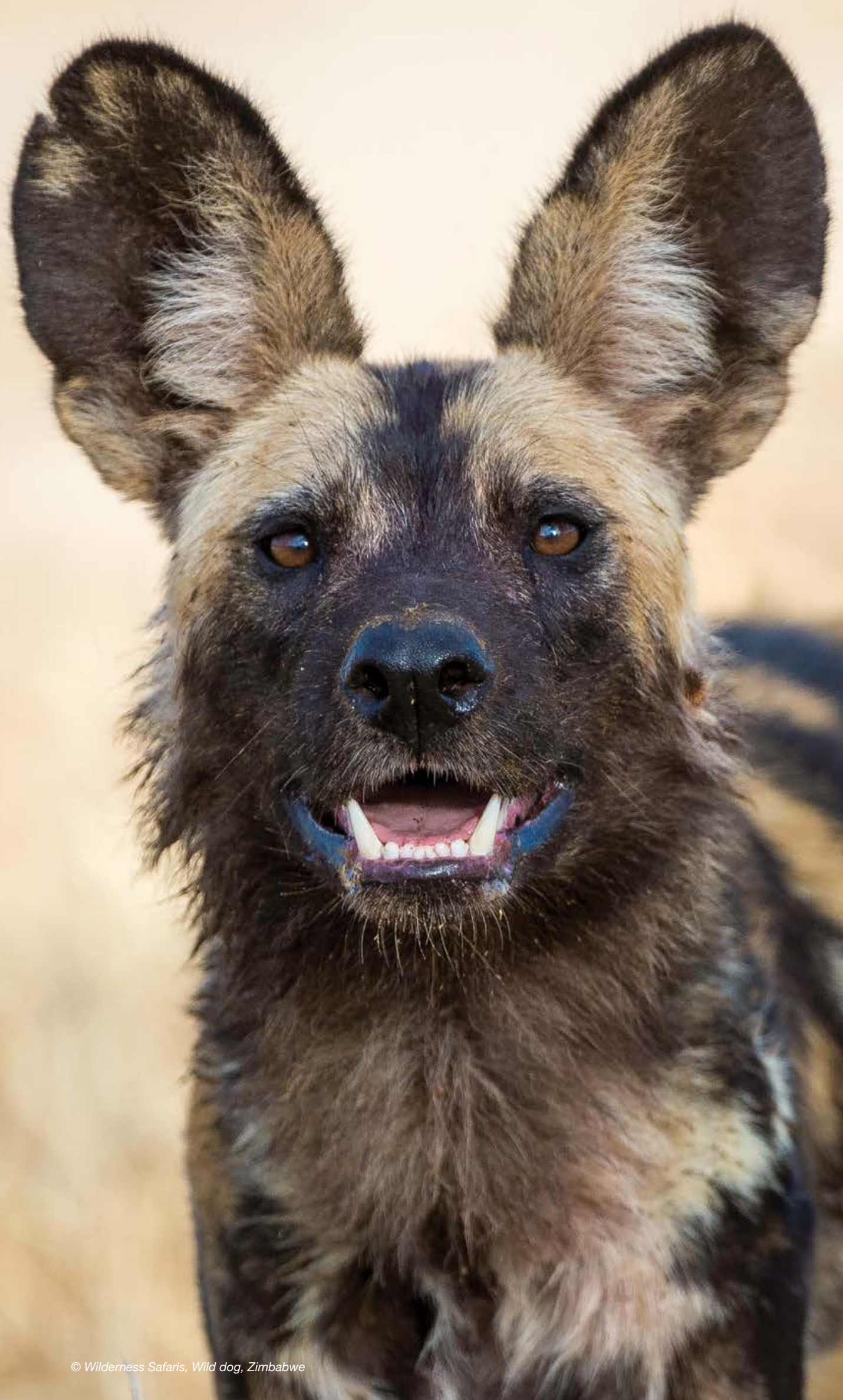

Part III - Governance and management effectiveness

\section{Protected area governance and equity $^{106}$}


Protected areas are a cornerstone of global conservation efforts; they protect biodiversity, restore degraded landscapes, provide ecological services and livelihood opportunities and remain a place for people to reconnect with nature. However, protected areas have also been a focus of frequent concerns about unfair outcomes for people, including social justice and human rights issues. Recent reports from the United Nations Special Rapporteurs have highlighted the breadth of these issues, particularly with regard to Indigenous Peoples and local communities (UN, 2016).

Since the early 1980s, these issues have been considered in the conservation community at the international level (McNeely \& Miller, 1984), and notably at the 2003 Vth IUCN World Parks Congress (IUCN, 2005a; 2005b). In 2010, Aichi Target 11, adopted by the 193 State Parties to the CBD, stated that protected areas must be equitably managed by 2020 (CBD, 2010b). The word 'equity' captures the notion of fairness, and the rationale for instilling it into area-based conservation is articulated in the text supporting the Programme of Work on Protected Areas (PoWPA): "Protected areas should also be established and managed in close collaboration with, and through equitable processes that recognise and respect the rights of indigenous and local communities, and vulnerable populations" (SBSTTA, 2010). These elements of Aichi Target 11 remain poorly reported on (Gannon et al., 2019). This is linked to both the complexity of the concept of equity, and to a lack of adequate assessment systems.

While there have been limited attempts to understand and assess equity in conservation, there has been substantial work on these issues in the similar context of payments for ecosystem services (McDermott et al., 2013). This work concludes that equity can be conceptualised as having three core dimensions: recognition, procedure and distribution.

In the context of protected area conservation, the three dimensions of equity can be understood as follows:

- Recognition refers to the acknowledgement of and respect for the rights and diversity of identities, values, knowledge systems and institutions of rights holders and stakeholders (see also Box 9.1).

- Procedure refers to transparency and accountability and inclusiveness of rule- and decision-making.

- Distribution refers to mitigating costs that affect Indigenous and local communities and equitable sharing of benefits resulting from the management of protected areas (Schreckenberg et al., 2016).

Based on this framework, CBD Parties adopted voluntary guidance on equity at COP14 in November 2018, which was intended to be applied in any context for nature conservation and sustainable development (CBD, 2018).

Enhancing equity increases the contribution of protected areas to human well-being both through increasing and more fairly sharing benefits and reducing costs (equity in distribution) and also through the direct contribution to subjective well-being of stronger recognition and respect for stakeholder (equity in recognition) and fairer processes (equity in procedure) (Franks et al., 2018). There is evidence to show that enhancing equity can contribute to more successful and effective biodiversity conservation (Oldekop et al., 2016).

In this chapter, two distinct but interrelated entry points for addressing equity in conservation are considered:

(1) By improving governance using governance assessments to identify governance weaknesses to be addressed and strengths to be reinforced; and

(2) By increasing benefits and reducing costs using social assessments to better understand the positive and negative impacts of protected areas on peoples' well-being.

Another avenue for increased equity in area-based conservation is the emerging concept of 'conserved areas'. Section 2.3 of this report addresses conserved areas in further detail and CBD's recognition of the concept through the term 'other effective areabased conservation measures' (OECMs).

\subsection{Governance of protected areas}

Governance is a powerful concept for equity, rights and livelihoods. Indeed, equity in conservation is first and foremost a matter of governance (Franks et al., 2018).

The definition of governance by IUCN takes a dynamic perspective: addressing governance is not just about understanding who makes the decisions, but it goes beyond to consider the interactions among structures, processes and traditions that determine how power and responsibilities are exercised, how decisions are taken, and how citizens and other stakeholders have their say (BorriniFeyerabend et al., 2013).

\section{Box 9.1 Rights holders vs stakeholders: What is the difference?}

In the context of protected and conserved areas, we refer to rights holders as actors socially-endowed with legal or customary rights with respect to land, water and natural resources.

Stakeholders on the other hand possess direct or indirect interests with respect to the natural resources, but they do not necessarily possess legal or social entitlement (Borrini-Feyerabend et al., 2013).

In the context of protected areas, governance is concerned with who is making decisions, how these decisions are made and how appropriate, adaptive and fair those decisions are to all concerned. This is critical as governance must consider a host of factors: from diverse actors to different processes and phenomena that lead to decisions being taken. It also addresses who has the mandate and resources to decide, and who should be held accountable and responsible for those decisions. 


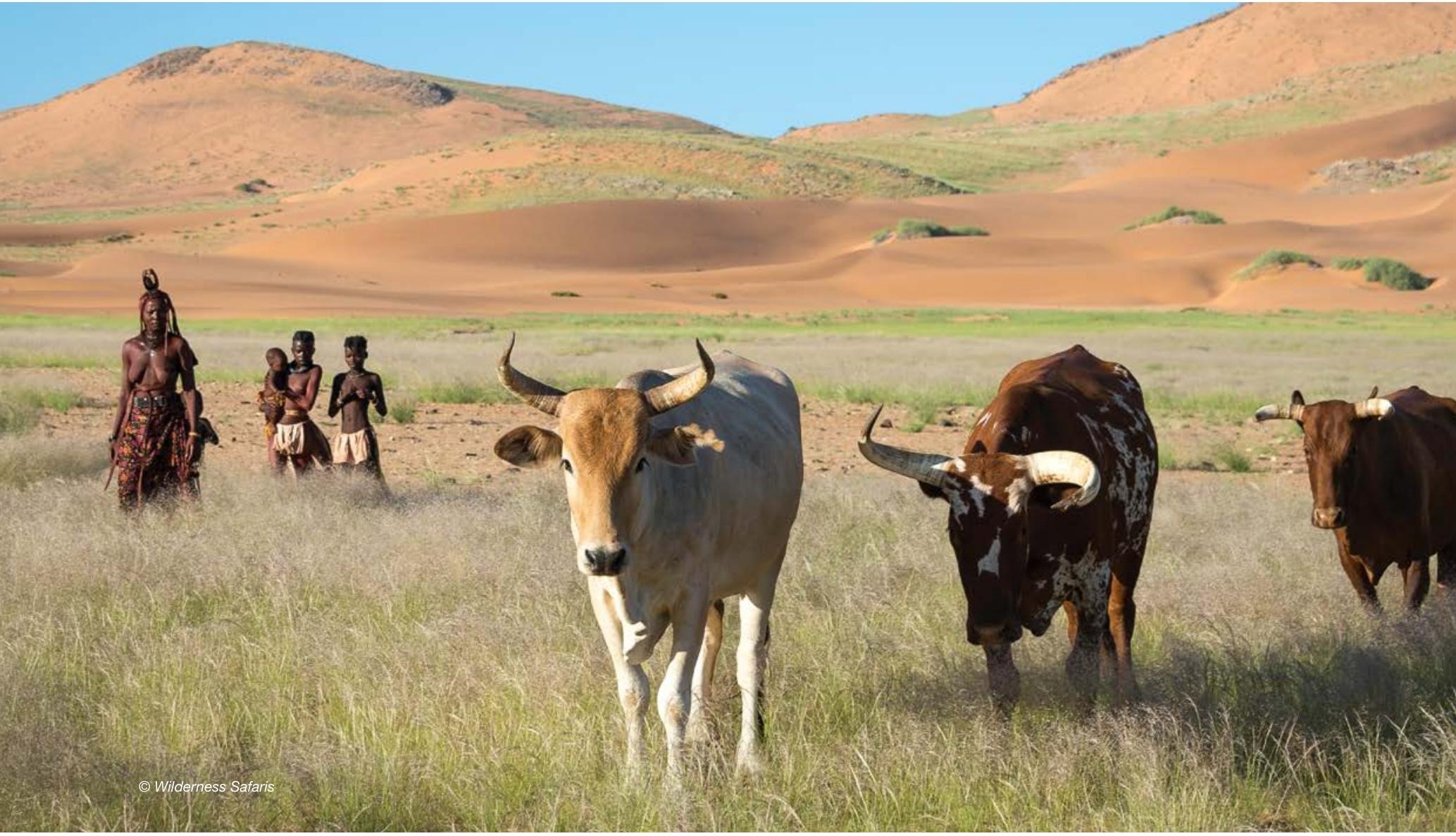

A mandate for governance can be legitimised either through de jure (legal) recognition as in the case of a government protected area agency or by de facto recognition where certain actors are regarded as legitimately taking decisions (for example, a community adopting their own no-go fishing rules for restoration), see Box 9.2.

Governance must be distinguished from management, although the two terms are closely linked. While management concerns the activities that are carried out to reach certain objectives, such as the activities and resources outlined in a management plan, governance is concerned with the actors who decided to draw up the management plan and what considerations were taken. Governance is commonly discussed and increasingly assessed in two dimensions, governance diversity (or governance type) and governance quality (or good governance).

\subsubsection{Governance diversity}

Governance diversity is concerned with recognising the broad spectrum of governance actors, both de jure and de facto, who hold responsibility and authority for protected areas. To date, most protected areas in the region have been established by state governments through laws and policies at the national level. This is reflected in the WDPA data (UNEP-WCMC \& IUCN, 2019b). However, many existing protected areas have their roots in some form of local governance arrangements, by communities in their own conserved areas or through private initiatives. In addition to government-run protected areas, there are protected areas that are established by Indigenous peoples, local communities, private individuals, ecotourism operators and others. As with the six management categories of protected areas ranging from strict nature reserves (Category la) to protected landscapes and seascapes with sustainable use of nature resources (Category VI), IUCN and the CBD also encourages full recognition of the diversity of governance types in national systems of protected areas. In this regards, four broad governance types for protected areas are recognised (see Table 9.1), which between them represent a full spectrum of governance diversity in the system of protected areas (Belle et al., 2015; Borrini-Feyerabend et al., 2013; CBD, 2004 \& 2010a; Dudley, 2008).

Across the continent of Africa, most protected areas are governed by government (type $A$ ) although types $B$ and $C$ are also represented but they are not always reported or well understood (UNEP-WCMC, 2019a; UNEP-WCMC \& IUCN, 2019a). Protected areas range from government-led national parks, to shared protected areas jointly governed by state agencies and communities, to privately owned reserves, as well as public-private partnerships between governments and private companies or NGOs. The fourth category, or Type D, perhaps least understood, but full of potential, is Indigenous peoples and communities conserved territories and areas (ICCAs). ICCAs are recognised not only in the CBD, but also in other international agreements and policy, and link strongly to UN instruments on human rights and Indigenous peoples. ICCAs may be counted as part of the national targets under Aichi Target 11 under the provisions for OECMs. Locally-managed marine areas 
Table 9.1 IUCN governance types for protected areas

\begin{tabular}{|c|c|}
\hline Governance type & Sub-types \\
\hline Type A: Governance by government & $\begin{array}{l}\text { - National Ministry or a protected area agency } \\
\text { - Sub-national agency (at all levels) }\end{array}$ \\
\hline Type B: Shared governance & $\begin{array}{l}\text { - Transboundary governance arrangements } \\
\text { - Collaborative governance (through various ways in which diverse actors and } \\
\text { institutions work together) } \\
\text { - Joint governance (pluralist board or other multi-party governing body) }\end{array}$ \\
\hline Type C: Private governance & $\begin{array}{l}\text { - Individual landowners } \\
\text { - Religious entities } \\
\text { - Non-profit or for-profit organisations }\end{array}$ \\
\hline $\begin{array}{l}\text { Type D: Governance by Indigenous people } \\
\text { and/or local communities (often called } \\
\text { ICCAs or territories of life) }\end{array}$ & $\begin{array}{l}\text { - Indigenous peoples' conserved territories and areas, established and run by } \\
\text { Indigenous peoples } \\
\text { - Community conserved areas - established and run by local communities }\end{array}$ \\
\hline
\end{tabular}

Source: Borrini-Feyerabend et al. (2013).

(LMMA) represent a governance model that is established and run with strong community and local government involvement (see Box 9.3) that may similarly be recognised as a protected area or OECM.

At the policy level, the PoWPA (CBD, 2004) has called upon Parties to the CBD to:

- support innovative types of governance for protected areas (see Box 9.3 for an example from Zimbabwe);

- acknowledge these in national legislation or via other effective means;

- seek equity and effectiveness in conservation while expanding coverage;

- intensify restoration efforts; and

- engage indigenous and traditional knowledge, skills and institutions.

It is critical to note that there is no universal and 'best' governance arrangement in any given context. It is more realistic to examine how appropriate, legitimate and useful these arrangements are in different circumstances. A governance arrangement for a given protected area can only be considered as appropriate when it is tailored to its historical and social context, and effective in delivering lasting conservation results and livelihood benefits. All the principles of governance quality identified in Section 9.1.2 should be applicable in any site regardless of governance type, though the level of involvement of stakeholders and rights holders will vary.

\subsubsection{Governance quality}

Encouraging the full spectrum of governance types in a national context is one of the key enabling conditions for equity (Schreckenberg et al., 2016), although it does not ensure that all such protected areas are being equitably or effectively governed.

At the site level, other concerns also emerge, such as:

- How are decisions being made about the protected area?

- Are those decisions equitable?

- Which values guide those decisions?

- How transparent is the decision making?

- Were rights holders (those with legal or customary right to land and resources) involved?

- Were stakeholders (those with a direct or indirect interest) included?
With these questions and drawing on the United Nations principles for good governance (Graham et al., 2003), a sense of governance quality, at times referred to as good governance (Table 9.2) begins to build up.

The principles of good governance offer ways to operationalise rights-based approaches, and address gender equity and equality, and the inclusion of marginalised groups. As such, good governance empowers rights holders and other stakeholders, allowing for the better integration of protected areas into the local landscape and the wider concerns of society (see Box 9.5).

Taken together, governance diversity and governance quality are the cornerstones of both equity in protected area conservation and the long-term effectiveness of biodiversity conservation (de Koning et al., 2016; Eklund \& Cabeza, 2017; Gutiérrez et al., 2011; Schultz et al., 2015; Stoll-Kleeman et al., 2006).

Reporting on governance diversity and quality using governance assessment is now a key area of focus in the conservation community (see section 9.4).

\subsection{Good governance and the IUCN Green List of Protected and Conserved Areas}

As described in Section 2.4, the IUCN Green List of Protected and Conserved Areas Standard (IUCN Green List Standard) is the new international sustainability standard to benchmark protected and conserved areas that are both effective and equitable (Hockings et al., 2019).

The IUCN Green List Standard describes a globally consistent set of 17 criteria categorised under four components, accompanied by 50 indicators for protected and conserved areas, for successful conservation at the site level. The first component of the standard focuses on good governance or governance quality.

Sites that voluntarily commit to joining the IUCN Green List programme as a candidate site will first examine the criterion of the IUCN Good Governance component which concerns legitimacy 


\section{Box 9.2 Kick-starting marine conservation through local fisheries management}

In Andavadoaka, Madagascar, voluntary and temporary closures of octopus fishing grounds are used as a point of entry for community-based conservation. Closures typically cover $25 \%$ of a community's overall octopus fishing area and are in place for 2-3 months at a time. There is compelling evidence that this improves fishery yields and local incomes, thereby building support to protect natural resources through locally managed marine areas (LMMAs), areas where the management of marine resources are at least in part under community control. LMMAs often employ marine management strategies, such as bans, on destructive fishing practices and communityenforced permanent no-take zones.

Some of the challenges experienced in the region include climate change, overfishing, rising coastal poverty and food insecurity and lack of conservation incentives. Many marine conservation efforts fail. Top-down declaration that large areas are permanently off-limits to fishing all too often puts conservation at loggerheads with the needs of coastal communities, disenfranchising the people who depend on fisheries for their livelihoods. For many tropical coastal communities, forgoing fishing in protected areas represents extremely severe economic sacrifice and significant opportunity cost.
Research into the effectiveness of the octopus closures has shown that they can improve catches and income, with landings from closed fishing sites increasing by more than $700 \%$ in the month following the lifting of a closure, boosting the catch per fisher per day by almost $90 \%$ over the same period. In Madagascar, the success of early closures has led to other communities following suit, with more than 270 closures having taken place to date. Adoption continues to grow each year, not only in Madagascar, but now in other countries in the region. The approach has also been introduced to artisanal fisheries for mud crab and spiny lobster. Following the successful establishment of the closures, fishing communities across Madagascar have grouped together to establish more than 190 management associations and 70 LMMAs that ban destructive fishing practices. MIHARI, Madagascar's LMMA network, now covers over $17 \%$ of the island's seabed, and is championed at the highest levels of government. At the end of 2017, Blue Ventures' work in Madagascar is improving the lives of over 200,000 people. The imperative now is to bring this successful approach to coastal communities across the Indian Ocean.

Contributed by Rupert Quinlan (Blue Ventures, Madagascar).

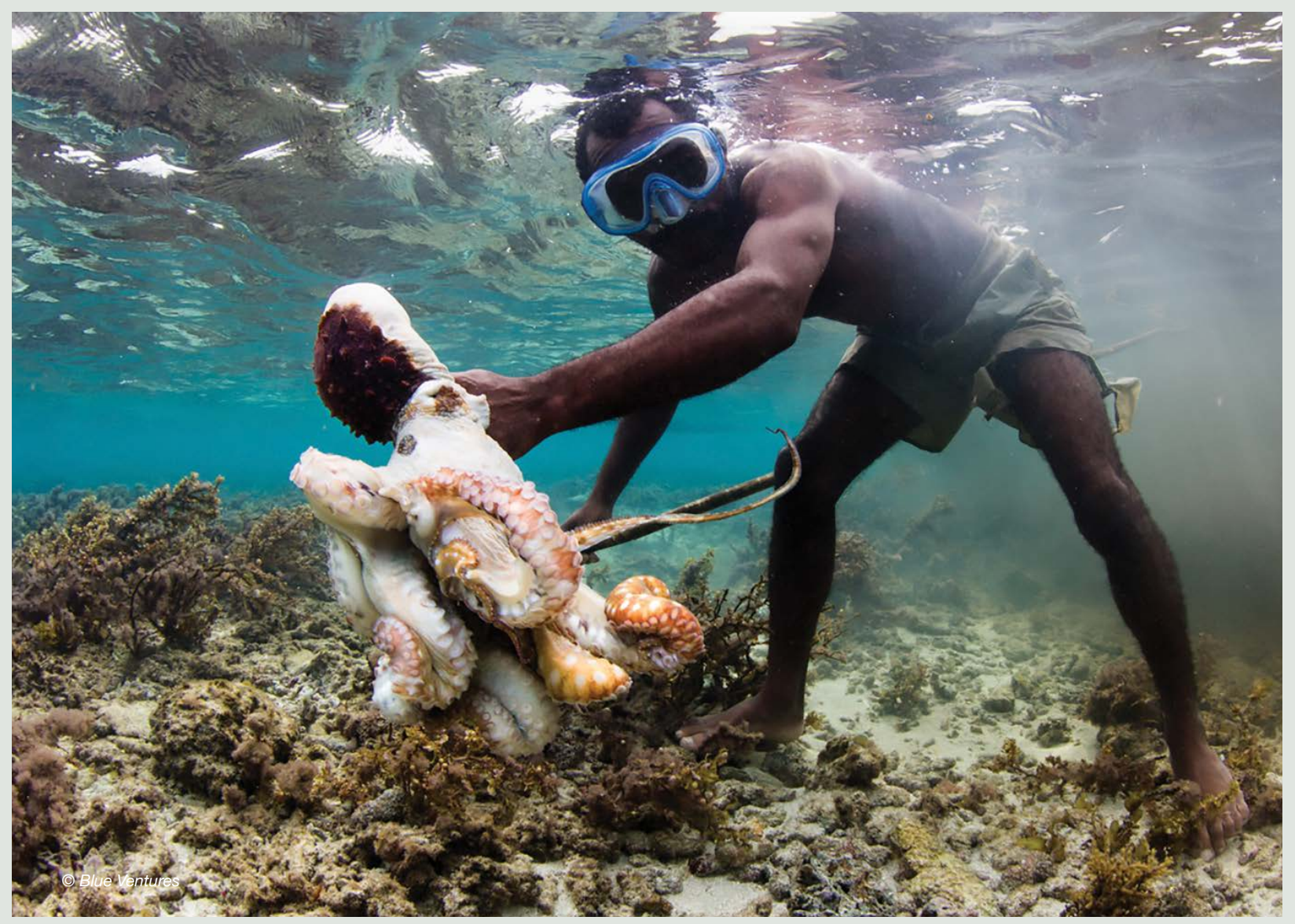


and voice. This seeks to ensure that a fair, functioning and legitimate governance authority is in place, and that it considers the voices and interests of all concerned local rights holders and stakeholders in a meaningful way. The assessment begins with the governance authority itself, and examines the legitimacy of the authority and how it functions. Thereafter, the standard seeks to ensure that active dialogue is being maintained with all rights holders and stakeholders, in particular women. The focus is on finding solutions that meet, at least in part, the concerns and interests of everyone, while promoting mutual respect amongst all actors.

The second criterion of the IUCN Good Governance component seeks to ensure that the governing authority are held accountable to the public as decision makers, including that people know who is responsible and answerable about the fulfilment of differing responsibilities at various levels. This is to uphold the integrity and commitment of all decision-makers, while ensuring that the avenues to demand accountability are accessible to all.

The third and final criterion concerns governance vitality. It examines the extent to which planning and management draw on the best available knowledge of the social and ecological context of the site, and use an adaptive management framework that anticipates, learns and responds. In particular, the criterion focuses on whether there are procedures in place to ensure that the results from monitoring inform management decisions. This can include whether management considers historical changes which will help to inform future projections of social, ecological and climate conditions. It examines the responsiveness of decisions to issues raised by rightsholders and stakeholders. An example of the deployment of the IUCN Green List is outlined in Box 9.6.

\subsection{Measuring and assessing governance}

Governance assessment approaches range from rapid assessment and evaluation processes, to participatory assessment processes that may comprise research, validation and discussion with a wider variety of actors such as government authorities, rights holders and stakeholders, as well as conservation specialists. The particular process of governance assessment should be chosen once the scale and scope of interest has been decided. Governance assessment should be seen as a social and political process beginning with a diagnostic analysis of issues, moving towards a solution and action-oriented component. Assessments can be undertaken at multiple scales and multiple tools have been developed for different objectives (Campese \& Sulle, 2019).

\section{Box 9.3 Governance diversity in action: initiating locally-managed marine areas to combat fish decline in Kuruwitu, on the North Kenya coast}

Kuruwitu Conservation and Welfare Association (KCWA) was set up in 2003 by members of the community concerned about the degradation of their seas. On the north Kenya coast, overfishing and effects of climate change needed to be addressed before the marine ecosystem was damaged beyond repair. Fishers and concerned residents who remembered how healthy and productive the sea had been in the past felt it necessary to act before it was too late. In 2005, they took the unprecedented step of setting aside a 30-hectare MPA. This was the first coralbased locally managed marine area (LMMA) in Kenya. Twelve years on, the area has made a remarkable recovery. With fishing prohibited within the MPA, fish have grown in abundance, size and diversity. Fish catches have improved, and alternative income generating enterprises have been introduced. Kuruwitu has become a model for sustainable marine conservation, with KCWA sharing their knowledge with other local and regional coastal communities regularly.

The development of sustainable non-fishing-based initiatives, such as crafts, furniture making, bee-keeping and tailoring, has shifted dependence on subsistence fishing thus taking pressure off the fishing grounds. Fish stocks have improved dramatically within the LMMA, and an independent report shows a considerable increase in fish biomass and biodiversity of all marine life in the area. This has increased fish catches in the neighbouring fishing grounds and improved livelihoods. Turtles and nests in the area are protected through a community compensation scheme. Communities from along the coast and from other neighbouring countries visit Kuruwitu to see our living classroom. At least 20 other similar projects have started by other coastal communities inspired by KCWA.

KCWA demonstrated the importance of community involvement in natural resource management plans; a principle that has influenced a change of policy away from the state to the local communities. Kuruwitu has been chosen to pilot a comanagement initiative working with various stakeholders covering an area of approximately 100 square kilometres. This is one of the first collaborative management schemes of its kind on the Kenyan coast and will set a precedent in the future.

Contributed by Des Bowden (Kuruwitu Conservation and Welfare Association). 


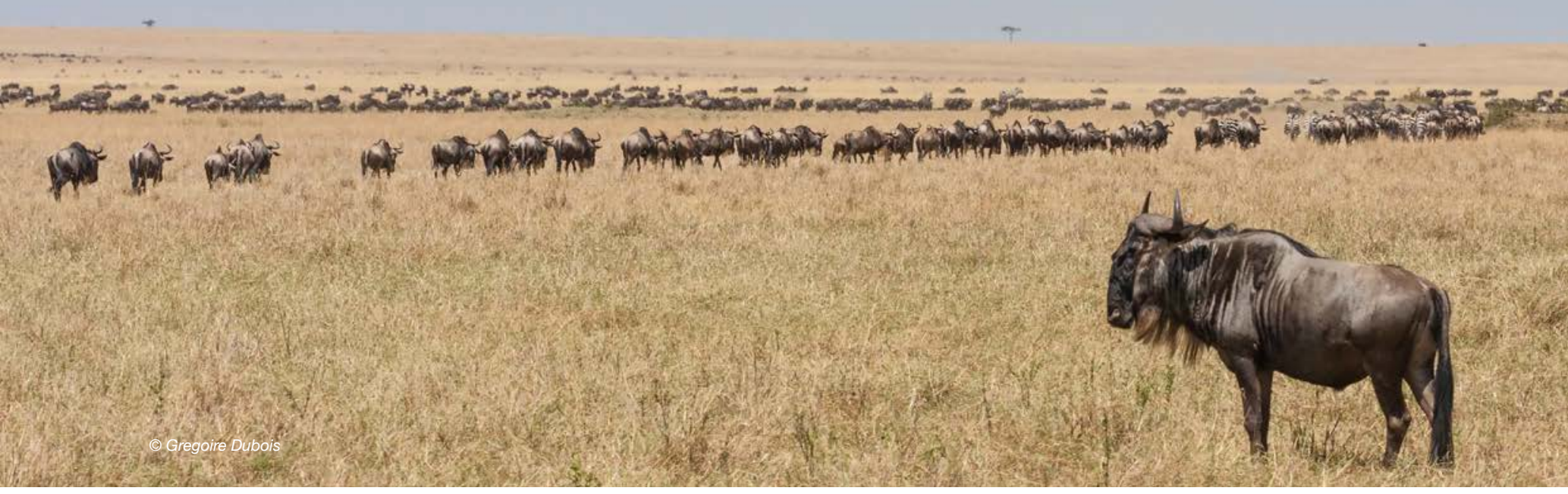

\section{Box 9.4 Co-management of Gonarezhou National Park}

Gonarezhou National Park is Zimbabwe's second largest National Park, spanning an area of $5,053 \mathrm{~km}^{2}$. It is a member of the Great Limpopo Transfrontier Park (GLTP), which includes Kruger National Park in South Africa and Limpopo National Park in Mozambique, covering a combined area of $36,000 \mathrm{~km}^{2}$.

In 2007, the Zimbabwe Parks and Wildlife Management Authority (ZPWMA) partnered with the Frankfurt Zoological Society (FZS) to establish the Gonarezhou Conservation Project, which provided financial and technical assistance to ZPWMA operations on the ground. Despite significant successes in the general protection and conservation of the Park, it was still felt that the park's potential was not being realised, and that the management model in place at the time was not sufficiently geared towards acting on the specific opportunities and threats presented by this complex landscape. Long-term financial sustainability was not being addressed, staffing levels were insufficient to pursue key biodiversity projects, such as the reintroduction of Black Rhino, and relationships with neighbouring communities were weak and conflict-ridden.

The situation led to a review of the partnership in 2013, culminating in the establishment of the Gonarezhou Conservation Trust in 2017 , a purposefully mandated entity and co-management model between ZPWMA and FZS. The Gonarezhou Conservation Trust is tasked with the day-to-day management and development of Gonarezhou National Park for the next 20 years. The formation of the Trust builds on the reputation of Zimbabwe's Wildlife authority to be willing to embrace change and to search for innovative solutions, such as the establishment of CAMPFIRE in the 1980s which directly involved communities in wildlife management and introduced benefit sharing.
The key aspects of the Trust include:

- governed by a Board of Trustees, with equal representation between ZPWMA and FZS;

- devolved management, headquartered in the park;

- responsibility for all management costs;

- directly in charge of all staff;

- a stated focus on local employment and building meaningful relationships with communities; and

- retention all tourism income, and in control of tourism planning and development.

One of the challenges has been to overcome some distrust on both local and national levels, which is derived from the perception that management of a Zimbabwean national asset has been outsourced. It has required setting structures in place at park level (such as human resources, tourism management), which used to be the responsibility of the ZPWMA headquarters, and building a sustainable funding base needed to cover all management costs.

The Trust has:

- invested heavily in law enforcement, significantly reducing poaching levels;

- pioneered a community engagement model 'Mphfuka' (pilgrimage), based on communities being a key part of the conservation-centred economy; and

- begun re-developing its tourism offering in an effort to make tourism work for conservation and communities, and not the other way around.

Through the gains made, not only in law enforcement but in relationships with communities, and the growing presence of tourists to the park, the key issues prompting the formation of the Trust are steadily being addressed.

Contributed by Elsabé van der Westhuizen (Frankfurt Zoological Society). 


\section{Box 9.5 Working with communities for conservation}

The Peregrine Fund (TPF) started its work in Madagascar in 1990. The country programme aims at conserving threatened endemic species, in particular birds of prey, water birds and other biodiversity, in order to prevent extinction of these species and to preserve their habitats. TPF focuses on national capacity building on biodiversity conservation for staff, students and local communities.

Since 1991, TPF has worked at the Manambolomaty wetland area (a Ramsar Site) surrounded by a typical tropical dry forest in western Madagascar. The area is home to many water birds, including more than $12 \%$ of the global population of the raptor species Madagascar fish eagle (Haliaeetus vociferoides), a critically endangered species, endemic to Madagascar. Overfishing at the site in the 1990s threatened the population of the Madagascar fish eagle, resulting in the need for a process to manage the areas to protect the critically endangered bird species and other biodiversity as well as improve the livelihood of the local communities.

Since 2001, TPF has worked closely with local associations to manage the lakes and surrounding forest. Meetings with stakeholders (heads of villages, local authorities and the community) were convened. From these meetings, a roadmap for natural resources management was developed. It included fish opening and closing period, a core area inside the lakes, limits on the number of fishermen and a temporary camp for the fishermen.
Furthermore, an alternative livelihoods programme was developed to provide school support and agricultural equipment for farm activities. Working closely with regional agencies, capacity building activities in fish and forest management were organised for the communities.

TPF worked closely with members of local associations to assist with management and surveillance of the reforestation program. Each year, through the programme, members planted seedlings. The programme provided fibre canoes to fishermen with the aim of decreasing the felling of big trees for wood canoes.

Nowadays, the local community is convinced of the importance of natural resources for their future generation. Very few trees have been removed from the protected area and the local communities are active in planting trees. Income from fish management has increased, their children are able to go to school, farm and agricultural activities are more lucrative. After 18 years of collaboration with local communities, this protected area is considered an important site for communitybased conservation in Madagascar.

\section{Contributed by Lily-Arison Rene de Roland (The Peregrine} Fund, Madagascar).

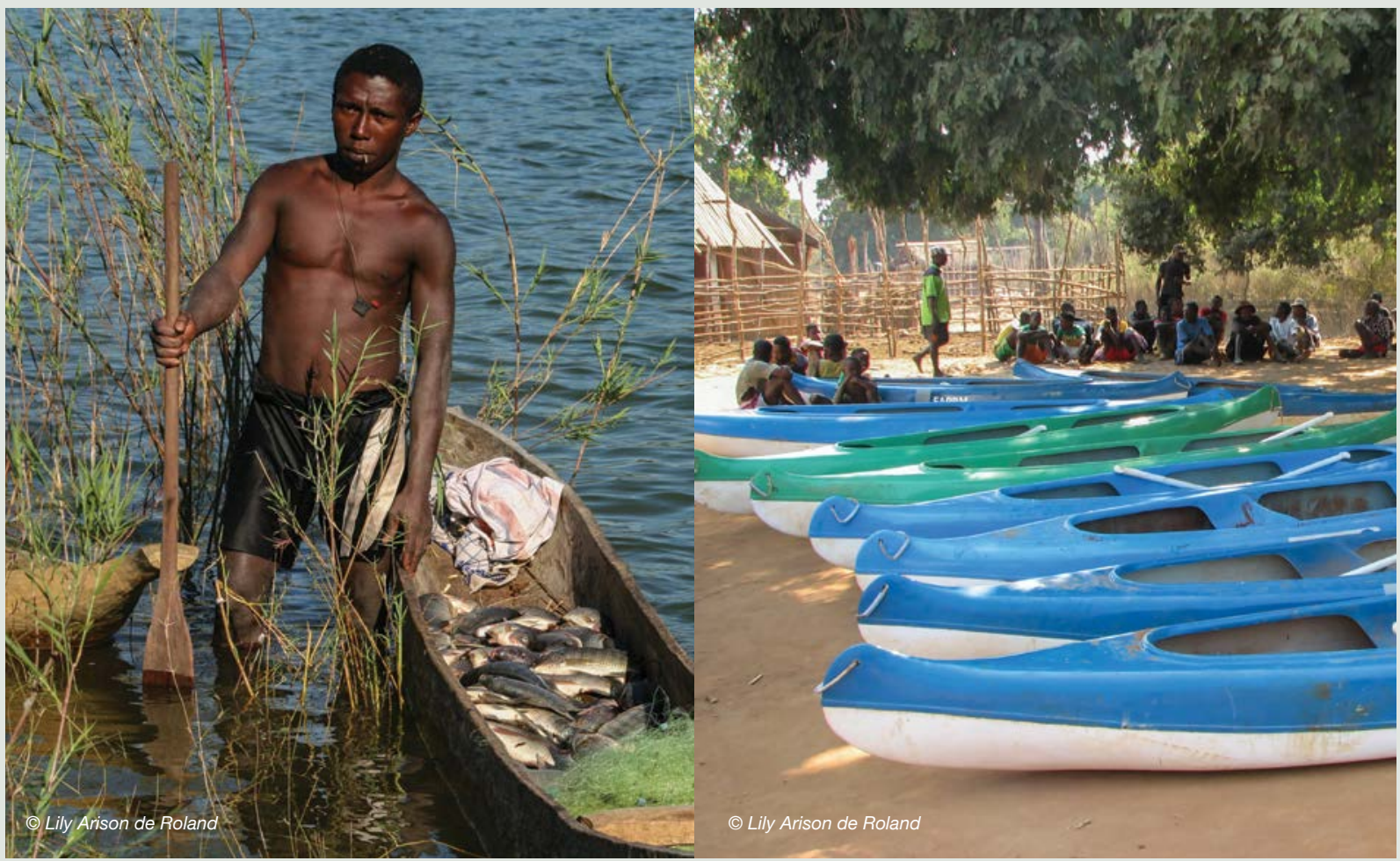




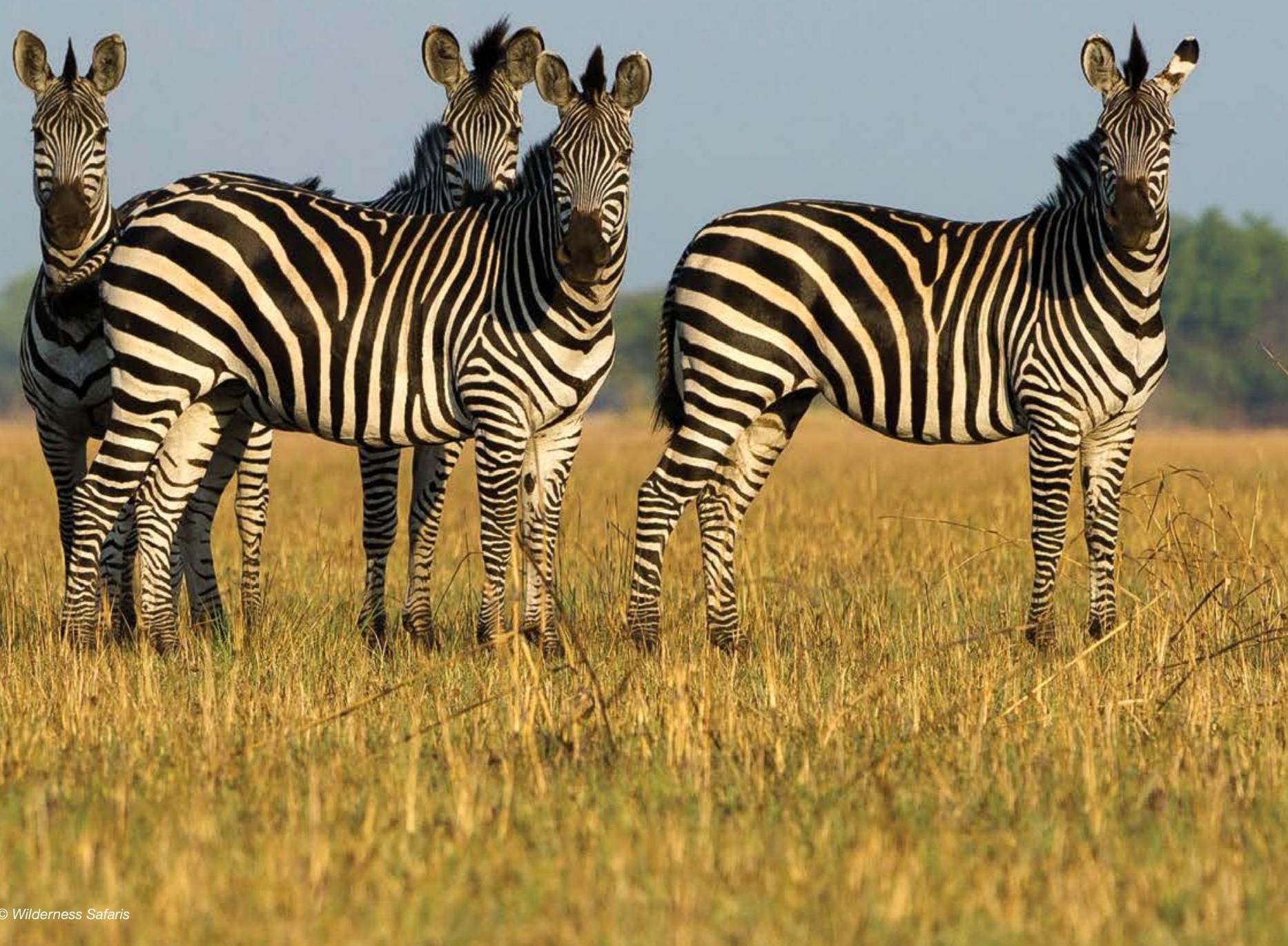




\section{Table 9.2 IUCN principles of good governance for protected areas}

\begin{tabular}{|c|c|}
\hline Principles & Considerations related to the principles \\
\hline $\begin{array}{l}\text { Legitimacy and } \\
\text { voice }\end{array}$ & 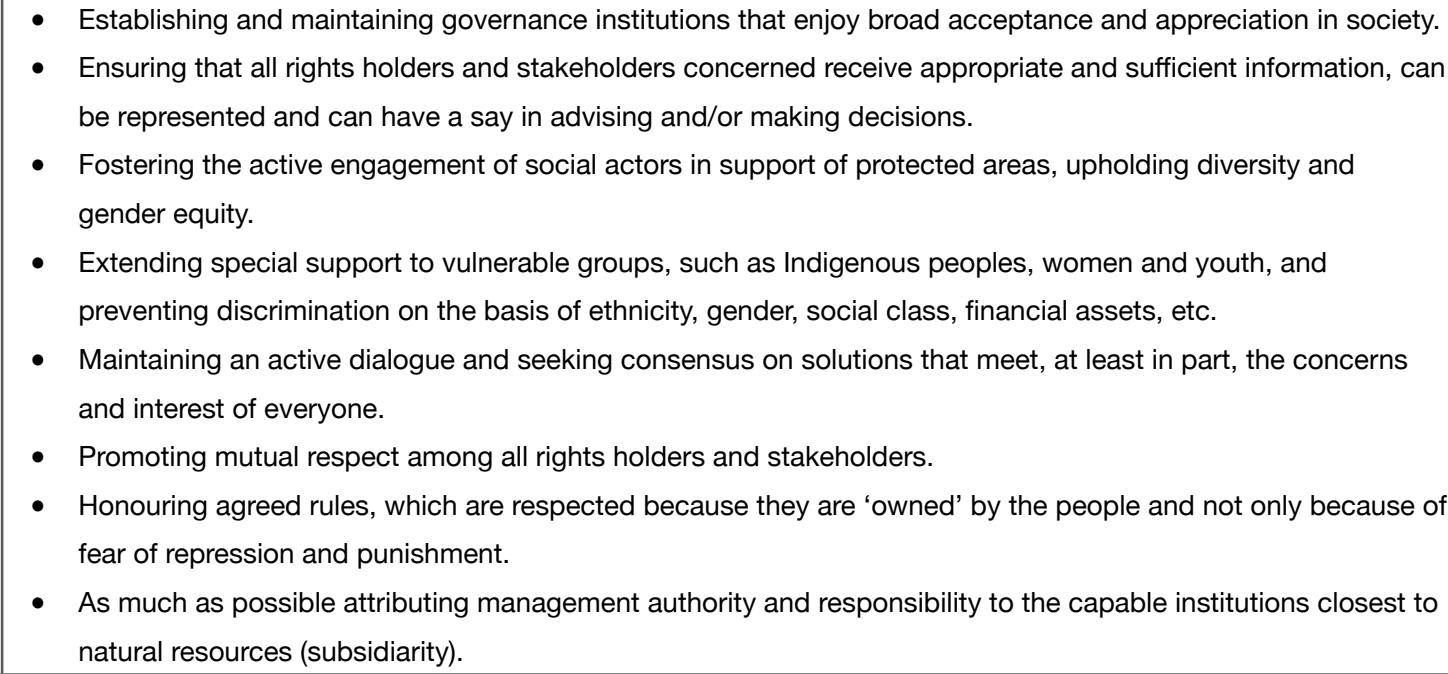 \\
\hline Direction & $\begin{array}{l}\text { - Developing and following an inspiring and consistent strategic vision (broad, long-term perspective) for the } \\
\text { protected areas and their conservation objectives, grounded on agreed values and an appreciation of the } \\
\text { ecological, historical, social and cultural complexities unique to each context. } \\
\text { - Ensuring that governance and management practice for protected areas are consistent with the agreed } \\
\text { values. } \\
\text { - Ensuring that governance and management practice for protected areas are compatible and well-coordinated } \\
\text { with the plans and policies of other levels and sectors in the broader landscape/seascape, and respectful of } \\
\text { national and international obligations (including CBD PoWPA). } \\
\text { - Providing clear policy directions for the main issues of concern for the protected area, in particular contentious } \\
\text { issues (e.g., conservation priorities, relationships with commercial interests and extractive industries), and } \\
\text { ensuring that those are consistent with both budgetary allocations and management practice. } \\
\text { Evaluating and guiding progress on the basis of regular monitoring results and a conscious adaptive } \\
\text { management approach. } \\
\text { Favouring the emergence of 'champions', generating new ideas and carefully allowing/promoting the testing of } \\
\text { innovations, including governance and management innovations for protected areas. }\end{array}$ \\
\hline Performance & $\begin{array}{l}\text { - Achieving conservation and other objectives as planned and monitored, including through on-going evaluation } \\
\text { of management effectiveness. } \\
\text { - } \text { Promoting a learning culture for protected area policy and governance practice on the basis of mechanisms, } \\
\text { - } \text { Engaging in advocacy and outreach for the benefit of protected areas. } \\
\text { - Being responsive to the needs of rights holders and stakeholders, including by providing timely and effective } \\
\text { - Ensuring that protected areas staff, rights holders and stakeholders, as appropriate, have the capacities } \\
\text { - } \text { necessary to assume their management roles and responsibilities and that those capacities are used } \\
\text { - } \text { Promoting an efficient use of financial resources and promoting financial sustainability. } \\
\text { and emerge strengthened from the experience. }\end{array}$ \\
\hline
\end{tabular}




\begin{tabular}{|c|c|}
\hline Principles & Considerations related to the principles \\
\hline Accountability & $\begin{array}{l}\text { - Upholding the integrity and commitment of all in charge of specific responsibilities for the protected areas. } \\
\text { - Ensuring transparency, with rights holders and stakeholders having timely access to information about: what is } \\
\text { and howe in decision-making; which processes and institutions can exert influence; who is responsible for what; } \\
\text { - Ensuring a clear and appropriate sharing of roles for the protected areas, as well as lines of responsibility and } \\
\text { reporting/answerability. } \\
\text { - Ensuring that the financial and human resources allocated to manage the protected areas are properly } \\
\text { - targeted according to stated objectives and plans. } \\
\text { - Evaluating the performance of the protected area, of its decision makers and staff, and linking quality of } \\
\text { - Establishing communication avenues (e.g., web sites) where protected area performance records and reports } \\
\text { are accessible. } \\
\text { - Encourage performance feedback from civil society groups and the media. } \\
\text { Ensure that one or more independent public institution (e.g., ombudsperson, human rights commission, } \\
\text { governing bodies and staff. }\end{array}$ \\
\hline $\begin{array}{l}\text { Fairness and } \\
\text { rights }\end{array}$ & $\begin{array}{l}\text { - Striving towards an equitable sharing of the costs and benefits of establishing and managing protected areas } \\
\text { - } \text { Making fairness in taking all relevant decisions. } \\
\text { protected areas do not create or aggravate poverty and socially-disruptive migratory patterns; and the costs } \\
\text { of protected areas, especially when born by vulnerable people, do not go without appropriate compensation. } \\
\text { - } \text { Making sure that conservation is undertaken with decency and dignity, without humiliating or harming people. } \\
\text { - Dealing fairly with protected area staff and temporary employees. } \\
\text { - Enforcing laws and regulations in impartial ways, consistently through time, without discrimination and with a } \\
\text { - } \quad \text { Takint to appeal (rule of law). } \\
\text { - } \text { water and natural resources related to protected areas, and to redress past violations of such rights. } \\
\text { and consultation of rights holders and stakeholders; fair conflict management practices; and non- } \\
\text { discriminatory recourse to justice. } \\
\text { - Respecting human rights, including individual and collective rights, and gender equity. } \\
\text { Respecting the rights of Indigenous peoples, as described in the UN Declaration of the Rights of Indigenous } \\
\text { Peoples. } \\
\text { - Ensuring rigorously the free, prior and informed consent of Indigenous peoples for any proposed resettlement } \\
\text { related to protected areas. } \\
\text { Promoting the active engagement of rights holders and stakeholders in establishing and governing protected } \\
\text { areas. }\end{array}$ \\
\hline
\end{tabular}

Source: Borrini-Feyerabend et al. (2013). 


\subsubsection{IUCN WCPA Best Practice Guidelines}

IUCN has published a set of best practice guidelines for both system and site-level governance assessments (BorriniFeyerabend et al., 2013). The guidelines offer concepts and tools to understand the four main protected area governance types and the set of principles of good governance recognised by IUCN, on the basis of examples from all over the world. It also offers practical guidance for those willing to embark on the process of assessing, evaluating and improving governance for their systems of protected areas or for individual protected area sites.

\subsubsection{System-level assessment}

A system-level assessment is a long-term and macro-level approach to evaluating and assessing governance of protected areas. It is focused on the system of protected areas, meaning the existing spatial system of protected areas, its corresponding legal framework and the diversity and range of both IUCN protected area management categories and governance types. A system-level assessment assumes that no protected area will be effective or equitable, if it is not considered within its broader landscape. Most threats to protected areas stem from outside the boundaries of the protected area itself (Davey, 1998), including encroachment, poor connectivity in the wider landscape and a lack of resources (Schulze et al., 2018). Protected areas are not islands but are rather part of a mosaic of land uses and diverse interests. A system-level assessment firstly examines the potential for the full range of governance types in a given country and makes recommendations for recognition and support of existing de facto governance arrangements. Secondly, it examines the entire landscape and in particular examines the coordination of these interlocking sectors and land-uses.
IUCN offers guidance on what a system of protected areas is and notes at least five key characteristics of such a system (Davey, 1998). These include: representation, comprehensiveness and balance; adequacy; coherence and complementarity; consistency; and effectiveness and equity. A system-level governance assessment led by IUCN is being undertaken in Tanzania (see Box 9.5).

\subsubsection{Site-level assessment}

A site-level governance assessment focuses on governance quality (see Box 9.6) for an example from Zambia). Unlike a system-level assessment, it does not review the choice of governance type but rather assesses the extent to which the governance arrangements are true to the type of governance, i.e. which stakeholder has primary decision-making authority in reality and the level of influence on decision-making of other stakeholders.

Site-level governance assessments can also examine the components of diverse governance models, and examine their strengths, challenges and enabling factors (see Box 9.7).

\subsubsection{Site-level governance and equity assessment (SAGE)}

SAGE is a methodology for assessing the quality of governance of a protected or conserved area, including equity, using a framework of 10 governance and equity principles based on IUCN and CBD guidance (IIED, 2020). It is a rapid process that enables stakeholders at a site to identify governance challenges and potential actions to address them, and provides managers at higher levels with an assessment of governance quality that can be used for management oversight, reporting and IUCN's Green List process.

\section{Box 9.6 OI Kinyei Conservancy and the IUCN Green List}

The OI Kinyei Group Ranch was one of the traditional grazing areas for the Maasai, north of Mara National Reserve (MMNR). In the early 1990s the Group Ranch leaders embarked on the sub-division of their lands to the north of the MMNR. Most of the sections were subdivided into plots ranging from 60 to 150 acres. With the fragmentation of the Group Ranches, the wildlife dispersal areas surrounding the MMNR became increasingly threatened, as the rangeland was rapidly being converted into agricultural small holdings and community settlements. In 2005, the OI Kinyei Conservancy partnered with landowners and tourism operators to jointly manage the conservancy and establish an area of protected wildlife habitat. This was to promote the regeneration of vegetation and increase wildlife biodiversity and populations, which in turn supported eco-tourism. The land leases (initially approximately 5,000 acres and currently standing at 18,500 acres) generate income and employment for local communities. The OI Kinyei committed to the IUCN Green List and began the process of assessment against the Green List
Standard. To comply with the first criteria of the Good Governance component, 'legitimacy and voice', the governing structure needed to demonstrate how the various community groups are involved in the decision-making processes, how representatives are chosen and, the extent to which these groups have had their views taken into account by the executive body. To demonstrate the second criteria, accountability and transparency, decisions made by the highest decision-making body needed to be publicly available and upon request. A timely and effective grievance mechanism was also put in place for dealing with stakeholder complaints.

The shared governance structure has created a stable platform for conservation and ensured a fair distribution of the benefits derived from conservation among its landowner community members, thus developing a greater sense of ownership, appreciation and understanding of the importance of conserving Kenya's wildlife heritage.

Contributed by Beatrice Chataigner (IUCN PAPACO, Kenya). 


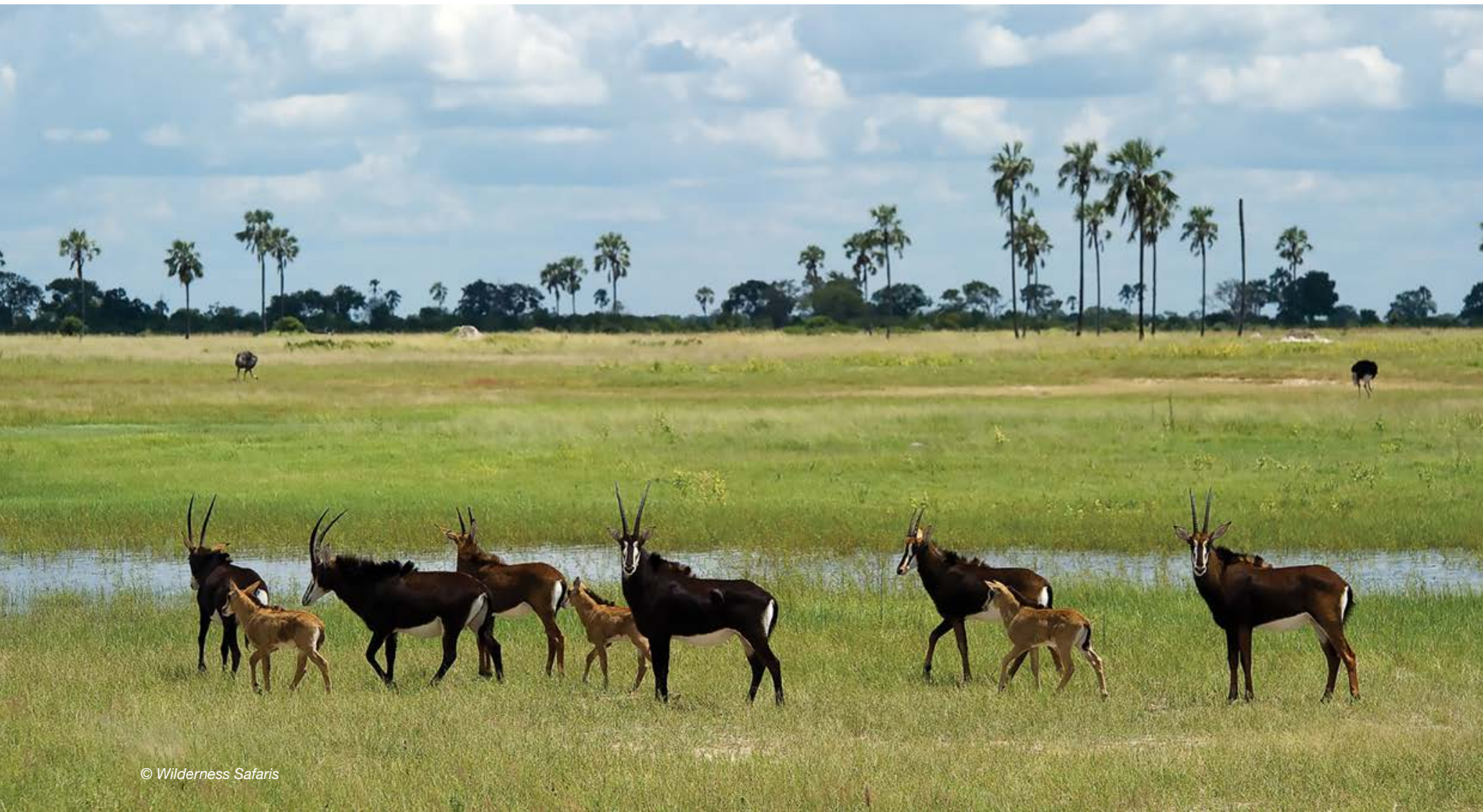

As with many PAME methodologies, SAGE generates rating data using a questionnaire with around 40 questions (3-5 questions for each principle). SAGE uses a multi-stakeholder process. The main activity involves a one- to two-day workshop which starts with different stakeholder groups doing the assessment separately, thereby revealing different stakeholder perspectives. Stakeholders then discuss the reasons for any differences in scoring, and identify actions to improve governance and equity that might be taken up by one or more stakeholders.

\section{The output of SAGE has three main elements:}

a) Site profile - of the protected or conserved area and contextual issues relevant to governance and equity;

b) Impact analysis - including both the environmental impacts from the activities of people and other hazards (i.e. threats to the site) and the social impacts of the site and its conservation on people; and

c) Governance and equity scorecard with the scores and supporting evidence from different stakeholder groups for each of the 40 questions, average scores and scoring ranges by question and principle, and suggestions for action to strengthen governance.

While SAGE identifies governance strengths and weaknesses, it is not a diagnostic tool that can explore deep underlying causes of governance problems. For an in-depth assessment, the Governance Assessment for Protected and Conserved Areas (GAPA) would be the more appropriate tool (Franks \& Booker, 2018; IIED, 2018) (see next section).

\subsubsection{Governance assessment for protected and conserved areas (GAPA)}

GAPA is a multi-stakeholder assessment for use by site managers, communities living within and around a protected or conserved area, or other stakeholders and rights holders at local and national levels (Franks \& Booker, 2018; IIED, 2018). The primary goal of GAPA is to improve the governance of the target site and any related conservation and development activities.

The methodology uses a combination of: (i) key informant interviews and focus group discussions to identify the governance strengths and challenges and ideas for action; and ii) stakeholder workshops to discuss and validate the results and review the ideas for action to improve the situation. There is an optional extra: iii) a site-level governance scorecard to provide a quantitative assessment of site-related governance issues and the diversity of views on these issues within and across communities. The assessment itself typically takes five to 10 days depending on the size of the area and logistics. Following the assessment, is an action phase comprising a set of activities to support stakeholders in the implementation of key actions to improve governance that were suggested by the assessment. A detailed users' manual is available (Booker \& Franks, 2019). For an example of GAPA results, see the case study from Zambia (Box 9.6). 


\section{Box 9.7 System-level governance assessment in Tanzania}

Tanzania is home to tens of millions of people and is one of the world's most biodiverse countries, boasting thousands of species and ecosystems. It includes nine major river catchments, Africa's highest peak, drylands, savannah and coastal and marine areas. Since 2017, IUCN has been leading a participatory system-level governance assessment in Tanzania in conjunction with national partners and stakeholders to examine issues around fairness in the protected area (PA) system. The work comprises a mixture of desktop and workshop related activities including historical research, legal analyses, the documenting of all four IUCN/CBD governance types and the examining of diverse governance settings using good governance principles. The process has revealed Tanzania as one of the richest countries on Earth with regard to its conservation estate and it has committed to ambitious national targets for conservation. Its current system of PAs far exceeds the minimum global targets for coverage. The range of diverse governance types in the conservation estate is equally impressive.

The system is vast, ranging from government led protected areas (Type A) such as the four natural World Heritage Sites: Ngorongoro Conservation Area, Kilimanjaro National Park, Selous Game Reserve now Nyerere National Park and Serengeti National Park. It also includes shared governance models (Type B) such as the Burunge Wildlife Management Area as well as other participatory models across a range of Forest Nature Reserves, Village Forests and Game reserves. The privately owned Chumbe Island Coral Park (Type C) serves as an example of voluntary nature conservation within the system. The fourth category, ICCAs- territories of life - (Type D), areas that are under traditional governance, management and custodianship have demonstrated long-term conservation effectiveness. These include areas which are currently undergoing documentation via the Certificates of Customary Right of Occupancy (CCROs). Work is being undertaken to map and document these ICCAs - territories of life, as well as registering them nationally and in the ICCA Registry hosted by the WDPA. For example, traditional institutions for landscape conservation in the Matengo Highlands illustrate how traditional knowledge under the customary Sengu system can achieve both sustainable livelihoods and conservation of the landscape. The Sengu system has its governance structure formalized in the Tanzanian regulatory framework. This reveals an impressive rooting of conservation in both traditional and modern national cultural identities which can serve as a range of illustrative examples for the rest of the world

Contributed by Jennifer Kelleher (IUCN) and Grazia BorriniFeyerabend and Emmanuel Sulle (ICCA Consortium).

\subsubsection{Indicators}

While the scale of an enquiry is one important component, the development of actual indicators linked to the governance assessment is a core feature for effective reporting on governance and equity. Borrini-Feyerabend et al. (2013) provide a long list of examples of governance indicators in the annexes of the publication. More recently, a global study has led to the development of such indicators and displays results from a host of countries (ICCA Registry, n.d.; Zafra-Calvo et al., 2017). The GAPA Manual provides a practical framework of principles and indicators (called themes) which forms the basis of both the GAPA and SAGE methodologies.

More details on the most commonly used governance assessment methods and tools are available in Campese and Sulle (2019).

\subsection{Social assessments}

The contribution of protected areas to poverty alleviation, by providing employment opportunities and livelihoods to people living in and around them, has been noted by CBD's PoWPA (CBD, 2004). At best, protected areas should in all cases strive to reduce poverty, and the costs and benefits should be equitably shared (linked to the distribution element of the CBD equity framework). In 2008, a study revealed more than 30 methods to assess the social impacts of protected areas (Schreckenberg et al., 2010). From this, a social assessment methodology has been specifically tailored for the protected areas context. The social assessment of protected areas (SAPA) methodology is designed to help protected area managers and other stakeholders to understand and promote positive social impacts, while reducing the negative impacts (Franks et al., 2018; IIED, n.d.). Like GAPA, it uses a multistakeholder approach to ensure that all concerned stakeholders and rights holders are fully engaged in the design of the assessment, information gathering, interpretation of the results and development of recommendations for action. Box 9.8 provides an example of SAPA results from Kenya.

\subsection{PAGE in Eastern and Southern Africa}

This section of the report draws on the analysis completed by Jessica Campese and Emmanuel Sulle in their report, Management Effectiveness, Governance, and Social Assessments of Protected and Conserved Areas in Eastern and Southern Africa: $A$ rapid inventory and analysis to support the BIOPAMA programme and partners, prepared for the BIOPAMA programme (Campese \& Sulle, 2019). The report considered management effectiveness, governance and social assessments in terrestrial and/or marine protected or conserved areas in Eastern and Southern Africa. The primary focus was on methodologies developed specifically to assess one or a combination of these issues and intended for replicated use. 


\section{Box 9.8 Site-level governance assessment at Mumbwa GMA in Zambia}

Game Management Areas (GMAs) cover 22\% of the land area of Zambia. They have a vital role, both ecologically as dispersal areas and corridors that link the major national parks and financially as the source of much of the revenue that supports conservation in Zambia (through hunting concessions). GMAs are managed under a shared governance arrangement called Community-Based Natural Resource Management (CBNRM) between the government's Department of National Parks and Wildlife (DNPW) and the communities who live around and within the GMA's development zone. Most of these CBNRM arrangements were established over 20 years ago and have had little support in recent years. In recent years a number of reviews have noted weaknesses in governance as a major and growing problem that is seriously undermining both conservation and social outcomes.
In 2018, the Zambia CBNRM Forum with support from the International Institute for Environment and Development (IIED) and the Global ICCA Support Initiative of UNDP assisted the stakeholders - communities, government and hunting operators - of Mumbwa GMA which borders the Kafue National Park to conduct a governance assessment using IIED's GAPA methodology. Using this methodology, including key information interviews and focus group discussions, the stakeholders assessed governance strengths and weaknesses of the GMAs and identified actions to improve governance, focusing in particular on four good governance principles. The table below summarises some of the key findings and suggested ideas for action.

Contributed by Jennifer Kelleher (IUCN).

\begin{tabular}{l|l|l}
\hline Principle & Challenge & Ideas for action \\
\hline $\begin{array}{l}\text { Effective participation of } \\
\text { relevant actors in decision- } \\
\text { making }\end{array}$ & $\begin{array}{l}\text { Government departments dominate } \\
\text { decision making related to the GMA and so } \\
\text { communities have little influence over } \\
\text { decision making. }\end{array}$ & $\begin{array}{l}\text { All stakeholders need to sit down and meet to } \\
\text { recognise the voice of the community in } \\
\text { decision making. }\end{array}$ \\
\hline $\begin{array}{l}\text { Fair sharing of benefits } \\
\text { according to a targeting } \\
\text { strategy agreed by relevant } \\
\text { actors }\end{array}$ & $\begin{array}{l}\text { Traditional leaders share natural resources } \\
\text { within GMA with family and friends, } \\
\text { forgetting other community members. }\end{array}$ & $\begin{array}{l}\text { Government to help sensitise traditional } \\
\text { leaders on fair benefit sharing between } \\
\text { traditional leaders and the community }\end{array}$ \\
\hline $\begin{array}{l}\text { Transparency supported by } \\
\text { timely access to relevant } \\
\text { information }\end{array}$ & $\begin{array}{l}\text { Information takes a long time to reach } \\
\text { community members - for example } \\
\text { information about hunting quotas }\end{array}$ & $\begin{array}{l}\text { Use different methods to share information to } \\
\text { communities - flyers, SMS, churches - as well } \\
\text { as modern was of communication }\end{array}$ \\
\hline $\begin{array}{l}\text { Fair and effective enforcement } \\
\text { of laws and regulations }\end{array}$ & $\begin{array}{l}\text { Government is reluctant to remove some } \\
\text { encroachers from the GMA as they are } \\
\text { scared of losing votes }\end{array}$ & $\begin{array}{l}\text { increase in the salaries for officers from DNPW } \\
\text { and village scouts to help curb illegalities such } \\
\text { as tips and bribes }\end{array}$ \\
\hline
\end{tabular}

Source: Lubilo (2019).

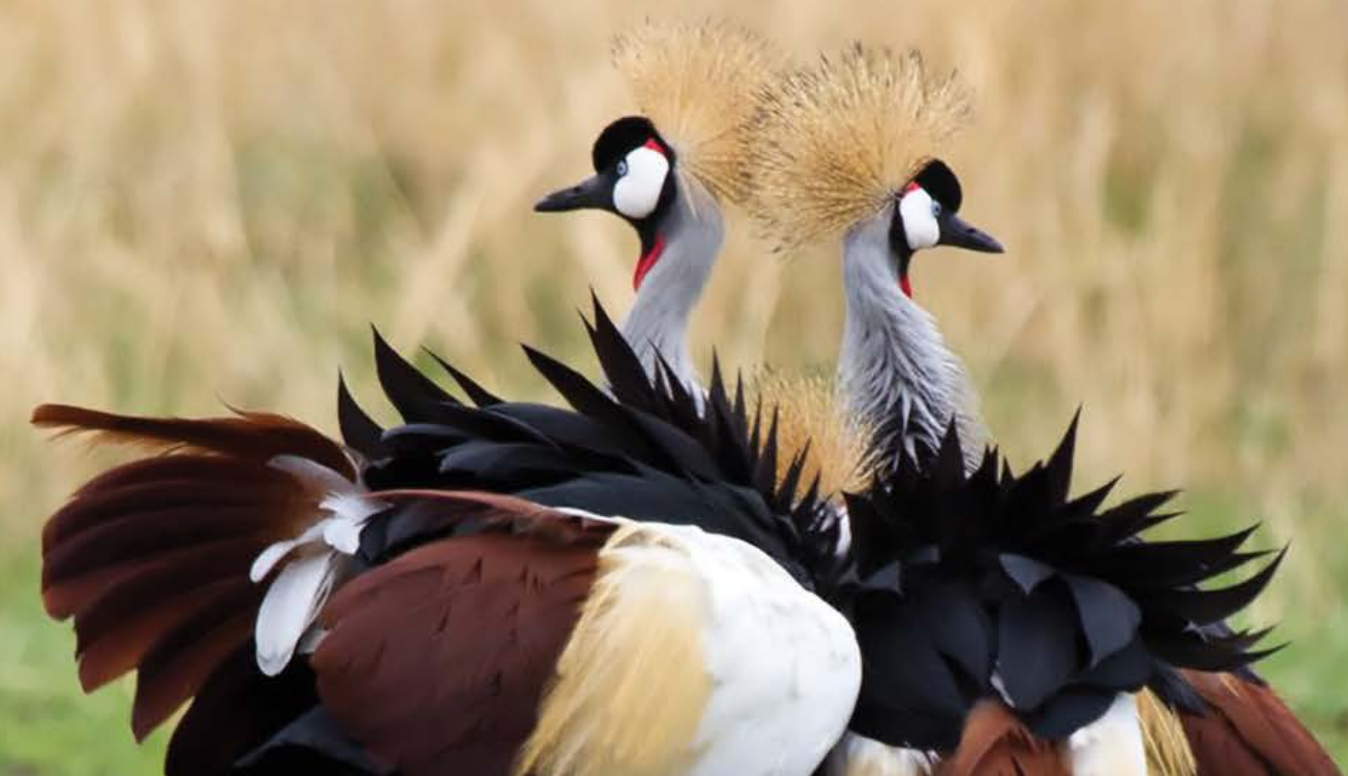




\section{Box 9.9 State of Indigenous and Community Conserved Areas in Tanzania}

Tanzania has one of sub-Saharan Africa's most wellestablished systems of local rural governance. Communities in rural areas are managed by over 12,000 village councils, which are in turn accountable to village assemblies. Legislation empowers villages to make their own by-laws, including over management of natural resources.

The importance of local institutional framework for local communal natural resource management and conservation in Tanzania cannot be overemphasized. Village councils and assemblies hold village council meetings provide the statutory mechanism for local community decision-making and collective negotiation regarding land and resource uses. The Village Land Act enables villages to zone communal and individual land areas through land use plans, and enforces these zones with village by-laws. This allows communities to support traditional land-use practices with statutorily recognised plans and by-laws. Hundreds or even thousands of Tanzanian Indigenous Community Conserved Areas (ICCAs) may exist as legal entities at the village level under this system, such as pastoralist dry season grazing reserves. Many of these locally-conserved areas are poorly documented, and enforcement at the local level depends on a range of factors.

Tanzania's forest policy and legislation also builds on the land tenure and local governance institutions present in the country to provide strong enabling conditions for local communities to own and manage forests. While Tanzania's historical forest management framework emphasized legal restrictions on harvesting and the establishment of central forest reserves, starting in the mid-1990s Tanzania began some formal experimentation with community-based forest management. In 1998 the country adopted a National Forestry Policy which aims to strengthen the "legal framework for the promotion of private and community-based ownership of forests and trees" (United Republic of Tanzania, 1998, p. 1). The Forest Act 2002 was subsequently passed calling for forests to be managed at the lowest possible level of government and providing flexible institutional arrangements for local forest management and ownership. These include village land forest reserves (VLFRs) which are managed by villages, as well as community forest reserves (CFRs) which may be managed by a sub-group of people within the village. This legal and policy framework is highly supportive of community management and ownership of forests, and has led to the rapid expansion of statutorily recognized local forest reserves (mainly VLFRs). Consequently, village land forests are recognised in law as a viable and increasingly important part of the forest estate under formal protection.

As with forestry, Tanzania underwent a wildlife sector reform process in the 1990s and released a new Wildlife Policy in 1998 and Wildlife Conservation Act No. 5 of 2009 calling for the devolution of wildlife management responsibilities and rights to villages through new statutory ICCAs called wildlife management areas (WMAs). The objectives of WMAs, described by the Wildlife Policy as areas conserved by and for the local communities with devolved managerial rights and control over benefits, are clearly in line with a working definition of ICCAs. However, the rights actually granted communities to manage wildlife in the WMAs according to the 2002 regulations are limited. For example, the communities have very limited rights to manage commercial hunting of wildlife in the WMAs and unclear control over revenues from wildlife in these areas. Concerns about retaining secure village land tenure in the WMAs have also led to resistance by some pastoralist communities to the concept. As presently developed, the WMAs are limited to a somewhat nebulous form of comanagement with government maintaining a considerable degree of authority, and probably should not qualify as ICCAs until (if) their institutional arrangements are revised.

ICCAs are also spread along coastal and mountain areas of Tanzania. Extensive knowledge systems exist in the communities living in these areas. Some of the ICCAs are formalised while some are not, but all performing the critical need of nourishing our landscapes. The Mpingo Group in the eastern coast, the Kumbi traditional system of political ecology organisation along Lake Malawi/Niassa/Nyasa shores and Ntambo land holding in the Matengo highlands in the southwestern part of Tanzania - all portray the significance of Indigenous knowledge systems in conserving communitybased natural resources.

Contributed by Stephen Nindi (Land Use Planning Commission, Tanzania).

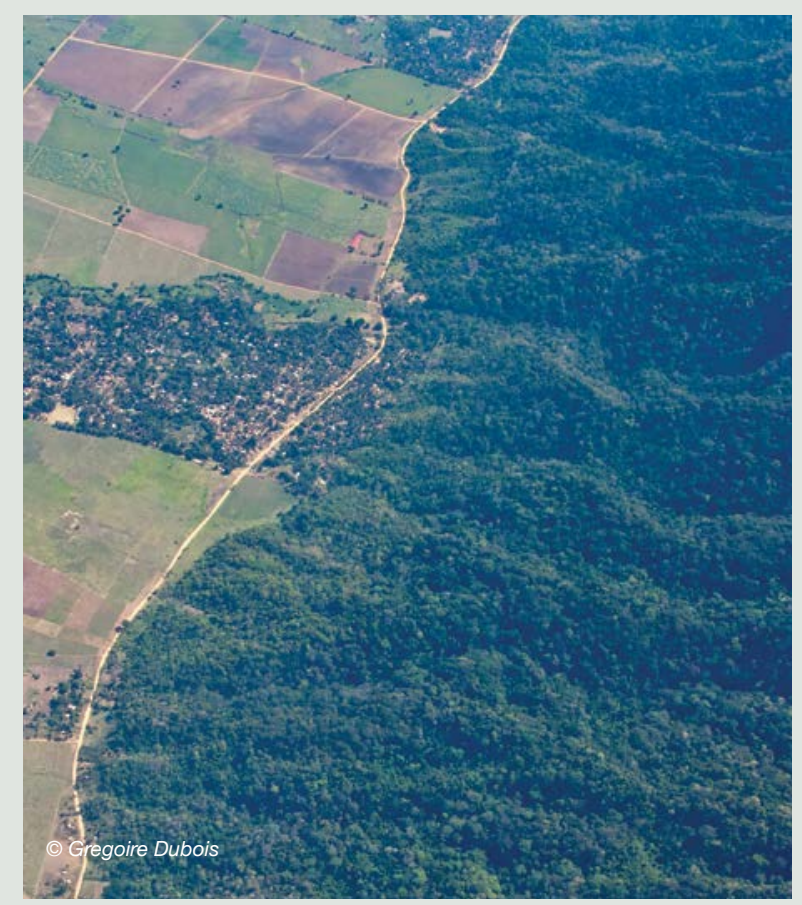


The inventory was not exhaustive. Not all of the inventoried assessments were included in the detailed analyses because they did not constitute complete assessments using readily replicable methodologies. These are categorized as "Other". ${ }^{107}$

\subsubsection{Governance assessments in Eastern and Southern Africa}

Three hundred and eighty governance assessments were inventoride (see Figures 9.1 and 9.2). Most were site-level assessments of community forests ${ }^{108}$ in Tanzania using the Community Forest Governance Dashboard. Seven GAPA assessments of protected areas were conducted in Kenya, Uganda and Zambia, of which two analyses using the 'choice and recognition' framework were inventoried from Kenya and Uganda. Finally, four assessments were inventoried using a prototype equity questionnaire in Kenya, Tanzania, Uganda and Zimbabwe. Governance assessments were inventoried for Tanzania, Namibia, Kenya, Madagascar, Uganda, Zambia, Zimbabwe and for multiple countries.

\subsubsection{Social assessments}

Fifty social assessments were inventoried, dating from 1996 to present, including 19 SAPA assessments in Ethiopia, Kenya, Malawi, Mozambique, Uganda, Zambia, and Zimbabwe (see Figure 9.3 and Figure 9.4). Full details of the methodologies used and countries in which they were conducted are available in the full report (see Figure 9.1 and Figure 9.3).

The importance of focusing on governance and equity of protected areas is clearer than ever (Bennett \& Dearden, 2014; Oldekop et al., 2015; Bennett et al., 2019;) - governance and equity are key factors in determining the effectiveness and efficiency of management in protected areas. They are central to ensuring that protected areas are fair and bestow ecological, social, economic and cultural benefits without burdening people with unfair costs. Accordingly, it fulfils the objectives set out in PoWPA wherein protected areas are considered as better integrated into the wider landscapes, but also into society as a whole.

\subsection{Results of social and governance assessments in Eastern and Southern Africa}

In the ESA region, only 18 sites in total have so far assessed social and governance components using the governance and equity framework from the GAPA, SAPA and SAGE tools by IIED (see Table 9.3).
Based on an analysis of these assessments, a number of strengths and challenges were highlighted. The strengths noted were on equitable benefit sharing, such as revenue derived for community development projects and access to resources in the protected areas. Communication channels to engage the community were also observed to be in place and decision making in some areas was done jointly, e.g. selection of projects to fund.

The issues noted revolved around participation in decision-making which, among others, included protected area officials and government representatives having more influence over decision making than local people. Other challenges included transparency and access to information and particularly in revenue sharing and awareness of rights. Fair and effective law enforcement was lacking in some cases where there was irregular application of the law.

\section{Figure 9.1 Inventoried governance assessments by methodology (total 378)}
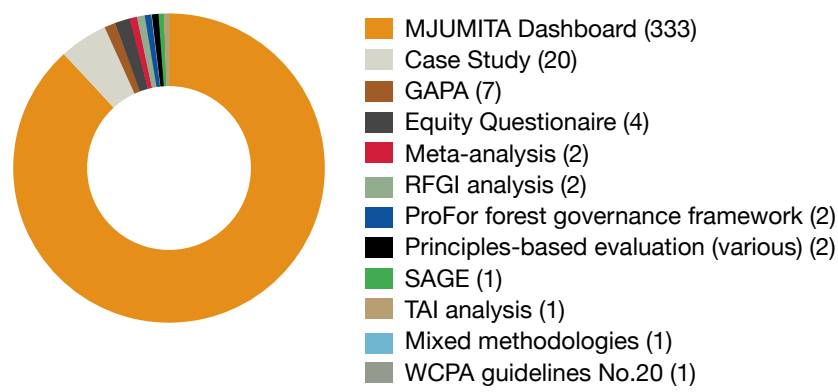

Source: Campese \& Sulle (2019, p. 48)

\section{Figure 9.2 Inventoried governance assessments by country (total 378 )}

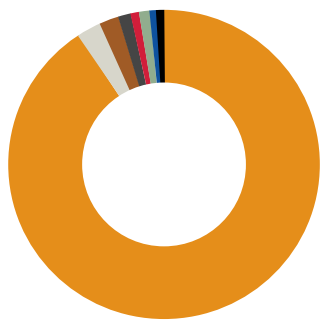

Tanzania (344)

Namibia (9)

Kenya (7)

Madagascar (6)

Uganda (4)

Multiple (3)

Zambia (3)

Zimbabwe (2) 
Figure 9.3 Inventoried social assessments by methodology (total 50)

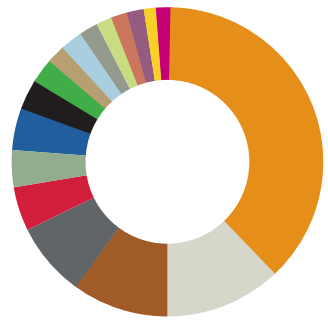

\author{
SAPA (50) \\ PEV (6) \\ RSIA (5) \\ Sustainable livelihoods framework (4) \\ BNS (2) \\ PA-BAT (2) \\ Poverty-forests linkages toolkit (2) \\ Wellbeing assessment (2) \\ SWIFT (1) \\ Millennium ecosystem assessment (1) \\ Mixed methodologies (1) \\ Participating video (1) \\ Discrete choice experiment (1) \\ Participatory mapping (1) \\ Socio-economic study (1) \\ Photovoice (1)
}

Source: Campese \& Sulle (2019, pg. 50).

\section{Figure 9.4 Total number of inventoried social assessments by country}

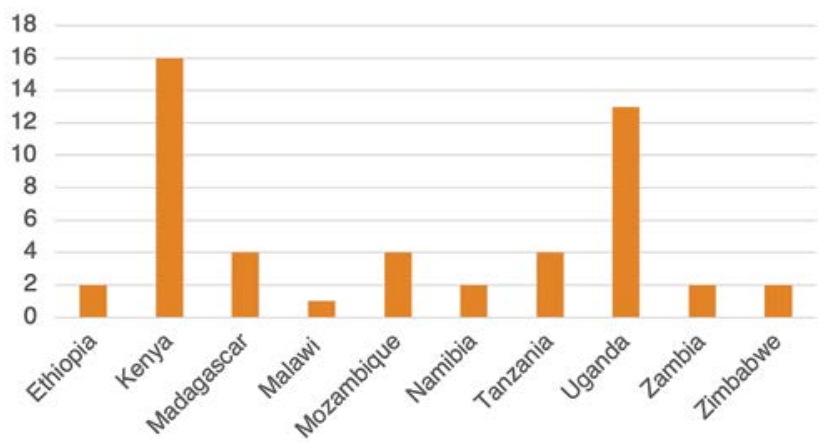

Source: Campese \& Sulle (2019, pg. 51).

\section{Box 9.10 Social assessment at OI Pejeta Conservancy in Kenya}

OI Pejeta Conservancy (OPC) is a private protected area in Kenya which is owned and managed by a conservation trust. Since its conversion from a cattle ranch to a conservancy in the early 1990 s and benefiting from substantial donor support, OPC has become a popular tourist destination, generating enough revenue to cover operational costs and provide substantial sums each year for its community programme which invests in education, health, agricultural extension and water supply.

In 2014, OPC conducted an assessment of the positive and negative social impacts of the conservancy on local communities using the SAPA methodology, and this was repeated in 2019. SAPA uses a participatory rural assessment method in selected communities to identify the more significance impacts, a short household survey to investigate these impacts in more detail and related governance issues (but with much less depth than GAPA), and finally a stakeholder workshop where key stakeholders review the results and identify ideas for action.

The 2019 assessment reiterated the findings of 2014 that the most significant benefits from a community perspective are the fencing around the conservancy, which has reduced human wildlife conflict, and the improvement in security provided by the presence of OPC law enforcement staff in an otherwise insecure area. This finding, that some park management activities appear to have greater value to the community than the development activities of the community programme, was a real eye-opener in 2014. It has led not to a cut in development activities but to a more focused approach that prioritises benefits people consider more valuable, notably school bursaries. Another key finding is that these bursaries seem to be more valued by wealthier households, suggesting some bias in their allocation that needs to be rectified. There was also a strong message that benefits were being allocated more to communities on the south-east side nearer to the main road. This has since been largely rectified. However, there continues to be a pattern of women and poorer people being more concerned about this issue. Some of the ideas to improve the situation include better communication, since the problem is partly caused by people simply not knowing what benefits are going to others and suspecting bias which may not actually be there.

A perception of bias in the allocation of development projects and jobs also appear as significant negative impacts along with crop damage by animals (despite fencing). However, these seem relatively minor concerns, as the overall picture of how communities perceive the protected area, taking account of all benefits and costs, has improved since 2014.

\section{Contributed by Jennifer Kelleher (IUCN).}

$80 \%$

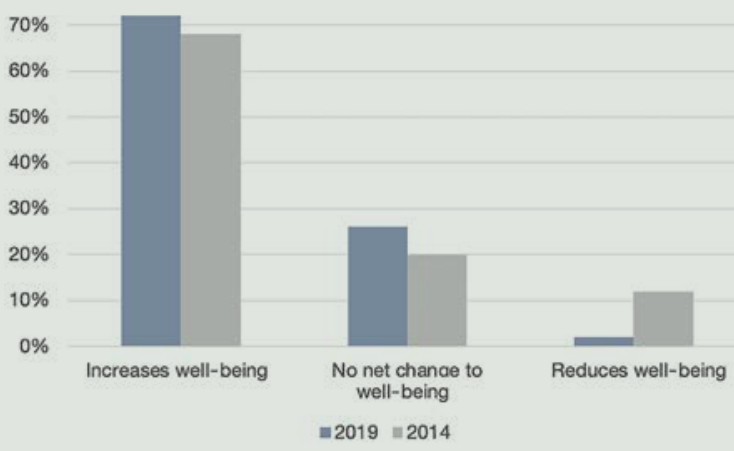

Source: Franks (forthcoming, 2021). 
Table 9.3 SAPA, GAPA and SAGE assessments conducted to date

\begin{tabular}{|c|c|c|}
\hline \multicolumn{3}{|c|}{ SAPA } \\
\hline Country & Area & Version \\
\hline Ethiopia & Awash National Park & v1 \\
\hline Kenya & Marsabit National Park/Reserve & v2 \\
\hline Kenya & OI Pejeta Conservancy & v2 \\
\hline Kenya & Borana Conservancy & v2 \\
\hline Kenya & Loisaba Conservancy & v2 \\
\hline Kenya & Kisite Marine Protected Area & v2 \\
\hline Kenya & Ruma National Park & v2 \\
\hline Mozambique & Maputo National Park & v2 \\
\hline Uganda & Ruwenzori National Park & v1 \\
\hline Uganda & Lake Mburo National Park & v1 \\
\hline Uganda & Kibale National Park & v2 \\
\hline Uganda & Mgahinga National Park & v2 \\
\hline Uganda & Murchison National Park & v2 \\
\hline Uganda & Bwindi National Park & v2 \\
\hline Zambia & Mumbwa Game Management Area & $\mathrm{v} 1$ \\
\hline Zambia & Lupande Game Management Area & $\mathrm{v} 1$ \\
\hline
\end{tabular}

\begin{tabular}{l|l}
\hline \multicolumn{2}{c}{ GAPA } \\
\hline Country & Area \\
\hline Kenya & Mara North Conservancy \\
\hline Kenya & Olderkesi Conservancy \\
\hline Kenya & Kalama Conservancy \\
\hline Zambia & Chiawa Game Management Area \\
\hline Zambia & Mumbwa Game Management Area \\
\hline
\end{tabular}

\begin{tabular}{l|l}
\hline \multicolumn{2}{c}{ SAGE } \\
\hline Country & Area \\
\hline Zambia & Mulobezi Game Management Area \\
\hline Tanzania & Randilen Wildlife Management Area \\
\hline
\end{tabular}

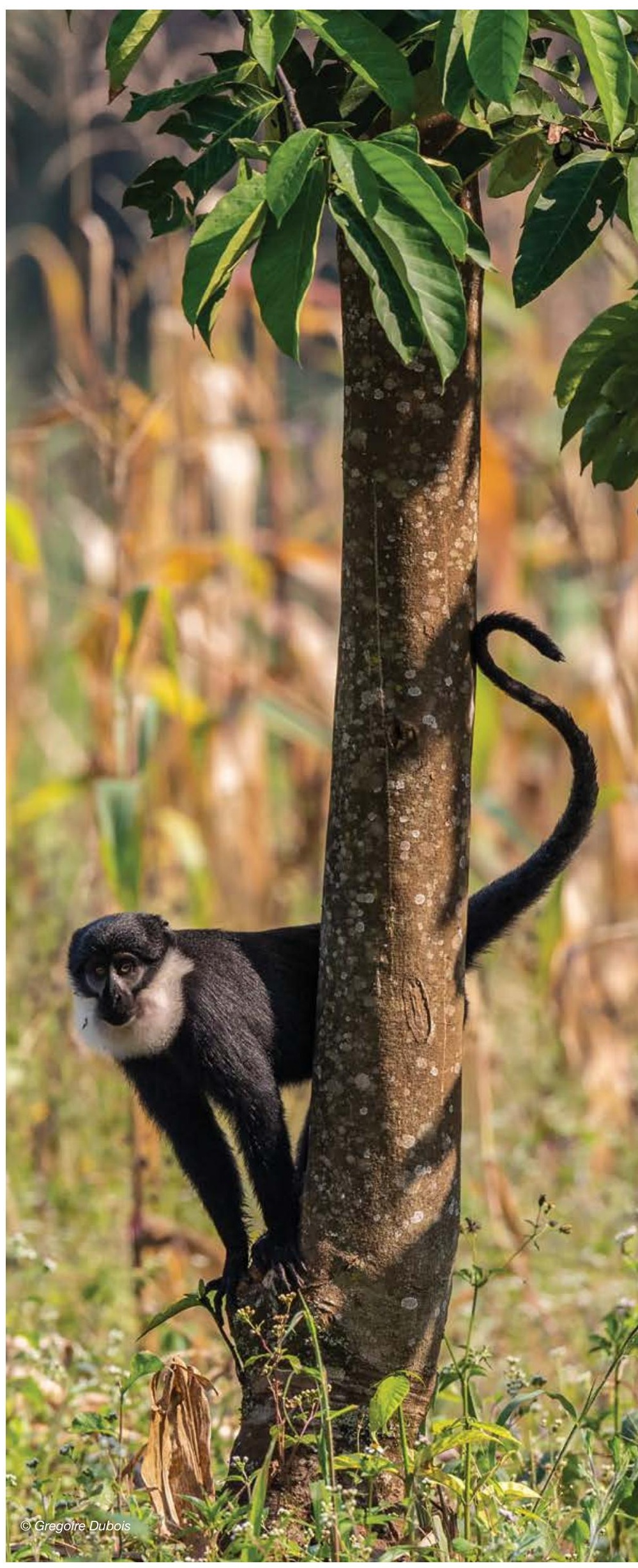




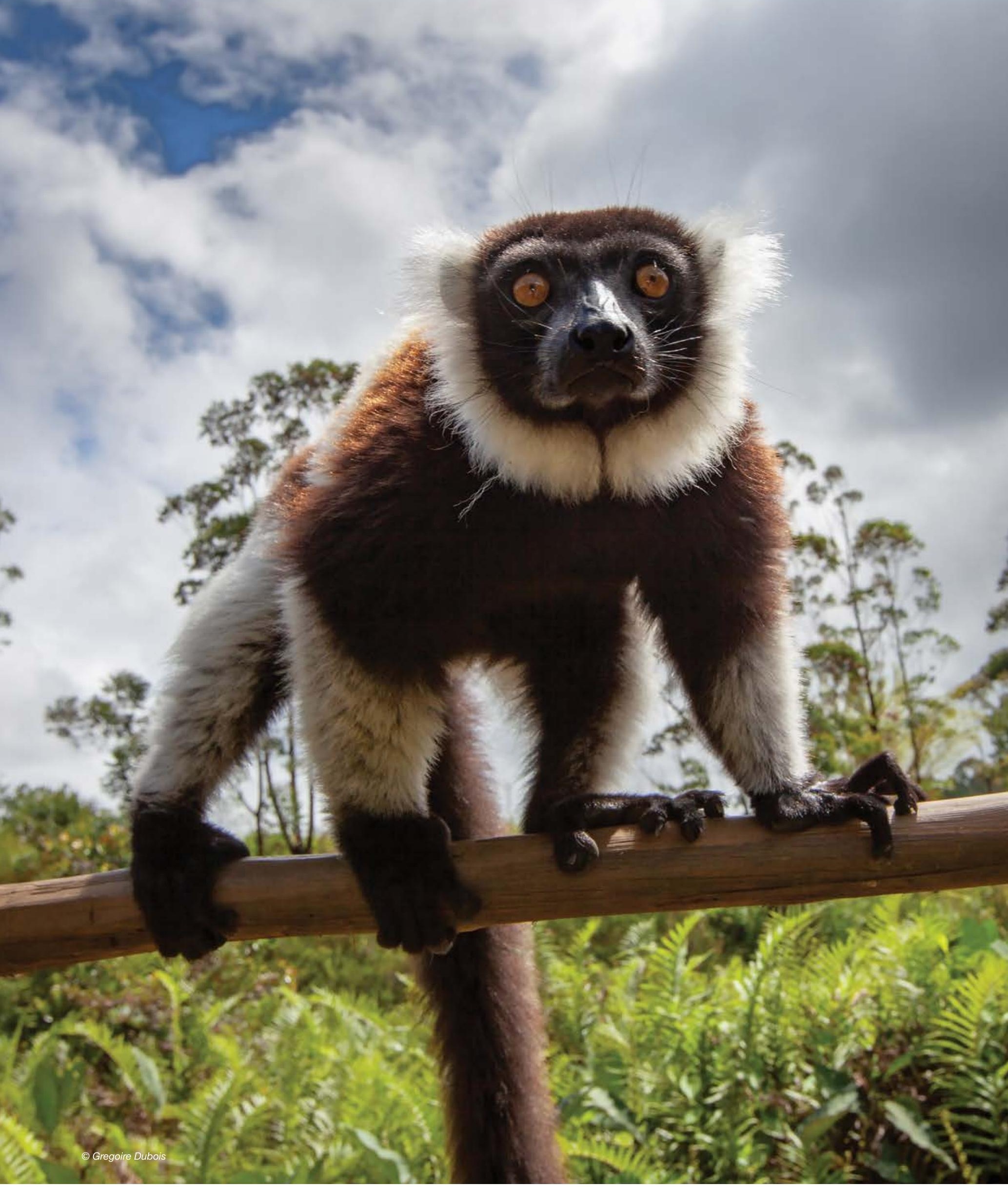




\section{Protected area management effectiveness}




\subsection{What is effective management?}

Management effectiveness relates to how well protected areas are being managed - primarily the extent to which management is effective at conserving values and achieving goals and objectives, such as protecting biodiversity (Hockings et al., 2006; Leverington et al., 2010). Specific components of good management vary with the context and the characteristics of each protected area: for example, a remote community-based protected area with few visitors needs fewer staff and recreational facilities than an iconic tourist destination.

Not all protected areas are managed effectively to protect the values that they were designed to conserve, and the quality of management of most protected areas is poorly understood (Geldmann et al., 2015). There is strong evidence to suggest that there are positive correlations between certain aspects of protected area management (such as staffing and budgets) and species conservation outcomes (Edgar et al., 2014; Geldmann et al., 2013). There has been a lot of work over the last 30 years to define general characteristics of well-managed protected areas, and then to measure how well individual areas match these standards. These desirable characteristics have been incorporated as indicators in methodologies, such as the management effectiveness tracking tool, and formed the basis of the 'common reporting format' for the global compilation of management effectiveness data (Leverington et al., 2010). More recently, the Green List process has undertaken a detailed and robust exercise to develop global standards for protected areas, which can be tailored and interpreted for different countries.

Some studies have been undertaken on particular types of protected area. For example, a study on the performance of protected areas for lion showed that protected areas tended to be more effective for conserving lions and/or their prey where management budgets were higher, where photographic tourism was the primary land use, and, for prey, where fencing was present. Lions and prey fared less well relative to their estimated potential carrying capacities in poorer countries, where people were settled within protected areas and where protected areas were used for neither photographic tourism nor trophy hunting (Lindsey et al., 2017).

\subsection{Assessing management effectiveness}

The evaluation of management effectiveness has been a growing theme in protected area management and global biodiversity conservation for many years (see Box 10.1). It provides a lens through which to look at important themes in protected area management, in particular:

1) Design issues relating to individual sites as well as protected area systems;

2) Adequacy and appropriateness of management systems and processes; and

3) Delivery of protected area objectives including conservation of values (Hockings et al., 2006)
Broadly speaking, management effectiveness evaluation can:

- Enable and support an adaptive approach to management of protected areas;

- Assist in effective resource allocation between and within sites;

- Promote accountability and transparency by reporting on effectiveness of management to interested stakeholders and the public; and

- Help involve the broader community of stakeholders, including government agencies, NGOs and local communities, build constituency and promote protected area values (Hockings et al., 2006).

As the global conservation community paid greater attention to the issue of management effectiveness and the need for tools to help assess it, it became clear that with such a variety of systems and contexts, designing a single assessment tool would not be practical. Management effectiveness assessment should be tailored to the particular demands of the site, given that each protected area has a variety of biological and social characteristics, pressures and uses.

In 2000, IUCN WCPA developed a framework to guide the development of assessment systems for evaluating management effectiveness. This framework was updated in 2006, and continues to be the framework to which most PAME approaches relate conceptually (Coad et al., 2015). The framework identifies six core components, each associated with different aspects of management effectiveness: context, planning, inputs, process, outputs, and outcomes (see Figure 10.1) (Hockings et al., 2006).

\section{Figure 10.1 The management cycle and evaluation of protected area management}

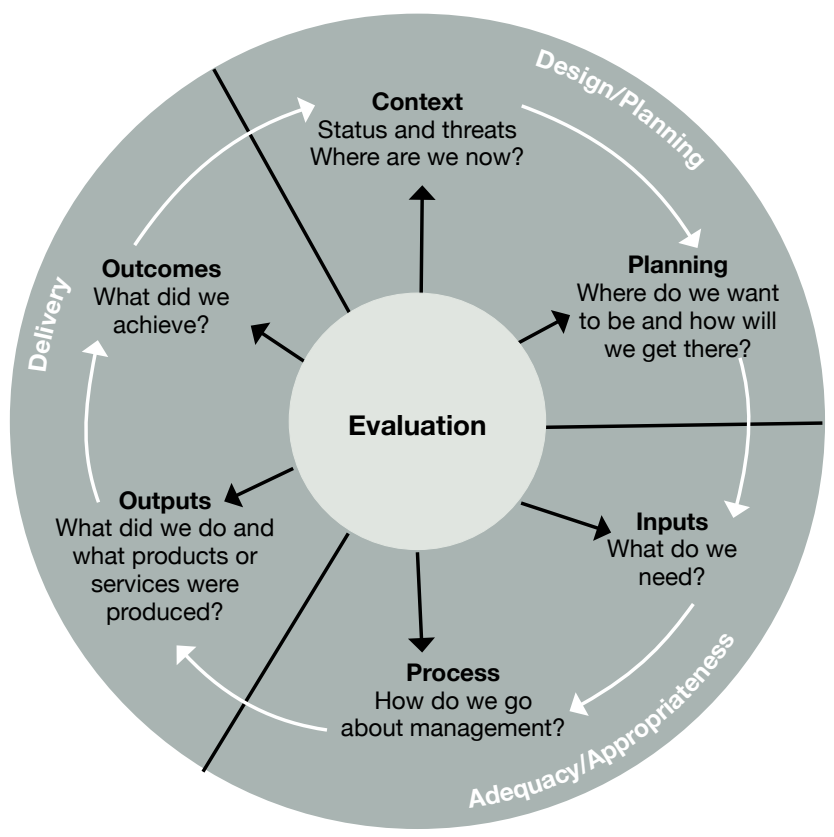

Source: Hockings et al. (2006, p. 12) 


\subsection{International commitments to management effectiveness evaluation}

Aichi Target 11 recognises that increases in coverage alone will not halt the loss of biodiversity, and highlights the need for effective management:

Target 11: By 2020, at least 17 per cent of terrestrial and inland water areas and $10 \%$ of coastal and marine areas, especially areas of particular importance for biodiversity and ecosystem services, are conserved through effectively and equitably managed, ecologically representative and well-connected systems of protected areas and other effective area-based conservation measures, and integrated into the wider landscape and seascape (CBD, 2010a, p. 9).

PAME is included in multiple places in the CBD's PoWPA. For example, Goal 4.2 is "To evaluate and improve the effectiveness of protected areas management" (CBD, 2004, p. 20).

\section{CBD COP 10 Decision X/31 calls for Parties to}

... expand and institutionalise management effectiveness assessments to work towards assessing 60 per cent of the total area of protected areas by 2015 using various national and regional tools, and report the results into the global database on management effectiveness (CBD, 2010b, p. 5).

IUCN Resolution WCC-2012-Res-076 calls for the implementation of management effectiveness assessment systems for marine protected areas (IUCN, 2012), while IUCN Resolution WCC-2016Res-036-EN calls for greater evaluation of the effectiveness of privately protected areas in conserving biodiversity, natural heritage and ecosystem services (IUCN, 2016b).

\subsection{Global Database on Protected Area Management Effectiveness (GD-PAME)}

The GD-PAME was developed though a collaboration of universities, IUCN and non-government organisations, and is now maintained by UNEP-WCMC in collaboration with governments, non-governmental organisations, academia and industry (UNEPWCMC \& IUCN, 2019aa).

It comprises records of many thousands of assessments of PAME collated from around the world, showing which methodologies have been applied where and when.). As of 2019, over 240,000 protected areas were in the WDPA, with information on management effectiveness assessments available for $21,743(9 \%)$ of them. This equates to $20 \%$ of the area of all protected areas in the WDPA. A lack of systematic reporting, duplicate assessments of the same site, use of multiple assessment tools, and sometimes a lack of political will makes this element of Aichi Target 11 difficult to track (UNEP-WCMC et al., 2019). While each methodology collects different information, a 'common reporting format' has been developed, allowing the cross analysis of PAME information from a range of different assessment methodologies (Leverington et al., 2010). This can be used, in conjunction with qualitative analysis of

\section{Box 10.1 Why report on protected area} management effectiveness?

There are a number of reasons why countries might choose to report on assessments of management effectiveness:

- Meet country obligations under the CBD (PAME is an official indicator under Aichi Target 11).

- Inventory of national data stored in a systematic way provides a clear picture of the management effectiveness of the national protected area estate and can contribute to adaptive management.

- GD-PAME allows identification of areas of strengths and weakness in protected area management, providing information to assist countries to prioritise resource allocation and target capacity development. It also provides data on threats.

- Information in the GD-PAME can be analysed for the region, continent and world to understand better the relationship between management effectiveness and biodiversity outcomes.

To view the data and download the GD-PAME User Manual, please visit: https://pame.protectedplanet.net/.

To submit data or for more information, please contact: protectedareas@unep-wcmc.org or rcmrd@rcmrd.org.

management effectiveness reports and other literature, to generate detailed analyses and reports of management effectiveness, including key issues, strengths and weaknesses and threats, across regions of the world (Leverington et al., 2010; Nolte et al., 2010) (see Box 10.1). Unfortunately, the analysis has not been conducted since 2010.

\subsection{Tools to assess management effectiveness}

The IUCN WCPA Framework (see Figure 10.1) has informed the development of a wide variety of PAME assessment methodologies. These range from detailed site-level studies to broad system-level assessments using many different processes, including questionnaires and workshops, among others (Hockings et al., 2015; Leverington et al., 2010).

Methodologies have been developed for different types of protected areas, from those designated at national level to those designated under the scope of regional and international conventions and agreements, such as World Heritage Sites (see Table 10.1).

\subsection{Principles for PAME assessments}

There are many benefits to assessing protected and conserved area management effectiveness, but there are also challenges and 
Table 10.1 PAME methodologies used most commonly in Eastern and Southern Africa

\begin{tabular}{l|l}
\hline Acronym & Tool \\
\hline Birdlife IBA & Birdlife - Important Bird and Biodiversity Area Assessments \\
\hline EoH & Enhancing our Heritage (primarily for natural World Heritage sites) \\
\hline IEG & (World Bank) Independent Evaluation Group Assessments \\
\hline METT & Management Effectiveness Tracking Tool \\
\hline PAMETT & METT adaptation for Madagascar \\
\hline RAPPAM & Rapid Assessment and Prioritisation of Protected Area Management \\
\hline SAPM & Management Effectiveness Assessment for Madagascar's Protected Areas System \\
\hline SGBD / SMART & SMART variation specific to Madagascar \\
\hline SMART & Spatial Monitoring and Reporting Tool \\
\hline West Indian Ocean MPA & West Indian Ocean Marine Protected Area Assessment \\
\hline WH Outlook Report & World Heritage Outlook Report \\
\hline
\end{tabular}

limitations, and it is imperative that assessments are undertaken appropriately to mitigate these risks (Hockings et al., 2006). In order to support the selection and application of methodologies, eight principles for good management effectiveness assessments have been developed (Hockings et al., 2015).

Evaluations of management effectiveness of protected areas should be:

1) Part of an effective management cycle, linked to defined values, objectives and policies and part of strategic planning, park planning and business and financial cycles;

2) Practical to implement with available resources, giving a good balance between measuring, reporting and managing;

3) Useful and relevant for improving protected area management, for yielding explanations and showing patterns and for improving communication, relationships and awareness;

4) Logical and systematic, working in a logical and accepted framework with a balanced approach;

5) Based on good indicators, which are holistic, balanced and useful;

6) Accurate - providing true, objective, consistent and up-to-date information;

7) Cooperative and participatory with good communication, teamwork and participation of protected area managers and stakeholders throughout all stages of the project wherever possible; and

8) Focused on positive and timely communication and application of results.

Assessments, while highly technical, are also political and social processes. It is critical to examine who participates in the process, and whose perspectives are included in the results: there is a risk that people who are not included may dispute the findings, and their viewpoints may be very different. A comprehension of the underlying reasons for conducting assessments is also important to ensure buy-in and support. They must not be seen as a performance review of staff, as this will impact on the accuracy of the assessment.
It is also important to consider carefully the communication of assessment results. Without effective communication, results may be misinterpreted or used in inappropriate ways, such as making unwarranted comparisons (Campese \& Sulle, 2019). Assessment results can also be limited by the availability and quality of baseline data. Once results have been communicated, it is also important that the areas identified for improvement are acted upon and that there is sufficient funding and capacity available to ensure effective change to meet the threats/issues/challenges identified in the assessments. If this is not the case and nothing changes, it can lead to complacency and despondency from the protected area managers and reduced interest in conducting future assessments. Assessments, and the processes to conduct them, should lead to positive adaptive management which results in more effectively managed protected areas.

\subsection{Integrating management effectiveness with governance and social assessments}

Most PAME assessment methodologies do not address governance or social equity issues in detail. There is, however, substantial synergy between the different assessments and a lot to potentially be gained by doing them concurrently. All PAME methodologies do look at the extent of stakeholder involvement, the threats to protected areas, and some also explore benefits and related aspects of social aspects of management. A greater exploration of protected area governance and equity is available in Chapter 4.

Some standards and methodologies have been developed that integrate substantial elements of management effectiveness with governance and/or social assessment (Campese \& Sulle, 2019), such as the Green List of Protected and Conserved Areas (see section 9.2). 


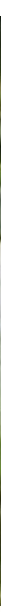

\subsection{PAME in Eastern and Southern Africa}

Analysis of the percentage of protected areas assessed by PAME in the GD-PAME (Figure 10.2) shows that Africa has done significant work in this area. Initially many assessments were related to donor funding requirements but over the years many countries in the region have institutionalised assessments and some, including Madagascar, South Africa and Zambia, have adapted the METT tool to their specific purposes. South Africa has been conducting METT assessments over a number of years, using METT targets to improve management and as a real way to address issues.

Unfortunately, there have been few analyses of the outcomes of these assessments to understand what the outcomes were at a region-wide level.

Since 1990, there has been a change globally in terms of who is leading PAME assessments. Initially most assessments were NGOled, but from 2010 to 2014 there has been an increase in being agency-led efforts (Coad et al., 2015).

In the GD-PAME, there are 681 protected areas with at least one PAME assessment in Eastern and Southern Africa (Table 10.2). This represents only $13 \%$ of the region's protected areas. Many of the protected areas have been assessed more than once, bringing the total number of assessments to 1,510. Figure 10.3 shows the number of protected areas with PAME assessments in GD-PAME for Eastern and Southern Africa, while Figure 10.4 shows the percentage of protected area with PAME assessments in the GDPAME.

\subsubsection{Inventory of PAME assessments in Eastern and Southern Africa}

This section of the report draws heavily on the analysis completed by Jessica Campese and Emmanuel Sulle in their report, Management Effectiveness, Governance, and Social Assessments of Protected and Conserved Areas in Eastern and Southern Africa: A rapid inventory and analysis to support the BIOPAMA programme and partners, prepared for the BIOPAMA programme (Campese \& Sulle, 2019). The report considered management effectiveness, governance, and social assessments in terrestrial and/or marine protected or conserved areas in Eastern and Southern Africa. The primary focus was on methodologies developed specifically to assess one or a combination of these issues and intended for replicated use.

The inventory included the GD-PAME, as well as academic studies and full or partial assessments contained within broader reports. It also included assessments that were reported in survey and interview responses, but were not reported in the GD-PAME. In particular, the analysis included 294 METT assessments in South Africa for 2015, 2017 and 2019 based on survey responses (and published documents) coupled with confirmations in follow up interviews that South Africa does SA-METT assessments at least every two years (in some sites annually) in all government governed terrestrial protected areas. Project-specific impact assessments and screening reports were not included. While the inventory is large, it is not exhaustive. Not all of the inventoried assessments were included in the detailed analyses because they did not constitute complete assessments using readily replicable methodologies. These are categorized as 'Other'.

In addition to the assessment types described below [or above, depending on where inventory graphs are in relation to this text], the inventory included governance and social assessments conducted in landscapes that host protected and conserved areas as well as broader, innovative processes involving elements of governance and social assessment. ${ }^{109}$ Biocultural Community Protocols (BCPs), for example, "articulate community-determined values, procedures and priorities" including (where relevant) in relation to protected and conserved areas. The process can include describing, reflecting on and enabling recognition of indigenous peoples' and local communities' territory governance systems and related rights and responsibilities. BCPs have been developed in several countries in the region, including Kenya, Madagascar, Namibia, and South Africa. (see Natural Justice website)

The full report is available online. ${ }^{110}$ 109 There are also many related experiences and resources not included in the inventory because, while relevant to the topic, they do not involve assessment per se. This includes
case studies from Eastern and Southern Africa included in the ICCA Registry.

110 https://biopama.org/node/349 
Table 10.2 PAME assessments in Eastern and Southern Africa

\begin{tabular}{|c|c|c|c|c|c|}
\hline Country & $\begin{array}{r}\text { Number of } \\
\text { protected } \\
\text { areas } \\
\text { (WDPA) }\end{array}$ & $\begin{array}{r}\text { Number of protected } \\
\text { areas with PAME } \\
\text { assessment records } \\
\text { (GD-PAME) }\end{array}$ & $\begin{array}{r}\text { Number of PAME } \\
\text { assessment records } \\
\text { (GD-PAME) }\end{array}$ & $\begin{array}{r}\text { Number of PAME } \\
\text { assessments } \\
\text { inventoried by } \\
\text { Campese \& Sulle (2019) }\end{array}$ & $\begin{array}{l}\text { Number of protected } \\
\text { areas with more than } \\
\text { one assessment }\end{array}$ \\
\hline Angola & 14 & 4 & 4 & 4 & 0 \\
\hline Botswana & 22 & 6 & 8 & 9 & 2 \\
\hline Comoros & 8 & 0 & 0 & 0 & $\begin{array}{r}\text { No assessments on } \\
\text { GD-PAME }\end{array}$ \\
\hline Djibouti & 7 & 1 & 1 & 1 & 0 \\
\hline Eritrea & 4 & 0 & 0 & 0 & $\begin{array}{r}\text { No assessments on } \\
\text { GD-PAME }\end{array}$ \\
\hline Eswatini & 14 & 0 & 0 & 6 & $\begin{array}{r}\text { No assessments on } \\
\text { GD-PAME }\end{array}$ \\
\hline Ethiopia & 104 & 17 & 20 & 27 & 3 \\
\hline Kenya & 411 & 41 & 70 & 112 & 18 \\
\hline Lesotho & 4 & 2 & 1 & 1 & 0 \\
\hline Madagascar & 157 & 78 & 79 & 476 & 1 \\
\hline Malawi & 133 & 19 & 23 & 29 & 4 \\
\hline Mauritius & 44 & 13 & 19 & 13 & 4 \\
\hline Mozambique & 44 & 10 & 44 & 45 & 11 \\
\hline Namibia & 148 & 18 & 40 & 44 & 10 \\
\hline Rwanda & 10 & 4 & 6 & 5 & 2 \\
\hline Seychelles & 40 & 6 & 10 & 12 & 2 \\
\hline Somalia & 21 & 0 & 0 & 0 & $\begin{array}{r}\text { No assessments on } \\
\text { GD-PAME }\end{array}$ \\
\hline South Africa & 1580 & 205 & 722 & 1606 & 173 \\
\hline South Sudan & 27 & 4 & 4 & 4 & $\begin{array}{r}\text { No assessments on } \\
\text { GD-PAME }\end{array}$ \\
\hline Sudan & 23 & 2 & 2 & 2 & 0 \\
\hline Tanzania & 840 & 183 & 329 & 340 & 80 \\
\hline Uganda & 712 & 37 & 54 & 53 & 10 \\
\hline Zambia & 635 & 22 & 65 & 70 & 12 \\
\hline Zimbabwe & 232 & 9 & 9 & 14 & 1 \\
\hline
\end{tabular}

Source: Campese \& Sulle (2019); UNEP-WCMC \& IUCN (2019a)

\section{Figure 10.2 Percentage coverage of management effectiveness assessments per region}

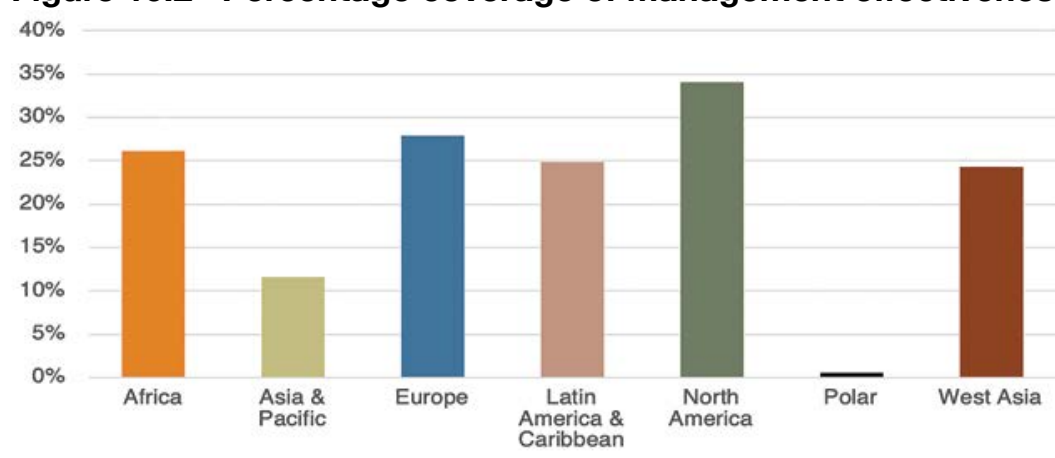

Source: UNEP-WCMC \& IUCN (2019a).

Note: Percentage coverage of all protected areas per region assessed for management effectiveness using different Protected Area Management Effectiveness (PAME) tools 
Figure 10.3 Number of protected areas with PAME assessments in GD-PAME for Eastern and Southern Africa

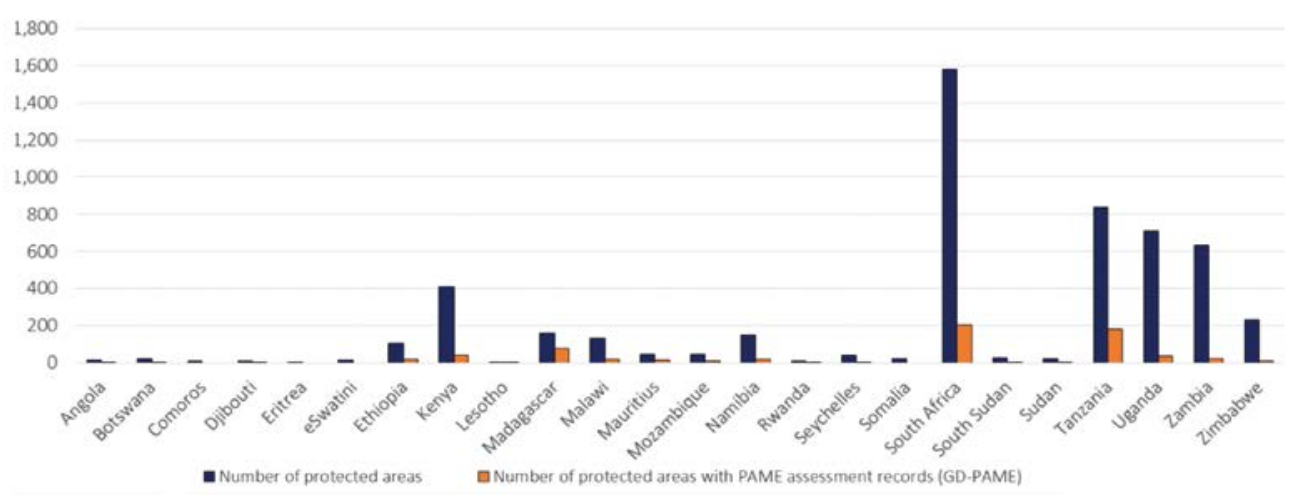

Source: UNEP-WCMC \& IUCN (2019a).

Figure 10.4 Percentage of protected area with PAME assessments in the GD-PAME

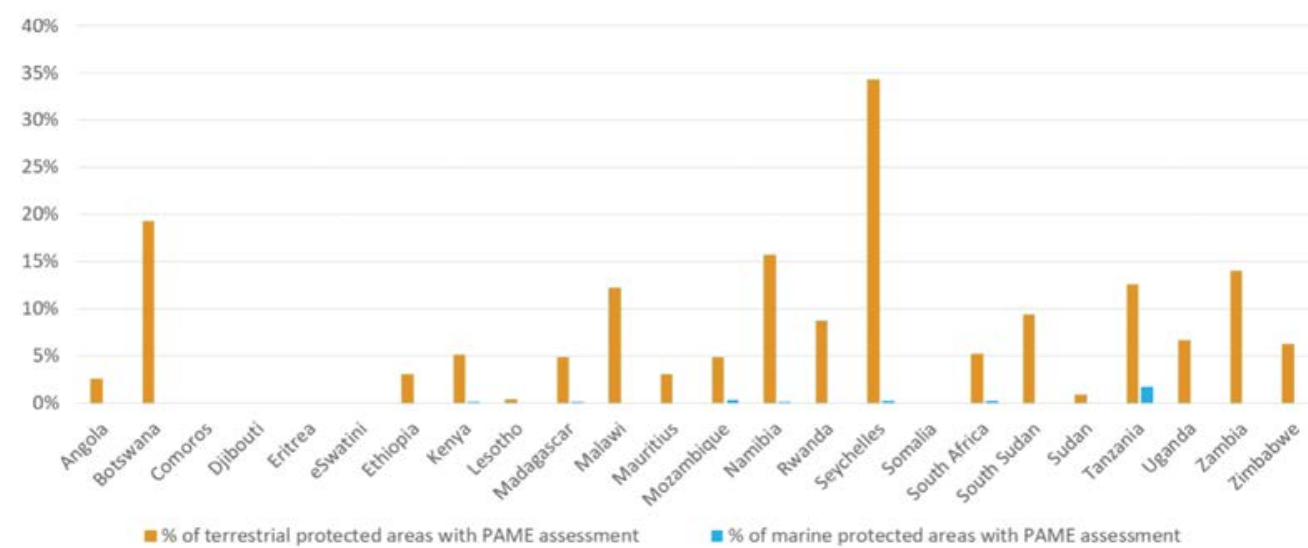

Source: UNEP-WCMC \& IUCN (2019a)

Figure 10.5 Inventoried PAME assessments in Eastern and Southern Africa by methodology/tool (total 2 878)
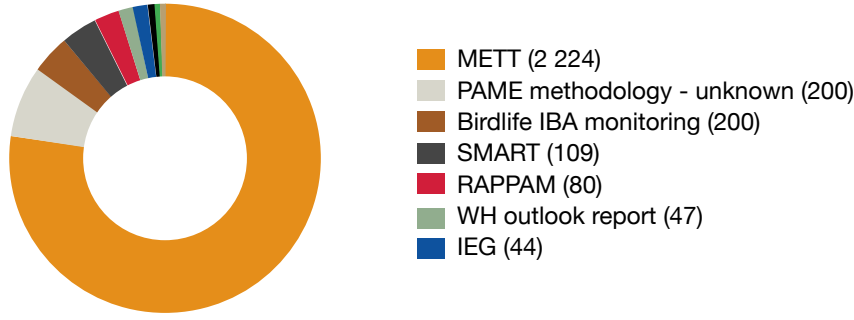

PAME methodology - unknown (200)

Birdlife IBA monitoring (200)

SMART (109)

RAPPAM (80)

WH outlook report (47)

IEG (44)

Source: Campese \& Sulle (2019, p. 44).

\section{Figure 10.6 Distribution of inventoried PAME assessments by country}

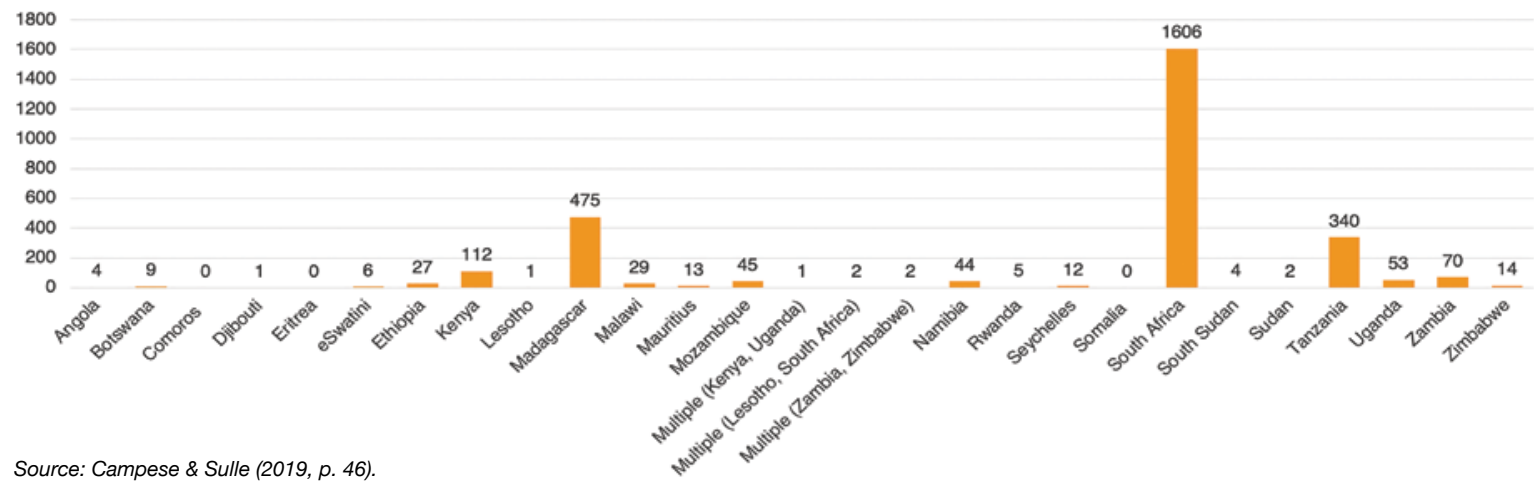


A total of 2,686 management effectiveness assessments were inventoried in the analysis of PAME by Campese and Sulle (2019). Eighty of these were part of system-level RAPPAM assessments. METT assessments, including country-adapted versions of METT, comprise the large majority - 2,035 (over $75 \%$ ) - of the inventoried PAME assessments (Figure 10.5).

PAME assessments have often been repeated in the same sites, in part because many donors, including the GEF and the World Bank require multiple assessments over time as a condition of their funding. METT assessments, in particular, have been repeated in many sites and, in more recent years, have been completed annually or bi-annually in state-governed protected areas in South Africa, Madagascar, and Zambia. World Heritage Outlook Reports were completed across 24 sites in 2014 and repeated in 2017.

Information about governance types was available for 2,046 of the PAME assessments. Over $95 \%$ were conducted in governmentgoverned protected areas, followed by community governance $(2 \%)$, private governance $(2 \%)$ and shared governance (less than $1 \%)$.

The majority of PAME assessments in the analysis were in South Africa (53\%), a country that has adopted METT at the national level for monitoring management effectiveness and has repeated assessments for multiple sites. Madagascar represents $18 \%$ of the assessments and Tanzania 13\% (see Figure 10.6). Only Comoros, Eritrea and Somalia have no reported assessments.

The number of PAME assessments completed annually in the region has been increasing over time (See Figure 10.7), with METT assessments in particular increasingly annually (See Figure 10.8).

\subsubsection{Inventory of combined assessments in Eastern and Southern Africa}

The inventory included an analysis of social and governance assessments for protected areas as well as for those methodologies that combine two or more elements - i.e. management effectiveness, social impact, and/or governance - in ways that make it difficult to place them in a single category. Figure 10.9 shows the inventoried 'combined' assessments by methodology/ tool.

Of the 31 assessments in the combined category, 20 used the Forest Stewardship Council (FSC) Risk Assessment approach, with five sites using the IUCN Green List (see section 9.2). The Green List includes explicit consideration of management effectiveness, governance and social assessment. FSC Risk Assessments, while not commonly cited among protected and conserved area assessments, were included in the inventory because the FSC-US Forest Management Standard includes questions on both forest management and governance, as well as some aspects of social impact, and these assessments have been relatively widely done in conserved forests in the region. This includes 17 village land forest reserves in Tanzania, assessed under a group FSC certificate with the Mpingo Conservation and Development Initiative (MCDI, 2019).

\subsection{Results of PAME assessments in Eastern and Southern Africa}

While there have been many PAME assessments conducted throughout Eastern and Southern Africa (see section 10.8), there has not been any recent and comprehensive attempt at the regional level to compile and analyse the outcomes of these assessments. The last global meta-analysis which included a regional analysis for Africa was conducted in 2010 (Leverington et al., 2010). In that analysis, a total of just over 960 assessments from Africa were recorded, and data was analysed for 644 sites using the most recent assessment available for each protected area. The overall mean effectiveness score (averaged across all individual indicators) was $49 \%$, which was below the world mean $(53 \%)$ and lower than any other region. Some $22 \%$ of the assessments scored in the bottom third of the scale (clearly unacceptable), while only $17 \%$ scored in the top third (sound management) (Leverington et al., 2010).

For natural and mixed (both natural and cultural) World Heritage sites, the IUCN World Heritage Outlook evaluates 14 different aspects of protection and management, including legislative framework, management system, relationship with local people, monitoring, boundaries of the site, education programmes, etc., followed by an overall assessment of protection and management effectiveness of each site. According to the most recent assessment from 2017 (Osipova et al., 2017), the conservation outlook of natural and mixed World Heritage sites in Eastern and Southern Africa, is either 'good' or 'good with some concerns' for $71 \%$ of sites, while $21 \%$ were assessed as 'significant concern' and $8 \%$ were considered 'critical'. For example, compared to the previous assessment in 2014, the results for Tsingy de Bemaraha Strict Nature Reserve in Madagascar declined from 'good' to 'good with some concerns', while Serengeti National Park in Tanzania improved form 'Significant Concern' to 'Good with some concerns'. The conservation outlook of all other sites in the region remained the same (Osipova et al. 2017). Half of the natural and mixed World Heritage sites in Eastern and Southern Africa were assessed as having 'mostly effective' or 'highly effective' protection and management, while $29 \%$ were assessed as 'some concern' and $21 \%$ as 'serious concern'. The individual ratings for the overall Conservation Outlook for each of the natural/mixed sites is given in Table 4.2.

An analysis of management effectiveness for East Africa, conducted through the BIOPAMA programme in 2017, used 25 headline indicators as defined in the Leverington et al. (2014) report representing all elements of the protected area management cycle (BIOPAMA, unpublished). The results showed that $8 \%$ of the assessed protected areas have a sound level of management in place, while $34 \%$ have basic management in place (see Figure 10.10). Almost half (40\%) of the protected areas in the analysis have basic management in place but with major deficiencies. Eighteen percent of the protected areas were found to have inadequate management. Figure 10.11 shows the location of some of the protected areas in the analysis as well as their level of management effectiveness. 
Figure 10.7 Inventoried management effectiveness assessments by year

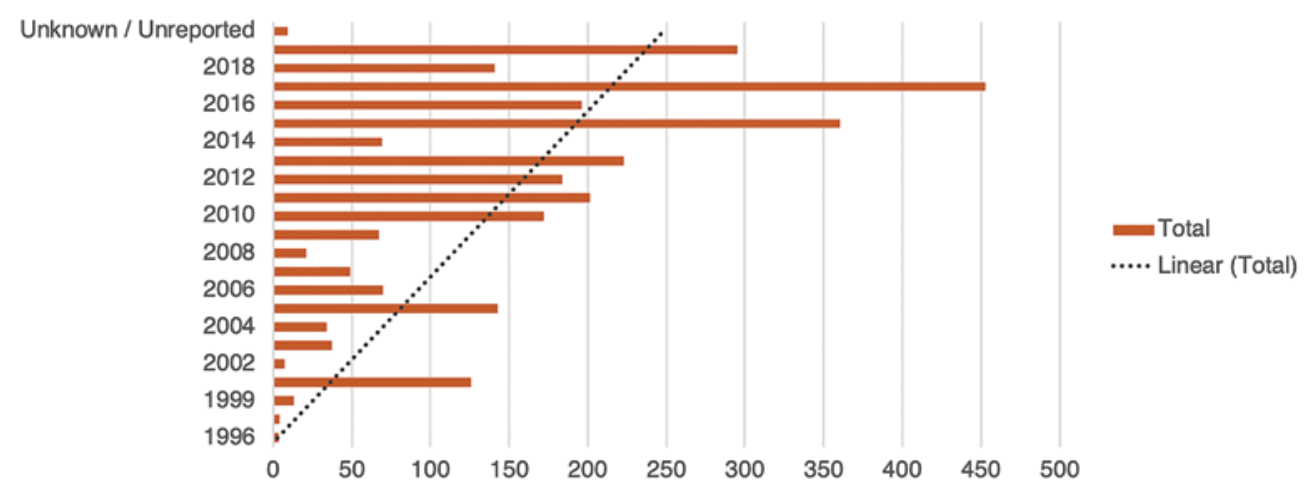

Source: Campese \& Sulle (2019, p. 47).

A small error in allocation of assessments between 2014 and 2015 was discovered since Campese \& Sulle (2019) was published. It has been corrected for this figure.

\section{Figure 10.8 Inventoried METT assessments by year}

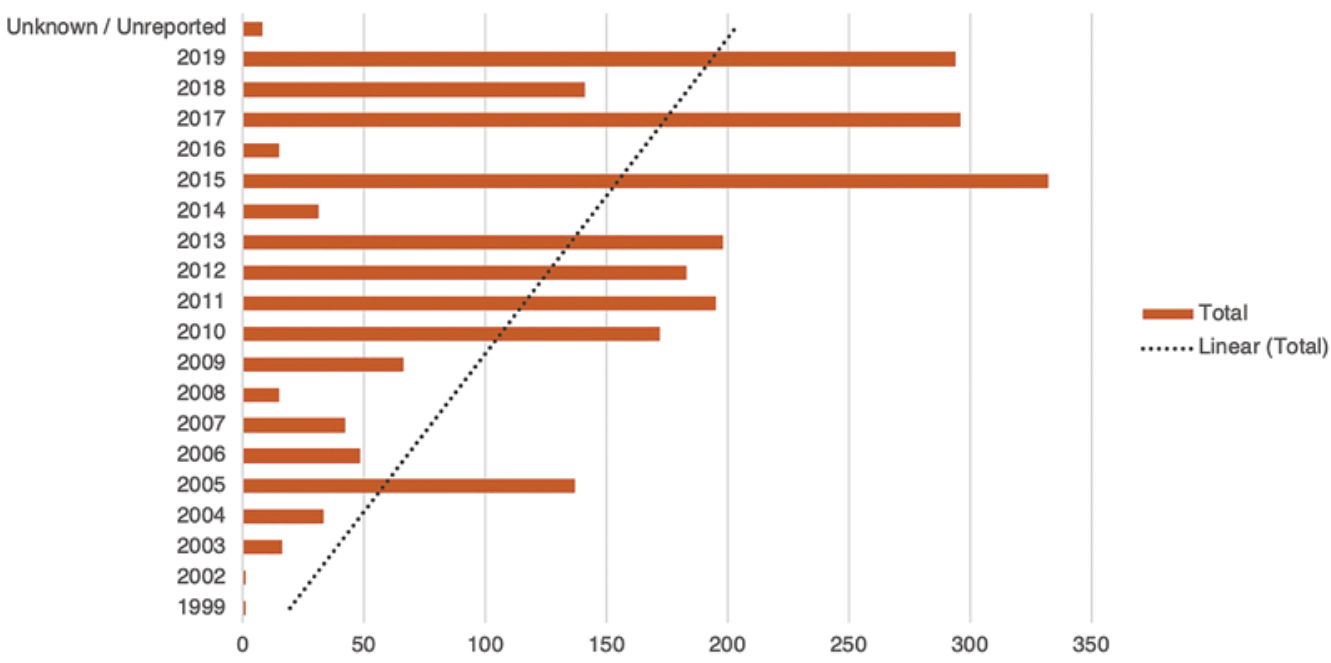

Source: Campese \& Sulle (2019, p. 52).

Figure 10.9 Inventoried 'combined' assessments by methodology/tool

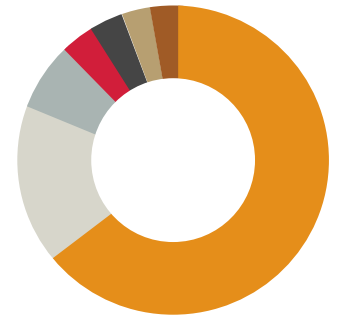

FSC Risk Assessment (20)

Green List (5)

Sensemaker (2)

Participatory Mapping (1)

Whakatane Mechanism (1)

Source: Campese \& Sulle (2019, p. 53).

Figure 10.10 Management effectiveness results for assessed protected areas in East Africa

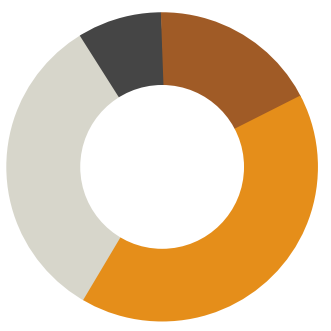

Basic (50-66\%)

Basic - major deficiencies (33.3-50\%)

Inadequate $(<33.3 \%)$

Sound $(>66 \%)$

Note: The protected areas were classified according to their mean management effectiveness scores (in brackets) from the most recent assessment. Source: BIOPAMA (2017). 


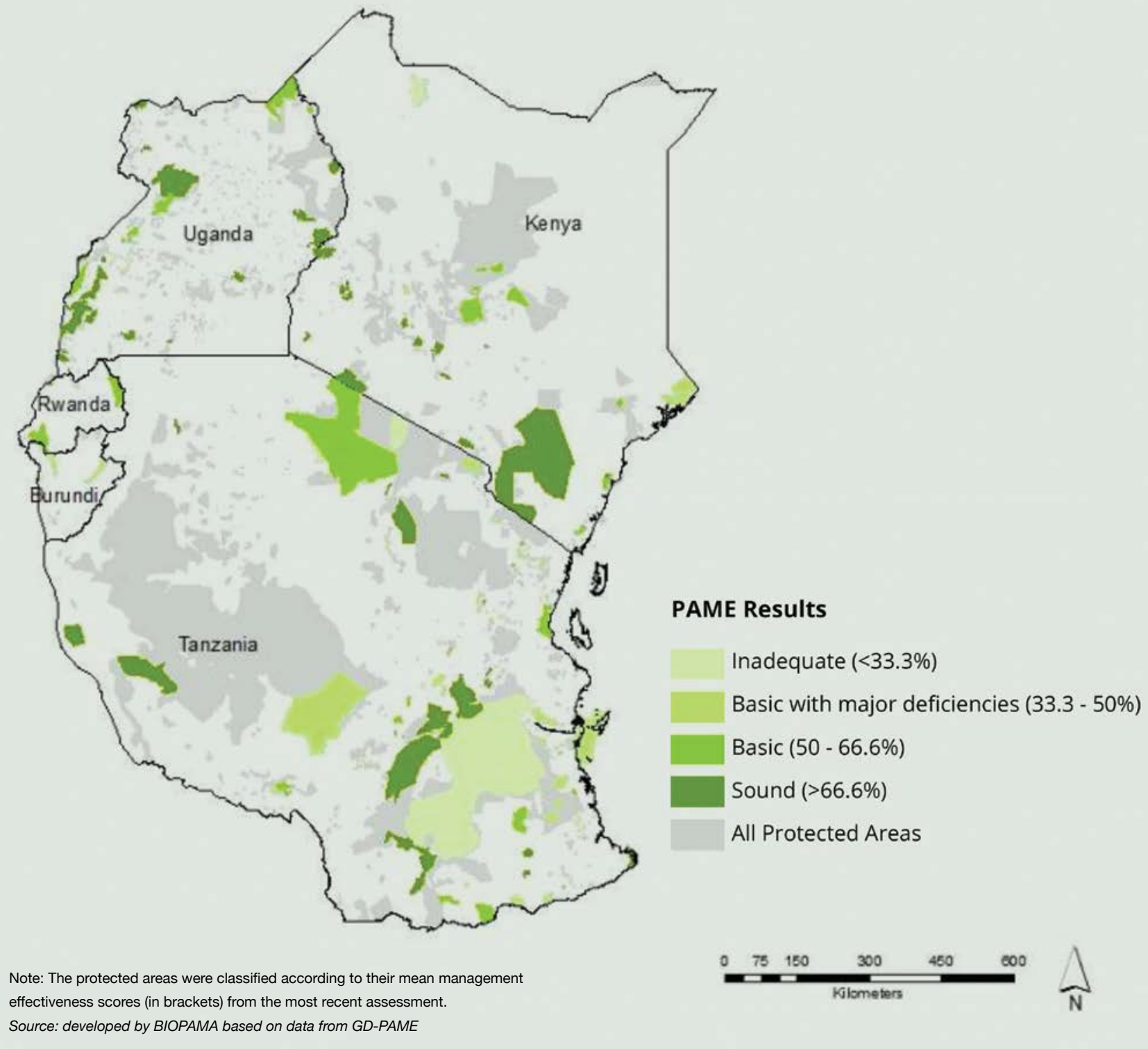

To know which aspects of protected area management are effective, further analysis of the assessments was carried out to show mean scores for individual headline indicators (see Figure 10.12).

Analysis is based on the most recent assessment for each protected area. Headline indicators with less than 20 samples were removed from the analysis.

Planning was the strongest element of management overall, especially regarding aspects of establishment of sites while management planning was somewhat weaker. Amongst Inputs, indicators reflecting availability of funding and equipment were amongst the weakest aspects of management. Some indicators showed mixed results - governance and leadership and involvement of communities and stakeholders were assessed as relatively strong, but this was not reflected in positive effects of the protected area on local communities.

There have been some country-wide assessments, for example in 2014, South Africa conducted an analysis of management effectiveness of marine protected areas (Chadwick et al., 2014). The analysis highlighted a number of improvements since the previous analysis in 2009, including monitoring programmes, enhanced enforcement capabilities and improved stakeholder engagement. It further noted continued limitations in budgets, administrative processes, inadequate regulations, availability of skilled MPA staff and development of strategic plans. 


\subsection{Financing and resourcing of protected $\operatorname{areas}^{111}$}

Protected and conserved areas play a key role in protecting biological diversity and ecosystem services upon which Africa's economy and people depend. These areas need reliable and sustainable sources of funding to maintain their daily management operations, meet conservation targets, provide quality visitor experiences, where appropriate, and provide benefits to communities living in proximity to the conservation areas.

Current sources of funding are, however, inadequate. A number of studies have been completed to assess the financial gap for protected area management (Credit Suisse et al., 2014; Emerton et al., 2006; Parker et al., 2012). While the exact figure may vary, there is general consensus that the current amount of funding available for the protection and management of conservation areas is wholly inadequate. A report by Credit Suisse, WWF, and McKinsey Group in 2014 estimated that US\$300-400 billion is required annually to fund global biodiversity protection. Even if the current governmental and philanthropic conservation efforts are doubled to roughly US\$ 100 billion per year, the report theorised, global biodiversity conservation is still faced with a global funding gap of US\$200-300 billion per annum (Credit Suisse et al., 2014). The United Nations
Development Programme (UNDP) Biodiversity Finance Initiative (BIOFIN) suggests a similar estimate of the global annual financing gap at US\$150-440 billion (BIOFIN, 2019).

The exact estimate of global spending on biodiversity and ecosystems services is challenging to provide, due to considerable gaps and inconsistencies in biodiversity finance reporting and tracking (OECD, 2019). According to Parker et al. (2012), global spending on biodiversity and ecosystem services reached US\$ 53 billion per year in 2010. OECD estimated the spending on biodiversity-relevant activities (based on available government budgets data) was US $\$ 49$ billion in 2015 (by comparison, the fossil-fuel and agriculture sectors received US $\$ 500$ billion of subsidies and government support per year (OECD, 2019). Of US\$ 53 billion allocated for biodiversity conservation, $74 \%$ was spent in the developed world, only 6\% in Africa (Parker et al., 2012) and 5\% in Latin America.

A recent study of 2,167 protected areas, representing $23 \%$ of the global terrestrial protected area estate, found that less than $25 \%$ of the protected areas have adequate resources, staffing or budget (Coad et al., 2019). In developing countries, this protected area financing gap was estimated to be approximately US\$ 0.2-0.9 billion per year in 2005 (CBD, 2005), while fewer than $6 \%$ of the

\section{Figure 10.12 Average scores for headline indicators from the most recent assessments}

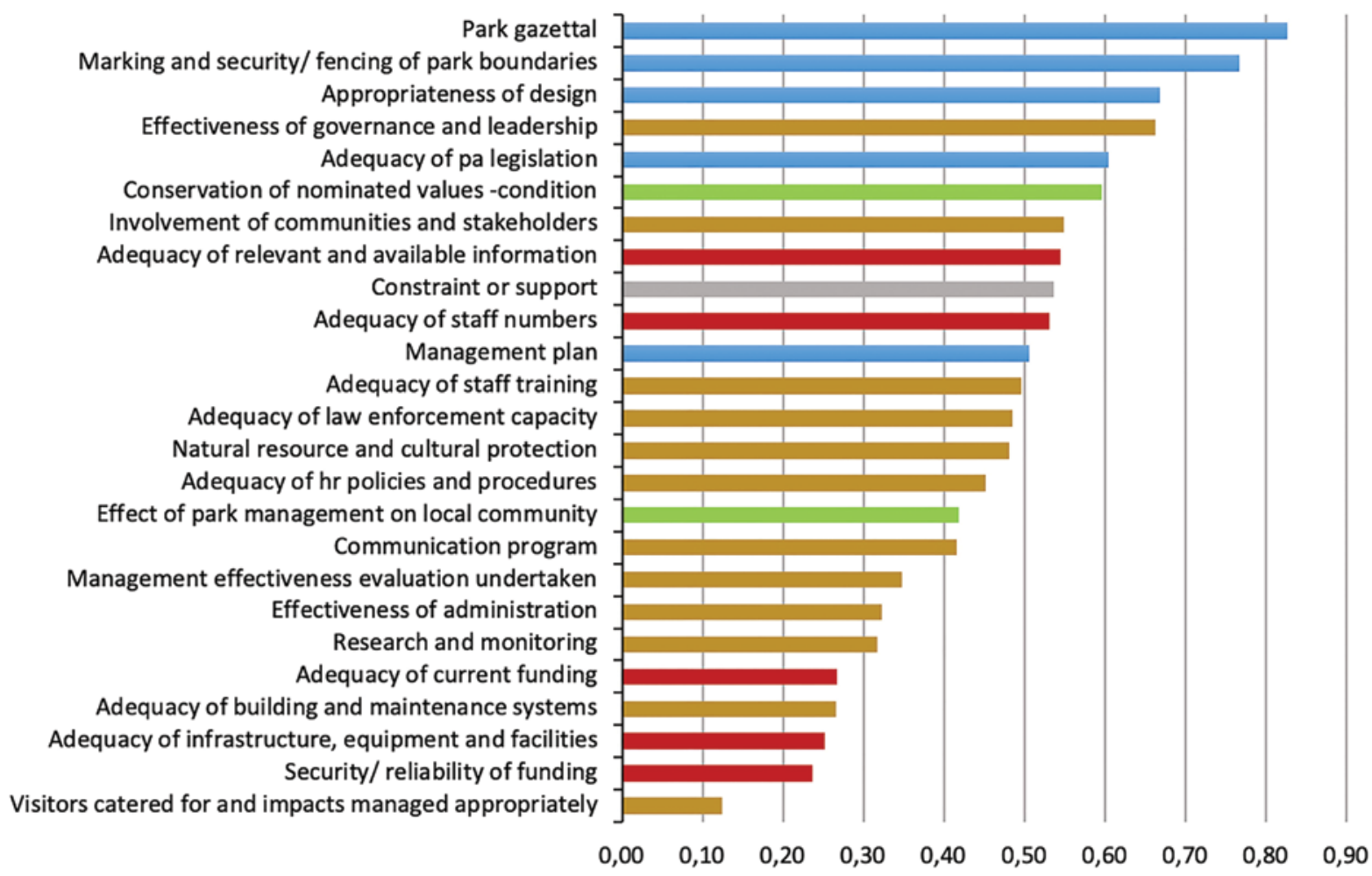

Context $\square$ Planning $\square$ Input $\square$ Process $\square$ Outcome

Source: BIOPAMA (2017)

111 Francois Barnard and Kathleen Fitzgerald (Conservation Capital) made significant contributions to this section. 
countries reporting to the CBD indicated that they had adequate resources for protected area management (Watson et al., 2014).

\subsubsection{The funding gap in Eastern and Southern Africa}

Eastern and Southern Africa's protected areas face a significant financing and resourcing challenge, especially those areas that protect large and wide-ranging mammals, such as rhino, elephant, lion and wild dog. A study found that the annual cost of managing protected areas that support lions is approximately US $\$ 2,000$ per $\mathrm{km}^{2}$ in unfenced areas and US $\$ 500$ per $\mathrm{km}^{2}$ in fenced areas (IUCN ESARO, 2020, p. 16). The findings were later confirmed by Lindsey et al. (2018), who estimated that effective management of protected areas with lion requires US $\$ 1,000-2,000$ per $\mathrm{km}^{2}$ (IUCN ESARO, 2020 , p. 16). However, the majority of protected areas in Africa are managed with less than US\$ 50 per $\mathrm{km}^{2}$ (Fitzgerald, 2017), suggesting that these areas are grossly underfunded by approximately $90 \%$ (IUCN ESARO, 2020, p. 16).

While the funding, management and associated staffing requirements of individual protected areas varies according to factors such as local geographical features, shape, climate, cultural context, species living in the area, adjacent land uses and populations, there is consensus that there is a significant funding gap across Eastern and Southern Africa.

A 2019 study assessed the management costs, revenue and subsidies of 282 state-owned protected areas with lions and concluded that available funding only satisfied $10 \%$ to $20 \%$ of management needs. In total, the funding gap of these protected areas was estimated at approximately US\$ 1.5 billion per annum (IUCN ESARO, 2020, p. 16).

A review of the financial data from protected areas across 15 countries in the region also showed that 12 of these countries face significant funding gaps (see Figure 10.13). Even though Eastern and Southern Africa generally have similar funding gaps (56\% and $64 \%$ ), some individual countries, such as South Africa, Kenya and Rwanda (see Box 10.2), appear to be better funded, suggesting that countries with enabling legislation (such as South Africa's wildlife ownership policies) and well-developed nature-based tourism are able to contribute more to the financing of their protected areas.

\subsubsection{Current sources of funding}

Traditional financing options for protected and conserved areas in Eastern and Southern Africa are generally limited to government funding, donor support and self-generated, market-based finance, such as for example revenue generated from nature-based tourism. While countries, protected areas and their associated funding requirements differ, there are very few protected areas that are able to generate sufficient revenue through internal means, making most dependent on some form of donor or government support. These external sources of finance however remain inadequate.

\section{External funding}

- Government support: Globally, approximately half of the expenses for biodiversity are covered by national government funding from the host country (Parker et al., 2012). In Eastern and Southern Africa, all protected area agencies receive some level of funding from their national governments. For example, in Kenya, 47\% of the Kenya Wildlife Service 2015 budget was provided by the Government of Kenya (Kenya Wildlife Service, 2015). However, governments frequently face competing needs for infrastructure, health care, education and food security, thus diverting funding from conservation to these social needs. Diversifying revenue, while increasing revenue from selfgenerating means, is therefore critical to ensuring the long-term sustainability of protected area finance and management. Similarly, investment in protected area management is also necessary to ensure that the required infrastructure is in place and wildlife or nature-based product is financially secure.

- Donor support and collaborative management: According to the study by Emerton et al. (2006), external grants, donations and philanthropic support, together with government support, remain one of the major sources of funding for conservation and management of protected areas in Eastern and Southern Africa. In 2018, for example, more than three quarters of the operating and capital expenditures of a Kenyan organisation - Northern Rangelands Trust - that supports 30 community conservancies, were covered by donor support (The Northern Rangelands Trust, 2018). In contrast, in South Africa, $80 \%$ of the revenue for South African National Parks is self-funded and comes from tourism.

Local and international conservation organisations also play an important role in supporting, financing and resourcing Africa's protected areas. For example, the Frankfurt Zoological Society (FZS), in partnership with Department of National Parks and Wildlife of Zambia, has supported conservation in the North Luangwa National Park and surrounding GMAs for more than 30 years (FZS, 2019). There are a number of different models for non-governmental support to the management of protected areas (see section 11.1). Financial data from 15 countries in Eastern and Southern Africa show that donor support represents more than $50 \%$ of funding (Lindsey et al., 2018).

Given its compatibility with conservation as a land use, naturebased tourism is often the major (and in many cases the only) source of income generated by protected areas. Nature-based tourism refers to tourism where the main purpose is viewing or enjoyment of the natural environment, which includes, amongst other activities, hiking, birdwatching, or wildlife drives. An analysis of the seven protected area authorities in Eswatini, Ethiopia, Kenya, Namibia, Tanzania, South Africa and Uganda (totalling more than 240 protected areas and 40 million hectares under management), shows that tourism generates approximately $80 \%$ of all internally generated revenue (see Figure 10.14).

There is a significant opportunity in a number of countries in Eastern and Southern Africa to increase revenue from existing tourism and to develop new forms of revenue generation through wildlife-based tourism. 
Figure 10.13 Funding gap and available financing resources in 15 countries in Eastern and Southern Africa
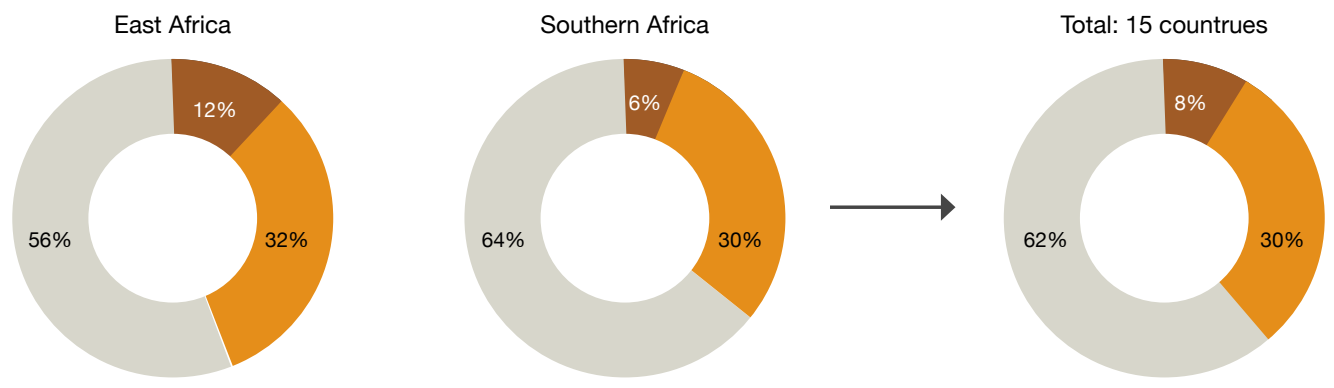

Source: IUCN ESARO (2020, fig. 5, p. 16).

Figure 10.14 Breakdown of internally generated revenue in seven countries: Eswatini, Ethiopia, Kenya, Namibia, South Africa, Tanzania, and Uganda

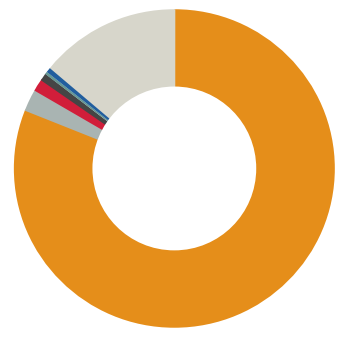
Tourism revenue
Hunting revenue
- Shop/merchandise sales
Harvesting sales of natural products
Carbon credits, biodiversity offsets, other PES
Marathons, filming and photography fees
Other

Source: Developed by Conservation Capital (2019) ${ }^{112}$

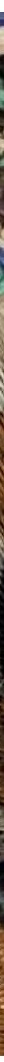

112 This graphic was developed by Conservation Capital using the following data sources: Financial and annual reports of Kenya Wildlife Service, Tanzania National Parks, South African National Parks, Eswatini National Trust Commission, Ethiopian Wildlife Conservation Authority, Uganda Wildlife Authority and Namibian Association of Community-Based Natural Resource Management. Category "Other" includes when specified: equipment and facilities lease, interest and royalties received, park fines, garage and labour fees, rescue fees, research and other income. 


\section{Box 10.2 Rwanda's robust tourism economy}

Rwanda has a strong and growing leisure travel market, with most of its 1.4 million visitors coming from neighbouring countries (43\% came from the East African Community (EAC) and $45 \%$ from other parts of Africa) (RDB, 2017), and 80,000 visitors coming from abroad (most notably Europe and India).

Business and conference tourism are becoming ever more important and generate the highest revenue share (RDB, 2017). For example, among air arrivals (excluding transit, returning residents and visit of friends and family), more than $50 \%$ came for business and conferences, with holidays accounting for $35 \%$ (National Institute of Statistics of Rwanda, 2017).

Tourism is Rwanda's top foreign exchange earner and is mainly driven by ecotourism, which has been prioritised by the Government of Rwanda as it recognises the social and economic benefits tourism provides. Total leisure travel revenues increased from US\$ 390 million in 2016 to US\$ 438 million in 2017, representing $14 \%$ of the country's gross domestic product (GDP) (KNOEMA, 2018).

Tourism in Rwanda supports 98,000 direct employees (or 5\% of total off-farm jobs), with a total (direct and indirect) employment of 250,000 (14\% of all off-farm jobs. Visitation to National Parks has increased by $54 \%$ since 2012 from 61,000 to almost 94,000 visits in 2017). The increase has resulted in a significant increase in revenues - US\$ 18.6 million in 2017, an increase of almost 50\% from 2012 (IUCN ESARO, 2020, p. 28).

The majority of Rwanda's ecotourism income is generated through gorilla trekking permits, which currently cost US\$1,500 per permit. Rwanda also has the highest community revenue share model in Africa, providing $10 \%$ of all park revenue to communities and an additional $5 \%$ to a HumanWildlife Conflict (HWC) fund for communities. Given the overreliance on mountain gorilla revenue, which generated US\$ 18.3 million in 2017 (RDB, 2017), Rwanda has started to broaden and diversify its nature-based tourism through developing and attracting investments into its other protected areas, such as the Akagera National Park in the eastern part of the country, which offers a different tourism product, a savannah landscape. By diversifying the product, the government aims to keep people in-country longer, thereby increasing revenue generation (RDB, pers. comm., 2019). Akagera National Park is co-managed with African Parks, a non-profit organisation headquartered in South Africa (see section 11.1).

\section{Contributed by Conservation Capital.}


Other key trends in protected area finance in East and Southern Africa are outlined below.

- There are significant revenue-earning differentials between protected areas and countries. For example, of 14 parks in Tanzania more than $75 \%$ of revenue in 2012/2013 was generated by only two parks, Mount Kilimanjaro (42\%) and Serengeti (33\%) National Parks. In Rwanda, Volcanoes National Park accounts for $38 \%$ of all visits and generates over $90 \%$ of all revenues (RDB, 2017).

- Revenue expenditure and retention is a key aspect of ensuring effective conservation management. Business plans for protected areas (individual and system) help ensure that any increase in funding is managed properly, driving enhanced conservation performance. Most protected area agencies in the region are required to remit their revenue to central treasury and then apply for their yearly budget, where some receive less than what had been generated. Therefore, even if one park is able to generate sufficient revenue to support its operations, these profits are used to subsidise less profitable parks. For example, in Tanzania, TANAPA manages 506 protected areas yet only two National Parks, Kilimanjaro and Serengeti, generate $74 \%$ of revenue in 2013 (Tanzania National Parks, 2013). In South Africa, out of the 19 national parks, Table Mountain and Kruger National Parks hosted $77 \%$ of all visitors in 2017-2018 generating significant revenue from conservation and concession fees (SANParks, 2018). In Rwanda, Volcanoes National Park accounts for $38 \%$ of all visits and generates over $90 \%$ of all revenues for the Rwanda Development Board, the department in charge of managing Rwanda's protected areas and wildlife (RDB, 2017).

- Dependence on the potential of revenue generation of the flagship species. Most funding is directed towards flagship areas, leaving many protected areas effectively non-functional. For example, a majority of Kenya Wildlife Service's budget is directed towards Amboseli, Tsavo and Mount Kenya National Parks, leaving other parks underfunded and non-operational due to a dearth in finance (BIOPAMA, unpublished). In Uganda, $58 \%$ of the Uganda Wildlife Authority's revenue were generated by mountain gorilla permits in 2015 (UWA, unpublished) while in Rwanda, $76 \%$ of tourists visiting the Volcans National Park participated in gorilla watching, accounting for US\$15.4 million or $86 \%$ of all revenues (IUCN ESARO, 2020, p. 27). While these flagship species and parks are an excellent draw to the respective countries, the long-term viability of the protected area system is reliant on these places and species, which presents a key risk. For example, if Ebola impacts a great ape population upon which a country's revenue depends, this not only impacts the species but the economics of the whole system.

In addition to generating revenue for protected areas, the tourism industry, if designed appropriately and sustainably, can be a deterrent to poaching and other illegal natural resource extraction activities. Worldwide, nature-based tourism was growing at $10 \%$ to 12\% per annum in 2004 (Space For Giants et al., 2019). An earlier study (Balmford et al., 2009) showed that visits to protected areas were growing in three quarters of the countries where data was available.
Eastern and Southern Africa is particularly well suited for wildlifebased tourism development given its unique natural and cultural assets, ease of access and spectacular wildlife. The region's land use is also compatible with wildlife-based tourism: $16.54 \%$ of the land is protected across Eastern and Southern Africa (see section 4), which means that there are 2.1 million $\mathrm{km}^{2}$ of land with a potential for wildlife-based tourism. This is more than some other major tourist destinations in the world having very diverse landscapes, such as the USA.

In Eastern and Southern Africa, travel and tourism contributed 9.5\% of GDP (or US\$ 75 billion) in 2018 (WTTO, 2019). Tourism spending in the region accounted for US $\$ 50$ billion, of which leisure was approximately US\$ 35 billion and spending by international visitors was around US\$ 25 billion (WTTO, 2019).

Tourism in the region is already playing an important role in generating revenue for the countries, providing employment, both directly and indirectly, and supporting vital social services.

Some highlights of its role are mentioned below:

- In South Africa, National Parks welcomed more than 7 million tourists and generated US\$109 million in tourism income for year ending 31 March 2018 (SANParks, 2017).

- An estimated 2.9 million visited Kenya's protected areas in 2018 (KNBS, 2019).

- Approximately $46 \%(590,000)$ of international visitors to Tanzania visited a protected area (Spenceley et al., 2017; The World Bank Group, n.d.).

- There were 305,000 visitors to Uganda's protected areas in the year ending June 2018, generating revenue of US\$ 28 million for the Uganda Wildlife Authority (UWA, 2018).

- Approximately $80 \%$ of tourists buying holidays to Africa come for wildlife-watching, according to a survey of 48 governmental institutions from 31 sub-Saharan African countries and 145 tour operators selling trips to Africa (WTO, 2014).

- Africa's protected areas attract an estimated 69 million recreational visitors annually, mainly international tourists (EC JRC, 2018).

Extrapolating the South African and Ugandan statistics and allowing for a significant margin of error, it is estimated that protected area authorities across the region could generate between US\$ 300 million and US\$ 1 billion in annual revenue through 30 to 50 million visits a year.

While wildlife-based tourism may not be appropriate in a number of places, there are still significant opportunities in Eastern and Southern Africa to develop sustainable tourism in a way that increases revenue for protected area management. The same enabling environment needed for wildlife-based tourism is also required for some of the creative financing mechanisms mentioned in the next section. A diversified approach is the best methodology for increasing finance and sustainability of protected area finance. For example, OI Pejeta Conservancy, a 90,000-acre conservancy in Kenya that serves as one of the most important black rhino refuges in Eastern Africa, generates revenue from tourism, wildlife compatible livestock and zoned agriculture (OI Pejeta 


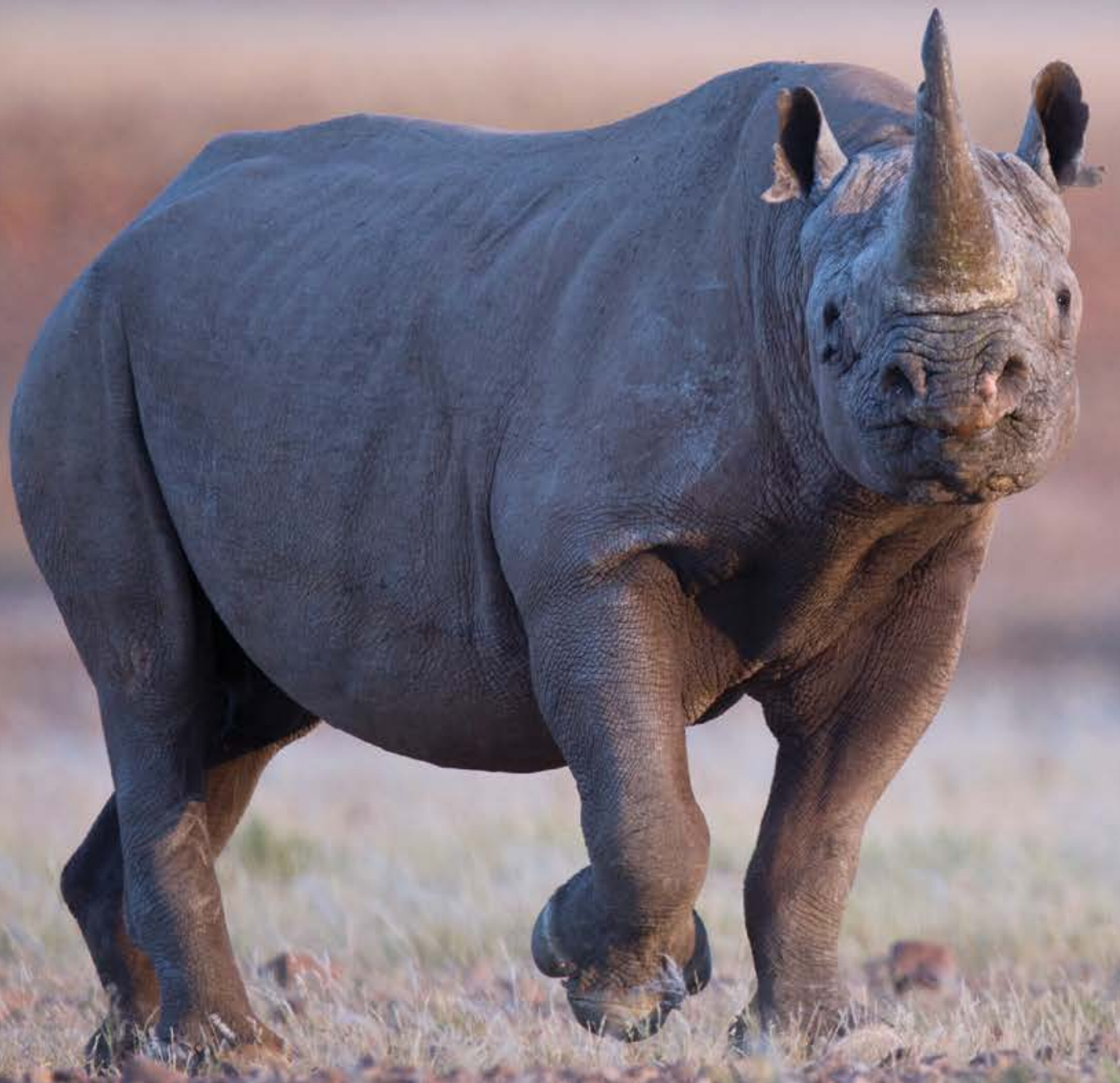

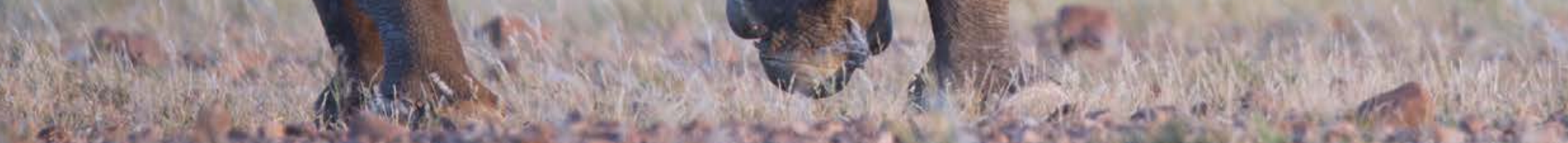

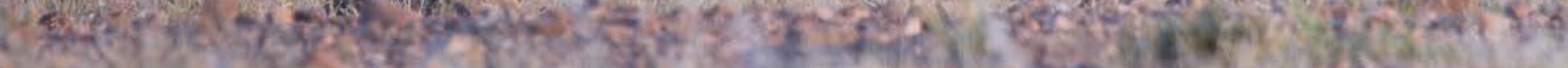

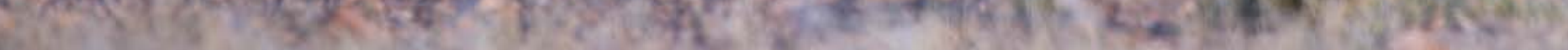

(c) Wilderness Safaris 
Conservancy, n.d.). This diversified approach enables them to withstand drought and the natural cyclical nature of tourism visitation. While these land uses may not be allowed in all protected areas, it shows the importance and potential of a diversified approach.

\subsubsection{New and emerging sources of finance for protected areas}

There is broad recognition that donor funding cannot and will not be able to fill the funding gap for protected areas due to the unstable nature of donor finance and competing challenges of host countries and donor priorities. A number of innovative financing mechanisms have been developed globally, such as:

- Debt-for-nature swaps. A debt-for-nature swap is an agreement that reduces a developing country's debt stock or service in exchange for a commitment to protect nature from the debtor government. These are voluntary transactions whereby the donor(s) cancels part or all of the debt owned by a developing country's government. In exchange, the debtor government commits to invest the accrued savings in biodiversity conservation, climate mitigation and landscape conservation. One such is the Seychelles Blue Bond (The World Bank Group, 2018).

- Taxation incentives, where landowners get a tax deduction for their conservation commitment when declaring nature reserves on privately owned land, such as in South Africa (Swart, 2019), see Box 10.3.

- Biodiversity offsets compensate for the net impacts of a development project after other mitigation measures have been implemented. Offsets should aim to achieve no net loss and preferably a net gain of biodiversity. Offsets can, for example, deliver biodiversity benefits (e.g. reforestation) through a transaction, where offset sellers (e.g. a conservation NGO or government) sell offsets to developers (e.g. a mining company or property developer) who seek to compensate the net biodiversity loss resulting from their activities (e.g. mining).

- Carbon offset programmes, such as the Wildlife Works Kasigau REDD+ Project in Kenya (Wildlife Works, n.d.). While carbon offsets can generate finance for conservation, it can only do so if there is a buyer willing to offset their carbon emissions by purchasing carbon credits from a protected area or conservation project. Carbon laws can overcome this hurdle by compelling polluters to purchase carbon credits.

- Conservation Trust Funds, such as in Uganda, the Biodiversity Conservation Trust Fund (Uganda Biodiversity Fund, n.d.). Conservation Trust Funds, sometimes called environmental funds, are defined as "private, legally independent grantmaking institutions that provide sustainable financing for biodiversity conservation and often finance part of the long-term management costs of a country's protected area (PA) system" (CFA, 2008, p. 1) or a specific protected area.

- Species impact bonds, such as the Rhino Impact Bond (UNDP Ecosystems \& Biodiversity, 2018).

- Payment for Ecosystem Services, such as the Kilombero Plantation Limited PES project (Athanas, 2018).

- Outcomes-based financing mechanisms are innovative financing instruments that attract investment capital to address issues traditionally funded by the public sector. Species bonds or protected area bonds are an example of such mechanisms. They are investment instruments with a set maturity, whose aim is to grow a sample of the population of a selected species at key sites. Investors in the bond receive a financial return only on the completion of the objective, with that return being funded by outcome payers.

- Green bonds can be used to fund a broad range of projects, which includes renewable energy, energy efficiency, sustainable waste management, sustainable land use, biodiversity conservation, clean transportation, and clean water (DuPont et al., 2016). However, green bonds have not yet been used to fund conservation at scale. In 2017, it was estimated that only $2 \%$ of bond proceeds went to land conservation and $4 \%$ to biodiversity conservation.

- Blue bonds. When a country's government commits to protect part of their near-shore ocean areas and engage in conservation work (e.g. improving fisheries management and reducing pollution), the cost of such a transition is often high, especially for Small Island States. Blue bonds help finance this transition: a government issues a bond, often with the assistance/ guarantee of an NGO and/or an agency such as the World Bank, leading to potentially lower interest rates and longer repayment periods. A portion of those savings fund the new marine protected areas and the conservation activities to which the country has committed.

- Project Finance for Permanence uses a project finance technique to facilitate full and upfront funding of large-scale conservation projects or areas by bringing together funders in one closing. Examples of such deals include a US\$ 57 million deal to protect 2 million hectares in Costa Rica and a US\$ 215 million project to conserve 60 million hectares of the Brazilian Amazon (Seol, 2016). By addressing piecemeal or insufficient funding upfront, it ensures that conservation interventions are properly planned and permanent and fully funded. To be successful, these projects need political commitment, a strong investment strategy and rigorous financial plans, and collaboration between governments, NGOs, and public and private funders.

- Lotteries are popular in most countries and can generate substantial income, often for socially beneficial purposes such as nature conservation (WWF, 2009). For example, in South Africa, the National Lotteries Commission distributes funds to a series of causes, including environmental charities (NLCSA, 2019).

- Branding. The Lion's Share (2020) is a conservation finance initiative launched in September 2018 where a small levy is charged on the use of animals in ad campaigns and distributed to conservation NGOs via The Lion's Share fund, with cofunding from the UNDP. The Lion's Share targets raising more than US\$ 100 million per year. Examples of private enterprises who have signed up include Mars Inc, Nielsen, International Airline Group, JCDecaux, The Economist and Batten, Barton, Durstine \& Osborn. In Eastern and Southern Africa, the Lion's Share is funding an African Elephant Economics Study to catalyse government investment in elephant conservation and the promotion of the nature-based economy. In Mozambique, 
the upgrade of the digital radio communication system of the Niassa National Reserve was also completed using funds from the Lion's Share.

- Other financial instruments: BIOFIN worked with nine countries in the region to identify the priority conservation finance instruments for each respective country (IUCN ESARO, 2020, p. 60).

While these innovative financing models exist, they have not yet been adopted or used at scale in Eastern and Southern Africa due to limited technical support, resources and enabling environments. Moreover, while these models do have potential for application and replication across the region, more traditional and proven sources of finance, such as nature-based tourism, although widely used in Eastern and Southern Africa, has yet to be developed to its full potential. However, the situation has worsened by the COVID-19 pandemic that has resulted in the shutdown of the tourism industry and therefore, a significant decrease in conservation-related funding for the protected areas whose main revenue is tourismbased (see Box 10.4). Across Africa, collaborative agreements are becoming increasingly popular tools to increase financial and capacity support for protected areas given that many of them are severely underfunded. In addition, some donors require collaborative agreements for financing. Collaborative management occurs when a non-profit organisation or a private sector entity partners with a state wildlife authority, where the authority either outsources aspects of management or specific conservation activities (e.g. ecological monitoring, education, community engagement, ecosystem restoration) to the partner organisation or enters into an agreement with the private partner that covers the full spectrum of management. This is increasingly taking the form of a public-private partnership (PPP) (see Section 11.1 for further information).

\subsection{Conclusions}

The frequency of management effectiveness assessments has been increasing across Eastern and Southern Africa over time. However, there is room for expansion of management effectiveness evaluation across more countries in the region and in areas under shared or non-state governance (Campese \& Sulle, 2019). In particular, PAME assessments should be included as part of the regular management cycle of protected areas, with the necessary follow up to implement measures to enhance management effectiveness.

METT is the most common methodology used at the site level and it is important to ensure that it is used in line with best practice (Stolton \& Dudley, 2016). A number of METT assessments are completed as part of donor requirements, and often contain no comments or 'next steps' which limits its usefulness. Nevertheless, a number of countries have adapted METT for use at the country level, particularly for state protected areas. RAPPAM is the methodology most commonly used at the system-level and also has many advantages. The use of integrated methodologies that take into account management effectiveness as well as issues of governance and social equity could be helpful in ensuring that protected and conserved areas are assessed adequately across the different aspects of Aichi Target 11, so that improvements can be made for biodiversity and people.

Additionally, other methods, such as a new tool developed under BIOPAMA, the Integrated Management Effectiveness Tool (IMET), have been designed to support protected area agencies and managers in planning, management and monitoring at the site level. IMET is a software which collects and organises data and information on protected area management, with internal statistical analysis, giving score-based estimations of the quality of management, as well as visual components to provide a decision support system. IMET is based on an IUCN framework for measuring the effectiveness of protected area management, and inspired by other tools, such as METT, Enhancing our Heritage toolkit, and others.

Donor requirements have resulted in greater attention to the issue of management effectiveness and an increase in the number of PAME assessments being completed. This is to be welcomed, but it is also critical to ensure that assessments are serving a substantive learning function, as well as improved management, and not just a box ticking exercise. 


\section{Box 10.3 South Africa's first effective biodiversity tax incentive}

South Africa's Income Tax Act (No. 58 of 1962) makes reference to a specific biodiversity tax incentive, section $37 \mathrm{D}$, which is geared towards creating financial sustainability for protected areas on private or communal land as well as motivating and rewarding landowner commitment. Section 37D allows the value of land declared as a Nature Reserve or National Park to be deducted from taxable income, reducing the tax owed by a landowner. This ensures greater liquidity for the conservation management and economic sustainability of the site. The tax incentive is both globally unique and a national first. This biodiversity finance success story was awarded the inaugural Pathfinder Award Special Commendation presented to Ms Candice Stevens and the Government of South Africa.

The two primary benefits of this specific biodiversity tax incentive include:

1) Support for the creation of robust privately and communally owned protected areas.

The requirements of the Income Tax Act correlate specifically to the requirements of South Africa's Protected Areas Act (NEMPAA No.57 of 2003) ensuring that the areas qualifying for this tax deduction are declared protected areas that boast legal certainty, permanence, management and long-term intent.

2) The creation of an innovative tool for the financial sustainability of landscapes.

Section 37D creates a substantial and tangible financial benefit that aids landowners in meeting management responsibilities, bolsters landowner motivation over the medium to long term, and facilitates tax efficiency essential to the sustained success of economic activities compatible with protected areas.

Contributed by Candice Stevens Wilderness Foundation
Africa).

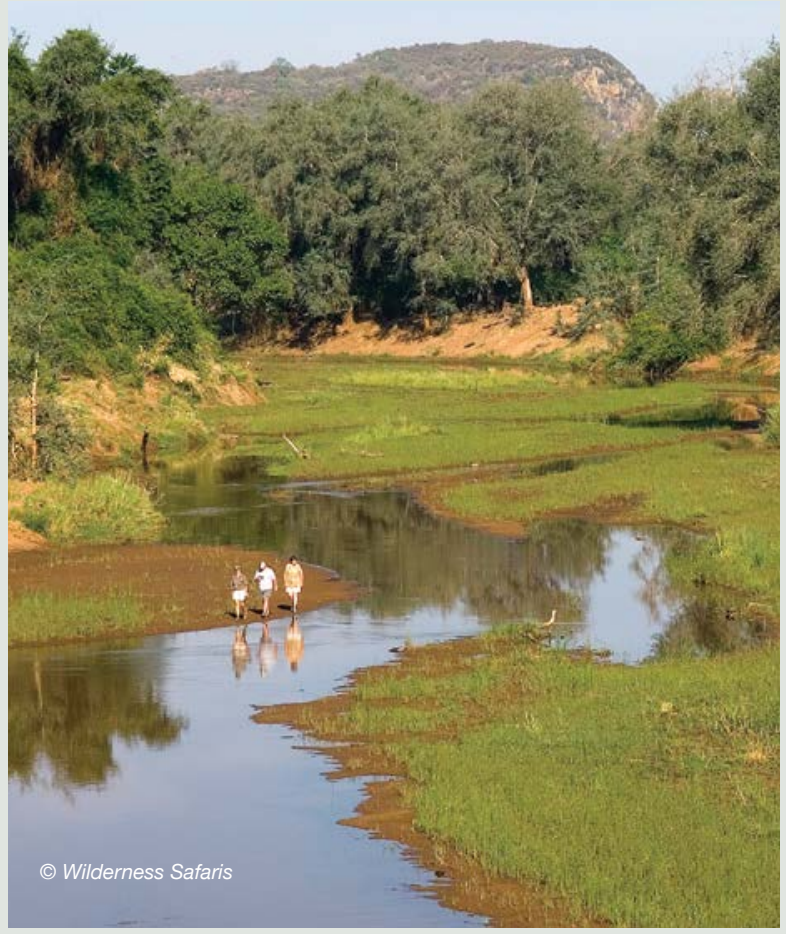

\section{Box 10.4 Impact of COVID-19 pandemic on protected areas in Eastern and Southern Africa}

The COVID-19 pandemic has created an urgent crisis for management of protected areas across Eastern and Southern Africa.

The pandemic has already resulted in a cascade of immediate impacts on protected areas:

- Closure of protected areas to people for tourism and recreation;

- Park staff being required to isolate, resulting in lower staffing levels;

- Reduction of ranger patrols due to reduced staffing, potentially leading to the increase of environmentallydamaging activities;

- Possible direct impacts on some charismatic threatened species, such as the Great Apes; and

- Suspension of routine management and restoration programmes.

The pandemic is associated with a global economic crisis. As this crisis takes hold, poverty levels are likely to rise, particularly in sub-Saharan Africa. There is a threat of increased and unsustainable use of natural resources, as well as the possibility of an increase in commercial poaching. These threats are growing at the same time that the financial inputs underpinning conservation and protected area management are dramatically declining. Financial support is likely to be reduced from all current sources, including bilateral and multilateral funders, private and high-net-worth donors, as well as the close to complete shut-down of the tourism industry.

While there may be some benefits associated with the tourism shut-down, such as the reduction of overcrowding on delicate ecosystems, the financial crisis facing protected areas, under all forms of governance, cannot be overstated. The recommendations outlined in this report regarding the diversification of revenue streams for protected area management are ever more urgent in the context of this global crisis.

Contributed by Leo Niskanen (IUCN, ESARO). 


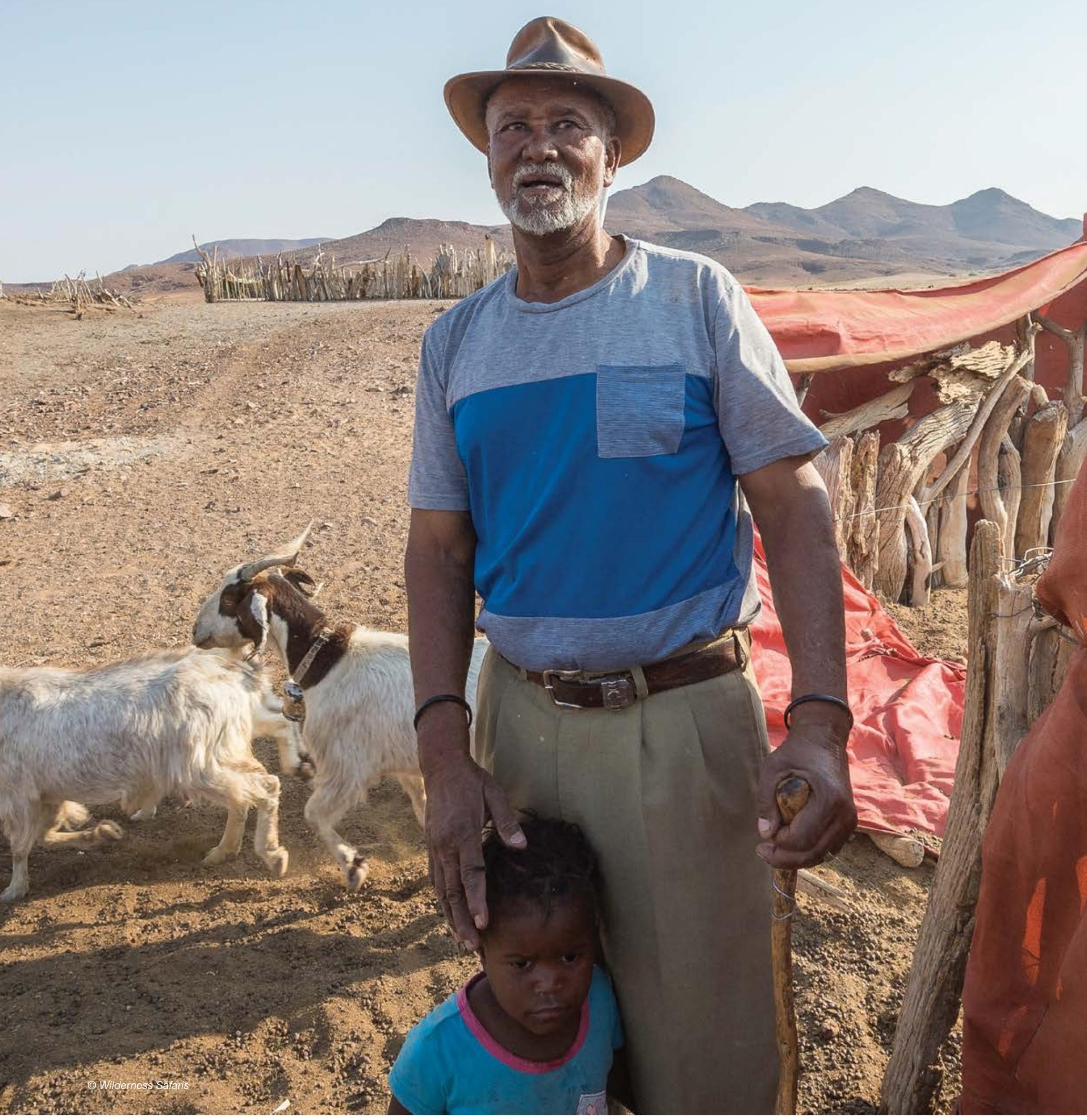




\section{Regional innovations and experiences}


There have been a number of innovations in the region in terms of improving management effectiveness, governance and equity, especially as technology has developed to support this. This section includes information on some of these innovations.

\subsection{Collaborative management of protected areas}

Protected areas are recognized globally as the most effective means of conserving biodiversity and associated cultural assets, as well as an important way of promoting sustainable rural development. Across Eastern and Southern Africa, large protected areas have been set aside for conservation. These protected areas support biodiversity of substantial global value, including the highest global abundance of megafauna (Ripple et al., 2016). On average, across sub-Saharan Africa, state funding is much lower than the recommended minimum of US\$500- US\$ 900 per $\mathrm{km}^{2}$ (Lindsey et al., 2017). Significant donor funding exists for some protected areas, but in many cases, there is insufficient capacity to effectively manage these funds to achieve the goals of the protected area (O'Connell et al., 2019).

The establishment of collaborative management partnerships with non-governmental organisations can be one important mechanism for overcoming these challenges, and has grown in its importance across the protected area estate in Eastern and Southern Africa. There are now many examples of collaborative management partnerships for protected area management. There are a variety of different models that have emerged.

A recent analysis has categorized these into distinct models (Baghai et al., 2018) and two categories: by governance, which concerns who has the power to set overall priorities and strategies (as well as how those decisions get made); and by management, which concerns the day-to-day operations and implementation on the ground (Borrini-Feyerabend et al., 2013) (see Table 11.1).

The analysis undertaken by Baghai et al. consisted of a series of semi-structured interviews and a workshop to develop the framework and understand the context under which each model occurs, as well as the strengths and weaknesses of each. ${ }^{113}$

Delegated management models have historically been found in the most severely under-resourced protected areas, in challenging situations (such as extreme remoteness or the presence of political instability), where the capacity and resourcing of state wildlife authorities is extremely low, and there is little or no income from tourism and where wildlife populations are severely depleted or in danger of becoming so. Such extreme circumstances require significant input of resources and technical expertise, and therefore are more apt candidates for delegated management. More recently, however, African Parks has been delegated authority to manage higher profile protected areas, which suggests a possibility that some states may be increasingly willing to engage this model more broadly.
Co-management models offer a more equal sharing of management responsibility than delegated management arrangements. They may enable the partners to capitalise on their unique strengths, combining the political legitimacy and local knowledge of the state with the innovation, efficiencies and expertise of the nongovernmental sector. Such a partnership presents less risk of the state wildlife authority feeling sidelined or dominated. However, the sharing of management authority between two entities with differing organisational structures, cultures, management and leadership styles may be prone to confusion, conflict and high transaction costs. In some cases, co-management agreements have evolved from financial-technical support partnerships that proved insufficient to achieve the partners' goals. Like the delegated model, the additional investment that comes with co-management models often leads the non-governmental partner to seek greater decision-making authority, and the sharing of which makes the two partners accountable to each other.

Financial-technical support partnerships are found in the widest range of countries and contexts. This model has been by far the most prominent model across Africa for many decades, and several respondents indicated that the move to more devolved models like co-management and delegated management was a result of long experience with the financial-technical support model and its inability in many circumstances to achieve desired outcomes. Nonetheless, it remains the most common and widespread model, and when implemented well in the appropriate contexts, it can be quite effective.

The lack of authority of non-profit associations for governance and management decision-making that characterises these partnerships is a product of varied factors. First, in some countries (such as Botswana, Kenya, Namibia, Tanzania and South Africa), there is significant state capacity, funding and commitment to managing protected areas, and especially national parks. In such countries, financial-technical support makes sense where there is solid government commitment for core management of the protected area, but there are some specific threats -challenges, or even opportunities - that the government is not able to tackle alone and that the non-profit can support. Second, as revealed by interviews, some countries may be reluctant to engage in models that involve sharing or delegating authority because of political and post-colonial sensitivities.

Third, some non-profits do not have adequate resources or expertise to take on significant management responsibility. Finally, some non-profits believe that their proper role is to support (not supplant) the state, which is seen as the appropriate management authority for protected areas, even where capacity is low. 
Table 11.1 Model framework for collaborative management partnerships

\begin{tabular}{l|l|l}
\hline Model & Governance & Management \\
\hline Delegated management & $\begin{array}{l}\text { Strategy and oversight typically handled } \\
\text { by a special purpose entity created by } \\
\text { both partners; non-governmental } \\
\text { organisation typically appoints park } \\
\text { manage }\end{array}$ & Run by non-governmental organisation \\
\hline Co-management & $\begin{array}{l}\text { Shared, to varying degrees, between } \\
\text { state and non-governmental organisation } \\
\text { (may or may not include the creation of a } \\
\text { special purpose entity) }\end{array}$ & $\begin{array}{l}\text { Shared, to varying degrees, between state and } \\
\text { non-profit, except in some cases for } \\
\text { management of law enforcement (run by State) } \\
\text { and employing personnel (particularly law } \\
\text { enforcement personnel), which may be run by } \\
\text { the state or independently by the partners }\end{array}$ \\
\hline Project co-management & $\begin{array}{l}\text { State leads strategy and oversight, with } \\
\text { involvement and consensus of non- } \\
\text { governmental organisation on project- } \\
\text { related areas; joint Steering Committee } \\
\text { appoints project leadership }\end{array}$ & $\begin{array}{l}\text { State oversees management of law enforcement } \\
\text { and management of all staff; shares authority } \\
\text { with non-governmental organisation for all } \\
\text { project-related and project-funded decisions }\end{array}$ \\
\hline $\begin{array}{l}\text { Financial-technical support } \\
\text { (implementation) }\end{array}$ & State is main authority & $\begin{array}{l}\text { State is main authority; non-governmental } \\
\text { organisation plays varying roles to support } \\
\text { shared goals, employing personnel and helping } \\
\text { to implement management decisions }\end{array}$ \\
\hline $\begin{array}{l}\text { Financial-technical support } \\
\text { (advisory) }\end{array}$ & State is main authority & \begin{tabular}{l} 
State is main authority \\
\hline
\end{tabular} \\
\hline
\end{tabular}

Source: Baghai et al. (2018).

Some of the co-management models in the region are:

- In Ethiopia, the Frankfurt Zoological Society-Bale Mountains Conservation Project (BMCP) was set up in 2005 to provide all aspects of management support to the Bale Mountains National Park (covering ecotourism development, community outreach, sustainable natural resource use, operations and ecological management). In 2007 a 10-year General Management Plan for the Park was ratified by the President of the Oromia region. FZS-BMCP is currently working in partnership with the authorities towards implementing this plan. (With new funding support from KfW, FZS has updated its co-management agreement with the government to enhance the management and governance of the Park. African Wildlife Foundation entered into a similar agreement for the support of Simien Mountain National Park.

- In Rwanda, the RDP entered into a delegated management agreement with African Parks for the management of Akagera National Park. Since the agreement was entered into, African Parks and the RDB have reintroduced wildlife and developed commercially-viable tourism facilities. Rwanda hopes that the development of Akagera National Park will help Rwanda diversify its tourism product from gorilla tourism alone and keep tourists in Rwanda longer.

- In Mozambique, an integrated co-management arrangement was established after the civil war for the management of the Niassa National Reserve between the government and a private Mozambican company chiefly representing a high net worth individual. This partnership, Sociedade para a Gestão e Desenvolvimento da Reserva do Niassa, was principally supported by Fauna \& Flora International and came to an end in 2012. As of end 2019, Wildlife Conservation Society (WCS) was trying to enter a bilateral co-management agreement for the reserve. In addition, different private sector partners and NGOs have management agreements for concessions across the reserve. In another example, the Carr Foundation signed a management agreement with the Mozambican government in 2008 to restore and protect Gorongosa National Park as a source of tourist income for the local population. Two agreements were signed in 2019 with the Peace Parks Foundation to provide technical and financial assistance in the Maputo Special Reserve for tourism development and to support the Banhine National Park in Gaza Province to combat poaching (Wright, 2018). In addition, APN has a delegated agreement over Bazaruto National Park.

- In Zimbabwe, the Gonarezhou National Park is governed by the Gonarezhou Conservation Trust, whose trustees are nominees from the Zimbabwe Parks and Wildlife Management Authority and FZS, represented equally. Built on the back of a strong relationship developed over nine years of support by FZS for Gonarezhou, the Trust is directly responsible for management of the Park for a period of 20 years and became fully responsible in 2017.

- Across Africa. African Parks is a non-profit conservation organisation created in 2000 that takes on the complete responsibility for the rehabilitation and long-term management of national parks in partnership with governments and local communities. It currently manages 17 national parks and protected areas (of which 10 are in Eastern and Southern Africa) in 11 countries covering approximately 14 million hectares. 


\section{Box 11.1 Building capacity to combat poaching: the case of the Southern African Wildlife College}

As an example, the Southern African Wildlife College ${ }^{114}$ identified a priority need for capacity to address the poaching crisis with an innovation in canine deployment and management for anti-poaching purposes. This expansion was strongly focused on non-traditional deployment of dogs in a pursuit or tactical mode in order to effect an arrest of poachers. A K9 training facility was established to house, select and train service dogs and dog handlers.

Over a period of three to four years various techniques were tested, with the growing use of the free-roaming pack model, supported by a dog handler and an anti-poaching ranger team. Dogs and dog handlers have been co-trained in conjunction with airwing and anti-poaching rangers in order to be deployed via helicopter and vehicles in anti-poaching operations. The use of advanced telemetry, collar tracking and data collection is very effective.

The lessons learned, challenges and benefits include:

1. The cost of establishing the training facility required intensive fund-raising support;
2. Joint training with SAWC and SANParks enabled efficient deployment and interoperability;

3. Dogs and dog handlers could be interchanged;

4. Continuous focused animal welfare and health was critically important to individual and pack success.;

5. There was a shortage of K9 training skills in South Africa, with most skills focused on training dogs for detection work; and

6. Data collected by the various $\mathrm{K} 9$ tracking sensors also represented an area for further innovation and research.

The model developed at SAWC has been adopted for K9 capacity development for anti-poaching operations in a dangerous game area. The SAWC K9 project has received several awards for its effectiveness as a game-changer in anti-poaching operations.

Contributed by Ashwell Glasson (Southern African Wildlife College).
Governments that have entered into these management agreements are strategically optimising partner relations. By selecting appropriate and capable partners, protected area authorities can increase revenue for protected areas and the system as a whole by leveraging the skills, experience and capital of partners and blending the different expertise brought by each partner. In addition, this helps decrease the risk by engaging other partners, which is appealing to a number of large bilateral and multilateral funders.

\subsection{Building capacity for protected and conserved areas}

Capacity building and institutional strengthening is critical to enhancing the ability of protected area authorities in achieving their objectives (EU, 2015). There are various institutions in the region with a mandate and focus specifically on capacity-building, including: the College of African Wildlife Management (Mweka) in Tanzania; the Southern African Wildlife College in South Africa (see Box 11.1); the African Leadership University School of Wildlife Conservation in Rwanda; Namibia University of Science and Technology, formerly known as Polytechnic of Namibia; RCMRD Nairobi; and Centre of Excellence in Biodiversity and Natural Resources Management in Rwanda, among others. These institutions are innovating and expanding their range of training in response to the needs expressed by governments and conservation organisations.

\subsection{The role of technology in managing protected areas ${ }^{115}$}

Over the past 10 years, conservationists have increasingly focused on the use of technology to solve wildlife conservation challenges. Technology's promise is data-driven management delivered at scale in (near) real-time and with a high level of detail in the data. The adoption of new technologies can improve real-time situational awareness for improved command and control capabilities. The initial impetus for this has come from a protection and enforcement requirement, but the focus is now shifting to broader protected area management needs.

Protected area managers have traditionally been slow to adopt technology. This is in no small part due to the history of disappointing results. Technology suitable for commercial or mass consumer settings is often not robust enough for the challenging environmental conditions of protected areas. Besides, robust technology is often beyond the reach of budgets available to protected area managers. Well-meaning technologists have donated suitable technology without long-term maintenance and sustainability plans in place, resulting in short-lived usefulness.

The situation has begun to change in Africa over the past five years as protected area managers progress as technology consumers and as a cadre of technologists dedicated to the wildlife conservation mission emerges. Today, managers are asking the 
right questions about staffing capacity requirements, maintenance costs, long-term business plans, connectivity requirements, training and support needs. They are better at turning away solutions not rooted in the realities of the problems of protected area management.

The emerging protected area management data and technology 'ecosystem' includes conservation NGOs, major technology corporations, private philanthropists and good social entrepreneurs. They are creating solutions grounded in an understanding of the challenges faced by protected area managers, solving issues such as generating the right data with advances in sensor technology, timely data delivery through advances in networking technology and analysis on platforms applying the latest in artificial intelligence and image recognition. The field of 'conservation technology' is becoming a reality (see Box 11.2).

It is helpful to think of technology application at protected areas in terms of a 'magic quadrant' with management maturity along the Y-axis, and technology adoption along the X-axis (see Figure 11.1). Most protected areas are in the lower left quadrant, with low management maturity and little technology infrastructure. In other words, most areas need to build management capacity before they think about applying sophisticated technology solutions. Welltrained and well-equipped ranger teams are required, as well as effective management plans and funding sufficient to deliver those basic operational needs.
The SMART partnership pioneered data-driven management of protected areas leveraging technology with the Spatial Monitoring and Reporting Tool (SMART) software. ${ }^{116}$ The goal was to move low capacity areas with minimal infrastructure towards data-driven management. The SMART Partnership and others have moved many parks to the upper left quadrant.

Thought-leading management organisations have begun to move protected areas they manage from the upper left quadrant to the upper right quadrant. New communications technology are being applied, and tests of camera traps capable of high precision image recognition are being carried out. Sophisticated software, which is capable of integrating data from heterogeneous sources into a single operational picture, is also being used. Finally, data is made available to technologists developing advanced artificial intelligence algorithms that hold the (yet to be realised) promise of predictive and proactive management. In five to 10 years, technology promises to move protected area management from reactive to proactive - yet grounded in the basics of good management and well-trained and well-equipped rangers (see Boxes 11.3 and 11.4)

\section{Figure 11.1 The magic quadrant for technology application in protected areas in Africa}

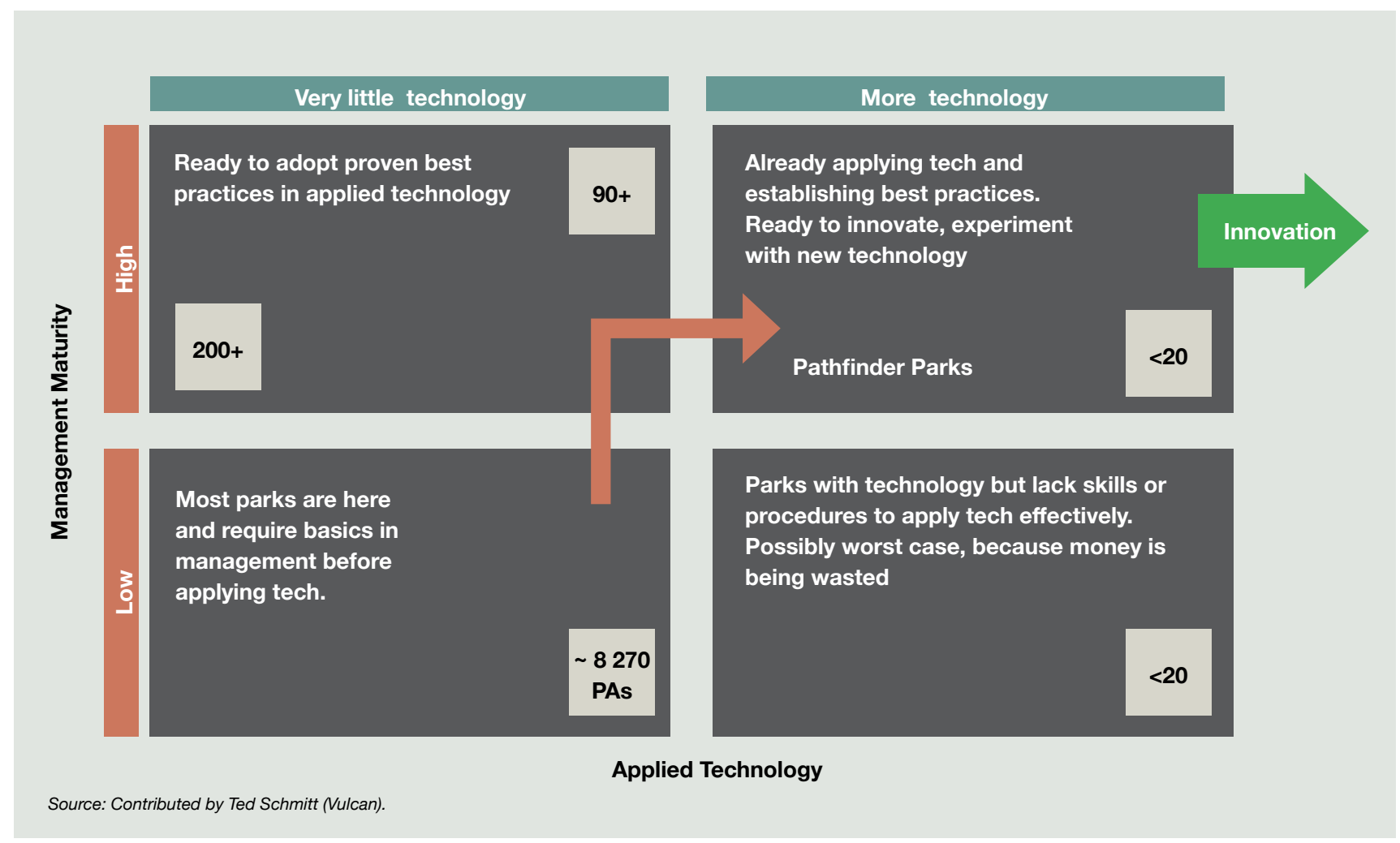

116 For more information, please see: https://smartconservationtools.org/. 


\section{Box 11.2 EarthRanger: situational awareness to secure protected areas and reduce human- wildlife conflict}

In recent years, park managers have increasingly introduced technology solutions to improve protected area management through real-time, data-driven decision-making. They use technology to gather observational data from patrols, provide communications, track animals and assets such as planes and vehicles, detect intrusions, and otherwise get an idea of what is going on in the protected area they manage. These data, some historical and some (near) real-time, have lived in separate data silos, each with their own user interface.

While the data in each of these silos can be useful, managers quickly become overwhelmed as they try to synthesise the data in their heads, or even on a physical map, in order to have a complete picture of the situation in the protected area. What is needed is a single visualisation that provides the situational awareness necessary to make decisions efficiently and effectively in real-time.

EarthRanger is an online software tool which collects, integrates and visualizes historical and real-time data available from a protected area - wildlife, rangers, spatial information and threat detection.* EarthRanger empowers protected area managers and rangers to take immediate, proactive actions to prevent and mitigate against threat incidents. The use of a central operations room with real-time visualisation has taken root with EarthRanger as the central nervous system of protected area operations.

The technology-producing data about what is happening in a protected area coupled with EarthRanger acts as a force multiplier for security operations with a visualisation capability that allows managers to gain a real-time, in-depth understanding of activities related to poaching and other habitat threats. In Tanzania, for example, Grumeti Reserve uses EarthRanger to track ranger movements as they carry out patrols and respond to incursion incidents. The tracking is coupled with camera traps that detect incursions and other technology giving them a full picture of the security situation at any given time and allowing the staff to respond safely and effectively to incursions.

In partnership with African Parks, the management team in Liwonde National Park in Malawi uses EarthRanger to monitor when elephants pass geographic boundaries in order to intervene before they reach farmers' crops. With geofences (virtual boundary set up around a geographical location) in place, rangers at Liwonde can continuously monitor the park boundary for potential human wildlife conflict from their operations room, and quickly respond to geofence breaks and intervene before a conflictual situation arises. Proactive mitigation of human wildlife conflict through timely and seamless alerts enable managers to reduce conflict incidents and help communities co-exist with wildlife.

Monitoring habitat - including wildlife use of the landscape through tracking and movement data, sensors and reports enables data-driven land use planning and management. Big Life, a wildlife conservation group based in Kenya's Amboseli ecosystem, created corridors that allow wildlife to move between protected areas. To ensure authorities that can maintain corridors and monitor how frequently wildlife are using them, staff at Amboseli utilise EarthRanger to consolidate data produced by various technologies and visualizes them on an intuitive map.

Protected area management organisations at more than 30 protected areas in 13 countries across Africa are now using EarthRanger to secure their areas, mitigate against human wildlife conflict and manage their ecosystems.

* For more information, please see: https://earthranger.com.

Contributed by Ted Schmitt (Vulcan).

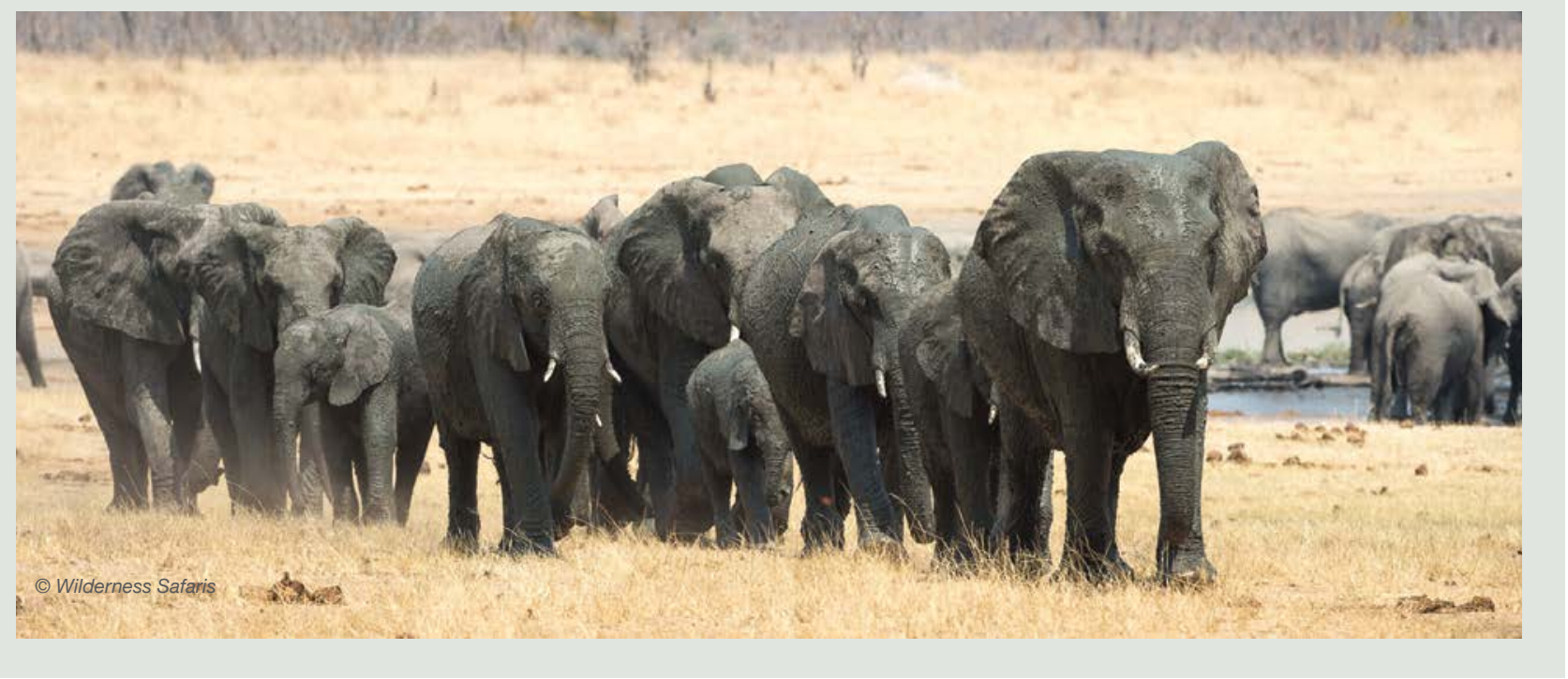




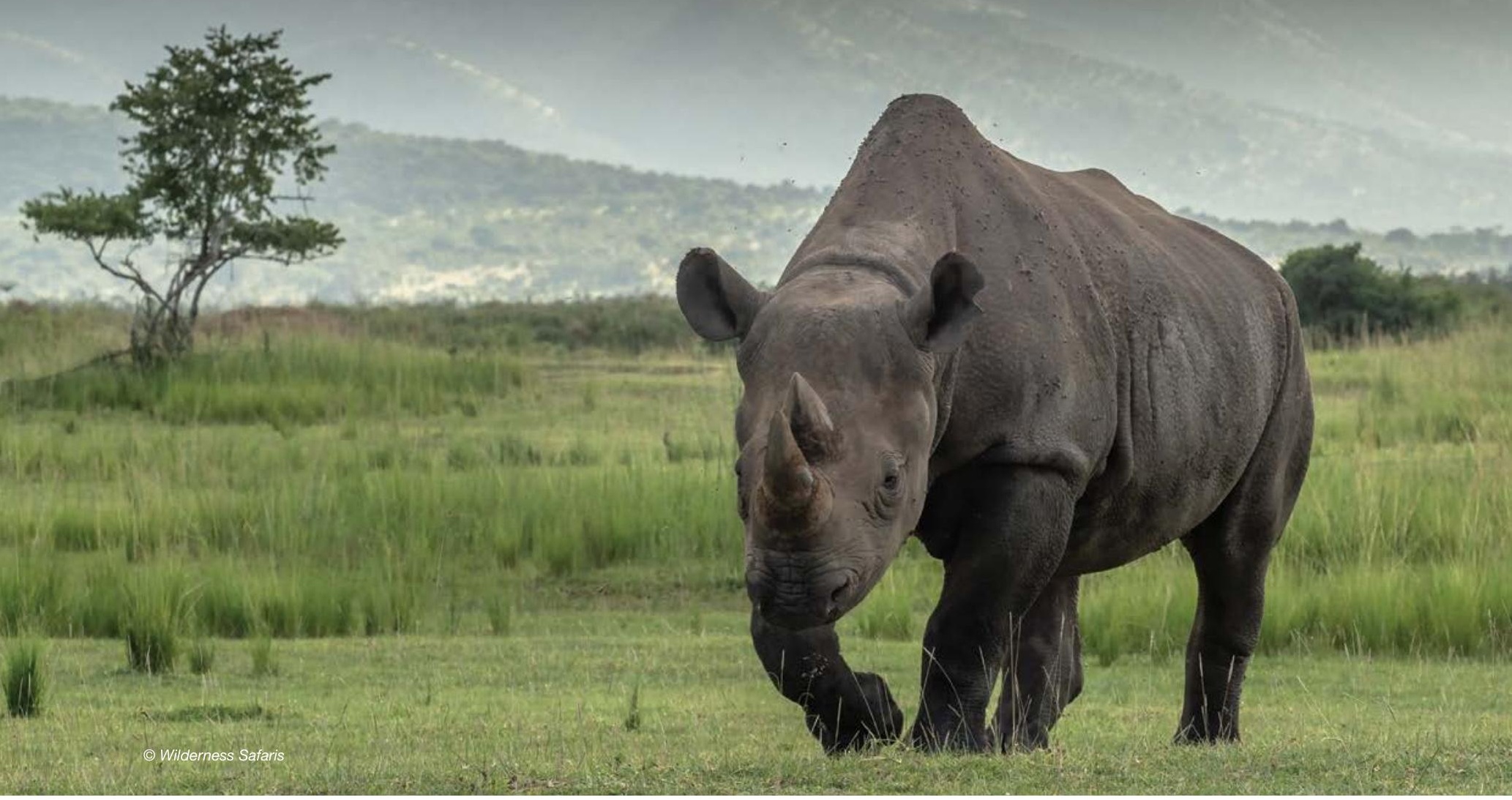

\section{Box 11.3 Rhino monitoring programme following reintroduction}

Landmark rewilding programmes require continual monitoring and maintenance to ensure success. Since the reintroduction of 17 Eastern black rhinos (Diceros bicornis michaeli) to Akagera National Park, Rwanda in May 2017, a multi-pronged monitoring programme has been employed to ensure safety of the new population and to monitor condition and behaviour. At the core of the programme is a team of rhino trackers. These individuals track rhinos daily to record condition, note physical injuries, record behaviours and observe social interactions between the animals. Priority for tracking is determined by a combination of recent condition trends, number of days since last sighting, and law enforcement factors in the area used by a specific rhino. Very high frequency (VHF) telemetry is used for some animals, while traditional tracking methods (spoor tracking) is used for other individuals without transmitters in the horns. The goal of the monitoring programme is to sight each animal once every 14 days.

Currently the rhino trackers are sighting each animal every eight days, and seeing nearly three animals per day, well exceeding the observation goals. High observation rates are aided by aerial tracking and camera traps. Helicopter flights flown every two weeks utilise VHF telemetry to focus in on individuals with transmitters. The increased speed of detection from the chopper allows for many more animals to be seen in a short amount of time; as many as 10 in two hours. Flights are used for quick condition scoring and security checks, but lack the ability to monitor behaviour. Camera trapping often fills in the gaps in behavioural data. Well-placed cameras along mud wallows and water holes, or commonly used game trails, allow for detection of social interactions and more natural behaviours without disturbing the animals. Camera traps also collect images at night, illuminating night-time activity and interactions between the rhinos.

To date, no animals have been lost to poaching, and useful data has been collected on home ranges, social interactions and dietary composition. Intimate monitoring programs allow for detailed understanding of the population and build the capacity for rapid response to security situations if they should arise. Monitoring will continue to become more advanced, with technological improvements constantly being tested and trialled. However, nothing will replace the boots on the ground approach to monitoring. Dedicated, motivated and wellresourced trackers, rangers, and staff make all the difference in ensuring the success of such reintroduction projects.

Contributed by Drew Bantlin (African Parks). 


\section{Box 11.4 Camera trapping for ecological monitoring and security}

Motion and heat-triggered remote camera traps allow for monitoring that would otherwise be impossible. In protected areas with few roads and challenging topography like Akagera National Park, Rwanda, camera traps can fill in gaps in understanding of the park's species and ecology. Multiple forms of camera trap deployment are utilised. Infrared camera traps with minimal disturbance to animals are placed systematically in $1-\mathrm{km}$ grid patterns across the park. This provides better understanding of the composition of species in the park and distribution across the landscape. Seasonal movements and habitat usage can be examined. Behavioural data and inter- and intra-species interactions can be gleaned from photos.

Several cameras are also reserved for special use outside of the grids. Cameras dedicated to rhino monitoring are moved often within areas used most frequently to monitor behaviour, condition and social interactions. Other cameras are used to monitor special items like hyena dens, carcass scavenging and decomposition, and human-wildlife conflict along the border of the park. White-flash camera traps provide clear images of species with pattered coats, like leopards, for individual identification.

Cameras allow for observation of behaviours that often would not be visible during more disruptive in-person sightings. Similarly, rare, hard-to-view and nocturnal species are often captured by cameras.

Cameras also serve an important law enforcement function. Following input for ranger teams on the ground, cameras are deployed along paths commonly used by poachers and along the fence line where poachers are known to cross into the park. Silent, invisible monitoring of poacher activities informs patrols, reactive patrols and law enforcement activities in the surrounding communities. Mostly unnoticed, cameras often provide images that can be used to identify the poachers. This has led to numerous arrests and has served as critical evidence in court during trials. Most importantly, cameras support ranger teams on the ground, supplying intelligence information and enhancing law enforcement operations in the park.

Contributed by Drew Bantlin (African Parks).

\subsection{Adapting to changing climate}

The planet is currently undergoing one of the fastest climatic transformations in Earth's history. Anthropogenic climate change has already impacted most ecological processes, from genes to communities, across terrestrial, freshwater and marine systems. These changes are causing large-scale ecological shifts, as species are forced to move to find new suitable habitat. Protected and conserved areas are one of the most effective tools for the protection of biodiversity. However, most of these areas were chosen without consideration of future climatic impacts. Proper planning for future redistributions of species and habitats may help maintain and improve biodiversity safeguards to preserve ecosystem services and reduce the threat of extinction. The Spatial Planning for Area-Based Conservation in Response to Climate Change (SPARC) project, for example, identified priority land areas for reducing climate risk in sub-Saharan Africa (see Box 11.5). 


\section{Box 11.5 SPARC: Reducing climate risk to conservation networks}

The planet is currently undergoing one of the fastest climatic transformations in Earth's history (Diffenbaugh \& Field, 2013). Anthropogenic climate change has already impacted most ecological processes, from genes to communities, across terrestrial, freshwater and marine systems (Scheffers et al., 2016). These changes are causing large-scale ecological shifts, as species are forced to move to find new suitable habitat (Parmesan \& Yohe, 2003). Conservation areas are one of the most effective tools for protecting biodiversity, however most of these areas were chosen without consideration of future climatic impacts. Proper planning for future redistributions of species and habitats can help maintain and improve biodiversity safeguards to preserve ecosystem services and reduce the threat of extinction.

The Spatial Planning for Area-Based Conservation in Response to Climate Change (SPARC) project used velocity of climate change (Loarie et al., 2009), environmental stratification maps (Metzger et al., 2013), 10 global climate models, and the future distributions of more than 28,000 species to determine the highest priority land areas for reducing climate risk in subSaharan Africa (Figure a). [For more information see sparcwebsite.org]

Angola, for example, possesses exceptional biodiversity. It has the largest diversity of biomes in Africa, forming a crucial transition zone from Congolian forest mosaic, across the woodlands, savannas and grasslands of the Angolan escarpment, to the Zambezian flooded grasslands and the Kaokoveld Desert (Huntley, 2019). If global emissions continue to rise, Angola may see a near complete transition of climatic zones nationwide within the next 50 years (SPARC).

Most of Angola's national parks are located in areas of high climate velocity, where species will have to travel long distances to track their preferred climate. The west, however, with its high altitudinal diversity and low climate velocity, offers significant opportunities for maximising the protection of species and habitats within the smallest possible area. Increasing conservation efforts, or formally protecting, the highest priority areas for climate resilience (Figure b) will help Angolan species avoid the worst impacts of climate change. In fact, maintaining a well connected western habitat corridor is one of the highest conservation priorities on the continent (Figure a), forming the backbone of a topographically diverse species movement corridor stretching from the Republic of the Congo to South Africa. This pathway will protect species along current migration routes which are projected to become increasingly important as a growing number of species disperse south, tracking cooler temperatures.
Figure a: Prioritising conservation efforts, or formally protecting, these climate resilient areas will help reduce the threat of extinction across Africa (based on projections to 2070 under RCP 8.5 ).

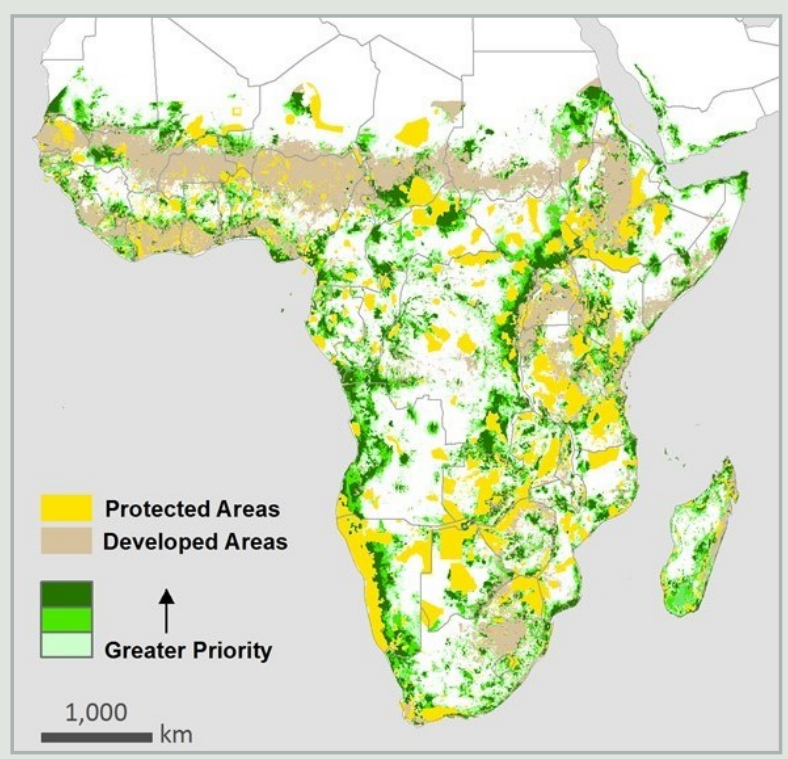

Figure b: A closer look at climate resilient priorities for Angola reveals the importance of protecting an interconnected western habitat corridor (based on projections to 2070 under RCP 8.5).

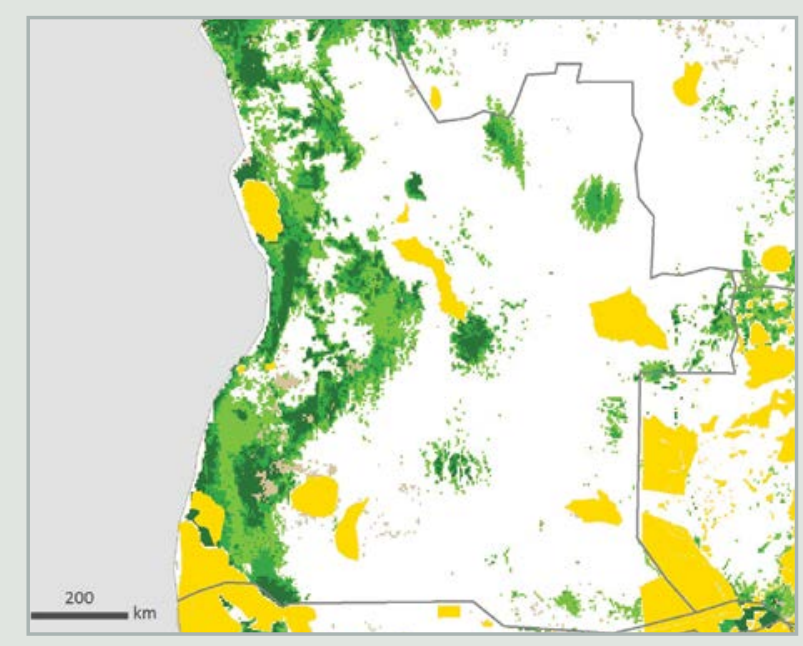

Source for Figures a and b: Hannah et al. (2020).

Text and map contributed by Caitlin Kelly (Spatial Planning for Area-Based Conservation in Response to Climate Change). 

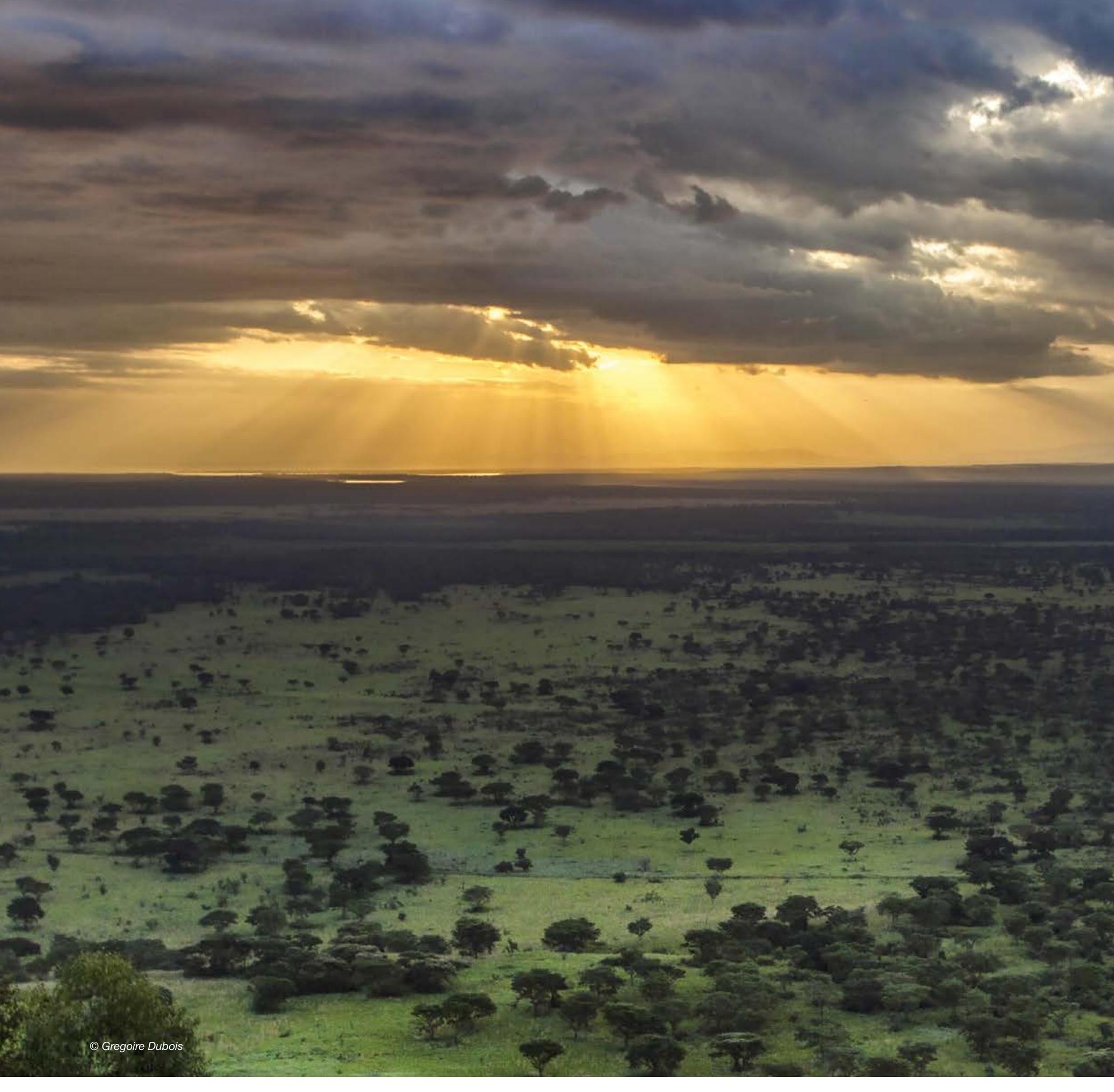


\section{Part IV}

\section{Recommendations}


Protected areas will continue to be an essential element of global biodiversity conservation efforts in the post-2020 era, shielding precious biodiversity, maintaining natural processes in the landscape and providing key habitats and refuges for species in an era of unprecedented and rapid change (Ceballos et al., 2015). Protected areas also provide livelihood benefits for people, from clean drinking water to food security in addition to a myriad of other cultural, spiritual and socio-economic benefits, but conservation measures can also have negative social impacts as well.

Challenges threaten the existence and efficiency of protected areas, as global biodiversity continues to deteriorate (Secretariat of the CBD, 2014; Thomas \& Gillingham, 2015). The key issues of climate change and biodiversity loss mean that an expanded and effectively-managed system of protected areas and other conserved areas is not just increasingly vital, but also needs a higher level of well-targeted and coordinated investment.

The following list of recommendations are priorities for attention by protected area authorities, donors, NGOs and partners throughout Eastern and Southern Africa in order to meet global targets as well as to ensure that protected areas are able to both conserve biodiversity and contribute to enhanced livelihoods throughout the region.

The BIOPAMA workplan, which was developed through national and regional consultation and assessment of national and regional needs, aligns with the recommendations outlined below. It includes capacity building and other activities related to each of the recommendations to support an improvement in management effectiveness, governance and equity.

\subsection{Increase sustainable financing and political support for protected and conserved areas}

Adequate and sustainable financing is essential for the management of protected and conserved areas. While the region is currently far from meeting this target, there are exciting new mechanisms for innovative financing of protected areas, and more work is required to pilot and scale up approaches in diverse contexts throughout Eastern and Southern Africa. In addition, more work is required to demonstrate the importance of protected and conserved areas in providing ecosystem services and supporting rural livelihoods. This may help increase the political will and commitments by governments, and hopefully lead to increased budgetary allocations towards the conservation sector which are needed to ensure longer-term sustainable support for these networks. The importance of the wildlife economy and the important role of biodiversity conservation are increasingly being acknowledged by stakeholders as a key to sustainable development in the region.

\subsection{Enhance capacities for protected and conserved area management}

Capacity building throughout the sector of protected area management and biodiversity conservation is urgently needed throughout the region. This includes support to front-line personnel, such as rangers, but also extends to 'head office' personnel as well as community support organisations, NGOs and donors. Capacity building for middle managers in the sector is also critical as many of these managers move from field positions and lack the necessary administrative, financial and negotiation skills required for success in their new position as middle managers of protected and conserved areas. Capacity building is required, not only in traditional protected area management and anti-poaching, but in conservation technology, community engagement, markets and business, innovative financing (e.g. carbon markets), and partnerships, including public-private partnerships.

\subsection{Diversify governance of protected areas and recognise effective local, community and co-management governance initiatives}

Eastern and Southern Africa is home to a great diversity of governance arrangements for protecting and conserving biodiversity. Continued support and enhanced enabling policy environments will strengthen this growing sector. The identification of OECMs is critical in order to understand and maximise the full range of opportunities for innovation in biodiversity conservation across the region. The establishment of collaborative management partnerships with non-governmental organisations can be one important mechanism for overcoming these challenges, and has grown in its importance across the protected area estate in Eastern and Southern Africa. Public-private partnerships represent a significant opportunity to increase the funding for, and improved management of, protected areas in the region. Policies, structures and staff need to be in place to facilitate and oversee such innovative arrangements.

\subsection{Address gaps in the coverage of marine and terrestrial ecosystems in protected and conserved area estates}

There has been, and will continue to be, an increase in technological tools available to analyse the connectivity and representativity of protected and conserved areas. It is necessary to use these tools to identify critical gaps in coverage, allowing for the process to ensure their protection to begin, as well as for stakeholders to focus more on a landscape approach, rather than isolated areas being conserved. The benefits of landscape conservation are increasingly being highlighted and the analyses of the overlap of important species (fauna and flora) and conserved areas need to be a key focus area for policymakers and land-use planners. 


\subsection{Enhance collaboration across borders and sectors to respond to existing and emerging threats}

In these times of dramatic climatic changes, accelerating biodiversity loss, growing illegal wildlife trade and rapid demographic shifts, Eastern and Southern Africa faces a monumental challenge in its quest to maintain a robust and connected protected area network. 'Business-as-usual' has not proven to be successful, and it is necessary to enhance collaboration across borders and sectors to respond to emerging threats, through increased use of information-sharing mechanisms. The BIOPAMA Regional Resource Hub provides an important platform for information sharing and knowledge exchange.

\subsection{Enhance transboundary conservation}

Eastern and Southern Africa is home to 30 established and potential transboundary conservation areas. These areas have the potential to support action at ecologically and economically meaningful scales, and are of interest to bilateral and multilateral funders. SADC has established a strong TFCA programme, which may serve as a useful model for Eastern Africa as it works to enhance transboundary conservation in the sub-region. A number of important conservation areas in Eastern Africa are transboundary and increased collaboration in the conservation of those areas is needed. In addition, marine and coastal conservation areas are generally underrepresented in the TFCA estate.

\subsection{Improve coverage of assessments of management effectiveness, governance and equity}

Currently, only $13 \%$ of protected areas in the region have had at least one assessment of management effectiveness, and a much smaller proportion have assessed governance and equity. Furthermore, no recent regional analysis of the outcomes of these assessments has been conducted. Aichi Target 11 states clearly that the target is to have effectively and equitably managed protected areas. In the absence of data, it is impossible to know the extent to which the region is meeting this important target. Improving capacity to carry out management effectiveness, governance and equity at local and national levels is therefore a priority. At the same time, it is also important to raise awareness and increase guidance on how to report through global platforms to monitor achievement of targets. These are important to ensure sustainability and enhanced institutionalisation of assessments. A thorough analysis of the outcomes of the recent assessments carried out in the Eastern and Southern Africa region is needed to help build a regional picture of the status of management effectiveness and equitable governance, and to guide future interventions.

\subsection{Enhance frequency and comprehensiveness of reporting to the World Database of Protected Areas}

The Eastern and Southern African region has almost achieved the Aichi Target 11 for terrestrial protected areas, almost reaching the target of $17 \%$ of the terrestrial land area covered by protected areas. For marine and coastal protection, the region has achieved just over half of the target of $10 \%$, with $5.6 \%$ of the coastal and marine area covered by protection. With the expansion of the target to include OECMs, countries are encouraged to report all protected and conserved areas to the WDPA. Since there is a high proportion of 'unreported' in the IUCN governance and management categories, countries are encouraged to clarify the categories into which existing protected and conserved areas fit. The WDPA data is used to set and measure many global and regional targets, which makes it crucial that countries ensure that the data is up-to-date and accurate. 


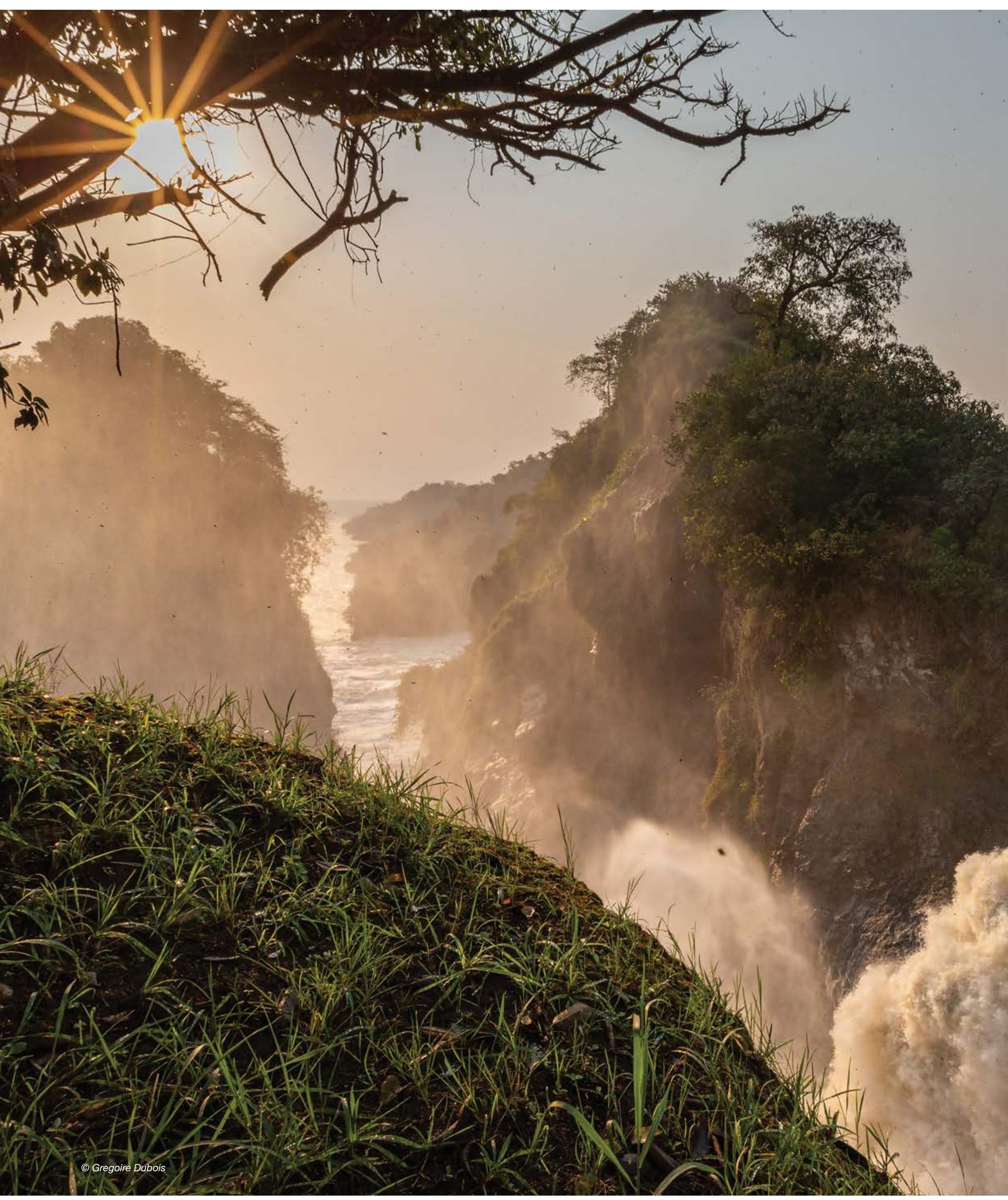




\section{References}

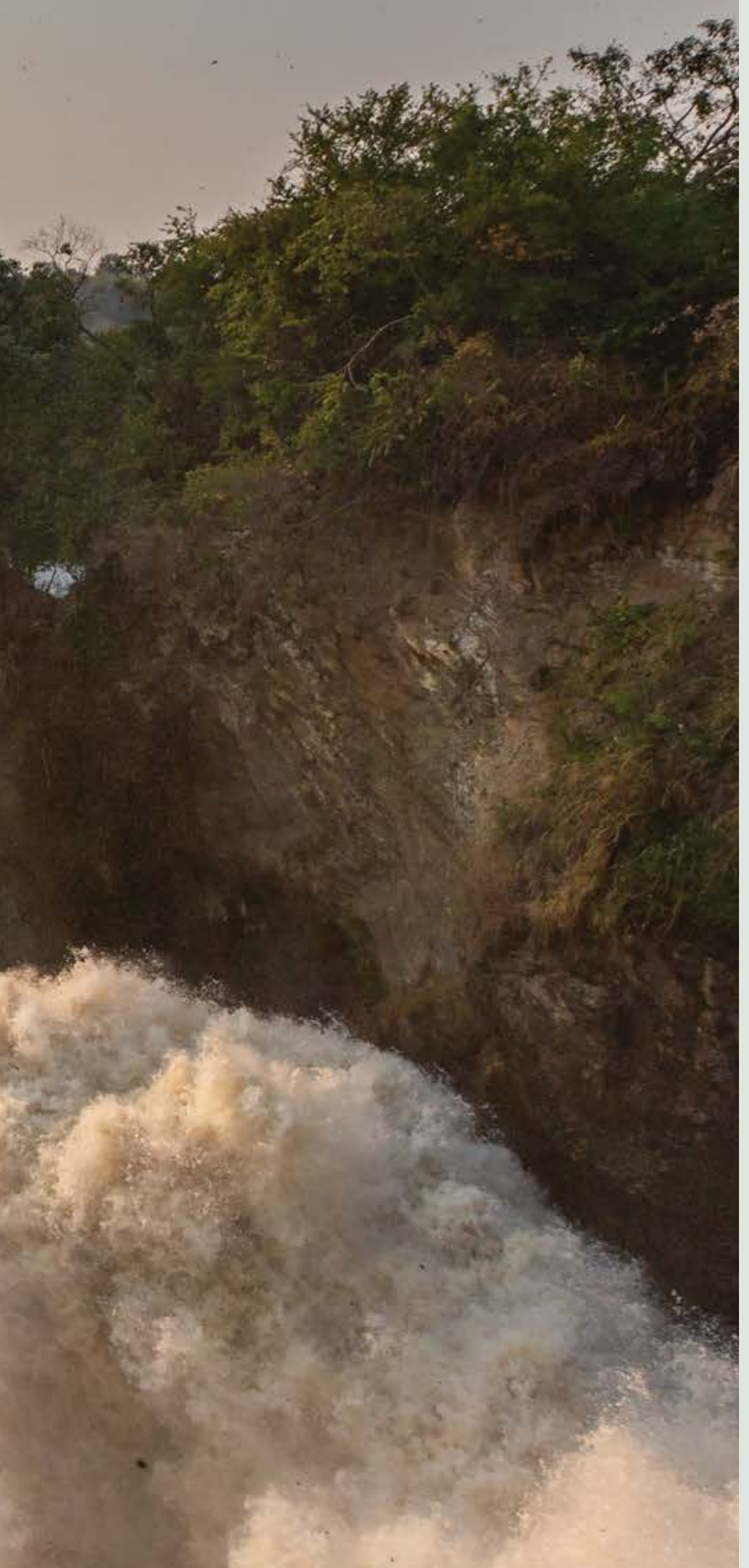


Athanas, A. (2018). 'Engaging business to boost sustainability in African agriculture'. Panorama [website], (22 November 2018). https:// panorama.solutions/en/solution/engaging-business-boost-sustainability-african-agriculture.

Alliance for Zero Extinction (AZE) Secretariat (n.d.). AZE [website] . http://zeroextinction.org/.

Baghai, M., Miller, J.R.B., Blanken, L.J., Dublin, H.T., Fitzgerald, K.H., Gandiwa, P., Laurenson, K., Milanzi, J. Nelson, A., Lindsey, P. (2018). 'Models for the collaborative management of Africa's protected areas'. Biological Conservation 218: 73-82. https://doi. org/10.1016/j.biocon.2017.11.025

Balmford, A., Beresford, J., Green, J., Naidoo, R., Walpole, M. and Manica, A. (2009). 'A Global Perspective on Trends in Nature-Based Tourism'. PLoS Biology 7(6): e100014. https://doi.org/10.1371/journal.pbio.1000144

Bastin, L., Mandrici, A., Battistella, L. and Dubois, G. (2017). 'Processing Conservation Indicators with Open Source Tools: Lessons Learned from the Digital Observatory for Protected Areas'. Free and Open Source Software for Geospatial (FOSS4G) Conference Proceedings 17(6): 101-111. https://doi.org/10.7275/R5XK8CQS

Belle, E., Wicander, S., Bingham, H. and Shi, Y. (2015). Governance of protected areas in Africa: A global review. Cambridge, UK: UNEP-WCMC. https://papaco.org/wp-content/uploads/2015/04/PAPACO-study-17_GOVERNANCE-STUDY-0-FINAL_REPORTCONTEXT.pdf

Bennett, N.J. and Dearden, P. (2014). 'Why local people do not support conservation: Community perceptions of marine protected area livelihood impacts, governance and management in Thailand'. Marine Policy 44: 107-116. https://doi.org/10.1016/j.marpol.2013.08.017

Bennett, N.J., Franco, A.D., Calò, A., Nethery, E., Niccolini, F., Milazzo, M. and Guidetti, P. (2019). 'Local support for conservation is associated with perceptions of good governance, social impacts, and ecological effectiveness'. Conservation Letters 12(4). https://doi. org/10.1111/conl.12640

Biodiversity Finance Initiative (BIOFIN) (2017). Biodiversity Finance Initiative [website]. https://www.biodiversityfinance.net/

(2019). 'Finance for nature, a commitment of the whole society to the sustainability of the planet'. BIOFIN [website], (1 July 2019). https://www.biodiversityfinance.net/news-and-media/finance-nature-commitment-whole-society-sustainability-planet.

Biodiversity and Protected Areas Programme (BIOPAMA) (Unpublished). State of Protected Areas Report for East Africap. Nairobi, Kenya: EAC, IUCN ESARO, JRC.

BIOPAMA and International Union for Conservation of Nature (IUCN) (2016). IMET (Integrated Management Effectiveness Tool) training summary report. Mbale, Uganda: IMET Training Workshop. Unpublished.

BirdLife International (2019a). 'Sites and Habitats (IBAs and KBAs)'. BirdLife International [website]. http://www.birdlife.org/worldwide/ programmes/sites-habitats-ibas-and-kbas

(2019b). World Database of Key Biodiversity Areas. Developed by the KBA Partnership: BirdLife International, International Union for the Conservation of Nature, Amphibian Survival Alliance, Conservation International, Critical Ecosystem Partnership Fund, Global Environment Facility, Global Wildlife Conservation, NatureServe, Rainforest Trust, Royal Society for the Protection of Birds, Wildlife Conservation Society and World Wildlife Fund. Available at: www.keybiodiversityareas.org. [Accessed (please insert date of download 20/10/2019)].

(2019c). 'Important Bird and Biodiversity Areas'. World Database of Key Biodiversity Areas. Developed by the KBA Partnership: BirdLife International, International Union for the Conservation of Nature, Amphibian Survival Alliance, Conservation International, Critical Ecosystem Partnership Fund, Global Environment Facility, Global Wildlife Conservation, NatureServe, Rainforest Trust, Royal Society for the Protection of Birds, Wildlife Conservation Society and World Wildlife Fund. Available at: www.keybiodiversityareas.org. [Accessed (please insert date of download 20/10/2019)].

Booker, F. and Franks, P. (2019). Governance Assessment for Protected and Conserved Areas (GAPA): Methodology manual for GAPA facilitators. London: IIED. https://www.sprep.org/attachments/Publications/articles/governance-assessment-protected-conservedareas.pdf

Borrini-Feyerabend, G., Dudley, N., Jaeger, T., Lassen, B., Pathak Broome, N., Phillips, A. and Sandwith, T. (2013). Governance of protected areas: From understanding to action. Best Practice Protected Area Guidelines Series No. 20. Gland, Switzerland: IUCN. https:// portals.iucn.org/library/node/29138 (Also available in French, Portuguese and Spanish)

Burgess, N.D., Malugu, I., Sumbi, P., Kashindye, A., Kijazi, A., Tabor, K., Mblinyi, B., Kashaigili, J., Wright, T.M., Gereau, R.E. et al. (2017). 'Two decades of change in state, pressure and conservation responses in the coastal forest biodiversity hotspot of Tanzania'. Oryx 51(1): 77-86. https://doi.org/10.1017/S003060531500099X

Campese, J. and Sulle, E. (2019). Management Effectiveness, Governance, and Social Assessments of Protected and Conserved Areas in Eastern and Southern Africa: A rapid inventory and analysis to support the BIOPAMA programme and partners. A report prepared for BIOPAMA Eastern and Southern Africa. BIOPAMA, IUCN ESARO. https://biopama.org/sites/default/files/Report_BIOPAMA\%20ESA_ Sept_2019_web.pdf 
Ceballos, G., Ehrlich, P.R., Barnosky, A.D., García, A., Pringle, R.M. and Palmer, T.M. (2015). Accelerated modern human-induced species losses: 'Entering the sixth mass extinction'. Science Advances 1(5). https://doi.org/10.1126/sciadv.1400253

Chadwick, P., Duncan, J. and Tunley, K. (2014). State of Management of South Africa's Marine Protected Areas. WWF South Africa No. 2014/Marine/001. South Africa: WWF. http://awsassets.wwf.org.za/downloads/final_wwf_marine_report_02_dec_2014_web_1.pdf

Coad, L., et al. (2015). 'Measuring impact of protected area management interventions: current and future use of the Global Database of Protected Area Management Effectiveness'. Philosophical Transactions of the Royal Society B: Biological Sciences 370(1681). https:// doi.org/10.1098/rstb.2014.0281

Coad, L., Watson, J.E., Geldmann, J., Burgess, N.D., Leverington, F., Hockings, M., Knights, K., Marco, M.D. (2019). 'Widespread shortfalls in protected area resourcing undermine efforts to conserve biodiversity'. Frontiers in Ecology and the Environment 17(5): 259-264. https://doi.org/10.1002/fee.2042

Conservation Finance Alliance (CFA) 2008. Rapid Review of Conservation Trust Funds. Second Edition. Prepared for the CFA Working Group on Environmental Funds by Barry Spergel and Philippe Taïeb. https://www.cbd.int/financial/trustfunds/g-rapidassess.pdf

Conservation International (Cl) and World Wildlife Fund (WWF) (n.d.). PADDDtracker.org Data Release Version 2.0 (May 2019). Arlington, VA and Washington, DD: $\mathrm{Cl}$ and WWF. DOI: 10.5281/zenodo.3371733 (accessed 13 August 2019).

Convention on Biological Diversity (CBD) (2004). Decision adopted by the Conference of Parties to the Convention on Biological Diversity at its seventh meeting VII/28. Protected areas (Articles 8 (a) to (e)). No. UNEP/CBD/COP/DEC/VII/28. Kuala Lumpur, Malaysia: Convention on Biological Diversity. https://www.cbd.int/decisions/cop/7/28 https://www.cbd.int/decisions/cop/7/28 (online); https://www.cbd.int/ doc/decisions/cop-07/cop-07-dec-28-en.pdf (PDF)

(2005). Options for Mobilizing Financial Resources for the Implementation of The Programme of Work by Developing Countries and Countries with Economies in Transition. No. UNEP/CBD/WG-PA/1/6. https://www.cbd.int/decision/cop/?id=11038 (online) and https:// www.cbd.int/meetings/PAWG-01 (links to six UN languages in Word and PDF).

(2010a). Decision adopted by the Conference of the Parties to the Convention on Biological Diversity at its tenth meeting X/2. The Strategic Plan for Biodiversity 2011-2020 and the Aichi Biodiversity Targets. No. UNEP/CBD/COP/DEC/X/2. Nagoya, Japan: Convention on Biological Diversity. https://www.cbd.int/doc/decisions/cop-10/cop-10-dec-02-en.pdf

(2010b). Decision adopted by the Conference of Parties to Convention on Biological Diversity at its tenth meeting: X/31. Protected areas. No. UNEP/CBD/COP/DEC/X/31. Nagoya, Japan: Convention on Biological Diversity. https://www.cbd.int/doc/decisions/cop-10/ cop-10-dec-31-en.pdf

(2018). Decision adopted by the Conference of the Parties to the Convention on Biological Diversity at its fourteenth meeting 14/8. Protected areas and other effective area-based conservation measures. No. CBD/COP/DEC/14/8. Sharm El-Sheikh, Egypt: Convention on Biological Diversity. https://www.cbd.int/doc/decisions/cop-14/cop-14-dec-08-en.pdf

Credit Suisse, WWF and McKinsey (2014). Conservation Finance: Moving beyond donor funding toward an investor-driven approach. https://www.cbd.int/financial/privatesector/g-private-wwf.pdf

Davey, A.G. (1998). National system planning for protected areas. Best Practice Protected Area Guidelines Series No. 1. Gland, Switzerland and Cambridge, UK: IUCN World Commission on Protected Areas. https://portals.iucn.org/library/node/7394 (also available in Arabic, Chinese and Russian)

Deguignet, M., Arnell, A., Juffe-Bignoli, D., Shi, Y., Bingham, H., MacSharry, B. and Kingston, N. (2017). 'Measuring the extent of overlaps in protected area designations'. PLOS ONE 12(11): e0188681. https://doi.org/10.1371/journal.pone.0188681

de Koning, M., Parr, J.W.K., Sengchanthavong, S. and Phommasane, S. (2016). 'Collaborative governance improves management effectiveness of Hin Nam No National Protected Area in Central Lao PDR'. Parks 22(2): 27-40. https://doi.org/10.2305/IUCN.CH.2016. PARKS-22-2MdK.en

Diffenbaugh, N.S. and Field, C.B. (2013). 'Changes in ecologically critical terrestrial climate conditions'. Science 341: 6145. https://doi. org/10.1126/science.1237123

Donald, P.F. et al. (2019). 'The prevalence, characteristics and effectiveness of Aichi Target 11's "other effective area-based conservation measures" (OECMs) in Key Biodiversity Areas'. Conservation Letters 12(5): e12659. https://doi.org/10.1111/conl.12659

Dubois, G. et al. (2016). 'Integrating Multiple Spatial Datasets to Assess Protected Areas: Lessons Learnt from the Digital Observatory for Protected Areas (DOPA)'. ISPRS International Journal of Geo-Information 5(12). https://doi.org/10.3390/ijgi5120242

Dudley, N. (ed.) (2008). Guidelines for applying protected area management categories. Gland, Switzerland: IUCN.https://doi. org/10.2305/IUCN.CH.2008.PAPS.2.en

DuPont, C.M., Levitt, J. and Bilmes, L. (2016). Green bonds and land conservation: The evolution of a new financing tool. Harvard Environmental Economics Program (Discussion Paper 16-67). https://doi.org/10.2139/ssrn.2700311

East African Community (EAC) (2010). East African Community Transboundary Ecosystems Management Bill, 2010. http://www.eala.org/ uploads/Transboundary_Bill.pdf 
(2018). Strategy to Combat Poaching, Illegal Trade and Trafficking of Wildlife and Wildlife Products 2017/18-2021/22. https://www. eac.int/documents/category/tourism-wildlife-management

Edgar, G.J., et al. (2014). 'Global conservation outcomes depend on marine protected areas with five key features'. Nature 506(7487): 216-220. https://doi.org/10.1038/nature13022

Eklund, J. and Cabeza, M. (2017). 'Quality of governance and effectiveness of protected areas: crucial concepts for conservation planning'. Annals of the New York Academy of Sciences 1399(1): 27-41. https://doi.org/10.1111/nyas.13284

Emerton, L., Bishop, J. and Thomas, L. (2006). Sustainable Financing of Protected Areas. A global review of challenges and options. Best Practice Protected Area Guidelines series No. 13. Gland, Switzerland: IUCN. https://doi.org/10.2305/IUCN.CH.2005.PAG.13.en

Eswatini (2014). Swaziland's Fifth National Report to the Convention of Biological Diversity. Eswatini Environment Authority. https://www. cbd.int/doc/world/sz/sz-nr-05-en.pdf

Eswatini Environment Authority (2016). Eswatini's Second National Biodiversity and Action Plan. National Biodiversity Strategy and Action Plan (NBSAP) No. 2. Ministry of Tourism and Environmental Affairs. https://www.cbd.int/doc/world/sz/sz-nbsap-v2-en.pdf

European Commission (EC) (2015). Larger than elephants: Inputs for the design of an EU strategic approach to Wildlife Conservation in Africa. Brussels, Belgium: EC. doi:10.2841/123569 EC Joint Research Centre (2018). Science for the AU-EU Partnership - Building knowledge for sustainable development. https://ec.europa.eu/jrc/en/publication/eur-scientific-and-technical-research-reports/ science-au-eu-partnership (provides link to main report and summary in six languages)

EC Joint Research Centre (JRC)/Digital Observatory for Protected Areas (DOPA) (2019a). An introduction to DOPA Explorer 4.0. DOPA Factsheet No. A.1. EC and DOPA. https://dopa.jrc.ec.europa.eu/sites/default/files/DOPA\%20Factsheet\%20A1\%20EN\%20An\%20 introduction\%20to\%20DOPA\%20Explorer_0.pdf. Accessed: 8/7/2019

(2019b). Regional factsheet 201910 Africa (Eastern) and (Southern). EC JRC /DOPA [website]. https://dopa.jrc.ec.europa.eu/en/ regional-factsheet. Accessed: 15/11/2019

(2019c). Connectivity of terrestrial protected areas. DOPA Factsheet C.1. https://dopa.jrc.ec.europa.eu/sites/default/files/ DOPA\%20Factsheet\%20C1\%20EN\%20Connectivity.pdf. Accessed: 8/7/2019

Federal Republic of Somalia (2014). Fifth national report on the implementation of the Convention on Biological Diversity of Somalia. National Report on Biodiversity No. 5. Mogadishu, Somalia: Ministry of Fisheries and Marine Resource. https://www.cbd.int/doc/world/ so/so-nr-05-en.pdf

(2019). Sixth National Report to the Convention of Biological Diversity. The Clearing-House Mechanism of the Convention on Biological Diversity. https://chm.cbd.int/pdf/documents/nationalReport6/248495/1 (PDF) or https://chm.cbd.int/database/ record?documentID=248495 (online)

Fitzgerald, K.H. (2017). 'The challenge of funding Africa's protected area system'. Swara (July-September): 59-61. https://swara.co.ke/ making-africa-s-protected-area-system-financially-viable/

Frankfurt Zoological Society (FZS) (2019). 'North Luangwa conservation programme'. FZS [website]. https://fzs.org/en/projects/ north-luangwa/

Franks, P. and Booker, F. (2018). Governance Assessment for Protected and Conserved Areas (GAPA): Early experience of a multistakeholder methodology for enhancing equity and effectiveness. IIED Working Paper. London: IIED. https://pubs.iied.org/ pdfs/17632IIED.pdf

Franks, P., Small, R. and Booker, F. (2018). Social Assessment for Protected and Conserved Areas (SAPA). Methodology manual for SAPA facilitators. Second edition. IIED, London. https://pubs.iied.org/pdfs/14659IIED.pdf

Franks, P., Booker, F. and Small, R. (eds.). (forthcoming 2021). Social Assessment for Protected Areas and Conserved Areas. IIED Results Report. London, UK: International Institute for Environment and Development.

Gannon, P., Dubois, G., Dudley, N., Ervin, J., Ferrier, S., Gidda, S., MacKinnon, K., Richardson, K., Schmidt, M., Seyoum-Edjigu, E. et al. (2019). 'An update on progress towards Aichi Biodiversity Target 11'. Parks 25.2 November 2019. http://dx.doi.org/10.2305/IUCN. CH.2019.PARKS-25-2PG.en

Geldmann, J., Barnes, M., Coad, L., Craigie, I.D., Hockings, M. and Burgess, N.D. (2013). 'Effectiveness of terrestrial protected areas in reducing habitat loss and population declines'. Biological Conservation 161: 230-238. https://doi.org/10.1016/j.biocon.2013.02.018

Geldmann, J., Coad, L., Barnes, M., Craigie, I.D., Hockings, M., Knights, K., Leverington, F., Cuadros, I.C., Zamora, C., Woodley, S. et al. (2015). 'Changes in protected area management effectiveness over time: A global analysis'. Biological Conservation 191: 692-699.

https://doi.org/10.1016/j.biocon.2015.08.029 
Golden Kroner, R.E., Qin, S., Cook, C.N., Krithivasan, R., Pack, S.M., Bonilla, O.D., Cort-Kansinally, K.A., Coutinho, B., Feng, M., Martínez Garcia, M.I. et al. (2019). 'The uncertain future of protected lands and waters'. Science 364(6443): 881-886. https://doi.org/10.1126/ science.aau5525

Godoy, F., Tabor, K., Burgess, N., Mbilinyi, B., Kashaigili, J. and Steininger, M. (2012). 'Deforestation and CO2 emissions in coastal Tanzania from 1990 to 2007'. Environmental Conservation 39(1): 62-71. https://doi.org/10.1017/S037689291100035X

Gorenflo, L.J., Corson, C., Chomitz, K.M., Harper, G., Honzák, M. and Özler, B. (2011). 'Exploring the Association Between People and Deforestation in Madagascar'. In: Cincotta, R.P. and L.J. Gorenflo (eds.). Human Population: Its Influences on Biological Diversity, pp. 197-221. Berlin, Heidelberg: Springer. https://doi.org/10.1007/978-3-642-16707-2_11

Government of Malawi (2014). Fifth National Report To The Convention on Biological Diversity.. Lilongwe, Malawi: Environmental Affairs Department. https://www.cbd.int/doc/world/mw/mw-nr-05-en.pdf

(2015). National Biodiversity Strategy and Action Plan II (2015-2025). Lilongwe, Malawi: Environmental Affairs Department. https://www.cbd.int/doc/world/mw/mw-nbsap-v2-en.pdf

(2019). Sixth National Report to the Convention on Biological Diversity.Ministry of Natural Resources, Energy and Mining. https://www.cbd.int/doc/nr/nr-06/mw-nr-06-en.pdf

Government of Seychelles (2014a). Fifth National Report to the Convention on Biological Diversity. Victoria. https://www.cbd.int/ doc/world/sc/sc-nr-05-en.pdf

(2014b). Seychelles National Biodiversity Strategy and Action Plan 2015-2020. National Biodiversity Strategy and Action Plan No. 2. https://www.cbd.int/doc/world/sc/sc-nbsap-v2-en.pdf

Graham, J., Bruce, A. and Plumptre, T. (2003). Governance principles for protected areas in the 21st century. The Fifth World Parks Congress in September 2003. Durban, South Africa: Institute On Governance. https://www.files.ethz.ch/isn/122197/pa governance2.pdf

Gutiérrez, N.L., Hilborn, R. and Defeo, O. (2011). 'Leadership, social capital and incentives promote successful fisheries'. Nature 470(7334): 386-389. https://doi.org/10.1038/nature09689

Hannah, L., Roehrdanz, P.R., Marquet, P.A., Enquist, B.J., Midgley, G., Foden, W., Lovett, J.C., Corlett, R.T., Corcoran, D., Butchart, S.H.M. et al. (2020). '30\% land conservation and climate action reduces tropical extinction risk by more than $50 \%$ '. Ecography 43: 943-953. https://doi.org/10.1111/ecog.05166

Hockings, M. et al. (2019). 'The IUCN green list of protected and conserved areas: Setting the standard for effective conservation'. PARKS 25(2): 57-66. https://doi.org/10.2305/IUCN.CH.2019.PARKS-25-2MH.en

Hockings, M., Leverington, F. and Cook, C. (2015). 'Protected Area Management Effectiveness'. In: Worboys, G.L., M. Lockwood, A. Kothari, S. Feary, and Pulsford, I. (eds.). Protected Area Governance and Management, pp. 889-928. ANU Press, Canberra. http://press-files.anu.edu.au/downloads/press/p312491/pdf/CHAPTER28.pdf

Hockings, M., Stolton, S., Leverington, F., Dudley, N. and Courrau, J. (2006). Evaluating effectiveness: A framework for assessing management effectiveness of protected areas. 2nd edition. Best Practice Protected Area Guidelines Series No. 14. Gland, Switzerland and Cambridge, UK: IUCN. https://portals.iucn.org/library/node/8932

Howard, P. and Bertzky, B. (2019). Natural world heritage in Africa: Progress and prospects. BIOPAMA Programme. Nairobi, Kenya and Ouagadougou, Burkina Faso: IUCN ESARO and IUCN PACO. https://portals.iucn.org/library/node/49029

Hummel, C., , Poursanidis, D., Orenstein, D., Elliott, M., Adamescu, M.C., Cazacu, C., Chrysoulakis, N., van der Meer, J., Hummel, H. (2019). 'Protected Area management: Fusion and confusion with the ecosystem services approach'. Science of The Total Environment 651: 2432-2443. https://doi.org/10.1016/j.scitotenv.2018.10.033

Huntley, B.J. (2019). 'Angola in outline: Physiography, climate and patterns of biodiversity'. In: B. Huntley, V. Russo, F. Lages, N. Ferrand (eds.), Biodiversity of Angola. Cham, Switzerland: Springer. https://doi.org/10.1007/978-3-030-03083-4_2

Huntley, B.J., Russo, V., Lages, F. and Ferrand, N. (eds.) (2019). Biodiversity of Angola: Science and conservation: A modern synthesis. Springer. https://doi.org/10.1007/978-3-030-03083-4

Indigenous and Community Conserved Areas (ICCA) Registry (n.d.). ICCA Registry [website]. http://www.iccaregistry.org/ Intergovernmental Science-Policy Platform on Biodiversity and Ecosystem Services (IPBES) (2018). IPBES regional assessment report on biodiversity and ecosystem services for Africa. Bonn, Germany: Secretariat of the Intergovernmental Science-Policy Platform on Biodiversity and Ecosystem Services. https://ipbes.net/sites/default/files/africa_assessment_report_20181219_0. pdf and https://ipbes.net/assessment-reports/africa (provides direct links to summary and other material and commentaries).

International Institute for Environment and Development (IIED) (2018). 'Assessing governance at protected and conserved areas (GAPA)'. International Institute for Environment and Development. https://www.iied.org/assessing-governance-protectedconserved-areas-gapa 
(2020). Assessing governance and equity at protected and conserved areas (SAGE). International Institute for Environment and Development. https://www.iied.org/assessing-governance-equity-protected-conserved-areas-sage accessed 23 January 2020.

(n.d.). 'Assessing social impacts of protected and conserved areas (SAPA)'. IIED [website]. https://www.iied.org/assessingsocial-impacts-protected-conserved-areas-sapa

International Union for Conservation of Nature (IUCN) (2005a). 'Governance of Protected Areas - New Ways of Working Together'. In: Benefits Beyond Boundaries. Proceedings of the Vth IUCN World Parks Congress, pp. 64-75. Gland, Switzerland and Cambridge, UK: IUCN. https://portals.iucn.org/library/node/8662. Also available in French: https://portals.iucn.org/library/ node/8755; and Spanish:https://portals.iucn.org/library/node/8756

(2005b). 'The Durban Accord'. In: Benefits Beyond Boundaries. Proceedings of the Vth IUCN World Parks Congress, pp. 219-223. IUCN, Gland, Switzerland and Cambridge, UK. https://portals.iucn.org/library/node/8662. Also available in French: https://portals.iucn.org/library/node/8755; and Spanish:https://portals.iucn.org/library/node/8756

(2012). Accelerating the global pace of establishing marine protected areas and the certification of their effective management. WCC-2012-Res-076-EN. IUCN. https://portals.iucn.org/library/node/44043 (link to English, French and Spanish versions)

(2016a). A global standard for the identification of Key Biodiversity Areas, Version 1.0. Gland, Switzerland: IUCN. https:// portals.iucn.org/library/node/46259

(2016b). Supporting privately protected areas. WCC-2016-Res-036-EN. IUCN. https://portals.iucn.org/library/node/46453 (link to English, French and Spanish versions)

IUCN Eastern and Southern Africa Region (ESARO) (2020). Closing the gap. The financing and resourcing of protected and conserved areas in Eastern and Southern Africa. Nairobi, Kenya: IUCN ESARO; BIOPAMA. https://portals.iucn.org/library/ node/49045

IUCN and World Commission on Protected Areas (WCPA) (2017). IUCN Green List of Protected and Conserved Areas: Standard, Version 1.1. Gland, Switzerland: IUCN. https://www.iucn.org/theme/protected-areas/our-work/iucn-green-list-protected-andconserved-areas/global-standard

IUCN-WCPA Task Force on Other Effective Area-based Conservation Measures (OECMs) (2019). Recognising and reporting other effective area-based conservation measures. Gland, Switzerland: IUCN. https://doi.org/10.2305/IUCN.CH.2019.PATRS.3.en

Jonas, H. and Sandwith, T. (eds.) (2019). Towards Recognising, Reporting and Supporting OECMs: Report of the Fourth Expert Meeting of the IUCN-WCPA Task Force on Other Effective Area-based Conservation Mesaures. Gland, Switzerland: IUCN. https:// www.bfn.de/fileadmin/BfN/ina/Dokumente/Tagungsdoku/2019/towards_recognising_reporting_and_supporting_oecms_-report_of_4th_meeting_of_the_task_force_on_oecms_-_june_2019bf.pdf

Key Biodiversity Area (KBA) Secretariat (2019). Key biodiversity areas proposal process: Guidance on proposing, reviewing, nominating and confirming sites. Version 1.0. Cambridge, UK: KBA Secretariat and KBA Committee of the KBA Partnership. http://www.keybiodiversityareas.org/userfiles/files/KBA\%20Proposal\%20Process-v1.0.pdf

KBA Standards and Appeals Committee (2019). Guidelines for using A global standard for the identification of Key Biodiversity Areas: Version 1.0. Prepared by the KBA Standards and Appeals Committee of the IUCN Species Survival Commission and IUCN World Commission on Protected Areas. Gland, Switzerland: IUCN. https://portals.iucn.org/library/node/47982

Kenya National Bureau of Statistics (KNBS) (2019). Economic survey 2019. Nairobi, Kenya: Kenya National Bureau of Statistics. https://www.knbs.or.ke/?wpdmpro=economic-survey-2019

Kenya Wildlife Service (KWS) (2015). Annual Report. Nairobi, Kenya: KWS. http://www.kws.go.ke/file/2559/ download?token=skN48S4I

Kingdom of Eswatini (2019). Sixth National Report to the United Nations Convention on Biological Diversity Project. Ministry of Tourism and Environmental Affairs. https://www.cbd.int/doc/nr/nr-06/sz-nr-06-en.pdf

Kingdom of Lesotho (2019). Sixth national report: Lesotho vision 2020. National Report on Biodiversity (draft) No. 6. https://www. cbd.int/doc/nr/nr-06/ls-nr-06-en.pdf

Knoema (n.d.). 'Rwanda - Contribution of travel and tourism to GDP as a share of GDP'. Knoema [website] https://knoema.com// atlas/Rwanda/topics/Tourism/Travel-and-Tourism-Total-Contribution-to-GDP/Contribution-of-travel-and-tourism-to-GDPpercent-of-GDP?origin=knoema.fr. Accessed: 27 March 2020.

Leverington, F., Lemos Costa, K., Courrau, J., Pavese, H., Nolte, C., Marr, M., Coad, L., Burgess, L.N., Bomhard, B. and Hockings, M. (2010). Management effectiveness evaluation in protected areas - A global study. Second edition - 2010. Brisbane, Australia: The University of Queensland. https://www.eci.ox.ac.uk/publications/downloads/coad11-protected-areas.pdf

Lewis, E., MacSharry, B., Juffe-Bignoli, D., Harris, N., Burrows, G., Kingston, N. and Burgess, N.D. (2017). 'Dynamics in the global protected-area estate since 2004'. Conservation Biology 33(3): 570-579. https://doi.org/10.1111/cobi.13056 
Lindsey, P.A. et al. (2017). 'The performance of African protected areas for lions and their prey'. Biological Conservation 209: 137-149. https://doi.org/10.1016/j.biocon.2017.01.011

Lindsey, P.A. et al. (2018). 'More than $\$ 1$ billion needed annually to secure Africa's protected areas with lions'. Proceedings of the National Academy of Sciences 115(45): E10788-E10796. https://doi.org/10.1073/pnas.1805048115

Loarie, S.R., Duffy, P.B., Hamilton, B., Asner, G.P., Field, C.B., and Ackerly, D.D. (2009). 'The velocity of climate change'. Nature 462: 1052-1055. https://doi.org/10.1038/nature08649

Long, S.A. (2002). Disentangling benefits: Livelihoods, natural resource management and managing revenue from tourism: The experience of the Torra Conservancy, Namibia. Directorate of Environmental Affairs, Ministry of Environment and Tourism. http:// www.met.gov.na/services/research-discussion-papers-rdp/158/

Lubilo R, Sitai N, Daka D, Kalaluka N, Booker F and Franks P (2019). 'Governance Assessment for Protected Areas and Conserved Areas (GAPA) '. Case study report. International Institute for Environment and Development. https://www.iied.org/assessing-governanceprotected-conserved-areas-gapa

Mascia, M.B. and Pailler, S. (2011). 'Protected area downgrading, downsizing, and degazettement (PADDD) and its conservation implications'. Conservation Letters 4(1): 9-20. https://doi.org/10.1111/j.1755-263X.2010.00147.x

Mascia, M.B., Pailler, S., Krithivasan, R., Roshchanka, V., Burns, D., Mlotha, M.J., Murray, D.R., Peng, N. (2014). 'Protected area downgrading, downsizing, and degazettement (PADDD) in Africa, Asia, and Latin America and the Caribbean, 1900-2010'. Biological Conservation 169: 355-361. https://doi.org/10.1016/j.biocon.2013.11.021

Mayaux, P., Pekel, J.-F., Desclée, B., Donnay, F., Lupi, A., Achard, F., Clerici, M., Bodart, C., Brink, A., Nasi, R. and Belward, A. (2013). 'State and evolution of the African rainforests between 1990 and 2010'. Philosophical Transactions of the Royal Society B: Biological Sciences 368: 20120300. https://doi.org/10.1098/rstb.2012.0300

McDermott, M., Mahanty, S. and Schreckenberg, K. (2013). 'Examining equity: A multidimensional framework for assessing equity in payments for ecosystem services'. Environmental Science and Policy 33: 416-427. https://doi.org/10.1016/j.envsci.2012.10.006

McNeely, J.A. and Miller, K. (1984). 'The role of protected areas in sustaining society'. In: National Parks, Conservation and Development. The role of protected areas in sustaining society. Proceedings of the World Congress on National Parks, Bali, Indonesia, 11-22 October 1982. Washington, DC, USA: Smithsonian Institute Press. https://portals.iucn.org/library/node/5846

Metzger, M.J., Bunce, R.G.H., Jongman, R.H.G., Sayre, R., Trabucco, A. and Zomer, R. (2013). 'A high-resolution bioclimate map of the world: a unifying framework for global biodiversity research and monitoring'. Global Ecology and Biogeography 22: 630-638. https://doi. org/10.1111/geb.12022

Millennium Ecosystem Assessment (MEA) (2005). Ecosystems and Human Well-Being: Synthesis. Washington, DC, USA: Island Press. https://www.millenniumassessment.org/documents/document.356.aspx.pdf

Mpingo Conservation and Development Initiative (MCDI) (2019). 'Group Certificate Members'. Mpingo Conservation and Development Initiative [website] http://www.mpingoconservation.org/what-we-do/forest-certification/certificate-members/?L=378

Namibian Association of CBNRM Support Organisations (NACSO) (n.d.). 'Regional Communal Conservancies'. NACSO [website]. http:// www.nacso.org.na/conservancies. Accessed 9/9/2019.

National Institute of Statistics of Rwanda (2017). Statistical year book 2017. Kigali, Rwanda. https://www.statistics.gov.rw/file/6157/ download?token=UErS25hP

Nolte, C., Leverington, F., Kettner, A., Marr, M., Nielsen, G., Bomhard, B., Stolton, S., Stoll-Kleemann, S. and Hockings, M. (2010). Protected area management effectiveness assessments in Europe: A review of applications, methods and results. BfN- Scripten No. 271a. Vilm, Germany: BfN. https://www.bfn.de/fileadmin/BfN/service/Dokumente/skripten/Skript_271a.pdf

O’Connell, M.J., Nasirwa, O., Carter, M., Farmer, K.H., Appleton, M., Arinaitwe, J., Bhanderi, P., Chimwaza, G., Copsey, J., Dodoo, J. et al. (2019). 'Capacity building for conservation: problems and potential solutions for sub-Saharan Africa'. Oryx 53(2): 273-283. https:// doi.org/10.1017/S0030605317000291

Oldekop, J.A., Holmes, G., Harris, W.E. and Evans, K.L. (2015). 'A global assessment of the social and conservation outcomes of protected areas'. Conservation Biology 30(1): 133-141. https://doi.org/10.1111/cobi.12568

Ol Pejeta Conservancy (n.d.). Ol Pejeta Conservancy [website]. https://www.olpejetaconservancy.org/about-us/our-story/. Accessed 5 January 2020.

Olson, D.M., Dinerstein, E., Wikramanayake, E.D., Burgess, N.D., Powell, G.V.N., Underwood, E.C., D’amico, J.A., Itoua, I. Strand, H.E., Morrison, J.C. et al. (2001). 'Terrestrial ecoregions of the world: A new map of life on earth: A new global map of terrestrial ecoregions provides an innovative tool for conserving biodiversity'. BioScience 51(11): 933-938. https://doi.org/10.1641/00063568(2001)051[0933:TEOTWA]2.0.CO;2 
Organisation for Economic Cooperation and Development (OECD) (2019). Biodiversity: Finance and the economic and business case for action, report prepared for the G7 environment ministers' meeting. https://www.oecd.org/env/resources/biodiversity/biodiversityfinance-and-the-economic-and-business-case-for-action.htm (link to report, summary and annexes; and French version)

Osipova, E. et al. (2017). IUCN World Heritage Outlook 2: A conservation assessment of all natural World Heritage sites. Gland, Switzerland: IUCN. https://doi.org/10.2305/IUCN.CH.2017.17.en

Packer, C., Loveridge, A., Canney, S., Caro, T., Garnett, S.T., Pfeifer, M., Zander, K.K., Swanson, A., MacNulty, D., Balme, G. et al. (2013). 'Conserving large carnivores: dollars and fence'. Ecology Letters 16(5): 635-641. https://doi.org/10.1111/ele.12091

Parker, C., Cranford, M., Oakes, N. and Leggett, M. (eds.) (2012). The little biodiversity finance book: A guide to proactive investment in natural capital - 3rd ed. Oxford: Global Canopy Programme. https://www.globalcanopy.org/sites/default/files/documents/resources/ LittleBiodiversityFinanceBook_3rd\%20edition.pdf

Parmesan, C. and Yohe, G. (2003). 'A globally coherent footprint of climate change impacts across natural systems'. Nature 421: $37-42$. https://doi.org/10.1038/nature01286

Qin, S., Golden Kroner, R.E., Cook, C., Tesfaw, A.T., Braybrook, R., Rodriguez, C.M., Poelking, C., Mascia, M.B. (2019). 'Protected area downgrading, downsizing, and degazettement as a threat to iconic protected areas'. Conservation Biology 33(6): 1275- 285. https://doi. org/10.1111/cobi.13365

Ramsar Convention on Wetlands (n.d.). 'Sites \& Countries'. Ramsar [website]. https://www.ramsar.org/sites-countries/the-ramsar-sites accessed 12 September 2019. https://www.ramsar.org/sites-countries

Republic of Angola (2014). 5th National Report on Biodiversity in Angola 2007-2012. Luanda, Angola. https://www.cbd.int/doc/world/ao/ ao-nr-05-en.pdf (in English); https://www.cbd.int/doc/world/ao/ao-nr-05-fr.pdf (in French);

Republic of Botswana (2015). Fifth National Report to the Convention of Biological Diversity 2015. Gabarone, Botswana: Department of Environmental Affairs. https://www.cbd.int/doc/world/bw/bw-nr-05-en.pdf

(2016). National Biodiversity Strategy and Action Plan. Gaborone, Botswana: Department of Environmental Affairs. https://www. cbd.int/doc/world/bw/bw-nbsap-v3-en.pdf

(2019). The Sixth National Report for the Convention of Biological Diversity. https://chm.cbd.int/pdf/documents/ nationalReport6/246394/1 (pdf) or https://chm.cbd.int/database/record?documentID=246394 (online)

République de Djibouti (2014). 5ème Rapport Convention sur la Diversité Biologique. National Report on Biodiversity No. 5. Ministère de l'Habitat, de l'Urbanisme et de l'Environnement. https://www.cbd.int/doc/world/dj/dj-nr-05-fr.pdf

(2017). Stratégie et Programme d'Action Nationaux pour la Biodiversite. (National Biodiversity Strategy and Action Plan). Ministère de l'Habitat, Urbanisme et l'Environnement, Direction de l'Aménagement du territoire et de l'environnement. https://www.cbd.int/doc/ world/dj/dj-nbsap-v2-fr.pdf

(2019). Gème Rapport. Convention sur la Diversité Biologique 2011-2020. National Report on Biodiversity No. 6. Ministère de l'Urbanisme, de l'Environnement et du Tourisme (MUET), Direction de l'Environnement et du Développement Durable. https://www.cbd. int/doc/nr/nr-06/dj-nr-06-fr.pdf

Republic of Ethiopia and Ethiopian Biodiversity Institute (2014). Ethiopia's Fifth National Report to the Convention on Biological Diversity. Addis Ababa. https://www.cbd.int/doc/world/et/et-nr-05-en.pdf

(2015). Ethiopia's National Biodiversity Strategy and Action Plan 2015-2020. Addis Ababa. https://www.cbd.int/doc/world/et/ et-nbsap-v2-en.pdf

(2019). Sixth National Report (2014-2018) to the Convention on Biological Diversity. https://chm.cbd.int/pdf/documents/ nationalReport6/245702/3 (PDF) or https://chm.cbd.int/database/record?documentID=245702 (online)

Republic of Kenya (2015). Fifth National Report to the Conference of Parties to the Convention on Biological Diversity 2015. Nairobi, Kenya: Ministry of Environment, Natural Resources and Regional Development Authorities. https://www.cbd.int/doc/world/ke/ke-nr-05en.pdf

Republic of Madagascar (2014). Cinquième rapport national de la Convention sur la Diversité Biologique de Madagascar Antananarivo, Madagascar: Ministère de l'Environnement et des Forêts. https://www.cbd.int/doc/world/mg/mg-nr-05-fr.pdf

(2016). National Biodiversity and Action Plan 2015-2025. National Biodiversity Strategy and Action Plan. Antananarivo, Madagascar: Ministère de l'environnement, de l'écologie, de la mer et des forêts. https://www.cbd.int/doc/world/mg/mg-nbsap-v2-en. pdf (English) and https://www.cbd.int/doc/world/mg/mg-nbsap-v2-fr.pdf (French)

(2019). Gème Rapport national sur la diversité biologique de Madagascar. Ministère de l'Environnement et du Développement Durable. https://www.cbd.int/doc/nr/nr-06/mg-nr-06-fr.pdf

Republic of Mauritius (2015). Fifth National Report on the Convention on Biological Diversity. Ministry of Agro-Industry and Food Security. https://www.cbd.int/doc/world/mu/mu-nr-05-en.pdf 
(2017). National Biodiversity Strategy and Action Plan 2017 - 2025. Ministry of Agro-Industry and Food Security. https://www.cbd. int/doc/world/mu/mu-nbsap-v2-en.pdf

Republic of Mozambique (2014). Fifth National report on the implementation of Convention on Biological Diversity in Mozambique. Maputo: Ministry for the Coordination of Environmental Affairs. https://www.cbd.int/doc/world/mz/mz-nr-05-en.pdf

(2015). National Strategy and Action Plan of Biological Diversity of Mozambique (2015-2035). Maputo: Ministério da Terra, Ambiente e Desenvolvimento Rural. https://www.cbd.int/doc/world/mz/mz-nbsap-v3-en.pdf

Republic of Namibia (2014). Fifth National report to the Convention on Biological Diversity (2010-2014). National Report on Biodiversity No. 5. Windhoek, Namibia: Ministry of Environment and Tourism. https://www.cbd.int/doc/world/na/na-nr-05-en.pdf

(2018). Sixth National Report to the Convention on Biological Diversity (2014-2018). Ministry of Environment and Tourism. https:// www.cbd.int/doc/nr/nr-06/na-nr-06-en.pdf

Republic of Rwanda (2009). Fourth national report to the Convention on Biological Diversity. National Report on Biodiversity No. 4. Kigali: Rwanda Environment Management Authority, Ministry of Natural Resources. https://www.cbd.int/doc/world/rw/rw-nr-04-en.pdf

(2014). Fifth National Report to the Convention on Biological Diversity. https://www.cbd.int/doc/world/rw/rw-nr-05-en.pdf

Republic of South Africa (2014). South Africa's Fifth National Report to the Convention on Biological Diversity. Pretoria: Department of Environmental Affairs. https://www.cbd.int/doc/world/za/za-nr-05-en.pdf

(2019). The Sixth National Report for the Convention of Biological Diversity. National Report on Biodiversity No. 6. https://chm.cbd. int/pdf/documents/nationalReport6/241240/2 (PDF) or https://chm.cbd.int/database/record?documentID=241240 (online)

Republic of South Sudan (2015). Fifth national report to the Convention of Biological Diversity. Ministry of Environment. https://www.cbd. int/doc/world/ss/ss-nr-05-en.pdf

(2019). National Biodiversity Strategy and Action Plan (2018-2027). Ministry of Environment and Forestry. https://www.cbd.int/doc/ world/ug/ug-nr-05-en.pdf

(2019). Sixth National Report to the Convention on Biological Diversity (6th NR) (Draft). Ministry of Environment and Forestry. https://www.cbd.int/doc/nr/nr-06/ss-nr-06-en.pdf

Republic of Sudan (2014). Sudan Fifth National Report to the Convention on Biological Diversity (CBD). Khartoum, Sudan: Ministry of Environment, Forestry and Physical Development, Higher Council for Environment and Natural Resources. https://www.cbd.int/doc/ world/sd/sd-nr-05-en.pdf

(2019). Sixth National Report for the Convention of Biological Diversity. https://chm.cbd.int/pdf/documents/ nationalReport6/241358/2 (PDF) and https://chm.cbd.int/database/record?documentID=241358 (online)

Republic of Uganda (2016). National Biodiversity Strategy and Action Plan II (2015-2025). Theme: Supporting Transition to a Middle Income Status and Delivery of Sustainable Development Goals. Kampala, Uganda: National Environment Management Authority (NEMA). https://chm.cbd.int/api/v2013/documents/13784B07-8850-A5BE-8960-90D65EAC1211/attachments/Uganda\%20-NBSAP-Resigned. pdf

Republic of Zambia (2015). Fifth National Report on Biodiversity. Lusaka: Ministry of Lands Natural Resources and Environmental Protection. https://www.cbd.int/doc/world/zm/zm-nr-05-en.pdf

(2019). Sixth National Report for the Convention of Biological Diversity. https://chm.cbd.int/pdf/documents/ nationalReport6/241363/3 PDF) or https://chm.cbd.int/database/record?documentID=241363 (online)

Republic of Zimbabwe (2014). National Biodiversity Strategy and Action Plan 2014. National Biodiversity Strategy and Action Plan No. 2. Harare: Ministry of Environment, Water and Climate. https://www.cbd.int/doc/world/zw/zw-nbsap-v2-en.pdf

(2015). Fifth National Report to the Convention on Biological Diversity. Harare: Ministry of Environment, Water and Climate. https:// www.cbd.int/doc/world/zw/zw-nr-05-en.pdf

(2019). Zimbabwe's Sixth National Report to the Convention on Biodiversity. Ministry of Environment, Tourism and Hospitality Industry. https://www.cbd.int/doc/nr/nr-06/zw-nr-06-en.pdf

Ripple, W.J., Chapron, G., López-Bao, J.V., Durant, S.M., Macdonald, D.W., Lindsey, P.A., Bennett, E.L., Beschta, R.L., Bruskotter, J.T., Campos-Arceiz, A. et al. (2016). 'Saving the World's Terrestrial Megafauna'. BioScience 66(10): 807-812. https://doi.org/10.1093/biosci/ biw092

Rwanda Development Board (RDB) (2017). 2017 Annual Report. Kigali, Rwanda: Rwanda Development Board. https://rdb.rw/wpcontent/uploads/2018/08/RDB-Annual-Report-2017-Final.pdf

Saura, S., Bastin, L., Battistella, L., Mandrici, A. and Dubois, G. (2017). 'Protected areas in the world's ecoregions: How well connected are they'? Ecological Indicators 76: 144-158. https://doi.org/10.1016/j.ecolind.2016.12.047

Saura, S., Bertzky, B., Bastin, L., Battistella, L., Mandrici, A. and Dubois, G. (2018). 'Protected area connectivity: Shortfalls in global targets and country-level priorities'. Biological Conservation 219: 53-67. https://doi.org/10.1016/j.biocon.2017.12.020 
(2019). 'Global trends in protected area connectivity from 2010 to 2018 '. Biological Conservation 238(108183). https://doi. org/10.1016/j.biocon.2019.07.028

Scheffers, B.R., De Meester, L., Bridge, T.C.L., Hoffmann, A.A., Pandolfi, J.M., Corlett, R.T., Butchart, S.H.M., Pearce-Kelly, P., Kovacs, K.M., Dudgeon, D., et al. (2016). 'The broad footprint of climate change from genes to biomes to people'. Science 354: 6313. https://doi. org/10.1126/science.aaf7671

South African National Parks (SANParks) (2017). South African National Parks Annual Performance Plan Financial Year 2018/19. Pretoria, South Africa: SANParks. https://www.sanparks.org/assets/docs/about/annual_performance_plan_2018-2019.pdf

(2018). Annual Report 2017/2018. Pretoria, South Africa. https://www.sanparks.org/assets/docs/general/annual-report-2018.pdf

Southern African Development Community (SADC) Secretariat (2013). SADC Programme for Transfrontier Conservation Areas. Gaborone, Botswana: SADC. https://www.sadc.int/files/4614/2122/3338/SADC_TFCA_Programme_FINAL_doc_Oct_2013.pdf

(2018). Guidelines for Community Engagement in Southern African Development Community Transfrontier Conservation Areas - Final Draft. Gaborone, Botswana: SADC. https://tfcaportal.org/sites/default/files/public-docs/SADC\%20TFCA\%20Guideline\%20for\%20 Community\%20Engagement $\% 20 \% 20$ in \%20TFCAs\%20-\%20\%20Nov\%202018-\%20English\%20-\%20not\%20yet $\% 20$ endorsed.pdf

SADC Transfrontier Conservation Areas (TFCA) (2019). SADC TFCA Portal [website] https://tfcaportal.org/sadc-tfcas. Accessed 13 August 2019.

Schreckenberg, K., Camargo, I., Withnall, K., Corrigan, C., Franks, P., Roe, D., Scherl, L. M. and Richardson, V. (2010). Social assessment of conservation initiatives: A review of rapid methodologies. Natural Resources Issues No. 22. London: IIED. https://pubs.iied.org/ pdfs/14589IIED.pdf?

Schreckenberg, K., Franks, P., Martin, A. and Lang, B. (2016). 'Unpacking equity for protected area conservation'. Parks 22(2): 11-26. https://doi.org/10.2305/IUCN.CH.2016.PARKS-22-2KS.en

Schultz, L., Folke, C., Österblom, H. and Olsson, P. (2015). 'Adaptive governance, ecosystem management, and natural capital'. Proceedings of the National Academy of Sciences 112(24): 7369-7374. https://doi.org/10.1073/pnas.1406493112

Schulze, K., Knights, K., Coad, L., Geldmann, J., Leverington, F., Eassom, A., Marr, M., Butchart, S.H.M., Hockings, M., Burgess, N.D. (2018). 'An assessment of threats to terrestrial protected areas'. Conservation Letters 11(3): e12435. https://doi.org/10.1111/conl.12435

Secretariat of the Convention on Biological Diversity (CBD) (2014). Global Biodiversity Outlook 4 - Summary and Conclusions. Montreal, Canada: Secretariat of the CBD. https://www.cbd.int/gbo/gbo4/gbo4-summary-en.pdf

Seol, M. (2016). 'New finance model brings extraordinary conservation measures to life'. Harvard Government Innovators Network [blogpost], 13 September 2016. https://www.innovations.harvard.edu/blog/new-finance-model-brings-extraordinary-conservationmeasures-life

Snyman, S. (2012). 'Ecotourism joint ventures between the private sector and communities: An updated analysis of the Torra Conservancy and Damaraland Camp partnership, Namibia'. Tourism Management Perspectives 4: 127-135. https://doi.org/10.1016/j. tmp.2012.07.004

South African National Lotteries Commission (NLCSA) (2019). National Lotteries Commission [website]. http://www.nlcsa.org.za/ wp-content/uploads/2019/02/National-Lotteries-Commision-54X10-Light-Blue-Final.pdf

Space For Giants, UN Environment and Conservation Capital (2019). Building a wildlife economy. Working Paper 1: Developing NatureBased Tourism in African State Protected Areas. https://spaceforgiants.org/wp-content/uploads/2019/06/Building-Africas-WildlifeEconomy-Space-for-Giants-Working-Paper-1.pdf

Spalding, M.D., Agostini, V.N., Rice, J. and Grant, S.M. (2012). 'Pelagic provinces of the world: A biogeographic classification of the world's surface pelagic waters'. Ocean and Coastal Management 60: 19-30. https://doi.org/10.1016/j.ocecoaman.2011.12.016

Spalding, M.D. et al. (2007). 'Marine Ecoregions of the World: A Bioregionalization of Coastal and Shelf Areas'. BioScience 57(7): 573-583. https://doi.org/10.1641/B570707

Spenceley, A. (2018). Development of a SADC Guideline on cross border tourism products in TFCAs. SADC Guideline for cross-border tourism products. https://www.tfcaportal.org/sites/default/files/public-docs/SADC\%20Guideline\%20on\%20Cross-border\%20 tourism\%20products\%20in\%20TFCAs_2\%20August\%202018\%20Final\%20Draft_\%20not\%20yet\%20endorsed.pdf

Spenceley, A., Rylance, A. and Laiser, S.L. (2017). 'Protected area entrance fees in Tanzania: The search for competitiveness and value for money'. Koedoe - African Protected Area Conservation and Science 59(1): a1442. https://doi.org/10.4102/koedoe.v59i1.1442

State of Eritrea (2014). The 5th National Report on the Implementation of the UNCBD.. Asmara, Eritrea. https://www.cbd.int/doc/world/er/ er-nr-05-en.pdf

(2015). Revised National Biodiversity Strategy and Action Plan for Eritrea (2014-2020). National Biodiversity Strategy and Action Plan (NBSAP) No. 2. Asmara, Eritrea: Ministry of Land, Water and Environment, Department of Environment. https://www.cbd.int/doc/ world/er/er-nbsap-v2-en.pdf 
Stattersfield, A.J., Crosby, M.J., Long, A.J. and Wege, D.C. (1998). Endemic Bird Areas of the World. Priorities for biodiversity conservation. BirdLife Conservation Series No. 7. Cambridge: BirdLife International. http://datazone.birdlife.org/info/pubEBAs

Stoll-Kleeman, S., Bender, S., Berghöfer, A., Bertzky, M., Fritz-Vietta, N., Schliep, R. and Thierfelder, B. (2006). Linking governance and management perspectives with conservation success in protected areas and Biosphere Reserves. Perspectives on Biodiversity Governance and Management No. Discussion Paper 01. Berlin: GoBi Research Group. https://citeseerx.ist.psu.edu/viewdoc/ download?doi=10.1.1.474.1324\&rep=rep1\&type=pdf

Stolton, S. and Dudley, N. (2016). METT Handbook: A guide to using the Management Effectiveness Tracking Tool (METT). WWF-UK, Woking. https://www.protectedplanet.net/system/comfy/cms/files/files/000/000/208/original/WWF_METT_Handbook_2016_FINAL_0. pdf

Subsidiary Body on Scientific, Technical and Technological Advice (SBSTTA) (2010). In-depth review of the implementation of the Programme of Work on Protected Areas. No. UNEP/CBD/SBSTTA/14/5. Nairobi: Convention on Biological Diversity. http://www.cbd.int/ doc/meetings/sbstta/sbstta-14/official/sbstta-14-05-en.pdf (English) and https://www.cbd.int/kb/record/ meetingDocument/67344?RecordType=meetingDocument (for links to Word formats and other languages)

Swart, I. (2019). 'Carbon tax effective from 1 June 2019 following Presidential assent'. Deloitte South Africa [online article]. https://www2. deloitte.com/za/en/pages/tax/articles/carbon_tax_2019.html. Accessed: 21 January 2020.

Symes, W.S., Rao, M., Mascia, M.B. and Carrasco, L.R. (2016). 'Why do we lose protected areas? Factors influencing protected area downgrading, downsizing and degazettement in the tropics and subtropics'. Global Change Biology 22(2): 656-665. https://doi. org/10.1111/gcb.13089

Tanzania National Parks (Unpublished). Annual report 2013.

Tessema, Y. (Unpublished). A review of policy and legislation related to protected area management, governance and equity in the Eastern and Southern Africa region. A report prepared for BIOPAMA Eastern and Southern Africa. BIOPAMA, IUCN ESARO.

The Lion's Share (2020). The Lion's Share [website]. https://thelionssharefund.com/

The Nature Conservancy (n.d.). 'IUCN-CMP Unified Classifications of Direct Threats and Conservation Actions'. Conservation Gateway [website]. https://www.conservationgateway.org/ExternalLinks/Pages/iucn-cmp-unified-classifi.aspx (accessed 20 November 2019).

The Northern Rangelands Trust (2018). State of Conservancies Report 2018. Kenya: The Northern Rangelands Trust. https://static1. squarespace.com/static/5af1629f12b13f5ce97ca0b5/t/5c9df55b71c10b45cbb2c862/1553856154045/SOCR2018

The World Bank Group (2018). 'Sovereign blue bond issuance: Frequently Asked Questions'. World Bank [online feature story], 29 October 2018. https://www.worldbank.org/en/news/feature/2018/10/29/sovereign-blue-bond-issuance-frequently-asked-questions.

Thomas, C.D. and Gillingham, P.K. (2015). 'The performance of protected areas for biodiversity under climate change'. Biological Journal of the Linnean Society 115(3): 718-730. https://doi.org/10.1111/bij.12510

Uganda Biodiversity Fund (n.d.). Uganda Biodiversity Fund. https://ugandabiodiversityfund.org/. Accessed 21 January 2020.

Uganda National Environment Management Agency (2014). Fifth National Report to the Convention on Biological Diversity. Kampala, Uganda: National Environment Management Authority, Ministry of Water and Development. https://www.cbd.int/doc/world/ug/ ug-nr-05-en.pdf

Uganda Wildlife Authority (UWA) (Unpublished). Annual Report 2015.

(2018). Uganda Wildlife Authority Corporate Report 2018. https://www.ugandawildlife.org/download/category/12-annualreports?download=39:corporate-annual-report-2018

United Nations (UN) (2016). Report of the Special Rapporteur on the Rights of Indigenous Peoples: Conservation Measures and Their Impact on Indigenous People's Rights. United Nations General Assembly, Seventy-first Session, A/71/229. New York: United Nations. https://www.un.org/en/ga/search/view_doc.asp?symbol=A/71/229

UNDP Ecosystems and Biodiversity (2018). 'Results for rhinos. Using innovative financing to achieve conservation outcomes'. Exposure [online article], 2 March 2018. https://undp-biodiversity.exposure.co/results-for-rhinos

United Nations Educational, Scientific and Cultural Organization (UNESCO) (1971). The Convention on Wetlands of International Importance especially as Waterfowl Habitat. Paris. https://treaties.un.org/doc/Publication/UNTS/Volume\%20996/volume-996-I-14583English.pdf

(1972). Convention Concerning the Protection of the World Cultural and Natural Heritage. Adopted by the General Conference at its seventeenth session, 16 November 1972. Paris: UNESCO. https://whc.unesco.org/archive/convention-en.pdf

(n.d.a). 'Biosphere Reserves'. UNESCO [website] http://www.unesco.org/new/en/natural-sciences/environment/ecologicalsciences/biosphere-reserves/ 
(n.d.b). 'World Heritage List'. UNESCO World Heritage Centre [website]. https://whc.unesco.org/en/list/

United Nations Environment Programme Wildlife Conservation Management Centre (UNEP-WCMC) and IUCN (2016). Protected Planet Report 2016: How protected areas contribute to achieving global targets for biodiversity. Cambridge, UK and Gland, Switzerland: UNEP-WCMC and IUCN. https://www.iucn.org/theme/protected-areas/publications/protected-planet-report

(2019a). Protected Planet: World Database on Protected Areas (WDPA) [On-line], September 2019. Cambridge, UK: UNEP-WCMC and IUCN. https://www.protectedplanet.net/

(2019b). Protected Planet: User Manual for the World Database on Protected Areas and world database on other effective areabased conservation measures: 1.6. Cambridge, UK: UNEP-WCMC. https://www.protectedplanet.net/c/wdpa-manual/wdpamanual-v16.

(2019c). 'Protected Planet: Protected area dataset for Angola'; The World Database on Protected Areas (WDPA)/The Global Database on Protected Areas Management Effectiveness (GD-PAME)] [On-line], September 2019. Cambridge, UK: UNEP-WCMC and IUCN. https://www.protectedplanet.net/country/AO.

(2019d). 'Protected Planet: Protected area dataset for Botswana'; The World Database on Protected Areas (WDPA)/The Global Database on Protected Areas Management Effectiveness (GD-PAME)] [On-line], September 2019. https://www.protectedplanet.net/ country/BW

(2019e). 'Protected Planet: Protected area dataset for Comoros'; The World Database on Protected Areas (WDPA)/The Global Database on Protected Areas Management Effectiveness (GD-PAME)] [On-line], September 2019. https://www.protectedplanet.net/ country/KM.

(2019f). 'Protected Planet: Protected area dataset for Djibouti'; The World Database on Protected Areas (WDPA)/The Global Database on Protected Areas Management Effectiveness (GD-PAME)] [On-line], September 2019. https://www.protectedplanet.net/ country/DJ.

(2019g). 'Protected Planet: Protected area dataset for Eritrea'; The World Database on Protected Areas (WDPA)/The Global Database on Protected Areas Management Effectiveness (GD-PAME)] [On-line], September 2019. https://www.protectedplanet.net/ country/ER

(2019h). 'Protected Planet: Protected area dataset for eSwatini'; The World Database on Protected Areas (WDPA)/The Global Database on Protected Areas Management Effectiveness (GD-PAME)] [On-line], September 2019. https://www.protectedplanet.net/ country/SZ

(2019i). 'Protected Planet: Protected area dataset for Ethiopia'; The World Database on Protected Areas (WDPA)/The Global Database on Protected Areas Management Effectiveness (GD-PAME)] [On-line], September 2019. https://www.protectedplanet.net/ country/ET.

(2019j). 'Protected Planet: Protected area dataset for Kenya'; The World Database on Protected Areas (WDPA)/The Global Database on Protected Areas Management Effectiveness (GD-PAME)] [online], September 2019. https://www.protectedplanet.net/country/KE.

(2019k). 'Protected Planet: Protected area dataset for Lesotho'; The World Database on Protected Areas (WDPA)/The Global Database on Protected Areas Management Effectiveness (GD-PAME)] [online], September 2019. https://www.protectedplanet.net/ country/LS.

(2019l). 'Protected Planet: Protected area dataset for Madagascar'; The World Database on Protected Areas (WDPA)/The Global Database on Protected Areas Management Effectiveness (GD-PAME)] [online], September 2019. https://www.protectedplanet.net/ country/MG

(2019m). 'Protected Planet: Protected area dataset for Malawi'; The World Database on Protected Areas (WDPA)/The Global Database on Protected Areas Management Effectiveness (GD-PAME)] [online], September 2019. https://www.protectedplanet.net/ country/MW

(2019n). 'Protected Planet: Protected area dataset for Mauritius'; The World Database on Protected Areas (WDPA)/The Global Database on Protected Areas Management Effectiveness (GD-PAME)] [online], September 2019. https://www.protectedplanet.net/ country/MU.

(2019o). 'Protected Planet: Protected area dataset for Mozambique; The World Database on Protected Areas (WDPA)/The Global Database on Protected Areas Management Effectiveness (GD-PAME)] [Online], September 2019. https://www.protectedplanet.net/ country/MZ.

(2019p). 'Protected Planet: Protected area dataset for Namibia'; The World Database on Protected Areas (WDPA)/The Global Database on Protected Areas Management Effectiveness (GD-PAME)] [online], September 2019. https://www.protectedplanet.net/ country/NA.

(2019q). 'Protected Planet: Protected area dataset for Rwanda'; The World Database on Protected Areas (WDPA)/The Global Database on Protected Areas Management Effectiveness (GD-PAME)] [online], September 2019. https://www.protectedplanet.net/ country/RW. 
(2019r). 'Protected Planet: Protected area dataset for Seychelles'; The World Database on Protected Areas (WDPA)/The Global Database on Protected Areas Management Effectiveness (GD-PAME)] [online], September 2019. https://www.protectedplanet.net/ country/SC.

(2019s). 'Protected Planet: Protected area dataset for Somalia'; The World Database on Protected Areas (WDPA)/The Global Database on Protected Areas Management Effectiveness (GD-PAME)] [Online], September 2019. https://www.protectedplanet.net/ country/SO.

(2019t). 'Protected Planet: Protected area dataset for South Africa'; The World Database on Protected Areas (WDPA)/The Global Database on Protected Areas Management Effectiveness (GD-PAME)] [Online], September 2019. https://www.protectedplanet.net/ country/ZA.

(2019u). 'Protected Planet: Protected area dataset for South Sudan'; The World Database on Protected Areas (WDPA)/The Global Database on Protected Areas Management Effectiveness (GD-PAME)] [online], September 2019. https://www.protectedplanet.net/ country/SS.

(2019v). 'Protected Planet: Protected area dataset for Sudan'; The World Database on Protected Areas (WDPA)/The Global Database on Protected Areas Management Effectiveness (GD-PAME)] [online], September 2019. https://www.protectedplanet.net/ country/SD.

(2019w). 'Protected Planet: Protected area dataset for Tanzania'; The World Database on Protected Areas (WDPA)/The Global Database on Protected Areas Management Effectiveness (GD-PAME)] [online], September 2019. https://www.protectedplanet.net/ country/TZ.

(2019x).'Protected Planet: Protected area dataset for Uganda'; The World Database on Protected Areas (WDPA)/The Global Database on Protected Areas Management Effectiveness (GD-PAME)] [online], September 2019. https://www.protectedplanet.net/ country/UG.

(2019y). 'Protected Planet: Protected area dataset for Zambia'; The World Database on Protected Areas (WDPA)/The Global Database on Protected Areas Management Effectiveness (GD-PAME)] [online], September 2019. https://www.protectedplanet.net/ country/ZM.

(2019z). 'Protected Planet: Protected area dataset for Zimbabwe'; The World Database on Protected Areas (WDPA)/The Global Database on Protected Areas Management Effectiveness (GD-PAME)] [online], September 2019. https://www.protectedplanet.net/ search?q=zimbabwe.

(2019aa). 'Protected Planet: Protected Area Management Effectiveness (PAME)'. The World Database on Protected Areas (WDPA)/ The Global Database on Protected Areas Management Effectiveness (GD-PAME)] [On-line], 10 August 2019. Cambridge, UK: UNEPWCMC and IUCN. https://www.protectedplanet.net/c/protected-areas-management-effectiveness-pame. Accessed: 10 August 2019.

UNEP-WCMC, IUCN and National Geographic Society (NGS) (2018). Protected Planet Report 2018: Tracking progress towards global targets for protected areas. Cambridge UK; Gland, Switzerland; and Washington, DC, USA: UNEP-WCMC, IUCN and NGS. https:// livereport.protectedplanet.net/pdf/Protected_Planet_Report_2018.pdf

(2019). Protected Planet Live Report 2019. Cambridge UK; Gland, Switzerland; and Washington, DC, USA: UNEP-WCMC, IUCN and NGS. Accessed in September 2019.

United Nations Global Compact (UNGC) and IUCN (2012). A framework for corporate action on biodiversity and ecosystem services. https://portals.iucn.org/library/node/10174

Union des Comores (2014). 5ème Rapport national sur la diversité biologique (Fifth National Report on Biodiversity of Comoros). https:// www.cbd.int/doc/world/km/km-nr-05-fr.pdf

(2016). Stratégie nationale et Plan d'Action Actualisés pour la Diversité Biologique V2.2 (Updated National Strategy and Action Plan for Biological Diversity V2.2). https://www.cbd.int/doc/world/km/km-nbsap-v2-fr.pdf

(2017). Stratégie d'expansion du système national des aires protégées aux Comores, 2017-2021 (Strategy to expand the system of national protected areas of Comoros, 2017-2021). Directorate General for Environment and Forestry (DGEF). PNUD/GEF Comores: DGEF, VP-MAPEATU.

(2019). Gème Rapport national sur la biodiversité de l'Union des Comores (Sixth National Report on Biodiversity of Comoros). Ministère de l'Agriculture, de la Pêche et de l'Environnement. https://www.cbd.int/doc/nr/nr-06/km-nr-06-fr.pdf

United Republic of Tanzania (1998). National Forestry Policy. Dar es Salaam, Tanzania: Tanzania: Ministry of Natural Resources and Tourism. http://www.fao.org/forestry/15159-06c36bd31a5b3877ae3168cc5bedadd18.pdf

(2014). Fifth National Report on the Implementation of the Convention on Biological Diversity. Dar es Salaam, Tanzania: Division of Environment, Vice President's Office. http://www.cbd.int/doc/world/tz/tz-nr-05-en.pdf

(2019). The Sixth National Report for the Convention of Biological Diversity. https://chm.cbd.int/pdf/documents/ nationalReport6/245938/1 (PDF) or https://chm.cbd.int/database/record?documentID=245938 (online) 
Visconti, P., Marco, M.D., Álvarez-Romero, J.G., Januchowski-Hartley, S.R., Pressey, R.L., Weeks, R. and Rondinini, C. (2013). 'Effects of Errors and Gaps in Spatial Data Sets on Assessment of Conservation Progress'. Conservation Biology 27(5): 1000-1010. https://doi. org/10.1111/cobi.12095

Watson, J.E.M., Dudley, N., Segan, D.B. and Hockings, M. (2014). 'The performance and potential of protected areas'. Nature 515(7525): 67-73. https://doi.org/10.1038/nature13947

Wildlife Works (n.d.). Wildlife works. REDD+ conservation programme [website]. https://www.wildlifeworks.com accessed 21 January 2020.

World Bank Group (n.d.). 'International tourism, number of arrivals'. World Bank DataBank [website], https://data.worldbank.org/ indicator/st.int.arvl. Accessed: 15 October 2019

Worldometer (n.d.). 'Africa Population'. Worldometer [website]. https://www.worldometers.info/world-population/africa-population/. Accessed: 17 December 2019.

World Tourism Organization (WTO) (2014). Towards measuring the economic value of wildlife watching tourism in Africa. Briefing Paper. Madrid: UNWTO. https://doi.org/10.18111/9789284416752

World Travel and Tourism Council (WTTO) (2019). 'Country reports'. WTTO [website]. https://www.wttc.org/economic-impact/countryanalysis/country-reports/

Wright, E. (2018). 'Leveraging PPPs in Mozambique to scale conservation and promote economic development'. World Bank [blogpost], 18 July 2018. https://blogs.worldbank.org/ppps/leveraging-ppps-mozambique-scale-conservation-and-promote-economicdevelopment. Accessed 27 March 2020.

World Wildlife Fund (WWF) (2009). Guide to Conservation Finance: Sustainable Financing for the Planet. Washington DC, USA: World Wildlife Fund (WWF). http://awsassets.panda.org/downloads/wwf_guide_to_conservation_finance.pdf

(2017). 'Southern Africa: Northwestern Madagascar'. The Global Ecoregions [website]. https://www.worldwildlife.org/ecoregions/ at0202 Zafra-Calvo, N., Pascual, U., Brockington, D., Coolsaet, B., Cortes-Vazquez, J.A., Gross-Camp, N., Palomo, I., Burgess, N.D. (2017). 'Towards an indicator system to assess equitable management in protected areas'. Biological Conservation 211 (Part A): $134-141$. https://doi.org/10.1016/j.biocon.2017.05.014

Zunckel, K. (2014). Southern African Development Community Transfrontier Conservation Guidelines: The establishment and development of TFCA initiatives between SADC member states. Gaborone, Botswana: SADC. https://www.academia.edu/12527362/SOUTHERN AFRICAN_DEVELOPMENT_COMMUNITY_TRANSFRONTIER_CONSERVATION_GUIDELINES_The_establishment_and_development_ of_TFCA_initiatives_between_SADC_Member_States 



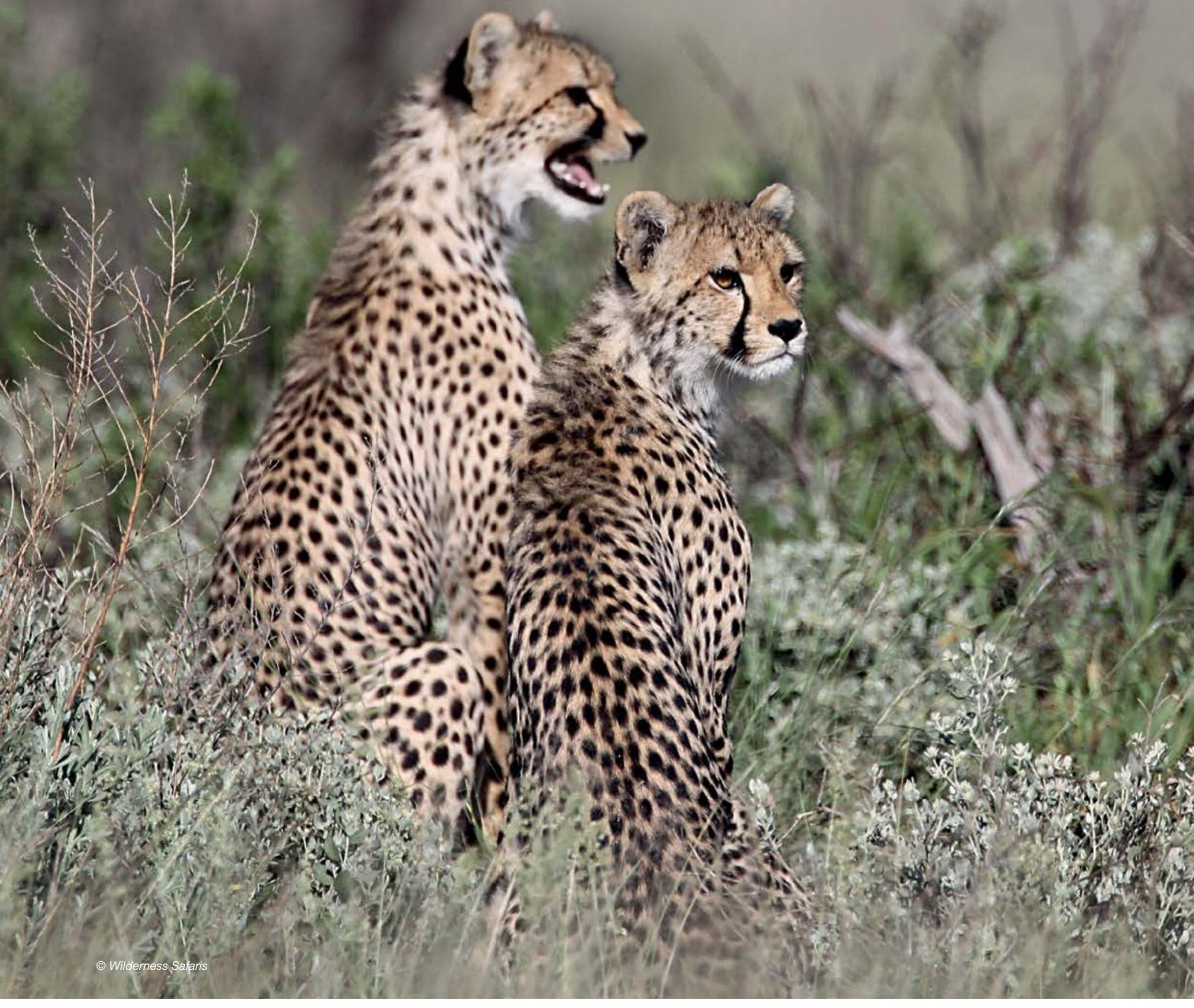




\section{Appendices}




\section{Table of contents}

Appendix 1. BIOPAMA Focal Points

Appendix 2. Regional statistics on protected and conserved areas in Eastern and Southern Africa 220

A2-Table 1. Terrestrial protected and conserved areas in Eastern and Southern Africa ......................................................220

A2-Table 2. Coastal and marine protected and conserved areas in Eastern and Southern Africa.........................................221

A2-Table 3. IUCN management categories of protected and conserved areas in Eastern and Southern Africa .......................221

A2-Table 4. IUCN governance types of protected and conserved areas in Eastern and Southern Africa ................................222

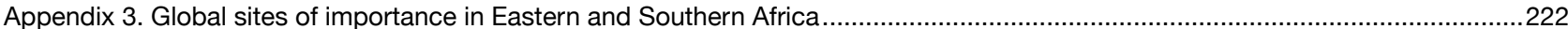

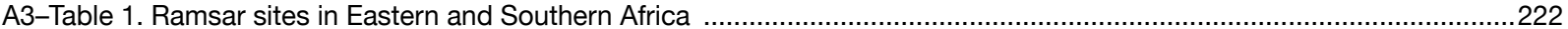

A3-Table 2. Man and Biosphere Reserves in Eastern and Southern Africa ..........................................................................226

Appendix 4. Ecological representativity in Eastern and Southern Africa ..............................................................................22

A4-Table 1. Ecological representativity in Eastern and Southern African protected areas ..................................................227

Appendix 5. Legal instruments supporting equity and non-State governance of protected areas ...............................................2228

Appendix 6. Protected and conserved areas in IUCN Management Categories per country .....................................................230

Appendix 7. Protected and conserved areas in IUCN Governance Types per country .............................................................236 


\section{Appendix 1. BIOPAMA Focal Points}

\begin{tabular}{|c|c|c|}
\hline Country & Name of focal point & Institution \\
\hline Angola & Marta Zumbo & Ministry of Environment, Head of Protected Areas \\
\hline Botswana & Bakang Mokime & $\begin{array}{l}\text { Department of Wildlife and National Parks, Ministry of Environment, Wildlife } \\
\text { and Tourism }\end{array}$ \\
\hline Comoros & Moina Hali & Direction Générale de l’Environnement et des Forêts \\
\hline Djibouti & Mohamed Elmni Obsieh & Ministry of Environment \\
\hline Eritrea & Estefanios Bein & Ministry of Land, Water and Environment \\
\hline Eritrea & Fatsum Hagos & Forestry and Wildlife Authority \\
\hline Eswatini & Thulani Methula & Eswatini National Trust Commission \\
\hline Ethiopia & Gebremeskel Gizaw Kassa & Ethiopian Wildlife Conservation Authority \\
\hline Kenya & Arthur Tuda for MPA & Kenya Wildlife Service (KWS) \\
\hline Lesotho & Mamasheane Motabotabo & Department of Environment, Ministry of Tourism Environment and Culture \\
\hline Malawi & Davis Kalima & Department of National Parks and Wildlife \\
\hline Madagascar & Ramanantsoa Seheno & Ministry of Environment, Ecology and Forests \\
\hline Madagascar & Rakotobe Domoina & Wildlife Conservation Society \\
\hline Mauritius & Kevin Ruhomaun & National Park and Conservation Service \\
\hline Mozambique & Raimundo Vasco Matusse & National Administration of Conservation Areas \\
\hline Namibia & Shayne Kotting & Ministry of Environment and Tourism \\
\hline Rwanda & Eugene Mutangana & Rwanda Development Board \\
\hline Seychelles & Selby Remy & Seychelles National Parks Authority \\
\hline Somalia & Mohamed Moallim Osman & $\begin{array}{l}\text { Director of Environmental Awareness, Office of Environmental Affairs at the } \\
\text { Office of the Prime Minister }\end{array}$ \\
\hline South Africa & Karl Naude & Department of Environmental Affairs \\
\hline South Africa & Thivhulawi Nethononda & Department of Environmental Affairs \\
\hline South Sudan & Malik Doka Morgan & Ministry of Wildlife Conservation and Tourism \\
\hline South Sudan & Lona Nalurit Darius & Ministry of Wildlife Conservation and Tourism \\
\hline Sudan & Noureldin Ahmed Abdalla & Higher Council on Environment and Natural Resources \\
\hline Sudan & Khidir Elsadig Jabir Arin & Wildlife Conservation General Administration \\
\hline Tanzania & Paul Banga & Tanzania National Parks Authority \\
\hline Tanzania & Dr James Wakibara & Tanzania Wildlife Management Authority \\
\hline Tanzania & Asanterabi Lowassa & Tanzania Wildlife Research Institute \\
\hline Tanzania & Prof Dos Santos (CEOs) & Tanzania Forest Service \\
\hline Uganda & John Makombo & Uganda Wildlife Authority \\
\hline Zambia & Chisha Moseni & Department of National Parks and Wildlife \\
\hline Zambia & Sydney Tembo & Department of National Parks and Wildlife \\
\hline Zimbabwe & Geoffreys Matipano & Zimbabwe Parks and Wildlife Management Authority \\
\hline
\end{tabular}




\section{Appendix 2. Regional statistics on protected and conserved areas in Eastern and Southern Africa}

\section{A2-Table 1. Terrestrial protected and conserved areas in Eastern and Southern Africa}

\begin{tabular}{|c|c|c|c|c|c|}
\hline Country & $\begin{array}{r}\text { Number of } \\
\text { protected areas* }^{*}\end{array}$ & $\begin{array}{r}\text { Terrestrial area } \\
\text { covered in } \\
\text { protected areas } \\
\left(\mathbf{k m}^{2 *}\right)\end{array}$ & $\begin{array}{l}\% \text { of terrestrial } \\
\text { area covered in } \\
\text { protected areas }\end{array}$ & $\begin{array}{r}\% \text { of terrestrial } \\
\text { area covered in } \\
\text { protected and } \\
\text { conserved areas }^{\star \star}\end{array}$ & $\begin{array}{r}\% \text { of terrestrial } \\
\text { area that is } \\
\text { protected and } \\
\text { connected }^{\star \star \star}\end{array}$ \\
\hline Angola & 13 & 87507 & $6.97 \%$ & $12.50 \%$ & $2.56 \%$ \\
\hline Botswana & 22 & 169370 & $29.14 \%$ & $29.10 \%$ & $18.37 \%$ \\
\hline Comoros & 5 & 173 & $10.15 \%$ & $22.00 \%$ & $10.21 \%$ \\
\hline Djibouti & 3 & 344 & $1.57 \%$ & $1.34 \%$ & $1.34 \%$ \\
\hline Eritrea & 4 & 5936 & $4.87 \%$ & Not found & $3.21 \%$ \\
\hline Eswatini & 14 & 738 & 4.26 & $3.90 \%$ & $2.7 \%$ \\
\hline Ethiopia & 104 & 200074 & $17.62 \%$ & $14.00 \%$ & $8.28 \%$ \\
\hline Kenya & 391 & 72545 & $12.36 \%$ & $8 \%$ & $5.55 \%$ \\
\hline Lesotho & 4 & 80 & $0.26 \%$ & $0.50 \%$ & $0.24 \%$ \\
\hline Madagascar & 109 & 33242 & $5.59 \%$ & Not found & $1.7 \%$ \\
\hline Malawi & 133 & 27190 & $22.88 \%$ & $15.12 \%$ & $11.39 \%$ \\
\hline Mauritius & 15 & 97 & $4.73 \%$ & $4.00 \%$ & $3.41 \%$ \\
\hline Mozambique & 42 & 170662 & $21.57 \%$ & $26.00 \%$ & $8.87 \%$ \\
\hline Namibia & 146 & 313534 & $37.89 \%$ & $17.00 \%$ & $28.08 \%$ \\
\hline Rwanda & 10 & 2320 & $9.11 \%$ & $10.10 \%$ & $5.75 \%$ \\
\hline Seychelles & 10 & 242 & $49.64 \%$ & $46.60 \%$ & $36.96 \%$ \\
\hline Somalia & 20 & $0^{117}$ & $0.00 \%$ & $0.80 \%$ & N/A \\
\hline South Africa & 1444 & 102060 & $8.34 \%$ & $12.96 \%$ & $2.47 \%$ \\
\hline South Sudan & 27 & 98214 & $15.50 \%$ & $13.00 \%$ & $6.65 \%$ \\
\hline Sudan & 19 & 42698 & $2.28 \%$ & $5.80 \%$ & $1.17 \%$ \\
\hline Tanzania & 709 & 361594 & $38.17 \%$ & $54.60 \%$ & $21.55 \%$ \\
\hline Uganda & 712 & 39059 & $16.06 \%$ & $18.00 \%$ & $6.66 \%$ \\
\hline Zambia & 635 & 286161 & $37.87 \%$ & $37.80 \%$ & $16.28 \%$ \\
\hline Zimbabwe & 232 & 106837 & $27.21 \%$ & $28.00 \%$ & $19.76 \%$ \\
\hline TOTAL & $4821^{118}$ & $2120112^{119}$ & $16.54 \%$ & $\mathrm{~N} / \mathrm{A}$ & $\mathrm{N} / \mathrm{A}$ \\
\hline
\end{tabular}

Sources: *World Database on Protected Areas (UNEP-WCMC \& IUCN, 2019a); ** National Reports to the Convention on Biological Diversity. *** EC JRC/DOPA (2019).

Note: See Chapter 8 for detailed information on the national reports to the CBD, from 2014 to 2019.

117 Somalia only has point data, with no reported area so percentage coverage can be calculated for the sites.

118 There are two transboundary protected areas within this table, falling within four countries (Lesotho/South Africa and Zambia/Zimbabwe). Each site is counted once in each country total; however, each site is only counted once in the total number for the region.

119 Calculated directly from the World Database on Protected Areas, rather than a simple sum of all the country areas. 
A2-Table 2. Coastal and marine protected and conserved areas in Eastern and Southern Africa

\begin{tabular}{|c|c|c|c|c|}
\hline Name & $\begin{array}{l}\text { Number } \\
\text { (WDPA) }\end{array}$ & $\begin{array}{r}\text { Coastal and marine area } \\
\text { covered in protected } \\
\text { areas } \mathbf{k m}^{2} \text { * }\end{array}$ & $\begin{array}{r}\% \text { of coastal and marine } \\
\text { area covered in } \\
\text { protected areas }{ }^{\star *}\end{array}$ & $\begin{array}{r}\% \text { of coastal and marine } \\
\text { area covered in protected } \\
\text { areas }\end{array}$ \\
\hline Angola & 1 & 24 & 0 & $0.0 \%$ \\
\hline Comoros & 3 & 37 & 0 & $0.02 \%$ \\
\hline Djibouti & 4 & 12 & $0.46 \%$ & $0.17 \%$ \\
\hline Eritrea & 0 & 0 & 0 & $0.0 \%$ \\
\hline Kenya & 20 & 904 & 0 & $0.8 \%$ \\
\hline Madagascar & 48 & 8998 & 0 & $0.75 \%$ \\
\hline Mauritius & 29 & 50 & 0 & $0.0 \%$ \\
\hline Mozambique & 2 & 12821 & 0 & $2.23 \%$ \\
\hline Namibia & 2 & 9646 & $0.01 \%$ & $1.71 \%$ \\
\hline Seychelles & 30 & 209930 & $0.03 \%$ & $15.66 \%$ \\
\hline Somalia & 1 & 0 & 0 & 0 \\
\hline South Africa & 136 & 224640 & $10 \%$ & $14.56 \%$ \\
\hline Sudan & 4 & 10662 & $0.03 \%$ & $15.96 \%$ \\
\hline Tanzania & 131 & 7330 & $6.50 \%$ & $3.02 \%$ \\
\hline TOTAL & 411 & 473815 & $\mathrm{~N} / \mathrm{A}$ & $5.60 \%$ \\
\hline
\end{tabular}

Sources: *World Database on Protected Areas (UNEP-WCMC \& IUCN, 2019a); ** National Reports to the Convention on Biological Diversity.

Note: See Chapter 8 for detailed information on the national reports to the CBD, from 2014 to 2019

A2-Table 3. IUCN management categories of protected and conserved areas in Eastern and Southern Africa

\begin{tabular}{l|r|r}
\hline IUCN Management Category & Number & Area (km²) $^{\mathbf{1 2 0}}$ \\
\hline la. Strict nature reserve & 9 & 3788 \\
\hline lb. Wilderness area & 17 & 103882 \\
\hline II. National park & 209 & 522053 \\
\hline III. Natural monument & 32 & 8388 \\
\hline IV. Habitat/species management & 164 & 147821 \\
\hline V. Protected landscape/seascape & 49 & 19918 \\
\hline VI. Protected area with sustainable use of natural resources & 155 & 384507 \\
\hline Not reported & 4538 & 1498805 \\
\hline Not applicable & 56 & 158898 \\
\hline Not assigned & 3 & 4019 \\
\hline
\end{tabular}

Source: (UNEP-WCMC \&IUCN, 2019a).

120 This is not a novel coverage by management category. Some of the protected areas overlap, and could have differing IUCN management categories. If two protected areas cover the same location but have different management categories, both categories are counted, 
A2-Table 4. IUCN governance types of protected and conserved areas in Eastern and Southern Africa

\begin{tabular}{l|r|r}
\hline IUCN Governance Type & Number & Area (km²) \\
\hline A. Governance by government & 2468 & 1424849 \\
\hline B. Shared governance & 18 & 5214 \\
\hline C. Private governance & 959 & 33271 \\
\hline $\begin{array}{l}\text { D. Governance by Indigenous Peoples and } \\
\text { Local Communities }\end{array}$ & 238 & 199957 \\
\hline Not reported & 1549 & 1131803 \\
\hline
\end{tabular}

Source: (UNEP-WCMC \& IUCN, 2019a).

\section{Appendix 3. Global sites of importance in Eastern and Southern Africa ${ }^{122}$}

\begin{tabular}{|c|c|c|c|c|}
\hline Country & $\begin{array}{l}\text { Date convention entered } \\
\text { into force }\end{array}$ & No. of sites & Sites & Area covered (ha) \\
\hline Botswana & 9 April 1997 & 1 & Okavango Delta System & 5537400 \\
\hline \multirow[t]{3}{*}{ Comoros } & \multirow[t]{3}{*}{9 June 1995} & \multirow[t]{3}{*}{3} & Lake Dziani Boundouni & \multirow[t]{3}{*}{16030} \\
\hline & & & Le Karthala & \\
\hline & & & Le Mont Ntringui & \\
\hline Djibouti & 22 March 2003 & 1 & Haramous-Loyada & 3000 \\
\hline \multirow[t]{3}{*}{ Eswatini } & \multirow[t]{3}{*}{15 June 2013} & \multirow[t]{3}{*}{3} & Hawane dam and Nature Reserve & \multirow[t]{3}{*}{118} \\
\hline & & & Sand River Dam & \\
\hline & & & Van Eck Dam & \\
\hline \multirow[t]{6}{*}{ Kenya } & \multirow[t]{6}{*}{5 October 1990} & \multirow[t]{6}{*}{6} & Lake Baringo & \multirow[t]{6}{*}{265449} \\
\hline & & & Lake Bogoria & \\
\hline & & & Lake Elmenteita & \\
\hline & & & Lake Naivasha & \\
\hline & & & Lake Nakuru & \\
\hline & & & Tana River Delta Ramsar Site & \\
\hline Lesotho & 1 November 2004 & 1 & Lets'eng-la-Letsie & 434 \\
\hline
\end{tabular}




\begin{tabular}{|c|c|c|c|c|}
\hline Country & $\begin{array}{l}\text { Date convention entered } \\
\text { into force }\end{array}$ & No. of sites & Sites & Area covered (ha) \\
\hline \multirow[t]{20}{*}{ Madagascar } & \multirow[t]{20}{*}{25 January 1999} & \multirow[t]{20}{*}{20} & Barrière de Corail Nosy Ve Androka & \multirow[t]{20}{*}{2094911} \\
\hline & & & Complexe des lacs Ambondro et Sirave (CLAS) & \\
\hline & & & Complexe des lacs de Manambolomaty & \\
\hline & & & Complexe des Zones Humides de Bemanevika & \\
\hline & & & Iles Barren & \\
\hline & & & Lac Kinkony & \\
\hline & & & Lac Sofia & \\
\hline & & & $\begin{array}{l}\text { Le Lac Alaotra: Les Zones Humides et Bassins } \\
\text { Versants }\end{array}$ & \\
\hline & & & Mangroves de Tsiribihina & \\
\hline & & & $\begin{array}{l}\text { Marais de Torotorofotsy avec leurs bassins } \\
\text { versants (watersheds) }\end{array}$ & \\
\hline & & & Parc de Tsarasaotra & \\
\hline & & & Parc national Tsimanampesotse & \\
\hline & & & Rivière Nosivolo et affluents (tributaries) & \\
\hline & & & Site Bioculturel d'Antrema & \\
\hline & & & Zone Humide de Mandrozo & \\
\hline & & & Zones Humides Ankarafantsika (CLSA) & \\
\hline & & & Zones humides d'Ambondrobe & \\
\hline & & & Zones humides de Bedo & \\
\hline & & & Zones humides de l'Onilahy & \\
\hline & & & Zones Humides de Sahamalaza & \\
\hline \multirow[t]{2}{*}{ Malawi } & \multirow[t]{2}{*}{14 March 1997} & \multirow[t]{2}{*}{2} & Elephant Marsh & \multirow[t]{2}{*}{286356} \\
\hline & & & Lake Chilwa & \\
\hline \multirow[t]{3}{*}{ Mauritius } & \multirow[t]{3}{*}{30 September 2001} & \multirow[t]{3}{*}{3} & Blue Bay Marine Park & \multirow[t]{3}{*}{401} \\
\hline & & & Pointe d'Esny Wetland & \\
\hline & & & Rivulet Terre Rouge Estuary Bird Sanctuary & \\
\hline \multirow[t]{2}{*}{ Mozambique } & \multirow[t]{2}{*}{3 December 2004} & \multirow[t]{2}{*}{2} & Lake Niassa and its Coastal Zone & \multirow[t]{2}{*}{4534872} \\
\hline & & & Zambezi Delta & \\
\hline \multirow[t]{5}{*}{ Namibia } & \multirow[t]{5}{*}{23 December 1995} & \multirow[t]{5}{*}{5} & Bwabwata-Okavango Ramsar Site & \multirow[t]{5}{*}{676564} \\
\hline & & & Etosha Pan & \\
\hline & & & Orange River Mouth & \\
\hline & & & Sandwich Harbour & \\
\hline & & & Walvis Bay & \\
\hline Rwanda & 1 April 2006 & 1 & Rugezi-Burera-Ruhondo & 6736 \\
\hline \multirow[t]{3}{*}{ Seychelles } & \multirow[t]{3}{*}{22 March 2005} & \multirow[t]{3}{*}{3} & Aldabra Atoll & \multirow[t]{3}{*}{44025} \\
\hline & & & $\begin{array}{l}\text { Mare Aux Cochons high altitude freshwater } \\
\text { wetlands }\end{array}$ & \\
\hline & & & Port Launay Coastal Wetlands & \\
\hline
\end{tabular}




\begin{tabular}{|c|c|c|c|c|}
\hline Country & $\begin{array}{l}\text { Date convention entered } \\
\text { into force }\end{array}$ & No. of sites & Sites & Area covered (ha) \\
\hline \multirow[t]{27}{*}{ South Africa } & \multirow[t]{27}{*}{21 December 1975} & \multirow[t]{27}{*}{27} & Barberspan & \multirow[t]{27}{*}{557028} \\
\hline & & & Blesbokspruit & \\
\hline & & & Bot - Kleinmond Estuarine System & \\
\hline & & & Dassen Island Nature Reserve & \\
\hline & & & De Hoop Vlei & \\
\hline & & & De Mond & \\
\hline & & & $\begin{array}{l}\text { Dyer Island Provincial Nature Reserve and } \\
\text { Geyser Island Provincial Nature }\end{array}$ & \\
\hline & & & Reserve & \\
\hline & & & False Bay Nature Reserve & \\
\hline & & & Kgaswane Mountain Reserve & \\
\hline & & & Kosi Bay & \\
\hline & & & Lake Sibaya & \\
\hline & & & Langebaan & \\
\hline & & & Makuleke Wetlands & \\
\hline & & & Natal Drakensberg Park & \\
\hline & & & Ndumo Game Reserve & \\
\hline & & & Ntsikeni Nature Reserve & \\
\hline & & & Nylsvley Nature Reserve & \\
\hline & & & Orange River Mouth & \\
\hline & & & Prince Edward Islands & \\
\hline & & & Seekoeivlei Nature Reserve & \\
\hline & & & St. Lucia System & \\
\hline & & & Turtle Beaches/Coral Reefs of Tongaland & \\
\hline & & & uMgeni Vlei Nature Reserve & \\
\hline & & & Verloren Valei Nature Reserve & \\
\hline & & & Verlorenvlei & \\
\hline & & & Wilderness Lakes & \\
\hline South Sudan & 10 October 2013 & 1 & Sudd & 5700000 \\
\hline \multirow[t]{3}{*}{ Sudan } & \multirow[t]{3}{*}{7 May 2005} & \multirow[t]{3}{*}{3} & Dinder National Park & \multirow[t]{3}{*}{2489600} \\
\hline & & & Dongonab Bay-Marsa Waiai & \\
\hline & & & Suakin-Gulf of Agig & \\
\hline
\end{tabular}




\begin{tabular}{|c|c|c|c|c|}
\hline Country & $\begin{array}{l}\text { Date convention entered } \\
\text { into force }\end{array}$ & No. of sites & Sites & Area covered (ha) \\
\hline \multirow[t]{12}{*}{ Uganda } & \multirow[t]{12}{*}{4 July 1988} & \multirow[t]{12}{*}{12} & Lake Bisina Wetland System & \multirow[t]{12}{*}{454303} \\
\hline & & & Lake George & \\
\hline & & & Lake Mburo-Nakivali Wetland System & \\
\hline & & & Lake Nabugabo wetland system & \\
\hline & & & Lake Nakuwa Wetland System & \\
\hline & & & Lake Opeta Wetland System & \\
\hline & & & Lutembe Bay Wetland System & \\
\hline & & & Mabamba Bay Wetland System & \\
\hline & & & Murchison Falls-Albert Delta Wetland System & \\
\hline & & & Nabajjuzi Wetland system & \\
\hline & & & Rwenzori Mountains Ramsar Site & \\
\hline & & & $\begin{array}{l}\text { Sango Bay-Musambwa Island-Kagera Wetland } \\
\text { System (SAMUKA) }\end{array}$ & \\
\hline \multirow{4}{*}{$\begin{array}{l}\text { United Republic } \\
\text { of Tanzania }\end{array}$} & \multirow[t]{4}{*}{13 August 2000} & \multirow[t]{4}{*}{4} & Kilombero Valley Floodplain & \multirow[t]{4}{*}{4868424} \\
\hline & & & Lake Natron Basin & \\
\hline & & & Malagarasi-Muyovozi Wetlands & \\
\hline & & & Rufiji-Mafia-Kilwa Marine Ramsar Site & \\
\hline \multirow[t]{6}{*}{ Zambia } & \multirow[t]{6}{*}{28 December 1991} & \multirow[t]{6}{*}{6} & Bangweulu Swamps & \multirow[t]{6}{*}{4030500} \\
\hline & & & Busanga Swamps & \\
\hline & & & Kafue Flats & \\
\hline & & & Luangwa Flood Plains & \\
\hline & & & Lukanga Swamps & \\
\hline & & & Mweru wa Ntipa & \\
\hline \multirow[t]{7}{*}{ Zimbabwe } & \multirow[t]{7}{*}{3 May 2013} & \multirow[t]{7}{*}{6} & Chinhoyi Caves Recreational Park & \multirow[t]{7}{*}{453828} \\
\hline & & & Cleveland Dam & \\
\hline & & & Driefontein Grasslands & \\
\hline & & & Lake Chivero and Manyame & \\
\hline & & & Mana Pools National Park & \\
\hline & & & Monavale Wetland & \\
\hline & & & Victoria Falls National Park & \\
\hline \multicolumn{4}{|l|}{ TOTAL AREA } & 32021044 \\
\hline
\end{tabular}

Source: (Ramsar Convention on Wetlands, 2019). 


\section{A3-Table 2. Man and Biosphere Reserves in Eastern and Southern Africa}

\begin{tabular}{|c|c|c|c|}
\hline Country & No. of sites & Biosphere Reserve & Year of designation \\
\hline \multirow[t]{5}{*}{ Ethiopia } & \multirow[t]{5}{*}{5} & Kafa & 2010 \\
\hline & & Yayu & 2010 \\
\hline & & Sheka & 2012 \\
\hline & & Lake Tana & 2015 \\
\hline & & Majang Forest & 2017 \\
\hline \multirow[t]{6}{*}{ Kenya } & \multirow[t]{6}{*}{6} & Mount Kenya & 1978 \\
\hline & & Mount Kulal & 1978 \\
\hline & & Malindi-Watamu & 1979 \\
\hline & & Kiunga & 1980 \\
\hline & & Amboseli & 1991 \\
\hline & & Mount Elgon & 2003 \\
\hline \multirow[t]{5}{*}{ Madagascar } & \multirow[t]{5}{*}{5} & Mananara Nord & 1990 \\
\hline & & Sahamalaza-Iles Radama & 2001 \\
\hline & & Littoral de Toliara & 2003 \\
\hline & & Belo-sur-Mer - Kirindy-Mite & 2016 \\
\hline & & Tsimanampesotse - Nosy Ve Androka & 2018 \\
\hline Mauritius & 1 & Macchabee/Bel Ombre & 1977 \\
\hline \multirow[t]{2}{*}{ Malawi } & \multirow[t]{2}{*}{2} & Mount Mulanje & 2000 \\
\hline & & Lake Chilwa Wetland & 2006 \\
\hline Mozambique & 1 & Quirimbas & 2018 \\
\hline Rwanda & 1 & Volcans & 1983 \\
\hline \multirow[t]{5}{*}{ Tanzania } & \multirow[t]{5}{*}{5} & Lake Manyara & 1981 \\
\hline & & Serengeti-Ngorongoro & 1981 \\
\hline & & East Usambara & 2000 \\
\hline & & Jozani-Chwaka Bay & 2016 \\
\hline & & Gombe Masito Ugalla & 2018 \\
\hline \multirow[t]{2}{*}{ Uganda } & \multirow[t]{2}{*}{2} & Queen Elizabeth & 1979 \\
\hline & & Mount Elgon & 2005 \\
\hline \multirow{10}{*}{ South Africa } & \multirow[t]{10}{*}{10} & Kogelberg & 1998 \\
\hline & & Cape West Coast & 2000 \\
\hline & & Waterberg & 2001 \\
\hline & & Kruger to Canyons & 2001 \\
\hline & & Cape Winelands & 2007 \\
\hline & & Vhembe & 2009 \\
\hline & & Gouritz Cluster & 2015 \\
\hline & & Magaliesberg & 2015 \\
\hline & & Garden Route & 2017 \\
\hline & & Marico & 2018 \\
\hline Zimbabwe & 1 & Middle Zambezi & 2010 \\
\hline
\end{tabular}

Source: UNESCO (2019). 


\section{Appendix 4. Ecological representativity in Eastern and Southern Africa}

A4-Table 1. Protection levels for terrestrial ecoregions represented within the region

\begin{tabular}{r|r|r|r|r}
\hline Protection & Ecoregion count & $\begin{array}{r}\text { Ecoregions } \\
\text { with }<75 \% \text { of area in } \\
\text { region }\end{array}$ & $\begin{array}{r}\text { Ecoregions } \\
\text { with 75-99 \% of area in } \\
\text { region }\end{array}$ & $\begin{array}{r}\text { Ecoregions } \\
\text { exclusive to } \\
\text { region }\end{array}$ \\
\hline 0 & 5 & 5 & 0 & 4 \\
\hline 0.01 to $4 \%$ & 7 & 3 & 0 & 4 \\
\hline 4 to $8 \%$ & 14 & 2 & 2 & 10 \\
\hline 8 to $12 \%$ & 8 & 0 & 1 & 7 \\
\hline 12 to $17 \%$ & 11 & 4 & 1 & 6 \\
\hline$>17 \%$ & 37 & 4 & 6 & 27 \\
\hline
\end{tabular}

Source: EC JRC/DOPA (2019).

A4-Table 2. Protection levels for marine ecoregions and pelagic provinces represented within the region

\begin{tabular}{r|r|r|r|r}
\hline Protection & Ecoregion count & $\begin{array}{r}\text { Ecoregions } \\
\text { with }<75 \% \text { of area in } \\
\text { region }\end{array}$ & $\begin{array}{r}\text { Ecoregions } \\
\text { with } 75-99 \% \text { of area } \\
\text { in region }\end{array}$ & $\begin{array}{r}\text { Ecoregions } \\
\text { exclusive to region }\end{array}$ \\
\hline 0 & 9 & 0 & 7 & 2 \\
\hline 0.01 to $5 \%$ & 10 & 2 & 3 & 5 \\
\hline 5 to $10 \%$ & 5 & 1 & 1 & 3 \\
\hline$>10 \%$ & 6 & 0 & 3 & 3 \\
\hline
\end{tabular}

Source: EC JRC/DOPA (2019). 


\section{Appendix 5. Legal instruments supporting equity and non-State governance of protected areas}

\begin{tabular}{|c|c|}
\hline Country & Relevant law, section and article \\
\hline Kenya & $\begin{array}{l}\text { The Wildlife Conservation and Management Act } 2013 \\
\text { Section } 4 \text {. The implementation of this Act shall be guided by the following principles } \\
\text { (a) Wildlife conservation and management shall be devolved, wherever possible and appropriate to those owners } \\
\text { and managers of land where wildlife occurs; } \\
\text { (b) Conservation and management of wildlife shall entail effective public participation; } \\
\text { (c) Wherever possible, the conservation and management of wildlife shall be encouraged using an ecosystem } \\
\text { approach; } \\
\text { (d) Wildlife conservation and management shall be encouraged and recognized as a form of land use on public, } \\
\text { community and private land; } \\
\text { (e) Benefits of wildlife conservation shall be derived by the land user in order to offset costs and to ensure the } \\
\text { value and management of wildlife do not decline; (pp. 1250-1251) } \\
\text { Environmental Management and Coordination Act (1999, revised } 2012 \text { ) and the Wildlife Conservation and } \\
\text { Management Act (WCMA) } 2013 \text { allow for conservation easements of land. }\end{array}$ \\
\hline Mozambique & $\begin{array}{l}\text { The Land Law (Law 19/97) } \\
\text { Article } 24 \text { (p. 1301) recognizes the role of local communities in natural resource management, conflict resolution, } \\
\text { among others; law also allows hunting under a simple license } \\
\text { The Forest and Wildlife Law covers protection of customary norms and practices: historical-cultural value and land } \\
\text { use; exploitation under a license } \\
\text { Biodiversity Conservation Law, Law No. 16/2014, } 20 \text { June, } \\
\text { Article } 4 \text { (p. 1297) addresses seven principles: ecological heritage; sovereignty, equality; citizen participation in } \\
\text { management and benefits; environmental responsibility; development; public-private partnerships; precautionary } \\
\text { and informed decision; and international cooperation } \\
\text { Article } 7 \text {, No. } 1 \text { (p. 1298) refers to the creation of the Council Conservation Area Management consisting of } \\
\text { representatives of local communities, the private sector, associations and local State bodies } \\
\text { Article } 9 \text {, Nos. } 1 \text { and } 2 \text { (p. 1298) stipulates that the State can establish partnerships with a view of creating synergies } \\
\text { in favour of conservation biological diversity. }\end{array}$ \\
\hline Namibia & $\begin{array}{l}\text { National Policy on Community Based Natural Resource Management, March } 2013 \text {, Section } 4.4 \text { (p. 9) } \\
\text { The government is committed, in compliance with its own laws on access and benefit sharing and global policies } \\
\text { and conventions, to protect the intellectual property rights of communities with regard to natural resources and the } \\
\text { management of such natural resources, and to have a fair and equitable distribution of benefits derived from the use } \\
\text { of natural resources. }\end{array}$ \\
\hline South Africa & $\begin{array}{l}\text { National Biodiversity and Action Plan Policy } \\
\text { Section 2(f) (p. 12) states that NEMPAA is "to promote the participation of local communities in the management of } \\
\text { protected areas, where appropriate ()". } \\
\text { Section } 42 \text { (p. 34) provides that "a co-management agreement may provide for" a range of matters, including } \\
\text { (among others): } \\
\text { •The delegation of powers by the management authority to the other party to the agreement; } \\
\text { The apportionment of any income generated from the management of the protected area or any other form of } \\
\text { benefit-sharing between the parties; } \\
\text { The use of biological resources in the area; } \\
\text { Access to the area; } \\
\text { Occupation of the protected area or portions thereof; and } \\
\text { Development of economic opportunities within and adjacent to the protected area. }\end{array}$ \\
\hline
\end{tabular}




\begin{tabular}{|c|c|}
\hline Country & Relevant law, section and article \\
\hline Uganda & $\begin{array}{l}\text { Uganda National Wildlife Policy, Section } 26 \text { (p. 22) } \\
\text { Historic rights of individuals in conservation areas } \\
\text { (1) The provisions of this Part shall not affect those persons whose rights have, until the coming into force of this } \\
\text { Act, been preserved by:- } \\
\text { (a) the Game (Preservation and Control) Act, namely:- } \\
\text { (i) persons, their wives and children actually residing in game reserves on the 1st July, 1959; } \\
\text { (ii) any persons actually residing in game reserves at the date of their declaration, for those game } \\
\text { reserves declared after the 1st September, 1959; } \\
\text { (b) the National Parks Act, namely, those persons who lawfully acquired rights in national parks before } \\
\text { the 3rd April 1952; } \\
\text { (c) the Forests Act, namely, those persons residing in forests whom the Minister may have exempted } \\
\text { from the provisions of that Act and which forests have since been declared national parks under the } \\
\text { National Parks Act. } \\
\text { (2) The authority may establish guidelines for access of communities neighbouring conservation areas to resources } \\
\text { which are crucial to the survival of those communities. }\end{array}$ \\
\hline Zimbabwe & $\begin{array}{l}\text { Parks and Wildlife Act (Chapter 20:14) } 1996 \\
\text { Section } 2 \text { confers privileges on owners or occupiers of alienated land as custodians of wildlife and offers "Appropriate } \\
\text { Authority" status to Rural District Councils over wildlife in their respective Communal Lands on behalf of their rural } \\
\text { local communities, referred to as "producer communities". } \\
\text { Policy for Wildlife Zimbabwe } 1999 \\
\text { The policy aims at empowering landowners to conserve and derive benefits from wildlife resources existing on their } \\
\text { land, inclusive of communal and private lands. } \\
\text { Wildlife Based Land Reform Policy } 2004 \text {. } \\
\text { Section 3: "to facilitate the indigenisation of the wildlife sector and to ensure more equitable access by the majority } \\
\text { of Zimbabweans to land and wildlife resources and to the business opportunities that stem from these resources". }\end{array}$ \\
\hline
\end{tabular}

Source: Tessema (n.d.)"issued":\{“date-parts":[["2019"]]\}\}]],"schema":"https://github.com/citation-style-language/schema/raw/master/cs/-citation.json"\} . 


\section{Appendix 6. Protected and conserved areas in IUCN Management Categories per country}

Protected and conserved areas in Angola in IUCN Management Categories

\begin{tabular}{l|r|r}
\hline IUCN Management Category & No. & \% Coverage \\
\hline II. National Park & 8 & 77.49 \\
\hline IV. Habitat / Species Management & 4 & 16.42 \\
\hline V. Protected Landscape / Seascape & 1 & 0.24 \\
\hline Not Reported & 1 & 5.26 \\
\hline
\end{tabular}

Source: UNEP-WCMC \& IUCN (2019c).

Protected and conserved areas in Botswana in IUCN Management Categories

\begin{tabular}{l|r|r}
\hline IUCN Management Category & No. & \% Coverage \\
\hline Ib. Wilderness Area & 7 & 61.12 \\
\hline II. National Park & 6 & 2.40 \\
\hline IV. Habitat / Species Management & 7 & 1.08 \\
\hline Not Reported & 1 & 37.78 \\
\hline Not Applicable & 1 & 12.07 \\
\hline
\end{tabular}

Source: UNEP-WCMC \& IUCN (2019C).

Protected and conserved areas in Comoros in IUCN Management Categories

\begin{tabular}{l|r|r}
\hline IUCN Management Category & No. & \% Coverage \\
\hline II. National Park & 1 & 17.74 \\
\hline Not Reported & 7 & 81.75 \\
\hline
\end{tabular}

Source: UNEP-WCMC \& IUCN (2019d).

Protected and conserved areas in Djibouti in IUCN Management Categories

\begin{tabular}{l|r|r}
\hline IUCN Management Category & No. & \% Coverage \\
\hline IV. Habitat / Species Management & 1 & $0.00 \%$ \\
\hline V. Protected Landscape / Seascape & 2 & $0.00 \%$ \\
\hline VI. Protected Area with Sustainable Use of Natural Resources & 1 & $0.00 \%$ \\
\hline Not Reported & 3 & $100 \%$ \\
\hline
\end{tabular}

Source: UNEP-WCMC \& IUCN (2019e). 
Protected and conserved areas in Eritrea in IUCN Management Categories

\begin{tabular}{l|r|r}
\hline IUCN Management Category & No. & \% Coverage \\
\hline IV. Habitat / Species Management & 3 & 100.00 \\
\hline Not Reported & 1 & \\
\hline
\end{tabular}

Source: UNEP-WCMC \& IUCN (2019f).

\section{Protected and conserved areas in Eswatini in IUCN Management Categories}

\begin{tabular}{l|r|r}
\hline IUCN Management Category & No. & \% Coverage \\
\hline II. National Park & 6 & 94.20 \\
\hline IV. Habitat/Species Management & 2 & 0.19 \\
\hline V. Protected Landscape/Seascape & 1 & 2.14 \\
\hline Not Reported & 5 & 3.09 \\
\hline
\end{tabular}

Source: UNEP-WCMC \& IUCN (2019g).

Protected and conserved areas in Ethiopia in IUCN Management Categories

\begin{tabular}{l|r|r}
\hline IUCN Management Category & No. & \% Coverage \\
\hline II. National Park & 17 & 17.35 \\
\hline IV. Habitat / Species Management & 8 & 11.69 \\
\hline VI. Protected Area with Sustainable Use of Natural Resources & 18 & 75.76 \\
\hline Not Reported & 58 & 0.02 \\
\hline Not Applicable & 3 & 0.07 \\
\hline
\end{tabular}

Source: UNEP-WCMC \& IUCN (2019h).

Protected and conserved areas in Kenya in IUCN Management Categories

\begin{tabular}{l|r|r}
\hline IUCN Management Category & No. & \% Coverage \\
\hline II. National Park & 36 & 46.15 \\
\hline IV. Habitat / Species Management & 5 & 0.65 \\
\hline VI. Protected Area with Sustainable Use of Natural Resources & 16 & 10.91 \\
\hline Not Reported & 345 & 46.19 \\
\hline Not Applicable & 9 & 5.23 \\
\hline
\end{tabular}

Source: UNEP-WCMC \& IUCN (2019i).

Protected and conserved areas in Lesotho in IUCN Management Categories

\begin{tabular}{l|r|r}
\hline IUCN Management Category & No. & \% Coverage \\
\hline IV. Habitat / Species Management & 1 & 86.89 \\
\hline Not Reported & 2 & 5.43 \\
\hline Not Applicable & 1 & 7.00 \\
\hline
\end{tabular}

Source: UNEP-WCMC \& IUCN (2019j). 


\section{Protected and conserved areas in Madagascar in IUCN Management Categories}

\begin{tabular}{l|r|r}
\hline IUCN Management Category & No. & \% Coverage \\
\hline Ia. Strict Nature Reserve & 3 & 2.00 \\
\hline II. National Park & 30 & 19.00 \\
\hline IV. Habitat / Species Management & 22 & 14.00 \\
\hline VI. Protected Area with Sustainable Use of Natural Resources & 7 & 4.00 \\
\hline V Protected Landscape / Seascape & 29 & 18.00 \\
\hline Not Reported & 61 & 39.00 \\
\hline Not Applicable & 5 & 3.00 \\
\hline
\end{tabular}

Source: UNEP-WCMC \& IUCN (2019k).

\section{Protected and conserved areas in Malawi in IUCN Management Categories}

\begin{tabular}{l|r|r}
\hline IUCN Management Category & No. & \% Coverage \\
\hline II. National Park & 5 & 25.60 \\
\hline IV. Habitat / Species Management & 4 & 14.03 \\
\hline Not Reported & 121 & 64.73 \\
\hline Not Applicable & 3 & 0.27 \\
\hline
\end{tabular}

Source: UNEP-WCMC \& IUCN (2019).

Protected and conserved areas in Mauritius in IUCN Management Categories

\begin{tabular}{l|r|r}
\hline IUCN Management Category & No. & \% Coverage \\
\hline Ia. Strict Nature Reserve & 1 & 0.21 \\
\hline II. National Park & 10 & 42.74 \\
\hline IV. Habitat / Species Management & 21 & 42.47 \\
\hline Not Reported & 10 & 0.32 \\
\hline Not Assigned & 1 & 0.01 \\
\hline
\end{tabular}

Source: UNEP-WCMC \& IUCN (2019m).

Protected and conserved areas in Mozambique in IUCN Management Categories

\begin{tabular}{l|r|r}
\hline IUCN Management Category & No. & \% Coverage \\
\hline II. National Park & 6 & 24.62 \\
\hline IV. Habitat / Species Management & 4 & 9.82 \\
\hline VI. Protected Area with Sustainable Use of Natural Resources & 3 & 0.71 \\
\hline Not Reported & 29 & 63.70 \\
\hline Not Assigned & 2 & 2.19 \\
\hline
\end{tabular}

Source: UNEP-WCMC \& IUCN (2019n). 
Protected and conserved areas in Namibia in IUCN Management Categories

\begin{tabular}{l|r|r}
\hline IUCN Management Category & No. & \% Coverage \\
\hline II. National Park & 9 & 31.01 \\
\hline III. Natural Monument & 2 & 0.00 \\
\hline IV. Habitat / Species Management & 1 & 0.00 \\
\hline V. Protected Landscape / Seascape & 3 & 0.16 \\
\hline VI. Protected Area with Sustainable Use of Natural Resources & 1 & 2.94 \\
\hline Not Reported & 131 & 72.49 \\
\hline Not Applicable & 1 & 9.52 \\
\hline
\end{tabular}

Source: UNEP-WCMC \& IUCN (20190).

Protected and conserved areas in Rwanda in IUCN Management Categories

\begin{tabular}{l|r|r}
\hline IUCN Management Category & No. & \% Coverage \\
\hline II. National Park & 2 & 50.98 \\
\hline IV. Habitat / Species Management & 3 & 45.38 \\
\hline Not Reported & 4 & 2.96 \\
\hline
\end{tabular}

Source: UNEP-WCMC \& IUCN (2019p).

Protected and conserved areas in Seychelles in IUCN Management Categories

\begin{tabular}{l|r|r}
\hline IUCN Management Category & No. & \% Coverage \\
\hline la. Strict Nature Reserve & 5 & 1.16 \\
\hline Ib. Wilderness Area & 1 & 0.00 \\
\hline II. National Park & 8 & 0.04 \\
\hline VI. Protected Area with Sustainable Use of Natural Resources & 6 & 0.00 \\
\hline Not Reported & 18 & 98.36 \\
\hline Not Applicable & 2 & 0.21 \\
\hline
\end{tabular}

Source: UNEP-WCMC \& IUCN (2019q).

Protected and conserved areas in Somalia in IUCN Management Categories

\begin{tabular}{l|r|r}
\hline IUCN Management Category & No. & \% Coverage \\
\hline Not Reported & 21 & 0.00 \\
\hline
\end{tabular}

Source: UNEP-WCMC \& IUCN (2019r).

Protected and conserved areas in South Africa in IUCN Management Categories

\begin{tabular}{l|r|r}
\hline IUCN Management Category & No. & \% Coverage \\
\hline Not Reported & 1567 & 97.75 \\
\hline Not Applicable & 13 & 5.15 \\
\hline
\end{tabular}

Source: UNEP-WCMC \& IUCN (2019s). 
Protected and conserved areas in South Sudan in IUCN Management Categories

\begin{tabular}{l|r|r}
\hline IUCN Management Category & No. & \% Coverage \\
\hline II. National Park & 9 & 52.35 \\
\hline IV. Habitat / Species Management & 3 & - \\
\hline V. Protected Landscape / Seascape & 1 & 1.18 \\
\hline VI. Protected Area with Sustainable Use of Natural Resources & 13 & 30.33 \\
\hline Not Reported & 1 & 24.66 \\
\hline
\end{tabular}

Source: UNEP-WCMC \& IUCN (2019t).

\section{Protected and conserved areas in Sudan in IUCN Management Categories}

\begin{tabular}{l|r|r}
\hline IUCN Management Category & No. & \% Coverage \\
\hline II. National Park & 3 & 39.19 \\
\hline IV. Habitat / Species Management & 1 & 2.17 \\
\hline VI. Protected Area with Sustainable Use of Natural Resources & 3 & 13.57 \\
\hline Not Reported & 13 & 46.66 \\
\hline Not Applicable & 3 & 4.84 \\
\hline
\end{tabular}

Source: UNEP-WCMC \& IUCN (2019u).

\section{Protected and conserved areas in Tanzania in IUCN Management Categories}

\begin{tabular}{l|r|r}
\hline IUCN Management Category & No. & \% Coverage \\
\hline Ib. Wilderness Area & 8 & 0.10 \\
\hline II. National Park & 14 & 11.77 \\
\hline III. Natural Monument & 1 & 0.00 \\
\hline IV. Habitat / Species Management & 53 & 19.95 \\
\hline VI. Protected Area with Sustainable Use of Natural Resources & 19 & 3.02 \\
\hline Not Reported & 738 & 70.98 \\
\hline Not Applicable & 7 & 18.76 \\
\hline
\end{tabular}

Source: UNEP-WCMC \& IUCN (2019v).

\section{Protected and conserved areas in Uganda in IUCN Management Categories}

\begin{tabular}{|c|c|c|}
\hline IUCN Management Category & No. & $\%$ Coverage \\
\hline II. National Park & 10 & 28.80 \\
\hline III. Natural Monument & 11 & 21.19 \\
\hline IV. Habitat / Species Management & 1 & 0.48 \\
\hline VI. Protected Area with Sustainable Use of Natural Resources & 13 & 12.74 \\
\hline Not Reported & 673 & 44.24 \\
\hline Not Applicable & 4 & 3.38 \\
\hline
\end{tabular}

Source: UNEP-WCMC \& IUCN (2019w). 
Protected and conserved areas in Zambia in IUCN Management Categories

\begin{tabular}{l|r|r}
\hline IUCN Management Category & No. & \% Coverage \\
\hline II. National Park & 19 & 21.13 \\
\hline III. Natural Monument & 16 & 0.03 \\
\hline IV. Habitat / Species Management & 1 & 0.04 \\
\hline VI. Protected Area with Sustainable Use of Natural Resources & 36 & 49.11 \\
\hline Not Reported & 562 & 38.15 \\
\hline Not Applicable & 1 & 0.01 \\
\hline
\end{tabular}

Source: UNEP-WCMC \& IUCN (2019x).

Protected and conserved areas in Zimbabwe in IUCN Management Categories

\begin{tabular}{l|r|r}
\hline IUCN Management Category & No. & \% Coverage \\
\hline Ib. Wilderness Area & 1 & 0.01 \\
\hline II. National Park & 10 & 25.15 \\
\hline III. Natural Monument & 2 & 0.02 \\
\hline IV. Habitat / Species Management & 19 & 0.12 \\
\hline V. Protected Landscape / Seascape & 12 & 3.41 \\
\hline VI. Protected Area with Sustainable Use of Natural Resources & 19 & 17.79 \\
\hline Not Reported & 166 & 54.84 \\
\hline Not Applicable & 3 & 6.33 \\
\hline
\end{tabular}

Source: UNEP-WCMC \& IUCN (2019y). 


\section{Appendix 7. Protected and conserved areas in IUCN Governance Types per country}

\begin{tabular}{l|r|r} 
Protected and conserved areas in Angola in IUCN Governance Types \\
\hline IUCN Governance Category & No. & \% Coverage \\
\hline Not Reported & 14 & 100.00 \\
\hline
\end{tabular}

Source: UNEP-WCMC \& IUCN (2019C).

Protected and conserved areas in Botswana in IUCN Governance Types

\begin{tabular}{l|r|r}
\hline IUCN Governance Category & No. & \% Coverage \\
\hline A. Governance by Government & 18 & 63.58 \\
\hline C. Private Governance & 1 & 0.44 \\
\hline D. Governance by Indigenous peoples and Local Communities & 1 & 0.57 \\
\hline Not Reported & 2 & 37.80 \\
\hline
\end{tabular}

Source: UNEP-WCMC \& IUCN )2019d).

Protected and conserved areas in Comoros in IUCN Governance Types

\begin{tabular}{l|r|r}
\hline IUCN Governance Category & No. & \% Coverage \\
\hline B. Shared Governance & 6 & 23.29 \\
\hline Not Reported & 2 & 76.19 \\
\hline
\end{tabular}

Source: UNEP-WCMC \& IUCN (2019d).

Protected and conserved areas in Djibouti in IUCN Governance Types

\begin{tabular}{l|r|r}
\hline IUCN Governance Category & No. & \% Coverage \\
\hline Governance by Government & 3 & 90.84 \\
\hline Not Reported & 1 & 8.43 \\
\hline
\end{tabular}

Source: UNEP-WCMC \& IUCN (2019e).

Protected and conserved areas in Eritrea in IUCN Governance Types

\begin{tabular}{l|r|r}
\hline IUCN Governance Category & No. & \% Coverage \\
\hline Not Reported & 4 & 100.00 \\
\hline
\end{tabular}

Source: UNEP-WCMC \& IUCN (2019f).

Protected and conserved areas in Eswatini in IUCN Governance Types

\begin{tabular}{l|r|r}
\hline IUCN Governance Category & No. & \% Coverage \\
\hline B. Private & 3 & 2.33 \\
\hline Not Reported & 11 & 97.29 \\
\hline
\end{tabular}

Source: UNEP-WCMC \& IUCN (2019g).

*Eswatini reports additional information not yet in the WDPA. Not all countries were updated in the WDPA prior to this publication of this report. Countries are encouraged to update their GIS and tabular data in the WDPA in any case where their data do not match up with those in this report. 
Protected and conserved areas in Ethiopia in IUCN Governance Types

\begin{tabular}{l|r|r}
\hline IUCN Governance Category & No. & \% Coverage \\
\hline Not Reported & 104 & 100.00 \\
\hline
\end{tabular}

Source: UNEP-WCMC \& IUCN (2019h).

Protected and conserved areas in Kenya in IUCN Governance Types

\begin{tabular}{l|r|r}
\hline IUCN Governance Category & No. & \% Coverage \\
\hline Governance by Government & 76 & 67.68 \\
\hline B. Shared Governance & 1 & 0.45 \\
\hline C. Private Governance & 16 & 2.59 \\
\hline D. Governance by Indigenous peoples and Local Communities & 51 & 1.97 \\
\hline Not Reported & 267 & 36.37 \\
\hline
\end{tabular}

Source: UNEP-WCMC \& IUCN (2019i).

Protected and conserved areas in Lesotho in IUCN Governance Types

\begin{tabular}{l|r|r}
\hline IUCN Governance Category & No. & \% Coverage \\
\hline Governance by Government & 3 & 92.32 \\
\hline Not Reported & 1 & 7.00 \\
\hline
\end{tabular}

Source: UNEP-WCMC \& IUCN (2019j)

Protected and conserved areas in Madagascar in IUCN Governance Types

\begin{tabular}{l|r|r}
\hline IUCN Governance Category & No. & \% Coverage \\
\hline Governance by Government & 8 & 3.50 \\
\hline B. Shared Governance & 2 & 0.05 \\
\hline C. Private Governance & 2 & 4.97 \\
\hline D. Governance by Indigenous peoples and Local Communities & 34 & 11.12 \\
\hline Not Reported & 111 & 89.83 \\
\hline
\end{tabular}

Source: UNEP-WCMC \& IUCN (2019k).

Protected and conserved areas in Malawi in IUCN Governance Types

\begin{tabular}{l|r|r}
\hline IUCN Governance Category & No. & \% Coverage \\
\hline Governance by Government & 10 & 41.87 \\
\hline Not Reported & 123 & 62.76
\end{tabular}

Source: UNEP-WCMC \& IUCN (2019l). 
Protected and conserved areas in Mauritius in IUCN Governance Types

\begin{tabular}{l|r|r}
\hline IUCN Governance Category & No. & \% Coverage \\
\hline A. Governance by Government & 42 & $82.74 \%$ \\
\hline C. Private Governance & 2 & $1.67 \%$ \\
\hline
\end{tabular}

Source: UNEP-WCMC \& IUCN (2019m).

Protected and conserved areas in Mozambique in IUCN Governance Types

\begin{tabular}{l|r|r}
\hline IUCN Governance Category & No. & \% Coverage \\
\hline A. Governance by Government & 28 & 69.94 \\
\hline B. Shared Governance & 1 & 2.00 \\
\hline D. Governance by Indigenous peoples and Local Communities & 1 & 0.00 \\
\hline Not Reported & 14 & 33.31 \\
\hline
\end{tabular}

Source: UNEP-WCMC \& IUCN (2019n).

${ }^{*}$ Other sites reported by Mozambique are not yet in the WDPA. Not all countries were updated in the WDPA prior to this publication of this report. Countries are encouraged to update their GIS and tabular data in the WDPA in any case where their data do not match up with those in this report.

Protected and conserved areas in Namibia in IUCN Governance Types

\begin{tabular}{l|r|r}
\hline IUCN Governance Category & No. & \% Coverage \\
\hline A. Governance by Government & 31 & 47.58 \\
\hline C. Private Governance & 2 & 0.89 \\
\hline D. Governance by Indigenous Peoples and Local Communities & 112 & 50.60 \\
\hline Not Reported & 3 & 10.12 \\
\hline
\end{tabular}

Source: UNEP-WCMC \& IUCN (20190).

Protected and conserved areas in Rwanda in IUCN Governance Types

\begin{tabular}{l|r|r}
\hline IUCN Governance Category & No. & \% Coverage \\
\hline Governance by Government & 3 & 94.88 \\
\hline Not Reported & 7 & 4.44 \\
\hline
\end{tabular}

Source: UNEP-WCMC \& IUCN (2019p).

Protected and conserved areas in Seychelles in IUCN Governance Types

\begin{tabular}{l|r|r}
\hline IUCN Governance Category & No. & \% Coverage \\
\hline Governance by Government & 20 & 1.20 \\
\hline Not Reported & 20 & 100.00 \\
\hline
\end{tabular}

Source: UNEP-WCMC \& IUCN (2019q).

\section{Protected and conserved areas in Somalia in IUCN Governance Types}

\begin{tabular}{l|r|r}
\hline IUCN Governance Category & No. & \% Coverage \\
\hline Governance by Government & 21 & 0.00 \\
\hline
\end{tabular}

Source: UNEP-WCMC \& IUCN (2019r). 
Protected and conserved areas in South Africa in IUCN Governance Types

\begin{tabular}{l|r|r}
\hline IUCN Governance Category & No. & \% Coverage \\
\hline Governance by Government & 645 & 92.29 \\
\hline B. Shared Governance & 1 & 0.18 \\
\hline C. Private Governance & 932 & 7.84 \\
\hline Not Reported & 2 & 0.81 \\
\hline
\end{tabular}

Source: UNEP-WCMC \& IUCN (2019s).

Protected and conserved areas in South Sudan in IUCN Governance Types

\begin{tabular}{l|r|r}
\hline IUCN Governance Category & No. & \% Coverage \\
\hline Governance by Government & 26 & 83.87 \\
\hline Not Reported & 1 & 24.66 \\
\hline
\end{tabular}

Source: UNEP-WCMC \& IUCN (2019t).

Protected and conserved areas in Sudan in IUCN Governance Types

\begin{tabular}{l|r|r}
\hline IUCN Governance Category & No. & \% Coverage \\
\hline Governance by Government & 9 & 73.50 \\
\hline Not Reported & 14 & 32.93 \\
\hline
\end{tabular}

Source: UNEP-WCMC \& IUCN (2019u).

Protected and conserved areas in Tanzania in IUCN Governance Types

\begin{tabular}{l|r|r}
\hline IUCN Governance Category & No. & \% Coverage \\
\hline Governance by Government & 777 & 87.24 \\
\hline B. Shared Governance & 4 & 0.15 \\
\hline C. Private Governance & 1 & 0.00 \\
\hline D. Governance by Indigenous peoples and Local Communities & 39 & 7.98 \\
\hline Not Reported & 19 & 33.54 \\
\hline
\end{tabular}

Source: UNEP-WCMC \& IUCN (2019v).

Protected and conserved areas in Uganda in IUCN Governance Types

\begin{tabular}{l|r|r}
\hline IUCN Governance Category & No. & \% Coverage \\
\hline Governance by Government & 699 & 98.00 \\
\hline Not Reported & 13 & 2.00 \\
\hline
\end{tabular}

Source: UNEP-WCMC \& IUCN ((2019w).

Protected and conserved areas in Zambia in IUCN Governance Types

\begin{tabular}{l|r|r}
\hline IUCN Governance Category & No. & \% Coverage \\
\hline Governance by Government & 49 & 66.35 \\
\hline Not Reported & 586 & 41.50 \\
\hline
\end{tabular}

Source: UNEP-WCMC \& IUCN (2019x).

Protected and conserved areas in Zimbabwe in IUCN Governance Types

\begin{tabular}{l|r|r}
\hline IUCN Governance Category & No. & \% Coverage \\
\hline Not Reported & 232 & 100.00 \\
\hline
\end{tabular}

Source: UNEP-WCMC \& IUCN (2019y). 


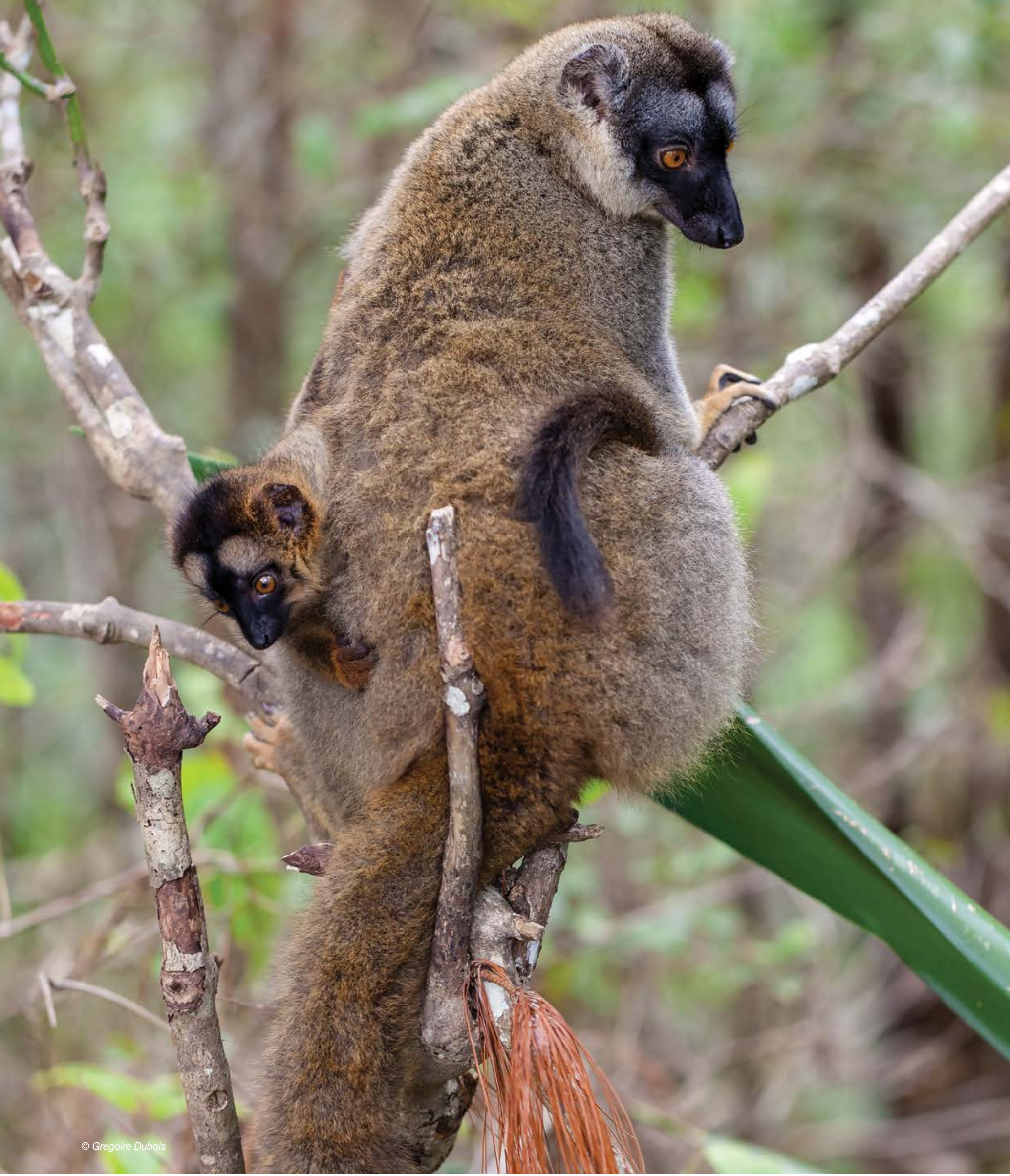





\section{IUCN}

INTERNATIONAL UNION

FOR CONSERVATION OF NATURE

Eastern and Southern Africa Regional Office

Wasaa Conservation Centre, Mukoma Road (off Magadi Road, City Square)

P. O Box 68200,200

Nairobi, Kenya

Landline: +254 20 2493561/65/70

Email: info.esaro@iucn.org

Website: https://www.iucn.org/esaro 